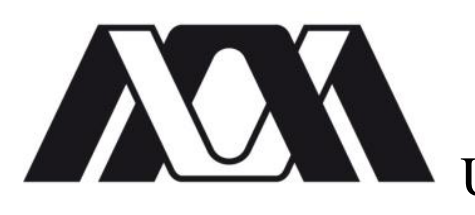

Universidad Autónoma Metropolitana

UNIDAD IZTAPALA

División DE CienCias Sociales y HuMANidAdES

Posgrado EN Filología MEdiEVAL, ÁUREA E HISPANOAMERICANA DE LOS SIGLOS XVI AL XVIII

\title{
AProximación a la VeSTimenta en los libros de Caballerías de Feliciano de Silva
}

TESIS QUE PARA OBTENER EL GRADO DE

DOCTORA EN HUMANIDADES-LITERATURA

PRESENTA:

Mtra.ANDREA Flores García

ASESORA:

DRA. María José Rodilla LeÓN

LECTORES:

Dr. Axayácatl Campos García Rojas

Dra. Karla Xiomara Luna Mariscal

Ciudad De MÉXICO, DICIEMBRe DE 2019 
A mi papá, quien desde el cielo me arropa.

A mi mamá, quien con sus brazos me abriga. 


\section{Agradecimientos}

A Dios por la vida, la sabiduría, la misericordia y el amor con los que todos los días me abriga.

A mis padres, Ramón y María, porque gracias a sus enseñanzas he tejido mi vida. A mis hermanos, Elizabeth, Abraham, Judith, Ruth, Sandra y Jonathan, por su ayuda incondicional y por tantas noches de desvelo para bordar nuevos proyectos.

A mis cuñados, Jaime, Benjamín, Rebeca y Frida, por las gemas que me han dado para decorar esta tela.

A mis sobrinos, Fernando, David, Ana, Saraí, Génesis, Pablo, Uriel, Carlos, Michelle,

Kevin, Alexis y Sofía, por aportar diferentes adornos durante estos cuatro años.

A la Dra. María José Rodilla León por todo su apoyo, paciencia y comprensión para confeccionar esta investigación. Gracias por ser partícipe de esta pasarela caballeresca y ayudarme a diseñar una gran variedad de enseres para los modelos principales, la dama y el caballero.

Al Dr. Alberto del Río Nogueras por los diseños zaragozanos que entretejió para ornamentar aún más esta tesis.

A los doctores Axayácatl Campos García Rojas y Karla Xiomara Luna Mariscal por hilvanar valiosas ideas para fortalecer los hilos de este trabajo.

A los doctores Juan Manuel Cacho Blecua y María Carmen Marín Pina por las sugerencias de colores y telas expuestas para esta investigación.

A María Ángeles por todo su apoyo para la búsqueda de fuentes textiles desde Zaragoza.

A mis amigos por todo el entusiasmo y apoyo para hilar muchas de las ideas aquí expuestas.

A mis compañeros del SENC por toda su ayuda en la búsqueda de más hazañas textiles. A Bethel por coser conmigo a través de sus oraciones. 
Índice

$\begin{array}{lr}\text { Introducción } & 8\end{array}$

1. La vestimenta en el siglo XVI 13

1.1. Tipos de prendas $\quad 14$

1.1.1. Prendas ocultas 14

1.1.2. Prendas para vestir a cuerpo 18

1.1.3. Prendas de encima $\quad 20$

1.1.4. Prendas exteriores $\quad 22$

1.1.5. Calzado 25

$\begin{array}{ll}\text { 1.1.6. Botones y agujetas } & 28\end{array}$

1.2. Leyes suntuarias 33

1.3. La moda desde la Edad Media hasta el siglo XVI 42

1.3.1. La idea de la moda en voz de los personajes caballerescos 48

1.4. Estado de la cuestión: La vestimenta en los libros de caballerías 58

2. Los libros de caballerías de Feliciano de Silva 62

2.1. Del Lisuarte de Grecia al Florisel de Niquea 63

2.1.1. Lisuarte de Grecia: Primeros modelos textiles 63

2.1.2. Amadís de Grecia: Entre el color y las telas 66

2.1.3. Florisel de Niquea I-II: Atuendos para cada personaje 68

2.1.4. Florisel de Niquea III: Entre joyas y antifaces $\quad 70$

2.1.5. Florisel de Niquea IV: Últimas galas 71

2.2. Telas, encajes, bordados e hilos: Los tejidos 74

2.2.1. Categoría de los tejidos $\quad 75$

2.2.1.1. Tejidos $\quad 78$

2.2.1.2. Base del tejido $\quad 78$

$\begin{array}{ll}\text { 2.2.1.2.1. Brocado } & 79\end{array}$

2.2.1.2.2. Seda $\quad 80$

2.2.1.2.3. Terciopelo $\quad 82$

2.2.1.2.4. Escarlata $\quad 83$

2.2.1.2.5. Carmesí $\quad 85$

$\begin{array}{ll}\text { 2.2.1.2.6. Tela de oro } & 87\end{array}$

2.2.1.2.7. Jamete $\quad 87$

$\begin{array}{ll}2.2 .1 .2 .8 \text {. Pieles } & 88\end{array}$

$\begin{array}{lr}\text { 2.2.2. Piedras preciosas } & 90\end{array}$

2.2.2.1. Las gemas en la tradición bíblica $\quad 91$

2.2.2.2. Los lapidarios medievales $\quad 94$

2.2.2.3. Las gemas en los libros de caballerías 96 
2.2.2.3.1. Diamante 101

2.2.2.3.2. Aljófar y perla 104

2.2.2.3.3. Rubí 106

2.2.2.3.4. Carbunclo 108

2.2.2.3.5. Esmeralda 109

2.2.2.3.6. Zafiro 111

2.2.2.3.7. Lincurio 113

2.2.3. "Una hermosa infanta al uso de esa aquella tierra" 116

2.2.3.1. Habiti 116

2.2.3.1.1. Traje de Sármata $\quad 118$

$\begin{array}{ll}\text { 2.2.3.1.2. Traje indiano } & 121\end{array}$

2.3. Desfile de prendas 124

2.3.1. Vestir para una boda $\quad 126$

2.3.2. Recibimientos 133

2.3.3. Atuendos ceremoniales 136

2.3.3.1. Vestidos de boda 137

2.4. Adornos para el cabello 164

2.4.1. Guirnaldas de fiesta 166

$\begin{array}{ll}\text { 2.4.2. Tocados de rueda } & 170\end{array}$

2.5. Joyas 172

2.6. Accesorios 178

2.6.1. Bolsos 179

2.6.2. Pañuelos y guantes 182

2.6.3. Prendas para cubrir la cabeza 185

2.6.3.1. Sombreros 186

2.6.3.2. Chapeo 189

2.6.3.3. Bonete 190

2.7. Calzado 192

2.8. De metales y telas: la moda masculina $\quad 200$

2.8.1. Vestiduras masculinas $\quad 202$

2.8.1.1. Prendas interiores 203

2.8.1.2. Jubones y calzas $\quad 205$

2.8.1.3. Mantos $\quad 207$

2.8.1.4. Aljubas 208

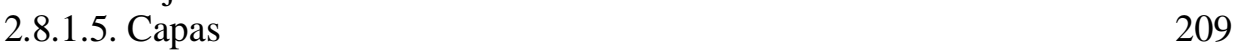

2.8.2. Vestimenta de gala 211

2.8.3. Desfile de caballeros 215

2.8.4. Prendas de protección masculina 217

2.8.5. Prendas para la cabeza 218

$\begin{array}{ll}\text { 2.8.6. Las armas } & 221\end{array}$

2.8.6.1. Armas de juego 222 
2.8.6.2. Primeras armas $\quad 225$

2.8.7. Armas defensivas $\quad 230$

2.8.7.1. El yelmo $\quad 230$

2.8.7.2. El escudo $\quad 233$

2.8.7.3. Las espuelas $\quad 235$

2.8.8. Armas ofensivas $\quad 237$

2.8.8.1. La espada $\quad 237$

2.8.8.2. La cimitarra 239

2.8.9. Armas de emergencia 240

2.8.9.1. Armas trozadas 241

2.8.9.2. Armas predestinadas 243

2.8.9.3. Armas como accesorio 247

2.8.9.4. Manto de combate 248

2.8.9.5. Combatir en galas $\quad 249$

2.8.9.6. Armas de guerra vs. Armas de cortesanía 251

2.9. El escudo 253

2.9.1. Elementos del escudo 254

2.9.1.1. Constitución del emblema 256

2.9.2. Los colores 261

2.9.2.1. Blanco 262

2.9.2.2. Oro y plata 264

2.9.2.3. Rojo 265

2.9.2.4. Azul 267

2.9.2.5. Negro 270

2.9.2.6. Púrpura 274

2.9.2.7. Verde 276

2.9.3. Escudos como microhistorias 282

2.9.3.1. Historias bélicas y amorosas 284

3. Simbolismo de la vestimenta 288

3.1. Prendas de amor y desafío: Letras bordadas 288

3.1.1. Bordados para los enamorados 289

3.1.2. Bordados de desafío 296

3.1.3. Ornamentos florales $\quad 299$

3.1.4. Flores de adorno $\quad 300$

3.1.5. Clavel 301

3.1.6. Flor de lis 308

3.1.7. Ramos de oliva $\quad 310$

3.1.8. Flor verde $\quad 311$

3.1.9. Lirio 313

3.2. Prendas de protección 316

$\begin{array}{ll}\text { 3.2.1. Toalla y rebozo } & 317\end{array}$

3.2.2. Antifaz 320

3.2.3. Motivos para cubrirse $\quad 329$

3.2.3.1. Para llevar mensajes $\quad 330$

3.2.3.2. Para evitar una pena 333 
3.2.3.3. Para ocultar las imperfecciones $\quad 334$

3.2.4. La armadura $\quad 336$

$\begin{array}{ll}\text { 3.2.4.1. El yelmo } & 337\end{array}$

3.3. Prendas de seducción: La vestimenta como estrategia de conquista 341

3.3.1. La camisa $\quad 342$

3.3.1.1. La camisa como cobertura del cuerpo 345

3.3.1.2. Entregar la camisa $\quad 350$

3.3.1.3. Dificultades de la tela 351

3.3.1.4. La camisa como deshonra 354

3.3.2. El abanico, el ventalle y el moscador 356

3.4. Prendas de luto $\quad 363$

3.4.1. El manto negro $\quad 365$

3.4.1.1. Paños para la ausencia $\quad 367$

3.4.1.2. Paños de encanto 368

3.4.1.3. Manto negro por pérdida de bienes 368

3.4.1.4. Armas de luto 369

$\begin{array}{lr}\text { 4.Feliciano de Silva frente a otros autores } & 372\end{array}$

4.1. Variedad de prendas $\quad 373$

4.1.1. Vestir acorde al estado de ánimo 374

4.2. Valor monetario de prendas y joyas 377

4.2.1. Joyas dedicadas 381

4.3. La vestimenta como generadora de males $\quad 384$

4.3.1. Prendas ruidosas $\quad 384$

4.3.2. Prendas asfixiantes $\quad 385$

4.3.3. Prendas travadas $\quad 388$

4.3.4. Prendas volumiosas y pesadas $\quad 389$

4.4. Prendas para ocultar la preñez 392

4.5. Ropa vejatoria $\quad 395$

4.6. Ropa para difuntos 396

4.7. Enredos en el vestir $\quad 399$

4.8. Usos de la manga $\quad 400$

4.9. Testimonios textiles a través de los grabados 403

4.9.1. Amadís de Gaula: Variedad de atavíos 405

4.9.1.2. Lisuarte de Grecia: Entre metales y telas 413

4.9.1.3. La Trapesonda: Pieles $\quad 417$

4.9.1.4. Espejo de príncipes y caballeros: Cuellos 424

4.9.2. Aportaciones indumentarias al género 433

$\begin{array}{ll}\text { Conclusiones } & 441\end{array}$

Bibliografía 446 


\section{Introducción}

En los libros de caballerías, cuando llega una dama a la corte, se usa una expresión típica para anunciar que viene "una donzella muy fermosa, vestida de muy ricos paños con muchas piedras y perlas por ellas sembradas", frase que aporta sólo un dato de su atuendo, el tipo de ornamento que lleva, piedras preciosas y perlas; sin embargo, el resto es un misterio, porque se desconoce la forma del vestido, el tipo de tela y los demás complementos que lo integran. Otros ejemplos más aparecen condicionados por las breves descripciones de los escritores, algunos revelan más detalles al nombrar alguna de las prendas como la saya, el jubón, la capa, etc., pero aún siguen sin presentar un modelo estructurado por los tres elementos base para su creación: tela, color y adornos, a partir de los cuales se tiene los materiales necesarios para diseñar un traje. Esta escasa información que aparece en los libros de caballerías genera el interés de investigar el tipo de vestimenta que los personajes de estos libros portan en diferentes situaciones, desde los bailes y las justas, hasta los encuentros sentimentales y los sucesos de duelo. Eventos que se caracterizan por la algarabía de los festejos, la discreción en el andar y la tristeza por la muerte, en donde se reúnen caballeros y damas de distintos reinos en donde la mirada se atrae por el modo de ataviarse de cada uno.

En los libros de caballerías hay numerosos pasajes en los que la vestimenta adquiere relevancia por el color de las telas y el diseño de los bordados, lamentablemente son pocos los estudios que hasta la fecha se han interesado en este aspecto, por lo que el propósito de esta investigación es hacer una primera aproximación a la indumentaria en los libros de caballerías de Feliciano de Silva, escritor escogido por su importante labor ficcional del género y por permanecer en la invención caballeresca durante 37 años, periodo que le 
permite conocer la moda de tres épocas, la de los Reyes Católicos, el emperador Carlos V y el príncipe Felipe II, modelos de confección que integra a sus obras con el afán de recrear lujosos e increíbles atavíos para sus personajes. Para conseguirlo, esta investigación se divide en cuatro capítulos en los que las prendas halladas se analizan desde dos aspectos: el uso funcional para cubrir el cuerpo y la función simbólica que genera acciones.

En el primer capítulo, "La vestimenta en el siglo XVI", se investiga la moda española de la época y siglos anteriores para identificar cada una de las prendas que componen el traje nacional, a partir de ahí se estudiaron los usos de procedencia extranjera y aquellas prendas que se adaptaron con características similares a las que las personas escuchaban en voz de los viajeros y comerciantes. Además, se da importancia a las leyes suntuarias, porque reglamentaban y restringían el uso de ciertos materiales para las diferentes clases sociales, apartado en el que se realiza el cotejo de prendas permitidas para todos los estamentos a partir de los manuales de sastres, libros de cuentas e inventarios, documentos en los que se recopilan datos sobre el costo, la medida de varas utilizadas para su fabricación, el tipo de adornos que deben unirse con cada tejido, la combinación permitida para los colores, así como las penas por quebrantar dichos lineamientos, que, en la mayoría de los casos, se debía destruir la prenda. Para el estudio teórico de la vestimenta se consideran los textos de Carmen Bernis, por ser la mejor especialista en la indumentaria española, además de que detalla y ejemplifica todas las prendas de los siglos XII al XVI, a partir de las influencias morisca, italiana, francesa, alemana, flamenca e inglesa que convergen en territorio español a partir de la llegada de Carlos V. También la obra de María Nieves Fresneda González, cuya aportación destaca la importancia del uso de los accesorios y las joyas desde el siglo XIII. Asimismo, se utiliza la obra de Albert Racinet por su detallada historia del traje desde la Antigüedad hasta nuestros días y la de Matthäus 
Schwarz, creador del primer libro de moda en el mundo, ya que es un referente clave para la comparación de estilos entre la moda de Europa. Además de estos textos, la crítica de la moda que más elementos aporta para esta investigación son las obras de Ulinka Rublack y Michel Pastoureau, porque la vestimenta transmite códigos de la persona que la usa, su nacionalidad, clase social, apariencias, emociones, pensamientos, etc., por lo que vestir no sólo significa cubrir el cuerpo sino transmitir algo por medio de lo que se porta.

El segundo capítulo, "Los libros de caballerías de Feliciano de Silva", se estructura en cuatro partes: 1) "Del Lisuarte de Grecia al Florisel de Niquea", donde se analiza la evolución de las prendas en cada uno de estos títulos, con el propósito de establecer cómo evolucionan las creaciones textiles del autor. 2) "Telas, bordados, encajes e hilos", en el que se investigan los tipos de telas del periodo para distinguir los tejidos que visten los personajes; para ello se toman como referencia los textiles y diseños introducidos en las cortes españolas a partir de 1517 , fecha en la que el emperador Carlos V llega al país y comienza la adecuación de las modas. Por lo que, además de los autores antes mencionados, se utilizan los estudios críticos de María del Carmen Marín Pina, Concepción Villanueva Morte, María del Carmen García Herrero y James Laver, principalmente, para analizar la moda histórica en la ficción, con ello, se pretende comparar los diseños creados por el autor con los modelos que traspasaron la escritura y que, a petición de la nobleza, fueron confeccionados en la realidad. Es decir, a través de las minuciosas descripciones de la indumentaria, se observan tintes de algunas personalidades de la época, reyes, príncipes, duques, etc., que, desde las portadas, es notoria su dedicatoria a través de los escudos y de algunas prendas con gran similitud a las que se observan en pinturas de algunos museos. El ambiente cortesano fue el medio por el que Feliciano de Silva logró captar y transmitir parte de la moda de la época e incrementar su valor al sellar sus creaciones ficticias con sus 
elaborados detalles, adornos que se analizan el tercer apartado. 3)“Accesorios femeninos”, en el que destaca la importancia de las piedras preciosas, que toman relevancia por tres aspectos: forma, cantidad y ubicación en la prenda; con estos elementos se propone que el grado de calidad de la vestimenta está determinado por la cantidad de accesorios que contenga, hipótesis que se comprueba a través de diversos ejemplos caballerescos e históricos. Por ello, la necesidad de recurrir a los libros de cuentas, saqueos, donaciones y testamentos, a fin de conocer las joyas que se crearon durante el siglo XVI. Aunado a estos testimonios, se consultan los lapidarios de Alfonso X, San Isidoro de Sevilla, Plinio y Gaspar Morales para relacionar el tipo, color y corte de cada gema con el personaje que la usa. 4) La moda masculina, se analiza su indumentaria desde dos ámbitos, las prendas de gala y la armadura en las que se realiza una comparación con el traje femenino para destacar el valor simbólico de cada uno y la importancia que adquieren en los mismos pasajes, esto permite determinar qué vestimenta tiene mayor notoriedad en bailes, torneos y entradas triunfales.

Para el tema de la armadura se consultan los estudios de Ramón Llull, Martín de Riquer, Maurice Keen, Diego de Valera, y Alfonso X; Michel Pastoureau para el color; Alberto Montaner Frutos para la heráldica, e Ignacio Malaxecheverría y Jean Chevalier para el simbolismo de los animales y motivos florales en escudos y yelmos. La función de las armas como traje bélico y festivo se hace equivalente a la tela, por lo que se propone que el protagonismo de las armas en las justas es semejante a la presencia del vestido en los bailes, en donde el caballero adquiere la misma relevancia en diseño, decorado y calidad del metal que la dama en confección, adornos e importancia del tejido, por lo que éste es uno de los apartados más importantes de esta investigación, porque no sólo se estudia a las 
armas como símbolo de honor y fama, sino como la adecuación del traje masculino para el campo de batalla.

En el tercer capítulo, "Simbolismo de la vestimenta", se proponen cuatro categorías principales: amor y desafío, protección, seducción y luto, clases que se establecen con base en el análisis de los episodios caballerescos para proponer la función de las prendas como generadoras de acciones. En primer lugar, se destacan las letras e imágenes pintadas en las armaduras para relacionarlas con los bordados femeninos, con el propósito de establecer un lenguaje entre prendas, que sólo descifra la pareja. En cuanto a las prendas de protección, se estudian los accesorios para cubrir el rostro, de modo que quien lo usa pueda ver sin ser visto. Asimismo, en las prendas de seducción se analiza la camisa como instrumento de conquista en donde la calidad de la tela determina el juego amoroso de la pareja. Por último, aparece la indumentaria de luto, que a través del color se manifiesta la tristeza causada por la muerte, la separación o el extravío de un ser querido.

Finalmente, en el capítulo cuarto, "Feliciano de Silva frente a otros autores", se presentan las innovaciones textiles y de diseño que el autor inserta en sus cinco obras. Esto a través de la comparación con los demás libros de caballerías del periodo para distinguir la influencia de Silva en ellos. Además del estudio de algunos testimonios gráficos que aparecen al interior de los capítulos para establecer una línea comparativa entre los diseños del autor con los realizados por los miniaturistas y así conocer más a detalle la moda del siglo XVI. Así es como el vestido presenta distintos valores a partir de las funciones que se estudian: elemento de abrigo, prenda de seducción, uso de duelo, ropa de guerra, atavío de protección de la identidad e indumentaria festiva; seis categorías en las que se explora su proceso de fabricación y transformación textil, aunado al significado que adquieren en cada una de las hazañas en las que están presentes. 


\section{La vestimenta en el siglo XVI}

Grandes festejos como bodas, banquetes, torneos y justas estuvieron presentes a lo largo del siglo XVI en toda España, desde el recibimiento del Emperador Carlos V hasta las bodas del rey Felipe II; sucesos en los que el derroche por el lujo no se limitó sólo a las prendas de los invitados, sino también a la decoración, el mobiliario y la comida que satisfacía a toda la sociedad nobiliaria. En cada una de estas ceremonias había un desfile de prendas caracterizado por el color, la brillantez y la elegancia de los trajes, que, a decir de algunos, eran un poco extravagantes en los adornos y en las formas; sin embargo, a pesar de estos comentarios, lo que la sociedad de la época veía era el esplendor de la creación textil variada y cambiante hasta la fecha, que tenía herencias de los siglos anteriores, principalmente desde el XIII, de cuyas labores textiles hay muestras en algunas miniaturas de obras; también algunas prendas de la época aún persisten en monasterios y museos, así como esculturas en las que se aprecian detalles de la vestimenta. Según François Boucher, en toda Europa, es en el Renacimiento cuando:

El artista se dedica a crear modelos de trajes y se preocupa por las combinaciones de líneas, colores y volúmenes para lograr elegancia y armonía. Este orgullo de la hermosura física, este refinamiento en el arte de gustar, aumentados por el traje, obtuvieron por el siglo XVI, el apoyo de materiales lujosos, telas vistosas y pesadas, bordados gruesos, joyas suntuosas, encajes airosos. Ninguna época, ni siquiera el Gran Siglo, lanzó sobre el hombre unas ornamentaciones más preciosas para la perfección de la hermosura humana ${ }^{1}$.

Perfección que se fue moldeando con el paso de los años a través de las importaciones de telas, encajes, pieles y metales que adornaban la indumentaria de la época. Para que los

\footnotetext{
${ }^{1}$ Françoise Boucher, Historia del traje en Occidente desde la antigüedad hasta nuestros días, Barcelona, Montaner y Simón, 1967, p. 219.
} 
nuevos materiales y accesorios llegaran a España, la industria textil se benefició del comercio mercantil proveniente de regiones francesas, italianas, flamencas, inglesas, alemanas y árabes, cuyas aportaciones dieron origen a nuevos trajes en los que se vieron elementos tanto nacionales como extranjeros en las mangas, cortes, telas y formas. ${ }^{2}$ En este siglo apareció una mayor variedad de prendas, en las que las telas, los bordados y las piedras preciosas tuvieron mayor relevancia que las personas que las portaban.

\subsection{Tipos de prendas}

\subsubsection{Prendas ocultas}

Hasta ahora, los atuendos de la época se conocen a través de la pintura, la escultura y la literatura, artes en las que se detallan los pliegues de las mangas, los botones, las plumas de los sombreros, las agujetas del calzado y muchos otros accesorios que lo conformaban. Sin embargo, había ciertas prendas que quedaban ocultas porque siembre iban pegadas al cuerpo, la camisa, las bragas y las calzas, ropa interior que se ajustaba, por lo que no se notaba a simple vista. La camisa, una prenda interior utilizada por ambos géneros, se caracterizaba por tener manga larga (fig.1), es "la vestidura de lienço que el hombre trae debajo de las demás ropas, a rayz de las carnes" (Tesoro de la Lengua). Se esconde bajo la saya, pero no del todo, pues según María Carmen Marín Pina tiene "partes visibles, el escote y las mangas"3 que la dama dejaba a la vista a través de las aberturas que se hacían en las cuchilladas (fig.2).

\footnotetext{
${ }^{2}$ Sobre esta nueva moda fue necesario que sastres, costureros, calceteros y demás fabricantes textiles aprendieran las formas nacionales y extranjeras para que adquirieran las formas correctas de cada región. De esta manera, la realeza, proveniente de otros países, pudo lucir ropa adaptada a la forma española sin olvidar sus orígenes. El principal portador de estas prendas fue Carlos V en sus viajes y festejos en España, sucesos en los que primero lucía trajes franceses y alemanes y posteriormente españoles, por lo que en el ámbito textil se familiarizó como la moda nacional. Carmen Bernis, Indumentaria española en tiempos de Carlos V, Madrid: Instituto Diego Velázquez/ CSIC, 1962, pp. 23-27.

3 María Carmen Marín Pina, "Seda y acero. La indumentaria en el Palmerín de Inglaterra como signo cortesano", Tirant, 16, 2013, p. 314.
} 


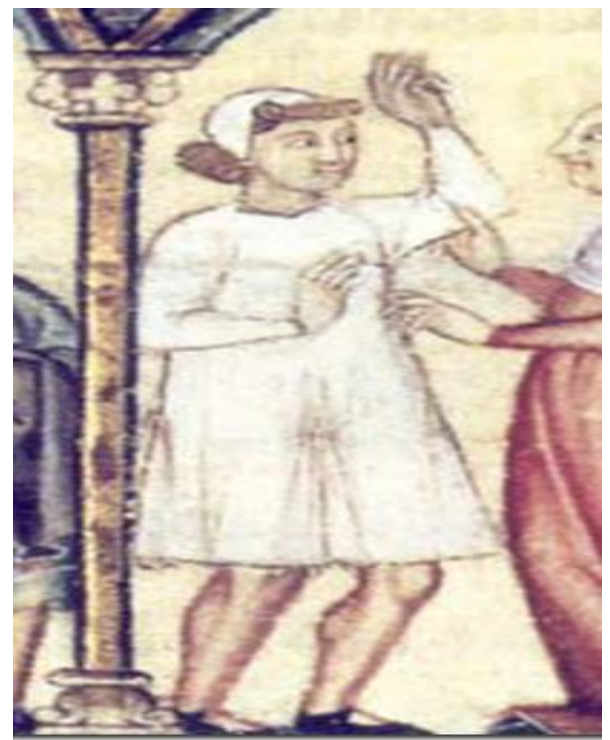

Fig. 1. Cantigas de Santa María Alfonso X el Sabio.

Camisa

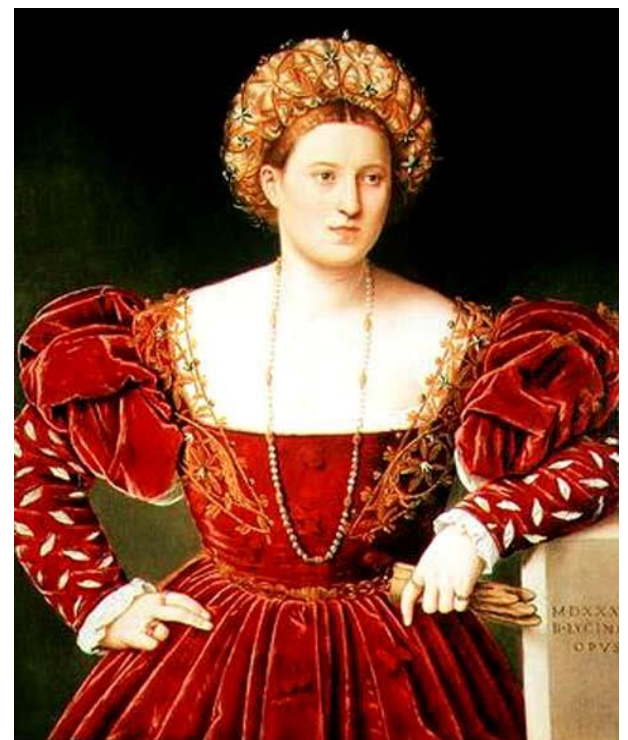

Fig. 2. Retrato de dama (s. XVI)

Bernardino Licinio.

Mangas acuchilladas que permiten ver la camisa.

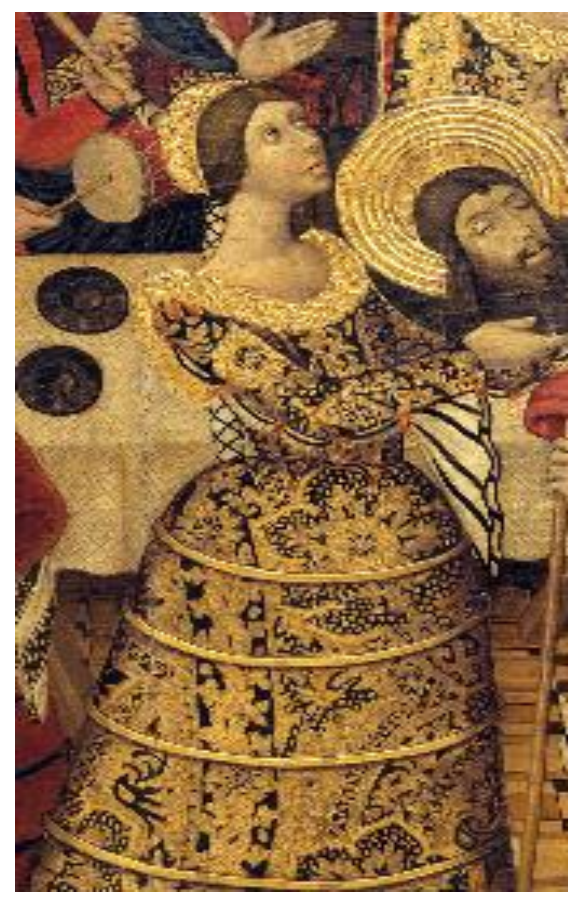

Fig. 3. El festín de Herodes (1480) Pedro García de Benaberre.

Mangas de camisa morisca con listas
El material con que se confeccionaba era el lienzo, tejido de lino que se utilizaba en la confección de prendas de interior y de algunas de encima, como el jubón; en las leyes de "Lanas y paños" se ordenaba que se usara para la fabricación de "calças y jubones" (fol. 6r), aunque también los había de otros materiales como el terciopelo y el tafetán. La camisa tiene una característica especial, la manga, extremidad que se podía adornar con encaje, cintas y pedrería que quedaba oculta bajo las prendas de encima (fig.3); era una forma de demostrar que las ropas ocultas también podían adornarse, aunque nadie las viera. 
En cuanto a los hombres, es menos común encontrar ejemplos de este tipo, ya que hay mínimas referencias a la camisa varonil, puesto que era menos larga de cuerpo y mangas $^{4}$ para que quedara debajo del jubón. La diferencia en la medida está en que las damas, con sus amplias faldas, podían cubrir cualquier prenda que llevaran abajo, mientras que los caballeros no. (fig.4)

Enseguida se vestían las calzas, los hombres las llevaban bajo el jubón. Estas dos prendas se componían en conjunto; las primeras cubrían la parte inferior y la segunda la superior, ambas se sujetaban con cordones o agujetas. Por la presión que ejercían al atarlas, daba la apariencia de un corsé femenino, pues en esa época los hombres comienzan a interesarse por lucir bien su figura ${ }^{5}$. En el jubón (fig.5) también se observó el interés de ornamentar las partes que quedaban al descubierto, pues al igual que las mujeres, para los hombres se decoraban las mangas y el cuello. Utilizaban telas llamativas con alguna aplicación de metal o alguna tela calada para dar la apariencia de que traían una joya.

En el caso de las mujeres, el corpiño era la estructura que moldeaba su cuerpo, generalmente quedaba descubierta la parte superior en la que se veía un triángulo sujetado con agujetas. La parte inferior se cubría con las "faldas interiores", las cuales quedaban a la vista cuando la dama alzaba su vestido para subir escaleras o para realizar alguna actividad doméstica, por lo que se podía ver gran parte de la prenda, tal como se aprecia en el cuadro Retablo de la Capilla de Santa Catalina en la que la dama alza su ropa y deja ver la faldilla (fig.6). Para fabricarlas se emplearon materiales como el brocado, terciopelo, tafetán, raso, etc., con lo que demostraban que el lujo no sólo estaba en las prendas de encima, sino también en las ocultas. Este es un rasgo importante para la época, ya que, como menciona

\footnotetext{
${ }^{4}$ Carmen Bernis, Indumentaria española en tiempos de Carlos V, p.13.

${ }^{5}$ Carmen Bernis, Trajes y modas en la España de los Reyes Católicos II. Los hombres, Madrid, Instituto Diego Velázquez/CSIC, 1979, p. 12.
} 
José Ángel García de Cortázar, "En la riqueza de los materiales y de los adornos, en definitiva, el precio era lo que distinguía unos de otros los vestuarios nobiliarios"6, de ahí que los detalles eran importantes en todas las prendas de la nobleza, no sólo en las que estaban a la vista de todos, sino también en las que se ocultaban, pues podrían necesitar quitarse la ropa de encima y quedar sólo con las interiores.

Pero las damas no estaban exentas de críticas, ya que esta acción de levantarse la saya y dejar al descubierto sus faldas fue criticada por los moralistas de la época, quienes veían en ello una forma para que las mujeres enseñaran sus prendas íntimas, lo cual podía provocar a los hombres. ${ }^{7}$

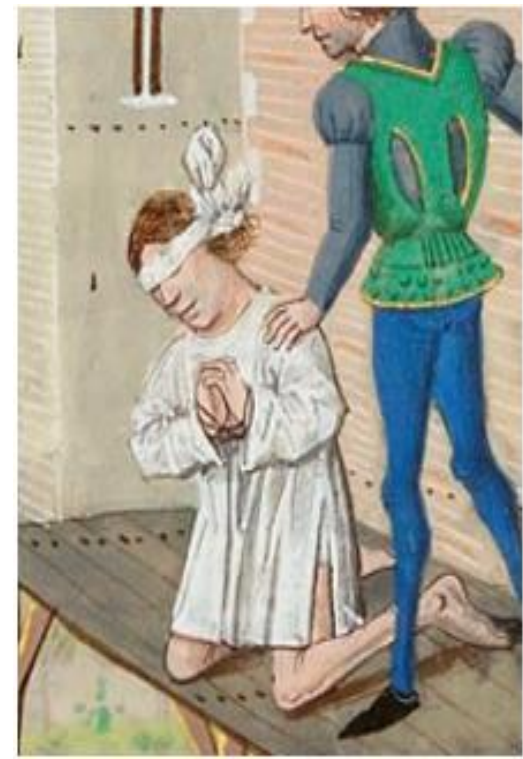

Fig. 4. Ejecución de Olivier IV de Clisson, (h.1470) Miniatura de Liédet Loyset. fol. 126

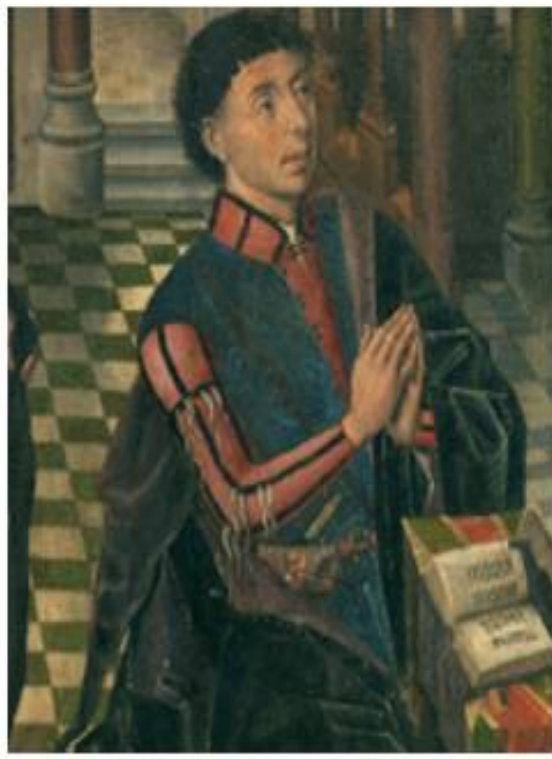

Fig. 5. Diego Hurtado de Mendoza (1470) Maestro de Sopetrán, Museo del Prado. Jubón con bandas negras en las mangas

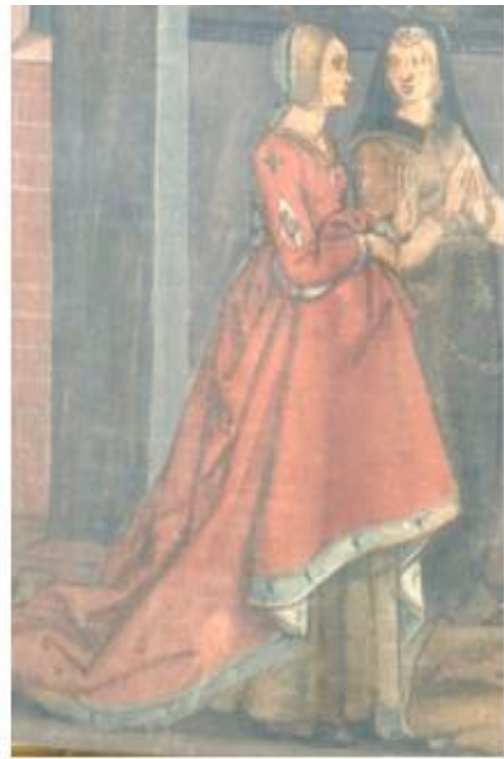

Fig.6. Retablo de la Capilla de Santa Catalina (h. 1495) Museo Nacional de Cataluña. Faldilla interior

\footnotetext{
${ }^{6}$ José Ángel García de Cortázar, "El vestido: de protector del cuerpo a signo exterior", en Historia de España. La época del gótico en la cultura española, Madrid, Espasa-Calpe, 1994, p.32.

${ }^{7}$ El que más criticó estos actos fue Fray Hernando de Talavera, quien consideraba que las mujeres no debían alzar sus faldas en ningún momento. Solazoso y prouechoso tractado contra la demasia de vestir y de calçar, y de comer y de beuer, Granada, Meinardo Ungut y Juan Pegnitzer Impresores, 1496.
} 


\subsubsection{Prendas para vestir a cuerpo}

En las prendas para vestir a cuerpo sobresalen el gonete, la saya, el brial y la basquiña. Estos cuatro usos conforman el primer traje femenino, seguido de los trajes de encima y por último del manto. El gonete (fig.7) era una especie de saco con aberturas triangulares en la parte inferior, con cuello cuadrado que permitía ver las prendas de debajo. Todo el filo estaba decorado con una cinta de color más oscuro para contrastar con la tela, también podía llevar bordados de flores o de alguna otra figura. A veces se sujetaba con una cinta. Las mangas podían ser estrechas o anchas, pero llevaban la misma ornamentación en el filo de los puños.

La basquiña era una falda ornamentada, pues iba encima de la faldilla, pero debajo del "traje de encima". Esta fue una de las prendas de mayor uso en la época, ya que aparece en numerosos documentos de cuentas, testamentos, cartas y libros de bienes. Por ejemplo, Juana la Loca tenía varias basquiñas de fustán vergado, una de chamelote de seda turquesa con tiras de brocado y una más de grana con tiras de brocado y terciopelo. ${ }^{8}$ De acuerdo a las descripciones, se puede conocer que los materiales empleados para su confección eran telas caras que las pragmáticas habían restringido sólo para la nobleza, además de los adornos que lleva en brocado, un material lujoso por la forma de su tejido.

Por último, la saya y el brial, aunque de corte eran parecidos, de calidad y uso no, puesto que la saya la vestían todas las clases sociales, mientras que el brial sólo la familia real ${ }^{9}$, debido a los materiales para su creación. Los había de seda, damasco, brocado y terciopelo, adornados con pedrería e hilos de oro. A diferencia de esta ropa tan adornada,

\footnotetext{
${ }^{8}$ José Ferrandis, Datos documentales para la historia del arte español III. Inventarios reales (Juan II a Juana la Loca), Madrid, CSIC, 1943, pp. 59, 294, 295.

${ }^{9}$ Carmen Bernis, Trajes y modas en la España de los Reyes Católicos II. Los hombres..., p. 121.
} 
está la saya, la cual era de paño forrada con lienzo. Es curioso que esta prenda sea tan mencionada en los libros de caballerías, principalmente en las princesas, quienes siempre las llevan bien aderezadas: "hallaron a la hermosa y discreta Gralasinda, vestida una saya de brocado carmesí, con infinitas piedras guarnida y encima una ropa de un tosco y negro paño" (Flor de caballerías, p. 107) (fig. 8). Es importante notar la diferencia entre las prendas, la de abajo es más llamativa por los adornos, mientras que la de encima es más escueta por el color y la textura del paño. Además de la calidad, lo único que diferenciaba a la saya y al brial era que este último "era un traje larguísimo que arrastraba varios palmos por el suelo"10 (fig.9), por lo que era más costoso al requerir más tela.

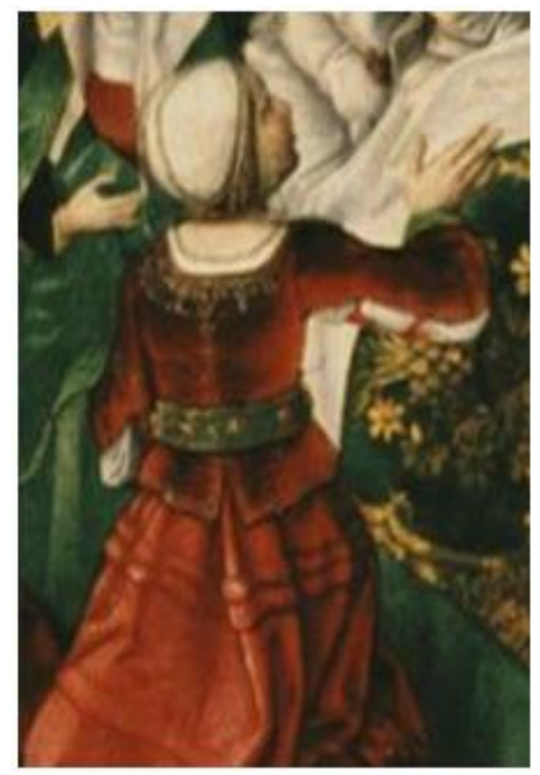

Fig. 7. Nacimiento de la Virgen (1490-1500) Pedro Berruguete, Retablo de Santa Eulalia Gonete

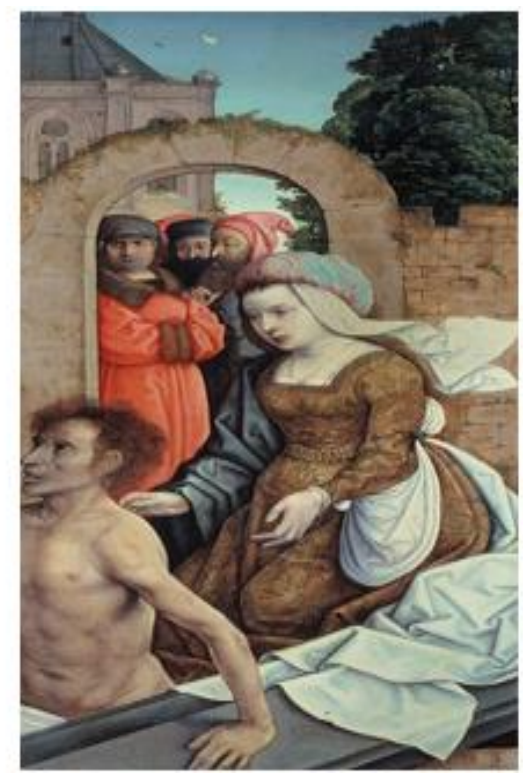

Fig.8. Retablo de la Catedral de Palencia Juan de Flandes (1519)

Saya de brocado con gorguera en el escote.

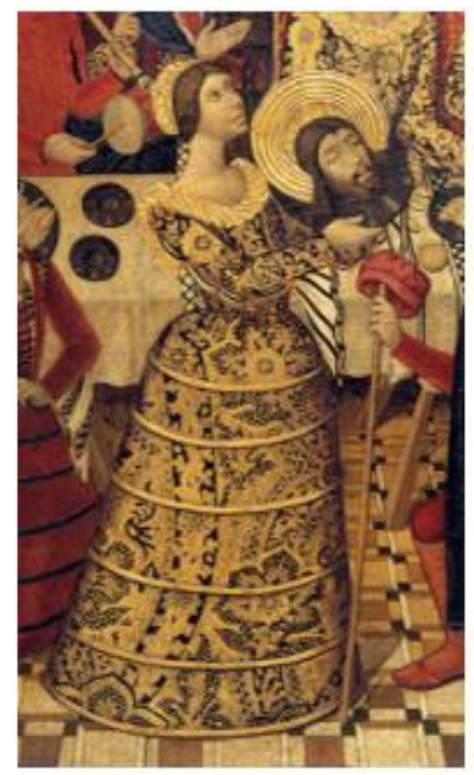

Fig.9. El festín de Herodes (1480) Pedro García de Benaberre Brial con verdugo

\footnotetext{
${ }^{10}$ Carmen Bernis y Gonzalo Menéndez Pidal, “Traje, aderezo y afeites”, en La España del siglo XIII, Madrid, Real Academia de la Historia, 1986, p.73.
} 


\subsubsection{Prendas de encima}

Es común ver en los retratos del siglo XVI que hombres y mujeres llevan una gran cantidad de prendas adornadas con joyas, pieles, metales y una gran variedad de accesorios como abanicos y bolsos. En damas como la infanta Clara Eugenia e Isabel de Valois, se observan los materiales que integran su ropa, la seda, el armiño, la tela de brocado y el tafetán, tejidos que se utilizan con más detalle y ornamentación en las "prendas de encima" porque son las que más lucen al completar la última etapa para vestir.

De estas se mencionan con mayor frecuencia el hábito, la ropa, la galera y la cota, prendas que se caracterizan porque eran holgadas ${ }^{11}$, además de que en ellas se utilizaban accesorios como los cinturones, las cintas de cadera y algunas bandas a manera de pretina para sujetar la pieza, de este modo se le daba forma a la prenda y se evitaba que se desacomodara. (figs.10-13)

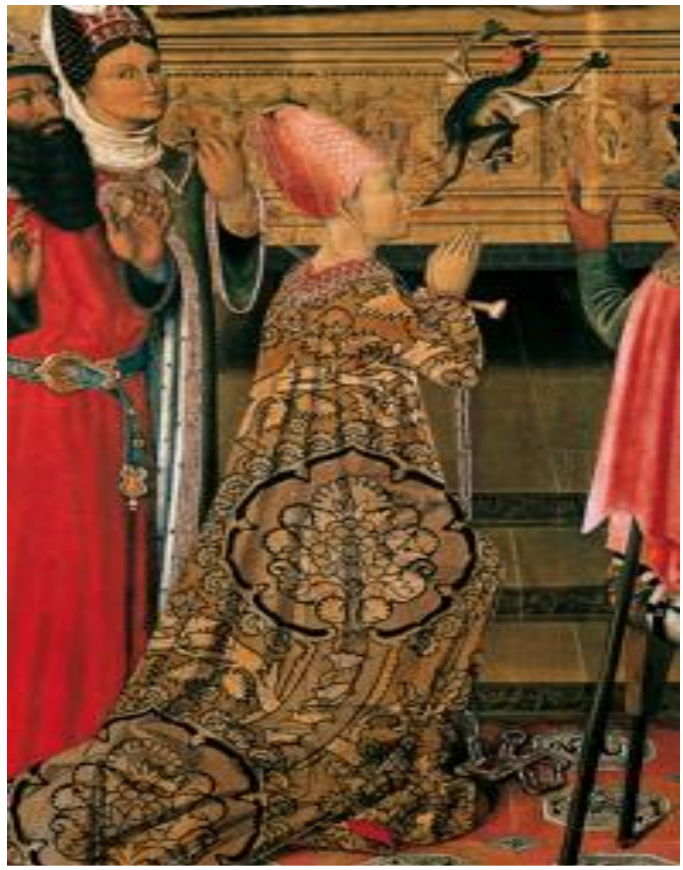

Fig. 10. Retablo de San Esteban (1495-1500) Joan Gascó, Museo Nacional de Arte de Cataluña Hábito

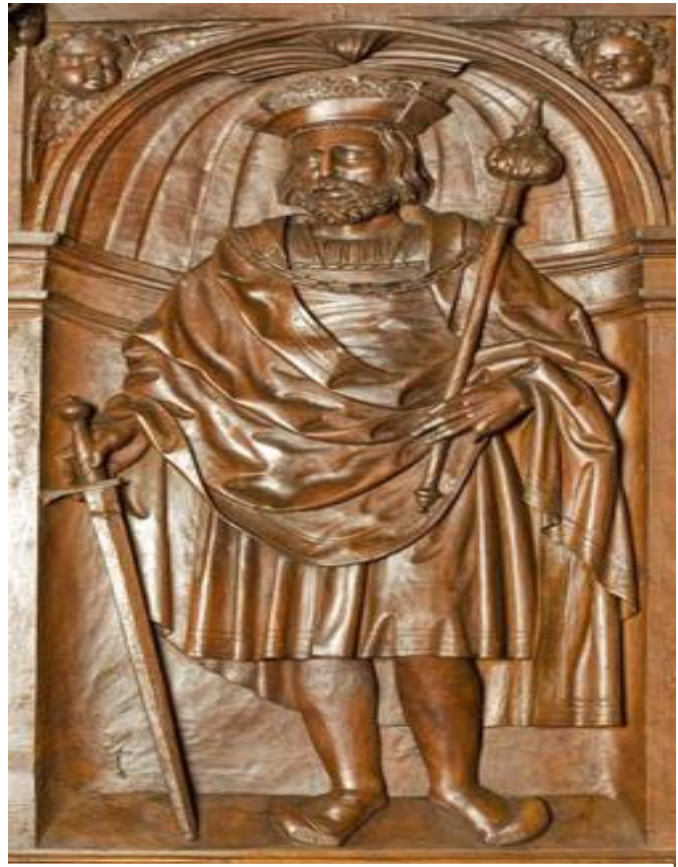

Fig. 11. Relieve de la sillería de San Benito Valladolid

Ropa

${ }^{11}$ Carmen Bernis, Trajes y modas en la España de los Reyes Católicos I. Las mujeres, Madrid, Instituto Diego Velázquez/ CSIC, 1978, p.15. 


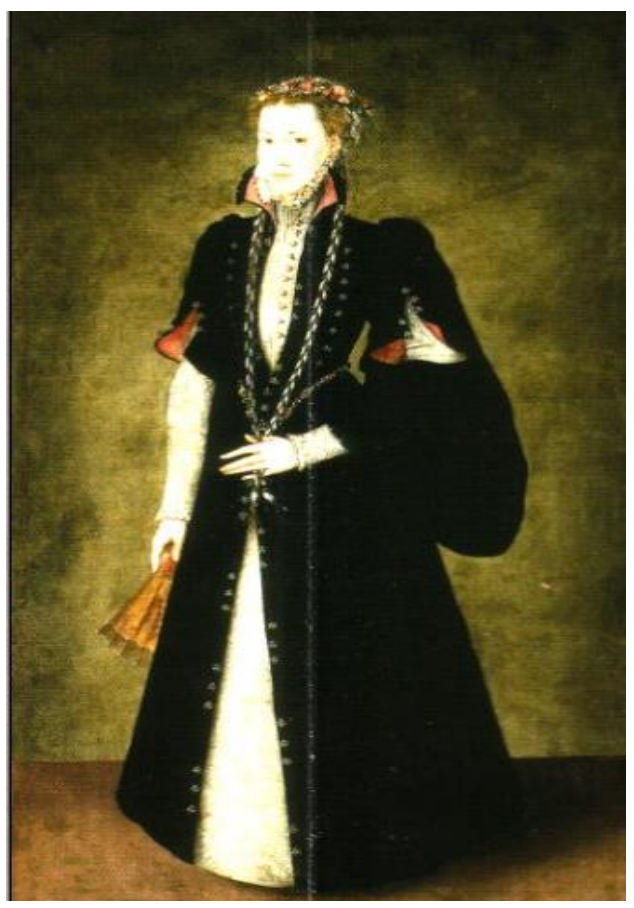

Fig. 12. Retrato Ana de Aragón y Borja (1561) Rolán de Mois, Palacio Villahermosa, Zaragoza. Galera

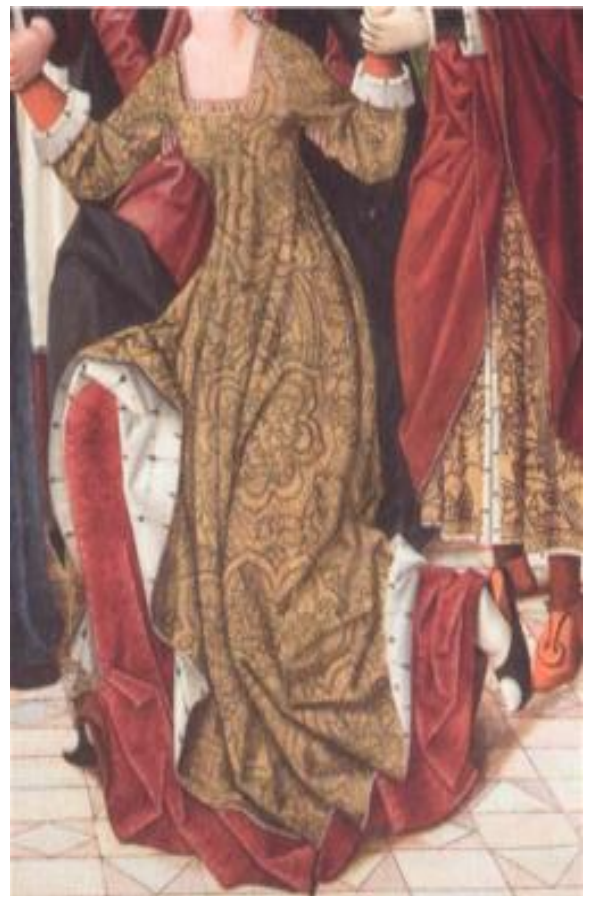

Fig. 13. Exorcismo de Santa Eudoxia (h.1400) Palencia.

Cota

Las telas para su creación eran las más finas, puesto que al estar a la vista de todos debían ser originales, creativas y llamativas en color, grabado y forma, de ahí que algunas parecieran extravagantes en sus detalles. La cota y la galera tenían una forma más definida por estar ajustadas al talle, por lo que definían la silueta de la dama. En contraste, la ropa no permitía ver estilizada la complexión de la dama, porque era holgada. Sin embargo, no había un concepto bien formado de esta última, ya que se designaba con este nombre a diversas prendas que se ponían encima, lo único que resaltaba era la forma en cómo las decoraban: "una ropa de escarlata muy fina toda sembrada de cruzes de oro e un capirote en la cabeça"12. Lo que podía descubrirnos la ropa son los elementos que la adornaban, en este caso, cruces bordadas con hilos de oro que la designan como una ropa de calidad al estar

\footnotetext{
${ }^{12}$ Feliciano de Silva, Lisuarte de Grecia, ed. de Emilio José Sales Dasí, Alcalá de Henares, Cestro de Estudios Cervantinos, 2002, p. 21. Todas las notas proceden de esta edición, en adelante citaré en el texto indicando entre paréntesis el número de capítulo.
} 
confeccionada con una insignia especial. De este modo, las prendas que en general no tienen una conceptualización específica, se pueden apreciar por la calidad de los materiales y los ornamentos que lleva, así se pueden crear clasificaciones de las prendas "generales" a partir de las características que las adornan.

\subsubsection{Prendas exteriores}

La parte final que completaba la indumentaria son los sobretodos. Estos eran comunes entre hombres y mujeres, pues se trataba de cubrir el cuerpo con prendas abrigadoras. Para conseguirlo, se usaban capas, tabardos, mantos, lobas y capuces. Para los varones se utilizaban las pieles como forro que cubrían toda la parte superior del cuerpo (fig.14). En prendas como capas y mantos era más común ver los forros de pieles de animales de gran calidad como la cebellina o el armiño: "El Rey, nuestro señor, se había puesto ese día un jubón de armar, de raso carmesí, y por encima una casaca de tela de oro y de tela de plata, acuchillada sobre un fondo de raso carmesí, un manto de tela de oro cernido, con fondo de cebellinas, una montera de terciopelo negro y una blanca pluma en ésta que cuadra tan bien a las gentes de armas como el jubón"13 (fig.15). Este ejemplo detalla cada prenda de acuerdo a su colocación que ya se ha establecido, por lo que, en esta última parte, es importante la manera como se describen los personajes, ya que se pueden identificar el tipo y posición de la ropa gracias a las categorías. Lo interesante son los elementos que las decoran, en este ejemplo, las cuchillas y la pluma, detalles que definen más la posición social de quien las porta, pues nuevamente está la idea de los accesorios como elementos de identificación social, propuesta que se establece a partir de los numerosos ejemplos

\footnotetext{
${ }^{13}$ Lorenzo Vital, Relación del primer viaje de Carlos V a España (1517-1518), Madrid, Estades, 1958, p.
} 286. 
hallados tanto en textos históricos como literarios, que permiten catalogar estos detalles para conocer cuáles eran los más utilizados y cuáles los más complicados para fabricar.

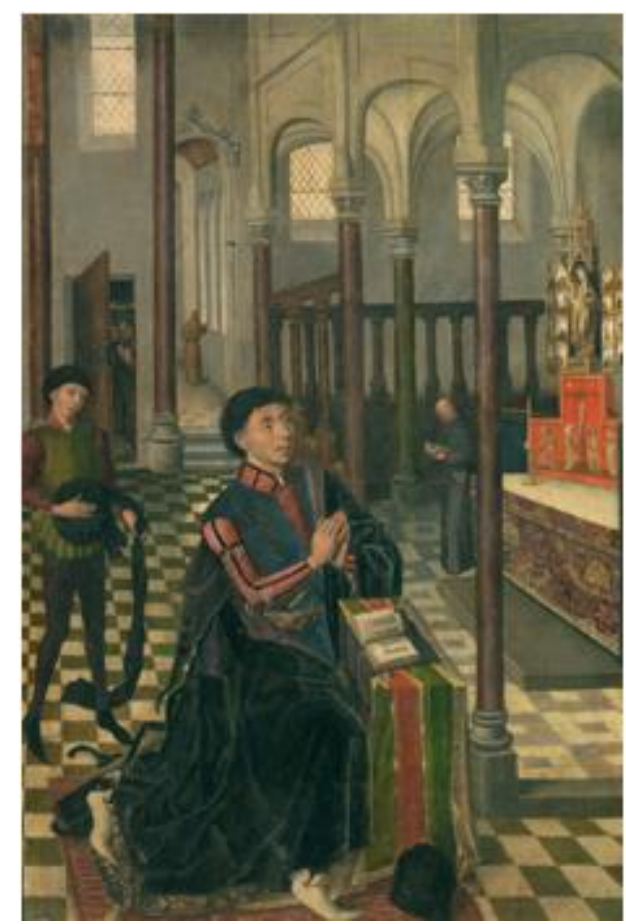

Fig.14. Diego Hurtado de Mendoza (1470) Maestro de Sopetrán, Museo del Prado. Tabardo

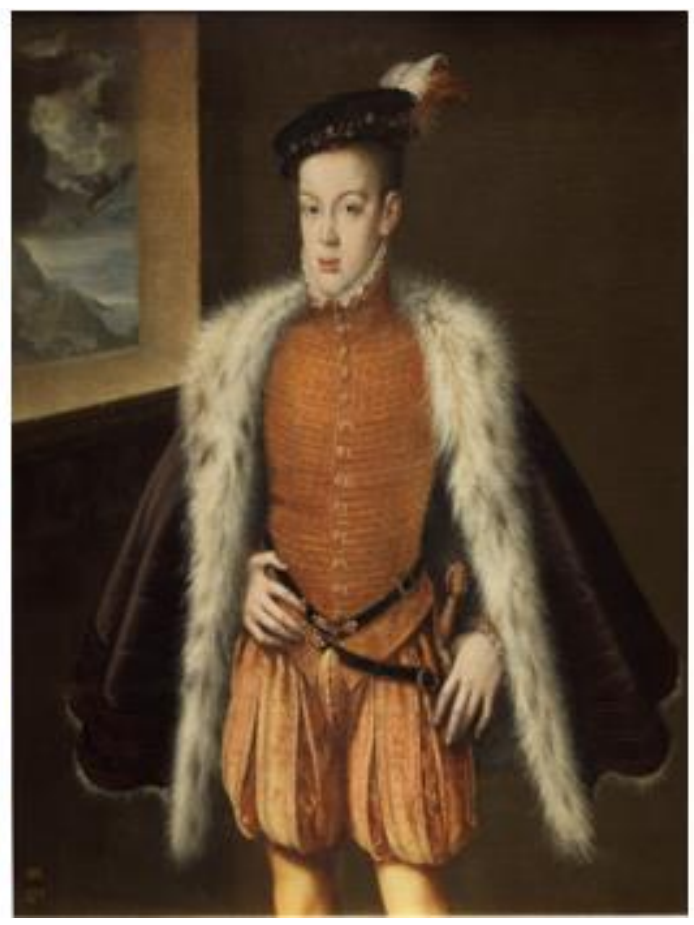

Fig.15. Príncipe don Carlos (1555-59)

Alonso Sánchez Coello, Museo del Prado. Capa forrada de armiño, montera con pluma y jubón.

Otra descripción minuciosa de los sobretodos masculinos se halla durante los viajes de la nobleza en el siglo XVI, como ejemplo durante su travesía en barco, Carlos V padecía por los fuertes fríos del viento en el mar, por lo que ordenó a su sastre que le hiciera:

Un jubón de raso carmesí, de cuello alto forrado de escarlata, y por encima se ponía un coleto a manera de justillo, sin mangas, con fondo de martas, que apenas le pasaba de la cintura un palmo y que se sujetaba con una agujeta; sobre las calzas de escarlata llevaba unas medias largas a manera de calzas marineras y, como calzado, botas forradas de escarlata. Se hacía recoger el pelo y luego se ponía una forrada montera de escarlata que se ataba bajo la barbilla, de modo que el viento no le podía dañar; además se ponía un manto de cuello alto ceñido por encima, que era de 
terciopelo delicado con muchas pieles de cordero de Rommenye y que le mantenía, al tiempo, cuerpo, cuello y brazos en calor; y, sin embargo, cuando se había puesto todo, no parecía que tuviese demasiada carga ni impedimento de tan cómodamente como se encontraba vestido ${ }^{14}$.

En este pasaje se mencionan varias prendas: un jubón, un coleto, unas calzas, unas medias, unas botas, una montera y un manto de cuello, ropas pertenecientes a las distintas categorías, ya antes mencionadas. Nuevamente predominan la combinación de colores y telas. Hasta este ejemplo se han visto las constantes referencias a las pieles, entre las más destacadas, están el chamelote, el armiño y la cebellina.

De esta última se da una característica en una Carta del licenciado Alonso Zuazo al padre Fray Luis de Figueroa, prior de la Mejorada, en la que se menciona: "una marta cebellina muy bien adobada: hice pesar una dellas, no pesó más de seis onzas. Dicen que en el tiempo del invierno una abasta para encima de la camisa, sin otro cobertor, ni más ropa encima de la cama" ${ }^{\prime \prime}$, su grosor, por lo que era común que se utilizara como forro para las prendas de encima, tales como la capa, ya que protegía de la intemperie. Ésta junto al armiño, eran materiales destinados para la realeza, debido a su alto costo, pues para forrar un abrigo de mujer se necesitaban cerca de 15,000 pieles de armiño. Algunas de las muestras más emblemáticas, en la época de este material, están en las pinturas de Claudio Coello, en donde se aprecia este forro en capas, mantos y gorros.

Las mujeres también lucieron sus sobretodos, especialmente, mantos, lobas y mantillas, que, a juego con sus vestidos, reflejaban su condición social a través de los decorados que llevaban (fig.16). Se fabricaban en seda, terciopelo, damasco y brocado, y todas iban forradas de pieles o de algún género que brindara calor. En ellas era más común

\footnotetext{
${ }_{14}^{14}$ Ibid, pp.97-98.

15 Real Academia Española: Banco de datos (CORDE) [en línea]. Corpus diacrónico del español. $<$ http://www.rae.es> [10/10/2016]
} 
ver las orillas, gorros y mangas forradas de armiño, color que contrastaba con el resto de ropa. Es importante establecer que los mantos se utilizaban tanto para ceremonias como para la vida diaria, por lo que el diseño y los materiales variaban un poco según la festividad. (fig.17)

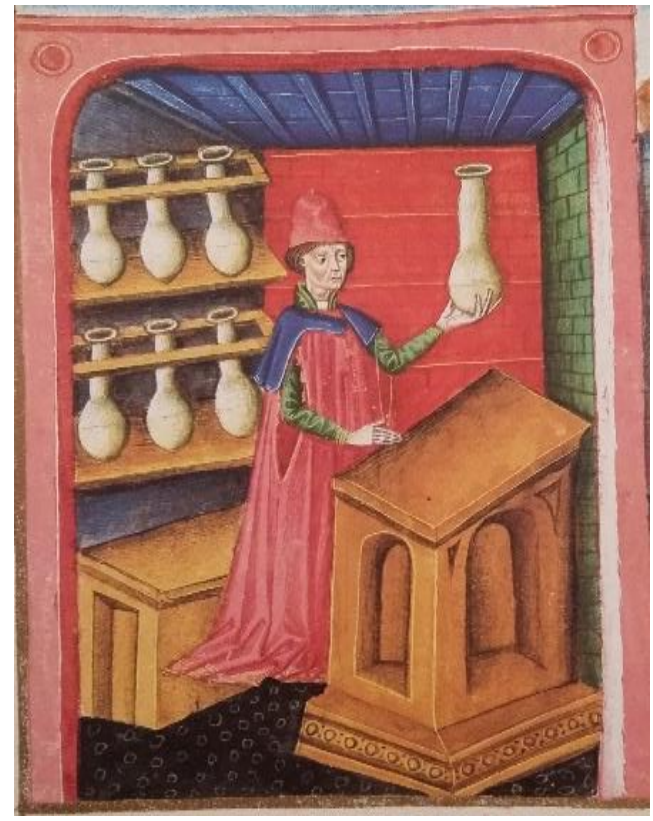

Fig. 16. Zifar, fol. 97v. Loba

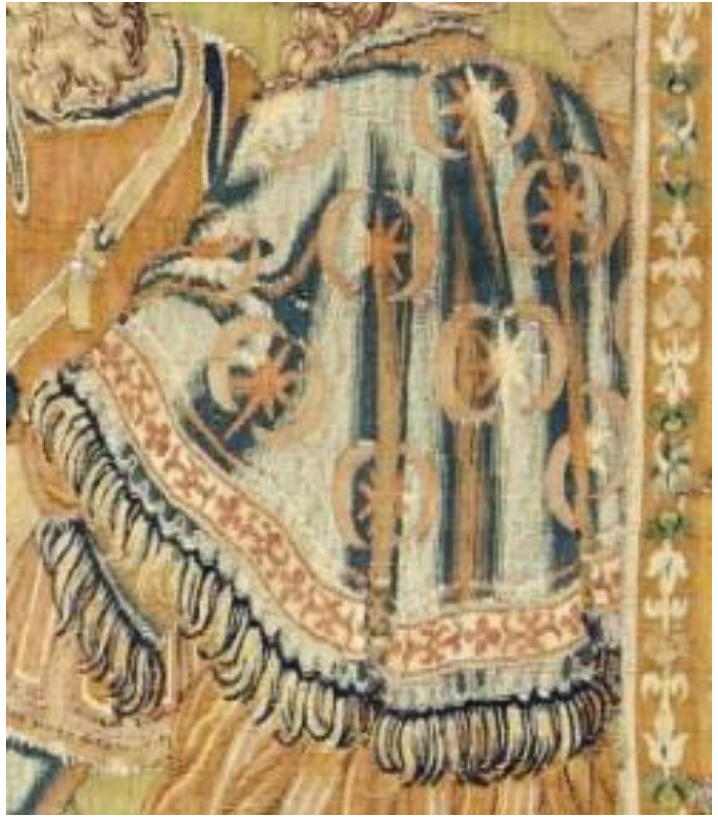

Fig. 17. Tapiz La decapitación de Holofernes (s. XVI) Iglesia de San Nicolás. Manto con lunas y estrellas

\subsubsection{Calzados}

La última prenda que conforma el atuendo es el zapato; fabricados con materiales como piel, tela, corcho y madera, la sociedad los usaba acorde a la ocasión. Para los hombres estaban los zapatos, botas, borceguíes, alcorques y galochas ${ }^{16}$ (figs. 18-23). Fabricados en piel y cuero, fueron más fáciles de distinguir que los de las mujeres, porque todos los podían ver, mientras que los de las damas se ocultaban bajo la falda. Sobre los borceguíes encontramos una de sus características en la Celestina, en voz de Pármeno: “Calzas traigo, y aun borceguíes de esos ligeros que tú dices, para mejor huir que otro" (La Celestina); la

\footnotetext{
${ }^{16}$ Carmen Bernis, Indumentaria española en tiempos de Carlos V, p. 17.
} 
ligereza indica su confección con un material suave y flexible. A diferencia, están las botas, de material rígido y poco flexible que no requerían de ningún otro calzado para complementar.

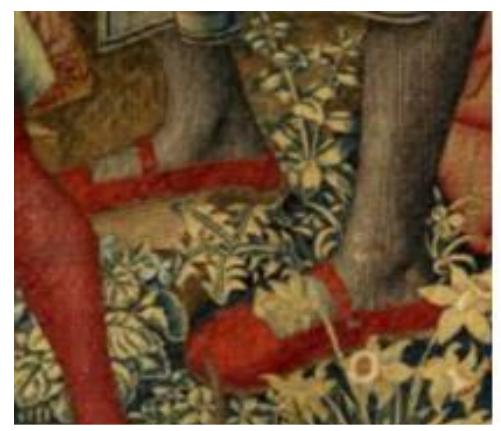

Figs.18-19. Tapiz Betsabé en el baño sorprendida por David (1505) Palacio Real de La Granja de San Ildefonso. Zapato, calzas bordadas

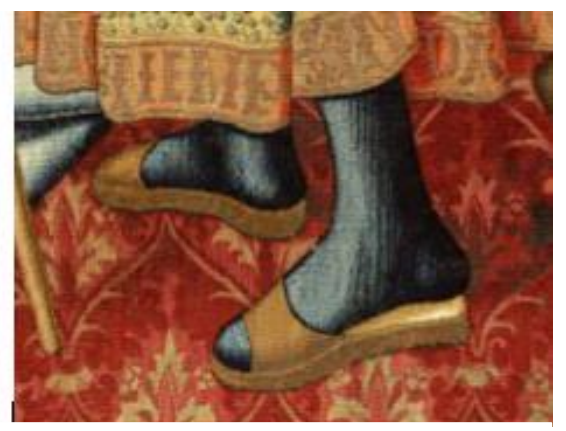

Fig. 20. Tapiz Casamiento de David y Betsabé (1505) Palacio Real de La Granja de San Ildefonso. Alcorques

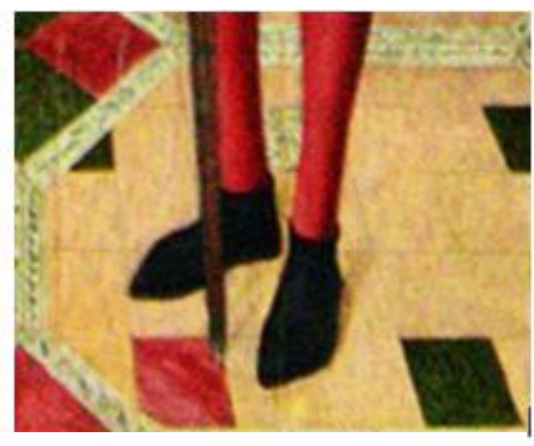

Figs. 21-23. Retablo de san Jerónimo, san Martín y san Sebastián (1445-55) Museo Nacional de Arte de Cataluña. Galochas, botas, botines

Para las mujeres, los zapatos tenían más relevancia porque iban en armonía con su vestido; sin embargo, a veces no se veían por las capas de tela del vestido. A pesar de esto, hay registro de algunos a través de la pintura y la literatura, como se ve en algunos tapices de Isabel la Católica ${ }^{17}$, en los que se distinguen distintos calzados como botas, sandalias y chinelas.

\footnotetext{
${ }^{17}$ Concha Herrero Carretero, Tapices de Isabel la Católica. Origen de la colección real española, Madrid,
} Patrimonio Nacional, 2004. 
Los chapines, de herencia musulmana ${ }^{18}$, resultaron los más novedosos para las damas de la época, quienes aumentaban su altura unos centímetros debido a las altas suelas de estos zapatos. Su originalidad está en las suelas adornadas con tal cantidad de piedras que sobrepasaba a las incrustadas en la parte superior. Era en las suelas en donde radicaba la singularidad por el material y el grosor (fig. 24), característica que permitía utilizarlos como un arma de defensa o de castigo:

Y estando el rey en Madrid acaesçio que un dia corrieron toros e la reyna, por algun enojo que tenia, no quisso salir a los mirar, e mando a todas sus donzellas que ninguna los mirasse, e como doña Guiomar ya toviesse en poco a la reyna, no curo de obedeçer su mandado e subiosse en una torre, donde el rey e todos los de su corte la podian bien ver, e desde ally miro los toros. E como la reina esto supies e ovo dello muy grande enojo e pusose en la meytad del escalera, por donde doña Guiomar avie de deçender, e viendola le dixo muy feas palabras, e tomandola por los cabellos le dio muchos golpes con un chapin, en la cabeça y en las espaldas; e doña Guiomar dio tan grandes gritos quel rey los oyo en su camara, donde ya era venido, e vino a muy grand priesa, e llego a la reyna, e travole por el braço, e con grande enojo le dixo: reyna ¿bien os a paresçido esto? De lo qual la reyna fue tan turbada que cayo en tierra, y estovo mas de un ora amorteçida, que no la podian tornar con ninguna cossa de quantas en ella se esperimentaron, tanto que pensaron ser passada desta vida, de lo qual el rey mostro gran sentimiento. ${ }^{19}$

Y en la Segunda Celestina, de Feliciano de Silva, ocurre algo similar: "Palana. Seme testigos que me arrojó el chapín y me ha descalabrado con él” ${ }^{20}$. El material de este calzado era corcho y de piel o tela la chinela, con una agujeta para sujetarla o liso para meter el pie. Es curioso que, en El Cortesano, se considerara como una prenda bien aderezada por el lugar en el que se halla:

\footnotetext{
${ }^{18}$ Carmen Bernis, La moda en tiempos de Carlos V, p. 22.

${ }_{19}$ María Pilar Sánchez Parra (ed.), Crónica de Enrique IV de Castilla 1454-1474, Madrid, Ediciones de la Torre, 1991, pp. 84-85.

${ }^{20}$ Feliciano de Silva, Segunda Celestina, Madrid, Cátedra, 1988, p. 347.
} 
¿No habéis vosotros mirado cuando acaso acontece que yendo una dama por la calle, o estando en otro lugar burlando, se le descubre un poco el pie o el chapín descuidadamente, si entonces se vee bien aderezado lo que muestra, cuán bien parece? De mí os digo que huelga mucho de vello y creo que vosotros también; porque cada uno agradece más el aderezo en parte así ascondida que adonde siempre se vee ${ }^{21}$. (figs. 25,26)

En estos ejemplos se muestran tres características de los chapines, altura, dureza y ornamento, singularidad que los distingue de los otros calzados, pues podían llevar toda una serie de adornos en la suela acorde al vestuario con el que se usaba.

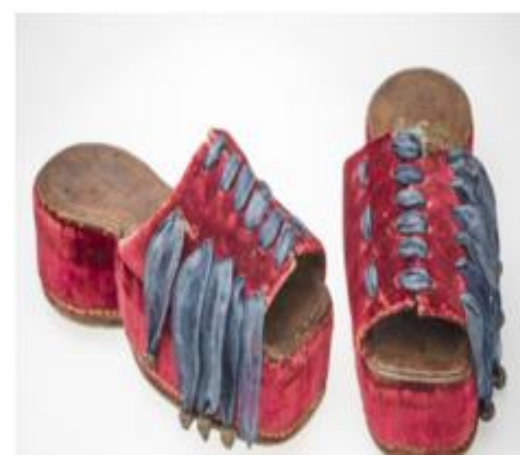

Fig. 24. Chapines españoles (1500-1600) Terciopelo rojo con cintas violetas. Foto de Quico Ortega

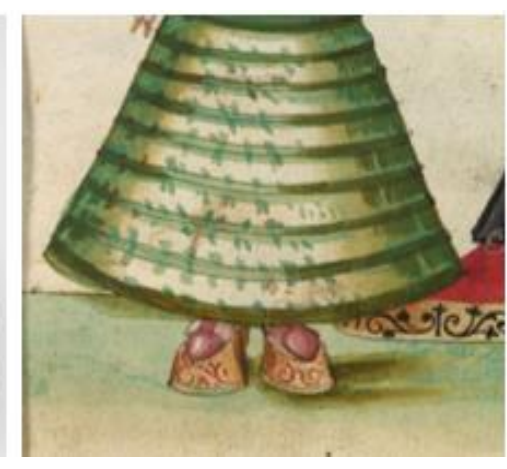

Fig. 25. Códice de trajes Biblioteca Nacional de Madrid. Chapines con suela de madera decorada

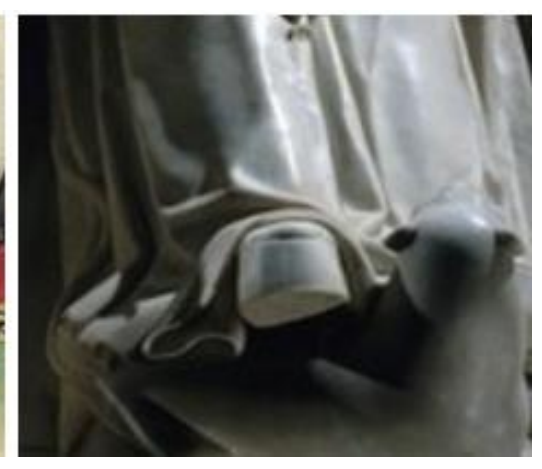

Fig. 26. Sepulcro Doña Juana y Felipe el Hermoso (1519) Capilla Real de Granada. Chapines de Doña Juana

\subsubsection{Botones y agujetas}

Uno de los lujos más interesantes fueron los botones, pequeñas piezas de metal que se llevaban en las mangas, pectorales y espalda, principalmente, en el atuendo femenino. Éste era un ornamento costoso que determinaba una posición elevada, ya que algunas damas mandaban poner una gran cantidad de botones a su ropa como marca de distinción. Por ejemplo, ya desde el siglo XIII, se tiene registro del gusto por esta pequeña pieza, tal como se menciona para la vestimenta de las damas de doña Violant d'Arenós ${ }^{22}$, quienes llevaban

\footnotetext{
${ }^{21}$ Baltasar de Castiglione, El Cortesano, Madrid, Cátedra, 1994, pp. 176-177.

22 Juan Vicente García Marsilla, "El lujo cambiante. El vestido y la difusión de las modas en la Corona de Aragón (siglos XIII-XV)”, Anales de Historia del Arte, 24, 2014, p. 231.
} 
gonelas rojas, cada una con 5 docenas de botones y para doña Violant, 10 docenas de botones. La distinción está en el número de botones, pues para identificar a la duquesa se debía poner más cantidad de estos (figs. 27-28).

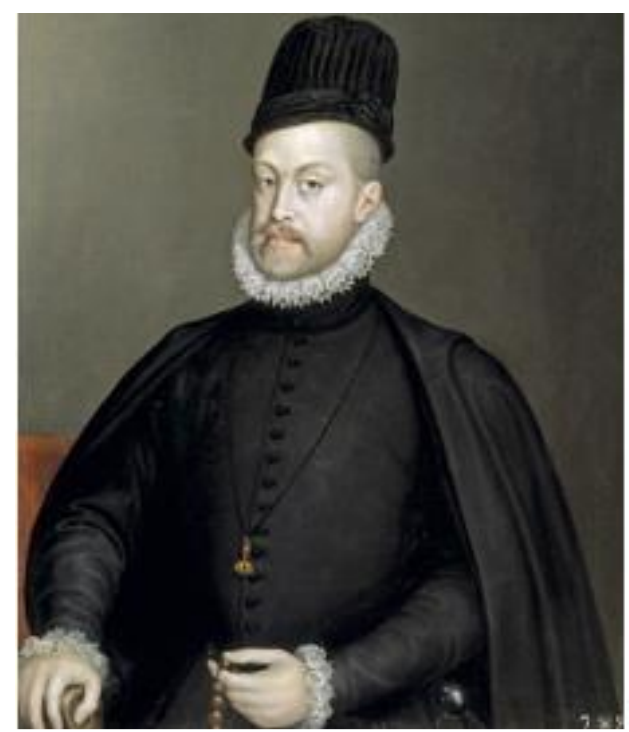

Fig. 27. Retrato de Felipe II (1573) Alonso Sánchez Coello, Museo del Prado. Jubón abotonado

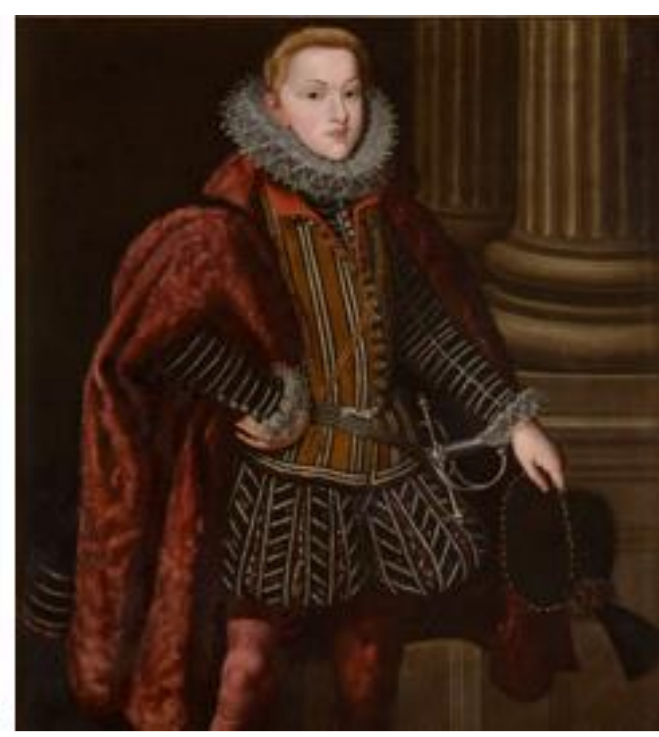

Fig. 28. El archiduque Leopoldo, cuñado de Felipe III (1608-17) Bartolomé González, Museo del Prado. Botones en el coleto y debajo de este lleva un bohemio abotonado.

En documentos como cartas, inventarios y cuentas son comunes los registros de los botones que se hallaban en las prendas de los monarcas, pues era un elemento poco común para la sociedad en general, ya que solían atar las prendas con tiras o agujetas. En la mayoría de los casos eran de oro, aunque también los había combinados con piedras preciosas: "una gorguera de ceti negro aforrada en tafetán que tiene cuatro botones grandes de oro rredondos ${ }^{23}$ los dos tienen dos diamantes grandes el uno punta y el otro de un lomoagudo e los otros dos dos rrubies el uno prolongado berrueco y el otro algo menor e dos cavos de oro en sus torcales de oro y seda"24 (figs. 29-30).

\footnotetext{
${ }^{23}$ Es curiosa la aclaración que se hace de la forma, "redonda", lo que indica que posiblemente había en otras figuras.

${ }^{24}$ José Ferrandis, Datos documentales para la historia del arte español III. Inventarios reales (Juan II a Juana la Loca, Madrid, CSIC, 1943, p.271.
} 


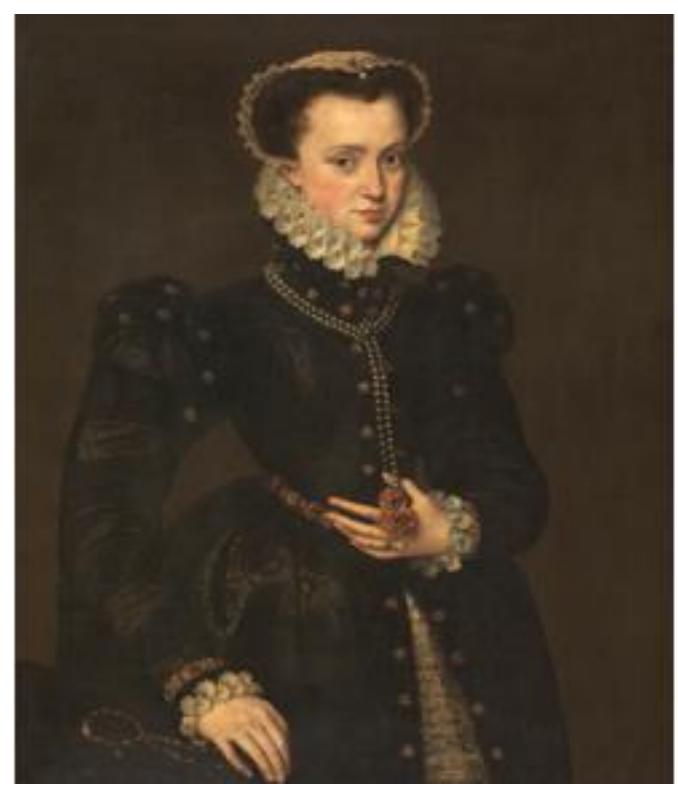

Fig. 29. Retrato de dama (1538)

Antonio Moro, Museo del Prado.

Botones de perlas con base de oro

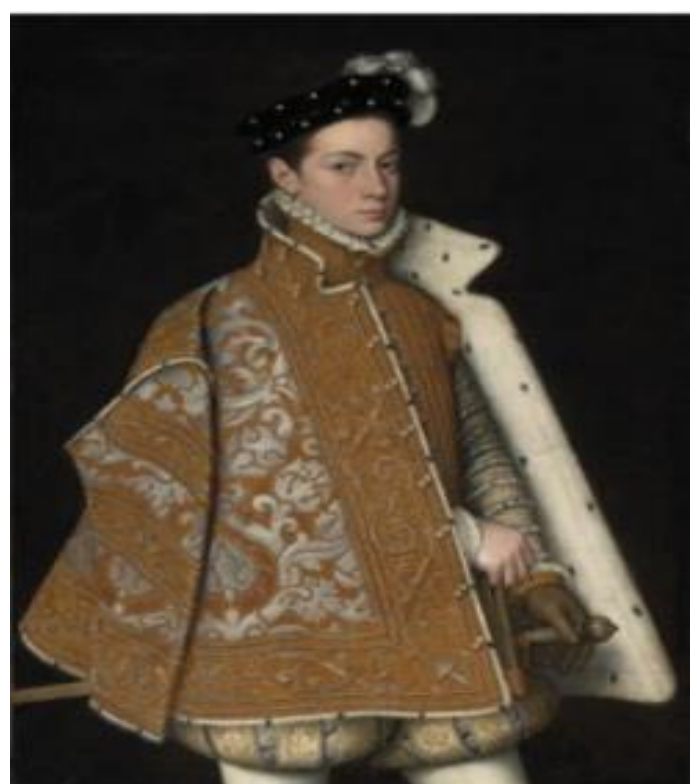

Fig. 30. Retrato del Príncipe Alejandro Farnesio (1560) Sofonisba Anguissola, Galería Nacional de Irlanda. Tudesco con botones de perla y forro de armiño

Es sorprendente que en los documentos reales se describa su uso para enseres de cama, tal como se hace en los bienes de Juana la Loca: "doze almuadas de estrado la una haz de aceytuni carmesí e la otra de azeytuni azul con sus borlas e botones de oro e grana”"25. El valor del botón aumenta al ser de oro y pertenecer al mobiliario del palacio. También los había de materiales como tela, granates, ámbar y cristal ${ }^{26}$.

Las referencias al uso de lo botones son pocas en los libros de caballerías, pero en el Adramón aparece un ejemplo muy útil para conocer cómo se llevaba la capa: "El Cavallero de las Damas tomó el cavallo por las rriendas, apartólo un poco; quitó un botón que en la capa tenya al collar y dexóla caer en tierra" ${ }^{27}$ Lo más común es que las perlas sean los botones y que, de esta manera, se describan en estas historias, generalmente con la frase

\footnotetext{
25 Ibid, p. 336.

${ }^{26}$ Nieves Fresneda González, Moda y belleza femenina en la corona de Castilla durante los siglos XIII y XIV, Madrid, Dykinson, p. 522.

${ }^{27}$ Gunnar Anderson (ed.), La corónica de Adramón, Newark, Delaware, Juan de la Cuesta, 1992, p. 453.
} 
“tenía una gruesa perla por botón". Por lo que son valiosos los ejemplos que se hallan acerca de este accesorio en toda la literatura del siglo XVI.

En cuanto a las agujetas, éstas se definen como "la cinta que tiene dos cabos, de metal, que como aguja entra por los agujeros" (Tesoro de la Lengua). Se utilizaban para sujetar el calzado como los chapines, pero también las mangas, los costados y como adorno frontal en algunas prendas como camisas, jubones y capas, tal como se describe, nuevamente, en el viaje de Carlos V, quien llevaba: "un coleto a manera de justillo, sin mangas, con fondo de martas, que apenas le pasaba de la cintura un palmo y que se sujetaba con una agujeta". Éstas son similares a los cordones y a las trenzas, las cuales además de sujetar, servían de adorno a la prenda (figs. 31, 32). A estas cintas se les podía dar otros usos, según diversos ejemplos que se hallan en los libros de caballerías, como lastimar: "Y atóle una piedra al cuello con un cordón de seda"28; aderezar: "E tomó el jacinto que a un cordón de oro asido estaba"29; y amar: "Y Lerinter llevaba atado encima del yelmo el cordón que su señora le diera" ${ }^{30}$.

\footnotetext{
${ }^{28}$ Arderique, ed. de Dorothy Molloy Carpenter, Alcalá de Henares, Centro de Estudios Cervantinos, 2000, p. 194. Todas las citas provienen de esta esdición, en adelante citaré en el texto indicando entre paréntesis el número de capítulo.

${ }^{29}$ Polindo, ed. de Manuel Calderón Calderón, Alcalá de Henares: Centro de Estudios Cervantinos, 2003, p.12. Todas las citas provienen de esta esdición, en adelante citaré en el texto indicando entre paréntesis el número de capítulo.

${ }^{30}$ Francisco de Enciso Zárate, Florambel de Lucea I-III, ed. de María del Rosario Aguilar Perdomo, Alcalá de Henares, Centro de Estudios Cervantinos, 2009, p. 255. Todas las citas provienen de esta esdición, en adelante citaré en el texto indicando entre paréntesis el número de capítulo.
} 


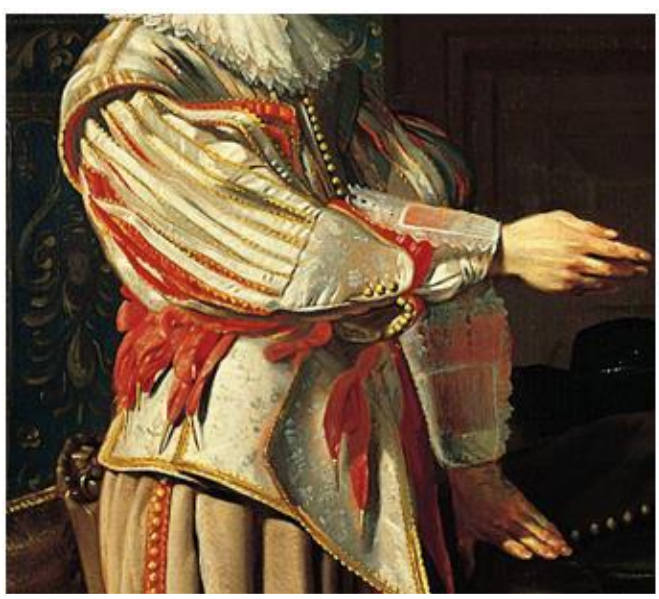

Fig. 31. Retrato de caballero con su hijo (1621) Thomas de Keyser.

Agujetas para adornar la manga.

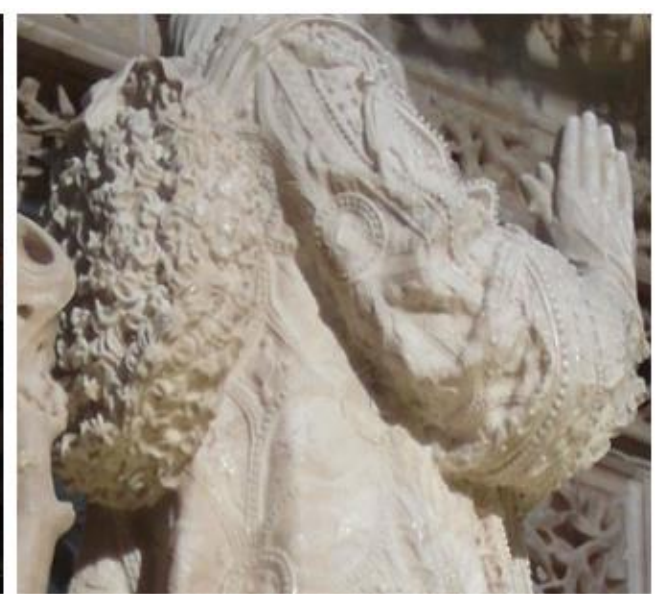

Fig. 32. Sepulcro del infante Alonso de Castilla (s. XV) Gil de Siloé, Cartuja de Miraflores, Burgos. En el hombro lleva agujetas para las aberturas de la ropa.

Pequeños detalles como moños, listones botones y encajes hacen la diferencia en el vestir, según la selección de los materiales, ya que "cada persona pasea los signos externos de su rango"31, y es aquí donde se reflejan las diferentes clases sociales a través de los materiales, detalles y adornos que integran en su conjunto todo el atuendo.

Para seguir enriqueciéndolo, las personas agregaban más elementos, motivo que llevó a muchos a la pobreza, por invertir toda su economía en prendas, esto obligó a las autoridades a ordenar el uso de la ropa y a limitar la compra de tejidos tanto para fabricantes como para consumidores.

\footnotetext{
${ }^{31}$ José Ángel García de Cortázar, art. cit., p. 29.
} 


\subsection{Leyes suntuarias}

La vestimenta descrita anteriormente refleja que el siglo XVI fue un periodo de esplendor en el ámbito textil, pues se impusieron modas con los nuevos diseños, algunos con influencia francesa e italiana, en los que los altos costos de materiales no fueron impedimento para que la sociedad los siguiera usando. Tales fueron los gastos que un sector gubernamental se quejó ampliamente ante la Corona para que impusiera restricciones en la indumentaria. De este modo, aparece una serie de limitaciones para el uso de telas y accesorios que, tras varios siglos atrás, ya impuestas, no se llevaron a cabo, las "Leyes suntuarias".

El antecedente más conocido es la Ley Oppia ${ }^{32}$, surgida en el año 216 a. C. en Roma, cuya principal prohibición era que las mujeres no debían tener más de media onza de oro entre sus joyas, ni usar vestidos púrpura ${ }^{33}$, principalmente, como una medida para frenar el lujo, pues era tal el aumento en gastos, que de alguna manera se tenía que apaciguar para no sobrepasar los límites establecidos por el gobierno. Sin embargo, no se cumplió del todo, ya que, después de varias protestas, las damas continuaron usando sus costosos vestidos.

Del mismo modo ocurre en países como China y Japón, cuyo exceso en el vestir, originó estatutos que regularon la vestimenta ${ }^{34}$. Este tipo de reglamentación llegó a España, en donde aparecieron alrededor de 18 pragmáticas empezando por la de Don Jaime I en

\footnotetext{
${ }^{32}$ La Ley Oppia es el primer antecedente de ley suntuaria para la restricción de vestimenta, antes de ésta existieron otras que se encargaron de controlar bienes materiales como tierras, caballos y muebles, que no se tomarán en cuenta para la presente investigación porque no competen al tema de la indumentaria.

${ }^{33}$ Martha Patricia Irigoyen Troconis, La mujer romana a través de fuentes literarias y jurídicas, México: Centro de Estudios Clásicos de Investigaciones Filológicas, 1985, p. 257.

${ }^{34}$ Rublack, Ulinka, Dressing Up, New York, Oxford, 2010, p.4.
} 
1234 hasta la impuesta por el rey Felipe en $1600^{35}$. Leyes que en el siglo XVI reglamentaron el uso de telas y adornos tales como la seda, el armiño, las telas de oro, el terciopelo, entre otras, a causa de que su fabricación tenía un alto costo de producción. Ya sobre esto, en 1445, Juan Rodríguez del Padrón establecía que la causa de la ruina de la gente era el anhelo por la elegancia de la sociedad de esa época, la cual deseaba poseer numerosos vestidos como los de la monarquía, adquisiciones que, en realidad, les dejaron grandes deudas:

¿Et qual soliçitud, qual estudio nin trabajo de muger alguna en criar su beldat se puede a la cura, al deseo e al afán de los onbres por bien paresçer, egualar, commo sea dellos la mayor occupaçión, non solamente en vestir cada hora ropas de nueva guissa, mas en las fallar, toda vez pensando estarles mejor? E les aviene asaz vegadas, por el contrario, vistiéndose corto o largo, por el modo que otros diferentes dellos se visten. ¿Et quántos son aquellos que sus faziendas, por tra(h)er ropas brocadas de sotil oro febrería, vendieron sinplemente, creyendo poderse dar aquello que les denegó la naturaleza, la qual se llama a engaño, e todas oras dellos reclama por diversos modos $?^{36}$

Se creía que tales lujos podían evitarse si en vez de leyes, la nobleza diera ejemplo de esto al despojarse de sus costosos vestidos y portara ropa moderada, de esta manera, las personas conservarían sus bienes. Sin embargo, esto era improbable debido a que los reyes y príncipes debían trasmitir, en su indumentaria, su poder y posición social, como ya antes se ha mencionado.

\footnotetext{
35 Algunas de las leyes suntuarias, en relación con la vestimenta, que se establecieron en España son las siguientes: 1. Don Jaime I en 1234; 2. Ordenamiento de Sevilla en 1252; 3. Don Alfonso en 1256; 4. Cortes de Valladolid en 1258; 5. Ordenanzas de la Casa Real en 1343; 6. Cortes de Alcalá en 1348; 7. Cortes de Valladolid en 1351; 8. Don Juan I en 1380; 9. Ordenamiento de Madrid en 1395; 10. Ordenamiento de Tordesillas en 1404; 11. Orden de Santiago en 1469; 12. Pragmática de Granada en 1499; 13.Cortes de Toledo en 1525; 14. Pragmática de la seda en 1550; 15.Ordenanzas sobre los obrajes de paños en 1552; 16. Pragmática en Monzón en 1563; 17. Pragmática en 1594; 18. Pragmática en Madrid en 1600. Posterior al siglo XVI, continuaron este tipo de restricciones hasta el siglo XVIII. Para esta investigación se hará referencia a las leyes de los siglos XV y XVI como marco para los libros de caballerías de Feliciano de Silva. 36 Juan Rodríguez del Padrón, "Triunfo de las donas", en Obras completas, Madrid, Editora Nacional, 1982, p. 223.
} 
Esta situación de las propiedades como medios para adquirir prendas continúa hacia finales del siglo XV, las quejas se dan en la ciudad de Toledo en 1498, en donde los procuradores protestan por el desorden que atrae el uso de costosas vestimentas, pues consideran que las personas "no gasten sus haciendas desordenadamente e las conserven e guarden para sus menesteres necesidades" 37 , motivo que obliga a los Reyes Católicos a restringir el uso de ciertos materiales y adornos, especialmente, la seda, el chamelote y a tafetán. A partir de esta legislación se determinan detallados elementos como los "ribetes y las pestañas de seda" ${ }^{38}$, especies de adornos que consisten en un holán en los extremos de la ropa y del vestido, y las otras son "orillas de raso o tela que ponen sobre las guarniciones y muchas veces las pican” (Tesoro de la lengua). Es decir que cofias, albanegas, jubones, sayas y demás prendas que trajeran estos adornos de más de un ancho de dedo infringían esta ley. Sólo las personas que tuvieran caballo y sus hijos menores de 14 años podían llevar estos adornos. Un ejemplo curioso está en el Polindo: "Y no tardó mucho que entraron cincuenta donzellas que venían vestidas de telas de plata e terciopelo verde a cuartos. Y entre las costuras, unas pestañas azules con unas letras por guarnición que dezían: $<<$ Lo onesto en todo priva $>>$ (Polindo, LXXIII), porque no sólo se usan las pestañas, sino que además llevan bordadas unas letras, lo que aumenta el valor a la prenda.

Además se impedía el uso de ropas de brocado, seda y chamelote, tres de los materiales más caros en producir, pues el brocado dependía del oro y la plata con los que se entretejía, mientras que del chamelote era más costosa su transportación desde Oriente, por

\footnotetext{
${ }^{37}$ Pragmática de los Señores Reyes Don Fernando y $D^{a}$. Isabel, sobre los trages; su fecha en Granada a treinta de septiembre de 1499 sobre el modo de vestir prohiviendo fuere de sedas y vordados, y de telas de ylo, oro, y plata, fol. $93 \mathrm{v}$.

${ }^{38}$ La prohibición para el uso del ribete es muy específica: "ribetes, e pestañas de seda de cualquier color que quisieren con tanto que en una ropa no traiga mas de un ribete e que non aya en los dichos ribetes pestañas más anchura de cuanto un dedo pulgar e que no se trayga en los ruedos de las ropas" (fol. 94 r).
} 
lo que se dejó de elaborar con piel de camello para hacerlo con "lana fina" 39 . Entre las posesiones de Juan II se hallan un capellar de chamelote verde forrado en tafetán colorado y una marlota de chamelote ${ }^{40}$, Se puede ver que este material estaba entre algunas prendas de la monarquía y era aún más ataviado con otros tejidos. La unión de telas era común en la época, pues era una manera de incrementar el valor y de hacer más vistoso el uso.

Las limitaciones a las telas y adornos continuaron; sin embargo, unos años después se volvió a prohibir el uso de brocados, los cuales eran de los preferidos por los miembros de la familia real. Se tiene constancia de que la segunda esposa del rey Fernando el Católico disfrutaba de eventos en los que el brocado, la seda y los broches de oro aparecieron nuevamente en toda la sociedad hasta que su hija Juana ordena la Pragmática de Burgos para limitar el uso de prendas. Es decir, son los propios reyes los que rompen las restricciones sobre el lujo que ellos mismos establecieron, pues al iniciar el desenfreno en banquetes y galas para asistir a ellos, provocan que la sociedad los imite, y, por lo tanto, retome sus hábitos de gastar en prendas costosas. Este hecho, a mi parecer, esconde una verdad, que no se puede privar del lujo a la sociedad, pues ésta ya está acostumbrada a vestir, comer y habitar bien, por lo que difícilmente dejará sus comodidades, $\mathrm{y}$, de hacerlo, será lentamente.

Las prendas más afectadas fueron las femeninas, pues en la Pragmática de 1550 se establecía que "las sayas y otras ropas de paño no puedan traer más de dos o tres tiras de seda o una faja entera, que los mantos no traigan ribetes a su alrededor y que las ropas enteras no traigan ribetes" (fol. 4r), la única excepción que se les permitía era que en las

\footnotetext{
39 María del Carmen Martínez Meléndez, Los nombres de tejidos en castellano medieval, Granada, Universidad de Granada, 1989, p. 170.

40 José Ferrandis, op.cit., pp. 104,117.
} 
mangas angostas podían traer cuchillas. Estas limitaciones no se cumplieron, pues los vestidos y trajes de las damas continuaron conservando sus numerosos adornos, tal como se lee en el siguiente ejemplo:

El 16 de febrero de 1518, los reyes presenciaron unas justas, suceso que conlleva un gran desfile de prendas. Doña Leonor iba ese día vestida con un vestido de tela de plata con fondo de tela de oro, y las doncellas de Fiennes, de Croy y de Reux, con vestidos de lo mismo, y todas las demás damas de honor con vestidos de raso blanco que tenían las mangas con fondo de tela de oro; o sea, con vestidos tales como el Rey les había ordenado, llevando las cotas sencillas de raso carmesí. Después, las damas de honor de la reina Germana iban todas ataviadas y vestidas de terciopelo negro, marcando en cierto modo el luto de su señora [...] llevaban los vestidos hendidos de anchas mangas, bordados muy ricamente con bordaduras de oro de diversas labores, como capullos, bellotas, ramitos y otras gentilezas hechas con oro batido y recamado, con muchas labores y divisas de formas raras, enriquecidas con perlas y piedras preciosas, de las que sus anillos, collares y pulseras estaban guarnecidos y ellas ricamente aderezadas. ${ }^{41}$

Recordemos que los forros de tela de oro, las bordaduras, los recamados y las piedras preciosas se restringieron en todas las pragmáticas, por lo que su uso traía castigos como los de romper las prendas o pagar una multa.

Hacia 1563 se da la Pragmática de los traxes en Monzón, en la que se prohíbe el uso de un material raro para la época, las lentejuelas: "Primeramente mandamos que ninguna persona, hombre ni mujer, qualquier condición no puede traer ni vestir ningún genero de brocado ni de tela de oro ni de tela de plata ni en ropa suelta ni en aforro", pero se tiene registrado que en el año 1617 en las Relaciones de fiestas de toros de Sevilla: "Don Fernando de Losada, del hábito de Santiago, y García de Quadros metieron doze lacayos: los ocho de don Fernando, vestidos de raja azul, largueados de passamanos de oro y en los

\footnotetext{
${ }^{41}$ Lorenzo Vital, op.cit, p. 117.
} 
blancos sembrada lentejuela de oro, con penachos de plumas de colores, medias y ligas encarnadas y jubones de tela de la misma color y espadas plateadas" ${ }^{2}$.

Es probable que para este tipo de festividades se permitieran ciertas restricciones para la gente de entretenimiento. Sobre las lentejuelas, eran adornos en metal, planos y brillantes. No hay tantas menciones de este material en los libros de cuentas, al menos del siglo XVI, por lo que es probable que apenas comenzara su uso. Asimismo, se prohíbe el "brocado ni recamado ni entorchado ni chapería de oro ni de plata no de canutillo ni de martillo ni de ninguna ni cordon ni cordoncillo ni pasamano ni perfil de oro ni plata ni seda ni otra cosa aunque el adorno de oro y plata sean falsos” (fol. 230r). Es curioso que esta pragmática ponga más interés en los detalles que en las telas, pues se muestra la restricción en cuanto a los adornos, especialmente los metales, ya que ni aun siendo falsos se permitían. El "entorchado" era un hilo usado en la ornamentación en cojines, muestra de éste se halla en las prendas conservadas en el Monasterio de las Huelgas, con lo que se observa la persistencia de esta forma de bordar y del material, pues después de cuatro siglos se limita su uso, lo que significa que fue muy usado para ciertos géneros de prendas.

Además de las telas, las pieles también se vieron afectadas por las legislaciones. Éstas sólo podían ser llevadas por la familia real. Este era uno de sus materiales preferidos para forrar capas, bonetes, mantos y otros "sobretodos”, pues era una manera de abrigarse y al mismo tiempo de lucir las pieles del armiño y de la cebellina.

A partir de las prohibiciones en las Leyes suntuarias, los fabricantes debieron ingeniárselas para inventar e innovar telas que tuvieran la misma textura de las que se

\footnotetext{
${ }^{42}$ Juan de Arguijo, Relaciones de fiestas de toros de Sevilla, 1617, pp. 412-413.
} 
prohibían; de esta manera surgen otras nuevas como el "brocatel y el filadiz" "43. Así, la sociedad continuaba vistiendo elegantes trajes sin infringir ninguna ley y la economía de los sederos no se afectaba.

El siglo XVI finaliza con la pragmática del rey Felipe II en 1600, en la que se retoman algunas restricciones antes mencionadas. Se prohíbe "vestir brocado, ni tela de oro, ni plata tirado, ni de hilo de oro, ni plata, ni seda alguna que lleve oro, ni plata, ni cordón, ni pespunte, ni passamano, ni otra cosa alguno dello, ni bordado, ni recamado de seda, ni cosa hecha en bastidor" (fol. 29 r). En esta se resumen las leyes suntuarias surgidas en el siglo XVI, por lo que es un indicio de que las restricciones de usos no se cumplían, sólo se aparentaba realizarlas por un momento para después retomar las galas cotidianas.

Estos ejemplos de ornamentos se hallan en los libros de caballerías, en los que el exceso en el lujo siempre está presente:

Otro día la reina dixo a su hija que se aparejasse ricamente para ir a ver a los príncipes, de que a ella no pesó; e vistióse una ropa de brocado muy rica, cairelada de perlas que la hazían parescer a nesgas el brocado, la una nesga de brocado raso y la otra de brocado pelo, golpeado lo uno sobre lo otro, con rico collar e cinta. Y sus cabellos llevaba sueltos y sobre ellos una guirnalda de muchas piedras de gran precio. Llevava delos cabellos a los lados de lazadas, hechas en cada parte una rueda a manera de arandela, y en medio de la rueda un joyel de muy resplandeciente diamante, cercada de rubíes, donde parescía como de punto de compás salir la orden de las lazadas que las ruedas hazían, con muy sotiles e ricos çarcillos que por debaxo pendían. Lo que quedaba de los cabellos llevava muy encrespados (que como un fino oro eran) esparzidos por sus espaldas. Y con tal hermosura, después de aver comido, a la tarde la reina y su hija, con muchas dueñas y donzellas hermosas entraron a ver los príncipes. Y la infanta llevaba cabe sí una donzella muy hermosa, ricamente guarnida, hija del duque de Gandi y heredera del ducado.

${ }^{43}$ François Boucher, op.cit., p. 214. 
Pues como entraron, con mucho acatamiento los príncipes las recibieron, teniéndoles en gran merced la visitación. Y don Rogel, que ya assentadas, paresciéndole en estremo bien la infanta y que traía la más nueva y hermosa manera de postura de cabellos que visto oviesse $e^{44}$ y desí parescióle bien en estremo Sarcira, la hija del duque de Gandi, y determinó servirla en cuanto allí estuviesse. (Florisel de Niquea III, CXIX) ${ }^{45}$

En el ejemplo sobresalen el uso del brocado, caireles y cintas, además de la gran cantidad de joyas que hay en todo el vestido. La creación de los autores estaba dada por la época, por los trajes que veían a diario y a los que agregaban algunos adornos un tanto complicados de imaginar, pero que serán algunas de las descripciones más detalladas en este periodo.

El vestido además de protector del cuerpo se transforma en marca, distinción y rango, por ello está la necesidad de que haya una variedad de prendas, colores y materiales que se puedan lucir por todas partes. Para lograrlo, el siglo XVI dio cabida a una gran cantidad de atuendos, tanto para mujeres como para hombres, de diversos materiales, principalmente, con influencia tanto francesa como italiana, sin dejar de mencionar los trajes propios de cada región de España.

Las características más relevantes de esta indumentaria son el color, la tela y los adornos que la complementan, pues estas tres partes conforman el muestrario de trajes descritos en las obras de la época, en las que se detallan desde la grandeza de la tela hasta la

\footnotetext{
${ }^{44}$ En esta frase se encierra un nuevo acercamiento: "Los estilos de peinados en los libros de caballerías", pues debido a las palabras de don Rogel, el lector puede deducir que nunca antes se había visto un peinado como el de la infanta Marinda; al describirlo como "la más nueva y hermosa manera de postura de cabellos" se intuye la novedad en el peinado.

Varela Merino describe los diferentes peinados durante el reinado de Carlos V, los más característicos, a su parecer, consistían en "el trenzado, un peinado con dos mechones que caían por delante de cada oreja, la toca usual (pieza que cubría la cabeza y el cuello), tocadillos alemanes, tocas anudadas semejantes a las italianas, mantellinas adornadas o no con pinjantes, etc." Elena Varela Merino, Los galicismos en el español de los siglos XVI y XVIII, Madrid: CSIC, 2009, p. 242. Ninguno de ellos se acerca al de la infanta Marinda.

${ }^{45}$ Feliciano de Silva, Florisel de Niquea III, ed. de Javier Martín Lalanda, Alcalá de Henares, Centro de Estudios Cervantinos, 1999, p. 365. Todas las citas provienen de esta esdición, en adelante citaré en el texto indicando entre paréntesis el número de capítulo.
} 
minuciosidad de los botones, todo un conjunto que estandariza quiénes son los mejor vestidos y los más ricos, ya que por medio de estos adornos las personas identificaban la clase social, porque cuantos más se llevaran, más rico se era.

Sin embargo, no todo fue agradable para la sociedad, ya que la imitación de la realeza llevó a la ostentación de la sociedad, hecho que dejó deudas por los excesivos gastos en la compra de telas y adornos para la confección de prendas similares a las de la familia real, por lo que fue necesario establecer normas que regularan el uso de prendas para toda la sociedad. Tales decretos, en su momento, tuvieron alguna influencia en la industria textil, porque limitaron el comercio de ciertos gremios juboneros, calceteros, zapateros, etc., pero después se permitieron por las protestas de los vendedores y de la sociedad en general. 


\subsection{La moda desde la Edad Media hasta el siglo XVI}

El concepto de moda proviene del latín modus, medida, y del francés mode, modo, para definir "cualquier cosa de gusto o de uso general en una época determinada" ${ }^{46}$, en el ámbito de la confección se refiere al gusto por un tipo de prendas por la sociedad durante un tiempo específico, que caracterizan dicho lugar por el modelo de los trajes y los elementos que los decoran. Este concepto se refuerza con las aportaciones de Ulinka Rublack, quien menciona que "the etymologically distinctive English word 'fashion' as referring to a temporary mode of dress" ${ }^{47}$, es decir, un tiempo determinado para un modelo específico que marcará un estilo según las costumbres de la época. Sin embargo, esta palabra no aparece como tal en las obras de la Edad Media, sino que es hasta 1640 que se registra la primera aparición del término "moda" en relación al traje en un documento de viaje: "El Señor Duque de Alburquerque está ya vestido de color a la moda, para partir a Flandres con el puesto de Maestre de Campo"48 y en la obra literaria El diablo cojuelo en 1641: "vieron entrar por la posta, tras un postillón, dos caballeros soldados vestidos a la moda"49, en ambos ejemplos se trata de una referencia general que no especifica el diseño, ni el tipo de tela, además de que solo aparece una vez en los textos.

La idea de la moda se debe hallar en la acumulación de dibujos de los tipos de vestimenta de todo el mundo, principalmente de Europa y Asia durante el siglo XV, y posteriormente los de África y América en el XVI, fecha que permite conocer los hábitos de los indígenas durante la llegada al nuevo continente.

\footnotetext{
${ }^{46}$ María Moliner, Diccionario de uso del español, Madrid, Gredos, 2007, p. 1967.

${ }^{47}$ Ulinka Rublack, Dressing up. Cultural Identity in Renaissance Europe ..., p. 14.

48 José Pellicer de Ossau Salas i Tovar, Avisos, Jean-Claude Chevalier y Lucien Clare, Paris, Éditions Hispaniques, 2002, p. 114.

${ }^{49}$ Luis Vélez de Guevara, El diablo cojuelo, Madrid, Castalia, 1980, p. 225.
} 
Para la confección en la península ibérica se deben reconocer, en primer lugar, las importantes aportaciones de Carmen Bernis, la mayor especialista en la moda española en la Edad Media y en el Siglo de Oro. Ella expresa que ésta es la exposición de "las prendas de vestir que componían el vestuario de los grupos sociales, sus nombres, características, variantes y función de cada una de ella", ${ }^{50}$ además de que "el traje de los grupos sociales privilegiados [...] cambiaba según las normas impuestas por el fenómeno que llamamos moda"51. Para elaborar su propuesta toma como referentes las miniaturas pintadas en el códice parisino del Zifar del siglo XV para presentar el uso de la vestimenta en los personajes desde dos categorías, los que tienen mayor relevancia: reyes, príncipes, damas y caballeros, y los secundarios: campesinos, villanos, escuderos, sirvientes, moros, etc., tal como lo desarrolla en sus demás artículos. Pero no se limita a describir las numerosas prendas que estuvieron en auge durante este periodo, sino que también lo hace en los siglos posteriores, y contrasta la moda de los Reyes Católicos, la del reinado de Carlos V y la del Quijote. Esas formas de vestir las agrupa dentro de la moda nacional con los trajes típicos de cada región española y la extranjera, en donde nota las influencias moriscas, árabes y orientales. Su investigación se basa en los testimonios pictóricos de la corte española, los retablos de iglesias, las xilografías de textos literarios y los retratos de los miembros de las demás monarquías europeas.

En esta misma línea, Sigüenza Perlada considera a la moda como la preocupación femenina por su apariencia en la que se establecen "pautas estéticas

\footnotetext{
${ }^{50}$ Carmen Bernis, "El manuscrito de París. Estudio arqueológico", en Libro del caballero Zifar. Códice de París, estudios publicados bajo la dirección de Francisco Rico, Barcelona, Moleiro Editor, 1996, p. 195.

${ }^{51}$ Ibid, p. 196.
} 
que distinguen visiblemente el atuendo femenino del de los hombres" 52 , lo que le permite buscar diseños que enseñen su figura a través de los trajes ajustados que al mismo tiempo sean provocativos, lo cual construirá la idea de "los atributos femeninos en una silueta sinuosa y elegante" ${ }^{53}$. Esta concepción agrega un nuevo elemento, el deseo de lucir bien para alguien más, lo que demuestra la noción de mirar y ser mirado, con lo que se comenzarán a extraer más elementos de análisis respecto al uso del atuendo, como la intención de seducir a través de la tela y conquistar a través de la prenda.

Es importante considerar que se pone de manifiesto el auge de la moda española durante los siglos XVI y XVII. Esta presencia textil se halla en las obras literarias en voz de los personajes, porque ellos dan muestra del predominio de las prendas españolas y el relego del supuesto imperio textil francés e italiano. Esto se observa en la Lozana Andaluza: “ya no se usan vestes ni escarpes franceses que todo se usa a la española" ${ }^{4}$. Uno de los motivos de esta fuerte influencia se debió a la conexión directa entre las mujeres de la corte española que tuvieron una presencia prolongada en los reinos de Italia, como fue el caso de Lucrecia Borgia, quien a partir de su matrimonio con Alfonso de Este, en 1502, conserva los trajes de su patria y gracias al comercio entre ambos países se logra que imperen los trajes “a la catalana", 55 además de que en este siglo se impuso la moda de la casa de Austria con los Habsburgo, cuya característica principal fueron los atuendos negros. En este

\footnotetext{
52 Cristina Sigüenza Perlada, "La moda femenina a finales de la Edad Media, espejo de sensibilidad. Costumbres indumentarias de las mujeres a través de las artes plásticas del gótico en la Rioja", Berceo, 147, 2004, p. 251.

${ }^{53}$ Idem.

${ }^{54}$ Francisco Delicado, La Lozana andaluza, ed. de Bruno M. Damiani, Madrid, Castalia, 2001, p. 403.

55 Benedetto Croce, España en la vida italiana durante el Renacimiento, trad. de Francisco González Ríos, Sevilla, Renacimiento, 2007, p. 61.
} 
sentido se suman más elementos de análisis, el color, el diseño, las referencias a distintas provincias españolas y la competencia de estilos entre los franceses, alemanes, italianos e ingleses contra los españoles, los cuales encabezan la confección textil durante el siglo XVI.

Esta jerarquía de estilos se trasladará al ámbito literario, en donde aparece una serie de creaciones dignas de imitación por parte de los lectores porque en sus páginas hallaban los modelos que podían utilizar en diferentes ocasiones. Sobre esto, Jennifer Craik presenta otro aspecto de la moda, el cual:

Often, clothing behavior is determined by pragmatic criteria and situations. Choosing the appropriate clothes for going to college, for studying, or for doing housework, gardening or yardwork, going grocery shopping, or going to the beach do not require much more than criteria of comfort. On the other hand, dressing for a job interview, a dinner party, for a wedding, or as a law enforcement officer, entail specific calculations about clothing behavior and milieu. Thus, rather than seeking some essential explanation of fashion, we must look for more localized rationales. ${ }^{56}$

En este sentido, la presencia de la indumentaria en los libros de caballerías guarda estrecha relación con la idea que propone Jennifer Craik, puesto que en voz de los propios escritores aparece esta preocupación por usar el tipo de prenda adecuado para cada ocasión, desde las actividades de palacio como los bailes y justas, hasta las conocidas batallas y en un sentido particular, las bodas, de las cuales son pocos los pasajes que aparecen en sus páginas, pero que, como en el caso de Silva, la utilización de los ajuares es una de las innovaciones más importantes de este tipo, no

\footnotetext{
${ }^{56}$ Jennifer Craik, The face of fashion. Cultural studies in fashion, London, Routledge, 1994, p. 10.
} 
solo por la referencia a la calidad del tejido que llevan, sino por los laboriosos detalles que permiten la clara distinción entre los trajes de diario y los festivos.

Pero además de todos los estudios de la vestimenta expuestos anteriormente es necesario tomar en consideración la propuesta de Roland Barthes, quien presenta su concepto de moda a través de tres estructuras. La primera se trata del vestido imagen, aquel que se percibe a través de una fotografía o dibujo; la segunda es el vestido escrito, el cual se conoce por medio de la palabra, mediante las descripciones que se hacen de cada uno de los detalles que construyen la prenda, es decir, "en uno, los materiales son formas, líneas, superficie, colores, y la relación es espacial; en el otro, son palabras, y la relación es, sino lógica, por lo menos sintáctica; la primera estructura es plástica, la segunda es verbal" ${ }^{57}$, a las que suma una tercera estructura, "el vestido real" 58 , aquel conformado por los materiales, en donde la costura, el corte y la materia construyen de manera física las dos anteriores, el vestido- imagen y el vestido-escrito. Estos rasgos aparecen en distintos grados en los libros de caballerías, de acuerdo al estilo narrativo de cada autor y al espacio de la ficción que les brindan a los episodios donde la indumentaria tiene relevancia. En el caso del vestido-escrito está presente en todos los libros de caballerías, ya que, por mínima que sea la descripción, hay un referente al modo textil de la prenda, principalmente en las armaduras. En el segundo, vestido-imagen está condicionado por los impresores y miniaturistas de la época, debido a que no todos colocaron

\footnotetext{
${ }^{57}$ Roland Barthes, Sistema de la Moda, Barcelona, Gustavo Gili, 1978, p.17.

${ }^{58}$ Ibid, p.18.
} 
xilografías en las que se pueden conocer los trajes de la época ${ }^{59}$. Por último, el vestido real, está más allegado al traje metálico del caballero del siglo XVI, ya que se conforma por las armaduras que se conservan en museos y armerías reales.

Pese a no hallar exactamente la palabra "moda", en los libros de caballerías se presenta su equivalente "vestida al uso de aquella tierra", en donde "uso" adquiere la misma connotación de moda, puesto que hace referencia al estilo de prendas que se llevan en una determinada región y que se diferencia entre uno y otro lugar por los detalles específicos como los adornos y el tipo de telas que se empleaban para su confección.

Por lo que para la presente investigación se entenderá el concepto de moda como la creación de modelos indumentarios en un determinado tiempo y espacio, cuyos elementos textiles y ornamentales influyen en la vestimenta de otras regiones, que al unirse con las características propias de dichas zonas se producirá la elaboración de nuevos atuendos al mezclar una variedad de telas, colores y adornos para dar paso a la transformación de estos diseños y crear una nueva indumentaria que se innovará conforme a las necesidades y exigencias de la sociedad de la época. Este atuendo se analizará con base en dos motivos: 1) Uso funcional para cubrir el cuerpo y 2) Función simbólica que genera acciones en tres situaciones esenciales: amor, guerra y luto.

\footnotetext{
${ }^{59}$ En el cuarto capítulo de esta investigación se expone la presencia de la vestimenta en los libros de caballerías a través de los grabados de la época. Se consideran los títulos caballerescos en cuyos capítulos aparecen xilografías que permitan conocer cómo eran algunos de los trajes descritos por los autores.
} 


\subsubsection{La idea de la moda en voz de los personajes caballerescos}

Como preámbulo a la presencia de la indumentaria en los libros de caballerías, aparece un tema nada alejado del ámbito textil, es la importancia que cobra la moda en voz de los mismos personajes, quienes en diferentes momentos expresan su interés por el conocimiento de las prendas que miran a su alrededor y que esta noción es muy cercana al concepto de la moda que se configura desde la Edad Media a través de los libros en los que se recrean los atuendos de diversas partes del mundo, de los que algunos aparecen dentro de los libros de caballerías, mientras que la mayoría de la indumentaria es resultado de la imaginación de los autores; de ella tres creaciones son las más relevantes: el "caballero con las armaduras propias del oficio, mientras las damas se visten según la moda del XV y los caballos se distinguen con vistosos paramentos", ${ }^{60}$ por ser parte del equipo de armas durante las justas.

En primer lugar, los escritores recrean los modelos textiles que gozan de fama durante el siglo XVI, por lo que introducirán de una forma sutil el comportamiento de las damas respecto a este tema. Primero, se insertan elementos que resguardan una gran variedad de prendas: "y les entregaron las llaves de muchos cofres, que en las recámaras de las quadras estaban aparejados de ropa blanca, y de ropas de diversas colores, de sedas y ricos brocados, y tela de oro, para que se vistiessen sus señoras, en tanta abundancia y riqueza, qual convenía al estado de cada una"61 (Florisel de Niquea IV, II, IX). Tres tipos de tela aparecen en este ejemplo, seda, brocado y tela de oro, tres referentes

\footnotetext{
${ }^{60}$ Emilio José Sales Dasí, "Pinturas, tapices y libros de caballerías", Destiempos, México, diciembre 2009 enero 2010, año 4, número 23, p. 58. http://www.destiempos.com/n23/sales.pdf

${ }^{61}$ Feliciano de Silva, Libro primero de la cuarta y gran parte de la choronica del excellentisimo príncipe don Florisel de Niquea, Salamanca, Casa de Andrea de Portonariis, 1551. Todas las citas provienen de esta edición, en adelante citaré en el texto indicando entre paréntesis el número de capítulo.
} 
a los tejidos de mejor calidad que ya desde la Edad Media cubrían el cuerpo de los integrantes de la realeza.

No es gratuita esta referencia a la acumulación de vestidos, sino que tiene una estrecha vinculación con los guardarropas de las reinas, quienes debido a los numerosos eventos que presidían tenían la necesidad de portar un atuendo diferente cada día. Esta misma idea aparece en el Libro segundo de don Clarián de Landanís, en donde hay un evidente interés por destacar de entre las demás damas a través del uso de diferentes prendas:

E tornando a la sabrosa vida que esta Reina tenía, dize que no havía día que no se vestía de nuevos trajes e se adornava de ricos y hermosos atavíos, lo cual todo le parecía muy bien a don Clarián porque, como estava transportado en el amor de su señora Gradamisa, cada vez que la mirava o fablava pensávase que era ella. (Clarián de Landanís II, XXX) ${ }^{62}$

Detrás de estos cambios de atuendo, se esconde la principal razón para la diversidad de diseños, buscar el elogio y retener la mirada del caballero, puesto que la dama se viste para enamorar a través de las telas, idea que otorga diferentes propuestas en torno al uso de tejidos como una estrategia de conquista.

Sin embargo, antes de que se desarrolle esta técnica de enamoramiento es necesario que las damas sean instruidas en el conocimiento de los tejidos, mediante sus actividades diarias. Sobre esto, Feliciano de Silva inserta su "Instrucción de princesas" en la cuarta parte del Florisel de Niquea, después de haber presentado un universo de materiales de confección en sus obras anteriores. En él hace énfasis en las labores

62 Álvaro de Castro, Libro segundo de don Clarián de Landanís, ed. de Javier Guijarro Ceballos, Alcalá de Henares, Centro de Estudios Cervantinos, 2000, p. 133. Todas las citas proceden de esta edición, en adelante citaré en el texto colocando entre paréntesis el número de capítulo. 
femeninas de las damas de la corte, entre las que destaca el conocimiento que deben tener sobre los géneros textiles y su modo de obrarlos:

ser instruidas en aprender lo que conviene saber a donzellas ylustres que es el leer, y escrivir, rezar y labrar, porque también parece a las tales donzellas hazer cosas señaladas con el aguja y sedas de hermosas colores en los campos de las delgadas olandas y canbrayes, como los cavalleros en los tendidos campos ejercitar en las armas la destreza de los cuchillos que en la niñez aprendieron. Y así como los cavalleros hermosean los campos con los cuchillos derramando sangre y quitando vida a bravas fieras y cavalleros, ansí a las ylustres donzellas parece bien en los campos que dije de las olandas y cambrayes derramando hermosos colores, con las agujas, y como los primeros con muertes de fieras, y cavalleros adornan la destreza de la gloria de sus espadas, ellas al reves adornen sus labores con vidas de ymagines de aves, animales, plantas, yerbas, y flores bivas y tan al vivo sacadas, y al natural, quanto el arte puede imitallo, para gloria de sus ingenios y manos y alabança del que les puso y dio gracia para podello hazer. (Florisel de Niquea IV, II, XLV) ${ }^{63}$ (fig.33)

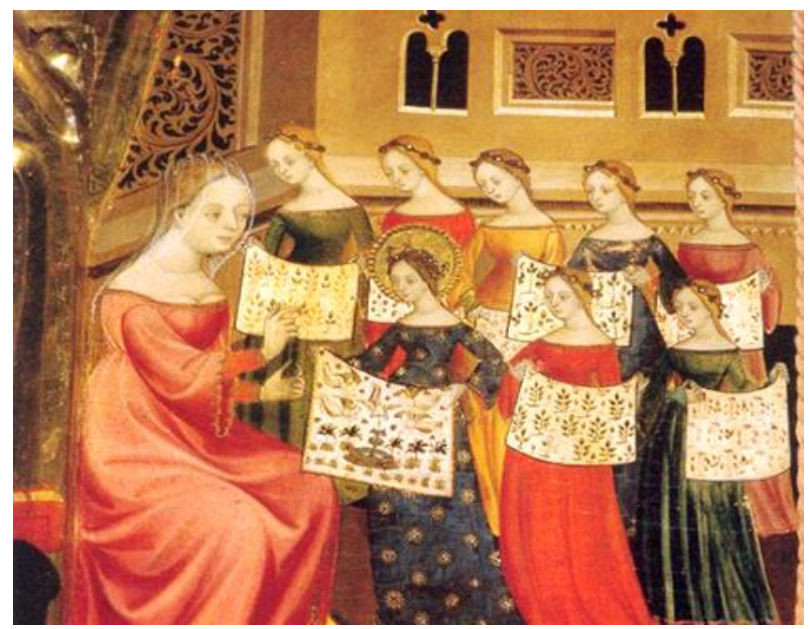

Fig.33. Enseñanza de la Virgen (1399)

Luis Borrasá, Barcelona.

Damas bordan distintas imágenes de la naturaleza.

\footnotetext{
${ }^{63}$ Feliciano de Silva, Libro segundo de la cuarta y gran parte de la choronica del excellentisimo príncipe don Florisel de Niquea, Salamanca, Casa de Andrea de Portonariis, 1551. Todas las citas provienen de esta edición, en adelante citaré en el texto indicando entre paréntesis el número de libro, parte y capítulo.
} 
Más allá de una enseñanza sobre el buen comportamiento que las damas de la corte debían tener durante sus "ratos de ocio" o de los elementos didácticos que Feliciano de Silva inserta como resultado de las críticas de los moralistas a este tipo de libros, hay un trasfondo que revela las actividades femeninas que se realizaban cuando no había festejos públicos. En el caso de las mujeres, el escritor destaca su formación textil desde pequeñas, con la realización de prendas tanto para ellas como para otras personas.

En las telas que se mencionan, la holanda y el cambray, se nota la relación comercial y la importación de géneros traídos de distintos países de Europa; la primera se utilizaba para la elaboración de enseres para cama, cortinas cojines y ropa interior. La segunda, proveniente también de los Países bajos, se empleaba para la ropa blanca, tocas, sábanas y manteles. El propósito de la variedad de paños consiste en el conocimiento de los tejidos para saber aplicar los ornamentos adecuados, puesto que había géneros a los que no se les podían colocar aplicaciones metálicas, por ello debían ser instruidas en la combinación de materiales. Esta noción será indispensable para la realización de los trajes que éstas hacen para los caballeros, especialmente en los mantos y las sobrevestes bordadas para que las luzcan durante las justas, por lo que implícitamente se aludirá al uso de la aguja en manos de las doncellas cuando éstas entreguen una prenda a los paladines.

Esta labor de tejer se enfatiza aún más en el Zifar, en voz de la propia reina, quien expresa que: “obrar lanas y paños es cosa de gran honestidad para todo el mundo y en general para toda mujer de cualquier estamento que sea, y en especial para las mujeres y damas nobles que hacen los lienzos para su vestir y el de su comitiva; que es cosa de gran provecho y más económica que comprarlos, lo 
sabemos todos" ${ }^{64}$. Esta organización de atuendos para un grupo de personas será más recurrente hallarla en el cortejo de damas de la reina, el cual va en sintonía con su señora por mandato de ésta.

El autor es consciente del público que leerá su obra, las damas en gran medida eran quienes se afanaban por conseguir las nuevas historias para ser partidarias con la imaginación de ese mundo caballeresco impregnado de aventuras y elementos que en su realidad no podían acceder. La crítica más severa era por vender sus pertenencías para conseguir los últimos ejemplares que se habían editado: “otras muy curiosas, que dejándose de vestir, gastan sus dineros alquilando libros y, porque leyeron en don Belianís de Grecia, en Amadís o en Esplandián, si no lo sacó acaso del Caballero del Febo, los peligros y malandanzas en que aquellos desafortunados caballeros andaban por la infanta Magalona, que debía de ser alguna dama bien dispuesta" ${ }^{65}$, como ellas en espera del héroe que les brindará todas esas aventuras que han leído. De manera inversa, en la ficción las damas desean vender algunos de sus bienes para comprarse enseres textiles: "después de todos acostados con todas las joyas que de oro tenemos nos vamos, y alongados de aquí compraremos palafrenes y los hábitos necessarios [...] y en una ciudad de Grecia vendieron muchas de las joyas que llevavan y compraron dos palafrenes con ricos guarnimientos e hizieron ropas y todas de donzellas, de finos paños de seda" (Florisel de Niquea III, XIV).

En ciertos momentos, para la creación de dichas prendas aparecen referencias a los instrumentos utilizados en la confección y la sastrería usados por estas damas: "y luego con unas tigeras de un estuche de la infanta una sávana hizieron tiras" (Florisel de Niquea III,

\footnotetext{
${ }^{64}$ Libro del Caballero Zifar, ed. de Cristina González, México, REI, 1990.

${ }^{65}$ Mateo Alemán, Guzmán de Alfarache II, ed. de Benito Brancaforte, México, REI, 1990, p. 351. Todas las citas provienen de esta edición, en adelante citaré en el texto indicando entre paréntesis el número de libro y de capítulo.
} 
XXVII), estuche que bien podría aludir al cajón de sastre medieval en donde se guardaban los artefactos esenciales para la costura: tijeras, dedal, aguja e hilo o que podían llevar con ellas. (fig. 34)

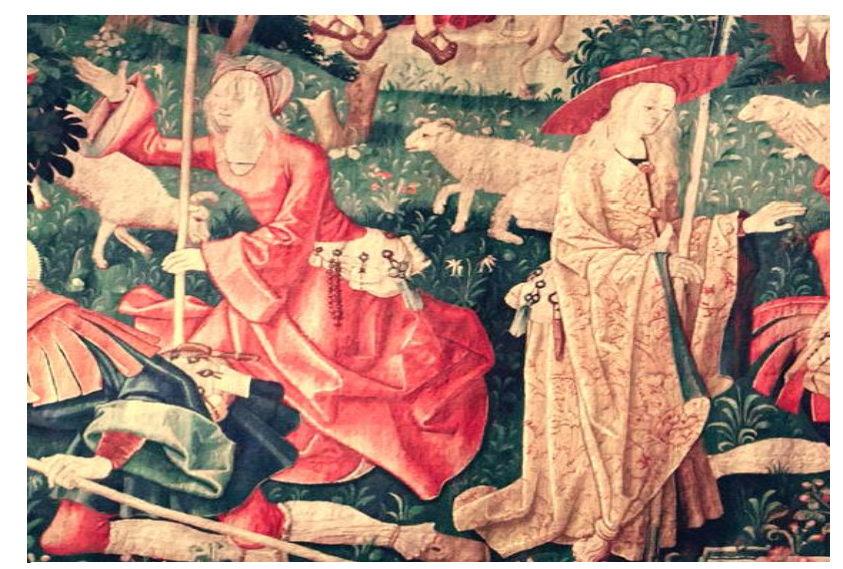

Fig. 34. La Main Chaude (1500-1520)

Museo Victoria y Alberto

Damas con instrumentos en la cintura, destacan las tijeras.

En otros momentos los caballeros son quienes perciben el interés de la moda en las damas, tal como se muestra en el Lepolemo: "Mas hablando verdad, pensávamos que hablávades de colores o de vestidos o de cosas labradas de oro o, lo más cierto, de afeites o de cosas para cabellos, qu'es la práctica más común de damas" (Lepolemo, CXLVII), a lo que la dama responde: “[...] de'essas cosas avíamos estado hablando y, de cansadas, buscábamos materia nueva en que hablar" (Lepolemo, CXLVII). Alusiones como ésta se hallan en varios libros de caballerías, como un referente de la importancia que las damas de la época daban a la necesidad de vestir bien y hallar modelos adecuados para cada situación y de mantener en buenas condiciones su apariencia física, como se nota en el Polindo: 
Las cuales de allí siempre andavan más loçanas e más alegres, vestiendo cada día muchas vestiduras muy ricas e parándose más galanas. Y ansí robavan más los coraçones de sus cavalleros, por lo cual bivían muy penosos en ver a sus señoras tan hermosas e de tal manera. Que ansí <como> es propiedad de mugeres que tienen amantes, como estas dos princesas, de vestirse e ataviarse con muchas vestiduras muy preciosas e tener en la mano un moscador para que sean más miradas, como dizen acá las comunes: <<mira la del moscador〉> o otra cosa semejante. E tanbién cuando las damas están juntas, adoba la una a la otra el tocado e quítalle los pelicos blancos de la ropa. E sacudirse el polvo de las sayas e adobarse en todas partes por que les vean las manos blancas e lindas; las cuales maneras son para que el hombre más se encadene en su querer e amor. (Polindo, XXXVII)

Es decir, la moda también se presenta como un instrumento para atraer la mirada de los caballeros y para conquistar sus corazones, como un medio en el que los diseños se convierten en herramienta de lenguaje a través de los hilos, pues ellas son conscientes de que deben usar diferentes atuendos cada día para retener la atención de los demás y ser admiradas por sus novedosos estilos.

Incluso, esta preocupación por la apariencia también está presente en la mentalidad varonil, cuya vestimenta en ocasiones es motivo de pena por el desgaste, la rasgadura o deterioro que sufren por diversos motivos y que ellos deben componer para evitar vergüenzas frente a la dama, así como se observa en el Tirante:

[Felipe] aquella noche, danzando, había roto un poco la calza y pensó que los suyos no vendrían tan temprano como él se levantase. Y los pajes estaban bien advertidos por la señora y ella estaba en un sitio que podía ver bien lo que Felipe haría.

Dijo Felipe a uno de los pajes:

-Ve, por favor, y tráeme una aguja con un poco de hilo blanco [...]

Felipe se levantó de donde estaba sentado para coger la aguja y coserse la calza (Tirant lo Blanc, I, CX) 
Y que incluso va más allá de los trajes de corte para bailes y actividades cotidianas, puesto que también hay un profundo interés por parte de los caballeros por destacar en el campo de batalla, ya sea por diversión o guerra, hay una afición por sobresalir en su traje de metal y seda, por lo que la necesidad de estar bien armado también está ligada a la idea de imponer nuevos estilos textiles en el ámbito bélico. Sobre esto, Mateo Alemán justifica la variedad de colores, plumas y cimeras en los enfrentamientos porque "alienta y pone fuerzas a un soldado para que con ánimo furioso acometa cualesquier dificultades y empresas valerosas" (Guzmán de Alfarache I, IX). En varios tratados de heráldica y de armas se alude a esta misma idea de la interacción del traje metálico masculino con el de tela femenino, cuya sintonización aparece en el conjunto de adornos que de ambas partes llevan, a fin de establecer un lenguaje privado, que sólo concierne a la pareja enamorada.

En esta comunicación oculta influye mucho el modo de preparación de las sobrevestes, pues en ellas se plasma parte del mensaje sentimental que se conecta con el que se lleva en la armadura, por lo que habrá dos etapas de creación masculina, una para la tela y otra para el metal.

El tiempo para la preparación de ropas también se ve reflejado en los caballeros, específicamente, en la armadura, cuyo principal soporte es el metal, pero también la tela, mediante las sobrevestes y gualdrapas que conforman la parte textil en el campo de batalla. Para su elaboración, se requería de armeros y sastres; su tiempo de producción dependía del modelo que desearan y del tipo de adornos que les colocaran, por lo que podían estar listas de una a cuatro semanas, esto se puede observar en varios libros de caballerías, por ejemplo, en el Florisel: “y con esto los embajadores se tornaron a su Real. Y por ambas partes se aparejavan las armas durando los cinco días de las treguas" (Florisel de Niquea $I V$, I, LXIX). El tiempo de descanso debía emplearse para la realización y reparación de las 
armas, que por los muchos golpes se desgastaban con rapidez; incluso la destreza con la aguja y el hilo se condicionaba por la premura de la batalla: "Mandole que luego le truxesse paños de oro y seda, que asaz el mercader tenía hartos, y hizo llamar dos maestros, a los cuales el mercader salarió muy bien, y el conde don Roldán se hizo hazer unas vestiduras de tan linda invención [...] y luego fue hecho, en tiempo de medio día y una noche, y todo fue tal como lo supo pedir y demandar". ${ }^{66}$

Incluso en esta marca de temporalidad se indica el tiempo de elaboración y de arreglo, en donde se revela el grado de dificultad y el número de prendas que se colocaban, una tras otra, lo que ocasionaba demora en su salida: "y pues vieron que ya no podía tardar el día, se començaron de vestir, y aún no lo havían acabado cuando la resplandeciente alva començó a dar los acostumbrad[a]s señales de su salida" (Valerián de Hungría, VI) ${ }^{67}$, con este pasaje se pone de manifiesto que en ciertas ocasiones el arreglo varonil supera en tiempo al femenino, debido a la colocación de prendas de metal y tela que conforman el modelo guerrero.

Sigüenza Perlada lo define como el "proceso dinámico del vestido conforme a los sucesivos gustos estéticos" $" 68$, que desde la Baja Edad Media "la aparición de cada prenda se producía en un momento determinado, posteriormente, se transformaba dando lugar a nuevas formas o bien cayendo en el olvido del desuso" ${ }^{\text {"69 }}$. Esta concepción transformacióndesuso es notoria en varios libros de caballerías, en donde una prenda puede aparecer en un solo capítulo, pero no se vuelve a mencionar durante el resto de la obra, mientras que, por

66 Pedro López de Santa Catalina, Libro segundo de Espejo de caballerías, Alcalá de Henares, Centro de Estudios Cervantinos, 2009, p.170. Todas las citas provienen de esta edición, en adelante citaré en el texto indicando entre paréntesis el número de capítulo.

${ }^{67}$ Dionís Clemente, Valerián de Hungría, Alcalá de Henares, Centro de Estudios Cervantinos, 2010, p. 31. Todas las citas provienen de esta edición, en adelante citaré en el texto indicando entre paréntesis el número de capítulo.

${ }^{68}$ Carmen Sigüenza Perlada, La moda en el vestir en la pintura gótica aragonesa, Zaragoza, CSIC, 2000, p.6. ${ }^{69} \mathrm{Ibid}, \mathrm{p} .179$. 
el contrario, una ropa puede ser modificada según las necesidades de la historia y ofrecer otro tipo de uso en la misma, ${ }^{70}$ esto es lo que regulará el tiempo de preparación, puesto que a mayor cantidad de prendas textiles, mayor demora en el vestir.

Todos los elementos antes mencionados permiten estar "assi diferenciados en el vestido, como en las condiciones y afectaciones" ${ }^{\prime 71}$, porque a partir de esta recolección de imágenes textiles se comienzan a establecer categorías de la vestimenta por el tipo de tejido y el diseño, en cuanto al aspecto físico, y en el estado emocional el color será la base para la creación de trajes. Estos recursos son los primeros indicios para conformar un concepto de la moda en voz de los personajes, son ellos quienes, a través de sus expresiones sobre la forma de vestir, el modo de elaboración y las condiciones físicas de las prendas otorgan algunas de las características más relevantes sobre el uso de géneros y su función para adecuarse al tie mpo y lugar en el que viven.

\footnotetext{
${ }^{70}$ El ejemplo más notorio estará en las mangas, cuya primordial función como cobertura del brazo y adorno del mismo, en ocasiones se deja de lado para servir como pañuelo, bolsa, soporte para escribir, etc.

${ }^{71}$ Pedro del Mercado, Dialogos de Philosophia natural y moral dirigidos al ilustrissimo y reverendissimo $S$. don Pedro Guerrero Arçobispo de Granada, Granada, Casa de Hugo de Mena, 1574, fol. 130 r.
} 


\subsection{Estado de la cuestión: La vestimenta en los libros de caballerías}

Hasta la fecha, sólo tres artículos han presentado una primera propuesta en torno al aspecto de la vestimenta en los libros de caballerías. El primero de Tomasa Pastrana Santamarta aparece en el 2012 titulado "La indumentaria como símbolo del poder en Renaldos de Montalbán", ${ }^{72}$ en él estudia el desarrollo y crecimiento social del protagonista mediante la vestimenta. La autora expresa que el traje es un "recurso para transmitir una imagen de poder"73, la cual funcionará a través de los materiales y de las aplicaciones que tenga; es decir, se establece una jerarquía entre clase social y atuendo, pues éste debe ser fabricado de acuerdo con el personaje que lo usará; si es rey llevará más elementos en oro y piedras preciosas, mientras que para los siervos y campesinos los accesorios disminuirán y serán poco detallados por los escritores.

En esta misma línea de investigación, María Carmen Marín Pina, en su artículo "Seda y acero. La indumentaria en el Palmerín de Inglaterra como signo cortesano", ${ }^{74}$ describe la importancia de la armadura como transmisora de la condición social del caballero. Para ello, hace un recorrido por la moda de la época, en donde menciona los cambios en los arneses, el color de las armaduras y los motes escritos en los yelmos, escudos y armas. Marín Pina dedica un gran apartado a la presencia de la moda extranjera, como la griega y la francesa, en el Palmerín, para comparar tejidos, accesorios y telas, de otros países con las de origen español de la época.

\footnotetext{
72 Tomasa Pastrana Santamarta, "La indumentaria como símbolo de poder en Renaldos de Montalbán", en El universo simbólico del poder en el Siglo de Oro, ed. Á. Baraibar y M. Insúa, Nueva York/Pamplona, Instituto de Estudios Auriseculares (IDEA)/Servicio de Publicaciones de la Universidad de Navarra, 2012, pp. 205217.

${ }^{73}$ Ibid, pp. 205-206.

${ }^{74}$ María Carmen Marín Pina, "Seda y acero. La indumentaria el Palmerín de Inglaterra como signo cortesano", Tirant, 16 (2013), pp. 295- 324.
} 
Un año más tarde, Tomasa Pastrana Santamarta retoma el tema de la vestimenta ahora en el Florindo ${ }^{75}$ su investigación se centra en las letras, los motes y las palabras bordadas en las prendas masculinas y femeninas. Primero realiza un recorrido por la historia del vestido en España, después localiza estas descripciones en la ficción para finalizar con la identificación de invenciones grabadas en piezas metálicas como anillos y cadenas. Pastrana Santamarta establece cuatro temas para estos motes: amor, religión, fortuna y fama, ${ }^{76}$ en los que se relacionan el pensamiento con la imagen.

Estos son los tres únicos artículos especializados en el estudio de la vestimenta caballeresca, cada uno de ellos, enfocados en un libro diferente, aportan el uso de la seda como el principal material para las prendas de los reyes. También describen los usos cotidianos más comunes de la época, entre los que destacan: la saya, la camisa, el manto y las calzas. Estos tienen en común ser prendas tanto para hombres como para mujeres, aunque también hacen mención de atavíos especiales para cada género.

Tanto Marín Pina como Pastrana Santamarta proponen la misma temática de que la condición social de los personajes se reflejada en el atuendo que porten, ambas se enfocan, brevemente, en el color, los materiales y adornos, así como en los motes e insignias grabados en algunas prendas, letras con diversos significados y utilizados por los caballeros en distintos eventos, principalmente para conquistar a la dama.

A pesar de los temas tratados por las anteriores críticas y ante la falta de más estudios especializados en la vestimenta caballeresca, a partir de esta investigación se han aportado nuevos enfoques en torno a los usos que aparecen en algunos libros de caballerías.

\footnotetext{
75 Tomasa Pastrana Santamarta, "El atuendo en el Florindo como portador de pensamientos", Historias Fingidas, 2 (2014), pp. 117-136.

${ }^{76}$ Yo agregaré uno más, letras de desafío.
} 
En el primero de ellos titulado "La vestimenta en el mundo caballeresco"77 se ofrece un panorama general respecto a la presencia de los modelos textiles a partir de tres características: las telas, los bordados y los colores como las tres bases para la creación de los atuendos y se establece una tipología, resultado de la unión entre el tipo de confección con el estado de ánimo de quien lo porta, con la que se puede proponer una primera clasificación de la función emotiva de las prendas.

El segundo, "Moda infantil en los libros de caballerías I. Trajes de corte"78 se analiza desde el primer contacto de los niños con la tela a través del manto con el que son hallados cuando son abandonados, hasta las referencias de los infantes en los actos de la corte como bailes y juegos de cañas en donde hay un referente a la vestimenta que portan, desde vestidos, mantos, jubones y calzas, hasta su primera armadura que reciben. Estos primeros trajes son un referente importante para conocer la evolución en el modo de vestir de los personajes, desde la continuidad en los tipos de adornos que más prefieren, hasta los que dejan de usar cuando crecen.

El tercero, “Atuendos galanes para criaturas extrañas en los libros de caballerías I: Los gigantes"79, se analizan los tipos de prendas más comunes que caracterizan a los gigantes y a los jayanes, pieles, cueros, conchas y huesos y se hace un contraste con algunos de estos personajes que se distinguen por cubrirse con telas bordadas, piedras preciosas y otros accesorios de gran calidad con el objetivo de presentar una nueva noción

\footnotetext{
${ }^{77}$ Andrea Flores García, "La vestimenta en el mundo caballeresco", en Caballeros, damas y maravillas: Aspectos de la literatura caballeresca, Axayácatl Campos García Rojas, Lucila Lobato Osorio, Gabriela Martin y Carlos Alberto Rubio Pacho (eds.), México, UNAM/FFyL, 2018, pp.37-45.

${ }^{78}$ Andrea Flores García, "Moda infantil en los libros de caballerías I. Trajes de corte", en El rey Arturo y sus libros: 500 años, Aurelio González, Karla Xiomara Luna Mariscal y Axayácatl Campos García Rojas (eds.), México, El Colegio de México, 2019, pp. 355-371.

${ }^{79}$ Andrea Flores García, "Atuendos galanes para criaturas extrañas en los libros de caballerías I: Los gigantes", En línea caballeresca 1, [en prensa].
} 
acerca del uso de trajes de gran precio en personajes que se caracterizaban por vestir acorde a su condición rústica.

En el último, "Flora de cristal, tela y tinta. La rosa blanca en el Claribalte" $" 80$ se analiza el uso de algunos tipos de flores bordadas y pintadas en la indumentaria de los personajes, además de otras hechas de cristal colocadas en los tocados femeninos como una forma de representación del sentimiento amoroso entre las parejas y como un lenguaje que sólo es descifrable entre el caballero y la dama, además de que el color y el tipo de flor tienen relación con el lugar en el que se desarrolla la hazaña por ser emblemática de esa tierra y cómo por medio del color se demuestra el estado de ánimo de quien la viste.

Las aportaciones de los artículos antes mencionados permiten conforman la base para el estudio de la vestimenta en los libros de caballerías desde diferentes perspectivas, debido a que, además de la ropa de gala que aparece en los festejos de la corte, hay otros elementos de análisis insertos en el resto de los personajes, espacios y sucesos narrativos que adquieren relevancia gracias al uso de textiles, como el modo de usarlos, la intención con la que están fabricados o las propiedades mágicas que los autores les agregan. Por ello, es necesario que continúen las propuestas de investigación sobre los diferentes motivos y las funciones del atuendo en los libros de caballerías.

8080 Andrea Flores García, "Flora de cristal, tela y tinta. La rosa blanca en el Claribalte", en Claribalte y sus libros: 500 años, [en prensa]. 


\section{Los libros de caballerías de Feliciano de Silva}

Feliciano de Silva, considerado como uno de los escritores de libros de caballerías más sobresaliente por su vasta producción ficcional y criticado por otros, debido a su estilo en el que predomina "la claridad de su prosa" ${ }^{81}$, es un autor que fue conocido dentro y fuera de España por las muchas impresiones y traducciones que se hicieron de sus cinco obras: Lisuarte de Grecia (1514), Amadís de Grecia (1530), Florisel de Niquea I-II (1532), Florisel de Niquea III (1535) y Florisel de Niquea IV (1551). A lo largo de 37 años pudo modificar los modelos narrativos establecidos por los primeros libros del género para crear los suyos e insertar nuevos tópicos en la ficción caballeresca. Sales Dasí expresa que "la narrativa de Feliciano de Silva consolidó el triunfo de la experimentación, de un manejo de temas, tonos y registros cuya finalidad primordial sería la «diversión y el entretenimiento»" ${ }^{» 2}$. Este cambio también se percibe en el ámbito textil, desde el manejo de telas, adornos y diseños, en los que se ve la influencia de las modas europeas, principalmente de la española, cuyo periodo abarca desde los últimos años de los Reyes Católicos hasta el Emperador Carlos V, pero que también aporta sus creaciones a la conformación de una moda caballeresca imitada por las damas de la época. Estos diseños resultaron de una estrecha vinculación entre la imaginación de la época y el contacto con el ámbito cortesano, pues al ser hijo de Tristán de Silva, cronista del Emperador Carlos V, no sólo tuvo acceso a las noticias del reino, sino que pudo trasladar parte del ambiente de la

\footnotetext{
${ }^{81}$ Miguel de Cervantes, Don Quijote de la Mancha, México, Real Academia Española/ Asociación de Academias de la Lengua Española, 2005, p. 28.

${ }^{82}$ Emilio José Sales Dasí. ¿Continuador o creador? «Las entricadas razones del famoso Feliciano de Silva» In: La escritura inacabada: Continuaciones literarias y creación en España. Siglos xiii a xvii [en línea]. Madrid: Casa de Velázquez, 2017 (generado el 20 agosto 2019). Disponible en Internet: <http://books.openedition.org/cvz/3333>. ISBN: 9788490960738.
} 
corte a sus libros, en los pasajes de bailes, justas y banquetes que guardan cierta similitud con los otorgados por el emperador durante el siglo XVI.

\subsection{Del Lisuarte de Grecia al Florisel de Niquea}

Mientras que en diversos estatutos se establece una necesaria moderación en la elaboración de prendas en cuanto a los adornos se refiere, en las páginas de estos libros es evidente el derroche imaginario por la acumulación de detalles, desde los preciados hilos de oro, hasta las brillantes piedras preciosas, elementos que configuraron un estilo de confección para cada escritor, de acuerdo a los modelos recreados en sus obras, lo cual se convierte en una estrategia de identificación propia de cada autor, al menos en aquellos en los que en sus libros sobresalen los modelos textiles como generadores de acciones y que a través de los bailes, torneos y entradas triunfales, se puede identificar los tipos de indumentarias: festiva, bélica, seductora y luctuosa.

\subsubsection{Lisuarte de Grecia: Primeros modelos textiles}

El primer acercamiento de Silva con la tela se da en el Lisuarte de Grecia de 1514. En el primer capítulo se narra el viaje de Perión de Gaula y otros donceles que van hacia Irlanda y en el camino hallan a una "donzella ricamente guarnida e assaz hermosa [...] que traía a su cuello una espada muy ricamente guarnida e un escudo negro en el medio pintada una esfera de oro" (Lisuarte de Grecia, I). Esta primera alusión es muy general y común en todos los libros de caballerías, pues de manera ordinaria se trata de reducir a una sola expresión todo el conjunto de tejidos que implica la confección del atuendo. Sin embargo, en este acercamiento al uso, aparece el primer conector de la tela con el metal, materiales que serán la base de sus creaciones. 
A partir de este momento comienzan a aparecer varias situaciones en las que adquieren relevancia el color, como en las situaciones de luto: "estava una dueña vestida de paños negros de seda" (Lisuarte de Grecia, II) nótese que ya se indica el color y el tipo de tejido, la seda. Enseguida aparecerá el primer atuendo varonil: “el hermoso donzel Lisuarte, vestiéndose muy ricamente de una ropa de escarlata muy fina toda sembrada de cruzes de oro e un capirote en la cabeça de mucha pedrería" (Lisuarte de Grecia, VI). Claramente hay una especie de rapidez textil en el ingenio de Silva, quien en tan solo seis capítulos ya ha conformado las principales piezas de la sastrería: tejido, color y adorno, este último favorecido con las piedras preciosa y un elemento más, su primer accesorio, el capirote.

Es evidente que a partir de este momento las próximas apariciones serán más elaboradas, al menos en lo que respecta a los trajes festivos de corte: "Lisuarte se levantó e vistió una garnacha de oro sembrada de muchas perlas, que estava tan apuesto que todos se espantavan de le ver. Florestán se vestió un manto de terciopelo azul bordado de mayas muy rico, que muy apuesto cavallero era. Parmíneo e Galvanes se púsieron sendos mantos de grana bordados de bastones de oro" (Lisuarte de Grecia, VI, 24). Detrás de esta variedad de trajes se oculta una nueva aportación de Silva, la competencia en el vestir para destacar entre los demás. Implícitamente hay un interés dentro y fuera de la historia, en los personajes para ver quién es el mejor vestido y en los escritores para demostrar quién es el más ingenioso en la creación de trajes. Además, esta idea de niveles en el vestir se refuerza con las expresiones que acompañan a los cuatro jóvenes, desde la belleza que espanta hasta el apuesto. Junto a ellos están las damas: "La princesa Onoloria traía los sus muy hermosos cavellos sueltos, con un prendedero de oro e una guirnalda de mucha pedrería sobre su cabeça" (Lisuarte de Grecia, VI), con esta dama se introducen los adornos para el cabello. 
Más adelante aparece una nueva categoría, los trajes para personajes ajenos a la corte:

entró por la puerta del palacio una donzella tan grande que jayana parescía. Y era tan fermosa que todos fueron espantados. Traía vestida una ropa de brocado que cuatro braças le arrastravan por el suelo, e un tocado en la cabeça sobre los cabellos que sueltos traían, que muy ruvios eran, de dos tampas muy altas llenas de mucha pedrería. Traíanla por los braços dos cavalleros ancianos con las barbas e cavellos muy largos $\operatorname{tr}[\mathrm{e}]$ nçados con cuerdas de oro, e vestidos de ropas largas negras. E tras ellos venían diez cavalleros armados de todas sus armas. (Lisuarte de Grecia, VII)

Además de los tocados, los peinados también tendrán importancia, debido a que a través de las madejas se sostendrán algunos adornos metálicos. Junto a ella vienen dos ancianos y diez mil caballeros, lo que indica el primer desfile de armas de este autor.

Una de las características que más acentuará son los detalles de las prendas, por ejemplo, la infanta Melía toma a Lisuarte "por el collar del aljuba de brocado que traía vestida" (Lisuarte de Grecia, X). Este tipo de acciones permite que el lector conozca cómo eran las prendas en el siglo XVI, para que los detalles como botones, cintas, agujetas y hebillas adquieran mayor relevancia durante el desarrollo de las acciones.

Otra de las apariciones más recurrentes e incógnitas que abundan son las referencias a los atuendos de cierta región que en un principio no están determinados geográficamente, sino que sólo se aluden con la frase "una hermosa infanta vestida al uso de aquella tierra", condición que dificulta determinar de qué región se trata y aún más qué prendas lo componen.

Una curiosidad es que aparecerán contrastes entre en el modo de vestir y de quien lo usa: "en medio traían una jayana vieja vestida toda de una ropa muy larga, muy extrañamente labrada con muchas perlas, e traía un tocado alto e de las orejas colgados muy 
ricos cercillos" (Lisuarte de Grecia, XII). La utilización de ricas prendas por parte de los antagonistas se tratará de diversas formas, desde la abundancia de adornos para agraciar a los personajes o por elementos cómicos que pueden provocar desajustes entre el físico y los adornos. Asimismo, comienzan a aparecer las joyas, toda clase de aretes, collares y anillos. Los personajes mágicos también tendrán diseños especiales acorde a su naturaleza: "la infanta Melía, vestida [de] una ropa que parescía que en vivas llamas ardía, por tan estraña arte era hecha" (Lisuarte de Grecia, XXIII). Pero ciertamente, una de las inserciones más importantes consiste en el intercambio de prendas, como una necesidad de usar la ropa de la dama por la del caballero a fin de permanecer en un lugar sin ser descubierto: "Vestid estos mis vestidos e yo los de mi donzella, e assí nos saldremos [...] e desnudando una rica ropa que traía vestida, la hizo vestir a Lisuarte e púsole el su tocado de [es]tampas muy rico” (Lisuarte de Grecia, XXV).

En este primer libro se encuentran 59 pasajes en los que está presente la vestimenta, en la mayoría sobresale por su tipo de confección, la intención del uso y las acciones que genera. Puede aparecer en situaciones de lamento, festividad, amor, engaño y pruebas mágicas.

\subsubsection{Amadís de Grecia: Entre el color y las telas}

Después de este primer libro, Feliciano de Silva continúa con su labor creadora con el Amadís de Grecia en el que se observa un incremento considerable en torno a las acciones y la forma de emplear el uso de la vestimenta. El primer cambio notorio es que el Lisuarte tiene 100 capítulos, mientras que éste está dividido en dos libros, el primero con 72 capítulos, el segundo con 134, un total de 206. 
Desde el segundo capítulo aparece la vestimenta, ahora relacionada con la moda infantil. Se trata de un niño de tres años, quien es despojado de su aljuba d'escarlata, misma que le ocasiona problemas porque debido a su modo de confección un león logra alcanzarlo y trabarlo por la falda de la aljuba.

También se hallan nuevos tipos de tela y características sobre el largo de los vestidos: "entró por la puerta de la sala una donzella muy hermosa en demasía, vestida de paños de oro que más de dos braças le arrastravan por el suelo" (Amadís de Grecia, I, XIV). La importancia de este tipo de ejemplo es que se nota la influencia de la moda traída por el Emperador Carlos V, especialmente las faldas amplias con cola alargada.

Continúa la presencia de jayanes, especialmente sobresale el nuevo tipo de prendas que lleva: "venía toda vestida de conchas de pescado muy menudas cosidas en una ropa que por el suelo de encima de un gran palafrén más de dos braças rastrava. En su cabeça traía un tocado muy alto hecho de conchas de caracoles por muy extraña manera en él texidos” (Amadís de Grecia, I, XXIV). En este libro, los jayanes se caracterizarán por ir cubiertos con conchas. Nótese cómo permanecen las faldas largas.

Ciertamente, uno de los motivos que mejor elaborará Silva es el de llevar el rostro tapado: "toparon una dueña encima de un palafrén vestida de paños de seda negra; ella venía el rostro muy atapado que aun los ojos tan a mala ve[z] se le veían; con ella venían diez cavalleros todos armados y cuatro donzellas ricamente guarnidas y ansimismo muy atapadas" (Amadís de Grecia, I, XLV). A partir de este episodio, este ornamento está presente en todos los demás libros, en los que presenta considerables modificaciones en el modo de cubrir la cara y el motivo por el que se usa, por lo que Feliciano será quien mejor utilice el antifaz en los libros de caballerías, a pesar de haber aparecido por primera vez en el Amadís de Gaula. 
Este primer libro finaliza con la aportación de la transmisión emocional de dos personajes a través de sus nombres, Esperança y Desesperación, condición que se refuerza en los colores que usan: “dos donzellas vinieron para mí, la una tan hermosa cuanto la otra flaca, amarilla y fea. La una venía vestida de una ropa de brocado verde con un tocado de muchos rubíes [...] la otra desemejada, venía toda vestida de amarillo con tocado de lo mesmo" (Amadís de Grecia, I, LXXII). También a partir de este momento comenzará a tener más presencia el uso de los colores tanto en las armas como en los vestidos como un recurso de manifestación de los sentimientos.

Otro de los pasajes que comenzarán a sobresalir son los desfiles de armas, en donde varias damas lucirán sus armas por todo un recorrido que realizan para llegar al palacio: "traía quinientas mujeres de las suyas todas armadas de ricas armas y todas en unicornios muy grandes por cavallos, con tan ricas armas y guarniciones que precio no tenían y ellas eran extremadamente hermosas” (Amadís de Grecia, II, XLI).

En este segundo libro aparecen 121 pasajes en los que la vestimenta ya presenta un diseño más elaborado. Lo más característicos serán los desfiles de prendas que es una de las bases más importantes en el ingenio de Silva.

\subsubsection{Florisel de Niquea I-II: Atuendos para cada personaje}

Para 1532 ya se ha fortalecido la moda española en toda Europa, la influecia de los trajes negros es primordial en las cortes por ser considerado un color de distinción. Para este momento, Feliciano de Silva publica su tercer libro, el cual será considerado la base de un nuevo modelo narrativo, en el que los tópicos de lo pastoril, el disfraz, la doncella guerrera y las inserciones poéticas presentan mayores innovaciones. En el ámbito textil, sus 
aportaciones son más detalladas, con más elementos de decoración y con una especial amplitud en los pasajes relacionados con los desfiles.

Nuevamente distribuido en dos libros, el primero consta de 70 capítulos y el segundo 64, en total 134 .

En el segundo capítulo aparece la primera referencia a la vestimenta: "doze donzellas vestidas de ropas amarillas, con hachas en sus manos encendidas" ${ }^{83}$. Una de las características es que en varios pasajes las doncellas llevarán hachas encendidas, primera diferencia con los dos títulos anteriores, pues ahora se le da un espacio a las damas que alumbran el camino y se les confieren trajes con cierto grado de calidad en las telas. Asimismo, se conserva la presencia de los jayanes, pero ahora se les cubre con tela.

Dedica varios capítulos al aspecto pastoril y también a la vestimenta que portan: "Silvia se desnudó una ropa de seda de la forma pastoril que sobre otra traía" (Florisel de Niquea I, XII). Como se observa, hay un interés por introducir nuevos tejidos adecuados para cada personaje; telas resistentes para las labores rudas y delicadas para los trajes de gala. En el aspecto de la rudeza, se agrega un nuevo personaje, la virgo bellatrix, cuyo atuendo tiene dos cualidades, la primera, el traje completo de la armadura, la segunda, en algunas ocasiones, lleva medias armas, esto es, de la cintura para abajo usa falda y de la cintura para arriba metal.

Otro de los elementos que se desarrolla más es el intercambio de prendas, los hombres vestidos de mujer y viceversa, con el propósito de estar cerca uno del otro.

A las damas tañedoras también se les describe su traje: "veinte y cuatro donzellas vestidas de brocado, con arpas y otros instrumentos" (Florisel de Niquea I, LI).

\footnotetext{
${ }^{83}$ Feliciano de Silva, Florisel de Niquea I-II, ed. de Linda Pellegrino, rev. de María Coduras, prefacio de Anna Bognolo, Alcalá de Henares, Universidad de Alcalá, 2015, p. 18. Todas las citas provienen de esta edición, en adelante citaré en el texto indicando entre paréntesis el número de libro y de capítulo.
} 
Se puede ver que en este libro hay una diversidad de trajes para diferentes personajes, en los que la tela debe ser acorde al oficio que desempeñan, por ejemplo, para ir de cacería era común llevar: "una aljuba de brocado a la forma de montero vestido" (Florisel de Niquea II, IV). El movimiento de las manos que permite la aljuba es necesario para la persecución de los animales.

Al igual que los dos títulos anteriores, predomina el estilo retórico durante sus descripciones, hay una gran variedad de telas, la presencia del antifaz continúa. Pero la invención más original son los vestidos de novia a los que el autor dedica una amplia y detallada descripción de todos sus ornamentos.

Fueron 111 los pasajes localizados en los que la ropa tiene una presencia relevante por la variedad de adecuaciones que se le da a la tela para cada personaje, además de que destacan algunos accesorios como abanicos, capirotes, joyas y un uso que se le da a la manga como pañuelo para mojar el rostro.

\subsubsection{Florisel de Niquea III: Entre joyas y antifaces}

Con su cuarta obra publicada en 1535, la Tercera parte del Florisel de Niquea continúa en la misma línea de variedad de trajes para los pastores, músicos, jayanes y doncellas guerreras que aparecen nuevamente. Entre sus 170 capítulos el primer atuendo aparece en el capítulo diez, se trata de un manto de escarlata con figuras de fénix bordadas para el Cavallero del Fénix.

Una diferencia con las obras anteriores es la constante mención a las joyas, como regalo y como piezas para vender y comprar nuevos vestidos. Los accesorios también adquieren más relevancia, este es el caso del antifaz, el cual se utilizará para jugar con los demás a fin de no revelar quién es la persona que lo usa: “-Pues alçad esse antifaz que traéis 
sobre el rostro - dixo él-, para que vea quién me ruega, que por el vestido no sé si sois hombre o mujer" (Florisel de Niquea III, XVII). Claramente se asume que habrá una variedad de enredos por llevar el rostro cubierto.

La condición de la ropa se nota por las palabras de los personajes, al referirse a ellas como "vestidos rotos y viejos", característica que antes no se había mencionado. Además, hay un elemento nuevo, la petición de una pequeña de no llevar el mismo atuendo que las otras damas, pues desea destacar entre las demás y no dejará de llorar hasta conseguirlo. En los 76 pasajes donde la indumentaria tiene una importante presencia, la mayoría se trata de las prendas para ocultar la identidad. Del mismo modo, hay varias referencias a la preocupación de las damas por cuidar su apariencia y arreglarse para el caballero, argumentos femeninos que antes no habían tenido una alusión constante.

\subsubsection{Florisel de Niquea IV: Últimas galas}

El último libro de la saga de Feliciano de Silva aparece en 1551, nuevamente dividido en dos partes, la primera tiene 88 capítulos y la segunda 99, un total de 187 con los que finaliza su ingenio textil.

En el capítulo cuatro aparece una doncella "vestida una garnacha de carmesí de escarlata" (Florisel de Niquea IV, I, IV) que llora junto a un árbol porque otra dama le robó su caballo. Esta acción será el inicio de una constante aparición de damas a caballo, en donde la inserción de grandes ejércitos femeninos marcará la diferencia con los de los caballeros, ya que de éstas se dice que "trayan unas ropas hasta el suelo plegadas y muy ceñidas, a nesgas de carmesí pelo y tela de plata, y los braços armados de limpios braçaletes, en los pechos trayan unos petos a manera de plastrones de limpio azero y en el medio va rostro de donzella de tan estraña hermosura" (Florisel de Niquea IV, I, X). Esta 
doncella es el modelo a imitar de las demás mujeres guerreras que combatirán, porque se dice que tras ella deberán ir mil doncellas vestidas igual que la primera. Esta conformación de ejércitos femeninos empieza a tener más desarrollo a partir de este momento, pues en las anteriores obras se trataba de doncellas guerreras con armaduras completas más apegadas a la imagen tradicional del caballero, mas ahora hay un intento de modificar esta imagen bélica con nuevos elementos en los que se conjuga el metal y la tela, pero sin que se pierda la delicadeza de la dama.

Otros de los elementos que sobresale es el elevado número de apariciones de pastores. Hay constantes referencias al traje de pastor acompañados de los instrumentos que los caracteriza y los versos que cantan están intercalados en diferentes momentos.

Hay una considerable reducción de la presencia varonil en trajes de armas, ahora se favorece su estancia en vestidos de pastor o atuendos de damas, con el cuidado de llevar el rostro cubierto para evitar ser identificados.

Los constantes cambios de trajes no son motivo de descuido en la aparición de las prendas de gala o de los atuendos especiales a manera de ajuar nupcial. En este caso, el Caballero Constantino es el primero en recibir unas prendas matrimoniales: "sacaron del unas muy buenas y fuertes armas, las cuales eran todas indias, pobladas de almarraxas de oro, y el escudo de la mesma color, con una almarraxa en medio" (Florisel de Niquea IV, I, XXIX) más adelante se dirá: "en señal de la prenda que de casamiento os di, y me diste" (Florisel de Niquea IV, I, XXIX).

En repetidas ocasiones aparecen los tocados femeninos, de estos uno tiene mayor relevancia por su disposición en la cabeza, ya que era "un tocado que ni era sombrero ni lo dejaba de ser" (Florisel de Niquea IV, I, LII), una especie de adorno que oscila entre el 
rollo, la gorra, el bonete o la toca, por ser los más cercanos a la imagen del sombrero, pero sin serlo.

Para el libro segundo de esta cuarta parte los modelos antes mencionados continúan apareciendo. En el caso del antifaz hay una intención interesante en su uso, que las damas puedan vigilar a sus esposos: "representando entre sí la suerte que se avían de disffraçar y fengir no conoscer a sus esposos si los topassen" (Florisel de Niquea IV, II, VII). El juego y la curiosidad son los nuevos elementos que impregnados en las prendas ocasionan nuevas acciones, ahora entre los esposos. Es importante notar cómo a pesar de su condición civil, las damas aún participan en hazañas bélicas, no permanecen en la corte, como sí sucede en otros libros del género, sino que estas esposas toman el control de su libertad, pero con un cuidado especial para no ser descubiertas.

El ventalle es un nuevo accesorio que tiene una presencia relevante, no sólo por su uso, refrescar a las damas, sino por su estructura en la que lleva un espejo engastado con el cual puede ver el rostro de su amado.

El último diseño textil de Silva lo portan unas doncellas danzantes: "una dança de muy hermosas donzellas vestidas de raso verde acuchillado sobre tela de oro con guirnaldas en la cabeça cantando suavemente" (Florisel de Niquea IV, II, XCVII). En este último ejemplo se encierra toda la creatividad de Feliciano de Silva, la estructura base de todo atuendo, tela, color y adorno, además de los accesorios que enriquecen aún más la vestimenta.

Considerablemente incrementó el número de pasajes en los que aparece un tipo de prenda, 135 referencias al diseño de la tela, formas, tamaños, funciones y colores.

Para este apartado sólo se extrajeron algunos de los ejemplos del tipo de prendas que aparece en los cinco libros de Silva como una especie de introducción para conocer la 
riqueza textil que guarda el resto de los pasajes. Cada uno de ellos se analizará con base en la función que presente en las obras, desde las descripciones más sencillas, hasta las situaciones en que generen acciones bélicas, amorosas, festivas, momentos de enredo y de lamento, así como la conexión que haya en los diseños de las parejas sentimentales.

\subsection{Telas, encajes, bordados e hilos: los tejidos}

Para confeccionar un traje se necesitan dos elementos base, el hilo y la tela, el primero para unir, el segundo para cubrir. A partir de éstos, los diseñadores y modistas agregaban un sinfín de elementos al atuendo con la intención de destacar y sobresalir de entre las demás composiciones textiles que existían, para ello colocaban listones, perlas, encajes y demás adornos, a fin de armonizar todas estas características con el uso y la función que se le daba al vestido; de esta forma, no sólo se obtenía un diseño único, sino que, en relación al motivo de su creación, adquiría mayor relevancia al portarlo.

Sin embargo, antes de agregar estos adornos era necesario conocer todos los aspectos del tejido: calidad, color, dureza, tipo, textura, etc., con el propósito de considerar qué ornamentos podían ir con cada tipo de tela, no sólo por las regulaciones, ya mencionadas anteriormente, en las leyes suntuarias, sino por la combinación de tejidos y la apreciación de paños con ciertos adornos metálicos, además de la delicadeza de algunos al

llevar piezas de mayor peso como broches, que podían rasgar la tela o tejidos que no se podían combinar entre sí, por el color y la textura. 


\subsubsection{Categoría de los tejidos ${ }^{84}$}

Se debe considerar que "la adaptación técnica hispana o la imitación de la producción textil peninsular a las corrientes de producción y modas europeas originaban la aparición de tejidos de producción hispana, pero con denominaciones europeas" ${ }^{85}$ esto ocasionaba la duplicidad de telas con nombres parecidos como brocado y brocatel que se diferenciaban por la baja calidad de los hilos. Esta reproducción de telas produjo la aparición de más géneros, que se fueron incluyendo en los inventarios conforme la gente exigía modelos nuevos. Esta búsqueda de innovación responde a la necesidad de la sociedad de estar "a la moda" ${ }^{86}$, como una petición de ponerse al día con los diseños nuevos provenientes del extranjero, lo cual requería de "sastres especializados" ${ }^{\text {87 }}$ para cubrir la demanda textil que requería cada prenda, tanto para hombres como para mujeres, e inclusive, para el sector infantil. Esto obligó, en un primer momento, a llevar una especie de control sobre las telas que entraban y salían de España, con el propósito de conocer los gustos de los sectores más privilegiados para satisfacer sus necesidades; así al registrar cada paño, se creaba un catálogo internacional.

Basándose en esas anotaciones, así como en los impuestos de trajes, libros de cuentas y testamentos, se tuvo conocimiento de los tipos de telas empleados para la confección de atuendos. A partir de ellos se realizaron especies de diccionarios en donde se

\footnotetext{
${ }^{84}$ Para establecer una clasificación de los tipos de tejidos existentes en la Edad Media, fue necesario indagar en los registros históricos, jurídicos y literarios que se conservan en archivos, bibliotecas y museos, así como obras digitalizadas que por motivos de conservación no pudieron ser consultadas de forma física.

${ }^{85}$ María Martínez Martínez, La industria del vestido en Murcia (siglos XIII-XV), Murcia, Universidad de Murcia, 1988, p.145.

${ }^{86}$ Tomás Puñal Fernández, "El trabajo de los paños, elaboración y transformación en el siglo xv: modelos de producción y jerarquización en el eje Burgos-Madrid-Toledo", Anuario de Estudios Medievales, 48/1, enerojunio 2018, p. 288. ISSN 0066-5061, https://doi.org/10.3989/aem.2018.48.1.09

${ }^{87}$ Idem.
} 
registraron todas las referencias de los tejidos extraídos de la literatura y registros históricos.

Una de las primeras investigadoras es Jesusa Alfau de Solalinde ${ }^{88}$, quien en su Nomenclatura de los tejidos españoles del siglo XIII, recoge de forma general 176 palabras textiles, que no agrupa en ningún formato, sólo las coloca de forma alfabética, da su etimología, una breve definición y un ejemplo. En seguida aparece el estudio de María del Carmen Martínez Meléndez, cuyo título Los nombres de tejido en castellano medieval, acopia 132 tipos, que categoriza en 7 apartados: 1) tejidos de lana, 2) tejidos de seda, 3) tejidos de lino, 4) tejidos de pelo de cabra, mixtos, algodón, cáñamo y estopa; 5) tejidos elaborados con diferentes materias primas; 6) tejidos documentados en textos aragoneses y 7) tejidos no identificados. Para cada término remite a Alfau (si es que ella también lo recoge), al Tesoro de la lengua y al Diccionario de autoridades. Da una breve explicación del periodo histórico y coloca varios ejemplos de diferentes obras, tanto históricas como literarias.

\footnotetext{
${ }^{88}$ Jesusa Alfau de Solalinde, Nomenclatura de los tejidos españoles del siglo XIII, Madrid, Anejos del Boletín de la Real Academia Española, (XIX), 1969. Los 176 nombres que recoge son: aboxuila, aboyuilla, affeytado, albadén, albornoz, alcotonía, alholla, alquice, ambray, anglatera, arengue, Ávila, balanquín, baldoque, baragán, barradete, barrandete, beluas, bifa, bifalat, biffalarte, bisso, blanco, blanqueta, blao, blauina, bocarán, bouilla, bruía, brujas, bruneta, burel, burges, buriel, buriello, cabecoas, cabicoas, cam, camaloz, cambral, cambray, camelín, camisalium, camua, camuna, Carcasona, cárdeno, carnotense, carnotensium, cartanel, casteldum, casteldún, çeçir, celestre, celicio, cendal, cicatrón, ciclatón, çisclatón, coco bistinto, contrafecho, cuerda, chalons, chastel, destampas, devarado, diaspre, dibet, dicamua, doay, dovarada, ensay, ensayez, escanbie, escarín, escarlata, esclatón, escloa, esembrún, estamenna, estampas, estanford, estandfort, estopa, esamín, frisa, fustán, galabrún, galambran, gante, gerca, gotado, grana, inglés, ipre, jacinto, jaspe, leste, letia, lienzo, lila, lino, longamarca, luca, llana, mabuga, mabura, malinas, marbí, márfaga, mezclado, molfán, mompesler, moret, mosterol, naranje, ontaria, orofrés, panno, papelingas, pardillo, pardo, parelingas, paressina, partenes, petabino, picote, piffalarte, pimparel, pitarún, plano, plumas, polímita, pórpola, pres, preta, prieto, queça, rançán, raz, recambort, rems, roan, rosada, rosset, sanguina, santomer, sayal, scutulado, seda, segoviano, silicio, simitel, sirgo, suerte, suria, tarar, tela, terliz, tinto, tiritana, tornay, trías, ualanchinas, valenciana, veluz, verde, verdescur, viadiello, viado, violet, xamet, ymbres, yncola, ypre, ysembrum, çafrín.
} 
El estudio más reciente pertenece a Miguel García Herrero ${ }^{89}$, Los tejidos en la España de los Austrias. Fragmento de un diccionario, quien reúne 200 términos y los divide en 6 categorías: 1) sedas; 2) lanas; 3) lencería; 4) mixtos; 5) bordados, recamados y labores de adorno y 6) varios. A diferencia de las dos anteriores, introduce costos de producción, formas de tejer, medidas de vara e imágenes.

Estos tres investigadores son los especialistas ${ }^{90}$ en el estudio y la clasificación de los tejidos a partir de la Edad Media y se consultarán para proponer una primera clasificación de los tejidos en los libros de caballerías, género en el que aparece un gran número de referencias a telas de España y del resto del mundo y que puede contribuir a la aparición de nuevos géneros.

\footnotetext{
${ }^{89}$ Miguel García Herrero, Los tejidos en la España de los Austrias. Fragmento de un diccionario, Madrid, CEEH, 2014. Las 200 telas que cataloga son: Seda, terciopelo, felpa, piñuela, aceituní, ceutí o cetí, altibajo, tirela, raso, espolín, damasco, gorgorán, gurbión, perpetuán, chamelote, brocado-raso, brocatel, tabí, lama, buratos, estameña, anafalla, tercianela, capichola, mantos, tafetán, rayadillo, ormesí, tiritaña, sarga, velillo, esterilla, albangala, lana, albornoz, anascote, barragán, bayeta, bernia, buriel, caña, carisea, chamelotón, cordellate, droguete, escarlatín, esparragón, espolín, espumilla, fernandina, filderretor, filichin, florete, frisa, grana, guirnalda, imperialete, jerguilla, lamparilla, lanilla, malacuenda, márfega, momperado, palmilla, palomilla, peceta de Aragón, Pedro López, peldefebre, pelo de camello, peña, peñasco, resolea, sarga, sayal, sempiterna, silicio, telilla, trilla, lencería, lienzo, adataide, amburgo, angeo, angulema, arliense, aroca, arpillera, balegate, batista, beatilla, belfaza, bierzo, blancarte, bocací, bocadillo, bocarán, bofetán, bombasí, bramante, Bretaña, brin, buenbatido, calicut, cambray, caniquí, capa-de-rey, catalarraus, cava, cazas, cernadero, cerrón, clarín, contray, cotanza, cotonía, crea, crisol, damasquillo, damisela, descanso, Diego Giles, dorete, dublión, Escocia, espumilla, esterlín, estopa, estopilla, estrella, florete, Galicia, gante, garra, gasa, genovisco, guingao, holán, Holanda, hoandilla, humaina, india, lorenzana, luintín, llantés, malacuenda, mandil, margas, matinohe, mauro, melinge, menaje, mitán, morlese, paño de rey, parises, peñasco, percalúe, pincel, pita, platilla, precilla, rabiancho, raniz, racilla, ribera, ruán, saca-bocado, Santiago, sarampolión, silesia, sinabafa, telillas, tomadillo, tramado, ventanillas de Madrid, zamalo, zamorano, mixto, bayetilla, borlón o borloncillo, brocatillo, catalufa, cristal, bordado, recamado, labores de adorno, abalorio, acuchillado, colchado, entorchado, faja, franja, gandujado, molinillo, pasamano, pino de oro, punta y encaje, fustán, picote, picardía, bancal.

${ }_{90}$ Existen otros trabajos relevantes sobre la vestimenta desde la Edad Media, pero no profundizan en el estudio de las telas, sino en la forma de las prendas y los colores. Véase: Carmen Bernis, Trajes y modas en la España de los Reyes Católicos. I. Las mujeres, Madrid, CSIC, 1978; Carmen Bernis, Trajes y modas en la España de los Reyes Católicos. II. Los hombres, Madrid, CSIC, 1979; Auguste Racinet, The complete costume history, (2 vols.), Taschen, Köln, 2012; Matthäus Schward, The first book of fashion, ed. De Ulinka Rublack and Maria Hayward, London, Bloomsbury, 2015; Ulinka Rublack, Dressing up. Cultural identity in Renaissance Europe, Oxford, Oxford University Press, 2010.
} 


\subsubsection{Tejidos}

De acuerdo a las clasificaciones dadas por los anteriores investigadores y considerando las telas que se mencionan en los libros de caballerías, la propuesta de categorías para esta investigación es la siguiente:

Tejidos de gala: Sedas

Brocado

Raso

Terciopelo

Lino

Xamete

Tejidos de color: Escarlata

Carmesí

Tela de oro

Tejidos de piel: Chamelote

Armiño

Cebellina

Para realizar la clasificación anterior se tomaron en cuenta varios aspectos como el material, la textura, el grosor, el estampado y la mezcla de materiales para telas especiales, tomando en consideración los ejemplos hallados tanto en los libros de Feliciano de Silva, como en los demás títulos caballerescos y otras obras del periodo que se analiza.

\subsubsection{Base del tejido}

De acuerdo con Herrero García, cuatro son las bases para la formación de las telas: seda, lana, lino y algodón ${ }^{91}$, a partir de las cuales se crean una infinidad de tejidos en los que se considera, primordialmente, la textura, el peso, el color y los adornos, además se debe agregar la importancia de la calidad, la cual es visible con sólo mirarla y aún más al tacto, por lo que será relevante el anhelo de las clases bajas por acceder al uso de las telas finas,

\footnotetext{
${ }^{91}$ Miguel Herrero García, op. cit., p. 21.
} 
ya prohibidas en las Leyes suntuarias, pero no en el deseo de la población, la cual exigirá a los pañeros la existencia de una producción para el "consumo popular" 92 que tenga características semejantes a las de alto costo, pero a menor precio. Esto ocasionará no sólo la aparición de nuevos tipos de tela, sino la presencia de un nuevo sector comercial, los identificadores de paños falsos.

\subsection{Brocado (fig. 35)}

El más caro de los tejidos, por su composición de seda entretejida con oro y plata ${ }^{93}$ que al unirse las urdimbres crea una especie de bordado sobre la tela, aparece como una tela ajustable a todos los personajes de los libros de caballerías porque al ligarse los hilos con las piezas de metal crea una gran variedad de imágenes: flores, figuras geométricas, animales, letras, etc, que permanecen a la vista de los demás, según la longitud de la vestimenta: "Traía vestida una ropa de brocado que cuatro braças le arrastraban por el suelo" (Lisuarte de Grecia, VII). Lo usan todas las clases sociales, desde la monarquía: "La una venía vestida de una ropa de brocado verde con un tocado de muchos rubíes" (Amadís de Grecia I, LXXII), hasta sirvientes: "vieron una gran barca que seis marineros con remos guiavan; todos ivan vestidos de brocado muy rico". (Amadís de Grecia I, [L]VII)

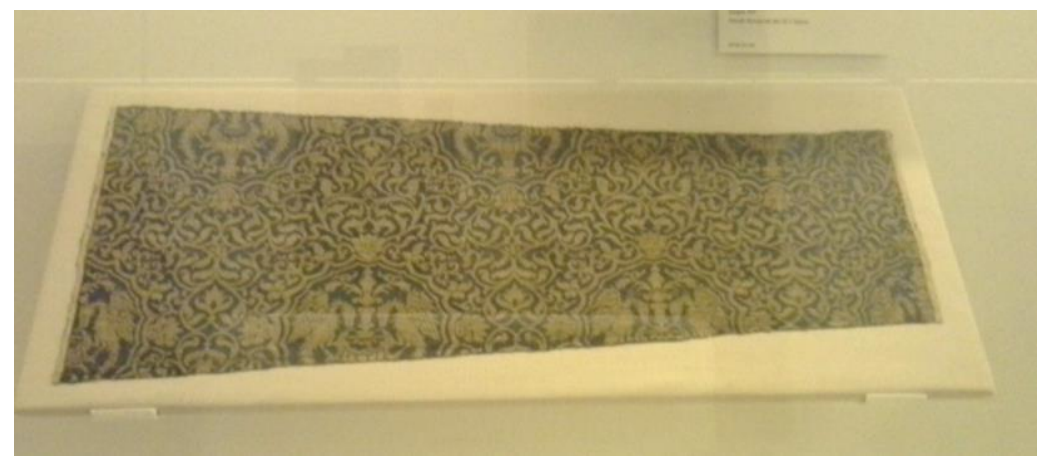

Fig. 35. Brocado de raso y seda (1500)

Museo del Diseño de Barcelona

\footnotetext{
92 Miguel Gual Camarena, "Para un mapa de la industria textil hispana en la Edad Media", Anuario de estudios medievales, $\mathrm{N}^{\circ} 4,1967$, p. 116.

${ }_{93}^{93}$ María del Carmen Martínez, op.cit., p. 257.
} 
Es de las principales telas para llevar sobre las armas: "En esta forma él iva todo armado de unas fuertes hojas de azero y de la cinta para arriba sobre ellas una ropa de brocado carmesí muy rica" (Amadís de Grecia II, CXXIV), al igual para cubrir la parte inferior de los justadores: "De la cinta para abaxo traía unas como cubiertas de azero con sobrecubiertas de brocado rico" (Amadís de Grecia II, CXXIV). Además de que la mayoría de los combatientes se visten del mismo color y esta tela es la que más se utiliza para las justas: "Ivan alderredor d'ellos y de Amadís de Grecia dozientas mugeres de la reina con ropas de muy rico brocado indio sobre ricas armas" (Amadís de Grecia II, CXXIII). Por último, también se utiliza para la fabricación de enseres para el camino: "un cobertor de brocado que cuatro cavallos traían" (Lisuarte de Grecia, LXXIX); "unas andas que traían cubiertas con un cubertor de brocado muy rico (Amadís de Grecia I, XXXV).

Se ha visto la practicidad de esta tela para la elaboración de diversos elementos de casa, viaje, bélico y gala por la estructura del brocado que permite crear varios diseños y adecuarlos a la situación. En practicidad permite que aparezca en todos los libros de caballerías, ya que todos los justadores y damas portan algún accesorio de brocado, desde un vestido, hasta un bonete o manto.

\subsection{Seda ${ }^{94}$ (fig. 36)}

Es el término general que designa la base de todo tejido y de ella misma. Su función principal era establecer la base para crear los tejidos como el brocado, el terciopelo o el raso, pero también para hacerse a sí mismo una tela lujosa y delicada por la textura lisa de su superficie.

\footnotetext{
${ }^{94}$ Más de 500 documentos registran este tejido, principalmente en los libros de cuentas y en la mayor parte de la literatura española de los siglos XVI y XVII aparece un personaje con alguna prenda de este material o que hace alusión a los sederos. Esta es la única tela que aparece en todos los libros de caballerías hispánicos, desde el Amadís de Gaula, hasta la última parte del Espejo de príncipes y caballeros.
} 


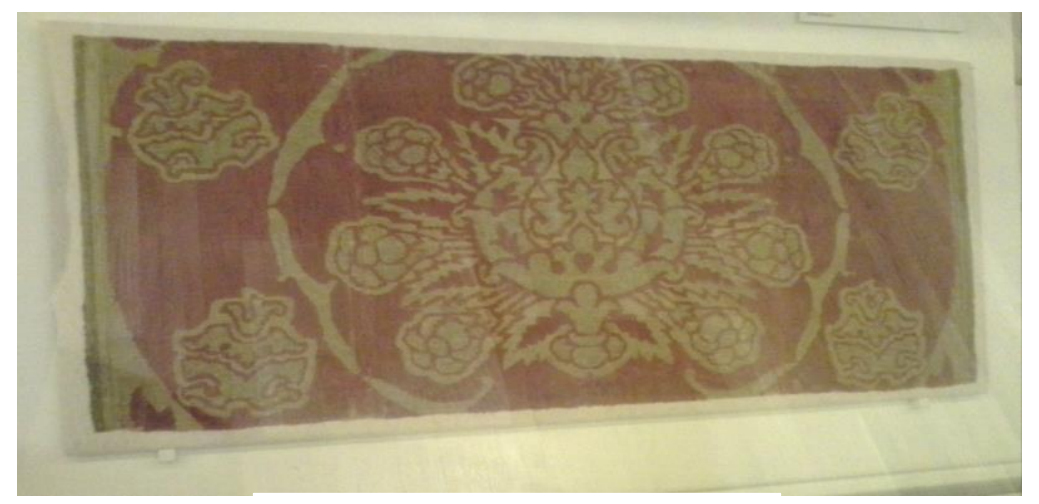

Fig. 36. Tejido de seda y oro (1475-1525)

Museo del Diseño de Barcelona

Las primeras apariciones de la seda en las obras de Feliciano de Silva, van acompañadas de la vestimenta de luto:

estava una dueña vestida de paños negros de seda e otra corona de oro de la mesma forma en la cabeça. (Lisuarte de Grecia, II)

donde hallaron a la puerta de una sala a la reina Oriana vestida de paños de seda negros, que por la absencia del rey Amadís no se quiso ella vestir más ricamente (Amadís de Grecia I, XLVII)

toparon una dueña encima de un palafrén vestida de paños de seda negra (Amadís de Grecia I, XLV)

En ellos no se introducen más detalles para lucir, puesto que el motivo de su uso es por una muerte, ya sea física o sentimental. Sin embargo, en ejemplos posteriores ya habrá más variedad de telas: "el Soldán le hizo luego cortar muchas ropas de oro y seda y mandola meter en su cámara" (Amadís de Grecia II, LXXXVII). Además de aludir al color: "Pusiéronse sendas ropas al trage de Sarmata, de seda verde con muchos caireles de oro" (Florisel de Niquea III, XVIII). Con esta combinación de telas y colores empieza a experimentar Feliciano para la combinación de telas, no sólo para hacer nuevas creaciones, sino para establecer nuevos modelos de uso de la tela, a través de los bordados entre colores metálicos y sombríos. 


\subsection{Terciopelo ${ }^{95}$ (fig. 37)}

Sin duda alguna, el terciopelo es de los tejidos más utilizados durante la Edad Media, porque es "el rey de los tejidos de las sedas" 96 , su textura, pelo suave y velludo da origen a su nombre, "tres clases de hilo" $" 97$. Su superficie es adecuada para todo tipo de adornos, desde broches de metal, hasta perlas y encajes. Los colores más pedidos eran: carmesí, negro, azul, verde, morado y encarnado. ${ }^{98}$

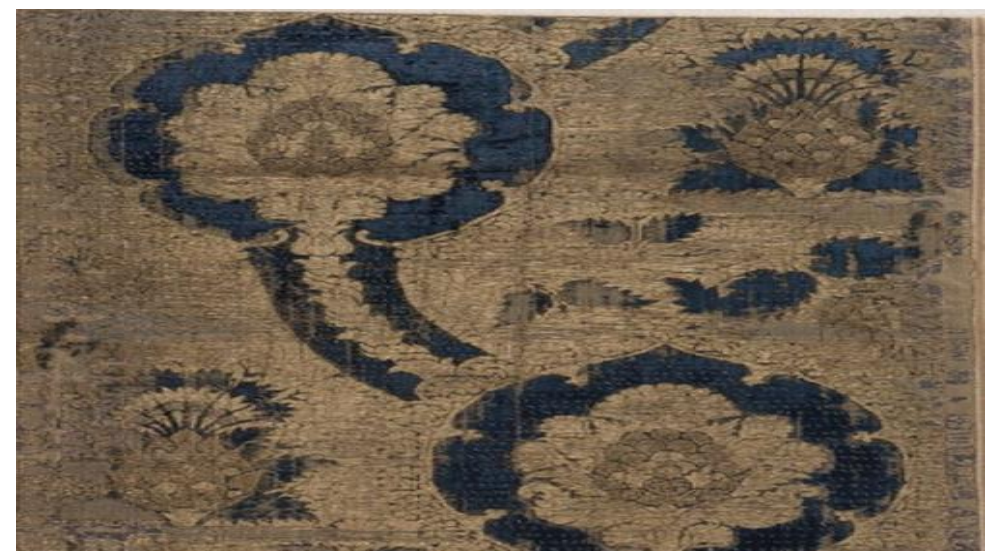

Fig. 37. Terciopelo, oro y seda (1450-1500)

Museo del Diseño de Barcelona

Feliciano de Silva presenta una evolución en el uso de este material en sus obras, ya que en el Lisuarte de Grecia no hay ninguna prenda elaborada con este material. Posteriormente, en el Amadís de Grecia II, solo hay un ejemplo: "Venían armados de una armas indias y paramentos y sobreseñales de lo mismo de terciopelo indio, todas sembradas de arcos de oro" (Amadís de Grecia II, CVI); a partir de esta prenda, considero que el autor pensó en la falta de este tejido en sus obras, pues en muchos títulos del género ya

\footnotetext{
${ }^{95}$ Hasta 1615 hay cerca de 400 obras en que aparece, sin considerar que varias de ellas se tratan de libros de cuentas e inventarios que recopilan información sobre las prendas de vestir de la monarquía, así que este número es sólo una parte de la gran cantidad de prendas fabricadas con este material. En los libros de caballerías aparece en Palmerín de Olivia, Baldo, Flor de caballerías, Policisne de Boecia, Arderique, Polindo, Febo el troyano, Espejo de príncipes y caballeros, Florindo, Amadís de Gaula, Sergas de Esplandián, Corónica de Adramón, Cirongilio de Tracia, Lepolemo.

${ }^{96}$ Miguel Herrero García, op. cit., p. 33.

${ }^{97}$ Idem.

${ }^{98}$ María del Carmen Martínez, op. cit., p. 364.
} 
presentaban interesantes diseños con el terciopelo, así que debió buscar nuevas confecciones e introducirlas en sus obras posteriores. Así, para el Florisel de Niquea ya se hallan siete:

Con el ornamento de una ropa de oro que vestida traía, bordada de arcos de terciopelo verde, con gruessas perlas por ella bordados (Florisel de Nique I-II, XXXVII)

Una ropa de las que sus donzellas traían se vistió, que de terciopelo azul sembrada de mayos de oro era (Florisel de Niquea I-II, XLIII)

Las trenças y ebillas d'ellas con sobreseñales de terciopelo verde, bordadas con harpías en ellas (Florisel de Niquea I-II, LIV)

Cada uno de los tres ejemplos anteriores presenta un diseño diferente en armonía con el oro. Este manejo de los colores, base oscura y adornos brillantes es una estrategia de los autores para lograr atraer la atención de los lectores y, en el plano ficcional, la de los propios personajes, al establecer imágenes relacionas con el amor en las prendas. De esta manera, las arpías bordadas, más que adornos, son elementos de retención de la vista, para lucir más la prenda y cautivar la mirada de la dama. Además, es ejemplo de vestimenta lujosa, similar a algunas de la monarquía. ${ }^{99}$

\subsection{Escarlata (fig. 38)}

Sobre la escarlata, se le consideraba una tela lujosa, de base de lana cuyo color hace referencia a su nombre. Con ella se vestían "los grandes príncipes” (Tesoro de la lengua). El $C O R D E^{100}$ registra su primera aparición en una carta de venta del Reino de Castilla

\footnotetext{
99 En el caso de Isabel la Católica, se conoce la compra de varias varas de terciopelo para la confección de cojines, bonetes, sayas, gualdrapas, etc., en las que gastaba entre 2000 y 4000 maravedís.

100 En el periodo que se analiza aparecen 203 referencias tanto en obras de prosa, teatro y documentos jurídicos. En los libros de caballerías que aparece son Sergas de Esplandián, Palmerín de Olivia, Primaleón,
} 
(1223) en la que se menciona un manto de escarlata; sin embargo, hay una referencia anterior a ésta, entre 1076-1094 que muestra un "trapo grueso et de scarlata et de galabrun" 101 .

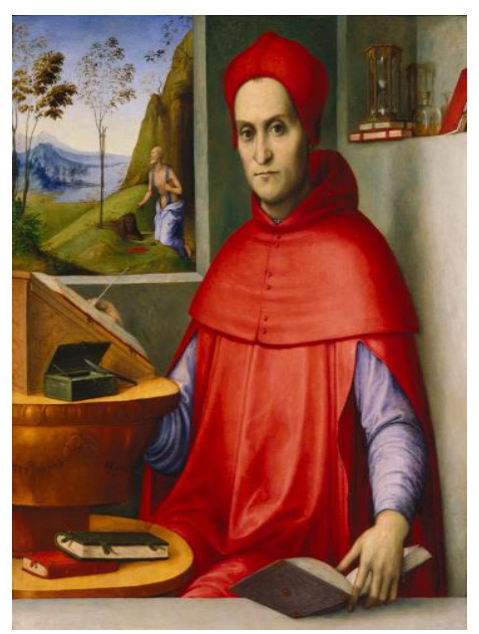

Fig. 38. Cardenal en su estudio (1519) Atribuido a Lorenzo Costa

Lleva puesta una loba de escarlata.

El registro obtenido lo coloca como un paño muy recurrente para los miembros de la corte, quienes lo utilizaban para la fabricación de cobertores, capas, vestidos, calzas, etc. En las obras de Feliciano de Silva hay ocho apariciones, en tres como tejido de ropa:

El hermoso doncel Lisuarte, vestiéndose muy ricamente de una ropa de escarlata muy fina (Lisuarte de Grecia, VI)

Vieron luego salir a Alquifa la donzella con nueve doncellas con muy ricas ropas de escarlata (Lisuarte de Grecia, XXXII)

Salieron de la nao nueve donzellas con ropas d'escarlata muy finas (Amadís de Grecia I, XXXVIII)

En tres se menciona en mantos para salir:

El Cavallero de la Vera Cruz se levantó cubriéndose un manto d'escarlata para irse (Lisuarte de Grecia, XLVI)

Belianís de Grecia, El caballero del Febo, Platir, Flor de caballerías, Clarián de Landanís I, Clarián de Landanís II, Policisne de Boecia, Febo el troyano y Lanzarote del Lago.

${ }^{101}$ María del Carmen Martínez, op.cit., p. 76. 
Cubriéndose con un manto de escarlata, tomando su espada salió muy passo (Lisuarte de Grecia, LVIII)

Otro día ellos se vistieron muy ricamente cubriéndose dos mantos d'escarlata (Lisuarte de Grecia, XCVI)

Y otras como tejido que al quitárselo deja al descubierto una marca de nacimiento:

Llamando a la donzella Fradamela, se descubrió un manto d'escarlata que vestido traía (Amadís de Grecia I, XXVIII)

Y desnudando al doncel una aljuba d'escarlata que vestida traía le mostraron una espada que en los pechos el doncel tenía (Amadís de Grecia I, II)

Incluso en el Quijote, aparece una parodia sobre el modo de llevar esta tela durante los recibimientos de los caballeros: "al entrar en un gran patio llegaron dos hermosas doncellas y echaron sobre los hombros a don Quijote un gran mantón de finísima escarlata, y en un instante se coronaron todos los corredores del patio de criados y criadas de aquellos señores, diciendo a grandes voces: - ¡Bien sea venido la flor y la nata de los caballeros andantes!"102, por ser un color llamativo que atrae la mirada de los demás personajes.

\subsection{Carmesi $1^{103}$ (fig. 39)}

Perteneciente a las telas de base de seda, por su color rojo se usaba, principalmente, para las prendas eclesiásticas. También es recurrente hallar enseres para la cama, ropa y sobrevestes para las armas. La primera referencia indica que aparece en la Gran conquista de ultramar: "una ropa de carmesí traía vestida sobre la loriga, con aljófar de muy ricas labores é extrañas, en que estaban figuradas bestias é aves é flores de muchas maneras" (Gran Conquista de ultramar, 174 a, lín.19) Aunque su presencia es menor en comparación con la

102 Miguel de Cervantes, Don Quijote de la Mancha, México, Real Academia Española/ Asociación de Academias de la Lengua Española, 2005.

${ }_{103}$ Aparece en Baldo, Floriseo, Polindo, Palmerín de Olivia, Platir, Flor de caballerías, Policisne de Boecia, Arderique, Febo el troyano, Claribalte y Florindo. 
escarlata, pues se registran 60 apariciones en el contexto histórico que se estudia, su color permitirá que destaquen los detalles que sobre él vayan bordados; por ejemplo, en la loriga antes mencionada, llama la atención el contraste del aljófar, los animales y el rojo; lo mismo ocurre en el Amadís de Grecia, única referencia que aparece en las obras de Silva: “Tendió la falda de un manto de carmesí, que vestido tenía, sembrado de mucha y rica pedrería" (Amadís de Grecia II, CXXIV). La utilización de la pedrería incrementa el valor de la prenda, no sólo por tratarse de una especie de seda, sino porque desde el siglo XV ya era considerada como una tela fina al aparecer en varios inventarios en los que se describe la vara de esta tela a 250 maravedís, un alto precio para la época.

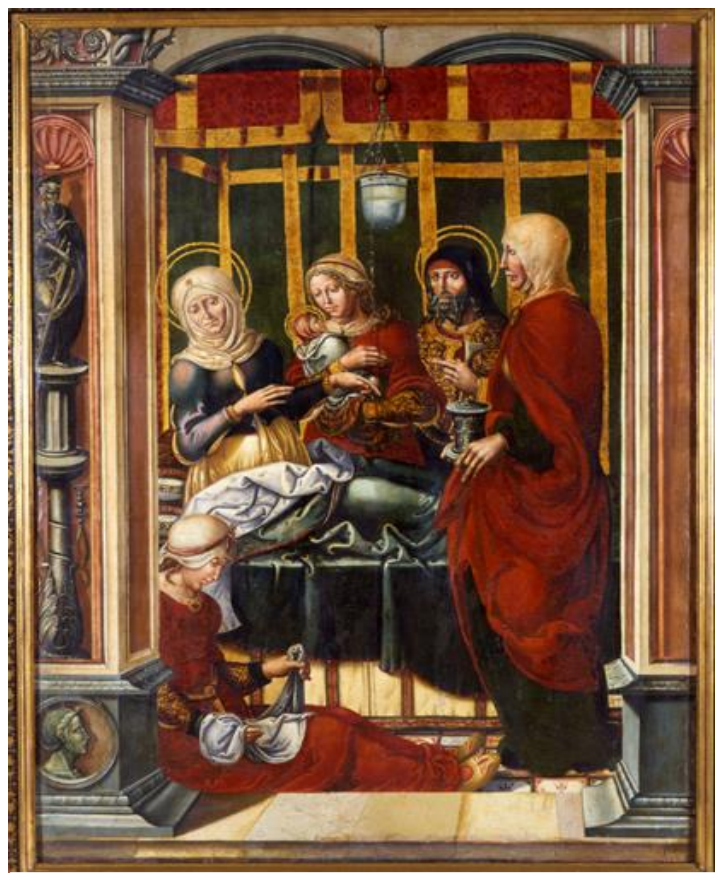

Fig. 39. Nacimiento de la Virgen (1515-1519) Maestro de Sijena, Museo de Huesca. Dama con manto carmesí.

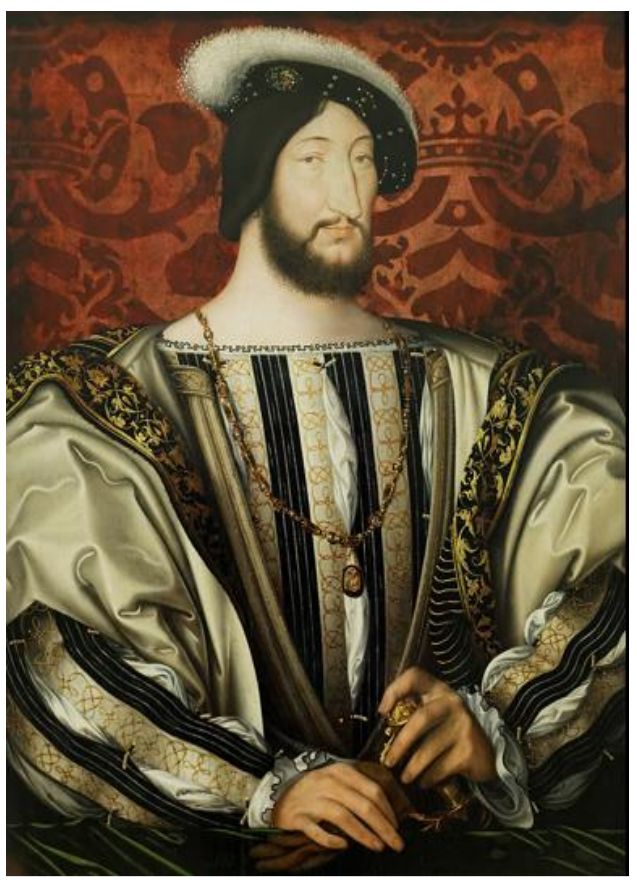

Fig. 40. Francisco I de Francia (1530) Jean Clouet, Museo de Louvre. Ropa francesa de tela de oro. 


\subsection{Tela de oro ${ }^{104}$ (fig. 40)}

De manera general se clasifican todas las denominaciones que remiten a la tela más un material (oro, plata, red). Su entramado le da apertura para ubicarse dentro de las cuatro anteriores bases: seda, lino, lana y algodón, puesto que, al ser parte de las mismas bases, sólo se le agregan los hilos que requiera para convertirse en un nuevo tejido. En este caso, se trata de hilos de oro que incrementan el costo de la prenda: "Una infanta, a sus ojos la más hermosa que visto avía, vestida de una ropa de oro muy extrañamente labrada" (Amadís de Grecia I, XV). El uso de la tela de oro remite al orofrés por ser el único que está tejido sólo con oro, así que este término es el más cercano a los ejemplos hallados, ya que no presentan ningún otro elemento con el que se pueda relacionar con otros tejidos: "Estava vestida de una ropa toda de oro muy rica" (Amadís de Grecia I, XXIX). El lujo de este material se puede deducir del costo de producción, oscilaba entre los 2000 y 3000 maravedís. Su mayor registro se halla en los inventarios de Isabel la Católica. ${ }^{105}$

\subsection{Jamete ${ }^{106}$}

Una tela de textura maravillosa por tener una base de seda satinada, fue considerada de gran lujo por los efectos que el sol producía sobre ella:

El panno de la tienda era rico e sobeio

era de seda fina de un xamet uermeio

como era tecido ygual mente pareio

quando el sol rayaua luzia como espejo

(Alexandre, estrofa 2377)

\footnotetext{
104 Aparece en 350 obras. En los libros de caballerías se localiza en los siguientes títulos: Corónica de Adramón, Polindo, Baldo, Belianís de Grecia, El caballero del Febo, Palmerín de Olivia, Flor de caballerías, Clarián de Landanís II, Policisne de Boecia, Febo el troyano, Espejo de príncipes y caballeros y Florindo.

105 Véase: Cuentas de Gonzalo de Baeza, tesorero de Isabel la Católica (1492-1504), T. II, ed. de Antonio de la Torre, Madrid, CSIC, 1956.

${ }^{106}$ Se conocen 47 referencias en algunas obras de la época; sin embargo, a pesar de ser un tejido valioso, en los libros de caballerías es muy poca su presencia: Amadís de Gaula, Baladro del sabio Merlín, Clarián de Landanís I, Clarián de Landanís II, Lanzarote, Baldo.
} 
Su superficie se adaptaba a cualquier adorno, desde hilos de oro, hasta pedrería. En el caso de los libros de caballerías, es un material que determina una condición social elevada por el tipo de prendas y el color con el que se confeccionan. Las más recurrentes son las tonalidades rojas y azules: "Estas veinte y cuatro venían de xamete indio bordadas sus ropas de oro" (Amadís de Grecia II, LII), tanto para mujeres como para "Hombres vestidos todos de xamete bermejo" (Amadís de Grecia II, LVIII). Una característica será la utilización de esta tela para la confección de trajes en grupo, portados en desfiles y justas para atraer más la mirada de los espectadores. Pero también se necesitará para crear trajes especiales para el caballero protagonista: "Hizieron a un maestro de ropas que traían que hiziesse a Amadís de Grecia una ropa [d]e xamete indio bordada de trenas de oro", (Amadís de Grecia II, LXXXVII) por tratarse de un disfraz con el que debe permanecer mucho tiempo, así que la resistencia de la tela es importante en ciertos pasajes.

\subsection{Pieles ${ }^{107}$ (figs. 41-43)}

La más recurrente de las pieles es el chamelote o camelote, procedente de Oriente, estaba hecha con pelo de camello o cabra ${ }^{108}$. De este aparece un tipo de menor calidad denominado "camelín"109, cuyas fibras se mezclaban con otras materias textiles, lo cual permitía una identificación más fácil para evitar falsificaciones de pieles.

Al igual que el terciopelo, la presencia de tejidos de piel es mínima en las dos primeras obras de Feliciano de Silva, Lisuarte de Grecia y Amadís de Grecia, en donde sólo aparece un ejemplo: "Traía delante sí un lío cubierto de un chamelote bermejo"

\footnotetext{
${ }^{107}$ Se tiene registro de su presencia en 100 obras de la época, principalmente, en inventarios de bienes. En los libros de caballerías sólo se localiza en: Flor de caballerías, Baldo, Amadís de Gaula y Florindo.

${ }^{108}$ Posteriormente, se realizará de fibras sintéticas que asemeje la textura del pelo del camello.

109 Jesusa Alfau, op. cit. p. 70.
} 
(Amadís de Grecia I, LXII). Generalmente, lo visten los gigantes como parte de su atuendo a juego con sus armas y algunos caballeros encima de su armadura.

En el caso de las damas, el gusto por las pieles es mayor para lucir en los festejos, pues se colocan como parte de la vestimenta para adornar mantos, cuellos y gorros, además de servir como forro para las prendas: "Una ropa de carmesí raso tan larga que por el suelo dos braças arrastrava, toda sembrada de mayas de oro aforrada en peñas armiñas con una bordadura de perlas" (Amadís de Grecia II, LXX[X]IX). También se utiliza la marta como forro para las prendas: "Niquea, que con poco sosiego y mucho cuidado estaba, se levantó y tomó una ropa de brocado aforrada en martas" (Amadís de Grecia II, XC[I]). Sin embargo, en las cuatro partes del Florisel de Niquea hay una mayor presencia, especialmente de los armiños.

El armiño, la cebellina, la marta y el chamelote son los tres tipos de pieles que adornan las prendas de los personajes caballerescos, tomados de las vestiduras monárquicas, que, en esa época, decoraban las orillas de las capas, debido al contraste que se producía entre lo blanco del armiño con el rojo o azul del terciopelo. De esta forma, a pesar de su poca presencia, es notorio el contraste de colores que establece durante los festejos. 


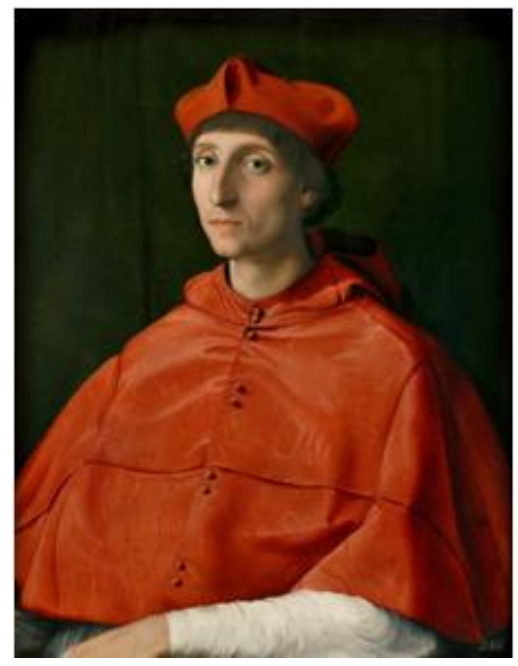

Fig. 41. El cardenal (1510-1511) Rafael, Museo del Prado

Hábito coral de chamelote de aguas.

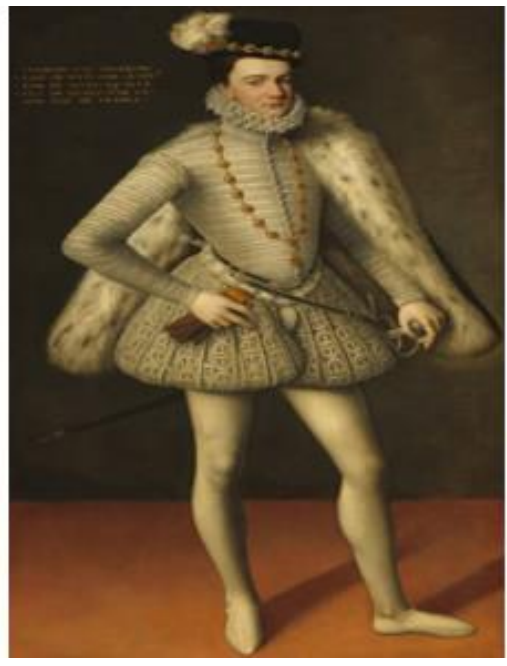

Fig. 42. Francisco de Anjou (1572) Galería Nacional de Arte, Washington Capa completamente forrada de armiño.

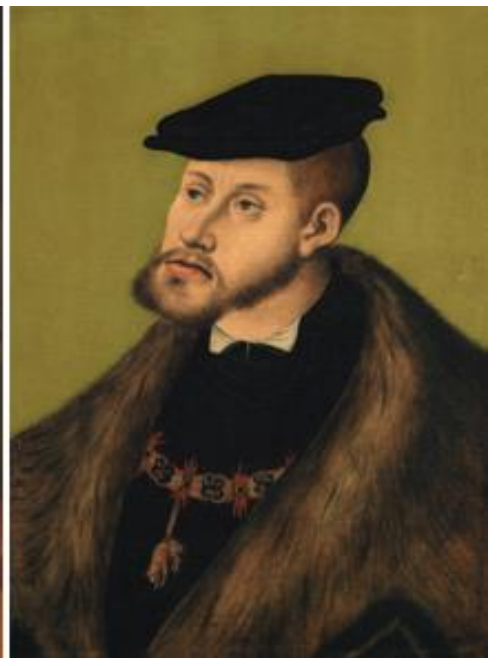

Fig. 43. Emperador Carlos V (1533) Lucas Cranach el Viejo,

Museo Nacional Thyssen-Bornemisza Cuello de cebellina en la ropa.

\subsubsection{Piedras preciosas}

Una de las características principales de un rey es su manera de vestir y calzar, pues debe reflejar ante los demás su imagen regia a través de lo que usa, sobre esto, en las Partidas de Alfonso X se dice que: "Vestiduras façen mucho conosçer a los hombres por nobles o por viles; et por ende los sabios antiguos establecieron que los reyes vestiesen paños de seda con oro et con piedras preciosas, porque los homes los pudiesen conoscer luego que los viesen a menos de preguntar por ellos" (Partidas, II, V, V). A pesar de las constantes restricciones en el uso de ciertas telas y materiales para la confección de trajes establecidas por las pragmáticas de la época, el vestido de los monarcas quedó exento de estas prohibiciones, por lo que su indumentaria podía gozar de toda clase de adornos como encajes de la más fina calidad, metales como el oro y la plata y las preciadas perlas. Sin embargo, uno de los elementos que adquirió más notoriedad fueron las piedras preciosas, presentes en la tela, el calzado (fig. 44) y las joyas como una forma más de demostrar la posición social de quien las usaba. 


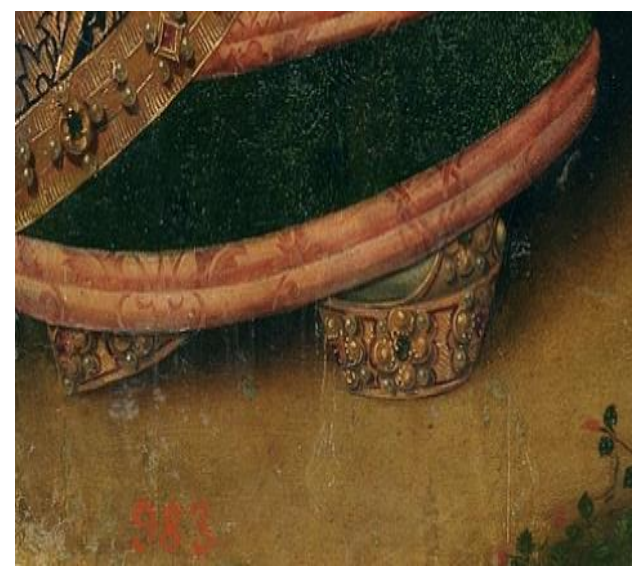

Fig. 44. La decapitación de San Juan Bautista (1490-1500) Maestro de Miraflores, Museo del Prado Chapines decorados con perlas y piedras preciosas

Desde su descubrimiento en Arabia, las Indias Orientales, Egipto, Libia, Cerdeña ${ }^{110}$, etc., las piedras preciosas se han considerado como un elemento de estudio por sus propiedades curativas, religiosas y zodiacales, vistas desde distintos ámbitos de la historia, tal como lo mencionan los diferentes autores, como san Isidoro de Sevilla, Alfonso X y Gaspar Morales, por mencionar algunos, que destacan las cualidades de cada una, así como sus virtudes maravillosas y la relevancia de su color; para conocer algunas de estas características recurrieron a los antecedentes hallados en la Biblia, por considerarse la fuente primaria para establecer una categoría referente al valor simbólico-moral que adquieren en las vestiduras sacerdotales, de la cual parten los lapidarios medievales.

\subsubsection{Las gemas en la tradición bíblica}

Los registros más antiguos que el CORDE recoge de las piedras preciosas están en el Libro de los doce sabios o Tratado de la nobleza y lealtad (1237) y en el Lapidario de Alfonso X (1250); sin embargo, la presencia de las gemas fuera de España se remonta hasta tiempos del cristianismo, en donde la recurrente referencia a éstas era para adornar las prendas de

\footnotetext{
${ }^{110}$ Alfonso X, Lapidario, Madrid, Castalia, 1997.
} 
los sacerdotes y posteriormente las de los reyes, como un mandato divino que debían obedecer. También sirvieron como elementos de construcción y decoración para los palacios.

En tres ejemplos adquieren relevancia las piedras preciosas, el primero de ellos es la ordenanza para su colocación en el efod o vestido sacerdotal de los judíos:

Harás asimismo el pectoral del juicio de obra primorosa, lo harás conforme a la obra del efod, de oro, azul, púrpura, carmesí y lino torcido. Será cuadrado y doble, de un palmo de largo y un palmo de ancho. Lo llenarás de pedrería en cuatro hileras de piedras: la primera hilera llevará una piedra sárdica, un topacio y un carbunclo; la segunda hilera, una esmeralda, un zafiro y un diamante; la tercera hilera, un jacinto, un ágata y una amatista; la cuarta hilera, un berilo, un ónice y un jaspe. Todas estarán montadas en engastes de oro. Las piedras serán doce, como los nombres de los hijos de Israel; grabadas como los sellos, cada una con su nombre, conforme a las doce tribus. (Éxodo 28:15-21) (Figs. 45-46)

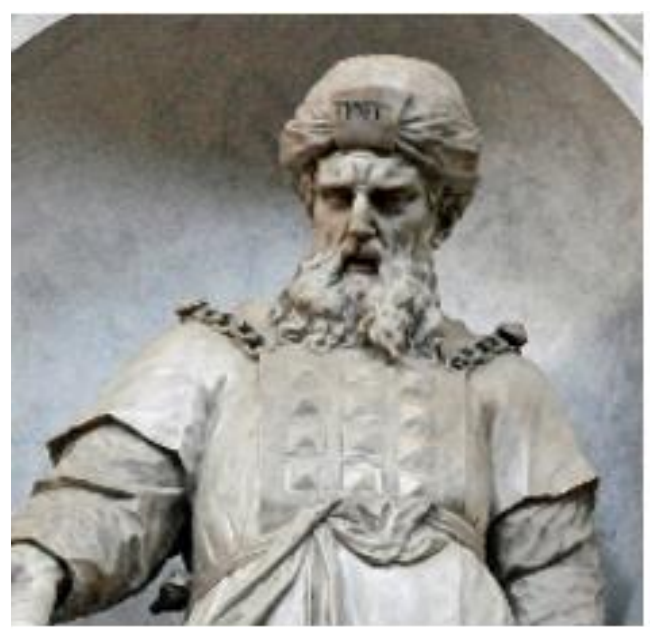

Fig. 45. Aronne in Santa Maria del Rosario (1750-51) Giovanni Maria Morlaiter, Venecia. Efod con las doce piedras.

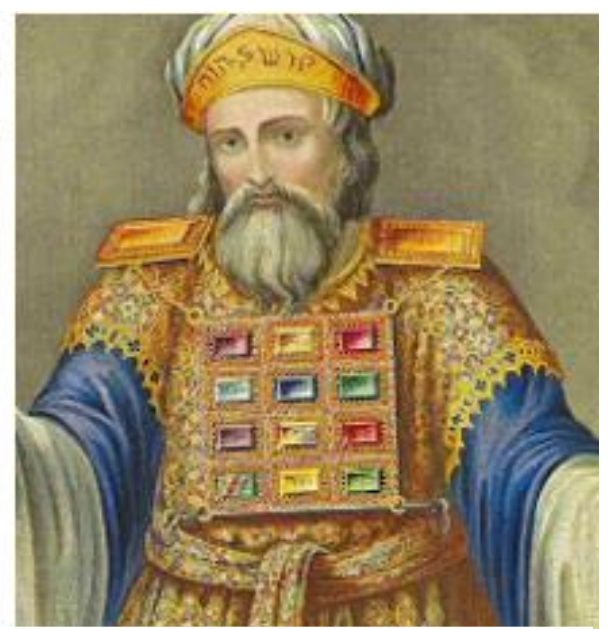

Fig. 46. Color de las doce piedras 
Más adelante, la mención de algunas de estas gemas se hace para rememorar la riqueza que poseía el rey de Tiro, pero que perdió a causa de su iniquidad:

\author{
De toda piedra preciosa \\ era tu vestidura: \\ de cornerina, topacio, jaspe, \\ crisólito, berilo y ónice; \\ de zafiro, carbunclo, \\ esmeralda y oro. (Ezequiel 28:13)
}

Por último, la utilización de las piedras preciosas en la arquitectura de la nueva Jerusalén:

El material de su muro era de jaspe, pero la ciudad era de oro puro, semejante al vidrio limpio. Los cimientos del muro de la ciudad estaban adornados con toda clase de piedras preciosas. El primer cimiento era de jaspe, el segundo de zafiro, el tercero de ágata, el cuarto de esmeralda, el quinto de ónice, el sexto de cornalina, el séptimo de crisólito, el octavo de berilo, el noveno de topacio, el décimo de crisopraso, el undécimo de jacinto y el duodécimo de amatista. Las doce puertas eran doce perlas; cada una de las puertas era una perla. (Apocalipsis 21:18-21)

Tres referentes son la base para el estudio de las gemas: en la vestidura como signo de distinción entre el sumo sacerdote, los sacerdotes y los levitas; como comparación moral para las acciones de los hombres; y como material empleado para la construcción. Todos estos se hallan en la literatura medieval y en los lapidarios, gracias a los escritores que las retomaron y las introdujeron en sus obras, de las cuales identificaron otros valores, como las propiedades curativas y la transmisión del estado de ánimo de las personas por el color de la piedra. Este y otros simbolismos de las gemas que aparecen en el corpus seleccionado se estudiarán en relación a su presencia en la vestimenta y en las joyas. 


\subsubsection{Los lapidarios medievales}

San Isidoro de Sevilla se basa en la fábula de Prometeo como "el primero que engarzó un fragmento de piedra en un hierro y se lo colocó a modo de anillo, y de aquí comenzó la existencia de los anillos y las gemas"111 para establecer el origen de las piedras preciosas. Alfonso X remite a los antiguos filósofos para conocer las virtudes que Dios ha dado a cada piedra, convirtiéndolas en una maravilla por su estado, color, facción y dureza, así como las propiedades curativas que tienen. Mientras que Gaspar Morales parte del Éxodo, en la vestimenta de los sacerdotes, cuyo pectoral debía llevar doce piedras en representación simbólica de las doce tribus de Israel, éstas eran: sárdica, topacio, carbunclo, esmeralda, zafiro, diamante, jacinto, ágata, amatista, berilio, ónice y jaspe. Ordenadas en cuatro hileras de tres piedras, cada una debía estar montada en engastes de oro y llevar grabado el nombre de la tribu que le correspondía.

Estos tres indicios tienen en común el valor de las piedras preciosas por su rareza y por las virtudes que poseen. Basándose en culturas distintas, griega y hebrea, resaltan su utilización como elemento decorativo, así como la importancia de su colocación e inscripción y demás adornos que las acompañan. A ellos se les suma el Libro de las piedras preciosas reales de Abu al-`Abbās Ahmad del siglo XIII, quien estudia veinte cinco piedras de las que destaca su precio, lo cual fue una información de interés para los comerciantes y tasadores de la época. Esta información del precio de las gemas se halla principalmente en los episodios de mercaderes que ofrecen joyas a los príncipes, como aparece en el Clarián de Landanís, pero también Feliciano de Silva introduce el costo de alhajas durante el

\footnotetext{
${ }^{111}$ San Isidoro de Sevilla, Etimologías, José Oroz Reta (ed.), Madrid, Biblioteca de Autores Cristianos, 1983, p. 279.
} 
ofrecimiento de joyas como premio en las justas: "un joyel de un diamante que valga mil daricos de oro" (Florisel de Niquea IV, I, LXXIV).

Además de los lapidarios más conocidos, aparecen otras fuentes que brindan más detalles acerca del color y la forma de las gemas en relación con algunos elementos de la naturaleza; por ejemplo, Giovanni di Antonio da Uzzano enfatiza la tonalidad que deben tener las piedras preciosa de mejor calidad, a fin de distinguirlas de entre las de menor precio. Él expresa que:

Se vuoi sapere di quanti colori sono tutte le pietre naturali, e di che figure; figura di Rubino fine, buone granella di Melagrana, bene naturali e le più sono forate $[\ldots]$ figura di buono Smeraldo si è verde, e ponlo a lato di qualunque colore verde tu vuoi, si è più verde di tutti [...] figura del buono Zaffiro somiglia buono azzurro, e trae in bianco [...] figura di buono Diamante simiglia acciajo, e lucie come vetro, e da sopra sono acutí, e taglia lo ferro; figura d'altro diamante trae in giallo, ed è simile all' altro diamante [...] figura di buona Turchiessa sa somiglia bianca colombina, e non trae luce, e quella che è diritta, si à di sotto barbe nere. ${ }^{112}$

Aunque si bien, todas éstas no aparecen en el corpus seleccionado, sí hay una abundancia de cuatro: diamante, rubí, zafiro y esmeralda, y una más que no se menciona en el ejemplo bíblico, la perla. En menor medida, aparecen otras, como el topacio, el carbunclo, entre otras, y en particular hay un ejemplo singular que hace referencia a 45 tipos de gemas, se trata del capítulo 17 del Baldo que servirá de comparación con el resto de los títulos caballerescos para contrastar el mensaje moral que su autor agrega a cada una de ellas.

Estas piedras aparecen en la mayoría de los espacios y objetos caballerescos, desde salas, tapetes, sillas, vasos y puertas, hasta en todos los complementos de la indumentaria de gala: zapatos, vestidos y joyas y en la bélica: armadura, escudo y gualdrapa.

${ }^{112}$ Giovanni di Antonio da Uzzano, La pratica della mercatura, Firenze, Giuseppe Bouchard, 1766, pp. 283284. 


\subsubsection{Las gemas en los libros de caballerías}

Si se parte de que las piedras preciosas son "gemas por ser preciadas" tal como las define Covarrubias, entonces se tiene que hacer una clasificación de los objetos en los que aparecen por importancia de uso, es decir, desde la que tiene mayor presencia en eventos, como bailes, coronaciones y justas, hasta las que son poco mencionadas en dichos objetos, por lo que se iniciará con un interesante pasaje en el que las piedras cautivan a los caballeros por su esplendor y extrañeza:

Hallaron la boca de una muy vieja cueva, la cual estava llena de hollín y de carbones. Yendo más adentro, vieron muchos yunques, martillos, crisoles, escorias, pedaços de plomo y plata. De lo cual se maravillavan y de allí entraron a otra sala, la cual estava muy bien labrada. En el suelo vieron mucho vidrio y pedaços de piedras preciosas y toques. En la techumbre estavan los cielos pintados y a la redonda $<\mathrm{e}>$ las paredes estavan cubiertas de piedras preciosas en lugar de ladrillos, adonde se veían en cada una diversas figuras, las cuales comiençan a mirar a los cavalleros con mucha diligencia. En las primeras estava la piedra acates de grandeza espantable; luego estava la piedra acopis; en la cual estavan figuradas gotas de oro. Ésta, en olio echada, hirviendo, dizen que quita el cansancio a los untados en el juego de la palestra. Tras d'éstas venían la alabastrite que nasce en el Alabastro en Egipto de varios colores con un círculo blanco. A ésta acompañava la androdamas que resplandece como oro, semejante al marfil. La asbestis tenía color de hierro que nace en los montes de Arcadia. La aspi[s]ates avía color de fuego, que se halla en el nido de las aves de Aravia. La a[t]izone resplandecía como plata, tan grande como tres dedos, a figura de una lanteja. La afitone semejante a oro, adonde las hormigas se lo sacan, es de la naturaleza de la piedra imán que trae a ssí el oro y aún lo acrescienta. No muy lexos d'ésta estava la apistos, la cual, escalentada en el fuego, tiene el calor siete días. Era negra y pesada, dist[i]nguida con venas coloradas, aprovecha contra el frío. Tras d'éstas estava la balanite o balax. La bratrachites tenía tres divisiones: la una semejante a rana, la otra a marfil, la tercera a negra y colorada. La piedra belo tenía semejança de una niñilla del ojo. La bu[c]ardia era semejante al coraçón del búho, la broncia a cabeça de tortugas. Allí 
estava la piedra ceramides, la calaís, semejante a la mar; la croculla parescía fructa del cerezo. La calafenos era negra, la cual, quebrando, da sonido de aire. Passando delante los cavalleros, vieron la chalazia tener imagen de graniza, la ceraunia de rayo, la esmeralda de profundas y transparentes ondas, la carcinia de cancro, la echites de bívora, la sca[r]ites de un pesce llamado escaro, la hieracites de gavilán, la geranites de pescueço de grulla, la egoptalmo de ojo de cabra, la licoptalmo que imita con cuatro colores el ojo del lobo: resplandesciente, sanguíneo, negro y a la redonda blanco. La piedra cimea era toda negra, que tiene dentro semejança de hava, la drutes paresce a tronco de árbol, la narcissite de hiedra, la astrapia de rayo, la flegetontite dentro ardía, la antracitides tenía dentro muchas centellas, la crocia color de açafrán, la rodite de rosa, la calcite de metal, la etites de águila, la cual pone el águila en su nido porque, siendo muy fría, metigue su calor. Allí veían la piedra taos dar semejança de cola de pavón, la celidonia de la serpiente áspis, la mirmerites de hormiga, la cantaría de escaravajo, la escorpites de escorpión. No menos estava allí la piedra imán que atrae a ssí el hierro y lexos d'ella la piedra teamedes que de sí lo alança. Assí vieron todas aquellas piedras temedar en sus figuras las cosas naturales. Viendo Cíngar todo esto, como era astuto, abaxósse al suelo y toma una piedra de aquella que se dezían toques y tocó en ella una de las que parescían piedras preciosas. Donde luego vio cómo eran todas aquellas piedras hechas de vidrio porque luego se quebraban (Baldo, XVII) ${ }^{113}$

Único pasaje de este tipo, se halla en el Baldo, fechado hacia 1542, establece una serie de conocimientos de la alquimia resaltando que las verdaderas gemas no se rompen y que algunas son semejantes a animales, por su color o por su forma. En este pasaje se mencionan 45 tipos de gemas: 1) Acates: Término en desuso para referirse al ágata. Hace

\footnotetext{
${ }^{113}$ Para profundizar en sus características véase: Alfonso X, Lapidario, ed. de María Brey Mariño, Madrid, Castalia, 1997; Bernardo Pérez Vargas, De Re metallica, donde se trata de la forma y materia de los metales philosophicamente, [en línea] Madrid, Casa de Pierres Cosin, 1568. http://documentomovil.usal.es/visor.php?v=dicter\&f=metalurgia_bg_PerezVargasBernardo\#1; Gaspar de Morales, De las virtudes y propiedades maravillosas de las piedras preciosas, ed. de Juan Carlos Ruiz Sierra, Madrid, Editorial Nacional, 1977; Lapidario Órfico, traducción, introducción y notas de Carmen Calvo Delcán, Madrid, Gredos, 1990, pp.345-409; Plinio, Historia natural, traducción por Jerónimo de Huerta, Madrid, Luis $\quad$ Sánchez $\quad$ Impresor, 1624. http://alfama.sim.ucm.es/dioscorides/consulta_libro.asp?ref=X53330435X\&idioma=0
} 
invisible al que la trae. 2) Acopis: Probablemente "acopos", piedra preciosa semejante al vidrio, piedra esponjosa estrellada y de estrellas con gotas de oro. 3) Alabastrite: Como el alabastro. 4) Androdamas: Tiene la virtud de atraer la plata y el cobre, de color negro, dura y pesada. Si se tritura y se coloca en agua, ésta se tiñe de color sangre. 5) Asbestis: Se trata del asbesto que nace en las montañas de Arcadia y es del color del hierro. 6) Aspisates: Conocida como "aspisatim" se halla en Arabia, su color es como el del fuego y se utiliza para curar las enfermedades del bazo cuando se le aplican pelos de camello. 7) Atizone: Probablemente “Atizoen", piedra preciosa que resplandece como plata, del grandor de tres dedos, de figura de lenteja de olor suave. 8) Afitone: También se conoce como Crisocola, se encuentra en la India, donde las hormigas excavan el oro. 9) Apistos: Es oscuro, pesado y con venas rojas, si se pone al fuego se mantiene caliente durante siete días.10) Balaniteo o Balax: Probablemente "balanites", piedra preciosa un poco verde y semejante al cobre y metal de Corinthio, tiene una vena por el medio inflamada y encendida.11) Bratrachites: Presenta tres tipos, color a la rana, otra al marfil, otra es negro sobre rojo.12) Belo: Probablemente se trata de "El ojo de Baal", el cual es blanco y tiene pintado un ribete negro y brillando en medio como oro. Está dedicada al más venerado dios de los asirios.13) Bucardia: Tiene semejanza con el corazón del buey y nace solamente en Babilonia.14) Broncia: Es semejante a la cabeza de los galapagos. 15) Ceramides: Tiene el color de la cerámica. 16) Calaís: De menor precio y valor que el topacio, es poco conocida. 17) Croculla: Se parece a una cereza.18) Calafeno: Posiblemente se trata de la "chalcophonos" que es negra y tiene sonido metálico.19) Chalazia: Tiene la figura y color de granizo y es tan dura como el diamante y es tan fría que a gran pena o nunca se puede calentar por el fuego. Mitiga la ira, la lujuria y otras pasiones de esta manera calientes. 20) Ceraunia: Piedra de rayo. 21) Esmeralda: Gema transparente muy apreciada, variedad del berilo, 
teñida de verde por el óxido de cromo. 22) Carcinia: Imita el color del cangrejo de la mara Cathocites, es piedra de la isla Córcega y tiene como cola y goma viscosa, por eso se pega a las manos. 23) Echites: Tiene color verde oscuro con manchas como de víbora mezcladas. Cruda es sin provecho, pero cocida es provechosa a lo quemado. 24) Scarites: Su nombre lo toma del pez Scaro. 25) Hieracites: Tiene nombre del color del gavilán, pero de mayor virtud es que de color. 26) Geranites: Recuerda el cuello de la grulla. 27) Egoptalmo: Hay dos tipos, una parece el ojo de una cabra y la otra al ojo de un cerdo. 28) Licoptalmo: Es de cuatro colores, de luciente y sanguíneo y en el medio lo negro que tiene es ceñido de blanco, es dicha así por los ojos de los lobos. 29) Cimea: Se trata del "cyamias", el cual es negro y cuando se rompe produce algo similar a una judía. 30) Drutes: Su nombre proviene del tronco de los árboles y se quema como la madera. 31) Narcissite: Está moteado con venas de hiedra y tiene el olor de los narcisos. 32) Astrapia: Se trata de la astrapaea de color blanco o azul, le discurren por el centro unos rayos resplandecientes. 33) Flegetontite: Probablemente se refiere a la "phlogitide", la cual parece que en el interior se quemase una especie de llama. 34) Antracitides: Tiene chispas que vuelan y aparecen aquí y allá. 35) Crocia: Conocida como “crocian" es como el azafrán. 36) Rodite: Llamada "rhoditis” como la rosa. 37) Calcite: Es de color cobre. 38) Etites: Concreción de óxido de hierro en bolas informes, compuesta de varias capas concéntricas de color amarillo y pardo rojizo, generalmente con un nódulo de la misma sustancia suelto en el interior de la bola. Los antiguos creían que las águilas llevaban esta piedra a sus nidos para facilitar la postura.39) Taos: Es semejante al pavón. 40) Celidonia: Es de dos tipos, del color de una golondrina y el otro de ellos es purpúrea con puntos negros. 41) Mirmerites: Es el "myrmecitis" que tiene en su interior la imagen de una hormiga arrastrándose. 42) Cantaria: Forma de 
escarabajo. 43) Escorpites: Se trata de la piedra de los escorpiones. Se llama así porque se halla en la cola del escorpión marino, o porque su color y figura es semejante a este animal. 44) Piedra imán: Es admirable en atraer a sí el hierro y tanto que el anillo que atrae a sí la piedra imán o sortija de hierro como fila fuerza de la tal piedra se hubiese pasado al hierro que atrae al mismo hierro otro y el tercero al cuarto que parece una cadena. 45) Teamedes: Probablemente se trata de la "teame", una piedra a la cual algunos de los antiguos atribuían una propiedad contraria a la del imán, es decir, la de apartar y desviar el hierro. Se puede observar que la mayoría de las piedras mencionadas en este ejemplo del Baldo guardan una estrecha relación con el simbolismo que se les otorga en los lapidarios medievales.

Este episodio sirve, a manera de introducción, para notar que los escritores del siglo XVI tenían conocimiento de las piedras preciosas, algunos en mayor medida que otros, y que no sólo las introducían en sus historias como ornamento, sino con una función implícita, la de transmitir mensajes, primero de posición social y después de linaje, amor y guerra. Para ello, fue necesaria la imaginación de los escritores, ayudados de los informes de la época sobre joyas de la realeza, ventas, cuentas, etc., en los que necesariamente se debían describir las piezas a detalle. Por ejemplo, en el inventario de la reina Juana se describe "un joyel de unas flechas tiene un diamante muy grande e un rubí ambos en mucho precio con tres perlas muy gruessas redondas"114, ejemplo similar se halla en el Florisel "un joyel que a su cuello traía, de un excelente diamante con cuatro rubíes y gruessas perlas que pendían (Florisel de Niquea III, CXII). Para la confección de estas piezas se utilizaron perlas, rubíes y diamantes, unas de las gemas más valoradas durante este siglo, debido a la técnica de su tallado y a la lejanía de donde procedían ${ }^{115}$. Ejemplos como los anteriores

\footnotetext{
114 José Ferrandis, Inventarios reales (Juana II a Juana la loca), Madrid, CSIC, 1943, p.25.

115 Nieves Fresneda González, Moda y belleza femenina ..., p. 516.
} 
predominan en toda la literatura caballeresca, por lo que se describirá cada joya en dos categorías, su utilidad como adorno y su simbolismo como transmisora de mensajes de amor, desafío y pertenencia que, implícitamente, el autor les otorga dependiendo de la situación.

\subsection{Diamante}

Piedra de gran dureza, indomable, de materia pura e incorruptible. ${ }^{116}$ Isidoro de Sevilla lo considera "pequeño y sin belleza por ser de color del hierro y el brillo del cristal", ${ }^{117}$ ni el hierro ni el fuego lo dañan de ahí el significado de su nombre "fuerza indomable". ${ }^{118}$ Dentro de los libros de caballerías, el ejemplo que mejor guarda estas características del diamante se halla en el Lisuarte de Grecia de Feliciano de Silva, en el yelmo de diamante que aparece en la aventura de Alpatracio y Miraminia, la pareja encantada que poseen un yelmo de diamante y una corona de rubíes, esmeraldas y diamantes, objetos que serán entregados a la pareja que logre vencerlos en amor, bondad y belleza. Del yelmo se dice que era: "el más estraño y rico que jamás se vio, porque era todo de un diamante tan claro que todos los de la sala claramente en él se vían" (Lisuarte de Grecia, LXXIX); sin embargo, este ejemplo conserva una particularidad del diamante, su fragilidad ante "la sangre de cabrito cálida y reciente, y se puede así desmenuzar a golpes de hierro". ${ }^{119}$ Simbólicamente, en la profecía de la infanta Medea se advierte que el caballero "que en bondad y valentía por fuerça de armas y de amores gane lidiando con él el yelmo que el cavallero trae" (Lisuarte de Grecia, LXXIX), en este caso se trata de Lisuarte, quien está destinado a recibir el título del mejor caballero, puesto que su espada, en una especie de

\footnotetext{
116 Gaspar de Morales, De las virtudes y propiedades maravillosas ..., pp. 276-277.

${ }^{117}$ Isidoro de Sevilla, Etimologías ..., p. 1123.

${ }^{118}$ Idem.

${ }^{119}$ Idem.
} 
alegoría de la sangre de cabrito, es la única que traspasa el diamante, pero ante los golpes de la espada de los otros caballeros no puede romperse: "[Lisuarte] se levantó e con gran saña firió al cavallero encantado de toda su fuerza con su espada por cima del yelmo de diamante. Assí como en él dio, salió una llama d'él muy grande con un gran trueno, e dexó tanto humo tan negro y espesso que no los podían ver, pero en un punto fue desfecho, e vieron en el aire ir al cavallero sin yelmo" (Lisuarte de Grecia, XC). Ciertamente, la idea del diamante como un elemento fuerte e inquebrantable no solo presenta cualidades para su uso en sucesos bélicos, tales como la resistencia, sino también es adecuado para la elaboración de objetos femeninos que conservan el mismo simbolismo, ser creados para un personaje en específico como medio visual entre las parejas. Primordialmente, las damas son las destinadas a poseer dichos accesorios, en su mayoría, espejos que permiten la contemplación del rostro del caballero, tal como se lee en la primera parte del Florisel de Niquea con Arlanda y Florisel: "tomó de sus pechos un espejo de un hermoso diamante que en un joyel tenía" (Florisel de Niquea I, XLII) (fig.47).

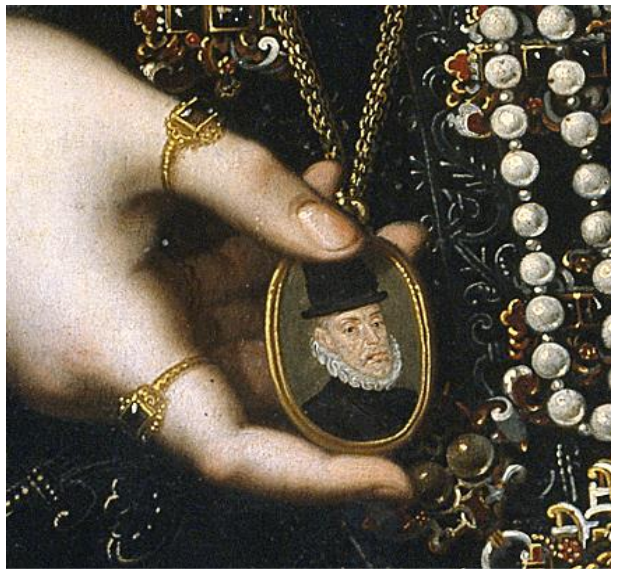

Fig. 47. Retrato de Isabel Clara Eugenia (1598-1599) Juan Pantoja de la Cruz, Museo del Prado.

Porta un joyel con la imagen de su padre el rey Felipe II 
Este anhelo de llevar siempre al ser querido cerca del pecho, a manera de prenderlo del corazón, es una forma sutil de pertenencia, en la que la imagen se sujeta de la tela para no sentir la ausencia, por ejemplo, la reina Zahara lleva "un joyel de resplandescientes diamantes en su cuello, en que estava el dios Mares en él bordado" (Florisel de Niquea I, LXVII). A manera de devoción, la reina Zahara presenta una modalidad de joyas para dioses, en donde, en sustitución por el caballero, la dama dedica su sentimentalidad a otros seres. Otra de las características que se le da al diamante es su tamaño: "no mayor al calco de una avellana"120; sin embargo, en los libros de caballerías lo que más predomina es el gran tamaño de esta piedras en algunas joyas, por ejemplo, la que aparece en el Claribalte: “el cavallero tenía a la garganta una muy delgada cadenica de oro y della colgava una ymagen de Venus que traýa metida en los pechos [...] Tenya esta ymagen, al pie della, un muy grande y hermoso diamante" (Claribalte, XVII). Las referencias a su tamaño pueden variar, pero lo que se conserva es su altos costo: "y quien sacase la mejor y mejor letra que recebiesse de la mano de su hija, Madama Tiberia, un diamante labrado en cuadra del tamaño de una cereza, que era de mucho precio y valor" (Florindo, XIV $)^{121}$.

Los anteriores fragmentos son algunos de los ejemplos del diamante que aparecen en estos libros, sin duda alguna es la piedra que más presencia tiene en las joyas y la que guarda mayor relación en torno a su simbolismo de pureza y dureza con el caballero que la recibe.

${ }^{120}$ Barthélémy l'Anglais, El libro de las propiedades raras, trad. de Vicente de Burgos, Burgos, 1494, p. 407.

${ }^{121}$ Fernando Basurto, Florindo, ed. de Alberto del Río Nogueras, Alcalá de Henares, Centro de Estudios Cervantinos, 2007. Todas las citas provienen de esta edición, en adelante citaré en el texto indicando entre paréntesis el número de capítulo. 


\subsection{Aljófar y perla}

Hallada solo en las conchas de $\operatorname{mar}^{122}$, por su presencia en diversas joyas se aprecia que su importancia consistía en realzar el tono de las gemas de colores, ya que, debido a su color blanco, todo elemento de color colocado sobre ellas alcanzaba un mayor predominio ante los ojos de los demás, de ahí que muchas veces la base de las prendas fueran miles de perlas y como adorno algunas incrustaciones de piedras, además de que era ideal para delimitar los contornos entre una y otra figura. (fig. 48)

Su origen muchas veces se determina por los propios personajes: "ella se vistió una ropa de tela de fino oro y encima de ella se hazía una red de que estava cubierta de gruessas perlas Orientales" (Florisel de Niquea IV, II, LXIV). Esta referencia al lugar de procedencia coincide con los orígenes del comercio perlero, el cual tenía su mayor centro recolector en el Mar Rojo, el Golfo Pérsico, China, India y Ceilán, ${ }^{123}$ lo cual también era un factor para la calidad de las perlas en color y tamaño. En este aspecto, se sabe que "la blancura de ella es muy espesa, pero es muy brillante por encima, como si estuviese pulida", esta tonalidad le permite ser muy notoria en fondos oscuros como el negro en mayor medida en el escote (fig. 49). Aunque su presencia también resulta del tamaño de éstas, tal como se indica en el siguiente ejemplo: “[Alastraxerea] venía vestida de una larga ropa toda plegada y muy ceñida de tela de gruessas perlas" (Florisel de Niquea I, LXVIII). La diferencia más notoria entre la perla y el aljófar es el tamaño y la calidad, de las cuales la segunda era más pequeña y no tan redonda, pero no por ello dejaba de lucir en las

\footnotetext{
${ }^{122}$ San Isidoro de Sevilla, op.cit., p. 119.

${ }^{123}$ Véase, Sevillano López y Soutar Moroni, "Comercio de perla entre los siglos II a.C. y X d.C.", Boletín Geológico y Minero, 123 (2), pp. 139-155.
} 
prendas: "traya una ropa muy ceñida de tela de fino aljófar" (Florisel de Niquea IV, II, VII).

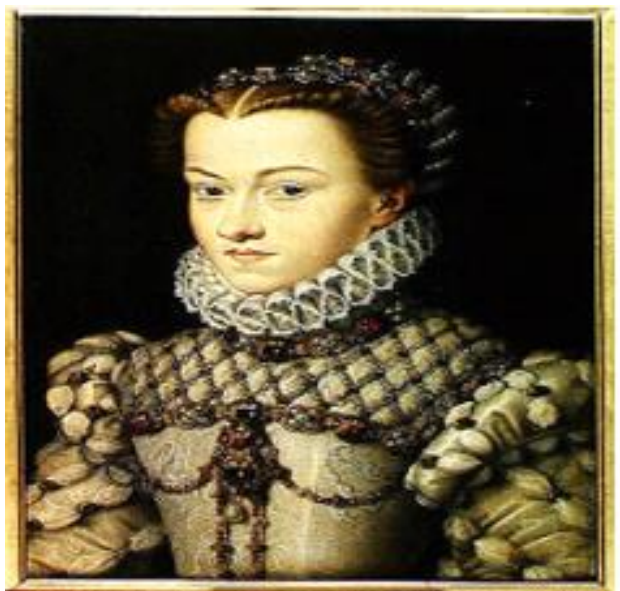

Fig. 48. Elizabeth de Austria, reina de Francia (s. XVI) François Clouet, Museo Condé. Nótense los detalles del cuello con los rombos que forman las perlas y el aljófar que cuelga del joyel.

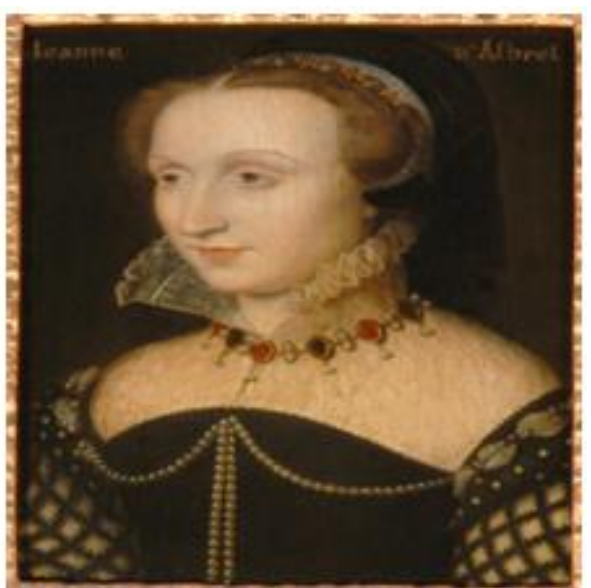

Fig. 49. Juana d'Albret, reina de Navarra (s. XVI) François Clouet, Museo Condé

Hay variedad de aplicaciones de perlas sobre tela negra, pueden ir bordadas o sobrepuestas para cambiar de joya y dar otra apariencia al vestido.

Pero sin duda, los tocados son los que presentan mayor abundancia de perlas ensartadas: "y sobre sus cabellos puso una red de oro con que los cojió con infinidad de argentería, y en cada ñudo una gruessa perla" (Florisel de Niquea I, LV). Esta descripción alude a la tradicional redecilla de perlas que desde la Edad Media aparece en distintas pinturas de damas nobles (figs.50-51); sin embargo, hay un elemento que se debe distinguir en el uso de la argentería para fijar las perlas y como medida de fineza textil, el nudo que finaliza cada hilera de perlas se cubre con una de mayor tamaño para cubrirlo, dedicación que denota el interés de las damas por llevar bien su tocado. 


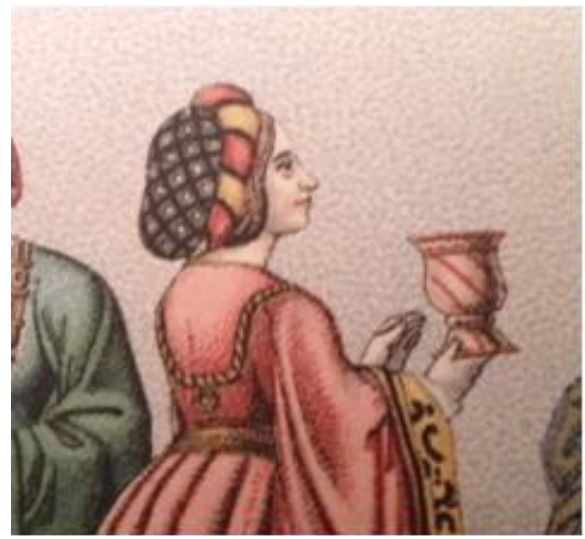

Fig. 50. Tocado de red, finales del s. XV.

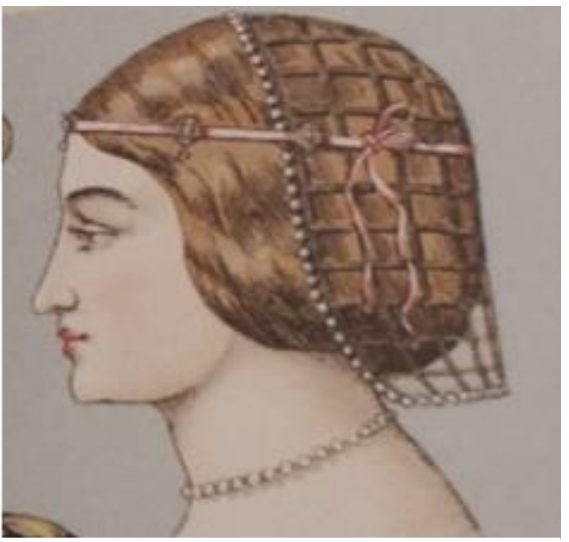

Fig. 51. Redecilla, s. XVI

Por último, se puede observar que varias formas de perla tienen semejanza a las frutas: "el tocadillo llegava hasta dexar dos dedos de cabellos encima la fruente con una buelta de un dedo en alto que de perlas de hechura de pequeñas peras eran las puntas" (Florisel de Niquea IV, II, LXXIII). Conocida como "perilla"124 o "perla pera"125 aparecerá esta figura en diversos tocados femeninos, algunas veces en sintonía con los diamantes en forma de gota a fin de estilizar más la estructura de las joyas.

La perla y el aljófar son las segundas gemas con más presencia en adornos, tocados, ropas y reliquias como coronas, cetros y arcas. Su tamaño y orificio en el centro le permiten ser insertada tanto en hilo como metal y por su tono va en combinación con todos los colores.

\subsection{Rubí}

A pesar de que muchos lapidarios incluyen al rubí junto con el carbunclo porque ambas son piedras ardientes, ésta presenta singularidades importantes dentro y fuera de los libros de caballerías. La primera de ella es que su uso aparece en igual medida para joyas como para

\footnotetext{
${ }^{124}$ Letizia Arbeteta, La joyería española..., p. 220.

125 Natalia Horcajo Palomero, Joyería europea del siglo XVI. Estudio tipológico y temático, (Tesis doctoral dirigida por D. Víctor Manuel Nieto Alcaide), Universidad Complutense de Madrid (Historia del Arte), 1991, p. 7 .
} 
la fabricación de objetos y muebles, como se nota en el Zifar: "e avie un rubi a cada uno de los cuatro cantones de la tabla, que cada uno dellos era tan grande commo una pelota, asy el menor dellos valie un grand reyno" (Zifar, p. 414), en este aspecto es una piedra de soporte para muebles de inestimable valor, que enriquece la sala del palacio. Este gran valor también se observa en los premios entregados durante las justas: "E si el cavallero del emperador vencía, ganava un muy rico y hermoso portacartas de un rubí que valía más que la gran cibdad de Constantinopla" (Polindo, XLVII). En estos casos se revela el valor monetario de la gema a través de su comparación con ciudades, pero también es importante su simbolismo en cuanto a su uso como elemento decorativo de la vestimenta.

Gaspar de Morales la incluye junto con el carbunclo por el color y brillo que se desprende de él. Él expresa que "el Rubi merece nombre de Carbunclo, porque ultra de ser tan hermoso, y más que las demás piedras, y mas resplandeciente, tiene más virtud que todas ellas"126; este valor comienza en la disposición de las gemas sobre la ropa, por ejemplo: "una infanta vestida de una ropa que toda parescía hecha de finos rubís sembrada" (Florisel de Niquea I, XL), en donde el efecto que se crea radica en la composición de la tela a base de rubíes. En seguida a modo de detalles que sobresalen por su ubicación: "los golpes todos tomados con prendederos de hermosos rubís" (Florisel de Niquea II, XLI). El valor de su tamaño incrementa al estar insertos entre los pliegues de la tela, al fungir como botón para sujetar las aberturas de la tela, pero al mismo tiempo como ornamento. Sin embargo, una de sus más notables apariciones será en los tocados, por la dificultad en las figuras que se fabrican con él, como los elementos florales: "y una guirnalda de oro sobre ellos de claveles de rubí" (Florisel de Niquea IV, II, LXXI). La elaboración de elementos vegetales predominará en la obra de Silva no sólo como ornamento, sino como elemento de

\footnotetext{
${ }^{126}$ Gaspar de Morales, op. cit., p. 273.
} 
reconocimiento de ciertos personajes, cuyo simbolismo se comprenderá con el contexto narrativo. (fig.52)

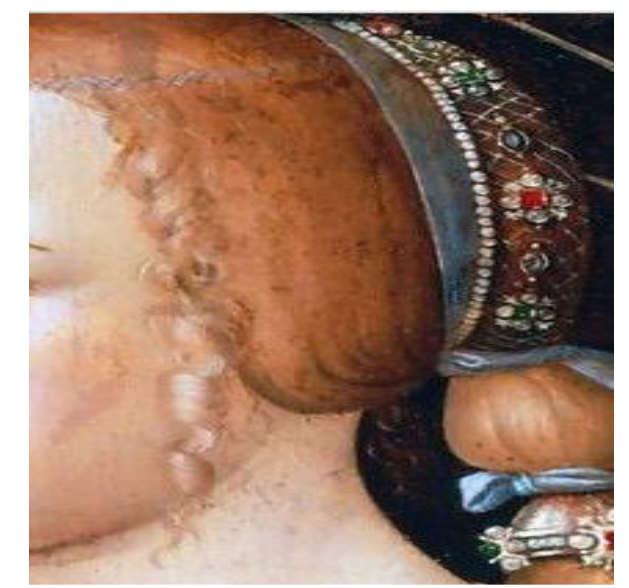

Fig. 52. Cofia de red con flores hechas con rubíes y esmeraldas

Una última aparición está en combinación con otras gemas, en donde se intensifica su significado por tratarse de dos piedras ardientes: "Traía por los pechos metida una muy rica espada que el pomo era de un carbunclo y el puño de un muy rico rubí que brasa parescía" (Lisuarte de Grecia, XXVII). La presencia del rubí presenta diferentes empleos para la fabricación de accesorios bélicos, amorosos y de decoración, cada uno con un simbolismo relevante que se dará acorde a su presencia en la historia y por las acciones narrativas que genere.

\subsection{Carbunclo}

Considerada la primera de las piedras ardientes en belleza y virtud. ${ }^{127}$ Esta beldad la obtiene por su significado, ya que recibe su nombre de su "color encendido como el carbón, cuyo fulgor ni siquiera la noche lo vence, pues luce en medio de las tinieblas" ${ }^{128}$. El brillo que proporciona aparece en varios ejemplos en los que su fulgor es motivo de asombro para

\footnotetext{
${ }^{127}$ Gaspar de Morales, op.cit., p. 272.

${ }^{128}$ San Isidoro de Sevilla, op.cit., p.1125.
} 
los personajes: "[llevaba] un ñudo en lo alto de la cabeça el cual atava un joyel del resplandeciente carbunclo del ydolo de Júpiter" (Florisel de Niquea IV, II, LXIV), no solo por la posición en el peinado, sino por la luz que se desprende de él:

y era cosa maravillosa de ver el gran resplandor del carbunclo que la Emperatriz en el ñudo de los cabellos llevava que mas que veynte hachas resplandecía y con la reverberación de su luz hazia en el resplandor de sus dorados cabellos y en la pedrería de los cercillos, collar y cinta y ropa no parecía sino que su estremada hermosura yva engastada en cien mil llamas de fuego del reflexo quel carbunclo en cada una de las piedras hazia (Florisel de Niquea IV, II, LXVI)

La fuerza de la claridad, brillantez y la intensidad del color no solo establecen al carbunclo como la piedra central del tocado, sino que éste asume tal cantidad de luz que la refleja en toda la tela del vestido, como una especie de prisma que provoca admiración en los espectadores. La ubicación de la piedra en el tocado recuerda a su origen en el carbunco, cuyo animal del que procede la piedra la lleva en la frente, de donde emerge un gran resplandor. Simbología que se mantiene en torno de la dama como un elemento de atracción hacia los demás personajes.

\subsection{Esmeralda}

Gema que recibe su nombre por ser "cosa esmerada" ${ }^{129}$, entre más verde es más preciada. ${ }^{130}$ Esta aparece tanto en ornamentos para el cuerpo como en objetos, como se observa en el siguiente ejemplo: “con las piedras que cayeron cayó una caxa pequeña que de una esmeralda era. El emperador la tomó en sus manos" (Lisuarte de Grecia, XXVII). La

\footnotetext{
${ }^{129}$ Gaspar de Morales, op.cit., p. 229.
}

${ }^{130}$ Alfonso X, Lapidario..., p. 49. 
dureza de la piedra se ve reflejada en este pasaje, puesto que, ante los movimientos del león y la caída de las piedras junto con la caja, ésta no se rompe.

Otra característica que destaca es su brillo que decora las alhajas: "Llevava una cinta y collar toda de piedras preciadas esmeraldas en muy hermosos engastes" (Florisel de Niquea III, XXXIII); la apreciación de esta piedra radica en su corte y tallado, el cual, una vez realizado, "refleja las imágenes como un espejo"131. Algunos de los atuendos femeninos con este tipo de joyas se pueden ver en el retrato de María de Inglaterra. (fig. 53 y detalle)
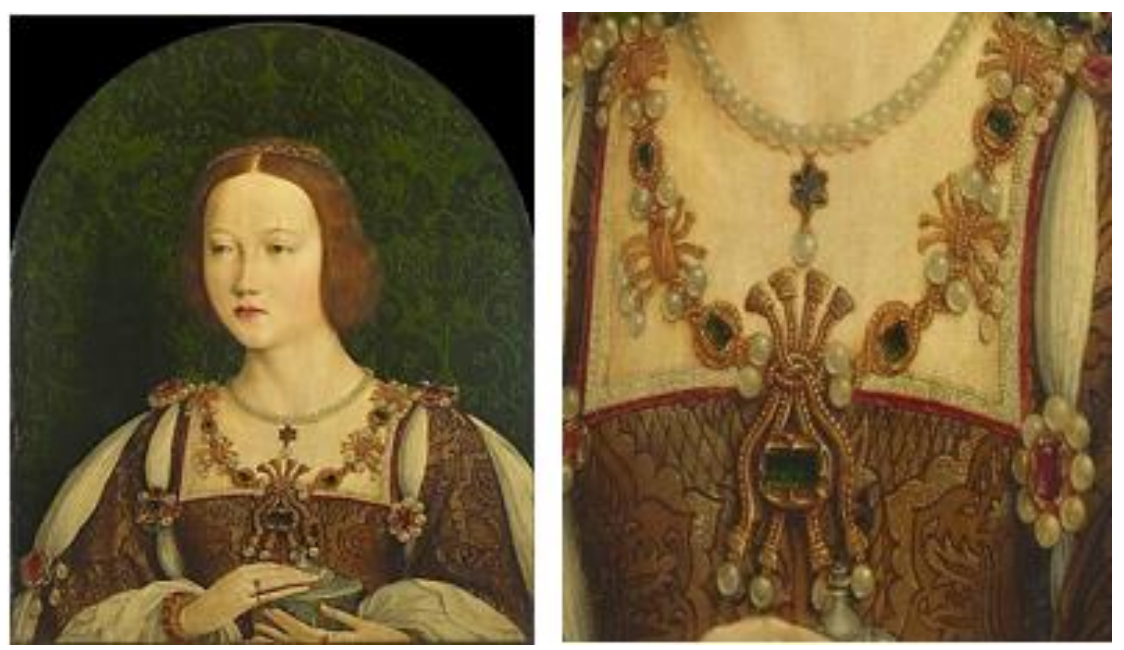

Fig.53. María de Inglaterra, Reina de Francia Collar con esmeraldas y perlas

Además de ser una gema, en la cuarta parte del Florisel de Niquea aparece una referencia directa con el nombre de un personaje, Esmerilda, dueña que es afrentada por su esposo Golisel porque la arroja del castillo para que él viva con otra doncella. Así que Esmerilda recorre los caminos en busca de un caballero que pueda restablecer su honor, lo cual es logrado por Amadís. En esta situación trágica donde impera la desdicha femenina, se inserta el sentido de la esmeralda como piedra preciosa, debido a que hay una connotación en la propiedad de la piedra que se traslada a la dama; se trata de "su color

${ }^{131}$ San Isidoro de Sevilla, op.cit., p. 1111. 
apacible, que alegra y regozija, es apacible a la vista y ahuyenta la tempestad"132, en este sentido, María Coduras propone la idea de que en cierto momento "las piedras preciosas son símbolo de una transmutación" 133 que llevan las situaciones de lo negativo a lo positivo y que se reflejan estas propiedades benéficas en los nombres. Es así que las cualidades de la esmeralda se fijan en Esmerilda durante el proceso en que el caballero la auxilia y recobra lo que había perdido.

\subsection{Zafiro}

Considerada "la piedra de las piedras", ${ }^{134}$ por ser "la más conveniente para traer los reyes en sus dedos", ${ }^{135}$ el zafiro se presenta como una gema de gran valor en cada uno de los objetos en los que aparece, no solo por la excelencia de su tono, sino por ser parte del color que adaptó la monarquía, especialmente la francesa, como un signo de distinción para marcar su elevada posición (fig.54).

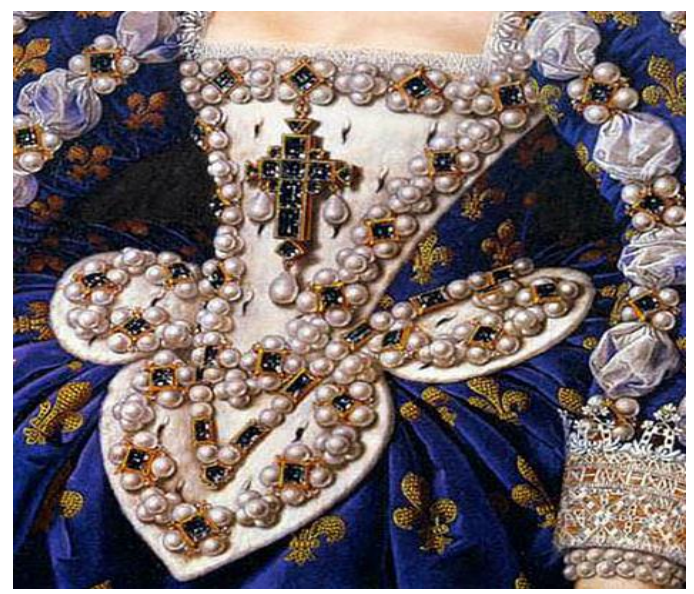

Fig.54. María de Médici (1611) Frans Pourbus el Joven. Nótese la utilización de la piel de armiño para crear una flor de lis invertida desde el pecho hasta la cintura. Lleva zafiros engastados en oro y perlas bordadas.

${ }_{132}$ Gaspar de Morales, op.cit., pp. 230-232.

${ }_{133}$ María Coduras Bruna, La antroponimia en los libros de caballerías españoles: el ciclo amadisiano, (Tesis doctoral), Universidad de Zaragoza, 2013, p.661.

${ }^{134}$ Barthélémy l'Anglais, El libro de las propiedades raras..., p. 421.

${ }^{135}$ Idem. 
Conserva varias propiedades; Alfonso $\mathrm{X}^{136}$ dice que es buena contra la melancolía y el dolor de vejiga. Pero en la ficción presenta otras dos propiedades especiales que se mencionan en el Zifar: "E ninguno no crea que en el safiro ay otra virtud sino estas dos, la una, contra la finchazón y, la otra, contra el fluxo de la sangre, que ciertamente es la tierra donde los çafires finos \& virtuosos vienen, y señaladamente de aquella tierra del reino de Çafira; y por ende le dizen aquel reino Çafira, porque tomó nombre de çafir” (Zifar, p. 450). Juan Manuel Cacho Blecua dice que la inserción del reino de çafir es un "sugerente anagrama del nombre del protagonista principal, Zifar" ${ }^{137}$, en donde se otorgan una serie de cualidades medicinales a manera de referencia para los viajeros. Nuevamente se presenta la relación del nombre de la piedra con un personaje, en donde se identifican algunas de las características entre ambos. En otro momento se indica el tamaño de un zafiro: "e en medio de la alcoba un çafir fecho commo pellota, ochavado, tan grande que dos gamellos non lo podrían levar, atan pesado es" (Zifar, p. 450). En los lapidarios referidos anteriormente aluden a su tamaño igual al de las otras piedras, por lo que en el Zifar se trata de una construcción de lo "maravilloso hiperbólico"138 en sintonía con los demás elementos mágicos que aparecen en estos libros.

$\mathrm{Al}$ igual que las anteriores gemas, su presencia en la ropa femenina tiene relevancia por el modo en como están colocados. Por ejemplo, en la primera parte del Espejo de príncipes y caballeros aparece una dama vestida "de una ropa de tela de oro sembrada toda de unos çafiros muy finos que hazian unas labores muy estrañas" (Espeio de príncipes y cavalleros I, II, XXI).

\footnotetext{
136 Alfonso X, Lapidario..., p.207.

137 Juan Manuel Cacho Blecua, "Las señales de las maravillas en el Libro del caballero Zifar", en Zifar y sus libros: 500 años, Karla Xiomara Luna Mariscal, Axayácatl Campos García Rojas y Aurelio González (eds.), México, El Colegio de México, 2015, p.54.

138 Ibid, p. 55.
} 
Por adorno o por sus propiedades curativas, el zafiro es una de las gemas que se aparece con particularidades significativas en algunos episodios de los libros de caballerías, como una forma de contrastar su uso en diversos objetos. Pero será en el Zifar en donde aparezca un desarrollo más detallado de esta gema, desde las propiedades curativas que brinda y el tono de color, hasta el origen de su nombre en relación con el espacio en donde se halla.

\subsubsection{Lincurio}

De entre todas las gemas hay una que presenta relevancia por su significado, su modo de creación y el posterior simbolismo en relación con el pasaje en el que se inserta, se trata del lincurio.

El $D R A E$ la define como "piedra conocida de los antiguos, que suponían que era la orina del lince petrificada, y que según los más es la belemnita, y según otros la turmalina” mientras que, de acuerdo con los lapidarios de la época agregan otras características como su color: "es amarillenta y atrae las hojas que se encuentren cerca de él"139. Esta referencia a la calidad de su tono se menciona casi al final del libro cuarto del Cirongilio de Tracia en donde hallan "un árbol todo de oro y cubierto de unas mançanas muy más resplandecientes que el cristal ni que claro lincurio, assentados por sus ramas muchos paxaricos" (Cirongilio de Tracia IV, XXIII). Además, se dice que debe caer en tierra para que solidifique más rápido, porque en agua se emblandece. ${ }^{140}$

Esta piedra aparece únicamente en el Cirongilio de Tracia, en la historia de Cirongilio y Astrea. Éste fue en auxilio de la condesa de Arox para enfrentarse contra

\footnotetext{
${ }^{139}$ San Isidoro de Sevilla, op.cit., p. 1129.

${ }^{140}$ Gaspar de Morales, op.cit., p. 344.
} 
Galafox y recuperar las propiedades de la condesa. Una vez realizada la hazaña descansa en el castillo de esta dama, en donde conoce a Astrea, hija de la condesa de Arox y quien se enamora del caballero. Después de varios días de permanecer junto a la dama y gozar de los favores entre ambos, Cirongilio se marcha, no sin antes dejar una prenda en señal de recordatorio de su amor por Astrea:

El cavallero sacó una rica sortija de su dedo del coraçón, de un lincurio muy excelente hecho a manera de cruz, y en medio engastado muy sotilmente un zafiro, en tal forma que parescía una mesma pieça. Ella lo tomó y púsolo en mucha guarda, y abraçandole y besando al cavallero muchas vezes, y derramando muchas lágrimas de sus ojos, se despidió d'él y encomendó a Dios que su vía endereçasse, dándole assí mismo una sortija de un diamante maravilloso, el cual él con alegre semblante tomó. (Cirongilio de Tracia I, XXX)

Durante toda su estancia, Cirongilio nunca revela su identidad, pues oculta su nombre y procedencia, a pesar de que la dama le insiste que le confiese quién es.

Sin embargo, ¿por qué la aparición de esta gema sólo en este ejemplo? La respuesta está en la intención de los linces:

La meada de los linces cristaliza o se solidifica, allí mismo donde es evacuada, en piedras parecidas a los carbunclos, de resplandeciente color de fuego, a las que llaman lincurio, y de ahí que muchos autores digan que también el ámbar amarillo se produce así. Los linces, envidiosos saben lo que ocurre y cubren su orina con tierra para que se solidifique más deprisa. ${ }^{141}$

Su presencia responde al simbolismo del ocultamiento del lincurio en relación con la identidad del caballero, ya que, así como los linces esconden su orina para que el brillo no atraiga a los demás animales, con la entrega de este anillo Cirongilio oculta su identidad a

${ }^{141}$ Félix Piñero Torre, "La tradición "apócrifa" del pasaje del carbunclo (Góngora, Soledad I, 74)", en Estudios sobre tradición clásica y mitología en el Siglo de Oro, Isabel Colón Calderón (ed.), Ediciones Clásicas, 2002, p. 29. Pp.27-36. 
Astrea, de este modo evitará que conozca su nombre y lo halle en el futuro. La principal razón es por la relación del caballero con Palingea y después con Regia, a quien ama verdaderamente y con quien se casa.

Aunque solo hay dos referencias al lincurio, la relevancia que aporta para el estudio de las gemas en los libros de caballerías es de suma importancia por el simbolismo que conlleva la simbología de esta piedra con el comportamiento del caballero, quien debe ser envidioso de su identidad y apartar a todo ser que desee descubrirla, tal como el lince lo hace con su orina.

La variedad de gemas halladas en los diversos ejemplos de los libros de caballerías, además de servir como adorno para las prendas y los objetos antes mencionados, presentan funciones mágicas, medicinales, conjuros de amor y desamor, de encantamiento, etc., por lo que en varios momentos adquieren relevancia el color, la forma y el grosor de cada una, a fin de contribuir como elementos significativos para el desarrollo de la hazaña. En este primer apartado se establecieron las características dadas por los lapidarios de las piedras preciosas que se hallan, principalmente, en los libros de caballerías de Feliciano de Silva, a manera de introducción para comprender el simbolismo que desarrollan en los diferentes episodios en los que aparecen.

Por lo que en el apartado sobre las joyas se considerarán los pasajes en los que las piedras, además de aparecer como ornamentos decorativos para la vestimenta y alhajas, cumplen una función simbólica ${ }^{142}$ en torno a la transmisión del amor entre la pareja, con la

\footnotetext{
${ }^{142}$ En varios estudios sobre las piedras preciosas en la literatura del siglo XVI se hace referencia a su presencia en los libros de caballerías sólo como decoración para las arquitecturas, objetos e indumentaria, sin proponer una función simbólica de las mismas para el desarrollo de aventuras sentimentales, mágicas, bélicas y medicinales, por ello el interés de profundizar en el aspecto sentimental como elemento de comunicación entre los enamorados.
} 
intención de proponer una línea de investigación del lenguaje amoroso a través de las piedras preciosas.

\subsection{3. "Una hermosa infanta vestida al uso de aquella tierra"}

No es extraño que durante su travesía el caballero se halle con diversos personajes en su camino, desde gigantes, sabias, caballeros y ermitaños, hasta doncellas provenientes de distintas regiones que por algún motivo son obligadas a dejar su hogar para ir en busca de ayuda. En su aparición, estas damas contribuyen a la recopilación de datos sobre la indumentaria de la época, gracias a las prendas que visten, las cuales, muchas veces, revelan el lugar al que pertenecen, mediante los elementos que conforman su atuendo.

En primera instancia, este hábito femenino se enuncia de manera general con la frase "vestida al uso de aquella tierra", en donde hay un desconocimiento total de todo el conjunto, pues la única posibilidad es identificar en qué lugar está el caballero, si es que se mencionó antes. Pero para profundizar en los detalles es necesario consultar fuentes históricas, libros de viaje y memorias para enlazar espacio-vestimenta-costumbres y así comprender más la función que cumplen ciertos personajes dentro de estas historias y el motivo por el que van con coberturas ajenas a la concepción moderna.

\subsubsection{Habiti}

En los libros de caballerías, cada pasaje en donde predomina la presencia de telas, ropas y accesorios se muestra como un catálogo local, porque presenta los diversos diseños textiles de cada reino, y forastero, cuya muestra de trajes extranjeros contrasta con los nacionales por la gran cantidad de detalles, colores y telas que sirven de referencia para extraer ciertos 
elementos y hacerlos propios. Es decir, escritores como Silva, Rodríguez de Montalvo, Moraes, Castro y muchos otros, introducen diseños de las modas europea, asiática y en menor medida, de la africana, para incrementar aún más sus propias creaciones, conservando, en ocasiones, los trajes extranjeros en su forma pura $y$, en otras, modificándolos un poco para adaptarlos a las necesidades de la ficción.

Este afán de seleccionar ciertos trajes no españoles se ve influido por las relaciones político-comerciales que España mantuvo durante el siglo XVI con sus vecinos territoriales, en los que ya desde la Edad Media tenían un gran interés por intercambiar productos para llevar hacia el Oriente y viceversa.

Gracias a los libros de recopilación de trajes, ${ }^{143}$ mejor conocidos como "habiti", ${ }^{144}$ que aparecen desde la Edad Media, se puede conocer el estilo de prendas que todos los grupos sociales vestían, el tipo de accesorios, los materiales con los que se fabricaban, el color, los tocados y demás complementos. En ellos hay una reunión de telas y estilos, lo que les permite convertirse en muestrarios, cuyas láminas coloridas y en blanco y negro recrean los modelos cotidianos y festivos de la indumentaria del mundo, algunos más especializados en su país, como Matthäus Schwarz en Alemania y otros que salen de sus fronteras para ir hasta el extremo oriental, China e India o más hacia el sur, hasta la punta de África; sin embargo, resultado de la llegada de Colón a nuevas tierras, la influencia de la vestimenta indígena también está presente en algunos de ellos.

\footnotetext{
${ }^{143}$ Los más destacados son: Cesare Vecellio, Habiti antichi et moderni di tutto il mondo, 1590. Il libro del sarto 1540-1550. Jean Jacques Boissard, Habitus variarum Orbis Gentium, 1581. Matthäus Schwarz, The Book of Clothes, 1520-1560.

Códice de trajes, siglo XVI.

${ }^{144}$ María Carmen Marín Pina, “Seda y acero. La indumentaria en el Palmerín de Inglaterra ...” p. 310.
} 
Estos trajes se deben considerar como "un atributo de identidad de las naciones y provincias", ${ }^{145}$ que en los libros de caballerías se hallan ambas vertientes. Por un lado, la idea general de una dama que va "vestida al uso de esta tierra" delimita la ubicación geográfica a través del contexto del pasaje.

Segundo, por medio de los recibimientos y torneos, es posible identificar a todo el séquito de cada corte que viene de diferentes países, no sólo por las menciones que el narrador hace en cada entrada, sino por las referencias a los trajes que portan y que permiten construirlos con ayuda de los accesorios que los distinguen, tales como plumas, pieles, tocados, faldas, etc.; aquí hay una intervención más directa del narrador, porque hace referencia al lugar del que proviene el personaje y describe su indumentaria, de la que destacan dos modelos, sármata e indiano.

\subsection{Traje de Sármata}

Los sármatas son una de las vestimentas que más aparecen en los libros de Feliciano de Silva, con la singularidad de que el escritor las utiliza para ocultar la identidad de sus personajes a fin de que puedan andar en diferentes lugares sin que los reconozcan y puedan aproximarse hasta su dama. De esta forma podrán disfrutar de su presencia por largos períodos:

-Vós sois tan moço que aún barvas no tenéis, y tan estremado en hermosura cuanto todas cuantas yo he visto sois muy más; que os pongáis en ábito de donzella del traje de Sármata y habléis la lengua, y yo hazerme mercader y sacaros he a vender al mercado en la ciudad de Niquea diciendo que ciertos del Rey de Alexandría os prendieron con otras mujeres amazonas que hazer daño andávades, y, como os vean

145 Alejandra Vega, «Trajes del teatro del mundo: vestimenta, sujetos y diferencia americana en la primera modernidad», Nuevo Mundo Mundos Nuevos [En línea], Debates, Puesto en línea el 03 junio 2014, consultado el 1 de julio de 2019. URL: http://journals.openedition.org/nuevomundo/66794 ; DOI : 10.4000/nuevomundo.66794 
tan grande y estremada en hermosura, llegarán a conpraros (Amadís de Grecia II, LXXXVII).

El traje de Sármata lo confeccionan de la siguiente manera:

hizieron a un maestro de ropas que traían que hiziesse a Amadís de Grecia una ropa [d]e xamete indio bordada de trenas de oro a la suerte de las mujeres que la reina Zahara traía, y, ella hecha, él se la vestió, y, cogiendo los sus muy hermosos cabellos, los prendió con una red de plata poblada de argentería, que de todo la nao venía bastecida porque la reina Lucida la mandó aparejar de todo, y, puestos unos ricos çarcillos en las orejas, quedó tan hermoso qu'el rey Gradamarte quedó espantado de lo ver. (Amadís de Grecia II, LXXXVI).

Sin embargo, esta descripción que presenta Feliciano de Silva tiene algunas variantes en el traje real de las mujeres sármatas, porque:

The dress of Sarmatian women, who, well-armed and mounted, followed their husbands into battle -among the Yaxamatians women formed the sole cavalry of their tribe, the men fighting on foot as archers- was almost the same as that of the men-, a long under-garment, with a shorter one over it. Both of these were sleeveless, and were girt high or low as the wearer pleased. The short upper garment sometimes had a long slit at the breast trimmed with ribbons, with which it could be tied. The female headdress was a tall cap like that worn by the Phrygians. ${ }^{146}$

La diferencia mayor se presenta en el tocado. Mientras que en el aspecto histórico se lleva un gorro alto, en la ficción se opta por cubrir los cabellos con una fina red de argentería, que armoniza con las trenas de oro de la ropa. Es decir, Feliciano se aleja de los elementos reales para preservar su artífice creativo e introducir el lujo de los metales y las piedras preciosas en una vestimenta que modifica a su gusto, además de que es necesaria dicha

${ }^{146}$ Carl Köhler, "Sarmatians, Dacians, and Illyrians", A History of Costume, New York, Dover Publications, 1963 , p.85. 
transformación por el lugar al que llegará, el palacio de su dama, así que, si el caballero desea permanecer con las damas, debe lucir como ellas.

En capítulos anteriores, el lector recordará que a la llegada de la reina Zahara ${ }^{147}$ con sus doncellas, el espectáculo de su entrada se debió en parte a la detallada descripción de sus trajes, a la manera de un desfile de damas guerreras, cuyas armas van en armonía con sus prendas. De este espectáculo, se conserva para Amadís la suntuosidad de la tela y de las piedras preciosas.

[Daraida y Garaya] pusiéronse sendas ropas al trage de Sarmata, de seda verde con muchos caireles de oro, y los cabellos cogidos con redes de oro, con mucha argentería travada de ñudos con ricos çarcillos. Y assí encima de sus palafrenes van poniendo espanto a cuantos las vían, mirando la extrañeza de su hermosura y de su hábito. (Florisel de Niquea III, XVIII)

La continuidad del traje de sármata en un nivel superior por los detalles de gala que agrega Feliciano de Silva, se mantiene hasta la tercera parte del Florisel, es decir, cinco años después de su primera aparición en el Amadís de Grecia, cuyos elementos permanecen con la misma calidad textil y ornamental. Pero en esta segunda aparición agrega un elemento que caracterizó a los sármatas, las armas:

Daraida se quitó las armas en una cuadra y tornó a salir a la sala, vestida una ropa de raso blanco golpeada sobre tela plata; en los cabellos traía dadas muchas lazadas y encima d'ellos una guirnalda de gruessas perlas para conformar el vestido con las armas. (Florisel de Niquea III, LI)

\footnotetext{
${ }^{147}$ En capítulos anteriores se cuenta la llegada de la reina Zahara a las bodas de Lisuarte y Onoloria, en cuya entrada es acompañada por más de quinientas mujeres con distintos vestidos, entre ellas "veinte y cuatro venían de xamete indio bordadas sus ropas de oro; eran tan largas, que por todas partes de las bestias en que venían arrastravan" (Amadís de Grecia II, LII), con quienes más sintonía presenta el traje de Amadís. Es relevante señalar el cuidado que Feliciano de Silva otorga para la conformación del traje de sármata en sus obras, al menos en el Florisel y el Amadís de Grecia, en donde se ve una conformación de este tipo de dama no sólo en el vestuario, sino en las cualidades que poseía este pueblo; por una parte, la bélica y el uso de armas, en especial, la espada, por el otro, su participación en la música, con lo cual no sólo se engalanan físicamente con la ropa, sino también en lo guerrero y lo musical.
} 
Daraida lleva consigo su espada, conservando así el uso de las armas de la mujer sármata guerrera, quien para la ficción se armoniza el metal con la tela, sin necesidad de olvidar la finura ni abundar la tosquedad. Este mismo diseño lo introduce Esteban Corbera en su Febo el troyano, quien, a pesar de intentar seguir los modelos de Feliciano, no consigue aportar alguna innovación a este ejemplo: "Doze hermosas donzellas, vestidas al traje de sármata y en estremo grandes como jayanes, vestidas de ropas de brocado. Cada una d'ellas traía en la mano siniestra una hacha encendida y en la derecha una limpia espada desnuda" (Febo el troyano, XXVI). Su falta de creatividad radica en la simpleza de los detalles, pues solo alude a las "ropas de brocado" sin abundar en los ornamentos.

\subsection{Traje indiano}

"[Persia] su vestidura era a la manera indiana, la cual era abierta en muchas partes y todas estas aberturas se prendían con perlas e piedras de muy gran valor. Y el tocado era todo texido con piedras de tan grande estima" (Félix Magno III, LXX[V]). Al igual que en otros libros del género, está presente la influencia de modas extranjeras, al menos en un personaje que, desde que conoce a Félix Magno, ha tratado de una u otra forma conseguir prender su amor y satisfacer sus deseos. Primero mediante la palabra y la petición de permanecer en su corte, ahora a través de la vestimenta, como un recurso de gala femenina para incrementar aún más su apariencia física. Sobre esto, Claudia Demattè expresa que "la infanta mora se presenta con vestidos seducientes con la intención de conquistar el corazón del caballero"148. A través de un atuendo extranjero, los diseños de toda Europa y Asia siguen presentes a lo largo

\footnotetext{
${ }^{148}$ Félix Magno III-IV. Guía de lectura, introducción y edición de Claudia Demattè, Alcalá de Henares,
} Centro de Estudios Cervantinos, 2002, p. 21. 
del siglo XVI. En la mayoría de los casos se trata de confecciones francesas, inglesas e italianas, principalmente, que, como ya lo ha observado Marín Pina, se trata de "una pasarela mundial por la que desfilan con vistosos y ricos trajes", ${ }^{149}$ que arriban a tierras españolas desde el extremo oriental; en este caso, se trata de la India, cuyas telas exóticas comienzan a vestir a las damas caballerescas.

La vestimenta indiana ${ }^{150}$ se puede conocer en el libro Habitus variarum orbis Gentium (1581) cuyas láminas presentan las denominaciones de indios occidentales, orientales y africanos. De acuerdo con la situación política de la época y las navegaciones a nuevas tierras, este ejemplo del traje de Persia corresponde a la imagen "fémina indica orientalis" por los rasgos de la tela y la forma del tocado. (fig.55)

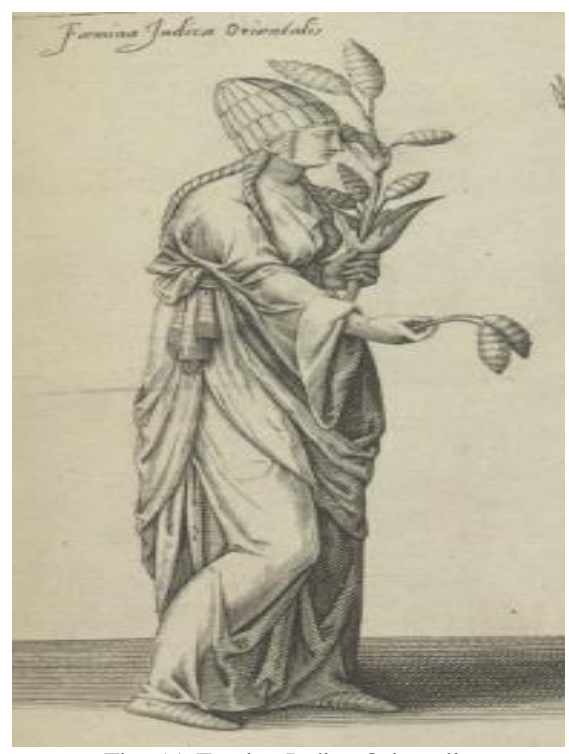

Fig. 55. Femina Indica Orientalis Habitus variarum orbis Gentium

\footnotetext{
${ }^{149}$ María Carmen Marín Pina, "Seda y acero...”., p. 309.

${ }^{150} \mathrm{La}$ influencia de este tipo de tela llega hasta México durante el periodo virreinal, en donde las telas de procedencia oriental como el chamelote y la persiana se utilizaban para tejidos eclesiásticos, entre éstas, las indianas se diferenciaban porque "eran telas pintadas de estilo hindú". Jesús Pérez Morera, "El tejido brocado en el México virreinal: sedas orientales y criollas", Cuadernos de Arte de la Universidad de Granada, 49, 2018, p. 183.
} 
Es así como Persia pertenece al grupo de mujeres seductoras por vestimenta, pues al no lograr atraer al caballero por el físico, utiliza la tela como medio de seducción para establecer un contacto visual por el color de su traje, pero falla en su intento, ya que el corazón de Félix Magno pertenece a otra dama.

Los libros dedicados a la conservación de los trajes a través de detallados dibujos se convirtieron en una suerte de catálogos disponibles para que las damas de cada corte seleccionaran los diseños de tierras lejanas y los mandaran a confeccionar, lo que ocasionó la mezcla de estilos por los accesorios, al quitar o agregar elementos propios de su lugar de origen.

Es decir, las marcas de confección, el tipo de tela y los detalles que la adornan, convierten a estas damas en una especie de catálogo ambulante que se sirven del camino para dar a conocer parte de su vida mediante el tejido, las costumbres en los accesorios y su estado de ánimo en el color. Son identidades propias de cada cultura que, por necesidad o placer, dejan rastros textiles en la imaginación de los lectores, pues no están habituados a detectar el modelo textil al que se hace referencia, por lo que se debe indagar en las ciudades cercanas para construir, a través de oídas, los tejidos extranjeros. Sin embargo, con la aparición de los "habiti" se logró almacenar los atavíos que el caballero encontraba en el camino para permitir que los lectores conocieran las confecciones del siglo XVI. 


\subsection{Desfile de prendas}

Torneos, justas, bodas, recibimientos y carros alegóricos son las festividades que más predominan en los libros de caballerías, en ellas sobresale la decoración del espacio a través del color de los estandartes, los tapetes y los manteles. Aunado a estos, hay otro elemento que presenta mayor relevancia por su elaboración, la vestimenta de los personajes, la cual, en estos eventos, se presenta como un desfile en el que los caballeros y las damas caminan por todo el reino para ser admirados por los demás. Situación que se repite tras cada logro bélico y que es motivo de fiesta para la corte.

Estas reuniones son esenciales para que el autor invente detallados atuendos y sean exhibidos durante toda la historia; sobre esto, Feliciano de Silva es uno de los mejores creadores de prendas debido a que casi todos sus personajes sobresalen por los laboriosos usos que él construye para cada uno de ellos. Desde vestidos, mantos y capas, hasta jubones, armaduras y gualdrapas, atavíos que van acorde a la ocasión y al personaje.

Cada uno de los trajes descritos tiene dos relevancias, la primera es ser el mejor vestido durante el evento y la segunda ser identificado por medio de la prenda, es decir, pasar ante los demás no sólo es para ser visto por todos, sino para crear vínculos visuales que facilitarán el reconocimiento de la persona debajo de la tela.

Esta propuesta inicia desde que la vestimenta funciona como un "conjunto de ropajes y adornos que configuran la apariencia y la identidad de las personas tanto a través del cuerpo físico como social" ${ }^{151}$, idea que anteriormente ya se ha establecido, pero que

\footnotetext{
${ }^{151}$ María Martínez Martínez, "Indumentaria y sociedades medievales (ss. XII-XV)", En la España Medieval,
} 26, 2003, p.39. 
ahora se abordará desde la creación de modelos a seguir entre los propios personajes, ya sea por costumbre o por el deseo de querer representar al reino en conjunto ${ }^{152}$ :

Pues assí estando todos callados, que ninguno hablava, levantándose en pie una hermosa dueña ricamente guarnida, levantáronse con ella hasta doze dueñas y doncellas todas del su mismo atavío vestidas, que esta costumbre tenían las dueñas de gran guisa y los ricos hombres de llevar a los suyos en semejantes fiestas bien vestidos como sus propios cuerpos (Amadís de Gaula, XXXI). ${ }^{153}$

Esta situación de las damas de compañía bien vestidas ${ }^{154}$ sólo aparece en los libros de caballerías en festejos como bodas, banquetes y justas, porque en los demás pasajes sólo hay breves menciones de sus prendas o incluso no se describe nada.

Implícitamente hay una intención de continuar demostrando su estamento por medio de la ropa, al ponerse de pie y atraer la mirada de los invitados, pues serán los propios personajes quienes expresen este deseo: "Ella estuvo essa noche pensando en qué forma iría para que su grandeza con su hermosura junto se pudiesse manifestar" (Amadís de Grecia, II, LI). La selección de las prendas es de gran importancia, pues de ellas depende, por un lado, la identificación del personaje por un atuendo específico ${ }^{155}$ y por el otro, la

${ }^{152}$ Esta propuesta también se estudia en el apartado del caballero y la armadura, en donde los jóvenes se distinguen por mandar a hacer sus armas de acuerdo al color de su reino.

${ }^{153}$ Garcí Rodríguez de Montalvo, Amadís de Gaula, ed. de Juan Manuel Cacho Blecua, Madrid, Cátedra, 2004. Todas las citas provienen de esta edición, en adelante citaré en el texto.

${ }^{154}$ Históricamente, se conocen eventos en los que las damas vestían valiosas prendas como las de la princesa en algunos eventos como bodas. Por ejemplo, en 1543, la princesa Doña María de Portugal se vistió "de terciopelo carmesí, guarnecido de cordones de oro, capa a la Castellana, forrada de brocado, mantellina asida al hombro, caída en lo demás como insignia propia de doncella, cofia de oro con una preciosa pedrería y gran comitiva de damas vestidas como cuando deseaban lucir cuanto podían". Enrique Flores de Setién, Memorias de las reinas católicas. Historia genealógica de la casa real de Castilla y de León, Madrid, Antonio Marín, 1770 , p. 887.

https://books.google.com.mx/books?id=CIhbAAAAcAAJ\&pg=PA887\&lpg=PA887\&dq=las+damas+pod\%C 3\%ADan+vestir+igual+que+la+princesa \&source=bl\&ots=vYj5RUQNBh\&sig=qnmSLtkbn9-

Fx3x7QntRhpF0318\&hl=es\&sa=X\&ved=0ahUKEwjGrtfLgvnLAhVkvYMKHeq3CGQQ6AEIQDAG\#v=one page\&q=las\%20damas\%20pod\%C3\%ADan\%20vestir\%20igual\%20que\%20la\%20princesa\&f=false

${ }^{155}$ Es importante señalar que en este aspecto se ubica el color y las letras e imágenes bordadas que adornan la prenda, pues a través de ellas se conoce a los personajes por sus ropas, tal es el caso del personaje Perión de 
diferenciación de clases por los accesorios que lo integran. Lo mismo se pretende con los elementos decorativos del palacio: "Assimismo aquella noche fue acordado entre aquellos grandes señores y señoras que se mostrasse su grandeza así por arreos de sus personas como de tapicería con ricas baxillas [...] y assí pasaron essa noche los unos y los otros adereçando para otro día lo que les era menester" (Amadís de Grecia, II, LI). La "baxilla" se consideraba como un "ajuar doméstico" "156 que adornaba parte de la mesa, mientras que la parte textil del comedor comprendía manteles, tapetes y cortinas, cuya confección se distinguía porque se realizaban en tejidos de seda ${ }^{157}$, principalmente.

\subsubsection{Vestir para una boda}

En el capítulo LII de la segunda parte del Amadís de Grecia se celebra la boda de Lisuarte y Onoloria, evento al que asisten personajes de distintos reinos. Entre ellos la reina Zahara y su séquito de amazonas. Pero en este episodio sobresale la extensa descripción de los vestidos de estas invitadas, guerreras que por un momento unieron las armas con la tela para cautivar al resto de los asistentes:

venían delante d'ella y todas sus mujeres veinte cuatro d'ellas con instrumentos tan extraños y dulces, que estraña cosa era el ruido que hazían con su dulce melodía. Estas veinte y cuatro venían de xamete indio bordadas sus ropas de oro: eran tan largas, que por todas partes de las bestias en que venían arrastravan. Eran todas estas veinte y cuatro mugeres negras y de buenas faciones, y en toda la compaña que la reina traía, que passavan de quinientas mugeres, no avía otras que negras fuessen. Venían cavalleras en bestias a manera de dromedarios tan negros como si

Gaula en el Lisuarte de Grecia que es reconocido en toda la obra por llevar un manto bordado con esferas doradas.

${ }^{156}$ Gual Camarena, Vocabulario del comercio medieval, Barcelona, El ALBIR, 1976.

${ }^{157}$ Entre los tejidos más comunes para cortinas sobresalen: el estambre, la estameña, la lana, el jamete y el terçenel. María del Carmen Martínez Meléndez, Los nombres de tejidos en castellano medieval, Granada, Universidad de Granada, 1989. 
de azavache fechas fueran. Luego tras estas venían dozientas mugeres con arcos muy fuertes, los palos d'ellos dorados y las cuerdas bermejas, con ricas armas armadas, con ropas encima de chamete verde bordadas de oro y con muchas perlas ceñidas con cordones indios doblados todos de flechas, las testas doradas; todas eran muy hermosas, y las cabeças eran desarmadas, hechos encima de sus mismos cabellos muy ruvios unos rollos cogidos por cima de las orejas con unas redes de plata pobladas de mucha argentería, con çarcillos de oro colgando de las orejas de tanto valor que no tenían precio; venían cavalgando en muy hermosos unicornios con muy ricas guarniciones. Tras estas venían otras dozientas mugeres armadas de la mesma suerte con ropas de carmesí y con muy ricas bordaduras de oro, con lanças puestas en las cuxas ${ }^{158}$, las astas todas doradas, las cabeças de la mesma suerte que las otras, cavalgando ansimismo en muy arreados unicornios. Tras ellas venían otras cient mugeres assimismo muy armadas con ricas ropas de brocado y con tocados de la misma suerte, cabalgando assimismo en muy arreados unicornios; todas traían en las manos espadas muy limpias desnudas, y colgadas de los arzones porras $^{159}$ de azero muy fuertes. Tras ellas venían doze donzellas ricamente guarnidas encima de unicornios con ropas de brocado hasta los pies d'ellos; estas no venían armadas; traían instrumentos con que tañían a manera de harpas con tan suave son que a todos ponían espanto. Tras ellas venía la hermosa reina Zahara armada toda de unas armas que no tenían precio, porque todas venían sembradas de perlas y piedras de gran valor. Traía sobre ella una ropa de madexas de oro pobladas de mucho aljófar tan larga, que hasta los pies del grande unicornio en que venía arrastrava, el cual traía una guarnición a manera de paramentos de la mesma suerte; el cuerno del unicornio venía todo sembrado de perlas y piedras muy resplandecientes. Ella traía los sus muy hermosos cabellos sueltos con una corona encima de tanta pedrería que a todos quitava la vista. Traía dos donzellas vestidas de oro cavalgando en dos unicornios que delante le traían un espejo tan grande como un grande escudo; este traía ella porque dezía que tal persona como ella no era razón en otra parte que menos fuesse ocupasse su vista. Las cinco reinas que con ella venían de la misma suerte que ella: la de Sármata le traía un escudo que todo era sembrado de piedras preciosas, en el cual d'ellos eran figurados en ella dos fuertes jayanes y juntos en una batalla avían venido; y la Reina de Ircania le llevava

${ }^{158}$ Muslos, Tesoro de la lengua.

${ }^{159}$ Mazas de acero, Tesoro de la lengua. 
el yelmo que de la misma suerte era; la hermosa Reina de Colcas le llevava un muy fuerte arco con doze saetas que todo parecía de oro; las otras do[s] reinas le llevavan a los lados dos cetros de oro. (Amadís de Grecia, II, LII).

Un evento tan importante como la boda de Lisuarte y Onoloria requiere que los trajes de los invitados estén por encima de lo cotidiano. Ejemplo de esto es la vasta decoración del vestido de la reina Zahara cuya confección sobresale por la gran cantidad de perlas y aljófares que cubren sus armas, piedras que en la época predominaban por su alto costo y que sólo podía portar la realeza. (fig. 56)

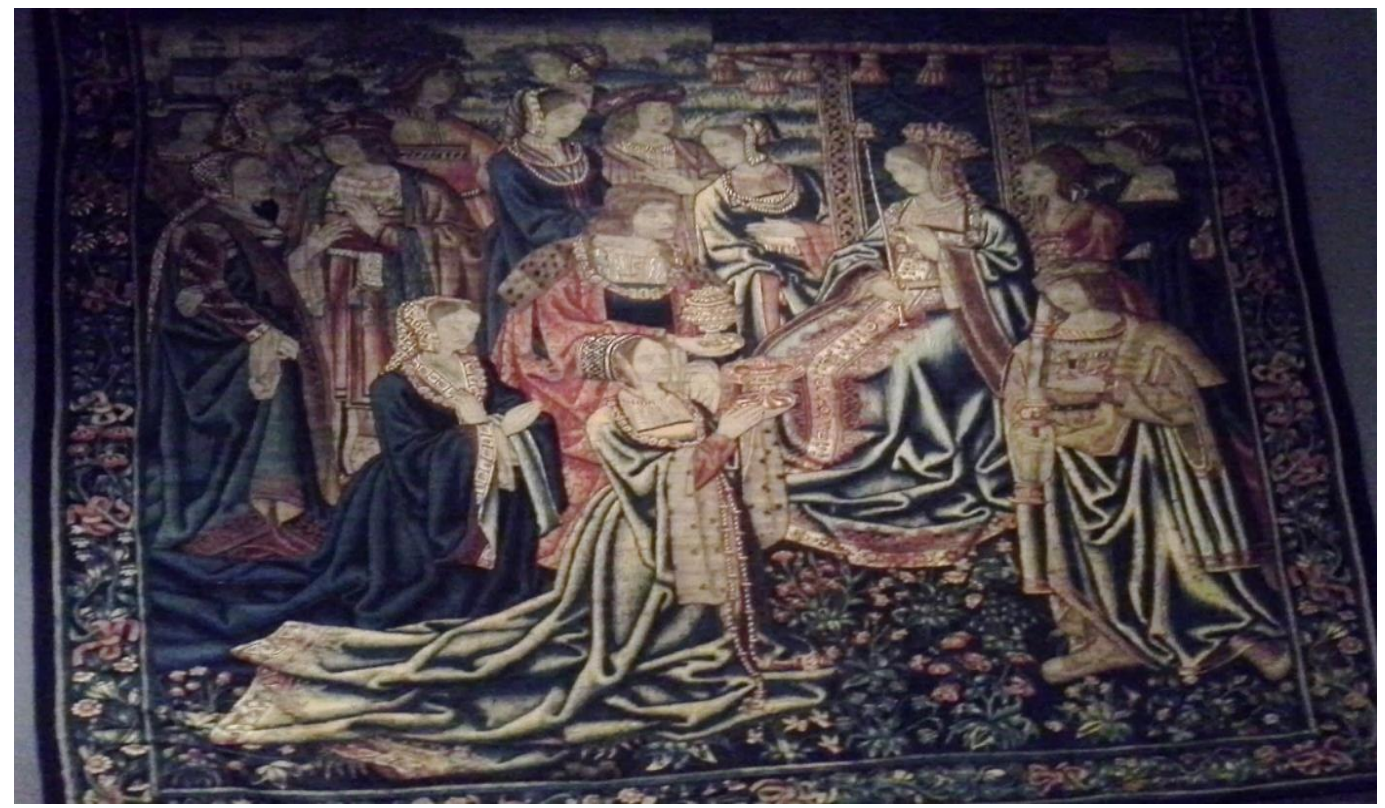

Fig. 56. Tapiz La Reina Dido (1500-1510)

Museo del Diseño de Barcelona

La escena recrea muy bien la semejanza con las fiestas de boda en los libros de caballerías. En el tapiz sobresalen los detalles de los vestidos de las damas y la diversidad de tocados, además de la gran cantidad de piedras de preciosas que adornan las telas.

El lector debe recrear en su mente cada una de las imágenes dadas por el autor hasta completar el vestido de la reina, forma difícil debido a la poca información que se tiene sobre algunos de los elementos que lo conforman, tal es el caso de la "ropa de madexas de oro"; en primer lugar, no hay una imagen concreta que defina a la ropa como una pieza única, sino que se tienen indicios de una posible especie de "sobretodo", "ropón”, "capa 
con mangas" ${ }^{160}$, etc., no hay una designación exacta, por lo que se puede considerar como un "traje de encima"161 que cubre, en este caso, la armadura de la dama y que sólo se entrevé por las aberturas de la ropa. Además de lo laborioso de esta prenda están los elementos que la adornan, las "madexas de oro". Este término se refiere al "hilo aspado que queda en círculo para devanarse y pulirse, le atravesaban unos hilos que se llamaban cuenda o cuenta" (Tesoro de la lengua). Aunque esta definición no es muy clara, se trata del hilo trabajado en una especie de telar formando unas cruces doradas ${ }^{162}$. El atuendo se complementa con una gran cantidad de aljófares que cubren la ropa. El último accesorio que se destaca es una corona de mucha pedrería. Esta joya es el signo que diferencia a la reina de las quinientas mujeres que van al frente, pues ninguna de ellas porta en la cabeza el símbolo de la realeza. Sobre esto, Michel Pastoureau expresa que "la vestimenta dice quién es una persona, en qué lugar o en qué rango se sitúa, a qué grupo familiar, profesional o institucional pertenece. De ese modo, en la simbología social y en el imaginario que la acompaña, el tejido obtiene, poco a poco, el primer lugar entre los demás materiales"163, es decir, si la reina Zahara no llevara puesta la corona ni los aljófares, parecería una más de las quinientas doncellas que la acompañan.

Antes de que la reina Zahara se aproxime, varias doncellas van al frente, todo un cortejo de damas que conforman varios grupos. En el primero hay 24, cada una tocando un instrumento van vestidas a la par de "xamete indio" con bordados de oro. Esta tela es de las más utilizadas por los reyes por su composición, es una "rica tela de seda que a veces se entretejía de oro" (DRAE). Tejido de gran valor por la composición de sus hilos, su acabado

\footnotetext{
${ }^{160}$ Carmen Bernis, Indumentaria española en tiempos de Carlos V..., p. 101.

${ }^{161}$ María del Carmen Marín Pina, "Seda y acero...", p.313.

${ }^{162}$ Aunque los términos no son muy conocidos en la actualidad, "aspado" se refiere a trabajar el hilo con dos palos para tejerlo y formar la tela; "cuenda" es el cordón que ata el hilo para que no se enrede. Tesoro de la Lengua.

${ }^{163}$ Michel Pastoureau, Una historia simbólica de la Edad Media occidental, Buenos Aires, Katz, 2006, p.86.
} 
brillante y el hilo de oro que se le cruzaba ${ }^{164}$, el color indio pocas veces se menciona, eran más comunes las prendas de esta tela en bermejo, verde y blanco ${ }^{165}$.

Las doscientas mujeres que siguen visten "ropas encima de chamete ${ }^{166}$ verde bordadas de oro y con muchas perlas ceñidas con cordones indios doblados todos de flechas, las testas doradas". Los adornos aumentan en este segundo grupo. Ahora, además de los hilos de oro, llevan perlas insertas en cordones azules, otro elemento que sobresale es la testa, que es la parte pectoral femenina que se cubría con el "cos", una especie de corpiño que se ponía debajo de la saya ${ }^{167}$. Su atuendo se complementa con los accesorios del cabello: "unos rollos cogidos por cima de las orejas con unas redes de plata pobladas de mucha argentería, con çarcillos de oro". Estos rollos parecen aludir al tocado "lados de cabellos" que las damas españolas solían peinarse durante el primer tercio del siglo XVI, pero lo más llamativo son los adornos de plata y oro que llevan las redes que hacen juego con los aretes, puesto que conforme aparecen los grupos se observa cómo va aumentando el arreglo femenino.

Las doscientas damas que siguen visten exactamente igual que las anteriores, la única diferencia es el color, éstas llevan vestidos de carmesí. A simple vista pareciera que no hay diferencia entre estos dos grupos; sin embargo, el color carmesí es el elemento que pone en un nivel superior a estas últimas damas; esto se debe al costo elevado para esta tonalidad, porque era "un paño exclusivamente de seda y tinto"168 que se obtenía de la

\footnotetext{
${ }^{164}$ María del Carmen Martínez, Los nombres de tejidos..., p.308.

165 Otros colores son: azul, amarillo, negro y simple, el precio variaba dependiendo del costo del teñido.

166 Variante lingüística de "xamete" y "jamete".

${ }^{167}$ Carmen Bernis, Indumentaria española..., p.85.

168 Paulino Iradiel Murugarren, Evolución de la industria textil castellana en los siglos XIII-XVI, Salamanca, Universidad de Salamanca, 1974, p.131.
} 
cochinilla $^{169}$. Por lo que el proceso para obtenerlo hacía que su precio fuera superior a los demás tintes.

Las siguientes cien damas traen "ropas de brocado". Aunque no se dan más detalles de sus vestidos, se puede conocer cómo era la tela con que estaban confeccionados. El brocado era una "tela de seda entretejida con oro o plata, de modo que el metal forme en la cara superior flores o dibujos briscados ${ }^{170},(D R A E)$. Esta tela era de mayor precio al ser importada de Florencia ${ }^{171}$, además de los dibujos que ya eran más elaborados.

Después aparecen doce doncellas igualmente vestidas de brocado, sólo que ahora se especifica que su ropa era más larga que las anteriores. Las últimas doncellas que vienen después de la reina Zahara van vestidas de oro. Esta descripción es muy general, puesto que en la época el término "de oro" describía prendas de ese color; jubones, sayas, capas, vestidos, cordones, etc., que podían llevar elementos metálicos, lo cual incrementaba su costo.

Las últimas cinco mujeres son reinas; sin embargo, si el narrador no las llamara así, el lector podría creer que sólo son damas de compañía porque no hay ninguna referencia de su vestimenta ni de su corona. Sólo se mencionan los escudos y las armas que le llevan a la reina Zahara.

Una parte interesante de esta pasarela son los animales que transportan a las damas. Los primeros son unos dromedarios negros sin ninguna tela, los siguientes tres grupos y las reinas vienen en unicornios con ricas guarniciones; aunque no se describen, pueden referirse a correas adornadas, colgaduras o gualdrapas. Nuevamente se observa un ascenso en los elementos textiles, pues de la sencillez se pasa a la abundancia de adornos, esto en el

\footnotetext{
${ }^{169}$ Para teñir 1 libra de seda se necesitaban 2 onzas de grana o cochinilla y 12 de alazor.

${ }^{170}$ Briscados: Rizos, escarchados.

${ }^{171}$ María del Carmen Martínez, Los nombres de tejidos..., p. 258.
} 
unicornio que lleva a la reina "el cual traía una guarnición a manera de paramentos de la mesma suerte; el cuerno del unicornio venía todo sembrado de perlas y piedras muy resplandecientes", una extensa tela cubre parte del unicornio y la misma decoración de la armadura de la reina está en el cuerno.

Con esto se ven dos propuestas de Silva, la primera es que los elementos textiles, implícitamente, destacan la posición social del personaje principal en un evento en el que pareciera que todos visten a la par; la segunda es que esta superioridad implícita también debe estar en el espacio y en los objetos que pertenecen al protagonista, en este ejemplo, está en los animales, cuya diferencia radica en las piedras preciosas más que en la tela.

Gómez- Salvago menciona que "la etiqueta regula la vida de la corte"172, en la que personajes y espacio asombrarán por las llamativas telas que lleven puestas. Desde tapetes, manteles y alfombras, hasta vestidos, capas y armaduras estarán a la vista de todos, serán objeto de admiración y de conquista. Por un lado, sobresaldrán los mejores usos, de mayor calidad y minucioso brocado, por el otro, la dama y el caballero mejor ataviados serán los que atraigan más miradas, tal como se reafirma en estos libros: "Las cuales de allí siempre andavan más loçanas e más alegres, vestiendo cada día muchas vestiduras muy ricas e parándose más galanas. Y ansí robavan más los coraçones de sus cavalleros” (Polindo, XXXVII). Es decir, la belleza se complementa con la vestimenta, en donde el color ${ }^{173}$, la tela y los adornos serán los elementos que realcen aún más el físico de los personajes y los que harán la diferencia entre las clases sociales. Aparentemente se verán que todos visten lujosas prendas; sin embargo, es importante destacar cada uno de los elementos que

172 Mónica Gómez-Salvago Sánchez, Fastos de una vida real en la Sevilla del quinientos, Sevilla, Universidad de Sevilla, 1998, p.101.

${ }^{173}$ Michel Pastoureau señala que la calidad del color es lo que diferencia la vestimenta entre ricos y pobres, ya que en la realeza "llevan ropas con colores vivos", resistente a los fenómenos climáticos, mientras que los tintes de las prendas de los pobres son de menor condición, y se desgastan con rapidez, es por ello que predominan colores grisáceos en la clase baja. Michel Pastoureau, Una historia simbólica ..., p. 141. 
conforman la indumentaria, desde el tipo de tela, la textura, el tinte, la forma del bordado y los adornos, porque estos indicarán cuál prenda es más costosa, más fina y por lo tanto quién es el mejor vestido.

\subsubsection{Recibimientos}

La llegada de un rey, una embarcación, un séquito o un grupo de princesas es motivo de fiesta para la corte que los recibe. Es un momento de convivencia en el que los invitados deben ser tratados con gran gala, deben ser deslumbrados con los preparativos y el color de los adornos, así como con la amabilidad y la algarabía de los habitantes del reino, quienes usarán sus mejores prendas para recibirlos, en las que reflejarán su estado y condición social. Esto se ve en el recibimiento que Grindaya y Filisea le dan al rey Amadís de Gaula y al emperador Amadís de Grecia. Su visita se debe a que serán jueces en un conflicto sentimental entre las dos hermanas. A su llegada ellas van de tal manera que:

semejávanse tanto que no se devisavan apartadas la una de la otra sino por los nombres, y era cosa maravillosa de ver la estrañeza de su vestido y fermosura, ambas venían de una manera vestidas, y el vestido era de tal suerte: Traían unas ropas en los pechos a manera de un peto de arnés, traían de fino oro engastadas <en> preciosas perlas e piedras que hazían hermosos lazos en los petos que muy ceñidos eran; y de la cintura salía como ropa, en que los petos estaban engastados con muchos pliegues, una tela que parecía toda de fino oro, con un vislumbre que en ellas se hazía de un azul muy fino. Las ropas eran tan largas que más de braçada y media arrastraban tres puntas que cada halda se hazían, con un botón hecho de gruessas perlas en cada punta, por donde tres hermosas donzellas cada una las faldas traían. Las mangas de la ropa eran hechas de la misma tela, en que se hazían muchas bexigas grandes de cabe los hombros a manera de braones, y assí ivan disminuyéndose hasta las muñecas; y lo que dividía cada pliegue o bexiga una de otra era una argolla de oro de martillo en que avía muchas piedras y perlas engastadas entre sotiles esmaltes, y las bexigas que se hazían tenía cada una seis golpes que las travavan desde argolla a argolla, los bordes de los golpes cairelados de gruesso aljófar, y descubrían otros papos de camisa 
muy delgada y blanca. Y de las muñecas salía assí mismo una punta de camisa que hasta el suelo llegava, con cintas de muchos joyeles que venían ceñidas. (Florisel de Niquea III, CXLVIII).

Una vez resuelto el conflicto, las damas se visten de gala, previo al enlace matrimonial, porque se requiere una presencia deslumbrante por parte de las demandantes, dos damas que, a través de su belleza física y espiritual, requieren lucir aún más bellas con ayuda de sus prendas. (fig. 57)

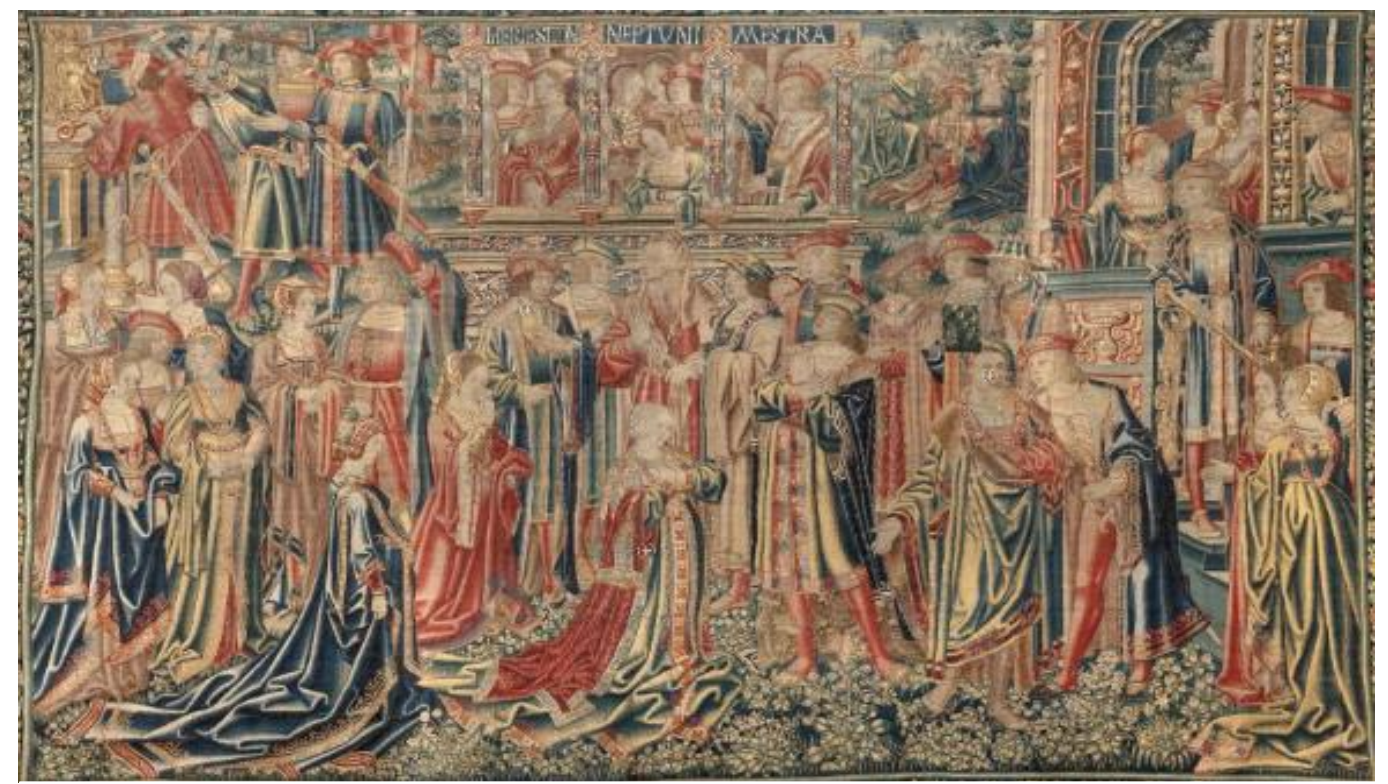

Fig. 57. Tapiz la suplicación de Mestra (1536)

Museo de Leida

Se pueden notar los tocados de rollo con redes, las gorras flamencas en los hombres, además de los zapatos franceses. La ropa lleva aplicaciones de gemas.

En este ejemplo se menciona que de las muñecas salía una punta de la camisa que hasta el suelo llegaba, este rasgo es importante porque en esa época era costumbre "mostrar la camisa a través de aberturas de distintas dimensiones aplicadas en las mangas del vestido" 174 , por lo que será común que en algunos pasajes se destaque el tejido de esta prenda, generalmente de color blanco y de tela delgada; habrá algunas excepciones, en

\footnotetext{
${ }^{174}$ Elena Varela Merino, Los galicismos en el español de los siglos XVI y XVII..., p.238.
} 
donde presentará algún adorno o estará fabricada con otro tipo de tela. ${ }^{175}$ Otro elemento que destaca son los "braones", especie de hombreras que caían desde los hombros hasta el brazo (Tesoro de la lengua), éstas daban realce a la manga de las sayas y eran un complemento para adornar la parte superior del vestido. Era común verlas en "sayos, ropillas y cueras" ${ }^{176}$, con el fin de agregar más accesorios a la prenda.

Por otra parte, “los seis golpes” Covarrubias los describe como un 'paño golpeado', es decir, aquel que "está muy tupido y golpeado al tejer con el peine”, técnica que consistía en hacer aberturas a la manga con una cuchilla para que saliera la tela de la prenda de abajo. Se hacía una especie de bultos entre cada espacio por la abertura, en este ejemplo son seis los cortes que tiene la manga. Carmen Bernis sitúa esta moda entre 1520 y $1535^{177}$, época de mayor auge para este tipo de corte.

De la muñeca sale una punta de camisa con cintas de las que va prendida una gran cantidad de joyeles, los cuales son una marca de una prenda costosa, ya que, al aumentar el número de piedras insertadas en la ropa, mayor será su valor monetario. Estas piezas eran consideradas de gran valor de acuerdo a su forma y tamaño, mientras que para las mangas y coronas eran pequeños, para la blusa y la falda debían ser más grandes, pues tenían que sobresalir de entre los encajes, listones y bordados que tuviera el vestido.

\footnotetext{
${ }^{175}$ Un interesante ejemplo está en el Florindo, en la vestimenta que usa la princesa Madama Tiberia para unas justas, pues en ella sobresalen las mangas del gonete por llevar bordado un árbol con una letra que dice: "Quien no teme la justicia/ El fruto come vedado/ Mas al fin paga el bocado" (Florindo, II, XVIII). Una especie de mensaje oculto lleva entre los pliegues de su ropa para ser descifrado y visto sólo por aquel que será merecedor de su mano. Será común hallar este tipo de invenciones ocultas entre la vestimenta como una forma de comunicación secreta entre las parejas.

${ }^{176}$ Carmen Bernis, Indumentaria española en tiempos de Carlos V..., p.39.

${ }^{177}$ Ibid., p.32.
} 
Esta será una nueva característica de Feliciano de Silva, porque en sus primeros libros no predomina este ornamento; al utilizar en gran medida el joyel ${ }^{178}$ como una alhaja que cuelgue de distintas partes de la dama, en las mangas, la falda, el tocado y el cuello, con ello propondrá una nueva forma de ornamentación basada en pequeños objetos colgantes que deslumbrarán con el brillo de las piedras que traigan.

En este recibimiento se presentan puras doncellas, pero Silva es ágil al intercalar damas y caballeros en los que presenta un desfile mixto, una variedad de atuendos que, de acuerdo a la festividad, podrá haber una similitud en usos masculinos y femeninos o una total desigualdad entre ambos.

\subsubsection{Atuendos ceremoniales}

Una de las funciones de la vestimenta es su uso para atraer la mirada del caballero y conseguir marido, una táctica sutil que ya desde la Antigüedad está presente en algunos tratados de amor, como en el Arte de amar de Ovidio, cuyo libro tercero expone una serie de actividades que las damas realizan para estar presentables para el caballero, entre las que destacan el cuidado del cuerpo, la variedad en el guardarropa, el arreglo del cabello, la utilización de joyas, además de algunos trucos para ocultar las imperfecciones ${ }^{179}$. En esta preparación el caballero debe ser recíproco con la joven, por lo que Ovidio le recomienda que: “-Si lleva púrpura de Tiro, ensalza la púrpura de Tiro. Si lleva seda de Cos, opina que le sienta bien la seda de Cos. Resplandece ella en oro: será para ti más preciosa que el oro. Si se viste con tela forrada, la tela forrada aprobarás" (Arte de amar, II, 297-300), en

\footnotetext{
${ }^{178}$ La diferencia entre Silva y otros autores en el uso del joyel es que éste lo utiliza como un accesorio más para adornar la imagen de la dama, mientras que los demás principalmente lo usan como una prenda en señal de amor.

${ }^{179}$ Ovidio, Arte de amar, ed. de Rubén Bonifaz Nuño, México, Universidad Nacional Autónoma de México, 1975, pp. 53-59.
} 
donde se indican algunos de los tejidos más comunes para las prendas femeninas. Ambos consejos aparecen en los libros de caballerías, cuyo interés por el arreglo de la apariencia femenina empieza con los padres: "y viéndome tan bien adereçada con estos vestidos que me hizo vestir mi padre, porque si passava por ende un cavallero con un hijo del cual se me hablava casamiento de mi vista recibiesse mayor contentamiento" (Valerián de Hungría, II, XL). El padre utiliza la indumentaria como elemento de atracción visual, un medio por el que hay un intercambio de miradas en donde ambos quedan prendados de su belleza. Es un instrumento que permite la comunicación en cuyos diálogos habrá una referencia directa al atuendo, a través del halago a las telas en referencia directa al cuerpo de la dama.

Culminado este proceso de conquista prosigue la certificación del amor a través del desposorio, el cual tendrá dos etapas, la primera secreta y la segunda pública.

\subsubsection{Vestidos de boda}

El enlace sentimental del caballero y la dama se configura como uno de los momentos más íntimos y secretos en los libros de caballerías, en ellos se hace una promesa de amor, un juramento en el que sólo son testigos los fieles sirvientes de la pareja, por lo que no hay una ceremonia pública ni preparativos de fiesta debido a la relación secreta que mantienen los jóvenes. Será hasta después de muchas hazañas y pruebas cuando los enamorados revelarán su relación y se realizarán las bodas ante la corte; sin embargo, en la mayoría de estos libros, esta unión se describe simplemente con la frase "las bodas fueron hechas con mucha argentería", en la que se encierra todo un proceso ceremonial que el autor deja a la imaginación del lector. (fig.58 y detalle) 


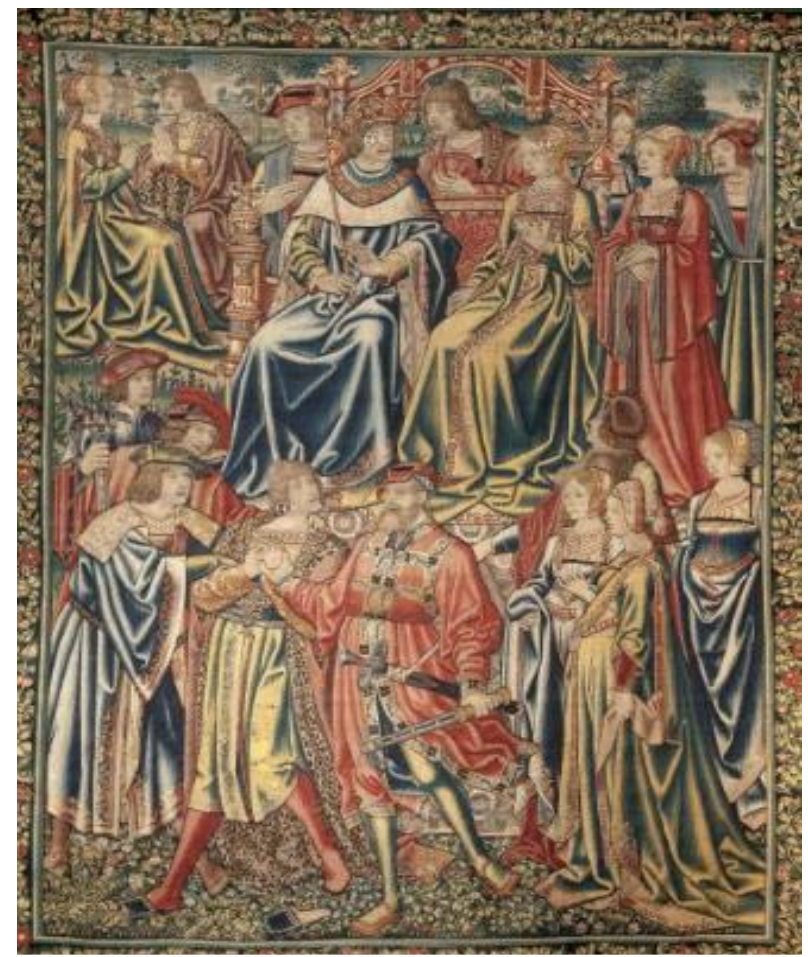

Fig. 58. Tapiz Jasón y Medea (1536)

Museo de Lleida

Realizadas las bodas continúan los festejos, en donde es característico que la pareja sobresalga entre los demás, ya sea por la ubicación en la que se colocan o por los accesorios que llevan. En esta imagen se distinguen por la corona y el rey por las ropas reales con armiño.

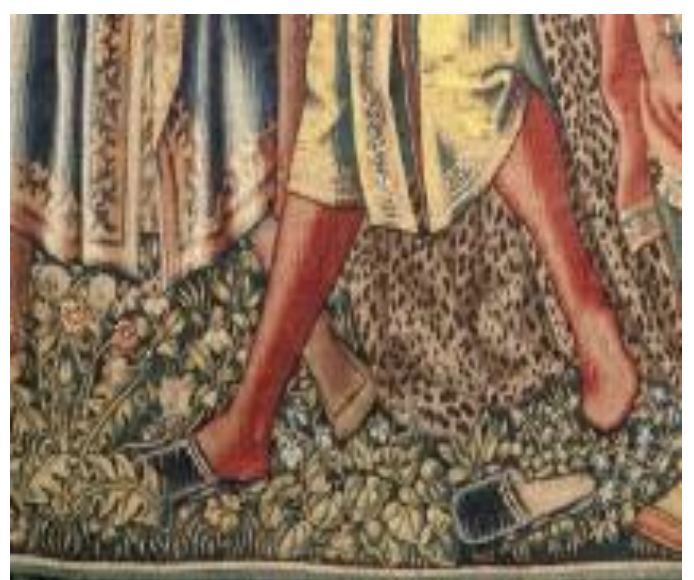

Nótese como a uno de los caballeros se le cae su pantuflo

Muestra de ello es el episodio de la boda entre Perión de Gaula y Elisena, de quienes se dice que "Aviéndose ambos con buen talante saludado y recibido y las bodas y las fiestas celebradas, acordaron los Reyes de se volver en sus reinos" (Amadís de Gaula, I, III), evento en el que no hay mayor demostración del enlace. De igual manera sucede con Oriana y Amadís, en donde Montalvo se limita a decir que: "Venido el día señalado, todos los novios se juntaron en la posada de Amadís, y se vestieron de tan ricos y preciados paños como su gran estado en tal auto demandava. Y assí mesmo lo hizieron las novias" (Amadís de Gaula, IV, CXXV), el único detalle que se da son los “ricos y preciados paños", que de 
acuerdo a algunos testimonios de la época hacen referencia a diversas telas y tejidos ${ }^{180}$ que eran apropiados para todas las clases, para la nobleza se especificaba la riqueza de los elementos de la tela, tipo de tejido, bordado e incrustaciones que pudiera tener, mientras que para la clase baja sólo se mencionaba la simplicidad de la tela. Por ejemplo, se tiene registro que para la boda del rey Felipe II con la reina María, en 1554, él vistió "un manto de paño de oro bordado en perlas [y ella] un manto de terciopelo negro cuajado ${ }^{181}$ de gemas" ${ }^{182}$. El paño de oro se conoce como una seda bordada con hilos de oro, éste también se usaba en la tapicería del palacio. Fresneda González da dos acepciones de éste: cualquier vestido y un tejido hecho con lana mezclado con algún pelo de camello ${ }^{183}$; el más preciado era el inglés, conocido como paño de Londres; además de éste había otros tipos de menor calidad como los paños tintos y los estambrados.

A diferencia de Montalvo, Feliciano de Silva sí presenta una primera propuesta de atuendo matrimonial para la ceremonia secreta, en donde se percibe la temprana inserción del autor en este tipo de confecciones por tratarse de trajes de diario, ya que con ellos realizan sus actividades durante el día y por la noche deciden permanecer así vestidos para el encuentro con las damas:

[Lisuarte e Perión] otro día ellos se vistieron muy ricamente cubriéndose dos mantos d'escarlata muy fina, bordados de oro e muchas perlas, tan apuestos que a todos ponían espanto [...] Venida la noche, después de todos acostados, Lisuarte e

\footnotetext{
${ }^{180} \mathrm{El}$ término paño se refería a la tela de lana, pero con el tiempo tuvo algunas variaciones que le dio varios significados, entre ellos, el de ser "cualquier vestidura", por lo que podían ser para hombre o mujer, de ámbito religioso o cortesano. María del Carmen Martínez, Los nombres de tejidos en castellano medieval, Granada: Universidad de Granada, 1989, pp. 136-137.

${ }^{181}$ Recargar tanto una cosa de adornos que impida verse lo principal. Manuel Núñez de Taboada, Diccionario de la Lengua Castellana, París: Imprenta de Lachevardière, 1825, p.416. https://books.google.com.mx/books?id=X3wCAAAAQAAJ\&pg=PA416\&dq=cuajado\&hl=es\&sa=X\&ved=0 ahUKEwjjup6Qg YDOAhXk54MKHWomBGQQ6AEINDAD\#v=onepage \&q=cuajado\%20\&f=false

En los libros de caballerías este término no aparece, sino que se dice "poblado o cubierto", de los cuales hay una gran cantidad de ejemplos de telas repletas de perlas, diamantes, hilos, aljófares y bordados.

182 Antonio Villacorta Baños-García, Las cuatro esposas de Felipe II, Madrid: RIALP, 2011, p.58.

${ }^{183}$ Nieves Fresneda González, Moda y belleza femenina ..., p.719.
} 
Perión, como vieron que era hora, assí como estavan ataviados se fueron al postigo de la huerta.

Onoloria e Gricileria tenían los sus muy fermosos cabellos sueltos sin otra cosa sobre ellos sino sendas redes de oro, sembradas por ellas muchas piedras e perlas. Dando las manos ellas a ellos, y ellos a ellas, se desposaron e passaron con mucho gozo. (Lisuarte de Grecia, XCVI)

Se debe destacar que, a pesar de que solo se menciona una prenda, el escritor establece sus primeras características como diseñador, el contraste en la variedad de colores y la mezcla de materiales, así como la creación de tocados femeninos en sintonía con los adornos que llevan los caballeros. Sin embargo, 1514 es aún una fecha temprana para exigirle a Feliciano de Silva que integre diseños más elaborados a su obra, porque se trata de la primera, lo que la convierte en un experimento de invención caballeresca. Este ensayo continúa con el Amadís de Grecia en donde hay tres bodas, pero una sola referencia a una prenda. La primera es entre Gricileria con Perión de Gaula y Lisuarte con Onoloria, durante una travesía en mar.

En la segunda se casa una gran cantidad de parejas encabezadas por Lucencio y Axiana, quien una vez bautizada junto con sus cincuenta doncellas a cada una le es dada en matrimonio caballeros del reino, pero en ningún momento se indica qué tipo de prendas llevaban.

En la tercera ocurre lo mismo con Amadís de Grecia y Niquea, quienes después de muchas travesías logran reunirse en secreto, momento en el que ambos hacen un juramento de matrimonio con el que se desposan, pero que se sellará varios episodios después en donde a Amadís le es entregada "una rica ropa de encima y puesto un capirote de mucha pedrería en la cabeça soltando los sus hermosos cabellos" (Amadís de Grecia, II, CXXIII). 
Con esta última pareja, se introduce una prenda masculina de gala llamativa por la pedrería del capirote.

Éste es la pauta que rompe con las tradicionales referencias generales a los atuendos nupciales, puesto que a partir del Florisel surge un proceso de invención por grados en el que Feliciano desbordará su imaginación con las principales parejas, en quienes se verán reflejados sus más asombrosos diseños. Muestra de ello está en el final de la segunda parte del Florisel de Niquea, en el que se celebran las bodas de cuatro parejas, en las cuales hay un importante recorrido del palacio a la iglesia en donde las parejas lucen sus trajes por el camino:

Yendo las hermosas novias en la forma siguiente vestidas con sus esposos. La linda Helena llevava una ropa de tela de oro sobre tela de plata golpeada, tomados los golpes a manera que harían una red relevada y todas las esquinas de sus mellas tomadas con gruesas perlas; la ropa era muy larga e ceñida y la ropa aforrada en armiños; llevava sus hermosos cavellos por las espaldas como fino oro esparzidos y puestos sobre ellos una red que todos los cubría, con tanta piedras y perlas que no tenían precio, sembradas por sus lados. Don Florisel iva de la suerte que la princesa vestido. La preciada infanta Alastraxerea llevava una ropa de raso blanco forrada en paños herminos y era de infinitos pliegues, toda cubierta de maçorca de oro que de las faldas hasta riba ivan diminuyéndose, y hazían desí unos joyeles, donde descubrían lo blanco de la ropa, en los cuales ivan unas estampas a manera de claveles, los peçones verdes y de oro, y las ojas de hermoso rosicler; en cada manga tenía cinco bexigas, una mayor que otra, que se apartavan y dilatavan hasta que la postrera que hazía la boca de la manga llegava al suelo; llevava sus hermosos cabellos sueltos y hechos de guedejas d'ellos, de los cuales pendían doze joyeles que no tenían precio, de forma de harpías hechos, y sobre la cabeça una guirnalda de una dança de joyeles de las mismas harpías, con tan ricos cercillos, collar y cinta que no tenían precio; y en las faldas se hazían seis largas puntas que seis donzellas hermosas de la suerte vestidas que ellas la llevavan. Don Falanges iva de una ropa como la infanta vestido, con un capirote de lo mismo en su guirnalda. La hermosa Oriana llevava vestida una ropa de terciopelo azul forrada en tela de oro y la tela en 
zebellinas toda golpeada con unos golpes que hazían unas <<aes〉> griegas, los bordes de gruessas perlas y tomados con cordones de oro y seda verde; la ropa era muy larga y ceñida, las mangas muy anchas de las bocas y del <del> nacimiento, muy apartadas con infinitos pliegues; los cabellos llevava hechos todos mil formas de ñudos en lo alto de la cabeça, y las lazadas que sobravan podían por más de cincuenta partes salir su hermosa garganta, con infinito número de gruessas perlas por ellas sembradas, y en lo alto de la cabeça, junto con resplandecientes semblantes d'argentería, con cercillos y collar y cinta tan ricos que no tienen precio. El fuerte Anaxartes iva vestido de la misma forma. La princesa Leonorina iva vestida una ropa de terciopelo verde aforrada en tela plata y la plata en zebellinas golpeada de muchos golpes y tomados con estampas de oro de unos luzeros relevados cuarteados de rosicler y llena de mucha pedrería, a manera de las egipcianas, con collar y cercillos e cinta de gran valor. Don Lucidor [Florisel] ${ }^{184}$ iva de la misma suerte, con capirote de mucha pedrería. Iva la duquesa Armida vestida de una ropa que toda era de oro de martillo, de una forma de cuñas encaxadas unas en otras con diversos colores d'esmaltes por ellas, muy largas y ceñidas; llevava los cabellos cogidos a guedejas en una guirnalda de mucha pedrería, con muchos joyeles que pendían de todas partes de las lazadas, con que ivan de los cabellos tiradas con ricos cercillos, y cinta y collar. El emperador Arquisil iva vestido de una ropa de la misma suerte labrada y todos los otros príncipes y princesas ivan tan ricamente vestidos que no tenían precio. (Florisel de Niquea II, LXIII)

La primera pareja en el recorrido es la de Florisel y Helena. Ella viste una ropa de tela de oro sobre tela de plata golpeada. Esta descripción es un poco complicada de definir porque la "ropa" es un término general que designa cualquier prenda, especialmente a las de encima, en los hombres se caracteriza por no llevar mangas, por lo que podría tratarse de un jubón, una capa o un sayo; mientras que en la mujer eran con mangas, como la basquiña y la gorguera.

\footnotetext{
${ }^{184}$ Hay un error de transcripción en la reciente edición del Centro de Estudios Cervantinos de 2015, colocan el nombre de Florisel, pero en las ediciones de 1532 y 1584 está el nombre de don Lucidor, lo cual es correcto puesto que Lucidor es la pareja de la princesa Leonorina.
} 
Es difícil establecer qué indumentaria usaban, pero debido a la festividad de este pasaje, es probable que Helena llevara una gorguera con tela de red similar a la que lleva la duquesa de Alba en 1550 (fig.59), ${ }^{185}$ además de que en su fabricación se empleaban telillas de oro y desde 1540 "se estilaron gorgueras de red; en las más ricas, la red se hacía de oro y plata hilados, de perlas o de aljófar" ${ }^{186}$. Estos elementos de la gorguera están presentes en este ejemplo, pues sobresale la tela, la cual al estar fabricada con hilos de oro la convierte en el tejido más lujoso que el resto de las demás damas ${ }^{187}$. Lo que sí es claro es que está ajustada al cuerpo, por lo que podría llevar una cinta. Aunque el texto no lo menciona, las prendas se ceñían con una correa, una faja o un cinturón ${ }^{188}$ que combinaba con las demás joyas que llevaran.

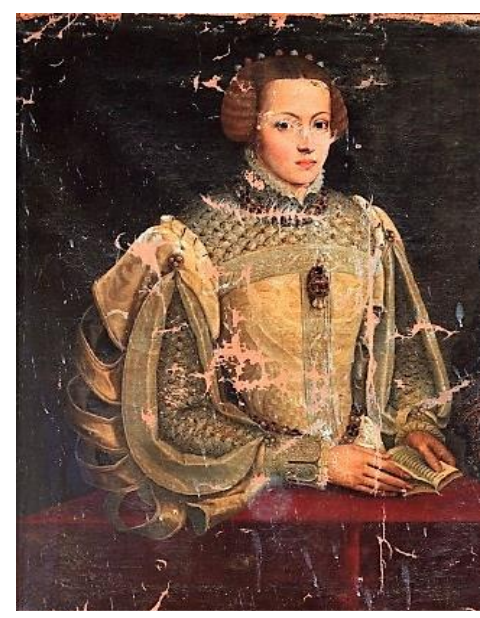

Fig. 59. Duquesa de Alba (1550-1560) El Castañar, Toledo. Las mangas caprichosas permiten ver las mangas con red de oro a juego con la gorguera.

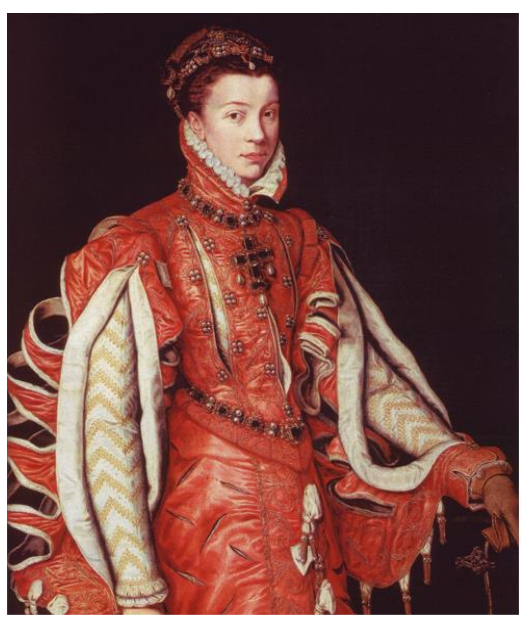

Fig. 60. Isabel de Valois (1560) Antonio Moro Traje de novia de Isabel de Valois para su boda con Felipe II. Lo más notable son las mangas caprichosas en armonía con las cuchilladas de la falda.

\footnotetext{
${ }^{185}$ Este tipo de atuendo que se observa en la pintura de la Duquesa de Alba es muy importante porque se trata del modelo del vestido de novia de la infanta Isabel de Valois con Felipe II. Carmen Bernis comenta que fue un modelo muy usado por las damas para asistir a la boda del duque de Sesa y en la de la condesa de Niebla, las dos en 1541. Carmen Bernis, Indumentaria española en tiempos de Carlos V..., p. 69.

Por lo que se trata de uno de los primeros modelos de moda para ceremonias matrimoniales y que de acuerdo al uso de telillas de red es muy posible que los escritores del género caballeresco recrearan ciertos elementos en sus obras. Véanse las imágenes 60, 61 y detalle, en donde Sánchez Coello continúa pintando este diseño en diferentes fechas.

${ }^{186}$ Carmen Bernis, Indumentaria española en tiempos de Carlos V..., p. 92.

${ }^{187}$ Este tejido fue condicionado por los Reyes Católicos en su pragmática, recordemos que sólo lo podían usar los caballeros del ejército durante la guerra. Ibid, p.15.

${ }^{188}$ Corominas describe un objeto llamado "ceñidor", un cinto de seda o lana con oro encima que se usaba para ajustar la prenda.
} 


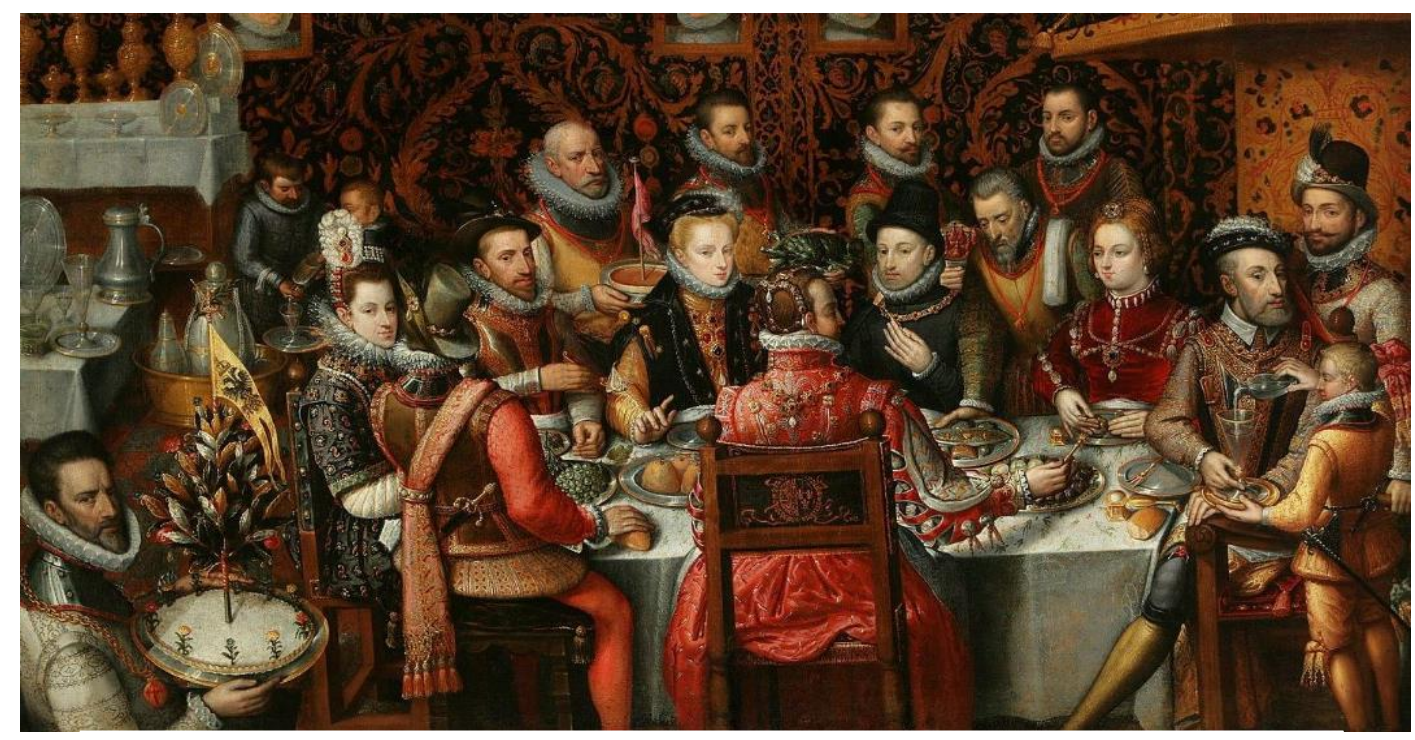

Fig. 61. El banquete real (1579) Alonso Sánchez Coello, Museo Nacional de Varsovia. Detalle de la parte de atrás del traje de Isabel de Valois en el que predominan las cuchillas en la falda y las mangas caprichosas.

En conjunto con la red del vestido está la del cabello, ambas tienen en cada pliegue una fina piedra. Sobre el tocado es posible que se trate de una albanega, una red suelta que cubría el cabello. Los materiales para su fabricación eran seda, hilos metálicos, cendal, etc. ${ }^{189}$ Aunque algunos autores consideren que este tocado tuvo su auge en los siglos XIII$\mathrm{XV}$, aún hay registros de su uso durante el siglo XVI, ejemplo de ello está en la boda de la infanta María de Portugal y el rey Felipe II, ella "vestía de raso blanco acuchillado de oro, con una gran capa morada sobre los hombros y el pelo cubierto por una red de oro"190, por lo que es común que los escritores de libros de caballerías las siguieran recreando en sus obras.

Los siguientes personajes son Alastraxerea y Falanges, en los que desde el inicio se ve una mayor prolongación en la descripción de su vestimenta, a comparación de la pareja anterior. La dama lleva "una ropa de raso blanco forrada en paños herminos", a comparación de la tela de oro, el raso es un tejido "de seda de más cuerpo que el tafetán y

\footnotetext{
${ }^{189}$ Nieves Fresneda González, op.cit., p.352.

${ }^{190}$ Antonio Villacorta, op.cit., p.27.
} 
menos que el terciopelo con brillo por una de las caras" ${ }^{\prime 191}$. De textura más rígida el raso será una de la telas más usadas por la burguesía ${ }^{192}$ a partir del siglo XV, el lujo de éste aumentará de acuerdo a las combinaciones que se hagan con otros tejidos y bordados; en este ejemplo se trata del armiño, Covarrubias menciona que por su piel blanca con la extremidad negra eran llevados "en las ropas rozagantes de los príncipes sobre los hombros de la prenda" (Tesoro de la lengua). Su especial uso se debe a que se utilizaban para cubrirse del frío.

Nieves Fresneda comenta que “eran lujosas y costosas, en 1268 su precio era de ocho maravedíes la docena y fue una piel controlada por la corte"193. Su auge inició desde su aplicación como orilla y cuello en las capas reales y mangas en los vestidos de las mujeres; en la pintura Carlos V y Felipe II, de Antonio Arias, se observa el contraste de la capa roja con el rodete de armiños.

El uso de esta piel hace que el traje de Alastraxerea resalte por el oro de "las mazorcas", que no son imágenes del maíz, sino que se trata de una técnica de bordado en cada pliegue que, por el grosor del hilo, se asemeja a la mazorca (Tesoro de la lengua ${ }^{194}$. El atuendo de la joven se complementa con una gran cantidad de alhajas que resaltan por su forma y color. En el vestido lleva numerosos joyeles con figuras de claveles de rosicler, y de sus cabellos también cuelgan gran cantidad de estos en forma de arpías que hacen juego

${ }^{191}$ María del Carmen Martínez, op.cit., p.325.

192 Ángel Santos Vaquero, La industria textil sedera en Toledo, Cuenca: Ediciones de la Universidad de Castilla-La Mancha, 2010, p.51.

193 Nieves Fresneda González, op.cit., p.174.

${ }^{194}$ En el Quijote aparece una alusión a este tipo de bordado en el capítulo X de la segunda parte Sancho le dice a don Quijote: "Pique, señor, y venga y verá venir a la Princesa nuestra ama vestida y adornada, en fin como quien ella es. Sus doncellas y ellas todas son una ascua de oro, todas mazorcas de perlas, todas son diamantes". En la nota se expresa que "Dicen que mazorca es voz de origen arábigo. Significa la husada o el bulto del hilo que rodea al huso después del hilado del copo. Por semejanza se dice de la espiga del maíz y otras plantas". Miguel de Cervantes, El ingenioso hidalgo don Quijote de la Mancha, ed. de Diego Clemencín, $\quad$ Madrid: $\quad$ E. $\quad$ Aguado, $1835, \quad$ p.173. https://books.google.com.mx/books?id=srFdAAAAcAAJ\&printsec=frontcover\&hl=es\&source=gbs_ge_sum $\underline{\text { mary_r\&cad }=0 \# \mathrm{v}=\text { onepage } \& \mathrm{q} \& \mathrm{f}=\text { false }}$ 
con la guirnalda que lleva la misma figura. Este atavío finaliza con las seis puntas que salen de la falda, las cuales son llevadas por seis doncellas como forma de cortejo. De este atuendo es importante extraer el diseño del tocado, el cual lleva “doze joyeles que no tenían precio, de forma de harpías hechos, y sobre la cabeça una guirnalda de una dança de joyeles de las mismas harpías" (Florisel de Niquea II, LXIII). No es gratuita la referencia a la cantidad de arpías que lleva en el cabello, pues se trata del equivalente a su nombre y en representación del sufrimiento de amor vivido por la pareja.

Detrás de ellos vienen Oriana y Anaxartes. La joven viste "una ropa de terciopelo azul forrada en tela de oro y la tela en zebellinas". Lo primero que predomina son los tipos de telas, terciopelo y cebellina; esta última es una "especie de marta cuya piel es muy fina y estimada"195, considerada uno de los materiales más finos de la época por su costo de producción, al igual que el armiño; solía llevarse alrededor del cuello como una especie de bufanda para la época de frío, aunque también las damas lo llevaban en las manos, a manera de bolso ${ }^{196}$. En este ejemplo la princesa lo lleva en su vestido junto a la tela de oro.

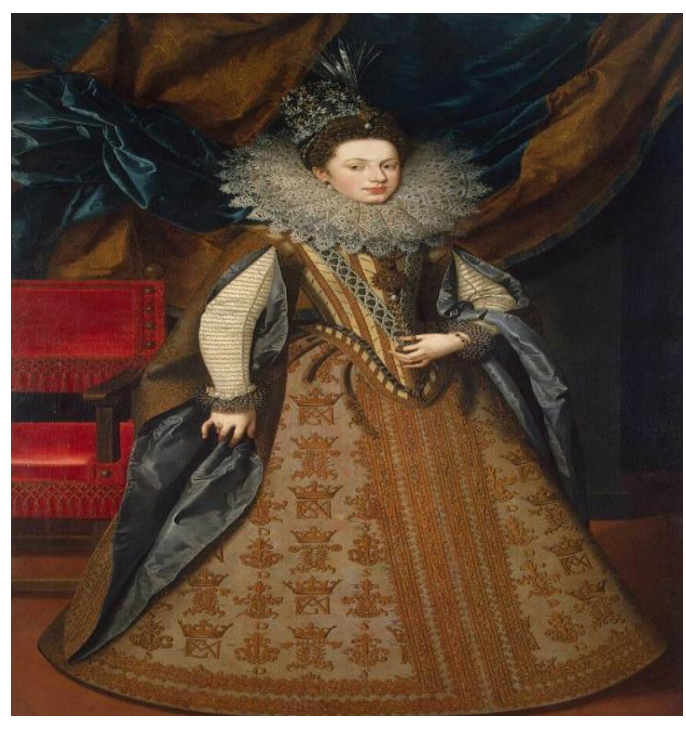

195 Manuel Nuñez de Taboada, op.cit., p. 297.

196 Letizia Arbeteta, La joyería española de Felipe II a Alfonso XIII ..., p. 74.

197 Acerca de estas "aes", se tratan en el apartado de "Letras bordadas" como una forma de comunicación secreta entre los enamorados y que para los demás personajes parecerá un adorno del vestido. Es una especie de lenguaje entre hilos.
Lo más vistoso será que tras cada cuchillada se fomen unas “aes” griegas ${ }^{197}$ (fig. 62)

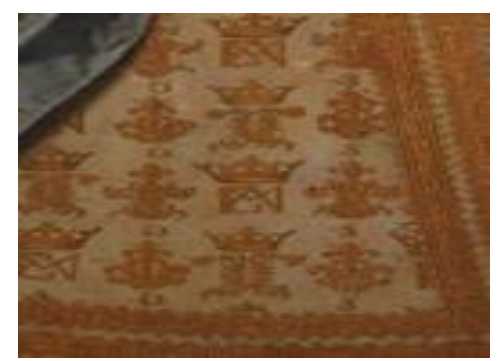

Fig.62. Margarita de Saboya (1608)

Frans Pourbus el Joven, Museo Hermitage.

En la falda aparece el monograma FGMA por su esposo

Francisco Gonzaga. 
La amplitud de la ropa la obliga a llevarla ceñida, modo que será muy utilizado porque debían darle forma al vestido para lucir su figura. De nuevo, este atavío se complementa con una gran cantidad de perlas que la joven luce en el vestido, cuello y cabello junto a otras joyas.

Enseguida aparecen Leonorina y Lucidor. Ella lleva vestida "una ropa de terciopelo verde aforrada en tela plata y la plata en zebellinas". A partir de esta pareja se ve que hay ciertos elementos que se repiten. Por un lado, la tela de plata que sirve de forro para el terciopelo y las zebellinas, que son otro animal preciado como el armiño (martas cebellinas). Sin embargo, sí contiene elementos que sobresalen del atuendo como "las estampas de oro de luzeros". Este accesorio se trata de una imagen de estrella dorada grabada en una pieza de rosicler que funge de botón entre cada golpe. En este pequeño rosicler se plasma una imagen importante, la de un lucero en representación de su amado Lucidor; es otra forma de llevar el nombre de su futuro esposo sin que nadie más lo descifre.

Por último, llegan Armida y Arquisil. La dama cierra el desfile con una ropa de "oro de martillo"198 Este material consiste en golpear el oro hasta obtener delgadas láminas del material, hasta tomar la forma de pequeños triángulos. Lo laborioso de este traje está en ordenar cada pieza encima de la tela para darle forma de vestido. Su tocado consiste en una guirnalda con mucha pedrería de la que cuelgan diversos joyeles.

El atuendo de los caballeros no se describe a detalle como el de las mujeres, sólo se menciona que llevan un capirote a la manera de la misma ropa que las princesas, por lo que

${ }^{198}$ En mi tesis de maestría, Doncellas, princesas, reinas y sabias: Interacción de la mujer en los libros de caballerías, investigué el "oro de martillo" usado en otros objetos como joyas, utensilios y espadas, la forma de trabajarlo consiste en colocar el grano de oro entre dos hojas y golpearlo con un martillo hasta formar una delgada lámina. 
podemos imaginar que Florisel llevaba un gorro dorado con plata, Falanges uno blanco, Anaxartes uno de color azul con oro, Lucidor uno de terciopelo verde con plata y Arquisil uno dorado con esmaltes de colores, todos ellos con las mismas piedras que sus damas. A semejanza de estos personajes, el rey Felipe viste igual que la infanta María en su boda, él lleva "un traje de seda blanca de pies a cabeza, gorra, jubón, calzas y zapatos con hebillas de plata"199

Se puede ver que hay una mayor espectacularidad en los vestidos femeninos que en los masculinos, por la gran cantidad de tela que requieren, las piedras incrustadas a las orillas de las mangas y entre cada golpe, así como las invenciones bordadas en las faldas. En contraste, hay una menor descripción del atuendo varonil, los autores reducen su creación a la frase "iba vestido igual que la princesa", por lo que sólo se requiere imaginar el jubón, el sayo y la capa con los brocados, colores e insignias del ajuar femenil.

A pesar de que la primera pareja, Florisel y Helena, usan la vestimenta más costosa por el material con que está hecha, hilos de oro, no es la más llamativa en cuanto a bordados y adornos, pues el traje de Oriana y Anaxartes presenta un nivel mayor de dificultad en cuanto a técnica por el bordado de sus letras; sin embargo, por la calidad y cantidad de pliegues sobresale el atuendo de Alastraxerea y Falanges, además de estar complementado de una infinidad de joyeles. En este capítulo será el lector quien decida cuál es la mejor vestimenta.

Con este pasaje presento una nueva propuesta, la de que las prendas más lujosas por el costo de producción no siempre son las más asombrosas en cuanto a diseño y creación, pues, como se vio en este ejemplo, los tres vestidos restantes tienen elementos más detallados y vistosos que oscurecen lo brillante del oro.

\footnotetext{
199 Antonio Villacorta, op.cit., p.33.
} 
En el Florisel de Niquea III sólo hay una boda la de Agesilao y Diana, la cual se realiza de forma breve: "y después de comer, algo tarde, Agesilao e Diana públicamente fueron desposados, porque ya era venida la licencia para ello del Sumo Pontífice. Y estando en gran regozijo Agesilao, puesto en la falda de Diana, él le dixo: -Mi señora, es tanta la gloria que recibo en teneros por mi señora" (Florisel de Niquea III, CLIV). Nuevamente sólo se menciona un detalle, la falda de la dama que sirve de reposo para el caballero. Pero en este episodio hay una excepción que permite la falta de atuendos, se trata de la rapidez con la que deben casarse puesto que la licencia matrimonial ya estaba dada y no podían esperar, por lo que esta situación justifica la ausencia de ricas prendas.

Con la cuarta parte del Florisel se retoman los prolongados pasajes matrimoniales:

[Archisidea] se vistió una ropa larga y muy ceñida de raso carmesí hazia se sobre ella una red de torcidos de raso blanco de anchura de un dedo que dexavan entre torcido y torcido en las vandas y tiras, que hazían la red descubierto tanto como medio dedo de ancho del carmesí y dexavan hechos los cuadrados de la red del tamaño de los cuadrados de una xedrez sobre los torcidos y vacíos que estrechos en medio de si hazían. Ivan puestas unas maçorcas de oro de canutillo, que se travavan por los cabos en las cruzes de la red, que los torzidos hazían tomadas con una gruessa perla oriental con un delicado flueco que della salía, de oro y blanco. Y en cada xaquel que la red hazía yvan en el medio d'él las unas flores que se llaman mayas, las yemas de oro, y las hojas de plata, que cosa hermosa era de ver los vislumbres que las maçorcas de oro sobre los torcidos y carmesí hazían. Llevava un tocadillo sobre su cabeça, hecho de una delicada red de oro de martillo toda de engastes de finos rubies y diamantes. En horden tanto de unos como de otros. De suerte que dexavan las xaqueles de la red que hazian harto abiertos y por cada xaquel salía una lazada de sus muy hermosos cabellos. El tocadillo llegava hasta dexar dos dedos de cabellos encima [de] la fruente con una vuelta de un dedo en alto que de perlas de hechura de pequeñas peras en las puntas para arriba se hazian y cada punta se rrematava con un flueco de la suerte que las perlas de la ropa de cada lado del tocadillo por la parte de delante y por la parte detras de cada oreja 
salían dos hermosas y largas guedexas de sus cabellos que dexavan sus muy ricas y resplandecientes arracadas por medio de sus cubiertas y las guedejas se cruzavan por embaxo atadas con un joyel de un rico diamante de cada parte y las puntas trocadas en la cruz que della se hazía, la una se esparzía por sus hermosos pechos y riquísimo collar de rubíes y diamantes que llevava y la otra por las espaldas juntamente con cinta de lo mesmo del collar. El hombro llevava a manera de derrocada con descuydo y mucha gracia y ayre una mantilla de tela muy delgada texida de diversas colores de seda y oro que hazían los vislumbres que las hermosas plumas de las aves orientales hazer suelen a la vista y las orillas della de hermosas perlas pobladas. Y de la misma manera salió la muy hermosa reyna Sinestasia y el emperador don Rogel y rey de Susiana llevavan ropas y capirotes a la manera de sus esposas. La hermosa princesa Diana llevava una ropa de muy larga falda de raso blanco muy golpeado sobre tela de oro fino y cada golpe tomado en un torçal de oro y blanco con puntas o cabos en cada torçal hechos de fino oro, largos, delicados y entorchados de rosicler y oro bruñido y la laçada de cada torçal tomada con una cifra de oro con hermosos esmaltes de rosicler y blancos. Llevava sobre sus hermosos cabellos con tocado a manera de celada antigua hechas de barrillas de oro todas atadas de infinitas laçadas de sus cabellos con delicadas arrandelas a los lados, pobladas de menudos rubies y en medio un hermoso diamante de punta, por detrás de cada arrandela salía una gruessa guedexa de sus cabellos y dava una vuelta por entre la arrandela y el tocado y tornavan a esparcirse por las espaldas. Llevava muy hermosos y ricos cercillos de resplandecientes piedras y collar y cinta de muy hermosos bolages con mantilla en el hombro de tela delgada de oro y blanco guarnecida de unas franjas hechas como lisonjas de gruesso aljófar. De la mesma manera, como diximos, yvan todas las otras no viendo allí ya Agesilao y sus esposos con ropas y capirotes de la misma suerte. Todos los emperadores y emperatrizes, reyes y reynas, y príncipes y infantas y preciados cavalleros, dueñas y donzellas, cada una en su estado se vistió lo mejor y lo más ricamente que pudo. Pues en tal manera con son de muchos menestriles fueron llevados los novios y novias a la capilla, donde con gran solenidad se dixo la missa y fueron velados. (Florisel de Niquea IV, II, LXXIII) 
Sin duda alguna, Feliciano de Silva mantiene la originalidad en cuanto al diseño y confección de los trajes de boda, no sólo porque en sus cinco obras es donde aparecen el mayor número de atuendos de este tipo frente a los demás libros de caballerías hispánicos, sino porque establece un método descriptivo que va de la minuciosidad a la generalidad. En este hace delicadas y detalladas referencias a todos los adornos que conforman el vestido, desde los hilos, los tipos de tela, las aplicaciones de metal y de cristal, la forma de los bordados, la combinación de colores, las figuras que se forman entre los hilos, hasta el tipo de tocado y la manera de llevar el cabello.

El primer elemento que destaca es el diseño, una ropa larga de dos telas, la base de raso carmesí y una red de torzales de raso blanco (fig. 63). Esta combinación carmesíblanco permite el contraste de colores y la formación de cuadros a manera de ajedrez. De este tipo de modelo hay varios retratos en los que las damas llevan un vestido con elementos cuadrados o rombos, como primer decorado de la tela (figs.64, 65). Sobre ella suelen llevar redes de oro hechas con torzales de este material o de otras aplicaciones, perlas y piedras preciosas que se engastan una a una para formar dichas figuras. Para lograr la simetría entre líneas era importante el uso de patrones para la alineación de las bandas. Sobre esto, el libro de la Geometría de trazas explica cómo debían hacer las banderas a cuarterones para conseguir la perfección de los cuadros (figs. 66-68); de la misma manera Silva explica la medida de los cuadrados de la red: "tanto como medio dedo de ancho del carmesí y dexavan hechos los cuadrados de la red del tamaño de los cuadrados de una xedrez" (Florisel de Niquea IV, II, LXXIII), expresión que permite intuir que el autor tenía cierto conocimiento en el gremio de sastres. 


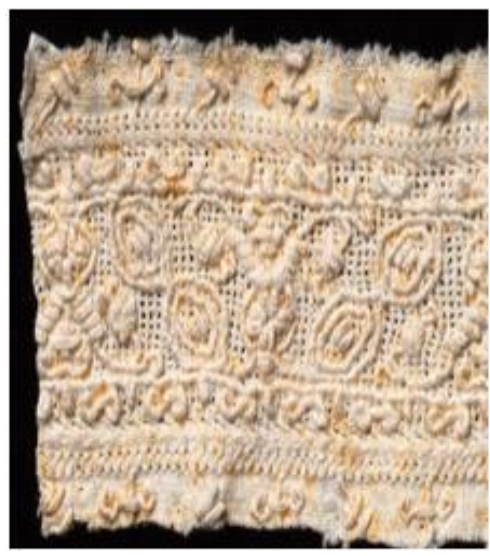

Fig.63. Italia (s. XVI)

Aplicación de encaje con hilo torcido.

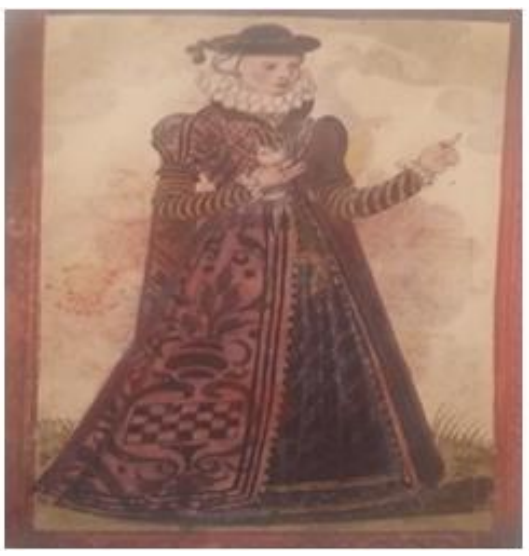

Fig. 64. Album Amicorum of Portner, honourable lady

The British Library, London.

Imagen de tablero de ajedrez en la falda.

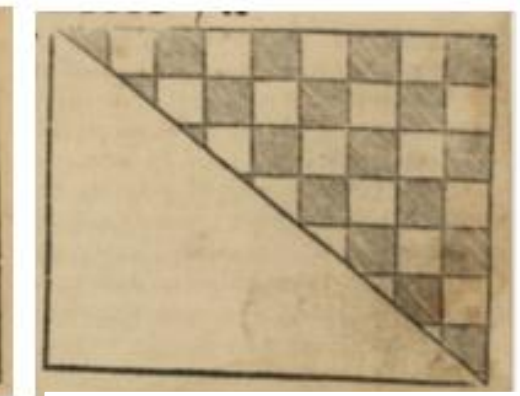

Figs. 66-68 Geometría de trazas

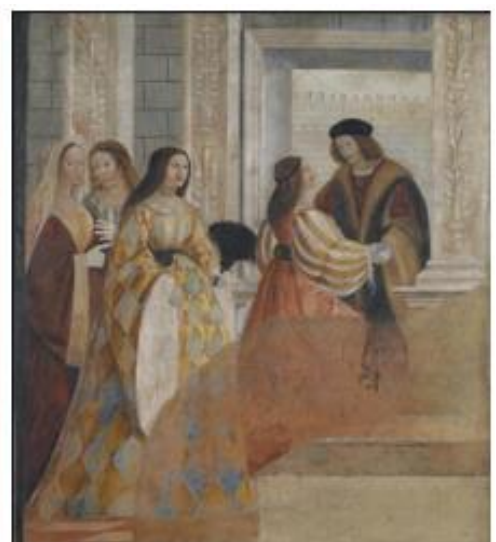

Fig. 65. Incontro degli sposi (1517-1518)

Floriano Ferramola, Santa Giulia, Museo della città, Brescia. Dama con vestido a rombos.

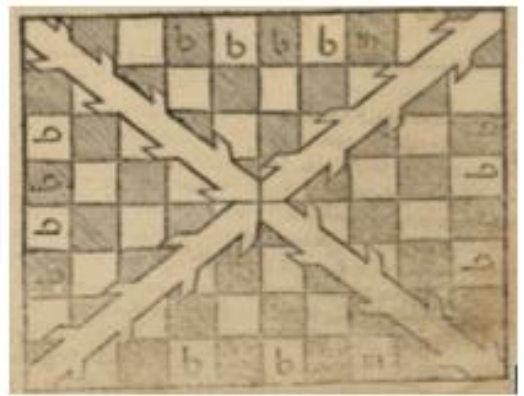

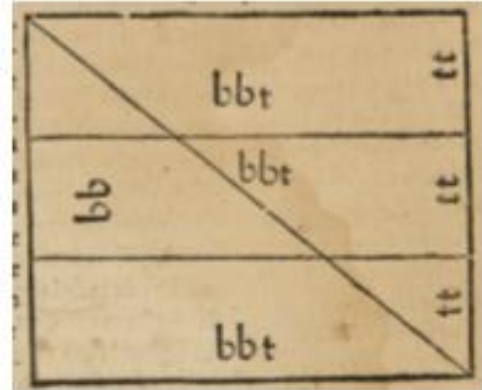

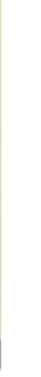

\section{(n)}


por dos motivos: 1) La imitación de los diseños textiles que imperan en las damas de las cortes europeas en donde cada reina tiene al menos un vestido con este tipo de aplicación floral que sobresale de la tela (fig.70 y detalle). 2) Feliciano es de los pocos escritores que alberga una gran variedad de elementos florales y vegetales para adornar las prendas.
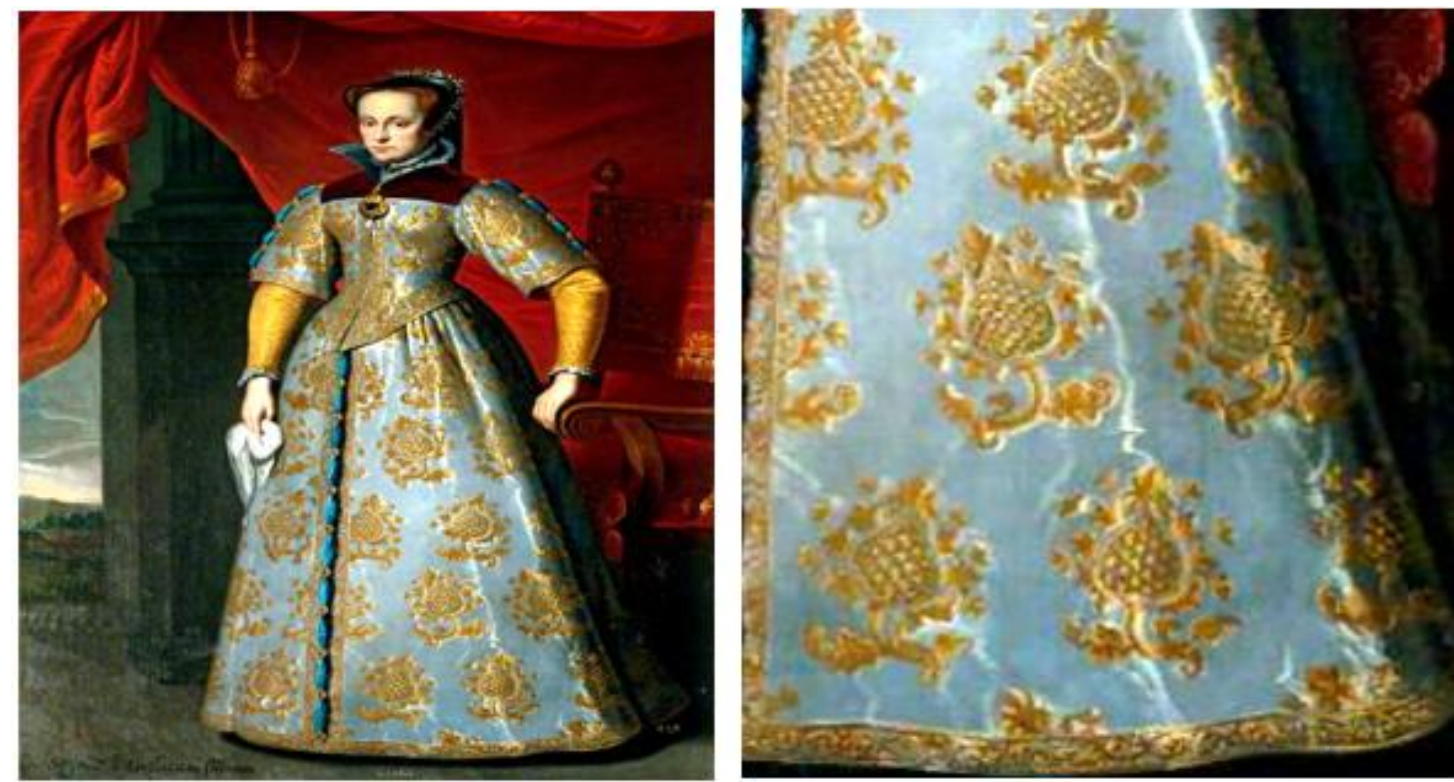

Fig. 69. María I de Inglaterra

Antonis Mor

El hilo de oro era la base principal para la realización de elementos florales, pues permitía delinear las separaciones entre los granos de mazorca, granada, alcachofa y piña.
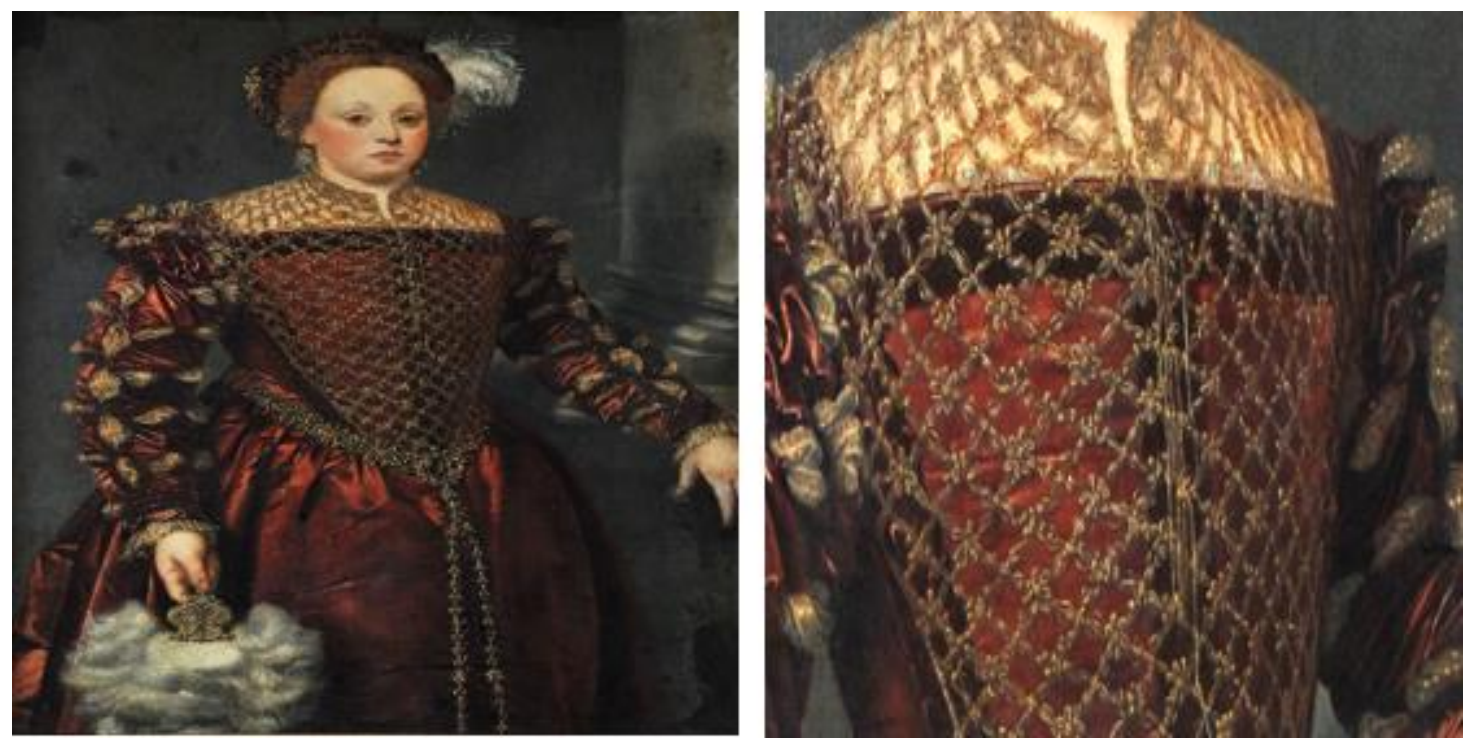

Fig. 70. Retrato de dama (s. XVI)

Museo de Arte Oriental y Occidental de Odesa, Ucrania

Dama italiana con aplicación de red de oro sobre el torso, en la unión de cada jaquel lleva una flor realzada. 
La composición del vestido se completa con el tocado de red que Archisidea lleva sobre sus cabellos. Éste mantiene la estructura a cuadros como la red del vestido. En donde se sustituyen las flores por las piedras preciosas insertas en cada punta, además de la forma de entresacar el cabello por medio del tocado. Además de las joyas que la adornan, el atuendo finaliza con la mantilla de colores que lleva sobre el hombro, ésta presenta una propuesta interesante. Primero se debe notar la forma en cómo la describe el narrador: "El hombro llevava a manera de derrocada con descuydo y mucha gracia y ayre una mantilla de tela muy delgada texida de diversas colores de seda y oro que hazían los vislumbres que las hermosas plumas de las aves orientales hazer suelen a la vista y las orillas della de hermosas perlas pobladas" (Florisel de Niquea IV, II, LXXIII), en el hombro un poco desacomodada, pero no por ello falta de riqueza textil, su base de seda y oro le permite crear un efecto de resplandor.

El interés de esta última prenda es su colocación porque solo la lleva de un hombro. Con lo que se propone la importancia de la ubicación y el arreglo de las prendas para permitir que se vean las de abajo, de modo que la belleza de cada una no se oculte bajo la tela de las prendas que van encima, por ello la necesidad del uso de una tela delgada, a manera de tul, para que permita observar los diseños que se ocultan tras el tejido. Por ello también la posición de las perlas, en la orilla de la mantilla para que el centro quede libre y sea más fácil distinguir la red del vestido.

Feliciano de Silva piensa en todos los detalles al momento de crear sus diseños, puesto que no sólo se trata de agregar una infinidad de adornos a las telas, sino de saber ubicarlos de modo que cada uno de ellos se puedan observar. Asimismo, se nota el conocimiento que tiene sobre los tipos de tela, porque sabe ubicar, de acuerdo al grosor del tejido cada una de las capas textiles de acuerdo a la transparencia que otorga, raso, red, seda 
delgada, composición que será más común ver en los cuellos y escotes de las damas nobles de la época. (fig.71)

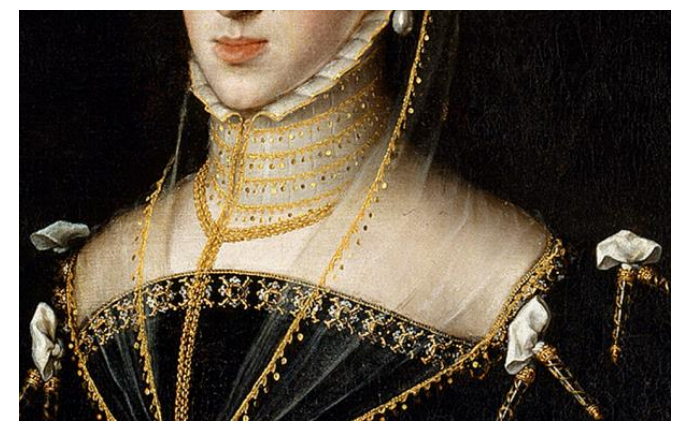

Fig.71. La emperatriz María de Austria, esposa de Maximiliano II (1551) Antonio Moro, Museo del Prado.

La orilla de la mantilla está adornada con aplicaciones de oro, el tul permite ver el terciopelo negro de la saya y la gorguera blanca.

De acuerdo con el traje de Archisidea, el modelo de la época que más se le parece por la semejanza de los detalles es el que aparece en el Retrato de Catalina de Medici (fig. 72), porque lleva una formación de rombos con perlas cosidas, en cada punta se inserta una piedra oscura; además de que dentro de cada jaquel aparece una flor bordada, el vestido se complementa con varias joyas como un broche de cruz en el pecho, una cinta de caderas con broche y numerosas aplicaciones de perlas pera. Enseguida se describe el traje de Diana, el cual se compone de raso blanco sobre tela de oro con golpes, es decir cuchilladas que en cada una lleva un torzal de oro con esmalte de rosicler y blanco. El primer detalle se da nuevamente por la combinación de colores, blanco y oro. Éstos se combinan a través de los cortes en el raso blanco, en la cual se deja entrever la tela de oro. (fig.73) 


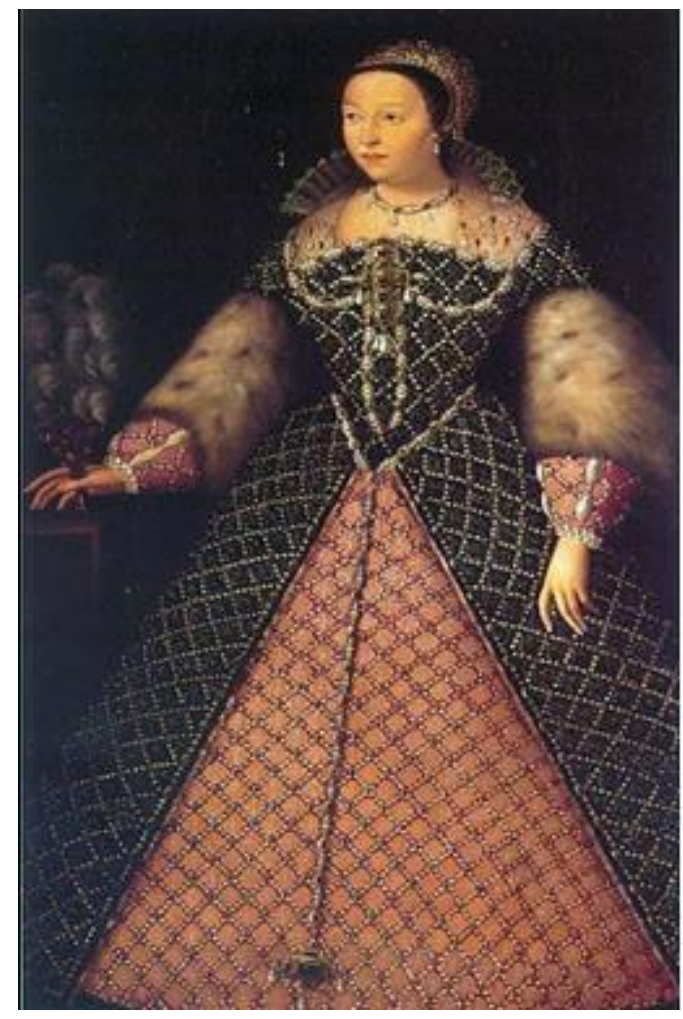

Fig.72. Retrato de Catalina de Medici (1547-1559) Gallería Uffizi, Florencia

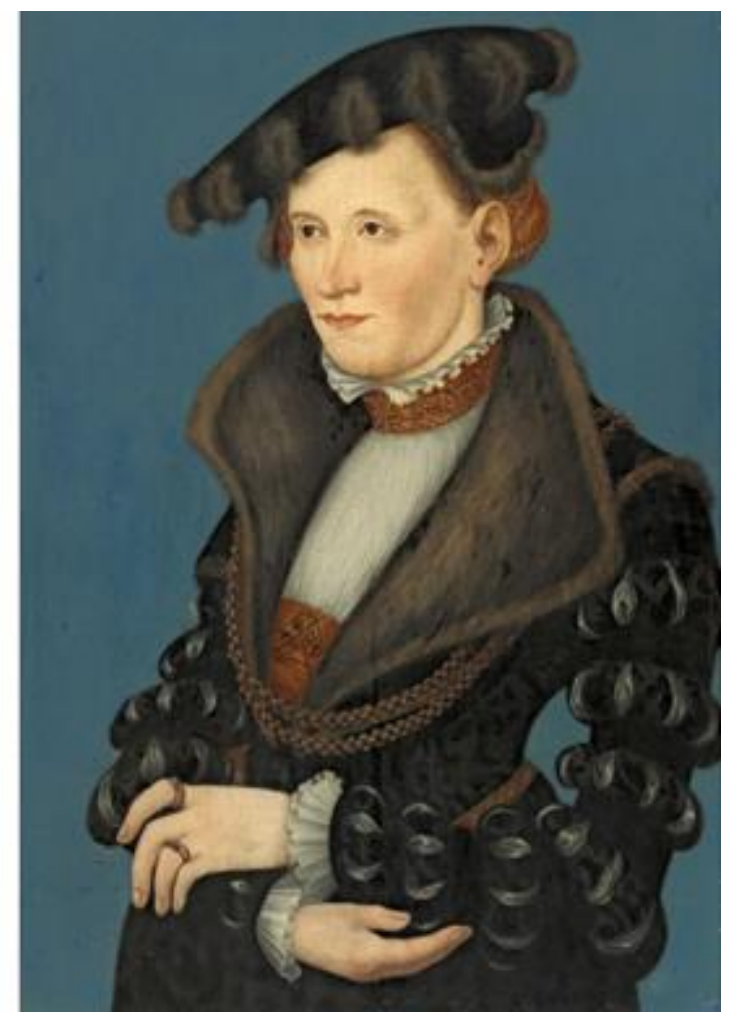

Fig. 73. Retrato de una mujer (1539)

Lucas Cranach el Joven, Museo Thyssen-Bornemisza Técnica del acuchillado en las mangas.

El accesorio más interesante es el tocado, el cual era "a manera de celada antigua hechas de barrillas de oro todas atadas de infinitas laçadas de sus cabellos con delicadas arrandelas a los lados, pobladas de menudos rubies y en medio un hermoso diamante de punta" (Florisel de Niquea IV, II, LXXIII). Una nueva estructura se integra al unir el metal con el cabello a modo de que éste se sujete. Lo vistoso es el diamante que sobresale de los rubíes.

También porta una "mantilla en el hombro de tela delgada de oro y blanco guarnecida de unas franjas hechas como lisonjas de gruesso aljófar" (Florisel de Niquea IV, II, LXXIII). Nótese que se conserva el tejido delgado para permitir ver las prendas de abajo. En este caso lleva los mismos tonos del vestido. 
El resto de los personajes, tanto esposos como acompañantes, van vestidos al modo de las damas, cada uno acorde a su esposa, forma de describir que ha caracterizado a Silva desde el principio de sus obras, en donde se nota la prolongación detallada para los trajes femeninos en comparación a la sintetizada referencia a los masculinos. Esta técnica responde a una característica singular del autor frente a otros de sus compatriotas, quienes refieren la falta de descripciones de los atuendos debido a que "querello poner en escripto sería no le poder acabar de decir" (Félix Magno IV, CXLVII); incluso en otras ocasiones este acto descriptivo lo consideran falto de cordura para el resto de los hechos: "no se podrá dar culpa al cronista si dexo de escrevir los atavíos y hermosuras de los que havéis oído, pues si lo cometiera no se le otorgara salir sin gran menoscabo de su crédito, con que pudiera dudarse todo lo otro que escrivió verdadero"201 (Valerián de Hungría, II, LXXXIV), como una forma de respaldar los hechos narrados en sus historias, algunos escritores desechan la idea de contribuir al conocimiento de las prendas por considerarlas inverosímiles.

La razón de estas largas referencias textiles se debe a dos motivos, el primero es porque se trata de una especie de espejo en donde se refleja la vida cortés a la que tenía acceso Silva gracias a su relación con la corte, en donde pudo apreciar de cerca los trajes de las damas nobles. El segundo es porque la indumentaria femenina se conforma de más elementos, lo que significa más variedad de accesorios, capas de tela, adornos, peinados, tocados, joyas, etc., que permite identificar los grandes guardarropas que se almacenaban en el palacio.

\footnotetext{
${ }^{201}$ Se debe notar la contradicción del escritor al negarse a describir los atuendos femeninos por considerar que debilitan la verosimilitud de la historia mientras que en el capítulo LVII de la primera parte sí detalla un traje de boda.
} 
Este tipo de pasaje de las bodas, en el que se ve el recorrido por el reino hasta la iglesia, es poco común en estos libros. Feliciano es el único autor que recrea todo un desfile para sus personajes, a los que viste de gran manera que es difícil decidir cuál pareja es la mejor vestida. Esta estrategia descriptiva responde a un modelo de preparación para las ceremonias de los Trastámaras en tres fases:

El primero, basado en el acto de los esponsales, fue el de mayor alcance político al atribuírsele un carácter legitimador y, en consecuencia, el de mayor proyección pública de todos los que se organizaban en torno a este acontecimiento. A este evento le seguía la ceremonia litúrgica, mientras que el tercer tiempo era el espacio de las fiestas, de las justas, de los torneos y de las corridas de toros. ${ }^{202}$

Etapas definidas por tres actos en los libros de caballerías: velación de los novios, ceremonia matrimonial y festejos para celebrar las bodas, tres momentos en los que la pluma del escritor se explaya en la descripción de los atuendos.

Frente a las confecciones matrimoniales de Feliciano de Silva, en algunos títulos caballerescos aparecen pocos pasajes en los que se describen los trajes de boda. Por ejemplo, en el Tirante se cuentan las bodas del rey de Inglaterra, éste llevaba:

un traje de brocado sobre brocado carmesí, forrado de armiño, y habiendo dejado la corona, llevaba en la cabeza un pequeño bonete de terciopelo negro con un cierre que estimaba valer ciento cincuenta mil escudos [...] la infanta llevaba una gorguera de brocado carmesí de hilo de oro tirado y donde se veía la seda se mostraban cuarteles de argentería bordados; los cabos de las alcachofas en lo alto eran de oro con esmaltes; la ropa era toda de chapería, sembrada de rubíes y de esmeraldas (Tirant lo Blanc, I, XLIV).

202 María del Cristo González Marrero, "Un vestido para cada ocasión: la indumentaria de la realeza bajomedieval como instrumento para la afirmación, la imitación y el boato. El ejemplo de Isabel I de Castilla", Cuadernos del CEMyR, 22, abril 2015, p. 171. Pp. 155-194. 
Tanto el caballero como la infanta van de brocado carmesí, sintonía que permite conocer el inicio del coordinado de trajes para bodas. Lo interesante del vestido de la dama está en los pequeños cuadros de plata bordados entre la seda y el hilo de oro, además de las imágenes de alcachofas esmaltadas en oro. Este tipo de figuras se pueden ver en las dalmáticas del XVI bordadas con hilos de oro con una base roja para resaltar la silueta de las flores, en semejanza al ejemplo presentado en el Tirante (figs. 74, 75). La calidad del traje varonil está en la piel, que, como ya se ha mencionado anteriormente, se trata de un tejido exclusivo para la realeza y es común verlo en las capas de coronación desde la Edad Media hasta la fecha.

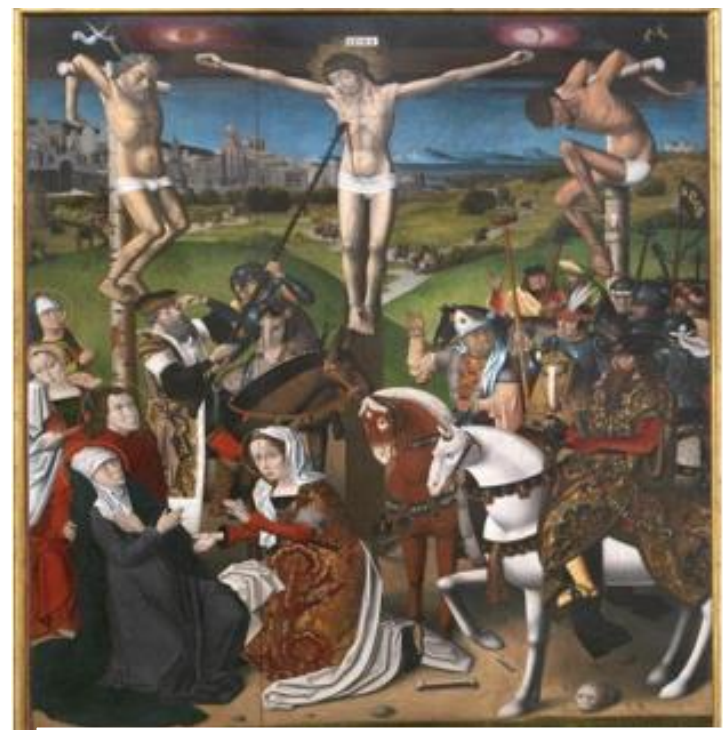

Fig.74. Tríptico del Calvario. Anónima (s. XV) Museo Baroffio de Varese (Italia).

Detalle del vestido con flores

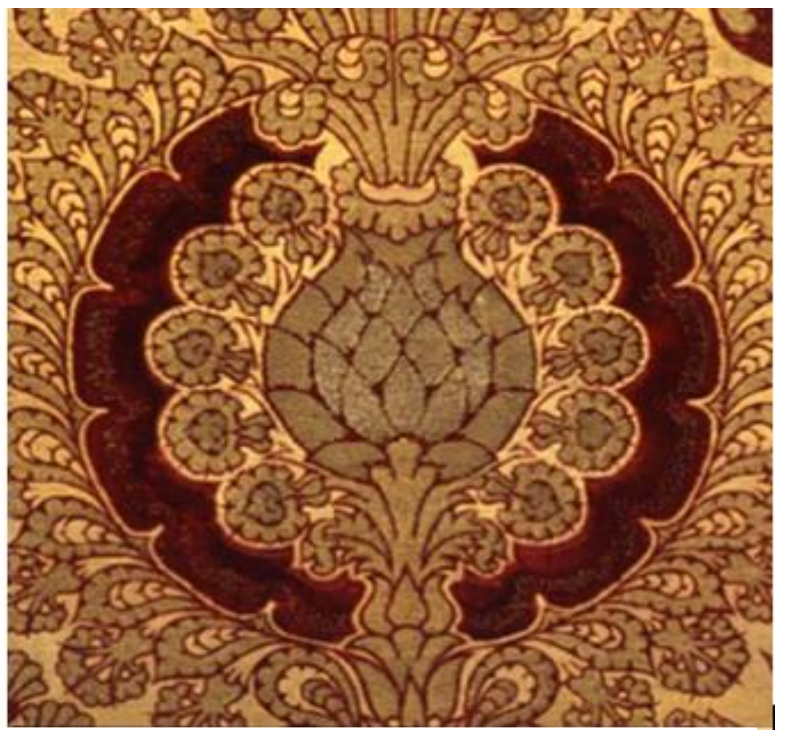

Fig. 75. Terciopelo labrado (s. XV).

Dentro de la misma línea se encuentra la historia de amor de Crispanela y Baldo, quienes en su afán de estar juntos ordenan los preparativos para su boda, de la cual se hace referencia al atuendo de la dama: 
Crispanela quería recibir de buena voluntad el bautismo, la cual salió vestida de una aljuba de tela de oro aforada en carmesí raso, toda acuchillada con sus cordones de oro que le abrochavan la delantera y los costados y un collar de tantas piedras y perlas orientales que le ceñían los pechos. Sus dorados cabellos ceñía un prendedero a la usança de Dalmacia y ellos hechos cordones como oro de Aravia, compuestos por la cabeça, de tal arte, que era gran cosa de mirar. (Baldo, II, XLV)

Una vez bautizada, la dama es desposada con Baldo; sin embargo, la felicidad es breve, debido a la maldad de la madre de Crispanela, quien, en su intento por envenenar a Baldo, es su propia hija quien consume el veneno y muere de inmediato.

En el ejemplo de esta boda sólo se describe el traje de la novia, una aljuba ${ }^{203}$ de oro con carmesí raso. De acuerdo con la forma de esta prenda, se trataba de una túnica con mangas que permitía ver las prendas de abajo (fig. 76). En este caso el decorado recae en los cordones y las cuchillas, por las cuales se podía ver el forro carmesí. Sin duda, el detalle más relevante se presenta en el prendedero "al uso de Dalmacia", el cual, de acuerdo a los testimonios de la época, había dos tipos, un broche o una cinta para sujetar el cabello.

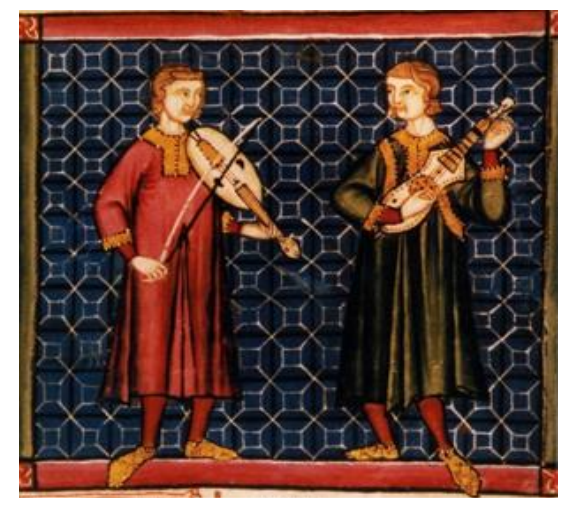

Fig.76. Cantigas de Santa María, Cantiga 140.

El músico de la izquierda viste una aljuba carmesí.

${ }^{203}$ En el inventario de "Tesoro de Muley Hacen, de Túnez a Málaga (1554)" se describen varias prendas, entre ellas una "aljuba de tela de oro carmesí, nueba y grande, con las mangas anchas, aforrada en lienço", muy similar a la descrita en este ejemplo del Baldo. Boletín de la Real Academia de la Historia, Madrid, tomo CCI, Número III,2004, p.418. 
Dionís Clemente, en su Valerián de Hungría presenta un pasaje en semejanza a los de Silva para describir dos atuendos nupciales:

Sacó aquel día la princesa Arinda, sobre sus no menos hermosos que rubios cabellos, una redecilla de filo de oro, en cada punta de la cual havía una piedra con su engaste de gran precio, sin levar otro tocado en su cabeça, porque según sus cabellos remedaban la color del oro, o por mejor decir el oro la color d'ellos. Aquellas piedras que vos deximos no parecían sino ser en su mesma cabeça engastadas, las cuales, como fuessen sin número, davan de sí tanta luz y resplandor, que por poco que la cabeça moviesse, puesto que a la sombra estuviesse, no dexavan de parecer a los ojos que las miravan estrellas muy reluzientes. Cubríale tan solamente la redezilla de la media cabeça hazía arriba y discurriendo por encima de sus oídos. Venía apretarle los cabellos cuasi en medio de las espaldas, colgando de allí, abaxó muchos de los filos de oro entre los mesmos cabellos, sin que conocer se pudiesse la diferencia d'ellos sino por la desigualdad del número. En su cabello traía un pequeño collar de diamantes y rubíes de tabla, y entre cada piedra una gruessa perla, el cual no tenía por de menor precio que la redezilla que vos diximos, según su valor. La lavor de su camisa, la cual gran parte de sus hermosos pechos cubría, era de un aljófar menudo e igual, y encima sobrepuestas unas cruzes de esmeraldas y rubíes, apartadas cuanto un pulgar, todo hecho por muy subtil artificio. La saya era de brocado verde con ricos lavores, y todas las aberturas y estremos sembradas de diversidad de piedras de gran precio, cuyas mangas eran aforradas de muy ricas martas, y debaxo de aquellas traía otras de damasco verde, y sobre ellas puestas unas estrellas de oro, tan menudas como espessas, con un esmalte en medio de cada una de color de muy fino rubí.

[Polidia] traía sobre sus hermosos cabellos un tocado alemán, que algo menos que la media cabeça le cubría, tan sembrado de piedras de gran precio, que cuasi no se podía ver el oro de que era hecho. El cual le tenía todos los cabellos a la parte de las espaldas, assí cubiertos y cogidos, que lo blanco de su cuello no dexava de mostrarse en menor grado que de la fría nieve, sobre el cual traía un pequeño prendedero de gruessas perlas, partidas de tres en tres, con un grande no menos que hermoso zafir, las cuales, si sentido tuvieran, bien quisieran por no mostrar la disminución tan grande, que tenían su blanco ilustre, ante quien las traía ser puestas 
en cualquier otra parte, adonde pudieran mejor parecer, según lo natural d'ella la sobrepujavan sin ninguna comparación, haziéndolas parecer de muy pequeño valor. El lavor de su camisa era de oro y seda blanca, con joyeles sobre él sobrepuestos, en cada uno de los cuales no havía más de tres piedras, puestas y engastadas en ellos a semejança de un coraçón. Era la saya de damasco blanco con muy estraños labores, aforrada de no menos blancos erminos, y todas las aberturas y estremos d'ella sebrados de los mesmos joyeles de la camisa, y todo el otro campo de la saya lleno de unas letras de oro, puestas por compás, las cuales eran F e P, tan juntas y entrelazadas de lazos del mesmo oro, que no era possible hallarse cabo para partirlas. Las mangas que debaxo de las de damasco salían, era de un raso violado, todas llenas de flores de azucenas de filo de plata y aljófar, a maravilla bien puestas. (Valerián de Hungría, I, LVII)

Lo más destacable del atuendo de Arinda es la labor de su camisa por llevar aljófares y cruces de rubíes y esmeraldas en el pecho y las dobles mangas que lleva, unas por estar forradas con piel de marta y las otras por llevar estrellas de oro con rubí. En el caso de Polidia, destaca el tocado alemán, el cual consistía en una especie de cofia un poco abultada de la parte de atrás (fig.77). También su camisa lleva muchos joyeles sobrepuestos. La saya es la que presenta el diseño más curioso, puesto que lleva bordadas las letras “F y P" en clara alusión al suyo y al del caballero Finariel, con quien se casa.

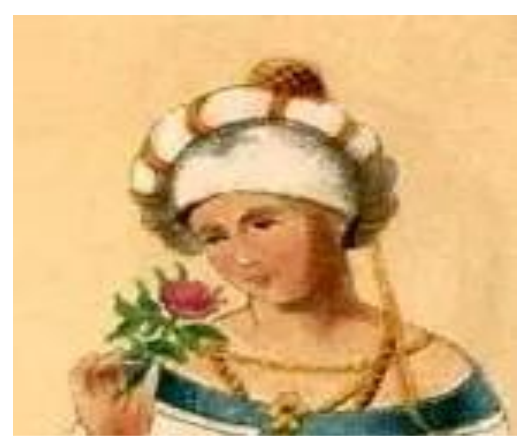

Fig. 77. Tocado alemán (1480) 
A pesar de presentar varios detalles, es necesario destacar el desinterés del escritor para realizarlos, debido a la búsqueda de pretextos que "supuestamente" dificultan el agregar más accesorios. El primero de ellos es el cabello, del cual dice: "sin levar otro tocado en su cabeça, porque según sus cabellos remedaban la color del oro, o por mejor decir el oro la color d'ellos" lo que revela el poco interés del autor para crear otro accesorio en tela, metal o cristal que sobresalga del tono dorado. Además, pareciera que el tocado es motivo de incomodidad al llevarlo, al menos eso se infiere del modo en cómo se expresa: "Venía apretarle los cabellos", aspectos que muestran su poco interés en este tipo de pasajes, como ya lo declarará en capítulos posteriores.

Estos son todos los ejemplos hallados en los libros de caballerías consultados cuyo protagonista es el vestido de novia, en donde sobresalen los detalles de los adornos. Como se ve, Feliciano de Silva es quien más atención dedica a la confección de los trajes para boda, por su ingenio, dedicación y minuciosidad con las que los elabora, además de que es la base en la que otros se apoyan para hacer sus diseños. Al respecto, hubo un autor que copió los mismos modelos de Feliciano de Silva, en su mayoría, porque también tomó ejemplos de otros autores, Esteban Corbera, quien, en su obra Febo el Troyano, hace una prolongada descripción del vestido de las novias, los cuales son los mismos que aparecen en el capítulo CXLVIII de la tercera parte del Florisel de Niquea que Feliciano de Silva crea para el juicio de bellezas femeninas; es decir, Esteban Corbera copia distintos modelos y sólo cambia algunos accesorios textiles para tratar de modificar un poco la creación de Silva.

Todo evento es una oportunidad de lucir las mejores prendas, los personajes presumen sus más preciados vestidos en justas, bailes, banquetes y bodas. Estos se convierten en escenas de recreo porque dan lugar a un sinfín de adornos, tejidos y 
accesorios con los que se maravillan las damas y los caballeros, pero especialmente el lector, quien ante cada página descubre las invenciones de los autores, las modas de la época y la forma de combinar cada accesorio; es una especie de convivencia entre telas, metales y piedras preciosas que el escritor toma de la indumentaria de la época y crea una nueva moda, misma que será objeto de deseo principalmente para las jóvenes de la época, tal como lo recuerda Mateo alemán en su Guzmán de Alfarache, en el que se critica la gran afición de las jóvenes por estos libros ${ }^{204}$.

Parte de esta moda será innovar las prendas ya existentes con adornos y bordados, especialmente para caracterizar a los personajes con usos especiales que los identificarán en toda la historia y que en los eventos se reconocerán por ellos. Esto permitirá que el lector compare y decida cuál prenda es mejor en calidad, color y tejido o cuál es más importante por pertenecer al personaje principal, todo esto a través de la comparación y la identificación de telas, pues se deben conocer los procesos de teñido, fabricación y bordado para establecer cuáles son los tejidos más costosos de acuerdo a estos tres procesos y así identificar en cada lectura qué personaje porta el mejor vestido.

\subsection{Adornos para el cabello}

Desde la Antigüedad la dama se ha caracterizado por su arreglo personal tanto en el cuerpo como en la cabeza, en ambos hay una armonía en cuanto al color, textura y formas que coinciden entre sí, pues desde el arreglo del cabello hasta el calzado, la mujer se caracteriza por su deseo de sobresalir de entre las demás personas. Para lograrlo, utilizará distintos materiales como cintas, lazos y elementos de la naturaleza, como flores, que llevará tanto en tela como en metal.

${ }^{204}$ Mateo Alemán, Guzmán de Alfarache II..., p. 351. 
Generalmente, el simbolismo de la guirnalda, en los libros de caballerías, tiene una connotación simbólica por el grado de belleza que otorga a la dama, ya que quien la recibe, posee el título de la más hermosa ${ }^{205}$ :“Que si yo fuere vencido que lleve mi escudo en señal de victoria y esta guirnalda en gloria de la hermosura de su señora, ganada de la [victoria] de la mía.” (Florisel de Niquea III, XXXVI). El más claro ejemplo se halla en el Amadís de Gaula, cuyo pasaje sobre "el arco de los leales amadores" es el antecedente para muchos autores que retoman el símbolo de la guirnalda como corona de belleza y premio para la más fiel amante. (figs. 78,79,80)

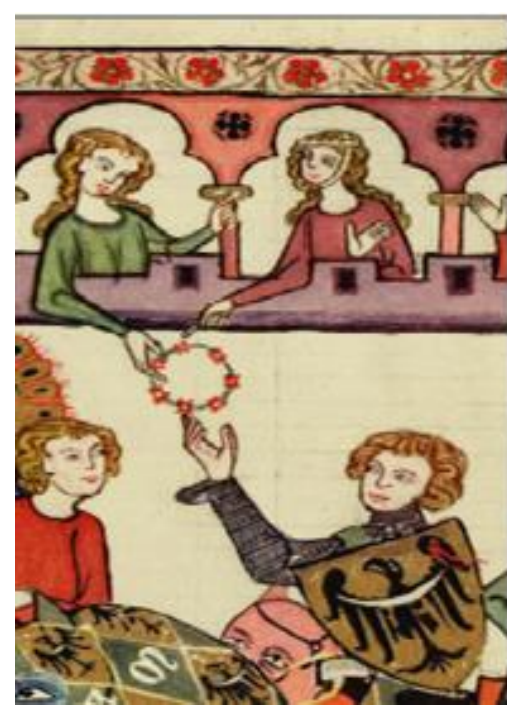

Fig. 78. Codex Manesse (fol. 11v) (s. XV) Guirnalda de flores

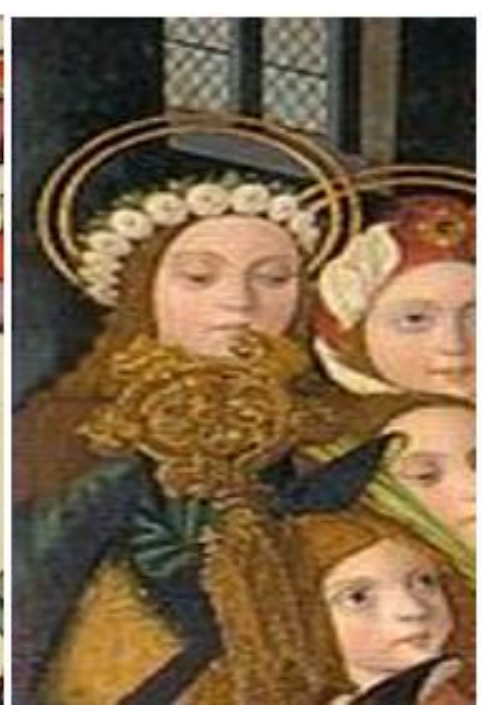

Fig. 79. Imposición de la casulla de San Ildefonso (1500), Soria. Guirnalda de flores

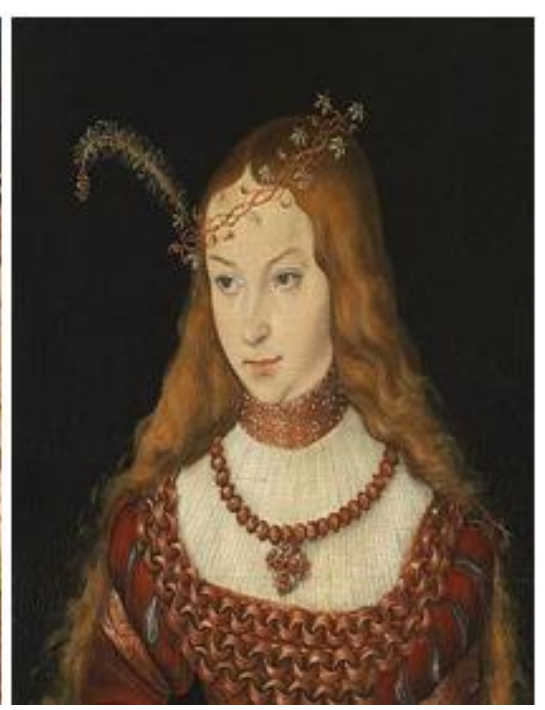

Fig.80. Princesa Sibylle de Cleves (1526) Lucas Cranach el Viejo. Guirnalda con pluma

Sin embargo, otro uso que se le ha dado a este accesorio es el de ser una "joya ornamental"206, porque adorna la cabeza femenina en armonía con el resto de la vestimenta

\footnotetext{
${ }^{205}$ En mi tesis de maestría, Doncellas, princesas, reinas y sabias: Interacción de la mujer en los libros de caballerías, México, UAMI, 2014, abordé el tema de la guirnalda como detonadora de acciones al enfrentarse los caballeros para ganar el título de las más hermosa para su dama, y aunque analicé distintos tipos de guirnaldas en varios libros de caballerías, en la presente investigación me centro exclusivamente en los ejemplos que aparecen en los libros de Feliciano de Silva, además de que analizo el significado de las piedras preciosas, así como las leyes suntuarias que limitan su uso sólo para ciertos grupos sociales de la época.

${ }^{206}$ Nieves Fresneda González, Moda y belleza femenina ..., p. 519.
} 
de las damas, a juego con las joyas que lleve la dama en el vestido, pero también con los bordados de la tela, como se verá con las guirnaldas de flores y de figuras de animales, imágenes que también estarán presentes en la ropa.

\subsubsection{Guirnaldas de fiesta}

Parte del atuendo de la dama son los tocados que porta en su cabello, de los que hay una gran variedad en los libros de caballerías (figs. 81-85), en los que destacan los materiales y la forma en cómo están hechos, así como el símbolo y el motivo por el que se usan. Para toda ceremonia es preciso un tipo de tocado, pues será necesario diferenciar los materiales como el oro y las piedras preciosas, para festividades como bailes, torneos y bodas, mientras que las flores y los listones se llevan durante juegos florales y reuniones de amigas.

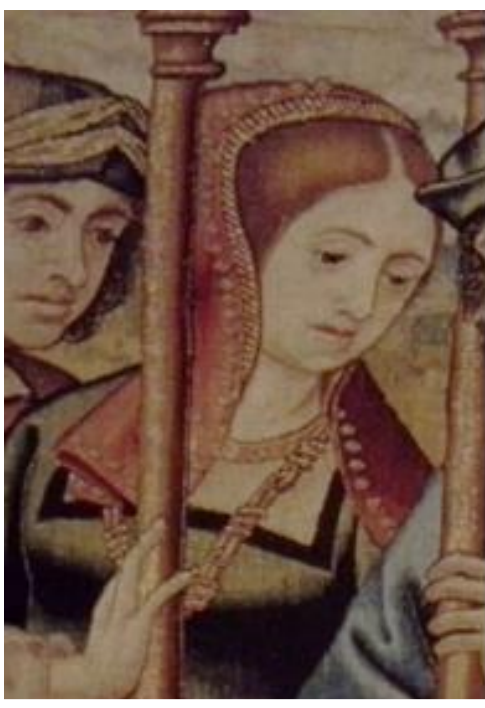

Fig.81. Tapiz Casamiento de David y Betsabé (1505) Palacio Real de La Granja de San Ildefonso.

Dama con toca con la orilla adornada con oro

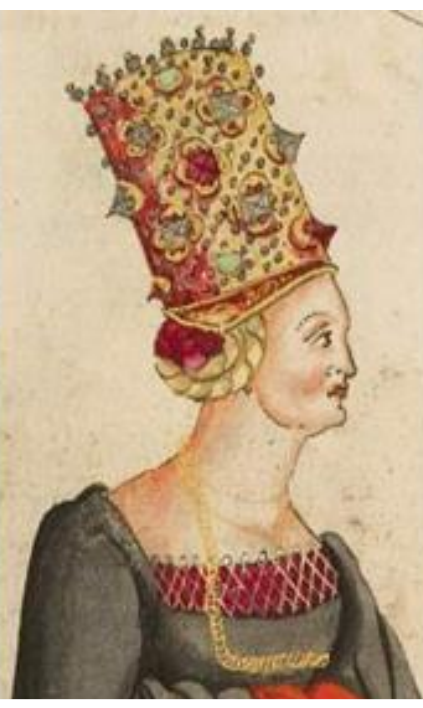

Fig.82. Kostüme der Männer und Frauen Augsburg und Nürnberg, Deutschland, Europa, Orient und Afrika (1600).

Dama con tocado alto adornado con piedras preciosas.

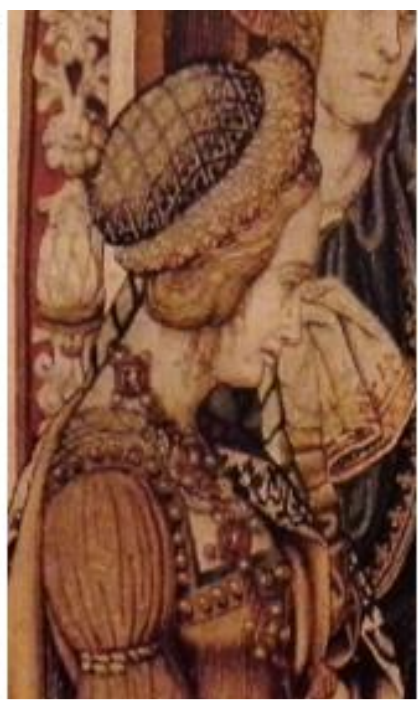

Fig.83. Tapiz San Juan se despide de sus padres (1515-1520) Palacio Real de Madrid. Dama con toca y rollo de tela floreada. 


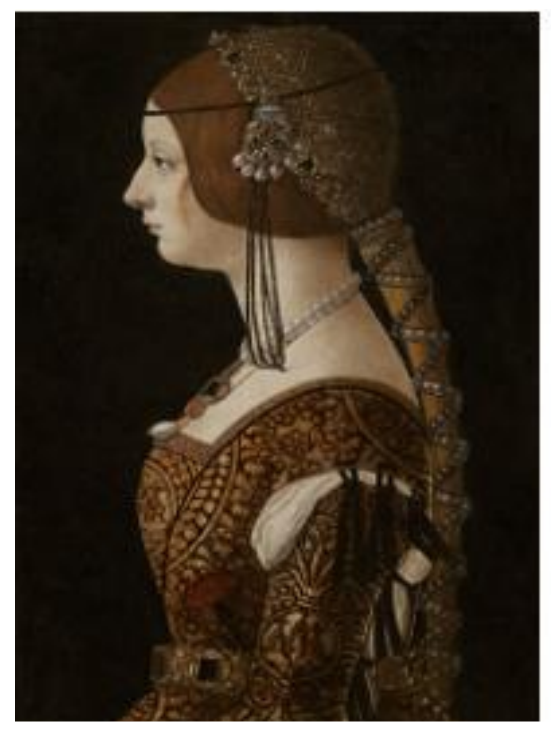

Fig. 84. Bianca María Sforza (1493) Ambrosio de Predis, Galería Nacional de Arte de Washington. Cinta con pinjante de perlas.

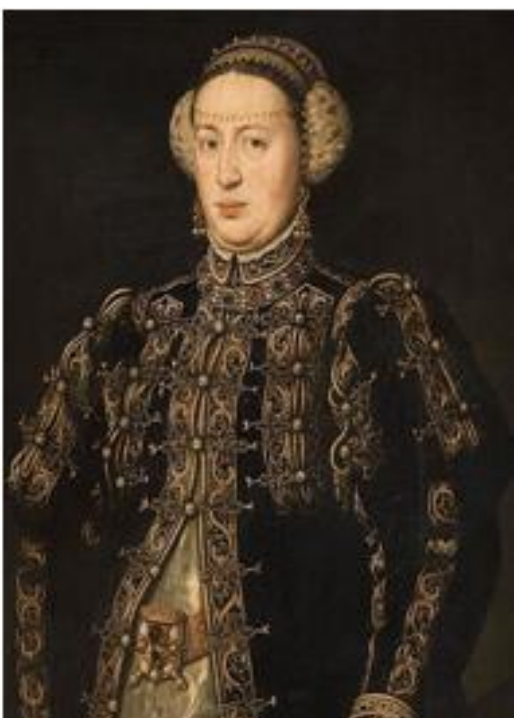

Fig. 85. Catalina de Austria (1552-1553) Antonis Mor, Museo del Prado.

Toca de cabos

Estos adornos, con los que las damas lucen sus cabelleras encrespadas, toman relevancia según los pasajes caballerescos, algunos de ellos bastantes complejos en cuanto a hechura y decoración, como los descritos en la tercera parte del Florisel de Niquea, en donde Feliciano de Silva retoma elementos de sus anteriores libros e incrementa su estructura y funcionalidad dentro de la obra.

Los tocados, que son más complicados porque se conforman de dos partes, una guirnalda y joyas entrelazadas en el peinado, aparecen hacia 1532, periodo de esplendor para la indumentaria y los tocados del siglo XVI, que ya Carmen Bernis ${ }^{207}$ y otros críticos han establecido como la época que más aporte dio a la vestimenta española, en telas, diseños y accesorios, estos últimos en los que los tocados fueron de los más representativos y usados por las damas, se trasladan al ámbito literario, o viceversa, en donde el autor une elementos cotidianos e imaginarios para crear interesantes diseños.

${ }^{207}$ Carmen Bernis, Indumentaria española en tiempos de Carlos V..., p. 20. 
Una de estas invenciones es usada por la infanta Artifira en una hazaña mágica: “y ella tenía una rica guirnalda en su cabeça, fixada con seis lazadas de sus hermosos cabellos, de que pendían seis joyeles de gran valor." (Florisel de Niquea III, LXX). La moda de la época presenta testimonios de cómo las damas llevaban sus tocados, ya fueran cofias, velos, redecillas o tiaras, todas iban sujetadas con broches más pequeños, pero de gran valor, que hacían juego con las demás joyas, ejemplo de estos son los joyeles, "pinjantes que cuelgan de las tocas" (Tesoro de la lengua) que, junto a otros accesorios como camafeos y brincos, ${ }^{208}$ servían de broche para sujetar los tocados. De esta manera, se pueden ver testimonios de dichas piezas en las pinturas de Sánchez Coello, en las que sobresalen los detalles de joyeles, tiaras de piedras preciosas y broches de oro que sujetan los velos y las tiaras de las damas. Sin embargo, otra forma de sujetar la guirnalda es a través de los propios cabellos, entretejidos sobre el metal para evitar que se caiga o se despeine la joven $^{209}$.

La complejidad del tocado aumenta conforme la historia lo pide, pues en eventos como bodas, bailes y recibimientos habrá más minuciosidad en los detalles: "y sus cabellos llevaba sueltos y sobre ellos una guirnalda de muchas piedras de gran precio. Llevava de los cabellos a los lados de lazadas, hechas en cada parte una rueda a manera de arandela, y en medio de la rueda un joyel de muy resplandeciente diamante, cercada de rubíes, donde parescía como de punto de compás salir la orden de las lazadas que las ruedas hazían" (Florisel de Niquea III, CXIX). Sobre el rubí, se dice que quien poseyere esta piedra "será amado y bien quisto de los hombres" ${ }^{210}$, tal como ocurre con la infanta de Esparta. Este

\footnotetext{
${ }^{208}$ Letizia Arbeteta, La joyería española de Felipe II a Alfonso III ..., p.24.

${ }^{209}$ Este tipo de arreglo es más común con tiras de perlas, las cuales se entrelazan en el cabello para formar una especie de corona alrededor de la cabeza.

${ }^{210}$ Alfonso X, Lapidario, Madrid, Castalia, 1968.
} 
amor se da tanto por el físico, como por el embellecimiento que las joyas dan a la joven, característica de las piedras preciosas, que según San Isidoro "con la hermosura de sus colores realzan la belleza del oro" ${ }^{211}$. Esta pieza se compone de un joyel de diamante, piedra irrompible y de dureza extraordinaria, que enriquece el valor de la guirnalda ${ }^{212}$ al ser un elemento que sólo podía usar la realeza.

La utilización de las piedras preciosas era importante para las clases nobles, pues a través de ellas transmitían su posición social, ya que cuantas más se llevaran, de más alta alcurnia se era. Generalmente, las damas caballerescas sobresalen por la gran cantidad de diamantes, rubíes y zafiros que llevan en su cabeza, pero también por los diseños de sus tiaras: "en la cabeça se puso una guirnalda a manera de claveles de muchos rubíes, iva fixada de cada lado con dos lazadas de cabellos, con dos joyeles de resplandecientes diamantes que daban mucho aire a su rostro" (Florisel de Niquea III, CXI). La importancia del rubí, piedra que más se menciona en estos libros, se debe a que hubo una gran producción de ésta en España desde el siglo XII ${ }^{213}$, hecho que se constata en los libros de bienes de los monarcas Isabel la Católica, Juana y Doña Margarita. Entre sus posesiones se hallan: un joyel de unas flechas con un diamante muy grande y un rubí, un joyel de una hebilla con un rubí en forma de pera, etc. ${ }^{214}$

Por otra parte, los broches que van a los lados, a manera de pasadores, podían ser el mismo cabello: "y sobres sus hermosos cabellos, que sueltos por las espaldas llevaba, puesta una guirnalda hecha de perlas y de rubíes fixada con dos guedejas por los lados de donde pendían de sus lazadas dos preciosos joyeles de diamantes" (Florisel de Niquea III,

\footnotetext{
${ }^{211}$ Isidoro de Sevilla, Etimologías..., p. 1133.

${ }^{212}$ En unas relaciones de viaje de 1601 se describe un tocado similar, perteneciente a una duquesa: "un tocado de perlas y arandelas con puntas de diamante". Elena Varela Merino, Los galicismos en el español ..., p.470.

${ }^{213}$ Nieves Fresneda González, op. cit., p. 515.

${ }^{214}$ José Ferrandis, Datos documentales para la Historia del arte español III: Inventarios reales (Juan II a Juana la Loca), Madrid, CSIC, 1943.
} 
LIII). Las "guedejas" eran mechones de cabello (Tesoro de la lengua) suelto que se pasaba entre el tocado para sujetarlo. ${ }^{215}$

Aunque pareciera que estos ejemplos de guirnaldas son minuciosos en los detalles por las piedras, perlas y la forma como se acomodaba el cabello para sujetarlas, hay otros tocados que son más laboriosos en su confección por los elementos que el autor recrea de la época y de los que difícilmente se tienen testimonios.

\subsubsection{Tocados de ruedas}

Una de las invenciones más llamativas, en cuanto a tocados, se halla durante un juicio de amor, una reunión entre reyes, princesas y caballeros en la que las damas expondrán sus sentimientos por los jóvenes y los reyes serán quienes decidan cómo se conformarán las parejas. Durante este proceso, las damas utilizan una herramienta a su favor, la vestimenta, con la que pretenden ser más admiradas por su belleza y por la originalidad de la indumentaria. Aunado a ello, arreglan su cabello de una manera muy particular, nunca antes mencionada en estos libros:

La extrañeza de los tocados era cosa maravillosa, porque avéis de saber que eran d'esta forma: A los lados de la cabeça se hazían dos ruedas acucharadas que hazían una punta hazia el hombro y levantávanse hazia arriba en altura de más de un palmo, haciendo una manera como de hueco. Todas eran de oro muy delgado, y labrado en ellas muchos lazos de muy hermosas y pequeñas piedras de rubíes, esmeraldas e diamantes; hazíasse de los lados en alto de la cabeza dos puntas de la manera que deximos que llevaban las doncellas, de más de tres palmos en alto de cada punta de oro, tan sotilmente labrado y trasflorado que cosa más maravillosa era. Y en la punta de cada tampa lo matava una gruessa perla de manera de pera, lo delgado hacia arriba. Salían del todo tres puntas a las espaldas con mucha pedrería, y por delante travava las ruedas de los lados una manera como de corona de rey,

\footnotetext{
215 Para conocer algunos de los peinados y tocados españoles en el siglo XVI véase: Concha Herrero Carretero, Tapices de Isabel la Católica. Origen de la colección real española, Madrid, Patrimonio Nacional, 2004.
} 
labrada de lo mesmo de las tampas de sus hermosos cabellos crespos, y como oro fino se hazían a los lados del rostro dos hermosas madexas, y las puntas d'ellos por entre las ruedas de los lados se esparzían por sus espaldas" (Florisel de Niquea III, CXLVIII). ${ }^{216}$

Feliciano de Silva es el primero en utilizar el término "acucharadas" en los libros de caballerías. Una imagen innovadora para la creación de un peinado en la mujer. Dos ruedas a los lados con puntas que alzan toda una serie de diversas piedras que cuelgan a los lados. Este arreglo finaliza con una perla en forma de pera que se coloca en la punta.

La corona, la guirnalda ${ }^{217}$ y los tocados son elementos que otorgan una relevancia al personaje que los porta porque le designan un poder; en el caso de la corona, le permite dirigir a la multitud al ponerlo en una posición elevada, entre lo divino y lo terrenal. En cuanto a las mujeres, la guirnalda es una muestra de la más hermosa, de la dama perfecta en amor, belleza y fidelidad, digna del amor del caballero; sin embargo, la guirnalda también la determina como la mejor vestida, en la mayoría de los episodios, pues ésta es un elemento que complementa toda su indumentaria.

La importancia de este accesorio está en su diseño y en los materiales con los que las elaboran, principalmente, las piedras preciosas y las flores naturales son las que más predominan en estos libros, elementos que enriquecen la indumentaria femenina al agregarle valor monetario, por la infinidad de piedras, y literario, por la creación de pasajes

\footnotetext{
${ }^{216}$ Esta misma descripción, pero con distintos nombres de los personajes, está en capítulo XXVII de Febo el Troyano, de 1576, por lo que Esteban de Corbera, recrea este pasaje al igual que el de otros libros de caballerías.

${ }^{217}$ Aunque su uso es más común para las mujeres, también los hombres utilizarán algunas especies de tocados como complemento de su armadura. Uno de los primeros ejemplos de tocados varoniles se halla en la Gran crónica de Alfonso XI, durante el banquete entre los reyes de Granada y Castilla: "le dio vn baçinete muy bien guarnido con oro en derredor de la guirnalda auia muchas piedras, espeçialmente auia dos rrubies, el vno en la fruente e el otro ençima del, que eran tamaños como castañas". Ambos intercambian regalos, el más llamativo es el bacinete con guirnalda de rubíes. En los libros de caballerías este tipo de tocados no aparece para los caballeros. Gran crónica de Alfonso XI, ed. de Diego Catalán, Madrid, Gredos, 1977, pág. 69.
} 
en los que las acciones giran en torno a un accesorio que muchas veces pasa desapercibido para los lectores.

\subsection{Joyas}

Los elementos que culminan el arreglo de la dama son las joyas, piezas metálicas de oro con piedras preciosas cuya principal función es adornar el cuerpo femenino, a través de los broches, collares, anillos, aretes, cintas de cadera y prendedores están presentes desde el cabello hasta los pies, puesto que en algunos momentos se indica la colocación de estas gemas en los zapatos. Pero también, aunado al valor monetario que incrementan al atuendo, aparece el simbólico, aquel que relaciona el uso de la joya con su forma, color y piedra con la persona que lo usa, por lo que es necesario unir su utilidad decorativa con su signficado de amor, pertenencia, agradecimiento que guardan en su estructura.

Una de las categorías de joyas más relevantes, en estos libros, son las de amor, aquellas que pertenecen a la pareja enamorada por decisión propia, pues deciden llevarlas en representación de la persona amada con el fin de demostrar, implícitamente, quién es el dueño de su corazón. Así mismo, están las preseas entregadas por petición o por deseo, es decir, las que la dama entrega al caballero en señal de su fidelidad y las que el joven le pide como prenda de valor para los combates, pues será un objeto que le dé impulso durante el enfrentamiento bélico. Una de las joyas más interesantes de este tipo está en el Lisuarte de Grecia, como prenda de fidelidad y confianza:

Luego, Alquifa sacó una caxa e, abriéndola, sacó una muy rica sortija de un diamante que no tenía precio su valor e, dándolo a Perión, dixo:

-Esse dad vós, mi señor, a la infanta que os ciñó la espada en señal que sois suyo, porque se acuerde de vos.

Perión lo hizo assí. La infanta lo recebió e lo metió en su mano derecha, e dixo que ella le prometía de no le quitar de allíi ${ }^{218}$. Perión le tornó a besar las manos (Lisuarte de Grecia, II). (fig. 86)

\footnotetext{
${ }^{218}$ Caso contrario ocurre en el Platir:
} 


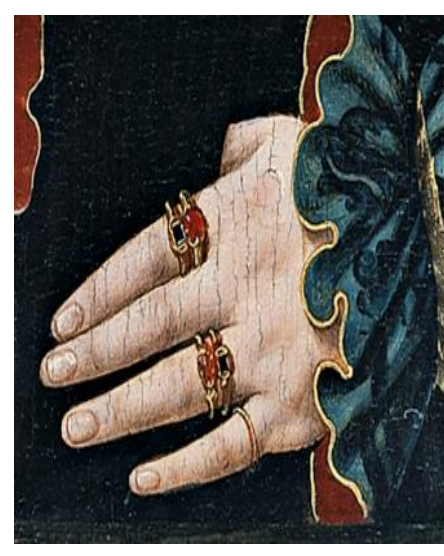

Fig. 86 Retrato de una mujer (15381539) Bartholomäus Bruyn el Viejo, Museo Thyssen-Bornemisza. Anillos de rubíes y zafiros.
La entrega del anillo representa la confianza entre Perión y Gricileria ante la lejanía que los separará por tiempo de un año. En este periodo, ambos deberán demostrar ser dignos uno del otro, por medio de ganar todas las batallas y de no perder el anillo. La joya adquirirá un valor simbólico superior, debido al esfuerzo de ambos para estar juntos. Se trata de una estima personal por el objeto que se convierte en representante del ser querido.

Pero el lenguaje de la pareja a través de las joyas también se puede dar con desconocimiento de uno de los enamorados, es decir, que sólo uno conozca el significado de la joya y el otro lo tenga que descubrir por medio de una prueba o hasta finalizar la historia. Esto sucede en el Valerián de Hungría, en el que hay una especie de revelación sentimental en voz de la dama, pero que el caballero no alcanza a comprender totalmente:

Desque don Duardos se vido solo con Herinda, suplicóle mucho le diesse una joya que llevasse al torneo y tanto la afiancó, que le dio un rico anillo qu'ella tenía en un dedo metido, y dixo:

-Agora quiero yo ver, cavallero, qué tanto vós me queredes y con cuánta honra torna mi anillo a mi poder. (Platir, XVIII).

Se trata de una joya prestada, pues, a diferencia de otras parejas, el anillo debe regresar a su dueña, pero con un valor simbólico agregado, la honra, la cual deberá ser resultado del esfuerzo del caballero durante el torneo. Esta intención de la dama es una especie de presión para el joven, pues debe de tener un desarrollo perfecto para ser el ganador de todos los enfrentamientos, de esta manera, no sólo gana fama, sino también, la dama se recompensa de los logros del caballero. Sin embargo, este pasaje presenta una singularidad frente al de otros libros de caballerías, se trata del regreso de la joya porque no hay un sentimiento recíproco, sino fingido, al menos de parte de don Duardos, quien, al haber sido apresado por el rey de la India, piensa que la única forma de salir de ese lugar es conquistando a Herinda. Bajo un falso enamoramiento, tratará de que ella lo ayude a salir para regresar con su verdadero amor, Flérida. Por este motivo es que el anillo debe de regresar a su dueña, debido a que el joven no puede quedarse con una reliquia de falso amor. Recuérdese el joyel que Claribalte da a Dorendaina antes de irse a Albania; el joyel que Polinarda da a Palmerín de Oliva; la cadena que Floriana le da a Lidamor, etc. Es de notar que estas preseas se dan entre las parejas porque son prendas de amor correspondido, por lo que serán conservadas por uno de los dos y no se regresarán. 
E sacándolas de una arca vieron entre las otras un prendedero de oro con muchas piedras de gran precio de oro en él engastadas, el cual tenía por pendiente un rubí muy ardiente e fino tallado a la semejanza de un coraçón.

Cuando Darinto lo vido, dixo:

-Paréceme, mi señora, que a estar asidos dos coraçones d'este prendedero, como está uno, éste sería el señal que más al propósito haría de cuantos yo he visto.

-Cómo eres necio, Darino -dixo Albericia-, e muestras no tener agudeza sino en maldades, pues no alcanças que de aquellos que bien e lealmente se aman sus dos coraçones, no ha de ser más de uno, como aquí ves, porque si dos o más fuessen, partidas serían sus voluntades e desseos, lo que no puede sostenerse porque assí como uniformes han de ser sus desseos e voluntades, assi han de proceder e causarse de un solo coraçón, pues, aunque sean en el número dos, están de tal manera puestos y enxeridos el uno dentro del otro que ninguno de sus dueños aunque se lo enseñassen podría conocer cuál es el suyo, por la conformidad que han de tener assí en cada una de sus partes como en todo junto (Valerián de Hungría, XIV).

En el ejemplo aparece una descripción más detallada sobre el prendedor, pues no sólo se menciona el material, el color y la forma, sino también su función simbólica dentro de la historia, unir el corazón de los dos enamorados, situación que sólo fue comprendida por Albericia y que tendrá que esperar hasta que Darinto comprenda el significado del corazón de rubí. El ingenio del Valerián de Hungría sobresale, al menos en el significado del prendedor, al de los demás autores caballerescos, incluido Feliciano de Silva, pues no sólo estructura una joya, sino que hace que su diminuto tamaño sobresalga de entre las preseas con más presencia.

La expresión del amor a través de las joyas presenta distintas variantes en cuanto a la forma en cómo se revela en los componentes de la indumentaria, pues cada autor propone una nueva manera de presentar el amor representado con distintas piedras, metales 
y adornos que entrelazan situaciones para demostrar que realmente es un sentimiento verdadero.

La entrega de una joya aparece por diferentes motivos, uno de ellos, el más destacado en los libros de caballerías, es el de la joya de amor, aquella que pertenece a los enamorados y que se entrega como señal de pertenencia. El más conocido de estos ejemplos se halla en el Amadís de Gaula, cuando Amadís pide una joya a la pequeña Leonoreta para ser su caballero y servidor; la niña, ajena al verdadero significado de la entrega de una joya así, se quita de su cabello un prendedor de oro de ricas piedras y lo da a Amadís (fig. 87). El significado de la prenda se conserva, pero con una ligera modificación, no hay un enamoramiento, sino sólo un amor fraternal entre el caballero y la niña, puesto que se trata de un juego de pertenencia.

También aparecen las joyas que se dan en retribución por un favor, rescate, compañía o defensa. Esta clase no es tan común en la pareja, más bien entre personas sin un vínculo amoroso, por ejemplo, entre amigas, hermanas y damas de compañía.

E Daraia, gozando mucho de lo que la niña hazía con ella, un joyel que a su cuello traía, de un excelente diamante con cuatro rubíes y gruessas perlas que pendían, lo quitó y con una cinta con que estaba prendido lo puso al cuello de la infanta, diciendo:

-Mi señora, esta joya resciba la vuestra merced de mí, en señal para que todas las vezes que la truxéredes, con vella trayan a la memoria la merced y favor que oy me avéis hecho, para que con tal acuerdo se acreciente la gloria que yo he rescibido de vuestros favores (Florisel de Niquea III, CXII). (fig. 88)

La joya deja de lado su valor monetario para adquirir un valor simbólico de agradecimiento por la fortuna otorgada a Daraida, es decir, el joyel se convierte, en este capítulo en una prenda de gratitud, como muchas otras que se otorgan para recompensar un servicio. 
Además de los anillos y collares también aparecen los pendientes (fig. 89), pequeñas piezas de metal que llevan algún tipo de incrustación como decoración. A diferencia de los collares y de los broches, en estos libros, los zarcillos no son descritos a detalle como las demás joyas antes mencionadas. Su escasa descripción ${ }^{219}$ dificulta que el lector pueda recrear estas piezas, de las cuales sólo se dice que las damas iban "con muy ricos çarcillos en sus orejas", por lo que los rasgos de su estructura, forma y color se deben hallar en los testimonios de la época, como testamentos y libros de cuentas, así como en obras literarias anteriores al siglo XVI para conocer los tipos de pendientes que se usaban.

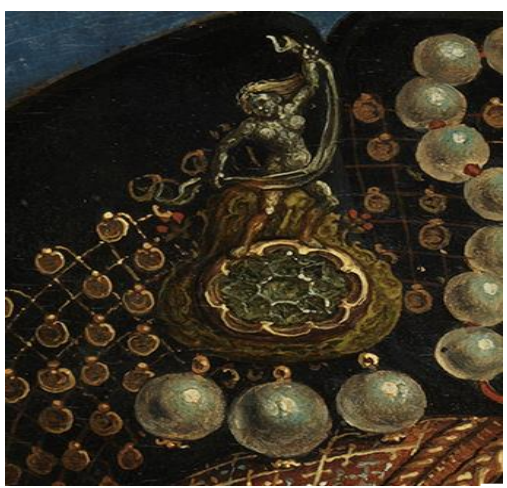

Fig. 87. Retrato de Ana de Hungría y Bohemia (1519) Hans Maler, Museo Thyssen-Bornemisza. Broche de gorra con perlas.

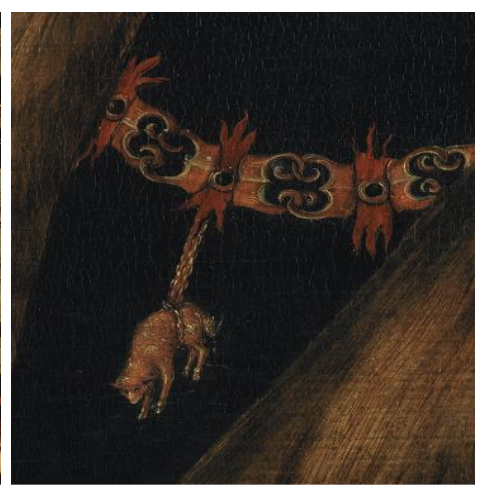

Fig. 88 Retrato del emperador Carlos $V$ (1533) Lucas Cranach el Viejo,

Museo Thyssen-Bornemisza.

Toisón de oro que pende del collar.

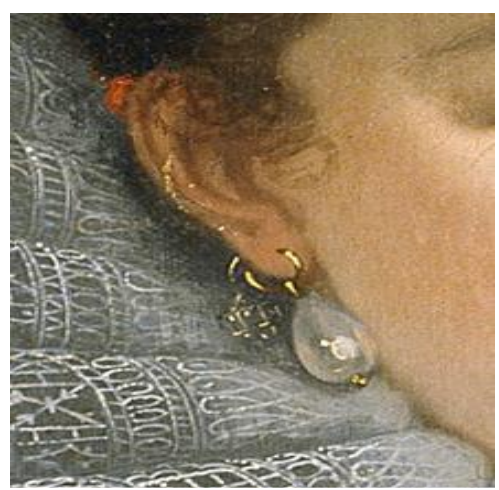

Fig. 89 La infanta Isabel Clara Eugenia (1598-1599) Juan Pantoja de la Cruz, Museo del Prado. Zarcillos de perla.

Uno de estos registros se halla durante el recibimiento de la princesa Isabel de Portugal para su boda con el emperador Carlos V, en donde se hace alarde de esta joya, pues entre su ajuar sobresalen "los çarcillos de dos piedras gruesas". No se especifica el tipo de gema, pero por la fecha, podría tratarse de unos aretes de diamante y perla ${ }^{220}$ por ser de las que más gustaban en la época.

\footnotetext{
${ }^{219}$ En el Libro de Buen amor se halla un ejemplo más detallado, pues se menciona el material con el que se fabrican: "Dam çarcillos de hevilla, / de latón bien rreluziente" (1004). Este material era para las clases bajas. ${ }^{220}$ Provenientes de Portugal, las piedras que más gustaban a las damas de la sociedad eran la perla, el aljófar, el diamante y el rubí, generalmente de tamaño grande. Fernando Checa Cremades, Los inventarios de Carlos V y la familia imperial: Isabel de Portugal, Madrid, Fernando Villaverde Ediciones, 2010, p.1214.
} 
En el ámbito literario, en el Amadís de Grecia aparece un ejemplo un poco más detallado, el único de toda la obra de Feliciano de Silva: "con çarcillos de oro colgando de las orejas de tanto valor que no tenían precio" (Amadís de Grecia II, LII), aunque es mínima la descripción, se conoce el material, de oro, y un poco el tamaño, pues al decir que colgaban, se deduce que eran largos o que pendía una piedra del lóbulo, de acuerdo con las pinturas de la época, solía colgar una perla en forma de pera. Feliciano de Silva es el único autor de caballerías que hace referencia a los zarcillos; hay un total de 16 apariciones de esta alhaja, de las cuales sólo se menciona "tan ricos çarcillos". Con este registro el autor sobresale, nuevamente, de entre los demás por no descuidar este pequeño elemento que complementa todo el atavío femenino. ${ }^{221}$

Es evidente la evolución que Feliciano de Silva tiene durante la creación de sus historias, pues desde el Lisuarte hasta la última parte del Florisel se ve un gran proceso de elaboración en cuanto a los tocados y la vestimenta. A la par de que integra nuevos textiles, metales y cristales, estructura todo un proceso simbólico que gira en torno a la prenda; por lo que hay un crecimiento imaginativo en los detalles, pasa de la simpleza a lo elaborado, ya que inicia con simples adornos de pedrería en los que no hay una composición particular, sino sólo piedras colocadas a juego con la indumentaria. Posteriormente crecen los detalles, pues introduce animales, plantas, figuras geométricas y letras con un significado implícito que sólo es comprensible si se conoce el linaje y la relación sentimental de los personajes, pues es a través de las formas que se crea una nueva forma de comunicarse. A la vez, la presencia de las joyas va más allá de un adorno, ya que

${ }^{221}$ Es importante aclarar que en el Primaleón aparece una descripción de tocado que podría confundir al lector porque se utiliza el término 'arracadas': "y estava vestida no de la manera de las otras mas muy estremados eran de los de aquella tierra y ansimesmo el su tocado, que tenía arracadas de oro con piedras preciosas que resplandecían como el sol y ansimesmo las sus vestiduras eran todas cercadas de aquellas piedras". En este ejemplo, la palabra arracadas designa a la forma, circular, que estructuran la corona, es decir, la dama lleva un tocado de círculos con pedrería, pero no se trata de aretes. 
sobresalen motivos como la entrega de la prenda, circunstancia que se subdivide en variantes como la prenda de amor, de reconocimiento y de agradecimiento, cada una con un tipo de joya especial con decoración acorde a la situación, pues la imaginación del autor inserta detalles que a simple vista no se perciben, como los animales de piedras preciosas, elementos con un trasfondo para el desarrollo de cada suceso en las historias.

\subsection{Accesorios}

Complemento de todo atavío son los accesorios que se llevan en la ropa, desde collares, pulseras, anillos y guirnaldas, hasta sombreros, becas, chías, guantes, bolsos, pañuelos y zapatos; sobre esta variedad de complementos las ordenanzas de oficio regulaban el uso de materiales para su fabricación. En el caso de las bolsas y los sombreros se restringían materiales como la seda enchapada de plata y oro para su fabricación para las clases bajas, mientras que para la nobleza se permitía el uso de trenzas, pestañas y caireles en este tipo de enseres. Lo mismo sucedía con el calzado y los guantes, de los cuales se conservan testimonios de los delicados materiales con los que se realizaban como el terciopelo, la seda y el brocado. Estas características que se mencionan en las leyes suntuarias permiten conocer un poco el modo de confección de estos objetos, así como los elementos que los integraban; sin embargo, aún hay un especial interés en conocer la minuciosa descripción en los adornos que llevan, desde cintas, botones, agujetas y bordados, elementos que no lucieron solos sino que estuvieron rodeados de otros detalles que conformaban en conjunto a la prenda en general, como las cintas de caderas y los cinturones, de los que pendían algunos objetos como abanicos, relojes y joyas; los sombreros, que llevaban plumas, broches, flores y colgantes alrededor de sus pestañas; las bolsas, decoradas con numerosas cintas, cordones y pedrería; así como los zapatos, los cuales se adornaron con piedras preciosas, para las mujeres y hebillas brillantes para los hombres. 
Estos enseres, aparte de ser un adorno más en la tela, presentan connotaciones en el ámbito literario, en el que tienen una función particular en los episodios narrativos en los que sobresalen. En el caso de los libros de caballerías, son poco los ejemplos que describen accesorios de este tipo, debido a que la mayoría de las referencias textiles se dedican a la extensa descripción de los vestidos de las damas y de las armaduras de los caballeros, por lo que las faldas, capas, jubones y sayas, por mencionar algunas, son las prendas que más relevancia adquieren; sin embargo, las mínimas apariciones de complementos como guantes, bolsos y calzados, poco estudiados hasta la fecha, presentan nuevas líneas de investigación en torno a las acciones narrativas que mueven a su alrededor, por lo que es necesario analizar la propuesta de su valor textil y actancial en el espacio en el que aparecen los personajes, por ello la importancia de este apartado dedicado a los guantes, sombreros, bolsos, pañuelos y calzados en el género caballeresco.

\subsubsection{Bolsos}

Accesorio que armoniza con el vestido, se define como el "saquillo de cuero para echar el dinero" (Tesoro de la lengua); es un guarda objetos que aparece en varias imágenes desde la Edad Media, ejemplo de ello son algunas de las miniaturas de los tapices de la Reina Isabel (fig. 90), las Bodas de Canaán (fig. 91), escenas de la vida del siglo XVI (fig. 92), etc., en los se aprecian diversos materiales para su confección, como cuero, tela y una especie de fibra de lazo. En ellas llevaban dinero, comida, ropa, joyas, piezas de metal, etc. Las más comunes fueron el zurrón, la limosnera y la cebadera ${ }^{222}$ utilizadas, principalmente, por los viajeros, aunque también eran del gusto de las damas y los caballeros de la corte, quienes las mandaban a fabricar con materiales costosos como la seda, el terciopelo y

\footnotetext{
${ }^{222}$ Gonzalo Menéndez Pidal, La España del siglo XIII ..., p. 209.
} 
adornadas con cordones de oro y piedras preciosas. De esto se tiene registro en los libros de cuentas: entre las pertenencias de doña Ana de Austria, una de ellas era "una bolsa de terciopelo carmesí, guarnecida con pasamanos y cordones de seda y oro, forrada en tafetán"223.

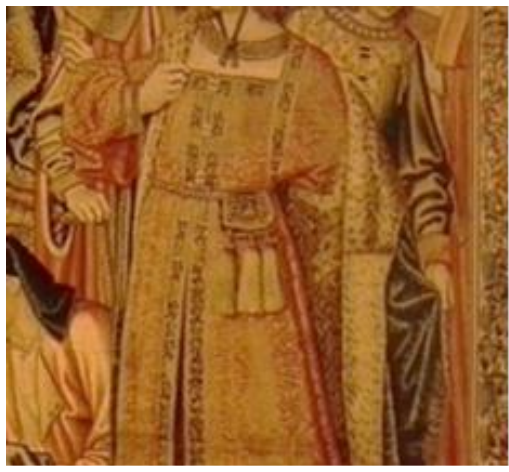

Fig. 90. Tapiz Bautismo de Cristo (1515-1520) Palacio Real de Madrid.

Detalle de bolsa en la cintura con tres barbillas.

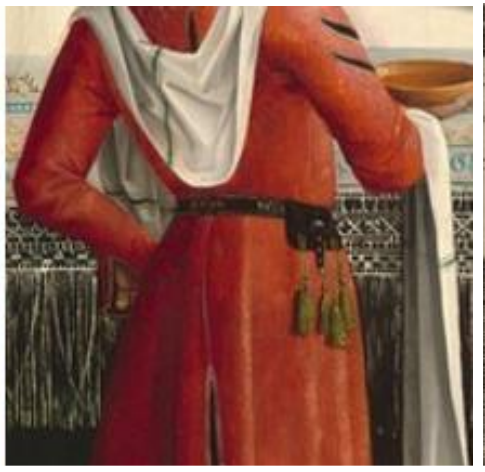

Fig.91. Las bodas de Canaán (1495-1497) Maestro de los Reyes Católicos Galería Nacional de Arte de Washington Detalle de bolsa en la cintura.

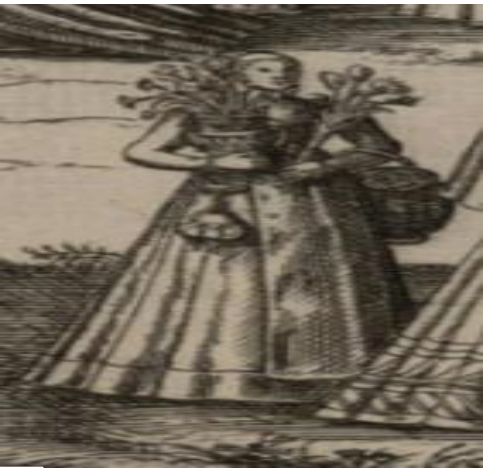

Fig.92. Civitates orbis terrarum. Liber primus (1588) Georg Braun. Dama de compañía con bolso y cesta de mimbre.

Las descripciones en los libros de caballerías son más sencillas, por ejemplo, en el Platir se lee: "y la llave que la donzella traía en una bolsa guarnida" en donde sólo se alude de manera general a la pieza, sin que el autor dé detalle de la tela ni de sus adornos.

A diferencia de la sencillez de esta descripción, se puede notar que en el siglo XIV ya hay bolsos con ricos grabados, entre los más distintivos están los franceses con bordados de escenas de la vida cotidiana como el amor y la cacería (fig. 93), cuyos hilos entretejen la historia de la pareja, este tipo de bordados será más común encontrarlos en las mangas y capas de los personajes caballerescos, pues para este accesorio, sólo se menciona su uso de guardar objetos y trajes. Estos requerían de una bolsa especial para cada elemento que se llevara, debido al tamaño de lo que se guardara, sería la medida de la bolsa; por ejemplo,

${ }^{223}$ Relación y memoria de las joyas de Ana de Austria, Madrid, Dalmiro de la Válgoma y Díaz-Varela, 1949, p. 51. 
para llevar dinero o joyas sería una especie de pequeño saquito, pero para los trajes, se requería de una medida mayor:

Y el escudero, desliando una pequeña burjaca, sacó della unos tan ricos vestidos quanto don Belianís otros viera, todos eran de color de un rubí, con tantos dellos y de otras piedras por guarnición, que no pequeña recreación hera mirarlos e quitándose las armas las dio al príncipe don Belianís y él se vistió de aquellos ricos atavíos. (Belianís de Grecia, XXIII)

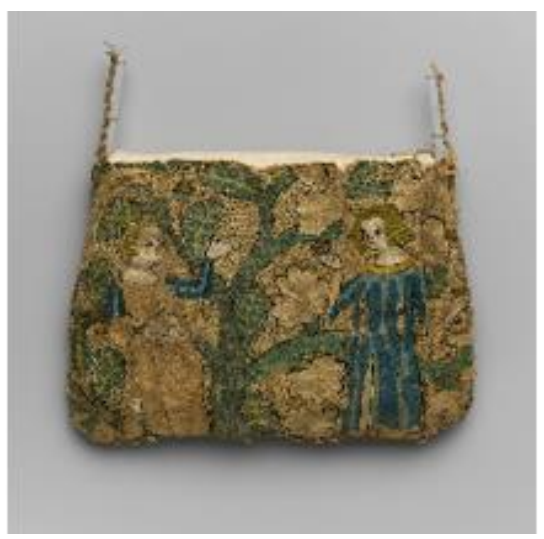

Fig. 93. Bolsa francesa (s. XIV)

Museo Metropolitano de Arte de Nueva York.

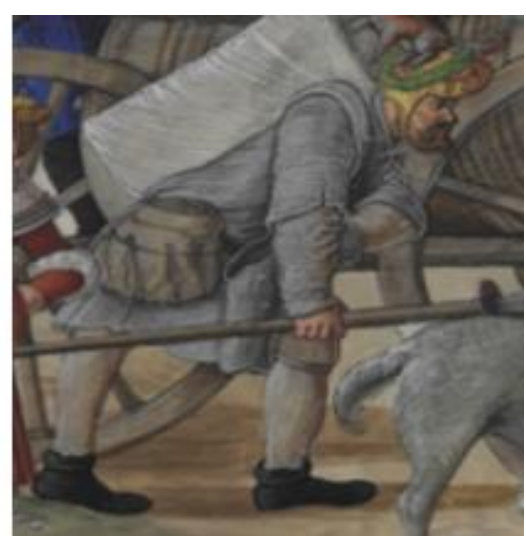

Fig. 94. Triunfo del Emperador Maximiliano I (ss. XVI-XVII) Detalle de bolsa

La burjaca (fig. 94) "cierto género de bolsa grande que de cuero u de lienzo llevan a las espaldas o colgada en la cintura los caminantes, y que no se cierra con cordones sino con una cubierta, y donde ponen sus menesteres" (Tesoro de la lengua), es la encargada de cuidar la ropa del caballero e impedir que se maltrate o ensucie, por lo que su funcionalidad es proteger y transportar. Pero también se llevan otros objetos con una intención dañina para el caballero:

Y luego sacó de la bolsa dos sortijas. Y miró a todas partes por ver si de ninguno podía ser visto. Y allegóse al duque y púsoselas, cada una d'ellas, en su mano, en los dedos más chicos. Y atóle una piedra al cuello con un cordón de seda, ca ya lo traía todo aparejado. Y luego començó de conjurar los malos spíritus. (Arderique, III, XVII) 
En contraste con este ejemplo, los remedios medicinales para aliviar y confortar también son llevados en bolsos: "Y de sí, sacando una bujeta de oro de una gran bolsa que traía colgando sacó d'ella un ungüento tan suave y oloroso que era para confortar a todo el mundo" (Florambel de Lucea I-III, XXXVII). Es decir, la utilidad de la bolsa es guardar algo que puede provocar salud o enfermedad, amor o tristeza, además de convertirse en un misterio lo que hay en su interior al estar rodeado por un material grueso que impide a los demás ser testigos de lo que se lleva y que sólo al momento de ser sacado se podrá conocer su relevancia para la historia.

\subsubsection{Pañuelos y guantes}

Entre los accesorios que se llevaban en la bolsa están el pañuelo y los guantes, el primero, una pieza de tela necesaria para ocultar ${ }^{224}$ ciertas evacuaciones del cuerpo que se consideraban inadecuadas en presencia de la gente, se utilizaba para la limpieza de la nariz y los ojos, aunque también era un elemento de distinción por su confección y el tejido con el que se fabricaba. Para Felipe II se compraron "nueve pañizuelos labrados de blanco"225 conocidos como "moqueros" 226 de tela adecuada para absorber líquidos y evitarle inconvenientes a la realeza, sobre todo en público.

En las pinturas de Alonso Sánchez Coello, especialmente en los retratos Ana de Austria e Isabel Clara Eugenia (figs. 95, 96) se contempla que cada una lleva un tipo de

\footnotetext{
${ }^{224}$ José Luis Gonzalo Sánchez-Molero, El aprendizaje cortesano de Felipe II, 1527-1546: la formación de un príncipe del Renacimiento, Madrid, Sociedad Estatal para la Conmemoración de los Centenarios de Felipe II y Carlos V, 1999, p.126.

${ }^{225}$ Idem.

${ }^{226}$ María Ángeles González Mena, Colección pedagógico textil ..., p.15.

También se conocen como "paños de narizes", de estos Alonso Enríquez tenía cuatro. Silvia Saladrigas Cheng y Joan Soler i Jiménez, El arte real de perseguir a los sombreros. Textos y documentos para la historia del tejido y la indumentaria en las monarquías hispánicas [s. XIV-XVIII], Barcelona, Centre de Documentación i Museu Téxtil, 2008, p. 85.
} 
pañuelo en la mano, caracterizados por tener la orilla calada en armonía con el color de su vestido; este tipo de detalles no se menciona en los libros de caballerías, sólo se dice que “començó a se limpiar con un paño las lágrimas que de sus ojos salieron” (Policisne de Boecia, XLII), por lo que la palabra pañuelo no aparece en este género, sólo se alude a su función de ocultar el llanto, aún más cuando se viene acompañado y no se desea que los demás descubran su estado de ánimo: "Detrás de todos venía uno, desarmada la cabeça, que señor de los otros parescía y tres escuderos tras él; y él venía limpiando con un paño los ojos, que en su semblante mostraba llevar gran duelo y tristeza" (Policisne de Boecia, LX). La debilidad del caballero se debe cubrir, por ello es que el pañuelo es un aliado en momentos de dolor por un rechazo sentimental o una separación entre el caballero y la dama. Con las doncellas también ocurre lo mismo, solo que en Feliciano hay una interesante modificación: "Y de tal suerte Diana la halló una vez e poniéndole con sus hermosas manos los cabellos tras sus orejas, que de el poco sossiego los tenía sueltos, con su propia manga le limpió las lágrimas de sus hazes" (Florisel de Niquea III, LIII). La manga se convierte en el sustituto del pañuelo por su gran tamaño y ante la falta de éste, se debe buscar otra prenda capaz de secar las lágrimas.

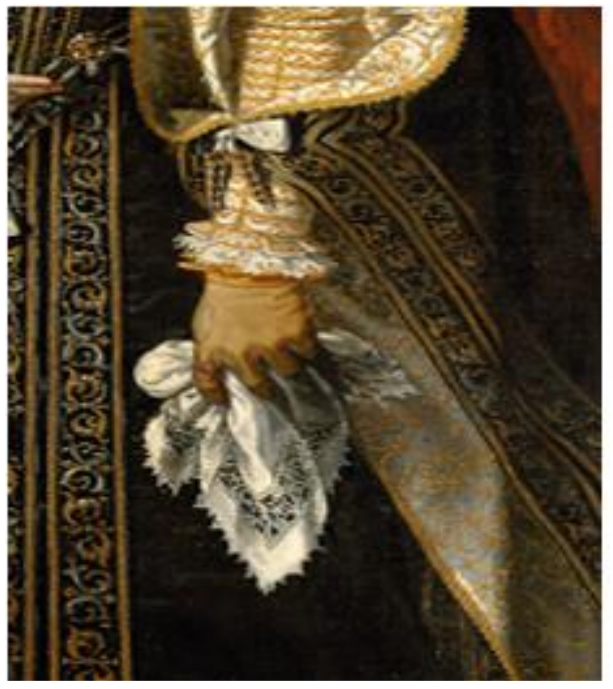

Fig. 95. Ana de Austria, reina de España (1571) Alonso Sánchez Coello, Museo Kunsthistorisches. Guante de tela y pañuelo calado.

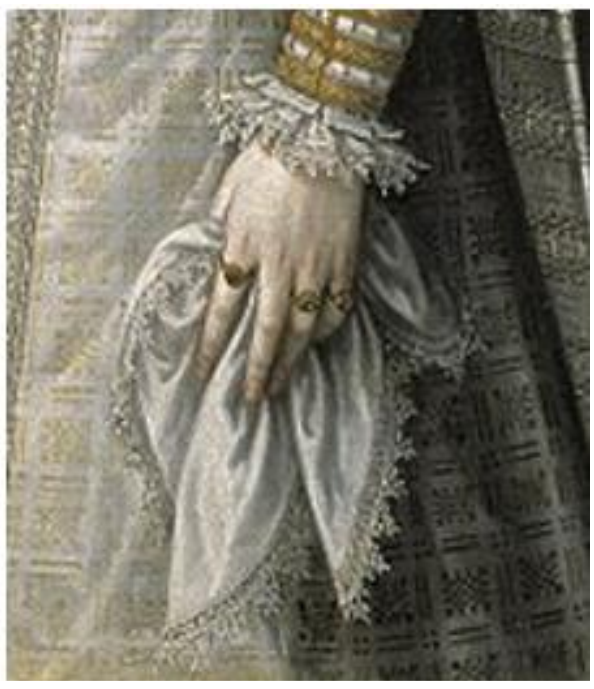

Fig. 96. La infanta Isabel Clara Eugenia (1579)

Alonso Sánchez Coello, Museo del Prado. Detalle de pañuelo con orilla de encaje. 
El siguiente elemento en la bolsa es el guante, también llamado lúa o luva, es un enser que sobresale en pinturas y grabados del siglo XVI y que generalmente era de seda, lino y terciopelo para las clases altas y de cuero para usar en la cetrería ${ }^{227}$ (figs. 97, 98). De esta prenda hay un ejemplo en la obra de Feliciano de Silva, no se menciona el tipo de material ni el diseño: "Y ella con mucha gracia descalçando un guante la mano en las suyas le puso" (Florisel de Niquea III, CX) ${ }^{228}$. Un descontento sentimental produce una petición de perdón con un beso en las manos, por lo que la joven se quita el guante para recibir tal acto.

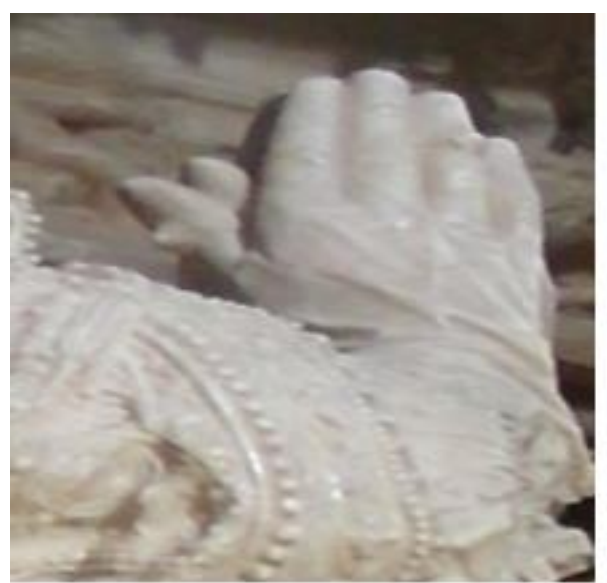

Fig. 97. Sepulcro del infante Alonso de Castilla (s. XV) Gil de Siloé, Cartuja de Miraflores, Burgos. Nótese el tallado de las manos para simular los guantes.

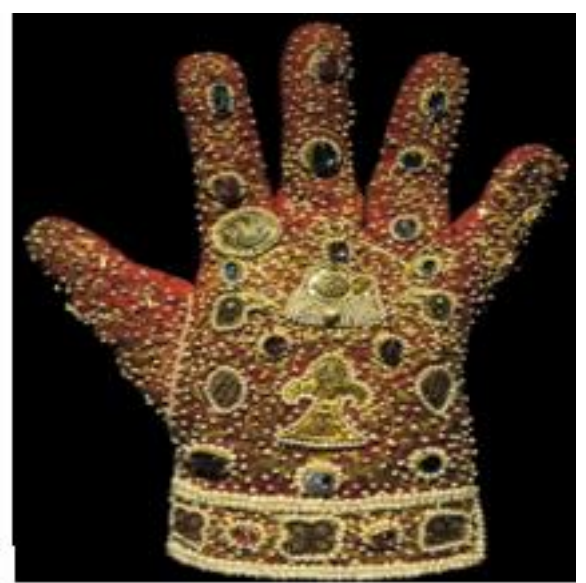

Fig. 98. Guante imperial de Palermo (h. 1220) Cámara del Tesoro Imperial de Viena. Bordado en perlas y piedras preciosas.

En oposición a este ejemplo, en el Amadís de Gaula aparece otra connotación de esta prenda: "Y vestía paños de duelo, y en la mano diestra tenía una lúa de paño blanco que al codo llegava" (Amadís de Gaula III, LXIX). La idea de un solo guante establece un simbolismo en torno a la protección de algo, en este caso se trata de ocultar la herida que Amadís hizo en la mano a Arcaláus, quien debe evitar ser identificado por la cicatriz y, de

${ }^{227}$ Gonzalo Menéndez Pidal, La España del siglo XIII..., p. 232.

${ }^{228}$ Este mismo ejemplo se repite en el capítulo XXXIV de Febo el Troyano. En el capítulo cuatro analizo la recreación de los modelos narrativos de Feliciano de Silva en la obra de Esteban de Corbera. 
algún modo, pretender ocultar su identidad hasta presentarse ante Amadís. Es decir, los accesorios protegen, aíslan una parte del cuerpo, lo dejan incomunicado con las demás personas con el propósito de encubrir cicatrices y marcas de nacimiento, para proseguir la aventura hasta llegar al clímax y así prolongar la hazaña, esto ocurre con Arcaláus, quien no es reconocido por los demás personajes, sino hasta que se encuentra frente a Amadís, por ello la importancia de conservar el guante y evitar quitarlo.

\subsubsection{Prendas para cubrir la cabeza}

En el siglo XV se establecen tres grupos fabricantes de enseres para la cabeza: boneteros, sombrereros y toqueros ${ }^{229}$ especializados en la elaboración de distintos tipos de accesorios para llevar sobre el cabello, desde bonetes, chapeos, gorras, tocados, piochas, guirnaldas, garlandas, cintas, crespinas, tocas, boinas, capiellos, etc., cada uno caracterizado por su forma, tela y aplicación. Los más característicos se realizaban en terciopelo y seda con adornos de oro, plumas y pedrería, para los nobles, mientras que la clase baja se conformaba con gorras de paños simples.

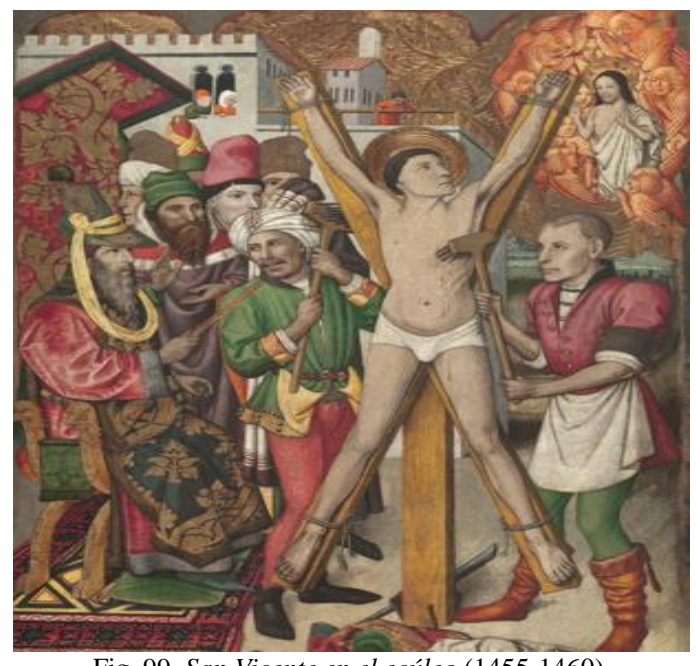

Fig. 99. San Vicente en el ecúleo (1455-1460), Jaume Huguet, Museo Nacional de Arte de Cataluña. Nótese la variedad de prendas para la cabeza.
Esta diversidad se halla en las pinturas y grabados de la época como las que se observan en el retablo de San Vicente en el ecúleo (fig. 99), en la que se ven varios tipos de bonetee, capirote, gorra y turbante a juego con la vestimenta de las personas. Esta variedad permite conocer la calidad y el modo en cómo se usaban.

\footnotetext{
${ }^{229}$ Carmen Bernis, Indumentaria española en tiempos de Carlos V, p. 78.
} 
Algunos de los accesorios, antes mencionados, tienen poca presencia en las obras de Feliciano de Silva; toda la variedad de sombreros que de ellos se tiene registrada durante la Edad Media y el siglo XVI es apenas visible, por lo que, en este aspecto, es necesaria la comparación con otros títulos como La corónica de Adramón, el Claribalte, el Lepolemo y el Arderique, en los que no sólo se hace mención de la prenda, sino del modo de llevar y usar en distintos momentos y del significado que adquiere de acuerdo con los sucesos narrativos.

\subsubsection{Sombreros}

Las miniaturas de los libros de caballerías son una prueba más de las prendas que los escritores diseñaban para sus personajes, con ellas se pueden hacer registro del tipo de ropas que se usaba, en el caso de los sombreros, sobresale el grabado del folio $19 \mathrm{v}$ del Claribalte (1519) en el que se aprecian dos mujeres con vestimenta larga, sombrero y toalla para proteger su identidad (fig. 100).

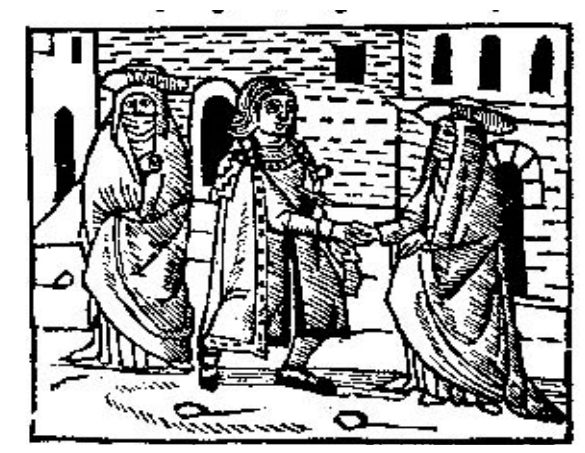

Fig. 100. Claribalte (1519) Gonzalo Fernández de Oviedo (cap. XVI, fol.19v.)

Esta imagen, aunque no es descrita en su totalidad en el texto, ya que sólo se mencionan las toallas, es un importante ejemplo, debido a que llevan un sombrero, que, de acuerdo a la clasificación hecha por Carmen Bernis y Menéndez Pidal, los "llevan solamente las personas que necesitan protegerse del sol, tales como caminantes [...] o de una doncella 
que se protege con un sombrero del calor de la hora sexta"230; su utilidad, protegerse del clima, se extiende a un simbolismo más importante, el taparse para no ser reconocida ${ }^{231}$ durante su trayecto al encuentro con su enamorado: "llevava una tovalla delante del rostro, porque nadie la pudiesse conocer" (Claribalte, XVI ${ }^{232}$. Se conserva el concepto del caminante, pero en una distancia corta, para un encuentro sentimental, por lo que la función de cubrirse del sol cambia a la de evitar el reconocimiento, es decir, iría tapada y la toalla aquí vendría a ser una suerte de manto. En la cita no se menciona ninguna otra prenda, sólo la toalla, por lo que el lector desconoce la forma en cómo debían vestir, damas y caballeros, al momento de salir. Pero por su fecha de publicación se tiene registro de una variedad de diseños como "sombreros, sombreretes, gorra, gorra de cabos, bonetes"233, modelos hallados en los libros de cuentas y que dan registro de la producción, costo y diseño de la época. (figs.101-105)

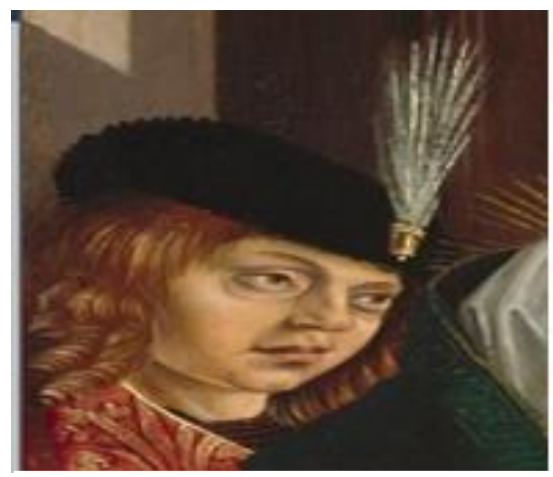

Fig.101. Las bodas de Canaán (1495-1497) Maestro de los Reyes Católicos Galería Nacional de Arte de Washington. Gorra con pluma.

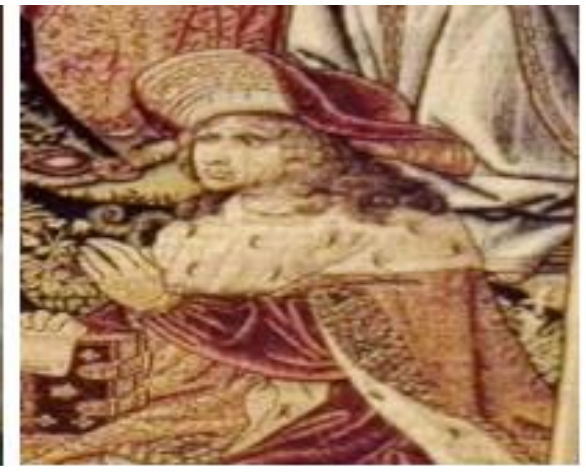

Fig.102. Tapiz Presentación en el templo (1502-1504), San Lorenzo de El Escorial. Hombre con sombrero, la solapa lleva adornos de hilo de oro.

${ }^{230}$ Gonzalo Menéndez Pidal, La España del siglo XIII ..., p.86.

${ }^{231}$ El simbolismo de las prendas de protección se analiza en el capítulo tres, por lo que, en este apartado, sólo se cita este ejemplo a modo de introducción para la tipología de sombreros que aparecen en el género caballeresco.

${ }^{232}$ Gonzalo Fernández de Oviedo, Claribalte, ed. de María José Rodilla León, México, UAM-I/UNAM, 2002. ${ }^{233}$ Saladrigas y Soler, op.cit., pp. 81-83. La mayoría de los diseños se conocen por los libros de cuentas que describían baúles con diversa mercancía entre la que sobresale las prendas para la cabeza, de los que se indican los detalles de costura, bordados y aplicaciones de metal, así como los costos de cada diseño. 


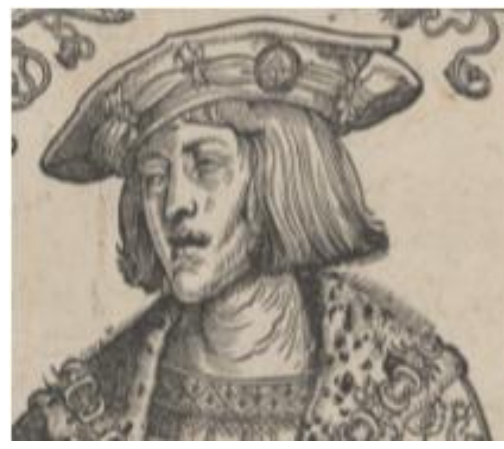

Fig.103. Carolus Rex Hispanie (1519) Hans Weiditz, Biblioteca Nacional de España. Gorra flamenca.

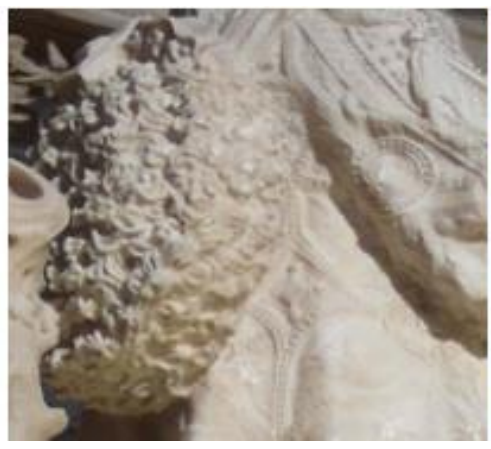

Fig.104. Sepulcro del infante Alonso de Castilla (s. XV)

Gil de Siloé, Cartuja de Miraflores, Burgos.

Gorra

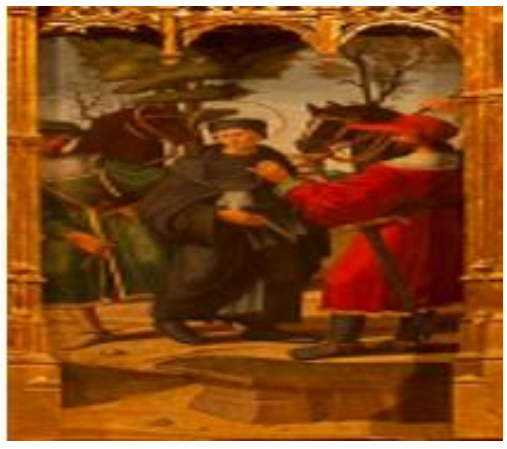

Fig.105. Retablo de san Martín de Tours (s. XVI)

Iglesia de San Martín, Uncastillo, Zaragoza.

Gorra con visera

Es decir, la imagen complementa a la descripción escrita, y el traje se puede estructurar de manera perfecta para comprender el significado que hay detrás de la tela. Carmen Bernis expresa que la "misión de la gorra era adornar, la del sombrero proteger"234; sin embargo, estas dos funciones se unen en ciertos pasajes para demostrar tanto la posición social como para encubrir la identidad, de la cual sólo se darán indicios sobre el origen de la persona al reflejar su riqueza a través de la calidad de las prendas, pero sin informar más allá de lo que se pretende.

En este ejemplo se trató de una necesidad de cubrir, por lo que no hay una estructura elaborada en los adornos del sombrero, implícitamente se evita cualquier accesorio para no ser reconocido, pero la presencia de otros tipos de sombrero sí requiere que sean elaborados a detalle con la intención de sobresalir entre los demás, lo que sucede principalmente en festejos de palacio.

${ }^{234}$ Ibid, p.17. 


\subsubsection{Chapeo}

Los ornamentos de cada gorro dependen de la clase social a la que se pertenece, Carmen Bernis expresa que los de la alta nobleza "se sentían obligados a expresar en sus trajes su privilegiada categoría" 235 , porque el diseño, el color, la tela y el bordado reflejaban la posición social, debido a que las modas se imponían y nuevos estilos aparecerían. Por ejemplo, en el Tristán el joven se detallan las joyas que lleva el chapeo:

El rey Mares llevaba por la mano a la infanta Iseo, la cual iba vestida de terciopelo verde, con una bordadura de oro de martillo ${ }^{236}$ ancho y llevaba un collar de oro lleno de pedrería, de valor muy grande. Los sus cabellos llevaba cogidos y volteados a la su cabeça, tan hermosos que delante d'ellos el oro perdía el color. Y encima de la cabeça llevava un chapeo de oro; y en la delantera del chapeo iva puesto un joyel con solo una piedra que echava rayos de sí como el sol.

Un vestido de terciopelo verde con guarnición de oro de martillo adornan a la infanta Iseo, durante su recorrido hacia el palacio; la joven asombra con la calidad de la prenda y de los accesorios que la acompañan; el chapeo, un sombrero dorado adornado con un joyel, fue una prenda criticada "por ser un adereço de camino con cordones de oro y plata para que lo destruya todo el aire y el polvo y el agua y los lodos" ${ }^{237}$. Esa crítica más bien se debe al alto costo del sombrero por los accesorios que lo adornaban, además de que la queja era para la clase baja que perdía sus haciendas por el afán de comprar ropas caras.

En el caso de las monteras y las gorras la relevancia está en la unión de broches, piedras y adornos metálicos con las plumas, que comenzaron a ser impuestas por las damas de la corte, como en el caso de doña Isabel Clara Eugenia, que lleva una piocha de plumas

\footnotetext{
${ }^{235}$ Carmen Bernis, Indumentaria española en tiempos de Carlos V..., p. 7.

${ }^{236}$ En mi tesis de maestría investigué el "oro de martillo" usado en otros objetos como joyas, utensilios y espadas, la forma de trabajarlo consiste en colocar el grano de oro entre dos hojas y golpearlo con un martillo hasta formar una delgada lámina.

237 Antonio de Torquemada, Coloquios satíricos..., p.67.
} 
blancas que contrasta con su gorra negra. Los hombres imitaron este diseño como ocurre con el Emperador Carlos V:

Se había puesto ese día un jubón de armar, de raso carmesí, y por encima una casaca de tela de oro y de tela de plata, acuchillada sobre un fondo de raso carmesí, un manto de tela de oro cernido, con fondo de cebellinas, una montera de terciopelo negro y una blanca pluma en ésta que cuadra tan bien a las gentes de armas como el jubón. ${ }^{238}$

Los colores más comunes de contrastar eran el negro y el blanco:

Y los reyes don Juan y don Tristán ivan vestidos de una librea de terciopelo negro, y el enforro de raso blanco: lo negro muy acuchillado, que lo blanco por todas las cortaduras se parecía; y las gorras del mesmo terciopelo, muy cavadas de oro con sendos plumajes blancos. (Tristán de Leonís, II, XVIII)

La similitud entre ambos gorros es muy parecida, por los detalles de las plumas, el color negro y el terciopelo, además de que ambos representan a figuras de autoridad, por una parte, el Emperador Carlos V en la realidad, por la otra, el rey don Tristán en la ficción. Ejemplos en los que se nota una posible influencia de modas.

\subsubsection{Bonete}

Aunque de uso más general para el sector eclesiástico y letrado, el bonete fue utilizado tanto por hombres como por mujeres de todas las clases sociales, su calidad dependía de los materiales y de los adornos que llevara. Se caracterizaba por "su armazón rígido y de forma circular que se sujetaba con una cinta en la barbilla" ${ }^{239}$. El Adramón es el principal libro en donde aparece este tipo de sombrero, al tener trece pasajes en los que se menciona el acto de reverencia a la partida y llegada de un personaje con bonete en mano: "Queriendo

\footnotetext{
${ }^{238}$ Lorenzo Vital, Relación del primer viaje de Carlos V a España ..., p. 286.

${ }^{239}$ Nieves Fresneda González, Moda y belleza femenina ..., p. 357.
} 
responder Fedrique, salió el duque, el qual, con el bonete en la mano, se vino al tio y le dio los buenos días" (Adramón, LXXXVII).

También se muestra una petición de baile con el bonete en la mano: "E como el duque de Clarencia fuese muy discreto, aunque otra cosa toviesse en el coraçón, se levantó de donde asentado estava, y con el bonete en la mano, haciendo gran reverencia y acatamiento a la duquesa Leonor, le rogó que con él quisiesse dançar" (Arderique, III, XIV). Acorde con la ocasión debían ser de dos colores con aplicaciones de oro, como pequeñas medallas, dijes o colgantes en la parte delantera de la pestaña, unos acompañados de alguna insignia o piedra. Por lo que la distinción en los bailes no sólo estuvo en el vestido y los sayos, sino que gorras, bonetes, sombreros y monteras comenzaron a tener una relevancia significativa en este tipo de festejos.

Aunque en muchos episodios no se describa a detalle el tipo de prenda que se porta, a veces los sucesos narrativos adquieren más relevancia que el diseño y el color de la ropa, obligando a ésta a adquirir un nuevo simbolismo y ser el elemento clave para cambiar el estado de ánimo de los personajes. Esto ocurre en el Lepolemo, cuando el protagonista desaparece: "Que os parece señor del fin de vuestro amado hijo, que alguna ballena o otra cosa semejante los ha comido que veys aquí el bonete y el çapato de vuestro hijo" (Lepolemo, VI).

Nuevamente aparecen las prendas de reconocimiento, las cuales, aunque no se describen físicamente, sí adquieren un valor narrativo importante al ser identificadas por los personajes y ser prueba de una posible desaparición del niño. Las dos piezas son halladas junto al mar, por lo que el temor de los padres aumenta al pensar que la criatura fue presa de algún animal marino. Éstas adquieren un significado melancólico por ser un constante recuerdo de la ausencia del hijo, por lo que el bonete y el zapato se convierten en ropa de 
lamento por causar la tristeza de los padres: "Y tomó de las manos a la emperatriz, el bonete y el çapato del príncipe, que no hazía sino mirarlos y hablar con ellos como si le ovieran de dar cuenta de su hijo. Y mandó que los pusiesen donde no los viesse la emperatriz" (Lepolemo, VI). Esta escena se vuelve una especie de dramatización entre la emperatriz y los objetos que la rodean, en este caso, a quienes, en su desesperación, personifica por la necesidad de saber qué sucedió con su hijo. La relevancia del bonete como prenda de distinción por estar creado con finos materiales desaparece ante la tristeza de los padres por la pérdida de su hijo. El lujo se olvida y en su lugar aparece el lamento, con lo que los accesorios toman distintos simbolismos en cada episodio.

\subsection{Calzado}

La riqueza de los materiales para la fabricación no fue exclusiva para los trajes, vestidos y capas, sino que el calzado ocupó un lugar muy importante como complemento de la indumentaria al combinar el color, aplicaciones y materiales con la ropa que se usaban. Sin

embargo, a pesar de los variados ejemplos de ropas, los escritores hicieron pocas referencias a los zapatos; dos de ellas se hallan en el Florisel y en el Tristán de Leonís, en donde se da importancia a la acción de calzar más que a la descripción del calzado. En el primero se dice que: "E assí era la verdad, que Diana era tan honesta que ni tan solamente el pie descalço ninguna de sus doncellas le vio" (Florisel de Niquea III, LVIII). Al despojarse de las calzas, las damas debían quitar antes el zapato, por lo que, implícitamente, se alude al uso de chapines, alcorques, galochas o chinelas (figs.106 y detalle) que eran el calzado femenino más común de la época, tal como se muestra en la pintura Santa Catalina 
de Alejandría disputando con los doctores paganos (fig.107 y detalle), en donde se dejan al descubierto las calzas.

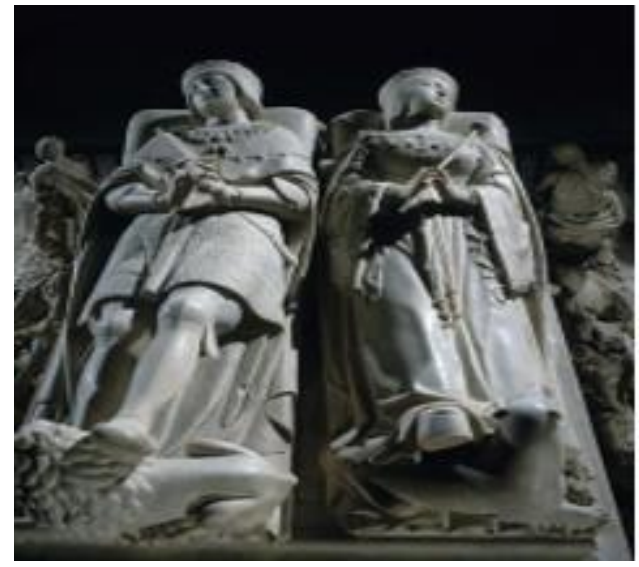

Fig.106. Sepulcro Doña Juana y Felipe el Hermoso (1519) Bartolomé Ordóñez, Capilla Real de Granada.

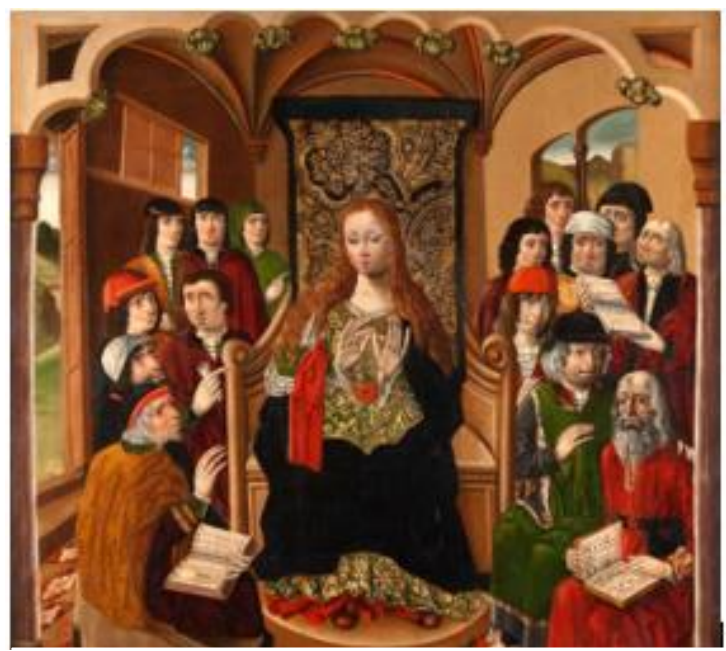

Fig. 107. Santa Catalina de Alejandría disputando con los doctores paganos (1485) Alonso de Sedano, Galería Bernat, Barcelona.

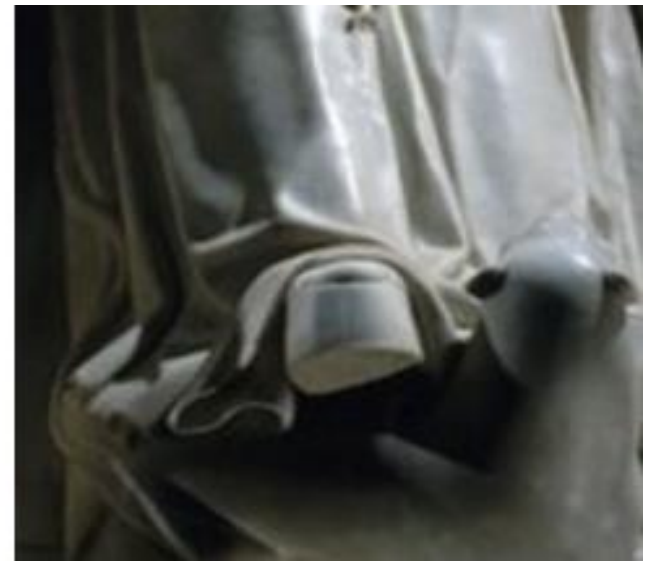

Detalle de chapín de doña Juana

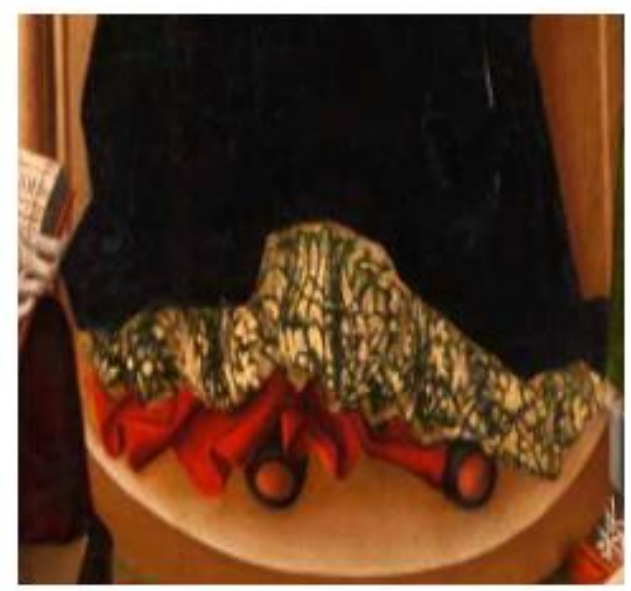

Detalle de las calzas femeninas

En el segundo ejemplo es un hombre quien viste zapatos: "E don Tristán salio de la cama, e vestiose una ropa de seda e calçose unos çapatos e tomó su espada y cubriose un manto" (Tristán de Leonís, LXXX). Para los caballeros se fabricó la bota, el borceguí, el botín, la abarca, el zapato, la galocha, el zapato francés y el pantufo (figs. 108-111). A pesar de esta variedad fue un accesorio poco descrito en los libros de caballerías, pero que en la literatura artúrica sobresale en un personaje, Merlín. 

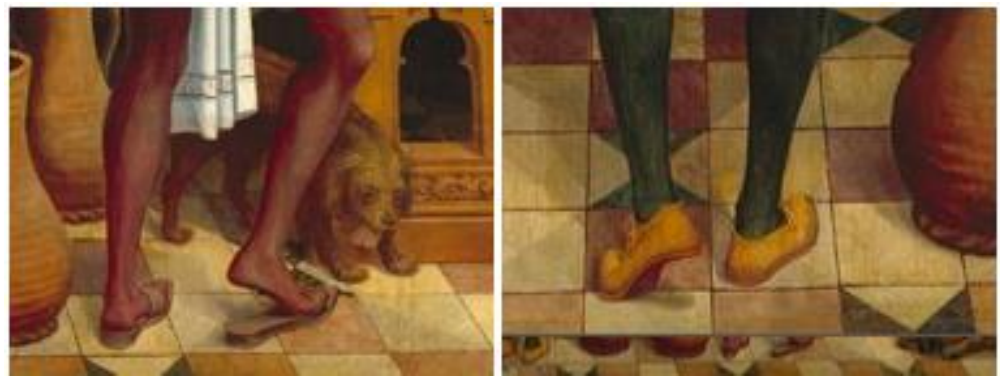

Figs. 108-109. Las bodas de Canaán (1495-1497)

Maestro de los Reyes Católicos, Galería Nacional de Arte de Washington. Alcorques y zapatos.

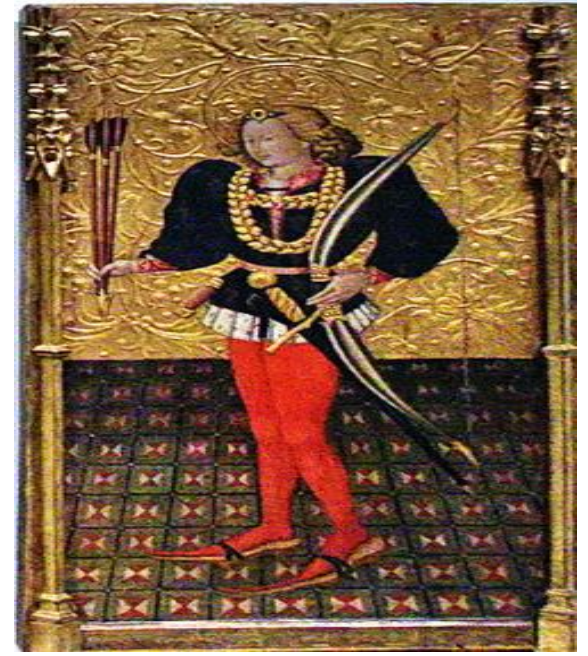

Fig.110. Retablo de san Jerónimo, san Martín y san Sebastián (1445-1455)

Jaume Ferrer II, Museo Nacional de Arte de Cataluña.

Galochas con suela de madera

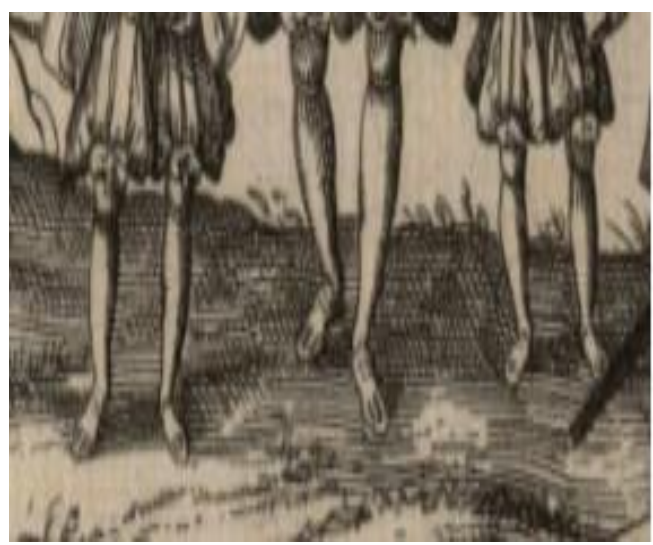

Fig. 111. Civitates orbis terrarum. Liber primus (1588) Georg Braun.

Zapato con punta y cuchillas.

Entre sus apariciones destacan las figuras de "pastor, anciano y joven", en las que la ropa presenta propuestas novedosas en los accesorios que la integran. Por ejemplo, en el Baladro, toma la forma "de un ombre que viene de monte, con su cuerda de lana en el cuello e sus çapatos guirnaldos e una saya vestida toda rota, pequeña, e de los cabellos rebueltos e la barva grande, así que bien parescía una cosa extraña (El baladro del sabio Merlín con sus profecías, X). La descripción de su atuendo nos obliga a conocer el calzado de la época, ya que la referencia a los "çapatos guirnaldos" (fig. 112) es muy general. 
Para ese periodo, el calzado estaba fabricado con materiales como piel, tela, corcho y madera ${ }^{240}$. Las "abarcas"241 (fig. 113) eran un zapato rústico compuesto de una pieza de cuero con una cuerda entre cruzada desde el empeine hasta el tobillo; generalmente lo usaban los pastores. También estaban las 'suelas', "especies de sandalias de suela baja que se ajustaban con correas"; los zapatos de diversas pieles que se sujetaban con cuerdas y, por último, las sandalias, de suela más alta, cerrada y con cintas en la parte de enfrente.

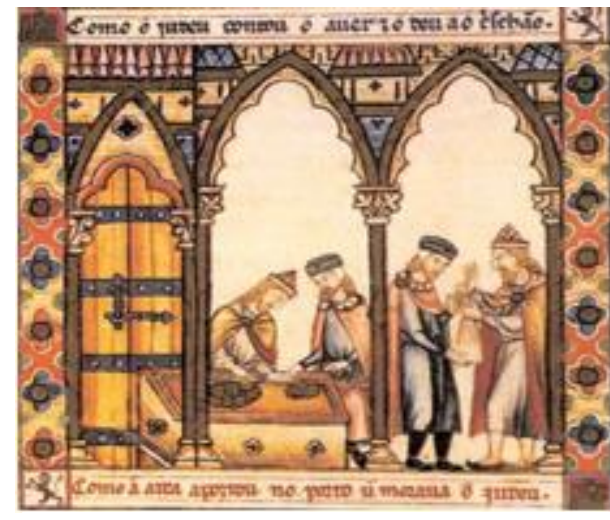

Fig. 112. Cantigas de Santa María. Detalle de los zapatos de Merlín.

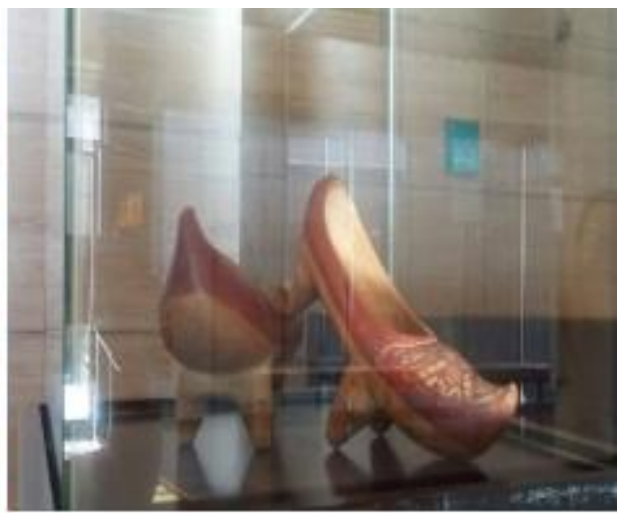

Fig. 113. Abarcas de madera, Museo del Traje de Madrid.

$\mathrm{Al}$ estar ocultos, en el caso de las mujeres, se consideraban como una prenda bien aderezada por el lugar en el que se hallaba:

¿No habéis vosotros mirado cuando acaso acontece que yendo una dama por la calle, o estando en otro lugar burlando, se le descubre un poco el pie o el chapín descuidadamente, si entonces se vee bien aderezado lo que muestra, cuán bien parece? De mí os digo que huelga mucho de vello y creo que vosotros también; porque cada uno agradece más el aderezo en parte así ascondida que adonde siempre se vee ${ }^{242}$.

\footnotetext{
${ }^{240}$ Carmen Bernis, Indumentaria española en tiempos de Carlos V..., p. 17.

${ }^{241}$ Gonzalo Menéndez Pidal, La España del siglo XIII..., p.99.

242 Baltasar de Castiglione, El Cortesano, Madrid, Cátedra, 1994, pp. 176-177.
} 
Ese aderezo escondido, en el personaje de Merlín es visible para los lectores, gracias a las descripciones que se dan de la forma en cómo están hechos. El primero aparece durante el banquete dado por la Señora del Paraíso, en donde Merlín entra con apariencia de joven: "las calzas eran de seda parda y los zapatos, de cordón blanco orlados con orofrés, se cerraban con dos lacitos de oro" (LXXXIX). Descripción que los asimila a las sandalias porque éstas llevaban lazos dorados para sujetarlos. El elemento característico del ejemplo de Merlín es el 'orofrés', metal dorado o plateado que se consideraba de uso para la realeza. La mención de esos zapatos es cercana a la que aparece en unas cuentas reales del siglo $\mathrm{XV}$ :

Zapatos vistosos (sotulas, solers, sotulares, subtillares, ínfulas, etc.) gastaban los señores, principalmente en materiales de raso azul bordados de lises, orofresados todo el empeine y sembrado de aljófar, con coronadas y margaritas en el espacio intercluso por los orofreses, además unas sandalias del mismo raso y orofreses, forradas de raso colorado con lazadas de oro y seda azul. ${ }^{243}$

Las descripciones del calzado indican una dedicación en el diseño y manejo de los materiales de la época, en los que se detallaban las cintas para sujetar, las hebillas, los botones y demás elementos que pudieran traer, por lo que la creatividad en los zapatos de Merlín está en los detalles que los decoran y la variedad de modelos que aparecen.

En La corónica de Adramón también hay varios modelos de esta prenda, el primero se trata de un par de chapines que regalan a la hija de un rey: "traya unos chapines, de hechura de pantufas baxas, con capelladas largas, con pyedras y perlas de gran valor" 244 . El primer detalle que destaca es la combinación de dos calzados, chapines y pantufas, éstas se

243 José Puiggari, Estudios de indumentaria española, Barcelona, Asociación Artístico-Arqueológica Barcelonesa, 1890, p. 311.

${ }^{244}$ La corónica de Adramón, ed. de Gunnar Anderson, Newwark, Delaware, Juan de la Cuesta, 1992, p.168. Todas las citas provienen de esta edición, en adelante citaré en el texto indicando entre paréntesis el número de libro y capítulo. 
caracterizaban por llevar la punta cerrada y descubierto el talón, mientras que los chapines ya se ha mencionado el enorme grosor de la suela, por lo que en esta unión lo más allegado a esta imagen sería la elaboración de unos chapines de punta cerrada con adornos de pedrería. (fig.114). En otro momento aparece otra mención: "abryeron el canastillo y sacaron los pantufos” (Adramón, I, XXXIX), unos zapatos bajos destalonados. (fig.115). Asimismo, hay algunas referencias al modo de vestirlos: "Quitaréme la capa y las botas y luego saldré" (Adramón, II, XXIII); al decorado: "tenya los çapatos de terciopelo carmesy con una cruz de horo en cada uno" (Adramón, II, XXXII) (fig. 116), éste se trata del calzado del papa, que de acuerdo con los estatutos religiosos debían ser rojos en memoria de la sangre de Cristo. También aparecen situaciones cómicas: "que el rrey, su padre, en la sala salyó con tanta prisa, syn chapines" (Adramón, II, XVII), en donde se relaciona el chapín con el hombre, cuando era un calzado especialmente para las mujeres. ${ }^{245}$

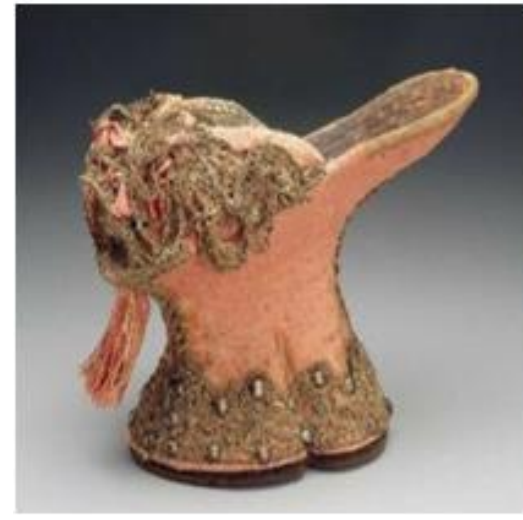

Fig. 114. Chapines venecianos (s. XVI) Museo del Traje, Madrid

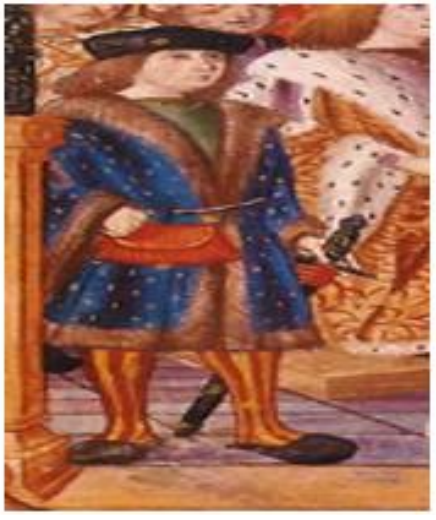

Fig. 115. Rimado de la conquista de Granada (1502), Pedro Marcuello Pantuflos

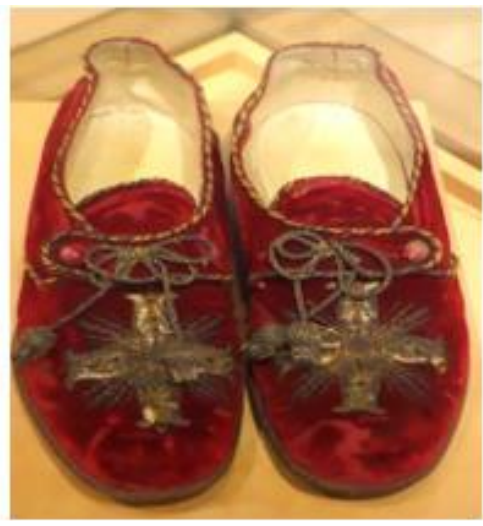

Fig. 116. Calzado eclesiástico

\footnotetext{
${ }^{245}$ Carmen Bernis, "Modas españolas medievales en el Renacimiento europeo II", Waffen und Kostümkunde, 1960, p. 33.
} 
En el Baldo hay una referencia directa a la condición física de éste y a su producción:

Y luego determiné de buscar calçado nuevo para poder andar. Adonde sin más dilación, yendo por una calle muy ancha, veo muchas tiendas y la una de un borzeguinero y çapatero. Adonde me paro mirando unos fermozos borzeguíes, pensando cómo los podría aver, y revolviéndolos. A lo cual se all[eg]ó el maestro, diziendo si los quería. Yo libremente dixe que sí. Luego el maestro, con mucha diligencia, méteme en su tienda, busca con mucha diligencia unos buenos borzeguíes y convenientes a mis piernas, y pónemelos. Él entonces dixo:

-O, ¡qué hermoso pareceríades con un par de çapatos de suela doblada! ¿Queréislos?

-Sí, señor, -dixe yo- pues que en otro cabo me los han de dar.

Los cuales fueron buscados y calçado. Yo luego loava los borzeguíes, loava los çapatos, gozándose el maestro con mi contento de su obra, teniendo esperança de venderla bien. (Baldo, I, XX).

Excelente ejemplo en el que se hallan numerosas referencias de este accesorio. El primero es sobre los gremios zapatero y borceguinero, los cuales estaban claramente diferenciados en la Edad Media porque cada uno sólo podía fabricar el tipo de calzado que se les había asignado. Además, al mencionar los zapatos de suela doblada se refiere a dos condiciones del borceguí: primero, por ser un zapato de cuero muy flexible se llevaba con otros, como chinelas, zapatos o pantufos; ${ }^{246}$ segundo, se podía realizar con suela reforzada, para evitar llevarlos con algún otro calzado. En el Baldo claramente se trata de la primera condición, ya que al personaje se le dan dos pares, uno de zapatos y otro de borceguíes.

Como se puede notar, son pocos los ejemplos en los que se describe el calzado en los libros de caballerías hispánicos, y apenas se dan breves características como el modelo, color o modo de llevarlos.

${ }^{246}$ Carmen Bernis, Indumentaria española en tiempos de Carlos V..., p. 79. 
Sin duda alguna, la presencia de complementos de la indumentaria, como los analizados anteriormente, refleja la dedicación que algunos autores dejaron en sus obras; en ellas representaron las prendas más pequeñas, por su tamaño, pero muy significativas por el valor simbólico que adquirieron en las narraciones, ya fuera como prendas de reconocimiento, melancolía o galanteo; además de otorgar un valor más al completar los trajes, desde la cabeza hasta los pies, finalizaron la moda perfecta, el gusto por el detalle y la coordinación entre color, material y forma, todo ello concluido con cinco accesorios importantes: sombrero, guantes, bolso, pañuelo y calzado. Cada uno de estos incrementa el valor simbólico en los personajes, desde los gorros como prendas de reconocimiento, cuyo material y decorados metálicos crean una gran variedad de modelos utilizados en la época por las distintas clases sociales, hasta los tejidos y costos para los guantes y pañuelos que orientan al lector acerca de la producción de paños de la época, y aunque fueron pocos los ejemplos hallados de estas dos prendas, se permitió profundizar en el simbolismo del guante como prenda de protección y de desafío. Los bolsos, como accesorios para guardar objetos, requirieron de un dedicado análisis al aparecer una gran variedad de ellos en la época y que se pudieron comparar con los descritos en estos libros.

Sin embargo, lo más novedoso fue la caracterización de los zapatos a través del personaje de Merlín, especialmente por su diseño, pues en ese aspecto, este personaje aporta más elementos a los dados en los libros de caballerías castellanos, porque al tomar la apariencia de distintas personas, contribuye al conocimiento del tipo de calzado que cada una usaba, lo cual permitió identificar el material, el diseño y algunos de sus adornos. Todas estas prendas concluyen la confección del traje, lo completan en todo sentido al darle forma y simbolismo y desarrollar aventuras que giran en torno a un atavío. 


\subsection{De metales y telas: la moda masculina}

Hablar de indumentaria en los libros de caballerías es adentrarse a un espacio donde el color, la textura y el diseño conforman el cincuenta por ciento de la estructura general de los atuendos, cuyas telas, bordados y adornos permiten la composición de una gran variedad de modelos que saltan de la imaginación de los escritores a la voz del narrador, y cuyo objetivo es hacer minuciosas descripciones de los elementos que cubren a los personajes; el otro cincuenta por ciento está estructurado por el simbolismo que la ropa adquiere en cada suceso, ya sea bélica, sentimental o de lamento, la vestimenta recibe sentido propio al fungir como protagonista en numerosos pasajes en los que la acción depende de ella más que de los personajes.

Esta presencia textil inicia con las conocidas frases "venía vestida muy ricamente y con mucha guarnición" que, en voz de los personajes, comienzan a atraer la atención del lector, principalmente con las damas, cuyas vestiduras abarcan cerca del sesenta por ciento del corpus caballeresco dejando para los caballeros el restante. Esta mínima diferencia se debe a que lo femenino siempre requiere más detalle, más elaboración en la confección y en la forma de lucir las prendas, por lo que hay una necesidad de transmitirlo de la misma manera; sin embargo, con lo varonil hay menos accesorios que describir en las vestiduras de gala, pero más simbolismo que descifrar en la vestimenta bélica, las armas.

De la misma forma que ocurre con las damas, el primer acercamiento a la indumentaria varonil inicia con una breve descripción que provoca el mismo efecto de asombro:

Quando la Reyna lo vido tan hermoso, con aquellos muy ricos paños, fue tan espantada, que por un gran rato, sin le poder hablar, le estuvo mirando, 
considerando, que nunca desde que el mundo se conmenço otra tan bella ni tan apuesta criatura en el se avia formado (Sergas de Esplandián, XCVII). ${ }^{247}$

La generalidad de los paños es una constante en los primeros títulos caballerescos, en donde los detalles son inadvertidos, principalmente en acciones realizadas dentro de la corte por un solo caballero, tales como las llegadas a la mitad de un banquete: "Estando de la manera que oís, entró por la puerta de la sala un doncel vestido de paños de oro muy ricos, por ellos muchas piedras e perlas de gran valor" (Lisuarte de Grecia, LXVIII); las visitas a la dama: “y al cabo d'estos días que ya don Lidiarte se començava a levantar, la primera visitación que fizo fue ir a ver a su señora la infanta Diadema. [Iba] vestido de muy ricos y preciosos paños" (Florambel de Lucea I, VIII); o las idas a misa: "hallaron al rey vestido, sus paños cubiertos de muy rica pedrería, que maravilla era de ver" (Policisne de Boecia, XVI), actividades cotidianas en las que no se explicita el tipo de prenda que se lleva, sino solo la calidad del material denotada con adjetivos como "ricos, preciosos, maravillosos", etc.

Este primer acercamiento al "paño de oro" es la base para la conformación de todo un guardarropa que, al igual que el de las mujeres, iniciará con las prendas interiores como la camisa hasta finalizar con los sobretodos, como la capa y el manto, pero, a diferencia de las damas, quienes se distinguen por llevar preciadas y maravillosas prendas en todo evento, el traje masculino se observa desde dos categorías, festiva y guerrera, y dos materiales, el primero de tela para llevar en distintos momentos de la historia y lucir en bailes, banquetes y actos no bélicos, y el segundo de metal, para portar en justas, torneos y

${ }^{247}$ Garci Rodríguez de Montalvo, Sergas de Esplandián, ed. de Carlos Sainz de la Maza, Madrid, Castalia, 2003. Todas las citas provienen de esta edición, en adelante citaré en el texto indicando entre paréntesis el número de capítulo. 
combates con el propósito de resguardar el cuerpo del caballero de los ataques del oponente.

Dicha clasificación dejar ver dos momentos importantes para la relevancia del atuendo masculino, el primero es desde su juventud hasta la vejez, en donde figuran prendas confeccionadas que en menor medida son descritas, el segundo es a partir de que toma las armas, momento en el que sobresaldrá el acero en la mayoría de los enfrentamientos bélicos por la minuciosidad de los detalles que llevan en metal, tal como sucede con las prendas femeninas descritas en los anteriores apartados en los que se ha resaltado su importancia actancial en diversos momentos, por lo que ahora es necesario destacar los usos varoniles e identificar cómo, en ciertos pasajes, pareciera haber una especie de competencia textil entre hombres y mujeres.

\subsubsection{Vestiduras masculinas}

Muchos de los testimonios que muestran el tipo de vestimenta que los hombres usaban en el siglo XVI se localizan en pinturas, catedrales y esculturas en las que se distingue una rica variedad de materiales, como la seda y el oro, con los que se confeccionaban. Materiales que sobresalían de entre las prendas de encima, como los mantos, y que difícilmente permitían ver los usos interiores, que se conocen más por los libros de cuentas, en donde se describe a detalle la cantidad de piezas, estilos y costos de toda la ropa que conformaban un traje de gala o de diario; estos elementos eran: "camisa y bragas como piezas interiores; calzas y jubón como semiinteriores; túnica de cubrirlas, aunque, a veces, prescindía de ella 
para mayor comodidad"248, además de una variedad de calzados y accesorios como bolsos y cintas para sujetar, de influencia española, francesa, morisca e italiana, principalmente.

En primera instancia pareciera una cantidad inferior a los materiales femeninos, por lo que es necesario rescatar aquellos que se mencionan en el corpus trabajado y destacar las innovaciones propuestas por los autores, así como la funcionalidad que presentan y que sirven de enlace con la estructura narrativa.

\subsubsection{Prendas interiores}

En comparación a la forma como se describe la camisa femenina, para los hombres se hallan menos ejemplos de este uso, a pesar de que desde el siglo $\mathrm{X}^{249}$ ya hay numerosos ejemplos del tipo y del material con el que se confeccionaban; para estas obras pareciera que no fue tan necesario profundizar en su confección, porque los ejemplos hallados sólo indican tres aspectos.

El primero es su ubicación para vestir: "el caballero tenía a la garganta una muy delgada cadenica de oro y della colgava una ymagen de Venus que traýa metida en los pechos, entre la camisa e la carne" (Claribalte, XVII), en donde su posición es clara, pegada directamente al cuerpo.

El segundo es el modo en que duermen los hombres: "E vinieron aí servientes e fincaron ante él los hinojos e los descalçaron e ayudáronlo a despojar e él hechóse luego en el lecho en camisa ${ }^{250}$ e en paños" (Lanzarote del Lago, CXLIV). Pocos son los pasajes que

\footnotetext{
${ }^{248}$ María Ángeles González Mena, Colección pedagógico textil de la Universidad Complutense de Madrid: estudio, 1994, Madrid, CSUCM, p.27.

${ }^{249}$ Carmen Bernis, Indumentaria medieval española, Madrid, CSIC, 1956, p.12.

${ }^{250}$ Este acto de desvestir al príncipe para llevarlo a dormir sucede con la realeza española del XVI, con el príncipe Felipe II: "Al final de la tarde regresaba a palacio para cenar y se acostaba temprano. De nuevo volvía a poder de mujeres, quienes le desvestían y le dejaban en camisa". José Luis Gonzalo Sánchez-Molero, El aprendizaje cortesano de Felipe II (1527-1546): La formación de un príncipe del Renacimiento, Madrid, Sociedad Estatal para la Conmemoración de los Centenarios de Felipe II y Carlos V, 1999, p.88.
} 
describen la forma de dormir de los caballeros y el hábito que usan por la noche. Aunque no se detallan, se conoce que los usos de dormir eran las camisas o camisones castillos ${ }^{251}$ de tela delgada que podían ser largos o cortos, según se prefiriera.

El tercero es un simbolismo en señal de deshonra; a mi parecer, el más relevante por la forma en que el caballero es despojado de sus prendas y dejado sólo en camisa: “Ansí anduvieron hasta que llegaron a un río grande ante el cual hallaron un castillo, y cabo él mucha compaña de cavalleros armados, los cuales tenían un cavallero desnudo en camisa con una soga a la garganta cabe un gran fuego" (Amadís de Grecia, XXI). La escena se establece como una especie de sacrificio en la que Brimartes será castigado porque una malvada dueña desea vengarse de todos los caballeros porque no fue correspondida en amores. Es importante notar la forma en cómo hallan a Brimartes, atado de manos y en camisa.

Situación similar le ocurre a Tristán, cuando es llevado preso a causa de su relación con la reina Iseo: "E Tristán iva cavallero en una mula, e en camisa e en pañetes"252 (Tristán de Leonís, XXXIV); el motivo por el que va preso en ropa interior es porque dormía y al momento de ser apresado no portaba más prendas. En ambos ejemplos hay una afrenta para los jóvenes, por la forma en cómo son llevados, misma que crece al ser vistos, en estas condiciones, por varios caballeros. Al estar confeccionada con tela delgada, el riesgo de que se transparentara el cuerpo es mayor, por lo que hay una doble exhibición de los jóvenes, la primera por dejar al descubierto sus miembros, la segunda al realizar el recorrido desde el lugar en el que fueron apresados hasta donde intentarán matarlos, por lo

${ }^{251}$ González Mena, op.cit., p.17.

252 Pañetes: Cierto género de bragas que usan los pescadores y curtidores, y los que andan desnudos. A estos llaman los religiosos paños menores (Tesoro de la lengua). Esta voz no aparece en otros libros de caballerías hispánicos. 
que el camino se convierte en una especie de "desfile de afrenta", contrario a los "desfiles de gala" femeninos.

En definitiva, este tipo de prendas adquiere otra connotación puesta en los hombres, cuyo enfoque está en mencionar su ubicación, pegada al cuerpo, y el simbolismo ofensivo que adquiere como castigo, sin hacer referencia, en ningún momento, a la parte erótica que caracteriza a las prendas femeninas ${ }^{253}$.

\subsubsection{Jubones y calzas (fig. 117)}

Después de la camisa y la braga, empiezan a destacar las segundas prendas, el jubón y las calzas, porque presentan un diseño más elaborado que ya aparecen con aplicaciones de oro y bordados con pedrería. De estos habrá una gran variedad de ejemplos en los que se destacará su forma: “assí Baldo se iva airando y, por derribarlo, le dio un pequeño golpe en los pechos, mas, dando la punta de la espada en cosa blanda, que era un jubón, se entró por los pechos atravesándole el coraçón" (Baldo II, XXXII). Su textura blanda se debe a su relleno de borra o algodón, elementos "para aparentar una robustez que no era real" 254 , con el propósito de que el caballero adquiriera forma en la parte del pectoral y así lucir una mejor figura que atrajera a las damas.

Fig. 117. La conquista de Orán (1513) Toledo. Calzas bragas bandadas.

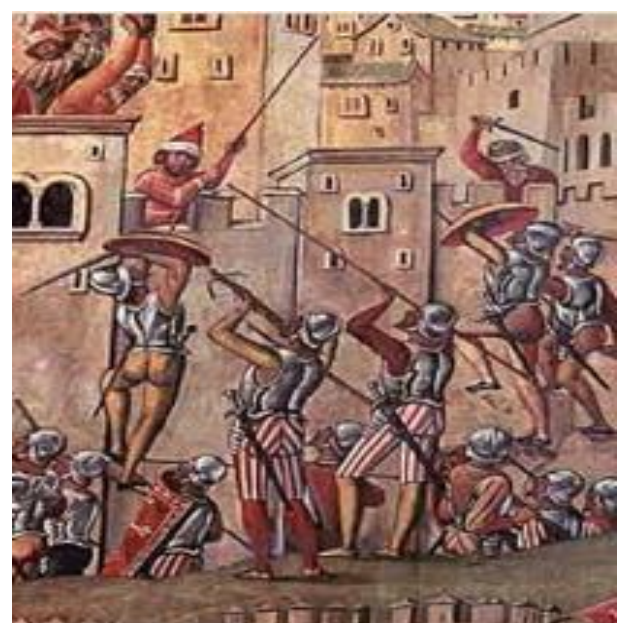

${ }^{253}$ En el personaje femenino hay una constante mención a la transparencia de su camisa que permite ver sus miembros, principalmente, cuando hay un encuentro con el caballero; sin embargo, a este elemento no se alude en ninguno de los ejemplos hallados para los hombres.

${ }^{254}$ Carmen Bernis, Trajes y modas en la España de los Reyes Católicos II. Los hombres..., p. 12. 
El segundo rasgo es que puede ser con y sin mangas: "Traía vestida una ropa a manera de jubón sin mangas hasta la cinta, tan justa que no le podían asir d'ella" (Felixmarte de Hircania, XXXIV); en este ejemplo se especifica la ausencia de mangas, por lo que la manga que se viera era la de la camisa; en contraste, los jubones con manga debían estar mejor confeccionados: "Llevava también un jubón y calças de tela de plata azul, hecha a cuartas, todo bordado de oro de martillo hilado y por ello perlas y piedras preciosas esparzidas" (Baldo II, XVIII).

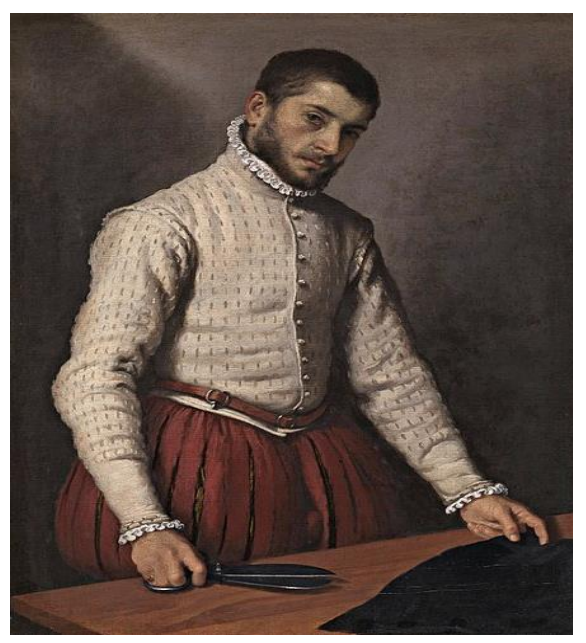

Fig. 118. El sastre (1565-1570)

Giovanni Battista Moroni, Galería Nacional de Londres.
Carmen Bernis expresa que las únicas partes visibles del jubón "eran las mangas y el <<collar $>>$ o cuello. Por ello, era costumbre emplear en las mangas y en el collar una tela más rica y de diferente color que la del cuerpo" 255 , como se observa en las pinturas El sastre (fig. 118) que muestran detalles importantes como el uso de botones y pequeñas cuchillas en las mangas, elementos que enriquecían más la prenda.

En el ejemplo del Baldo lo que incrementa el costo del jubón son los detalles bordados, el oro de martillo y las perlas y piedras preciosa que están en toda la tela, el atuendo se completa con las calzas, medias que podían combinar con el jubón o ser de otro color. En uno de los obsequios que el príncipe Felipe da, destaca el material y el color: "un jubón de raso blanco, calzas y zapatos de terciopelo del mismo color" ${ }^{256}$, la calidad de las prendas dependía del gremio jubonero y calcetero, quienes se especializaron en la combinación de materiales y en el corte de las calzas para que lograran sujetarse del jubón,

\footnotetext{
${ }^{255}$ Idem.

${ }^{256}$ Sánchez-Molero, op.cit., p.66.
} 
para ello, colocaban agujetas en la parte superior de las piernas con el fin de anudarlos. ${ }^{257}$

El estilo cambiará hasta que desaparezcan los sujetadores.

\subsubsection{Mantos}

De entre las prendas más detalladas para los caballeros sobresalen las de "encima", capas, aljubas y mantos (figs.119-121), que llevan como complemento para protegerse del clima y resguardar su identidad, porque en repetidas ocasiones cubren las insignias de la armadura y su rostro para no ser reconocidos por los demás ${ }^{258}$. Al ser una de las últimas prendas que visten, deben estar mejor diseñadas que los jubones, sayos y calzas, porque son reflejo de la condición social de quien las porta, son muestra de la riqueza monetaria que se tiene y de la importancia narrativa que el autor le otorga a cada personaje, es decir, cuanto más detallado sea su diseño, mayor importancia tendrá quien lo luzca.

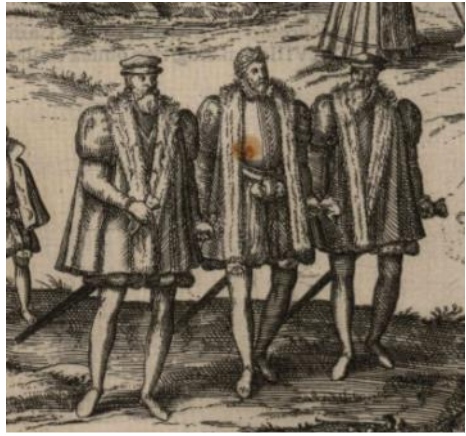

Fig. 119. Civitates orbis terrarum. Liber primus (1588) Georg Braun.

Caballeros con ropa francesa, nótese el forro de piel en todas.

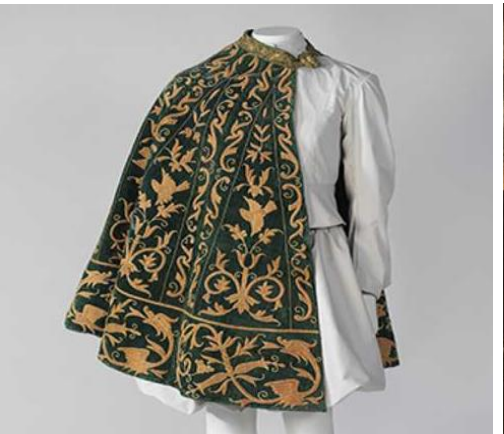

Fig. 120. Capa (1570-1580)

Museo del Diseño de Barcelona. Tejido de seda bordado en oro. Nótese la semejanza con una prenda descrita en el Lisuarte de Grecia (1514) en el personaje de Perión, quien borda un manto verde con esferas de oro.

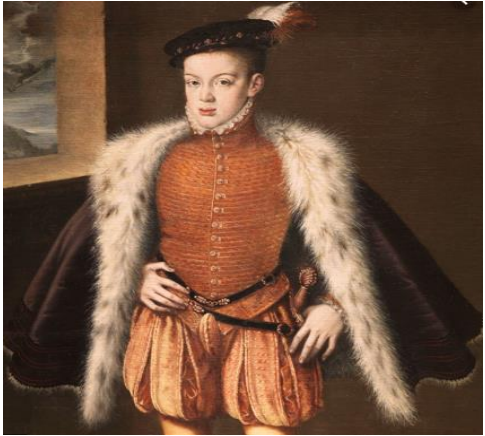

Fig.121. Retrato del príncipe don Carlos de Austria (1555-1559) Alonso Sánchez Coello, Museo del Prado Jubón, calzas y capa con forro de piel.

${ }^{257}$ Un ejemplo de las calzas sujetas al jubón se puede ver en la pintura Testamento y muerte de Moisés (1481). ${ }^{258}$ El simbolismo de los mantos como prenda de protección se analiza en el capítulo tres, en este apartado sólo se destacará su valor textil y su diseño, que sobresale por la cantidad de piedras preciosas que llevan bordadas. 


\subsubsection{Aljubas}

De influencia musulmana, la aljuba presenta una riqueza en su confección y diseño por su amplitud, perfecta para cubrir todo el cuerpo y aunque no es una prenda exclusiva de los hombres, sí presenta ciertas diferencias en torno a su uso y forma de llevar al modo de las mujeres, esto se debe a que muestra cierta relevancia en cuanto a la acción durante los combates, porque a veces puede ser pieza de tropiezo: "y al Duque se abalanço y acerto a travalle de la falda de la aljuba que vestida llevaba, desatinadamente torno a hazer presa en las cervices del caballo, de suerte que lo hizo venir al suelo con el Duque" (Florisel de Niquea IV, LIII); incluso, la amplitud de la tela es aprovechada por las bestias, porque les facilita alcanzar a los jóvenes: "el león lo alcanzó por una falda de una aljuba de monte que traía y, llevando en sus uñas la media, tiró tanto por el Donzel, que le hizo poner la una mano en el suelo" (Amadís de Grecia, III), es decir, el caballero resbala y posteriormente se levanta para herir al león.

Otra situación recurrente es que los animales destruyan parte de la ropa: “A esta ora, el bravo osso dio tal salto en él que, rompiéndole la aljuba de monte que traýa vestida, le hizo una gran herida en el braço" (Belianís de Grecia, II). La aljuba, al tener una estructura prolongada, larga y mangas anchas ${ }^{259}$, presenta mayor facilidad para ser atorada y alcanzar a la persona que es perseguida, en el caso de los hombres; en cuanto a las damas, este tipo de situaciones no aparece en su uso.

A pesar de que no hay una descripción textil de las aljubas varoniles, sí aparece un simbolismo que las convierte en un atavío relevante que genera acciones bélicas y dificulta el desarrollo del caballero.

${ }^{259}$ Carmen Bernis, “Traje, aderezo, afeites”, p. 65. 


\subsubsection{Capas}

La última pieza que completa el traje varonil es la capa o el manto ${ }^{260}$, cuyo diseño los coloca como intermediarios entre la vestimenta de corte y de combate por ser usados en ambos espacios como signo de identidad y medio para ocultar las prendas de "debajo", esto último en lides para evitar ser reconocido antes del enfrentamiento.

En primer lugar, destacan los materiales con los que están fabricados y los diseños que sobresalieron a partir del siglo $\mathrm{X}$, los más comunes son de terciopelo: "capa y gorra de terciopelo forrada en un cendal de plata" (Flor de caballerías, XV) y de raso: "una capa corta de raso pardo aprensado y bordado de oro y verde" (Flor de caballerías, LVII). La relevancia de las uniones de distintos tipos de materiales comienza a presentar mayor interés en cuanto al estudio de tejidos, porque, gracias a las creaciones de los escritores, se puede conocer el tipo de tela que había en su época y comparar sus ficciones con las que existían en realidad en las casas reales por medio de los libros de bienes y cuentas.

El segundo rasgo que distingue a la capa es la amplitud y la funcionalidad que ésta le brinda:

Como llamó a la puerta de la sala, el cavallero de la Espera que alterado estava salió muy presto de la cama; e tomando el escudo e la espada que a la cabecera tenía, fue e abrió la puerta, e dixo al cavallero:

- ¿Qué cosa es?

El caballero le dixo:

-Señor, mandad ir abrir la Puerta del Pozo, que sabed que Lisuarte vuestro sobrino está de fuera esperando que le abran.

- ¡Santa María, valame! -dixo él-. ¿Esso es verdad que dezís?

\footnotetext{
${ }^{260}$ Carmes Bernis incluye en el grupo de los "sobretodos" a la capa y al manto porque no hay descripciones claras que puedan separarlas, de la misma forma aparecen ambos términos en los libros de caballerías, en donde sólo se indica la descripción de la prenda, en cuanto al diseño del bordado, color y tela, pero no se dan más detalles del corte, cintas, botones o la amplitud, por lo que para este apartado se incluirán ambos en el mismo análisis, sólo indicando el nombre cuando se señale en el corpus.
} 
-Sí, sin ninguna duda, -dixo el cavallero.

El Cavallero de la Espera, tomando las llaves de su cabeçera e una capa solamente, assí en camisa, dixo:

-Andad, allá vamos a essa puerta que dezís (Lisuarte de Grecia, XXV).

El contexto brinda detalles del modo en cómo es apresurado a salir el caballero de su habitación, probablemente a media noche, sin tener tiempo de vestirse, por lo que sólo alcanza a cubrirse con su capa. Situación que indica que el uso de la capa va más allá de complementar un atuendo, ya que su funcionalidad depende de su longitud, es decir, a mayor tela, mayor protección.

El tercer rasgo importante es el diseño. Ya sean imágenes, bordados, pedrería o metales, toda prenda adquiere mayor relevancia si tiene elementos decorativos que ejerzan movimiento en la historia. Por ejemplo, cuando "Florestán se vestió un manto de terciopelo azul bordado de mayas muy rico, que muy apuesto cavallero era. Parmíneo e Galvanes se pusieron sendos mantos de grana bordados de bastones de oro. E así fueron do el emperador estaba oyendo missa, porque este era día de fiesta" (Lisuarte de Grecia, VI); lo primero que destaca son las imágenes "mallas y bastones de oro". En primera instancia estas imágenes no presentan alguna relevancia en cuanto a simbolismo, debido a que son sólo prendas de selección para lucir en palacio y ser vistos por las damas de las que se han prendado, aunque todavía no son correspondidos, por ello es que aún no pueden portar prendas dedicadas para su dama. Lo interesante es la mezcla de colores, azul-rojo-oro, con los que los autores empiezan a proponer innovaciones en el diseño, pues han pasado de lo simple a lo complicado por los detalles.

En palabras de Solanés Sotera "la capa iba a dejar de ser una pieza de abrigo, que a menudo cubría todo el cuerpo, para pasar a ser una prenda de vestir ornamental de la 
nobleza"261, decorativos que no sólo se restringían en el uso de pedrería y metales, sino también en la forma del diseño textil ${ }^{262}$ y en la mezcla de diferentes tipos de tela ${ }^{263}$.

\subsubsection{Vestimenta de gala}

Así como en el apartado "Desfile de prendas" se analizó la importancia de los tejidos como diferenciadores de clases sociales, en donde se estableció que la identificación de la dama mejor ataviada corresponde con la que lleva la mejor calidad de la tela y del diseño de los bordados, para el caso de los hombres es necesario establecer una categoría de atuendos de acuerdo a su presencia en la corte, dentro y fuera de ella, porque debido a su crecimiento y a su inclusión en el ámbito social, hay una necesidad de destacar entre los demás, por lo que es necesario identificar si el protagonismo que lleva en la historia coincide con su relevancia en el vestir o es opacado por los demás caballeros.

${ }^{261}$ María Concepción Solanés Soteras, La moda en la sociedad aragonesa del siglo XVI, Zaragoza, CSIC, 2009, p.104.

${ }^{262}$ Este tipo de mantos, con algún tipo de decoración, va a ser el antecedente de las prendas de dedicación de tema sentimental y bélico en justas y batallas, y uno más, imperial, para transmitir a través de las armas el reino al que pertenecen.

${ }^{263}$ Uno de los ejemplos más llamativos es la capa que usa el condestable de Castilla, Íñigo Fernández de Velasco y Mendoza en 1517:

También estaba allí el infante de Granada, que acompañaba al Rey hasta las lides con una capa a la española, toda de terciopelo carmesí con fondo de tela de oro frisado. Este infante iba montado en un brioso cordel ricamente enjaezado. También estaba allí el condestable de Castilla, vestido con un manto de tela de oro cernido, el más rico (a mi parecer) que se podía encontrar, con fondos de cebellinas de gran valor. Este vestido estaba cubierto con medios losanges recortados una mitad en terciopelo negro y la otra en oro batido en hojas.

(Lorenzo Vital, Relación del primer viaje de Carlos V a España (1517-1518), Madrid, Ministerio de educación, 1958, p.286-287).

De esta descripción tres elementos sobresalen, el oro frisado, el oro cernido y el oro batido, todos agregan texturas diferentes a los mantos, el primero en pequeños anillos rizan los hilos, el segundo es una especie de diamantina y el último en delgadas láminas, crean una singular manera de confeccionar el tejido con el metal; pero, a juicio de Vital, el manto del condestable de Castillo es el más valioso por la mezcla de telas en pequeños rombos, en los que el contraste entre el negro y el oro lo abrillanta más.

En cuanto al diseño "cubierto con medios losanges", el testimonio más similar que se conoce es el de "El Caballero de la Balmesiana" del s. XIII en Barcelona, que lleva tanto en las armas como en la gualdrapa del caballo medios losanges de dos colores. 
Primero es importante recordar que en el Libro de los Estados de don Juan Manuel se dice que el hombre de gran rango "debe guisar que ande de paños mejores et más presciados que las otras gentes de su corte" (Est. 62), porque desde su corta edad debe aprender que "la buena educación se refleja en múltiples signos externos, desde saber vestir adecuadamente para cada ocasión" ${ }^{264}$ hasta ser diestro en las armas y las letras, en conjunto, debe sobresalir de entre los demás. Esta distinción empezará por saber elegir el traje adecuado para cada ocasión. En un primer momento de manera individual, posteriormente en grupo:

y en una silla muy rica vio sentado en medio de la cuadra al infante Rosarán, vestido una ropa de oro sobre sus armas y abierta por delante, desarmadas las manos y la cabeça, y el escudo y el yelmo a los lados de la silla. Tenía el codo puesto sobre un lado de la silla y la cabeça reclinada sobre la mano con un capirote de vuelta delantera con mucha pedrería (Florisel de Niquea III, XL).

De los elementos que se describen, el capirote es el de mayor relevancia por los adornos que lleva, una gran cantidad de piedras como las que aparecen en las gorras de los príncipes de las pinturas de Sánchez Coello. Esto es uno de los elementos por destacar ya que "la moda masculina exigía que los pequeños detalles de la vestimenta, a veces realizados en pasamanería, estuvieran, en caso de ser metálicos, exquisitamente labrados en oro esmaltado y enriquecidos a veces con piedras preciosas, como sucede con las botonaduras o con las hebillas de los finísimos cinturones"265; de esta forma se tiene una especial colección de ejemplos caballerescos que anteceden a esta exigencia del siglo XVII, como se

\footnotetext{
${ }^{264}$ María del Carmen García Herrero, "La educación de los nobles en la obra de don Juan Manuel”, La familia en la Edad Media: XI Semana de Estudios Medievales, Nájera, del 31 de julio al 4 de agosto de 2000, coord. por José Ignacio de la Iglesia Duarte, 2001, p.88.

${ }^{265}$ Letizia Arbeteta, La joyería española de Felipe II a Alfonso XIII ..., p.22.
} 
observa en el Florisel de Niquea, en donde los acabados en metal y piedras son más abundantes.

En un intento por igualar la confección de trajes entre dama y caballero y distinguir quién viste mejor, es necesario comparar un pasaje para extraer los elementos que cada personaje viste.

\begin{tabular}{|c|c|}
\hline Vestimenta femenina & Vestimenta masculina \\
\hline $\begin{array}{l}\text { La reina salió vestida una ropa de raso verde } \\
\text { y encima d'ella se hazía una manera como de } \\
\text { red de las aves de su devisa, enlazadas con las } \\
\text { uñas e picos, todas de fino oro con las llamas } \\
\text { de roscicler. Llevava una cinta y collar todas de } \\
\text { piedras preciadas esmeraldas en muy hermosos } \\
\text { engastes: los cabellos llevava hechos lazadas } \\
\text { en lo alto de la cabeça, y sacadas las lazadas } \\
\text { por una manera de red hecha de la misma } \\
\text { devisa de los fénix hechos muy sotilmente de } \\
\text { oro, y los ñudos de la red eran de finos rubíes } \\
\text { para suplir las llamas de fuego de los fénix; de } \\
\text { cada lazada de las que sacan, pendía una } \\
\text { gruessa perla, con çarcillos tan ricos que no } \\
\text { tenían precio; de las mangas de la ropa por la } \\
\text { parte çaguera llevava tres golpes: uno en lo alto } \\
\text { y otro en derecho del codo y otro cerca de la } \\
\text { muñeca, por donde salí<n tres papos muy } \\
\text { grandes de camisa. (Florisel de Niquea III, } \\
\text { XXXIII) }\end{array}$ & $\begin{array}{l}\text { El rey venía preciosamente vestido con una } \\
\text { ropa de brocado de tres altos, aforrada en tela } \\
\text { de oro encarnada y por toda ella una cortadura } \\
\text { de la misma tela y una capa de brocado a la } \\
\text { española con una bordadura de tela de plata y } \\
\text { una guarnición de la misma tela de plata con } \\
\text { pieças de oro de martillo y perlas y por entre } \\
\text { ellas una bordadura de oro de cañutillo. Todo } \\
\text { junto venía hazer una labor. Llevava también } \\
\text { un jubón y calças de tela de plata azul, hecha a } \\
\text { cuartas, todo bordado de oro de martillo hilado } \\
\text { perlas y piedras preciosas esparzidas; llevaba } \\
\text { un tocado como sombrero, hecho de pelo de } \\
\text { seda azul, y encima un plumaje de la misma } \\
\text { color. (Baldo II, XVIII) }\end{array}$ \\
\hline
\end{tabular}

La riqueza de los trajes es algo que ambos comparten, pero cada uno tiene elementos que los distingue. En primer lugar, por el tipo de tela es más costosa la ropa del 
rey, por tratarse de un brocado de tres altos, el más caro por su forma de elaboración: “se llamaba primero al fondo de la tela, segundo a la labor y tercero al realce de los hilos de plata, oro o seda escarchada o briscada";266 aunque el raso sí era una tela de calidad, en este ejemplo no presenta una laboriosidad como la del rey, sólo lleva encima una red de oro que forman algunas aves.

Por otra parte, el valor de la ropa del rey aumenta por las otras dos piezas que lleva, el jubón y las calzas, que anteriormente ya se había explicado su valor por la diversidad de piedras, además del sombrero.

La ropa de la dama finaliza con la descripción de las mangas, cada una con tres golpes, piezas de oro que sujetaban las aberturas de las cuchillas para dejar que la tela de la camisa saliera por los pliegues.

Pero en cuanto a la utilización de las piedras preciosas, el vestido de la dama es superior al del rey por la composición de las imágenes. La reina lleva rubí, perla, esmeralda y rosicler, con las que forma los fénix y adorna su cabello, mientras que el rey tiene perlas y piedras preciosas, sin dar detalle de ellas. Con estos dos ejemplos se enfrentan: la calidad de los materiales y el diseño, dos de los elementos de la vestimenta que propongo para esta investigación, el tercero corresponde al simbolismo del uso que genera acciones, el cual está en la ropa de la reina en su divisa del fénix reproducido tanto en el tocado como en la falda, porque representa a su reino y a su caballero. Esta misma distinción ocurre entre caballeros del mismo y de diferente reino, una especie de competencia por saber quién usa las mejores galas.

266 Véase la nota 19, parte II, cap. X de la ed. de Diego Clemencín en Miguel de Cervantes, El ingenioso hidalgo don Quijote de la Mancha, Madrid: E. Aguado,1835, vol. IV, p.173. En línea:

https://books.google.com.mx/books?id=srFdAAAAcAAJ\&printsec=frontcover\&hl=es\&source=gbs_ge_sum mary_r\&cad=0\#v=onepage\&q\&f=false $(6 / 5 / 2017)$. 


\subsubsection{Desfiles de caballeros}

Es común en estas historias leer que un grupo de caballeros va a otro reino motivado por algo, desde entregar una carta, pedir un don, hallar a un compañero, visitar al rey, asistir a una fiesta o porque fue desafiado. Durante su trayecto es visto por muchas personas y a su llegada es descrita la forma en cómo van vestidos:

Eran -como an de ser todos- los cavalleros principales de anbas partes comedidos y por ver algo, los príncipes Belinflor, Miraphebo y Orisbelos con unos vestidos de terciopelo carmesí, labrados de flores, de tela de plata y unos mantos grandes de brocado de tres altos y con sus espadas en la cinta, cavalleros en sus alindados caballos salieron de la ciudad y començaron a pasear llevando su angélica disposición tras sí los ojos de quien ellos los ponían. Con no menos gracia y apostura por otra parte se paseaban aquellos señalados y valerosísimos cavalleros Rugerindo, Deifevo, Tirisidón, y Norsidiano con unas aljuvas de damasco verde, bordadas todas las labores del de trencilla de oro y plata, y unos mantos de terciopelo carmesí con unas anchas labores de raso amarillo y negro y mucha plata escarchada. (Flor de caballerías, XXXII)

Dos grupos de enemigos se hallan en el camino, llama la atención que antes de que pronuncien palabra se dedique una prolongada descripción al atuendo que cada uno lleva como si a través de las prendas también estuvieran compitiendo y así definir quién es mejor en combate y en la vestimenta. El primer grupo en ser descrito es el de los protagonistas del libro.

Los tres llevan vestidos y mantos de terciopelo y brocado de tres altos. Nuevamente aparece una de las telas más caras, pero con un detalle extra los vestidos llevan labradas flores de tela de plata. Cuando la tela era de oro o plata labrada como fondo y encima el brocado, el fabricante no la realizaba porque era un proceso complejo hacer las recortaduras de metal para que se vieran las imágenes, en este caso, las flores, así que debía ser enviado 
con el labrador de seda para posteriormente finalizar la tela. ${ }^{267}$ Esto implicaba mayor tiempo de producción y más gasto por el delicado trabajo que se debía obtener ${ }^{268}$.

El otro grupo lleva aljubas de damasco y mantos de terciopelo con raso. El damasco, tela de calidad, en menor nivel que el brocado, destaca por las trencillas de oro y plata, que fueron prohibidas por las Pragmáticas en 1570 por ser una guarnición fabricada con puro oro y resultaba excesivo su costo, mientras que la plata escarchada "era un bordado de oro y plata que va rizado o moteado"269. Los dos grupos presentan elementos relevantes que incrementan el costo de sus prendas, por una parte, las trenzas de oro y las labores escarchadas son técnicas que sobresalen por la minuciosidad con la que se debe fabricar. Mientras que, en el primer grupo, el elemento más costoso es el brocado que requiere tres niveles de composición tela, labor y realce del metal, además de que labrar imágenes requería un proceso especial para el metal.

Establecer el valor de una prenda según la calidad, el diseño y el material es complejo cuando se unen diferentes componentes que requieren un cuidado especial para obtener diseños llamativos; en el caso de los libros de caballerías, la imaginación del escritor supera la realidad, pero revela que el autor tenía conocimiento de los materiales que se utilizaban para la creación de vestimenta de diferentes clases y así dar sentido a sus historias colocando a cada personaje el atuendo que corresponde según su relevancia en el texto.

A pesar de la variada indumentaria masculina que se conoce desde los testimonios hallados en esculturas y pinturas de catedrales, museos, tumbas y castillos, su presencia en los libros de caballerías es inferior a la femenina, debido a que la dama mantiene una

\footnotetext{
267 Ibid, 621.

${ }^{268}$ Una muestra de esta tela se halla en el pellote de Leonor de Castilla (1244), con motivos florales.

${ }^{269}$ González Mena, op.cit., p.12.
} 
constante en el arreglo durante toda la historia porque su presencia en banquetes, torneos y justas requiere que su imagen sobresalga por la gala de su ropa; de la misma manera, el joven se esmera en sus usos en el espacio de la acción porque son generadores de acción al dificultar la aventura a través de la tela y al ser motivo de deshonra por el diseño de las mismas.

Sin embargo, en algo que ambos coinciden es en los pasajes que son narrados como si fueran desfiles de prendas. Por un lado, las damas se destacan por los accesorios que decoran su cabello, por el otro, los caballeros toman relevancia por ciertos adornos de sus prendas, especialmente por los sombreros y las capas. Es decir, en equivalencia al traje de corte de las damas, los caballeros mantienen el mismo rigor de confección, imagen y lucidez en el manto, el intermedio entre el traje de gala y el de combate.

\subsubsection{Prendas de protección masculinas}

En algunos pasajes es recurrente que el caballero tenga la necesidad de cubrir su rostro, ocultar su identidad para no ser revelada en ciertas hazañas, porque pueden perjudicar su honra y fama, principalmente cuando se dirige a ver a la dama y en las justas; en el primero no se debe revelar su relación sentimental y en el segundo debe ganar fama tras cada victoria bélica antes de ser descubierto su rostro.

Para lograr la discreción es necesario un traje que cubra su cara y su cabeza; sin embargo, son pocos los ejemplos con este tipo de indumentaria, ya que en la mayoría de ellos sobresale la calidad de la prenda, como los que aparecen en bailes y llegadas a un reino: "Sobre sus hermosos cabellos traya un capirote de mucha pedrería" (Florisel de Niquea II, XVIII). La calidad, formas y tipos de la indumentaria masculina ya se analizaron en apartados anteriores, por lo que ahora es necesario establecer una relación entre la 
longitud de la prenda y la capacidad que le permite cubrir el cuerpo del caballero, además de rescatar los pasajes en los que otros factores, ajenos al tejido, son los que permiten ocultar al personaje. A la par de la tela, aparece un elemento importante, el yelmo, no como la pieza de metal que resguarda la cara de los golpes, sino como el hierro que protege la identidad del caballero hasta ser merecedor de develar quién es.

\subsubsection{Prendas para la cabeza}

Es recurrente la presencia de objetos maravillosos que facilitan las aventuras del caballero, instrumentos que le son entregados por su protector mágico ${ }^{270}$, quienes, encargados de preservar la vida de los príncipes, formulan brebajes, lanzan encantamientos, adecuan las armas para evitar que traspasen las flechas y las espadas, inventan vehículos voladores, otorgan joyas protectoras y un sinfín de curiosidades con tal de que el joven complete la hazaña sin ningún riesgo. Estos elementos, estudiados desde hace tiempo ${ }^{271}$, colocan a la figura guerrera en un medio maravilloso junto a criaturas desconocidas y espacios encantados, todo a la vista de los demás personajes y con la posibilidad de acceder a ese

\footnotetext{
${ }^{270}$ Jesús Duce García menciona que los protectores mágicos, ya sean una sabia, un hada o un mago "tienen la misión de proteger a los elegidos, son sus consejeros y ayudantes, les supervisan en las difíciles empresas [...] tienen facultades especiales para originar los encantamientos más insospechados y espectaculares". "Magia y maravillas en los libros de caballerías hispánicos", en Amadís de Gaula: quinientos años después. Estudios en homenaje a Juan Manuel Cacho Blecua, Alcalá de Henares, Centro de Estudios Cervantinos, 2008, pp. 192193. Por lo que el mago utiliza el encantamiento y un instrumento, espacial, arquitectónico, temporal, objeto, líquido, personaje, vehículo, etc., para resguardar al héroe.

${ }^{271}$ Los estudios sobre la magia en los libros de caballerías son amplios, sólo coloco algunas fuentes, el resto aparece en la bibliografía: Aguilar Perdomo, María del Rosario, «La arquitectura maravillosa en los libros de caballerías españoles: a propósito de castillos, torres y jardines», Lingüística y Literatura, 51 (2007), pp. 127148; Duce García, Jesús, «Fantasías caballerescas: aproximación al motivo de los castillos encantados», en Parrilla, Carmen y Pampín, Mercedes (eds.), Actas del IX Congreso Internacional de la Asociación Hispánica de Literatura Medieval (A Coruña, 18-22 septiembre 2001), A Coruña, Universidad de Coruña, Toxosoutos, 2005, vol. 2, pp. 213-232; Esteban Erlés, Patricia, «Aproximación al estudio de la magia en los primeros libros del ciclo amadisiano», en Cacho Blecua, Juan Manuel (Coord.); Bueno Serrano, Ana Carmen, Esteban Erlés, Patricia y Luna Mariscal, Karla Xiomara (eds.), De la literatura caballeresca al «Quijote», Zaragoza, Prensas Universitarias de Zaragoza, 2007, pp. 185-199; Marín Pina, M. ${ }^{a}$ Carmen, «Motivos y tópicos caballerescos», en Rico, Francisco (coord.), Don Quijote de la Mancha. Edición del Instituto Cervantes (1605-2005), Barcelona, Galaxia Gutenberg, Círculo de Lectores, Centro para la Edición de los Clásicos Españoles, 2004, vol. 2, pp. 896-938.
} 
espacio de maravilla. De estas protecciones sobresalen dos, una en la mitología griega y la segunda en literatura germánica; en esta se halla el conocido pasaje sobre la prenda mágica que permite la invisibilidad de quien la porta, el mejor ejemplo está con Sigfrido:

Envuelto en su capa mágica, fue entonces Sigfrido a la puerta de la fortaleza que daba a la playa, allí encontró una barca. A ella subió en secreto el hijo de Siglinda. Luego se alejó rápido de allí como si lo llevara el viento.

Nadie veía al piloto, pero la barca avanzaba rauda, impulsada por la fuerza de Sigfrido, que era muy grande. Uno se imaginaba que era llevada por un viento huracanado, pero no, era el hijo de la hermosa Siglinda.

(Cantar de los Nibelungos, VIII, 482-483) ${ }^{272}$

Sigfrido lleva puesta la capa mágica de Alberico, cuya virtud es hacer invisible a quien la usa. El personaje la ocupa para ir en busca de sus guerreros y trasladarse con facilidad. La utilización de prendas mágicas pertenece al folklore literario y mitológico, desde Perseo, quien obtiene la cimera de Hades que también lo vuelve invisible, hasta los anillos y capas que otorgan otras protecciones a los personajes de la ficción del siglo XVI. Este motivo se presenta de distinta manera en cada una de las obras, desde la forma en cómo se obtienen, hasta las facilidades que otorga. Dentro de esta línea literaria está un libro de caballerías, la primera parte del Clarián de Landanís, de 1518, el cual obtuvo una buena aceptación entre los lectores. Para la fecha de su publicación es temprano el uso de un elemento mágico que utiliza, que no figura en los demás libros del género, la prenda mágica que cubre de la lluvia:

Entonces desembolvió de un paño negro, de muchas labores un manto y un chapeo y sacó de una caxeta un anillo, todas tres joyas tan ricas cuales hombres jamás nunca vieran. La pedrería y riqueza del manto, la sotil arte con que era labrado y

${ }^{272}$ Cantar de los Nibelungos, ed. de Emilio Lorenzo Criado, Madrid, Cátedra, 2007. 
texido no pudiera ser hecho por mano de hombres. El resplandor de las piedras que en él avía era tan grande que con gran pena los ojos lo podían mirar. El chapeo era el más rico que fablar se podría y las piedras preciosas que tenían, salían d'él por tal arte que no se podría conocer si el chapeo y ellas fuesse todo uno. En el medio d'él tenía una piedra que resplandecía como el sol, la cual se cubría con una cobertura muy rica que al chapeo estava pegada y como la donzella la descubriesse, todos ellos no pudieron tanto hazer que los ojos abriessen a la ver, que tan grande era el resplandor d'ella que lo no podían hazer.

$[\ldots]$

-Señor, el manto ha tal virtud que el que vestido sobre sí lo traxere, no avrá frío ni calor, tal temple tiene; ni será enartado por traición, que cuando al que lo traxere, traición le quisiessen hazer, luego la pedrería todo el resplandor y creed que, cuando se ofreciere tal caso, assí lo hallaréis por verdad. El chapeo ${ }^{273}$ es tal que cualquiera que en la cabeça lo tuviere ninguna ponçoña que beba lo tuviere le podrá dañar y no tengáis temor que os le hurten, que si no fuere aquel a quien vos querréis, ninguno otro que en la cabeça se lo ponga se podrá con él mover un passo y aquella piedra no se puede mirar si primero no se pone la mano en ella y se trae por los ojos. Assí mismo, creed que las piedras d'él son de tal materia compuestas que por mucho que llueva sobre el chapeo no caerá agua. El anillo es tal que el que consigo le traxere no será por encantamiento nuzido y cualquier ferida que con él fuere tocada luego la sangre será restañada. (Clarián de Landanís I, LX)

Junto al chapeo aparecen dos elementos más, un manto y un anillo, ambos labrados y tejidos de tal riqueza, en la que predominan las piedras preciosas. En primera instancia, se trata de una protección mágica otorgada por las tres prendas, cada una le permite al caballero estar en lugares de peligro sin recibir ningún daño físico. A diferencia de los dos ejemplos anteriores, en éste sí lo pueden ver, pero nada lo puede afectar, ni heridas, ni la

\footnotetext{
${ }^{273}$ Identificar si este tipo de motivo se presenta en los libros de caballerías castellanos es una nueva línea de investigación sobre la función de la vestimenta mágica, ya que, hasta la fecha, la bibliografía predominante sobre la magia se especializa en objetos, arquitecturas y brebajes, sin que haya muchos registros sobre la ropa y su uso para la protección contra el clima. Por lo que éste es un primer acercamiento a este tema, cuya primera dificultad es la poca presencia de este tipo de pasajes en otros libros de caballerías castellanos, el único elemento que sí aparece con frecuencia es el anillo.
} 
intemperie, por lo que aparecen nuevos elementos, la protección contra brebajes y la cobertura contra la lluvia.

La necesidad de esta triple protección se da porque Clarián se debe a los eventos futuros que tendrá, primero tiene que salir de Alemania para participar en unos torneos, después debe rescatar a su querida Gradamisa del ataque de unos leones y posteriormente, su enfrentamiento con Palamís origina un conflicto de linajes. Eventos que ponen en riesgo la vida del heredero al trono y en cuyos sucesos utiliza las prendas para librarse del peligro.

La magia es el recurso que brinda poder a la prenda, en conjunto, favorece el desarrollo del protagonista y la realización de la aventura con mayor facilidad. Aunque se trata de un temprano ejemplo para la fecha de auge de los libros de caballerías, presenta innovaciones sobre el uso de las prendas mágicas, en especial el chapeo, por la originalidad de evitar el contacto de la lluvia con el caballero; por lo que, en comparación con Feliciano de Silva, éste es una singularidad que no aparece en sus obras, sólo, en cierta medida, se le puede comparar el pasaje del yelmo de cristal, analizado en el capítulo anterior, el cual también está encantado, protege de los golpes y sólo puede ser usado por el más leal amador. De esta forma, este yelmo compite en originalidad con el chapeo, por la magia que otorgan.

\subsubsection{Las armas}

Para el oficio del caballero es menester una cobertura de acero que proteja su cuerpo de los golpes recibidos por el oponente, una estructura metálica creada conforme a los diseños establecidos por los armeros medievales y perfeccionada por grabadores, artesanos y talladores, quienes, a través de las imágenes labradas en el hierro, dejaron registro de los guerreros que las usaban. 
Nombre, linaje, fama y honor dieron testimonio de las victorias ganadas en el campo de batalla por medio de las andanzas del caballero por diversos lugares, en donde portaba su armadura y por la que era reconocido en cada sitio al que llegaba, por lo que la presencia de las armas en los libros de caballerías tiene una importante relevancia porque las justas, las batallas y los torneos abarcan de los episodios en estas historias, lo que convierte a la armadura en la protagonista por el color, diseño y grabado junto a los vestidos femeninos, los cuales adquieren relevancia en bailes, festejos y justas.

Para el análisis de las armas es necesario dividir el tema en dos partes, la primera comprende el estudio de cada una de las piezas que conforman la armadura, así como las armas y el uso que se hace de ellas en estos libros, desde el nacimiento de los caballeros hasta que reciben las armas y tienen sus primeras batallas, con el fin de conocer la evolución en el uso de la espada y el escudo, principalmente, y las repercusiones que presenta el portar muchos accesorios bélicos; la segunda consiste en el estudio heráldico de las imágenes, grabados y esmaltes que aparecen en ellas y la función actancial que presentan en los eventos en los que tienen mayor notoriedad. De esta forma, se elabora una tipología con el fin de recuperar los motes, las letras y las imágenes que aparecen pintadas o grabadas en el metal para agruparlas según el significado que adquieran dentro de los episodios.

2.8.6.1. Armas de juego (figs. 122, 123)

Desde que nacen los caballeros su destino está marcado por el amor y la aventura, "son personas predestinadas para cumplir las empresas que les están asignadas"274, por lo que deben salir en busca de hazañas y comenzar a obtener fama a través de las victorias tras cada enfrentamiento; sin embargo, para alcanzar la técnica de combate adecuada, la

${ }^{274}$ Juan Manuel Cacho Blecua, Amadís: heroísmo mítico cortesano, Zaragoza, CUPSA, 1979, p. 75. 
agilidad y destreza en el uso de las armas, es necesario que todo paladín tenga un periodo de entrenamiento a fin de estar preparado en el manejo de la espada, la lanza y el escudo, incluso antes de recibir la investidura.

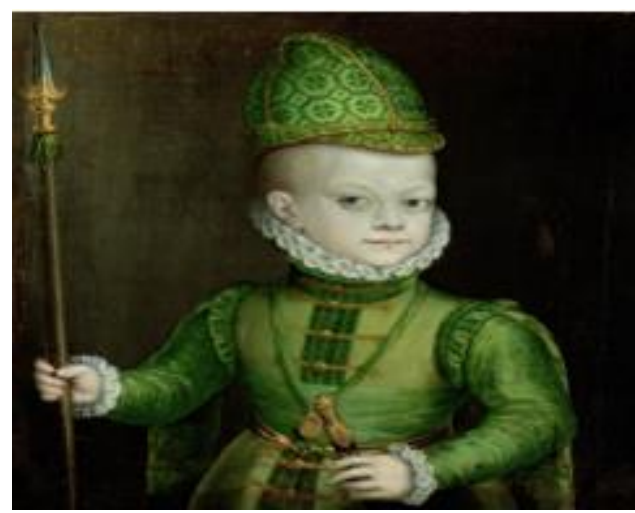

Fig. 122. El infante don Felipe, Alonso Sánchez Coello Museo de Arte de San Diego, Estados Unidos.

El infante lleva una lanza y una espada en las manos.

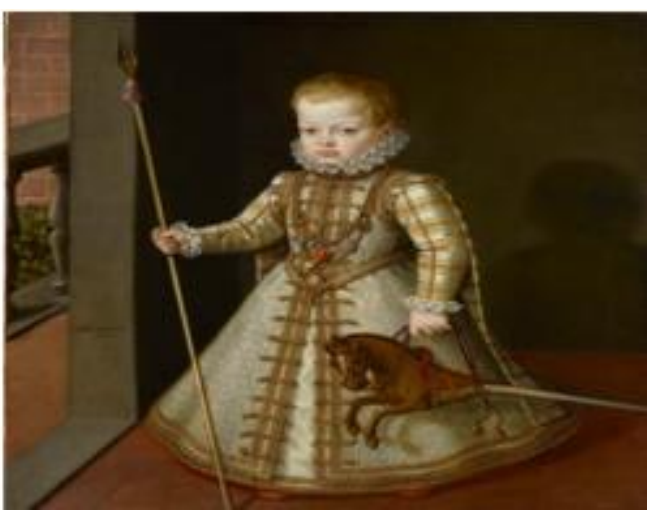

Fig. 123. El infante don Diego (1577) Alonso Sánchez Coello, Museo de Liechtenstein, Viena.

El infante tiene una lanza y un caballo de juguete.

Dicha formación comienza desde la infancia:

Pues como más cresciendo fuesse, le quisieron enponer en aprender todas las cosas que a un alto príncipe convenía. Ansí en las sciencias como en todas las artes de las armas le mostravan. [...] E ansí le inponían en un cavallo todas las cosas a él necesarias, ansí como jugar de lança, de diversas maneras justar. E ansí tanto en esto el príncipe don Polindo se viciava que muy diestro en ello era, ansí en esto como en dulçura de ciencia que su ama le amostrava. (Polindo, VIII)

Estos juegos inician a temprana edad, desde que el niño es capaz de sostener la lanza y equilibrar la espada y el escudo entre sus manos; generalmente, sus armas iniciales eran de madera, para facilitarle al pequeño su manejo; sin embargo, estas primeras "armaduras infantiles no deben ser consideradas como un juguete, sino como armas dotadas de un alto valor de representación al igual que las destinadas a los adultos"275, porque en ellas se verán

\footnotetext{
275 Álvaro Soler del Campo, "La real armería de Madrid”, Arbor, CLXIX, 665 (mayo 2001), p. 151.
} 
reflejados el dominio y la destreza que desde la infancia se adquieren; el poder para gobernar y la agilidad para esquivar golpes.

Los juegos de cañas se convierten en los primeros entrenamientos bélicos de los niños, quienes, en grupo, serán más comunes sus formaciones: "Por honrar d'estos infantes, el rey fizo venir a su corte muchos donzeles, hijos de altos hombres y cavalleros de su reino, que en ella se criassen d'esta guisa: cada día los viérades ensayar a luchar, correr, saltar, cabalgar a caballo, jugar de todas armas, justar y tornear" (Clarián de Landanís I, I). Para los pequeños miembros de la familia, las primeras armas consistían en juguetes con funciones bélicas, como caballos de madera, lanzas y espadas diseñadas al tamaño y peso corporal de los infantes, con la finalidad de poder ser maniobradas con facilidad. En el caso del príncipe Felipe II, sus inicios como guerrero se hallan en los obsequios que recibió desde Habsburgo: “entre los juguetes principescos, el caballero de plata, que cabe suponer sirvió para familiarizar a Felipe con el arnés para justar y guerrear que veía lucir a su padre y a los cortesanos. El caballero y su montura fueron adquiridos al tiempo que el Príncipe iniciaba su instrucción en el manejo de las armas" ${ }^{276}$, las dos piezas que conforman el juguete, caballero y caballo, dan indicios de la importancia que se le daba al metal y a la tela para la conformación de la armadura, pues desde la infancia se debía inculcar el uso de tejidos costosos para combatir, mismos que se empleaban para la decoración del muñeco y de la montura, ${ }^{277}$ sedas y acero dorado, materiales lúdicos que fueron el primer contacto con el traje de combate, la armadura.

\footnotetext{
276 José Luis Gonzalo Sánchez-Molero, El aprendizaje cortesano de Felipe II, 1527-1546: la formación de un príncipe del Renacimiento..., p.103.

277 Algunas pinturas de Sánchez Coello como el Retrato de don Diego (1577) con caballo y lanza en mano, dan detalle de este tipo de juguetes y primeras armas para niños durante el siglo XVI.
} 


\subsubsection{Primeras armas}

Muy conocidas son las armas que los caballeros utilizan en combate y con las cuales se identifican durante toda la historia, a pesar de que cambian sus gualdrapas, corazas y yelmos, hay algunas que predominan por la relevancia que adquieren en los episodios; por ejemplo, son significativas las armas negras de Beltenebros por representar la tristeza por el rechazo de Oriana; así mismo, el yelmo de cristal del caballero encantado que aparece en el Lisuarte y que sólo puede ser usado por el más leal amador; o el escudo negro de Palmerín que sobresale entre el de los demás caballeros porque detalla el amor de Polinarda con la imagen de un águila. Estas armas son en sí elementos de memorización para el lector, porque a través de las imágenes, letras y colores permanecen grabadas a quién pertenecen y en dónde fueron usadas, además de la prolongación y detalles que los autores les dedican a los capítulos en los que aparecen. Sin embargo, contrario a esta ampliación descriptiva de algunas armas de combate, hay una breve mención de la primera armadura que le es entregada al joven cuando es armado caballero, en donde predomina la presencia del color de las armas:

El sábado en la noche, como el rey Amadís ovo cenado, los tres príncipes d'España e Nápoles e su fijo del rey Norandel fueron armados de muy ricas armas con muchas piedras e perlas muy bien guarnidas, todas blancas como lo acostumbraban los cavalleros noveles, que el rey Amadís les hizo dar. (Lisuarte de Grecia, LXIX)

Los jóvenes que desean portar su primera armadura deben pasar por un proceso de investidura en el que se despojarán de sus trajes infantiles para usar su ropa de guerra, su propósito será ser identificado como caballero dentro y fuera de su reino. Generalmente se 
menciona este acto como un hecho "de incorporación a la élite de los defensores"278, en donde sobresaldrán las virtudes y principios morales de los jóvenes a fin de ser ejemplo para la sociedad. Alfonso X establece estos valores: cordura, fortaleza, mesura y justicia, los cuales se relacionan con el color blanco porque "remite a lo puro, a lo virgen, a lo limpio, a lo inocente [...] porque resulta relativamente más fácil hacer algo uniforme, homogéneo y puro con lo blanco que con los demás colores"279, además de esta concepción, en la Edad Media lo blanco representaba el color del pasaje ${ }^{280}$, de un cambio donde la imagen del renacer estaba presente. Los donceles que toman las armas se convierten en un ser superior porque dan paso a la madurez, a la búsqueda de una vida contraria a la pasividad que hasta ahora han llevado porque son conscientes de su destino, ayudar al menesteroso. Este deseo se conocerá dentro de la corte y sus resultados fuera de ella, porque el rey será el encargado de permitir este desarrollo en el joven, pero sus hechos esparcirán su fama fuera del reino. Sin embargo, no todos reciben la orden en el tiempo establecido:

Entró por la puerta de la sala un donzel vestido de paños de oro muy ricos, por ellos muchas piedras e perlas de gran valor. Él era de buen cuerpo y hermoso gesto, tanto que muchos se espantaron de su hermosura. Con él venían veinte cavalleros armados de ricas armas e otros tantos escuderos.

El caballero se dirige hacia el rey y de rodillas le dice:

Sabrás que a mí llaman Olorius d’España. Soy hijo del rey don Brián, tu muy verdadero amigo, que por mi petición a ti me embía para recibir de ti la orden de caballería, que ya a mi edad se le faze vergüença andar sin ella. (Lisuarte de Grecia, LXVIII)

\footnotetext{
${ }^{278}$ Cacho Blecua, op.cit., p.75.

${ }^{279}$ Michel Pastoureau, Negro, historia de un color, Madrid, 451 Editores, 2010, p.53.

280 Jean Chevalier, Diccionario de los símbolos, Barcelona, Herder, 1986, p. 190.
} 
En semejanza al blanco se presenta el color oro, cuya primera reminiscencia conduce a la calidad superior de los paños que se visten, además de la riqueza que le agrega la cantidad de piedras preciosas que llevan. Aunque en un principio Olorius se presenta con estas armas, al día siguiente, se las cambia por unas blancas para la ceremonia y para asistir a la capilla a la vela de armas. Este ejemplo tiene un significado importante en cuanto al primer color de armas que usa el caballero, el oro o dorado era la luz, "evocación del sol, la alegría, la vida, la energía"281, además de que "llevar oro o textiles adornados, o confeccionados, con oro era como vestir la luz" ${ }^{282}$. Este matiz está relacionado estrechamente con el futuro sentimental del personaje, debido a que su amada tiene por nombre 'Luciana' y de acuerdo con las armas que, posteriormente, lleva para defender a la dama en unas justas, tiene un lucero en el escudo, por lo que la presencia de este tono conlleva un significado de amor para la pareja. Las cuatro virtudes antes mencionadas, Alfonso X las traspasa a las armas que debían llevar:

Et por ende los antiguos por remembranza desto fecieron facer á los caballeros armas de quatro maneras; las unas que vistan et calzen, et las otras que ciñan, et las otras que paren ante sí, et las otras con que fieran: et como quier que estas sean en muchas maneras, pero todas tornan en dos, las unas para defender el cuerpo que son dichas armaduras, et las otras armas que son para ferir. (Partidas, II, tít. XXI, 1. IV)

Esta clasificación responde a la necesidad de proteger físicamente todo el organismo, pero también de saber usarlas en el espacio de batalla. Primero, para vestir y calzar, desde el yelmo, la coraza, el peto, la cota, el escarpe, etc.: "quitándose el peto de azero que tenía, se subió donde la infanta estava de pies" (Amadís de Grecia, CXIX). Segundo, las que se

\footnotetext{
${ }^{281}$ Michel Pastoureau, Breve historia de los colores, Barcelona, Paidós, p.238.

282 José Damián González Arce, "Los colores de la corte del príncipe Juan (1478-1497), heredero de los Reyes Católicos. Aspectos políticos, estéticos y económicos", Espacio, tiempo y forma, Serie III, H. Medieval, t. 26, 2013, p.198.
} 
ceñían de manera que se sujetaran al cuerpo pero que iban sobre la armadura, para que se pudieran quitar con facilidad, como espadas, dagas, cuchillos, flechas, etc., se detenían del cinturón, algunas colgaban de una cadena larga que le permitía tener longitud para utilizarla sin necesidad de desabrocharla: "Arremete con su enemigo por lo abraçar, el cual lo rescibió dexando colgar su espada de la cadena" (Polindo, XV). Tercero, las que "se paran ante sí”, el mango, el arriaz y el fierro, porque de estas partes el caballero sostiene su espada y la mantiene fija delante de sí (ejemplos poco mencionados en los libros de caballerías). Cuarto, las que se usan para herir como la espada, el hacha, el arco, etc.: “alçó la espada y diole tan gran golpe sobre el yelmo que malamente le hirió en la cabeça" (Arderique II, VIII). Esta ubicación se asemeja a la colocación de armas que aparece solamente en Flor de caballerías, cuando el príncipe Belinflor desea ser armado caballero. Acto realizado por las propias virtudes:

Llegó la Justicia y calçándole la manopla derecha le dixo:

-Cavallero, jamás con pasar la justicia a la izquierda mano la pongáis en olvido mientras con vuestra diestra mandáres.

Luego llegó Prudencia y calándole la visera del yelmo dixo:

-La Prudencia, cavallero, siempre en vuestras sentencias, en vuestro rostro la tened.

Luego llegó la Honra y ech[án]dole un escudo al cuello le dixo:

-En vuestr[os] hechos sienpre me tened delante, vent[ur]oso cavallero.

Luego llegó Fama y cal[án]dole la espuela dixo:

-La Fama, cavall[ero], os sea espuela para enprender grandes in[presas].

Luego llegó la Tenperança y dándole un pequeño golpe en el ombro con la espada le dixo:

-Cavallero, en buestras enpresas os encargo esta virtud de Tenperança.

Luego juró en manos de aquel emperador todo lo que se requiere para recevir la orden de cavallería; acabado el juramento, llegó la Fortaleça y ciñéndole la espada dixo:

No os encargo nada cavallero porque tenéis esta virtud muy cunplida. 
Acabado esto dixo el emperador:

-Cavallero sois. (Flor de caballerías, XIV) (figs. 124-126)

Se mencionan la manopla, la visera, el escudo, las espuelas y la espada, todas cubren las virtudes dichas por Alfonso $\mathrm{X}$ y se agrega una virtud más, la fama, resultado de la integración de las otras en su persona. A partir de esta ubicación física se puede hacer una clasificación por su uso, en defensivas y ofensivas, tal como las separa Alfonso X: "Las unas para defender el cuerpo que son dichas armaduras, et las otras armas que son para ferir" (Partidas, II, tít. XXI, 1. IV) y las agrupa Martín de Riquer: “ofensivas (lanza, maza, hacha, y espada) como las defensivas (yelmo, capellina, loriga y arnés, corazas y fojas, sobrevistas y sobreseñales, gambax y escudo)"283, ambas aportaciones se considerarán para este estudio, identificando cuáles de las anteriores aparecen en el corpus seleccionado y cuáles nuevas registra Feliciano de Silva como los demás escritores del género.

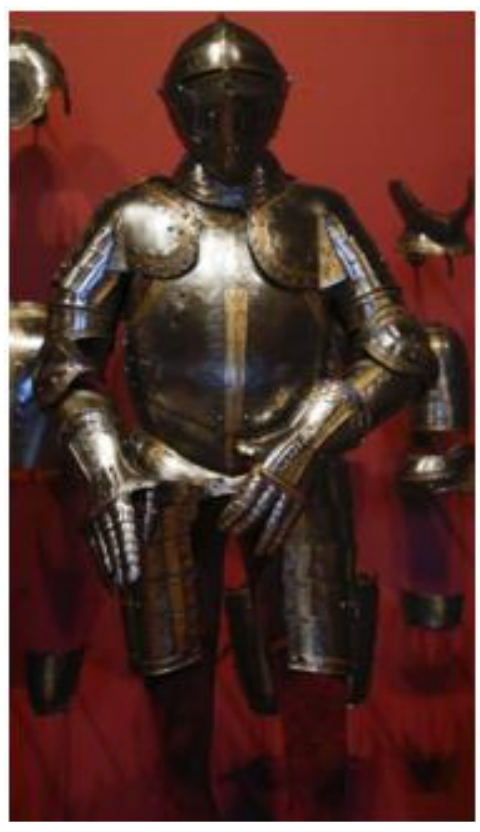

Fig.124. Armadura de Carlos V (1547) Real Armería de Madrid

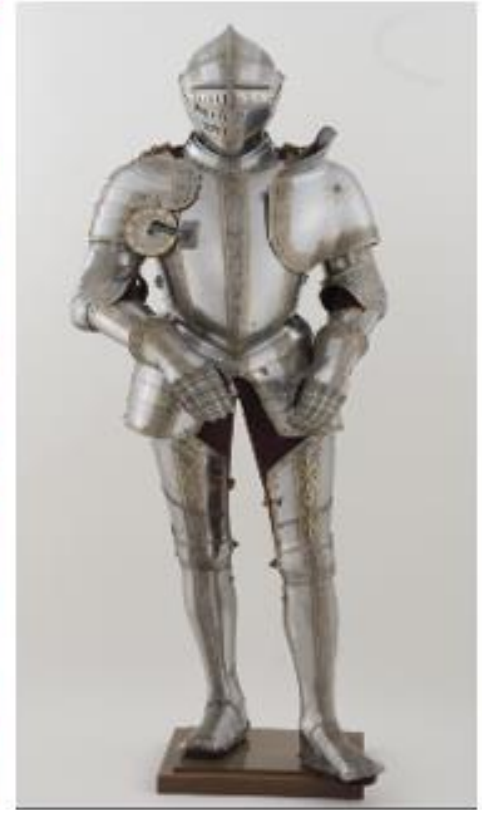

Fig. 125. Armadura Felipe II (1551) Real Armería de Madrid

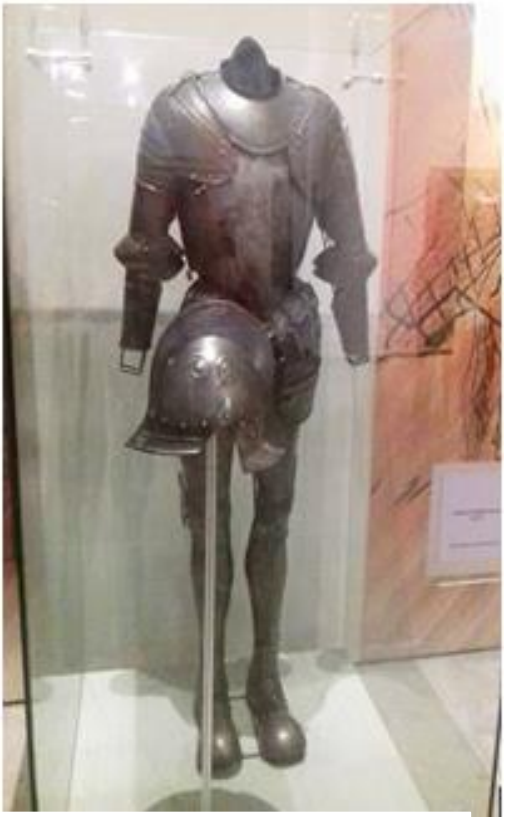

Fig. 126. Armadura (s. XVI) Centro Cultural Mexiquense Bicentenario, Texcoco.

${ }^{283}$ Martín de Riquer, "Las armas en el <<Amadís de Gaula〉>”, en Estudios sobre el Amadís de Gaula, Barcelona, Sirimio, 1987, p.55. 


\subsubsection{Armas defensivas}

2.8.7.1. El yelmo

Ramón Llull menciona que el yelmo "defiende la cabeza, que es el miembro más alto y principal que posee el hombre" ${ }^{284}$. De hierro en un principio y después de acero, el yelmo se convirtió en la principal protección de la parte superior del cuerpo. De diseños, primero cónicos y lisos, y después con grabados, su función principal era la de ocultar y defender el rostro de quien lo usaba. Este motivo es el que se repite de manera general en los libros de caballerías: "E poniéndose el yelmo en la cabeça, assí por no ser conocido como por si alguna cosa le acontenciesse" (Lisuarte de Grecia, LIIII), con la intención de cubrirse la cabeza por precaución y ocultación, para prevenir heridas y evitar ser conocido. Antes de retirarlo, debe cerciorarse de que no haya nadie cerca: "E viendo que no estava allí nadie que le conociesse, quitose el yelmo de la cabeça porque le dava mucho calor" (Lisuarte de Grecia, LIIII). Su forma provoca ciertos malestares físicos, el principal es ocasionado por la estrechez de su forma. Esto no impide que cumpla su función ocultarlo de los demás:

“-Buen cavallero, ruégovos que me digáis vuestro nombre para que aquellos cavalleros sepan quién les hizo tanta honra, e así mesmo vos quitéis el yelmo para que yo vos conozca doquiera que os vea para serviros" (Lisuarte de Grecia, LIII). No basta con el nombre, sino que es necesaria la identidad física del caballero, conocer su rostro, para que en el futuro lo pueda identificar en cualquier lugar en donde lo encuentre.

Una de las piezas del yelmo que adquiere relevancia en estos libros es la visera, debido a su diseño y función de proteger el rostro, se convierte en parte importante por su doble condición, movible y estática que permite acceder en parte a la identidad del caballero sin revelar su origen ni su procedencia. En el caso de la visera fija tenía rejillas o

\footnotetext{
${ }^{284}$ Ramón Llull, Libro de la orden de caballería, Madrid, Siruela, 2009, p. 91.
} 
$\operatorname{grilletas}^{285}$ por las que el caballero miraba sin ser identificado por el físico, pero que en ocasiones, esto no era suficiente para conservar su origen, ya que era reconocido por su voz: "Y con esto le dio tal golpe por encima de la cabeça, que ansi el yelmo como ella fueron en dos partes. A la boz que Lisuarte dio, la princesa le conoció" (Lisuarte de Grecia, XXXIV). Este tipo de reconocimiento puede provocar enredos, incluso dudar de la persona que está delante de sí, debido a que en muchas situaciones hay un juego de disfraces en el que las damas se visten de hombres y viceversa para realizar una determinada aventura:

El infante le dixo:

-No só yo don Roldán, mas desséole parecer en sus obras. Pero dime -dixo el infante-, ¿conoces tú de vista ese que nombras de nombre?

-Sí, por cierto - dixo el moro.

-Pues, mira si soy yo ese que dizes - dixo el infante.

E alçándose la visera del yelmo, le mostró su cara.

El moro dixo:

- ¡Por Mahoma juro nunca vi donzella pelear sino agora! Tú eres su espossa de don Roldán, la cual llaman Alda la Bella, que, según en estas partes he oído dezir, tan bien pelean las mujeres como los hombres (Espejo de caballerías II, LXVII).

Nótese que hay una prolongación en la conversación que no permite reconocer la voz, ni siquiera se distingue si es un hombre o una mujer quien está hablando; es hasta el levantamiento de la visera cuando el moro se sorprende de ver a una mujer. Las prendas más recurrentes para disfrazar la identidad son el yelmo, el antifaz y la máscara, porque cubren la cara y crean la duda por saber a quién tienen delante.

Sin embargo, una debilidad en esta arma puede ser provocada por su reducido espacio:

${ }^{285}$ Ramón Medel, El blasón español o la ciencia heráldica, Barcelona, J. Guerrero, 1846, p.62. 
el rey Neandro de Achaya, que muy tinto andava en sangre y ciego del mucho polvo que por la visera le entrava, adonde, poniéndose el uno contra el otro, el rey de Achaya alçó la espada y diole un rezio golpe en el yelmo que se lo partió hasta el almófar, pero el rey Cingarino, por pagarle el trabajo que avía tomado, le da en el hombro una mortal herida, con la cual el rey cayó abaxo y luego fue acabado de los peones. (Baldo III, XLIIII).

El polvo se convierte en un oponente más al provocar un desempeño tardío por cubrirse los ojos el combatiente; el diseño de la visera, para la época, generalmente era horizontal con una franja en el centro a la altura de la nariz o con perforaciones circulares para facilitar la respiración. Estos diseños dan apertura a que entre los ojos y el metal ocurran un sinfín de acciones acaecidas por partículas pequeñas ${ }^{286}$, como el polvo, las hojas, el calor, etc., por lo que el caballero no está totalmente libre de pequeños incidentes; algunos ocasionados por el contacto entre metales: "Y cerca de sí halló a Feridefonte, que tras él avía ido, y lo hirió de un revés en la visera, que con las centellas que le hizo saltar las cejas le chamuscó, dando con el cuerpo sobre las ancas del cavallo sin ningún sentido" (Espejo de príncipes y caballeros II, XXV). Aunque las molestias son menores, la apariencia del caballero y su desempeño son afectados por las chispas que debe apagar para evitar recibir más daño. Otros por la sofocación: "E como hazía calor, quitóse aquel muy fuerte yelmo de la cabeça e diole a su escudero" (Polindo, XII). El yelmo sí protege de la mayor parte de la cabeza y el rostro, pero hay ciertos elementos que con facilidad perjudican al caballero mientras

\footnotetext{
${ }^{286}$ Un curioso ejemplo en el que un elemento pequeño entra por la visera y causa una situación risible se halla en una serie de enseñanzas morales contra las blasfemias a Dios en donde un tahúr de oficio y jugador de profesión se burla de la existencia de Dios y reta a duelo a todos los hombres que piensan lo contrario; sin embargo, en castigo por su falta espiritual, es atacado por un mosquito: "A un loco como avía de ser, sino con hazer burla de él. Al punto, bolando un mosquito se le entró por la visera y empeçó a picarle tan crudamente por todo el rostro, que afligido al grave dolor, que le causava, después de acudir con la mano no le valía. Huvo de quitarse a toda prissa el Morrión, arrójalo al suelo. Y el mosquito sin cessar un punto de clavarle su aguijón por el rostro." El ejemplo proviene del Espejo grande de exemplos recogido en Juan Martínez de la Parra, Luz de verdades católicas, Barcelona, Rafael Figuer, 1705, p. 136.
} 
combate, debido a que no son percibidos cuando se aproximan, sino hasta que ya se han introducido en su rostro. (fig. 127)

\subsubsection{El escudo (fig. 128)}

La segunda arma defensiva es el escudo, sin duda alguna, es la pieza que más riqueza ornamental presenta porque puede llevar una infinidad de elementos naturales, animales, dibujos geométricos y escritos pintados tanto en el contorno como en el interior, además de que puede incluir otros elementos como piedras preciosas, perlas, tela y grabados que incrementan su valor.

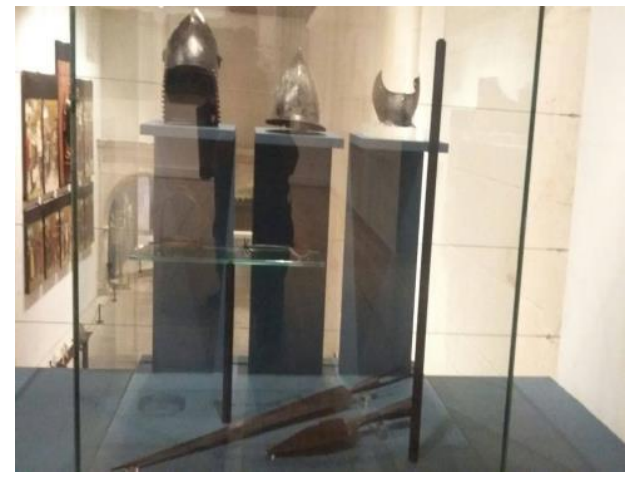

Fig.127. Cascos (s. XV) Museo de Historia de Burgos

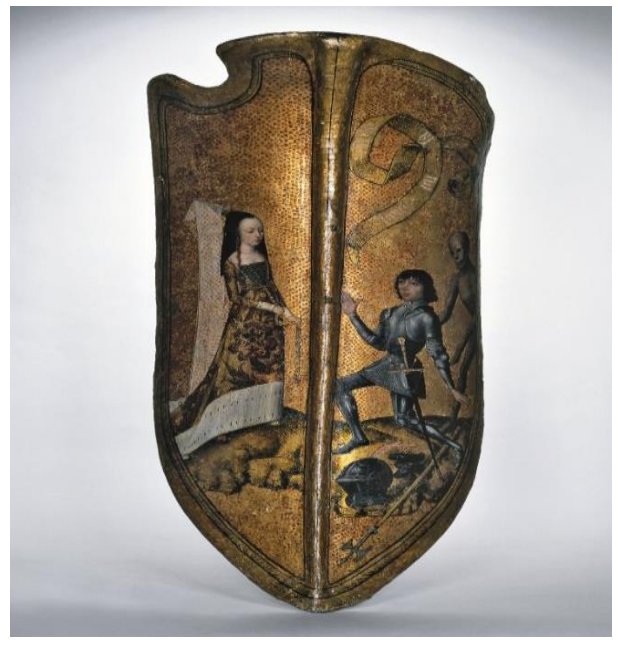

Fig. 129. Escudo (1470) Museo Británico. El escudo lleva la letra "Usted o la muerte" con la que el caballero expresa su amor hacia la dama.

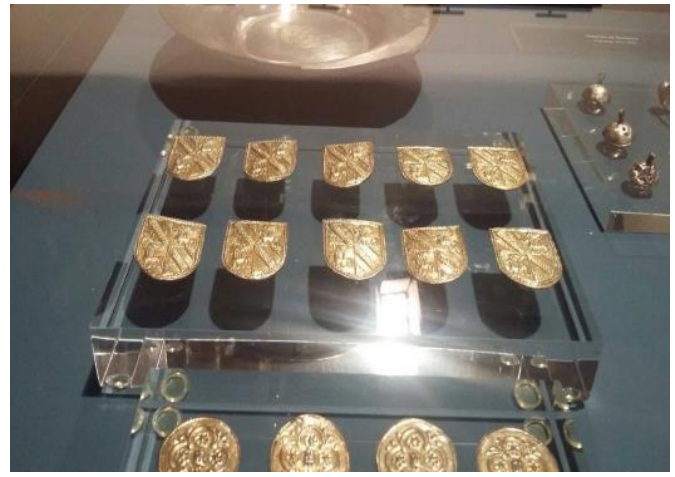

Fig.128. Escudos de oro (s. XV) Museo de Historia de Burgos

Se considera como "una cara del cuerpo humano, donde las figuras según su colocación conservan su puesto honorífico adecuado a sus partes honorables"287. El escudo es la presentación del caballero fuera de su reino, porque lleva la imagen que lo representa y el mote con el que será nombrado. (fig. 129)

\footnotetext{
${ }^{287}$ Medel, El blasón español..., p.13.
} 
Su ubicación en el cuerpo ocupaba dos espacios, en la espalda cuando no se combatía: "llevaba en el yelmo y testera del caballo, que puesto llevava, y su escudo al cuello" (Florisel de Niquea III, LXXXIX) y al frente cuando se estaba en batalla: "con mucha ligereza saltó fuera del cavallo y enbraçado su escudo se va para el rey, que para él venía” (Florisel de Niquea III, LXXXIX). También como penitencia se sujetaba al cuello: "Deseo justo e razonable es que los que en prisiones o fuera de su libre poder son, desear libertad; e como yo, vasallo e natural vuestro, sea en prisión de una señora de gran tiempo acá, en señal de la qual todos los jueves traygo a mi cuello este fierro, según notorio sea en vuestra magnifica corte e reynos, e fuera dellos, por los farautes que la semejante prisión con mis armas han llevado" 288 . La ubicación en el cuerpo es importante porque revela que no se trata de un arma oculta, sino que está a la vista de todos y, por lo tanto, puede ser reconocido:

Y partida d'él a poca pieça topó, gravemente llorando, al escudero del príncipe que a llamar a sus cavalleros venían; y como a la princesa vio, maravillado de tal aventura (y no sin misterio, como adelante se contará), conosciéndola en el escudo con gran goço dixo: - ¡Ay, mi soberana señora! ¡Socorred presto al excelente príncipe don Falanges de Astra si lo queréis ver bivo!" (Florisel de Niquea III, LXVII).

Podían estar fabricados de madera ${ }^{289}$ con cubierta de cuero o de metal, su resistencia se veía en el tiempo que tardaba en ser destrozado durante el enfrentamiento: "el cavallero encantado metió mano a su espada e comiença entre sí una brava batalla, tanto que en poca de hora el escudo de Dinerpio todo fue desfecho" (Florisel de Niquea III, LXXIX). En otros momentos el narrador comenta que la batalla duró más de dos horas sin referir el mal estado del escudo.

\footnotetext{
${ }^{288}$ Martín de Riquer, Caballeros andantes españoles, Madrid, Espasa-Calpe, 1967, p. 53.

${ }^{289}$ Martín de Riquer, “Las armas en el Amadís...”, p.148.
} 
Los escudos pueden tener cualidades mágicas, otorgadas por las sabias; sin embargo, no siempre resisten los golpes: “el príncipe alçó el escudo, el qual de arriba abaxo fue hecho dos partes, no le aprovechando la fineza que la sabia Velonia le avía puesto, porque a los fuertes braços del cavallero ninguna cosa parava" (Belianís de Grecia, VI). Este es un ejemplo único en el que la fuerza del enemigo está en el mismo grado de poder de la magia, ya que, aunque se trata de un objeto mágico, la fuerza del caballero resiste al encantamiento. Aunque, como en toda historia, después de un tiempo, el caballero del escudo vencerá.

Otra función que cumple el escudo es la de ofrecer comodidad al caballero para descansar: "y vio un cavallero armado de todas sus armas, que, acostado sobre el escudo, a la sombra de un árbol dormía" (Arderique, IX). Por la descripción, el lector puede suponer que se trataba de un escudo grande. Además, aunque no se menciona, el yelmo también tenía este aspecto: "la forma tubular del yelmo permite que, cuando los caballeros duermen en la soledad de los bosques, les sirva de almohada" ${ }^{290}$. La utilidad de las armas responde a dos necesidades, la primera como arma de defensa y la segunda para descansar y dormir.

\subsubsection{Las espuelas (fig. 130)}

Aunque están en lo más bajo del cuerpo, son importantes para montar a caballo, porque significan "diligencia, experiencia y celo con los que honran a su orden" ${ }^{291}$, son las que guían al caballo en cuanto a velocidad y las que lo detienen: "El de la Ardiente Espada sin le responder abaxó su lança; hiriendo su caballo de las espuelas, bien cubierto de su escudo, a todo correr se metió por la puente de madera" (Amadís de Grecia, XXVIII). Una característica que se repite en estos libros es que, cuando se usan, siempre se hace

\footnotetext{
${ }^{290}$ Ibid., p. 100.

${ }^{291}$ Llull, op.cit., p. 91.
} 
referencia al caballo, porque es el contacto entre el caballero y el acero, además de que las armas que siempre las acompañan son la lanza y el escudo, porque cuando se justa, las armas para montar se llevan en las manos, por lo que una debe ser larga, la lanza, para alcanzar al oponente, y otra debe proteger, el escudo, para esquivar los golpes.

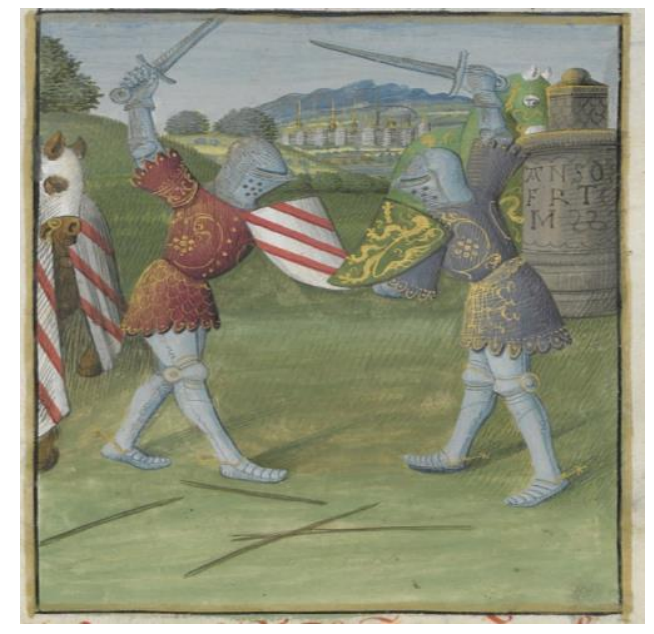

Fig. 130. Lancelot en prose (s. XV)

Biblioteca Nacional de Francia.

Caballeros combatiendo con espada, escudo, yelmo y espuelas. Nótese el bordado de flores que llevan en las sobrevestes.

Había cuatro tipos: acicate, vaqueras, pico y $\operatorname{secretas}^{292}$, aunque no se describen lo más aceptable es que tuvieran roseta, no tan grandes y ligeras para caminar con facilidad. Las damas también las usaban: "La princesa muy turbada d'estas palabras al cavallo de las espuelas fiere y a mucha priessa va, y todos la siguen" (Florisel de Niquea III, LXVII). Una de las armas a cuerpo que compartían hombres y mujeres y no tenían algún rasgo que las diferenciara.

${ }^{292}$ Leguina, op.cit., p.453. 


\subsubsection{Armas ofensivas}

2.8.8.1. La espada

Excalibur, Tizón y Colada son tres de las espadas más famosas en la literatura artúrica y española. De acuerdo con Alfonso X, representan "la cordura, fortaleza, mesura y justicia" (Partidas, II, tít. XXI, 1. IV), porque con el acero defienden a los menesterosos y hacen justicia. Esta es la primera en ceñirse: "Y después el rey armó cavallero a Florineo, y ciñéndole una muy buena espada que fuera del rey Guidelo su abuelo, le dio paz en el rostro" (Florambel de Lucea, I-III) y la que más importancia marcará en el desarrollo del héroe. El primer contacto que Amadís tiene con las armas es la espada del rey Perión, la cual servirá, en el futuro, como prenda de reconocimiento entre Amadís y sus padres para acceder a su posición como príncipe. Sin ella no se concibe la caballería ${ }^{293}$, porque para todo espacio y contra todo enemigo, maravilloso o no mágico, se utiliza. Ésta es la segunda en usarse en las justas, después de que la lanza se rompe, el caballero debe tomarla y continuar el combate: "Perión, que antes que la lança quebrase más de quinze cavalleros avía muerto, metió mano a su espada y anduvo por la batalla haciendo cosas maravillosas" (Amadís de Grecia, CI). La experiencia en el campo de batalla otorga destreza en el uso de las armas, por lo que la rapidez y la agilidad serán notorias en los torneos, principalmente, en el movimiento de las manos, tal como se menciona en el anterior ejemplo, en donde el cambio de armas debe ser con premura para evitar ser atacado mientras se deja la lanza y se desenvaina la espada.

La dureza de su hoja se nota en varios episodios en los que el acero de la espada destruye al acero de la armadura: "E ya la buena espada de don Polindo avía despedaçado las armas de los cavalleros, cortava en sus carnes donde los haze muchas llagas" (Polindo,

${ }^{293}$ Cacho Blecua, op.cit., p. 82. 
LXXV). Esta cualidad está presente en la mayoría de las espadas de los caballeros principales, porque deben superar y resistir cada combate e incrementar el número de muertes tras cada enfrentamiento.

Hay una relación más estrecha entre el caballero y su espada, debido a que lo representa en las justas porque va acorde al color de sus armas, es su defensa ante los enemigos y siempre la lleva consigo, pero si la pierde por descuido, sufre una gran pena: "De su peligro, aunque era muy grande, no se acordava y tanto se descuidó de sí que se le cayó su rica espada en la mar, uno de los graves dolores fue esto. Si por su discreción no se rigiera, ya se uviera echado en la mar" (Flor de caballerías, XXXIII). El apego emocional es el resultado del tiempo que ha pasado con su primera arma, aquella que conquistó después de recibir la investidura y con la que obtuvo su primer triunfo.

En la prueba de los enamorados, Lisuarte no logra utilizar su espada contra el caballero encantado, ni con sus manos es capaz de sostenerlo: “D'esta forma andivieron más de media hora, que por mucho que hazía golpe no le podía dar. Soltando la espada de la cadenilla, arremetió a él por cogerle entre los braços, pero no le avino assí (Lisuarte de Grecia, LXXIX). La prueba debían realizarla los más leales amadores, pero el caballero encantado se niega a enfrentarlo porque sabe su condición de desamor, por lo que no le permite usar su espada, ya que es una prueba para la que aún no está preparado debido al pesar sentimental que pasó con Onoloria y hasta que esta condición no se solucione, no es merecedor de utilizar su arma.

La espada es el arma ofensiva de la dualidad porque se protege y se termina con la vida de los enemigos, salva y peligra a los demás. Triunfa y se quebranta después de muchas batallas; es la primera pieza que conquista el héroe y por la que debe practicar para 
poder obtenerla. Su pérdida implica una nueva etapa en la que se deberá obtener otra espada con un significado superior a la anterior. (fig. 131)

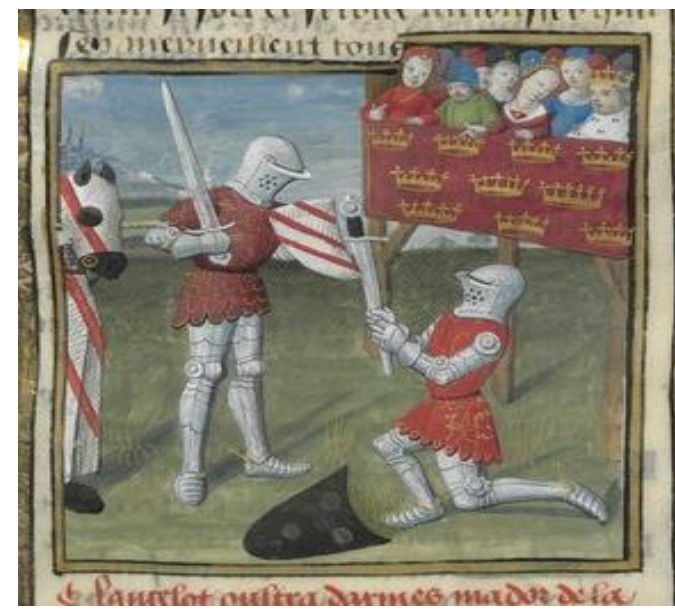

Fig. 131. Lancelot en prose (s. XV)

Biblioteca Nacional de Francia.

Entrega de la espada en señal de derrota.

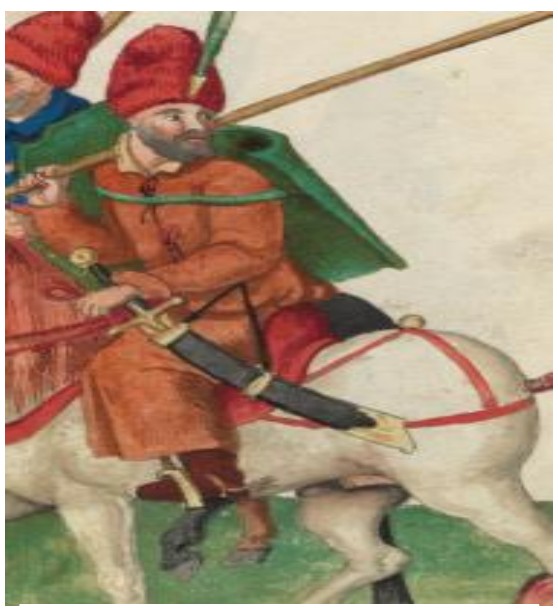

Fig. 132. Códice de trajes (s. XVI) Tipo de cimitarra

\subsubsection{La cimitarra (fig. 132)}

La cimitarra, procedente del Medio Oriente, es una especie de sable curveado que facilitaba su uso cuando se combatía a caballo ${ }^{294}$. La presencia de esta arma en la obra de Feliciano de Silva es mínima, uno de los pocos ejemplos se halla en el Lisuarte de Grecia: "Ardalid Canileo, qe a essa hora llegava, fue contra Golfón e diole con una cimitarra muy grande que traía sobre el hombro derecho que fasta la cinta lo abrió" (Lisuarte de Grecia, XXII), en donde se indica su tamaño. Esta misma característica aparece en el Cirongilio: "una gruessa lança y un fuerte escudo de muy fuertes hojas y una descomunal cimitarra en la cinta" (Cirongilio de Tracia, XX); también se dice el color: "E con gran ansia tomó con la siniestra mano una cimitarra turquesa, que en arzón del cavallo tenía" (Polindo, LXXXV). Nótese que la mención del color alude, probablemente, a que la armadura del jayán sea turquesa; y los problemas que origina su sencilla estructura: "Y el uno alçó su alabarda, y el

${ }^{294}$ Leguina, Glosario de voces de armería..., p.234. 
otro arremetió a él con su cimitarra" (Felixmarte de Hircania, L). En este ejemplo se enfrentan dos armas en desventaja, porque la cimitarra sólo posee una punta para herir, mientras que la alabarda posee tres puntas, la de la lanza, la cuchilla y la hoja de hacha, con las cuales es más fácil derrotar al enemigo, lo que sucede en este pasaje, ya que la alabarda pertenece al Donzel del Aventura, así que también es posible una categorización de armas mejor dotadas a favor de los protagonistas.

\subsubsection{Armas de emergencia}

Son poco comunes los pasajes en los que el caballero requiere armas prestadas para combatir, que por algún motivo las suyas se perdieron, quebraron u olvidaron en alguna parte del camino. El ejemplo más conocido es el de Lanzarote, cuya utilización de las armas prestadas dejó consecuencias para su futuro desarrollo, en su caso es la humillación por verse obligado a subir a la carreta como si fuera un rufián.

La obligación del caballero es continuar con la hazaña, su dificultad es no tener con qué defenderse, así que lo más recurrente será tomar la armadura de los enemigos ya muertos: "los cuales se armaron de las armas de los cavalleros muertos" (Clarián de Landanís I, XXI). Incluso, los caballeros que ya se han retirado de las hazañas, pero que por algún motivo deben emprender una aventura, solicitan ayuda para colocarse las armas:

El rey muy movido a piedad de la doncella y desseoso de emendar el tuerto que a su señora a su causa se hazía, en aquel bravo y fuerte coraçón que siempre tuvo sin que más atendiesse se apea de su caballo. E quitada el aljuba del monte dixo:

-Dad acá, ayúdame a armar d'estas armas d'este caballero muerto, e guíame por do llevan a vuestra señora, que palzerá a Dios que nos socorrerá como contino haze a los que d'él tienen necesidad. (Florisel de Niquea III, LX) 
La edad no es impedimento para que rememore sus años de lides, y como estaba alejado del combate debe mudar su prenda de gala para portar la guerrera. Esta necesidad de armas no es exclusiva de los defensores de la fe, sino que los oponentes también requieren de este favor: "Mas la jayana viéndolo venir tras sí en la sala, con un escudo y una espada de los cavalleros que allí estavan muertos lo atiende y comiénçalo de herir de muy grandes golpes" (Florisel de Niquea III, XXV). Evidentemente, el cuerpo de la jayana no está adecuado a la armadura de los hombres, por lo que sólo puede tomar las armas sueltas y defenderse con ellas. Una solución inmediata es hallada; sin embargo, no todas las piezas estarán en buenas condiciones, así que tendrán que ser abandonadas para buscar unas nuevas.

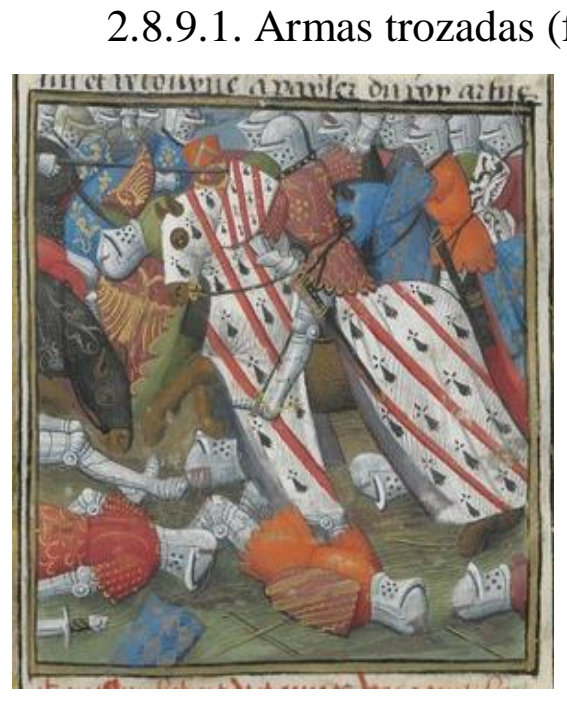

Fig. 133. Lancelot en prose (s. XV) Biblioteca Nacional de Francia. Caballeros caídos. Armas tiradas. Variedad de colores y divisas.
Hay numerosos ejemplos en los que es tan fuerte el enfrentamiento que las armas se rompen, ya sean lanzas, espadas, yelmos o corazas, hay una notable disminución del armamento a pesar de que está hecho de acero: "A esta hora Leonistán se vio menguado de su escudo, que muy poco d'él le avía quedado, sus armas despedaçadas y su yelmo de poco valor" (Clarián de Landanís I).

El primer detalle que sobresale es que el caballero ha perdido todas sus armas. Esta pérdida se relaciona con la condición física y emocional del caballero, porque en ciertos momentos el joven no está en condiciones de combatir porque sufre una pena amorosa al estar enojado con su dama; se puede recordar el ejemplo de Lisuarte, quien no puede 
terminar la aventura del yelmo a causa de un malentendido con Onoloria: "Lisuarte vos digo que estaba muy triste y pensativo por no aver acabado la aventura que por señor del mundo no quisiera allí verse hallado, ni que a oídos de su señora fuesse" (Lisuarte de Grecia, LXXIX). Además de este ejemplo, se debe recordar el más memorable en estos libros, el de Amadís y Oriana, cuando ésta duda del amor del caballero, lo que produce la penitencia de Beltenebros; ante esta fragilidad sentimental, la espada se rompe.

La mayoría de las armas rotas se debe a una situación sentimental: “Todas las reinas e dueñas e donzellas que en la sala estavan estavan muy espantadas; pues así como tengo dicho los cavalleros anduvieron cerca de una hora sin se conocer mejoría, despedaçando sus escudos que la sala estaba ya sembrada de las rajas d'ellos, pero la fortaleza de las armas resistía que las carnes no fuesen cortadas" (Lisuarte de Grecia, LXXIIII). El deterioro de las armas no es motivo de daño en el cuerpo de los combatientes, debido a la protección que brindan. Este es un ejemplo singular por el contraste entre resistencia-quebranto de los materiales, madera, cuero y metal sobre la piel. Estas pérdidas son aceptables por tratarse de la defensa de las damas.

De acuerdo con los tratados de caballería, el número de lanzas que el combatiente podía romper era tres ${ }^{295}$, en un solo enfrentamiento, después de esto no podía seguir contra otros caballeros, debía esperar cierto tiempo para tener derecho a una nueva lid. Generalmente, esto sucedía cuando se quería rescatar una prenda de la dama para restablecer su honor, así que cada día el joven justaba por una nueva doncella.

Aunque los caballeros demuestran fortaleza en sus batallas, a veces hay situaciones adversas que les dificultan el triunfo, principalmente su condición sentimental impera sobre su fuerza física, ya que, al estar enemistado con su dama, tendrá una mala participación; por

${ }^{295}$ Martín y Serrano-Piedecasas, op.cit., p.204. 
otra parte, las condiciones de las armas también influyen, pues, al no ser resistentes, los resultados serán desfavorables para el joven.

Todas las armas mencionadas anteriormente, defensivas y ofensivas, corresponden a un modelo tradicional en el que se repiten patrones de uso y de movimiento. Atacar con la lanza y la espada implicaba enterrar la punta en el costado, entre los ojos o cortar la cabeza, mientras que con la maza se golpeaba el cuerpo. Pero conforme se vive el ambiente histórico, la influencia de las guerras entre España y otros países es notoria en los títulos posteriores al Amadís de Gaula, por lo que el empleo de las armas variará un poco hasta pasar de las de mano a las de fuego y así crear combates con mayores dificultades.

\subsubsection{Armas predestinadas}

Sabias y magos tienen el poder de elaborar pruebas especiales para los caballeros desde antes de que estos nazcan. Su magia no se limita sólo a la creación de espacios, animales y pócimas maravillosas, sino que con ella pueden dejar marcas en la piel del personaje, escritos en piedras o mensajes orales que en ciertos momentos son revelados a los demás. Además, tienen la habilidad de fabricar armas especiales para ser usadas en las hazañas que les son destinadas. Éstas llevan una marca que en el futuro se conocerá a través de la revelación mágica, en el caso del Lisuarte será la propia maga Medea quien aclare el desenlace de la aventura cuando la unión de las dos espadas, la de Lisuarte y la del caballero encantado, se unan y terminen con el encantamiento. Por ello es que algunos caballeros "son seres elegidos para las aventuras destinadas a ellos" 296 por estar condicionadas a factores que se relacionan directamente con ellos, ya sea por su linaje, marcas de nacimiento o su devoción amorosa; ellos son preparados desde la infancia para

${ }^{296}$ Cacho Blecua, op.cit., p.64. 
este tipo de pruebas, que en su mayoría se tratará de enfrentamientos contra antagonistas con habilidades mágicas o de extrema fuerza y que por ello requieren de armas con la misma resistencia.

El ejemplo que se halla en el Lisuarte trata sobre una pareja enamorada que fue encantada hasta hallar a los leales amadores que los sobrepasen en virtud y amor. Cada uno porta un objeto mágico, la dama una guirnalda de flores ${ }^{297}$, el joven un yelmo. La descripción que se da de éste es la siguiente: "tras él venía un cavallero armado de muy ricas armas. En su cabeça traía un yelmo, el más extraño y rico que jamás se vio, porque era todo de un diamante tan claro que todos los de la sala claramente en él se veían" (Lisuarte de Grecia, LXXIX). Es importante destacar que en la descripción del yelmo se hace énfasis en el material con que está fabricado, diamante y no cristal, ya que la diferencia entre ambos elementos radica en que el cristal es más frágil y cambia de color si está en contacto con el frío o el calor, mientras que el diamante posee un valor superior por su cualidad, ya que "ni el hierro, ni el fuego no es possible à comprehenderla, ni à sujetarla, ni à hazer impression en ella, y mas que es mas precioso, que el oro" ${ }^{298}$, además de que es llamada ‘indomable' porque nada la puede afectar. Estas características pasan al plano literario y el lector es testigo de ellas a través de la descripción de los sucesos narrativos; por ejemplo, en un intento por alcanzar el yelmo con la mano "un caballero combatiéndose con él, pensando gelo quitar con las manos, en un punto le fueron quemadas" (Lisuarte de Grecia, LXXIX), el diamante no puede ser afectado por el fuego, pero él sí puede quemar, es su forma de protegerse para no ser separado de la persona a la que está destinado. Este receptor resulta ser Lisuarte, por ser el leal amador de esta historia y ser el más valeroso

\footnotetext{
${ }^{297}$ En mi tesis de maestría analicé las propiedades de la guirnalda como adorno femenino para el cabello. Para esta investigación profundizaré en el tema del yelmo como arma de protección para el caballero.

${ }^{298}$ Gaspar de Morales, De las virtudes y propiedades maravillosas ..., .277.
} 
caballero, quien a partir de ganar el yelmo lo utiliza en sus futuros combates, en los que se continúan viendo las propiedades del diamante: "Lisuarte alçó el escudo que no pudo desviarse del golpe. El jayán descargó en él que la mitad le derrocó en el suelo. El golpe fue por tal fuerça que, descendiendo al yelmo del fuerte diamante, como la espada en él no pudo cortar, con la gran fuerça que traía en tres partes fue quebrada, que no le quedó al rey sino solamente el puño en las manos" (Lisuarte de Grecia, XCV). Nuevamente se reitera su dureza: "yelmo del fuerte diamante" y se comprueba una de las cualidades que todos los lapidarios mencionan, que el hierro no puede traspasar esta piedra preciosa, por lo que toda arma, sea espada, lanza o escudo que intente quebrantar al diamante será destrozada en partes.

La función narrativa de este yelmo inicia a partir de su obtención por el caballero al que le estaba preparada esta misión, porque antes, sólo tenía una presencia llamativa por el material con el que estaba hecho, pero no cumplía su propósito, proteger la vida de Lisuarte, ya que desde el momento en que se lo coloca, no tiene ninguna afectación física en los enfrentamientos donde lo usa. Este motivo de la protección del caballero por medio de las armas mágicas se recrea en estos libros con diferentes matices; por ejemplo, en el Polindo también aparece un yelmo mágico que le es entregado al príncipe por las hadas que lo criaron: "un yelmo muy reluciente. Y encima d'él, una sierpe de oro muy bien entallada" (Polindo, XI). Aunque no se trata de un arma obtenida en combate, porque le es entregada directamente por las hadas, sí cumple su función protectora, ya que en una de las lides más importantes don Polindo no muere: "E diole un golpe a don Polindo por cima del yelmo con tanta fuerça que, si el yelmo no fuera encantado, lo matara” (Polindo, XLIX). Para el desarrollo de la historia "las cualidades mágicas de los objetos hacían mejores a sus 
portadores" 299 porque les dan mayor fuerza y aseguran su destino hasta el final de la trama, a fin de culminar las más importantes hazañas que no pueden ser realizadas por otros. En el yelmo de don Polindo, aunque no se menciona el material con el que está creado, sí sobresale la figura que lleva, una serpiente de oro, animal que lo identificará en toda la historia por ser la bestia que derrotó en su primera batalla.

Excalibur, la más famosa arma predestinada para ser sacada de la piedra, sólo por Arturo, es un motivo folclórico que dejó una larga tradición de piezas en espera de su poseedor, con el propósito de demostrar quién es el único y verdadero merecedor del objeto en correspondencia por sus virtudes, desde ser el más leal amador, hasta el mejor caballero del mundo, y por consecuencia, el único con derecho a heredar el reino; en equivalencia, una larga lista de nombres femeninos aparece para demostrar que las mujeres también son coherederas de esta tradición y, por lo tanto, tienen derecho a participar en dichas pruebas a fin de establecer su superioridad en belleza y en amor.

En los ejemplos analizados, el valor del objeto se incrementa por las cualidades mágicas que posee, ya que no sólo se trata de un yelmo de diamante, sino que tiene la propiedad de quemar las manos a todo aquel que no sea merecedor del yelmo, condición doblemente humillante para los caballeros porque revela su estado de "no correspondido en amores" y de "ambicioso" por querer obtener a la fuerza algo que no es para ellos. De esta manera, Feliciano de Silva no sólo preserva el modelo de hazaña de profecía amorosa, sino que reelabora el motivo de la prueba de los leales amadores agregando una connotación superior a la prenda en juego, lo que incrementa el valor de la hazaña y el significado del arma.

${ }^{299}$ Cacho Blecua, op.cit., p. 245. 


\subsubsection{Armas como accesorio}

Si se considera que la dama enriquece su vestido con las cintas de cadera porque están fabricadas en oro y piedras preciosas y de ellas cuelgan ciertos objetos como espejos, abanicos y joyas, entonces el cinturón que llevan los caballeros encima de su armadura cumple la misma función de incrementar el valor, monetario y estético, porque de él se ciñen armas como la espada, las flechas, el cuchillo, etc., además de que en ocasiones llevan otro tipo de armas: "Traía al cuello un escudo de una concha de pescado muy grande y fuerte, de la cinta traía colgada cada cimitarra muy buena y grande" (Amadís de Grecia, XXVIII). Es decir, no sólo se llevan las armas tradicionales, sino que también penden aquellas que son poco comunes.

Estos accesorios de acero tienen mayor relevancia cuando son combinados con materiales distantes a la dureza que los representa, como la tela y los cristales; en ciertos casos presentan una mayor atracción visual que los femeninos, tal es el caso de los yelmos: "El yelmo era el más rico que jamás hombres vieron, porque del cerco dél era todo cercado de muchas piedras de gran valor" (Lidamor de Escocia, LV). La vestimenta femenina que equivale al yelmo son los tocados: "venía vestida de una ropa de brocado verde con un tocado de muchos rubíes" (Amadís de Grecia, LXXII). Ambos comienzan a revestir de esplendor la imagen de la pareja desde la cabeza, en común tienen el metal con el que están fabricados sus accesorios, y la calidad se identifica por sus piedras preciosas.

La comparación de atuendos es el momento en el que compite la pareja por destacar entre los demás y para sobresalir no sólo como los más enamorados, sino como los mejor ataviados; sobre esto, Marín Pina expresa que "el vestido, de seda o acero, pasa a ser un signo cortesano, un medio de autoafirmación personal y de reconocimiento social para las damas y caballeros que pueblan estas cortes de ficción. Sus trajes nos transportan a un 
mundo colorista, sensual y rico" 300 que va en aumento conforme los escritores buscan destacar entre el gremio caballeresco para superar las creaciones de sus predecesores.(fig. 134)

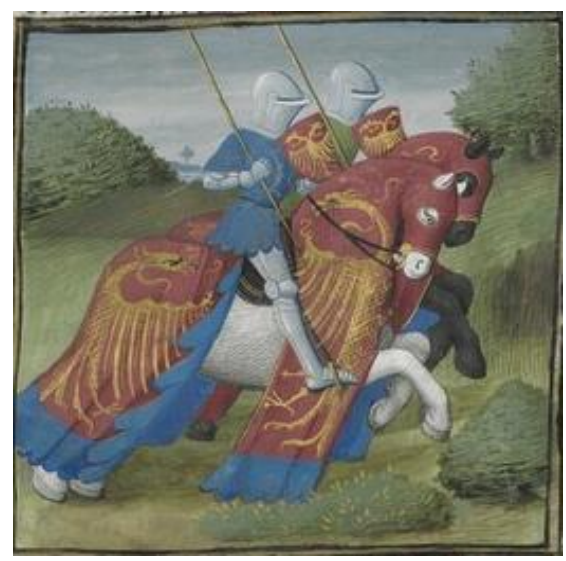

Fig. 134. Lancelot en prose (s. XV)

Biblioteca Nacional de Francia.

Misma divisa en los escudos y en las gualdrapas.

\subsubsection{Manto de combate}

Además de la capa, la sobreveste era la única pieza de tela que se llevaba sobre la armadura. La diferencia en la calidad de cada tipo de estas cubiertas está en sus forros, para los estamentos nobiliarios era de $\operatorname{armiño}^{301}$, para el resto de animales más comunes y de menor tamaño.

Como quedó desarmado, la princesa que bien avía entendido las razones que avían passado, ${ }^{302}$ mucho fue espantada y turbada, esperando ver a su amigo en tan peligrosa batalla, y, llamando a la donzella Fradamela, se descubrió un manto d'escarlata que vestido traía bordado con trenas de oro, y dándolo a la doncella, le dixo que lo llevasse al cavallero y se lo diesse, pues no tenía él manto para recibir los golpes; la donzella tomó el manto y llevolo al caballero y díxole cómo la princesa le embiava aquel manto por cuanto él no tenía ninguno con que la batalla

\footnotetext{
300 María del Carmen Marín Pina, "Seda y acero ...”, p.317.

${ }^{301}$ Medel, op. cit., p.114.

${ }^{302} \mathrm{El}$ motivo por el que el caballero no lleva manto es porque en una batalla anterior le fue destrozado.
} 
hiziesse. Él lo recibió con tanto gozo, cual jamás en su vida ovo. (Amadís de Grecia, XXVIII) (fig. 135)

El manto para combatir se conocía como "manto ducal" 303 , sus aberturas a los lados permitían el movimiento de los brazos, se colocaba encima de la cota de mallas. Llevaba el emblema que lo identificaba, por lo que era necesario que todo combatiente lo llevara, de esta manera, al participar en las justas, sería identificado por el color y la imagen bordada. No llevar este manto se consideraba una falta a las armas porque era su forma de presentación ante la corte para expresar quién era y con qué insignia se conocía.

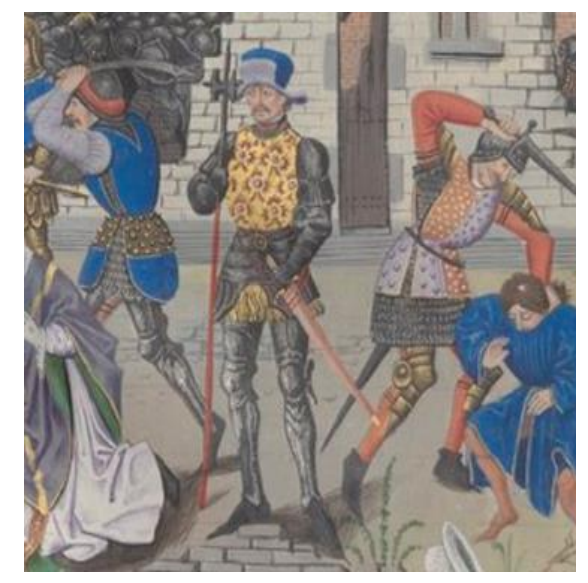

Fig. 135. Croniques abregies commençans au temps de Herode Antipas

(s. XV) Biblioteca Nacional de Francia. Caballeros con diferentes sobrevestes.

Nótese como el caballero principal usa un color más llamativo.

\subsubsection{Combatir en galas}

De los trajes de la infancia a las armas para lidiar hay una evolución en cuanto al estilo en el diseño de la armadura que se porta, ya que desde la niñez los caballeros adquieren un modo de vestir caracterizado por la riqueza de los detalles. Cuando pasan el rito de iniciación caballeresca comienzan a seleccionar sus armas y pasados los años, son capaces de diseñar sus propios trajes: "cubierto con un rico manto de fina escarlata bordada de fénix con llamas de oro que por él estaban sembradas" (Florisel de Niquea III, X). Sin embargo,

\footnotetext{
${ }^{303}$ Leguina, op.cit., p. 633.
} 
la influencia materna aún persevera $\mathrm{y}$, en ocasiones, son ellas quienes les mandan a confeccionar sus paramentos:

Esplandián va con Henil a recoger los paños que le había mandado hacer Oriana, su madre:

Henil los sacó del lio donde estavan, los quales eran muy hermosos, y sembrados de muchas flores y rosas de oro, cercadas de piedras y aljófar gruesso, y en algunas partes tenían aves, que parecía que bolassen, que la Reyna su madre los mando hazer a muy sutiles maestros, y puso en ellos aquellas hermosas piedras que de su padre y madre avia heredado. Esplandián los vistió, y ciñó encima su espada, y en la cabeça no otra cosa, salvo sus muy hermosos cabellos que los ombros les cubrían, que ante ellos el fino oro pendía su color y su haz se podía comparar a la de los Angeles. (Sergas de Esplandián, XCV)

Estas armas adquieren un valor monetario y simbólico superior porque lleva las piedras que heredó de sus padres. Las joyas y piedras sueltas ${ }^{304}$ eran de las pertenencias más valoradas entre la herencia que dejaban los padres y aún más si era una gran cantidad para adornar toda una prenda.

En el apartado anterior se analizó la vestimenta de corte para eventos como bailes y bodas, los cuales se caracterizaron por estar confeccionados por finas telas, ahora se presenta la necesidad de vestir para el espacio de las justas, sobre esto, Pelaez Flores expresa que "la función simbólica del atuendo precisa que, dependiendo del carácter del acontecimiento y según la ocasión, se tenga reservado un vestido adecuado, pues se trata, además, de una norma básica de la educación femenina" ${ }^{305}$, para Esplandián estaban guardadas estas armas, justo para iniciar su desarrollo en el ámbito bélico, por lo que su madre debía encargarse de preparar un atuendo especial, con la calidad textil que permitiera

\footnotetext{
${ }^{304}$ Diana Peláez Flores, "La imagen de la reina consorte como muestra de poder en el reino de Castilla durante el siglo XV. Construcción y significado", Medievalismo, 23 (2013), p.275.

${ }^{305} \mathrm{Ibid}, 276$.
} 
ser recordado y admirado por todos los asistentes. La armadura es el vestido del caballero, el metal se vuelve la tela que lo cubre y los esmaltes y grabados, los hilos y las piedras que adornan los vestidos; a partir de esta estructura, los atuendos masculinos y femeninos estarán en sintonía.

\subsubsection{Armas de guerra vs. Armas de cortesanía}

Las armas anteriores destacaron por su detallada composición de las imágenes con piedras preciosas en hilos de oro, cosidas para una participación en justas, tal como van vestidos la mayoría de los combatientes, pues su propósito es destacar entre los demás. Pero otro tipo de atuendo aparece con el mismo grado de confección y para el mismo espacio bélico; denominadas como armas de lujo, por ser portadas durante los eventos sin el propósito de combatir con ellas, sino sólo por la satisfacción de lucirlas en los festejos: "Traía cota y capirote francés trenado con leones de oro y una cinta de oro estrecha ceñida, y la saya y capirote se brochava con brochas de oro" (Amadís de Gaula, III, LXXIX). En esta ocasión, Esplandián sólo es espectador en las justas, su presencia se limita a estar en la palestra, pero, aunque no es el centro de atención, su condición noble le obliga a estar bien vestido al igual que las damas, quienes no lidian, pero sí es notoria su asistencia por lo llamativo de su ropa.

Esta intención crea una nueva modalidad en el uso de las armaduras, como trajes metálicos de gala, cuyo objetivo era equipararse al vestido femenino en los bailes; de este modo, el yelmo, la coraza, el escudo y la espada, conformarán un nuevo esquema de estudio para estas piezas como "el reflejo de las ideas y los temas del Humanismo mediante motivos alegóricos, religiosos, heráldicos y/o dinásticos, o recreando la tradición clásica de 
época romana" 306 , es decir, extraer el valor simbólico que el acero transmite a través de los emblemas y motes que llevan pintados y grabados con la finalidad de servir como medios de transmisión entre dos o más personajes, a fin de crear un lenguaje entendible sólo para unos pocos, pero visible para todos.

Ver las armas en función de las prendas, tanto de guerra como de gala, que distinguen al caballero entre los demás personajes por la calidad y el diseño de su armadura es un acercamiento más a la armadura desde la originalidad de cada autor, para balancear creatividad y diseño e identificar cuál dejó una mayor influencia en estas obras.

Durante el rito de iniciación, la vestidura adquiere una función importante porque simbólicamente se despoja de su indumentaria infantil para portar las prendas de caballero novel, aquellas que en un principio aparecen sin color, porque el blanco, además de simbolizar la pureza, será la base del futuro tono que adopte el caballero, cuando después de varias pruebas y enfrentamientos, fuera de su corte, se reconozca por un tipo de armas que lo inmortalicen en una batalla, por ejemplo, Perión de Gaula, en el Lisuarte de Grecia, se identificará por sus armas verdes con motivos dorados, mientras que en el Amadís de Gaula, el protagonista de esta historia será conocido como el "Caballero de la verde espada" en alusión al arma de ese color que lleva consigo. Asimismo, el uso de las armas, tanto de defensa como de ofensa, caracterizan al caballero en la destreza de una de éstas, ya sea porque le brinda rapidez, agilidad o fuerza, o porque con una sola es capaz de derribar a decenas de enemigos; aunque también es necesario resaltar aquellos elementos que le provocan obstáculos, como la dificultad en el movimiento por el peso del acero, o porque los factores climáticos no son favorables en el campo de batalla.

\footnotetext{
306 Soler del Campo, op. cit., p.148.
} 
En las armas hay una importancia narrativa por el color, la forma y el material con el que están fabricadas, además del uso que se les da y por su comparación con el traje femenino, el cual, visto desde su confección y su ornamentación, está al mismo nivel, ya que la tela es el equivalente del acero y los accesorios femeninos de las armas, porque ambos complementan el ámbito textil caballeresco dentro y fuera de la corte, así como en eventos de gala y de batalla.

\subsection{El escudo}

En el apartado anterior se estableció el uso del escudo como arma defensiva del caballero y como una de las principales protecciones en contra de los golpes de sus oponentes; sin embargo, estos dos aspectos responden a su función guerrera, en cuanto al modo de llevarlo y utilizarlo para proteger su cuerpo, pero también está el aspecto visual, en donde se establece como una de las cartas de presentación para introducir la figura del caballero en las cortes en las que participa en torneos, a través de las imágenes y letras que lleva pintadas en el acero, por lo que todos aquellos elementos, forma, color, letra e imagen, insertos en el escudo, se analizarán en conjunto para la conformación de la fama bélica del caballero y su transmisión a través de los emblemas creados a partir de estos aspectos; además de que serán la base de estudio para establecer una tipología en torno a las figuras geométricas, de animales, flores y cuadros descriptivos de escenas que cuentan historias

dentro del mismo escudo, con el propósito de conocer su trascendencia en la historia y su presencia en otros libros del género. 


\subsubsection{Elementos del escudo}

Ocultos tras una armadura de hierro, el único espacio para llevar algún tipo de distinción que los identifique se reduce a las armas, especialmente el escudo, por tratarse de la defensa con mayor superficie en la que se pueda plasmar una imagen de considerable tamaño y que sea visible para los demás; sin embargo, el escudo en sí mismo carece de sentido sin las otras piezas, especialmente el yelmo, puesto que éste, al ser colocado, cubre totalmente el rostro, impidiendo así que el caballero sea identificado por alguna seña (cicatriz, lunar, marca de nacimiento, etc.), por lo que el escudo lleva la responsabilidad de "ser un signo social gracias al cual se puede saber quién es o de quién es hijo o de qué feudo es señor el que embraza un escudo que lleva pintado determinado emblema"307. Es así que, a través de la selección de una imagen, el joven será conocido mediante su participación en justas y guerras, al menos con el sobrenombre otorgado por su insignia, misma que será recordada según los elementos que la integren; estos pueden variar en función de los elementos que se seleccionen para crear todo un emblema ornamental o servicial; es decir, como simple decoración para atraer la mirada de los espectadores, o al servicio del caballero, con el propósito de transmitir un mensaje capaz de ser identificado por una persona en especial, de tipo amorosa, o por todo un grupo de combatientes, de carácter bélico, que se sientan desafiados por la imagen que vean.

Acerca de estas imágenes, muchos tratadistas coinciden en la importancia y la necesidad de su presencia en la armadura del caballero; el primer crítico que destaca su importancia es Martín de Riquer, quien considera que las armas y el escudo "sirven para

\footnotetext{
${ }^{307}$ Martín de Riquer, Heráldica Castellana en tiempos de los Reyes Católicos, Barcelona, Quaderns Crema,
} 1986, p. 11. 
identificar a los caballeros" ${ }^{\text {308, }}$, mediante las formas y figuras que transmiten un rasgo de quien las usa; sin embargo, la primera descripción que se hace de ellas es muy general, porque sólo se indica que los caballeros son reconocidos por devisa: "mas desque llegados, conoscieron ser de su señor Amadís por los pendones y devisas que en las gavias traían, que eran los mismos que de allí avían levado" (Amadís de Gaula, LXXXIII), sin referirse a alguna seña particular. Ésta estará tanto en la armadura como en los elementos que conforman su equipo bélico, gualdrapas, blasones, telas y velas.

Posteriormente, se comienzan a dar una serie de rasgos con mayor carga simbólica, que conforman el escudo: "don Claribeo, armado de unas armas de color celeste y con unas coronas de oro por divisa y en el escudo, un campo verde, un rostro del cual salían unos rayos que en un coraçón daban, con una letra que dezía: "Árdome sin morir, / mas no espero de vivir" (Polindo, LXVII). Estas primeras características que sobresalen del escudo son el color, la imagen y la letra. Sobre ellas, Alberto Montaner expresa que "la heráldica se caracteriza por presentar la función emblemática identificadora, es decir, por vincular unas armerías a un titular concreto [y también] como miembro de una familia o (usadas como insignia) de una colectividad"309; para lograr esta relación imagen-pertenencia, se necesita un proceso de construcción del emblema, entendido como "cualquier elemento visible que es representación simbólica de una persona física o jurídica, singular o colectiva, y que traduce una identificación personal, un vínculo familiar o comunitario, una posición social o un mérito individual" 310 cuyos elementos se van entrelazando por partes; puesto que primero se indica el color: "Don Gervasio llevava un escudo, en el campo

\footnotetext{
${ }^{308}$ Martín de Riquer, "Las armas en el Amadís...”, p. 166.

${ }^{309}$ Alberto Montaner Frutos, "Identificación, evocación y conformación en los emblemas heráldicos: el caso de las armas parlantes", Emblemata, 18 (2012), p.46.

310 Alberto Montaner Frutos, "La emblemática caballeresca y la identidad del caballero», en Eva B. Carro Carbajal, Laura Puerto Morro, María Sánchez Pérez (eds.), Libros de caballerías (de «Amadís»al «Quijote»): Poética, lectura, representación e identidad, Salamanca, SEMYR, 2002, p. 268.
} 
verde" (Baldo, XVIII) de forma individual y posteriormente grupal: "el rey de Tiro armado de fuertes y ricas armas estava acompañado de los príncipes de su parte y las armas eran todas verdes" (Florisel de Niquea II, XXIV). Posteriormente se sitúa por la imagen, de igual manera como única para el caballero: "Y el escudo era bueno e traýan en él fegurada la cabeça de Amarán ansí como él gela cortó e la mano de Palmerín como la tenía por los cabellos; y alder[r]edor del escudo avía muchas piedras preciosas de gran valor" (Palmerín de Olivia, $\mathrm{XC}$ ), y en conjunto "ivan dozientos cavalleros con las sobreseñales verdes y sus devisas, armados de ricas armas" (Florisel de Niquea III, XXXIII). Finalmente, la de mayor dificultad para unir entre varios personajes están las letras, debido a que éstas responden a una necesidad de comunicar un mensaje propio, de acuerdo con las aventuras que cada caballero obtiene.

\subsubsection{Constitución del emblema}

La composición heráldica entendida como "l'association et la disposition des figures et des couleurs à l'intérieur de l'écu"311 intensifica el significado que adopta todo el escudo al momento de portarse en el campo, puesto que ya no se trata sólo de presentar un color específico, una imagen y una letra como medio de identificación al momento de combatir, sino que es necesario que esos tres elementos se integren al simbolismo que relaciona la personalidad e historia de cada caballero con el motivo por el que ha seleccionado una imagen específica.

Como inicio, hay dos casos en la adquisición de la divisa, por voluntad propia, o por imposición de algún personaje. En la primera situación, uno de los más memorativos ejemplos se halla con Amadís de Grecia, quien por un deseo amoroso decide llamarse

\footnotetext{
311 Michel Pastoureau, Figures et couleurs: études sur la symbolique et la sensibilité médiévales, Paris,
} Léopard d'or, 1986, p.205. 
"Caballero de los luceros", complementándolo con la imagen de un rostro en medio de un lucero que lleva en su escudo; en el segundo aspecto, su insignia se le impondrá por testigos, sus compañeros fieles o damas auxiliadas que al ser rescatadas, recompensarán al caballero con un sobrenombre, tal como sucede con Amadís de Gaula, conocido como el "Caballero de la verde espada": "no es aquél su derecho nombre, mas porque dizen que trae una grande spada de un guarnimiento verde" (Amadís de Gaula, III, LXXVII). Es así, como la representación de la fama se lleva por elección o imposición, conservando el momento de gloria por cierto tiempo a través de la imagen representativa que lo dará a conocer en otras cortes. Sin embargo, habrá un constante cambio de insignias, debido a las numerosas hazañas en las que participa, motivo por el que, tras cada participación bélica, según el grado de importancia narrativo, adquirirá nuevos sobrenombres y con ello, distintas imágenes que lo identificarán en varios momentos de la historia.

El grado de complejidad de la insignia responde al contexto en cómo se desarrolló la aventura y a los elementos significativos que en ella destacan, tales como palabras, imágenes humanas, elementos de armas, instrumentos femeninos, animales o flores, así como los colores predominantes que llevan relación con el proceso de la historia; como ejemplo, destaca el escudo del rey Grifilante en el que se integran todos los elementos mencionados anteriormente, especialmente el tono verde, en memoria de su victoria contra una sierpe, bestia que había atacado su reino por mucho tiempo: "traía unas armas verdes sembradas de sierpes, y en el escudo una sierpe con dos cabeças cortadas (esto traía él por una sierpe muy fiera que él mató, que mucho daño en su tierra fazía)" (Lisuarte de Grecia, XLII). La rememoración de las hazañas dependerá del guerrero, por su deseo de conservar el triunfo de su más grande hazaña a través de la pintura, o por una imposición externa, que 
determina la fama del paladín con cierto sobrenombre que portará hasta obtener una nueva aventura merecedora de plasmar en las armas. Lo mismo ocurrirá con las letras.

La mayoría de las veces estará en función de la selección personal del caballero el tipo de invención que desee llevar: "E como cada uno ordenase las invenciones que de sacar avía a estas justas, todos los oficios andavan faziendo sus obras con tanto rumor que parecía que todo el mundo se hundía" (Polindo, LXVI), pero la responsabilidad de plasmar la divisa en las armas recaía en los armeros, tinteros, orfebres y grabadores, según el material con el que se elaboraran. Si se trataba de la pintura debían disolver el polvo de pintura para aplicar una primera capa que protegiera el acero del óxido. En el caso del repujado se utilizaban láminas de oro y plata que eran martilladas ${ }^{312}$ hasta conseguir la figura realzada y aplicarla sobre el escudo.

Segundo, la unión imagen más letra debía estar en clara armonía para el espectador, de tal manera que entre los versos y el dibujo no hubiera necesidad de mayor explicación por tratarse de temas genéricos que todos conocen, como el amor: "Y en los escudos, unas puertas que con una llave cerradas estaban. E alrededor de los escudos, unas letras azules en campo dorado que dezían: Pues son cerradas las puertas / donde mi bien yazía, / ciérrense al alegría” (Polindo, LXX). La representación gráfica del amor aprisionado, ya sea por sufrimiento de la pareja o porque uno de los dos no corresponde a este sentimiento se demuestra a través de un espacio cerrado al que sólo puede acceder quien tenga la llave, es decir, el favor de la dama. Este motivo es visible en la corte española de los Reyes Católicos, con el rey Fernando, quien también en unas justas lleva una divisa similar en clara alusión a sus sentimientos por la reina Isabel: “Cualquier prisión y dolor / que se sufra es justa cosa, / pues se sufre por amor / de la mayor y mejor / del mundo y la más

${ }^{312}$ Matthias Pfaffenbichler, Armeros, Madrid, Akal, 1998, p. 70. 
hermosa" 313 , la imagen que acompaña a los versos se trata de una red de cárcel o reja, exhibida durante un torneo de Valladolid en 1475. Dicha invención se recoge en el Cancionero General de 1511. Este simbolismo de aprisionamiento amoroso no es exclusivo de las armas, sino también las damas responden a este deseo por medio de sus vestidos: "y la infanta estaba vestida de una ropa de seda verde, sembradas por ella muchas rejas de oro a significación que esperaba prender alguno". (Florambel de Lucea I-III, XVI).

Caso particular se halla en la complementación de la imagen y las letras entre el escudo del caballero y de sus escuderos: "El escudo no avía figura ninguna salvo unas letras que dezían: <<El Vencido de Diana〉>. Traía tras sí dos escuderos, cada uno traía tres escudos colgados de los arzones, todos con las imágenes de Diana" (Florisel de Niquea III, $\mathrm{XV}$ ). Esta disposición del mote y la imagen responde al nombre del personaje: "-Mi nombre, señora doncella -dixo él-, es el Cavallero del Letrero. -Digo's que por esas señas os tengo bien conoscido - dixo ella, mas viendo que se quería encubrir, para su compañera se torna" (Florisel de Niquea III, XV). Este es un ejemplo único de la conformación de la invención por medio de dos escudos; por una parte, la letra, por otra, el retrato. En este pasaje sí es necesaria la presencia de todos los escudos juntos, ya que el Cavallero del Letrero quiere reafirmar quién es su dama, y mostrarla a los espectadores; de no ser así, sólo los escudos con los rostros podrían evocar a cualquier dama.

El juego de palabras en unión con la imagen son condiciones que permiten la aparición de "nuevas estrategias de guerra verbal, trátese de poesía, trátese de motes o

\footnotetext{
${ }^{313}$ Nieves Pena Sueiro, Sagrario López Poza, "CUALQUIER PRISIÓN Y DOLOR / QUE SE SUFRA ES JUSTA COSA, / PUES SE SUFRE POR AMOR / DE LA MAYOR Y MEJOR / DEL MUNDO Y LA MÁS HERMOSA", en Symbola: divisas o empresas históricas. - BIDISO (Biblioteca Digital Siglo de Oro), A Coruña (España) [en línea]. Publicación: 16-08-2017. Actualización: 16-08-2017. <https://www.bidiso.es/Symbola/divisa/137> [Consulta: 13-11-2018].
} 
cualquier otro encuentro, exigen pronto ataque y defensa" ${ }^{\text {314 }}$. Lo visual de las letras no sólo se reduce a la ornamentación de las armas, sino a una invitación para participar en los torneos contra aquellos caballeros con los que cada uno se siente identificado, o, dicho de otra forma, en contra de quienes se han sentido desafiados por los mensajes implícitos de la armadura. Es decir, el campo de batalla se convierte en una suerte de repertorio poético en donde cada justador selecciona los versos que quiere borrar a través del duelo y aquellos que desea conservar por medio de la fama.

La importancia de las imágenes tan detalladas se debe a que hay "una tendencia a exagerar los rasgos más característicos de las figuras, que en la guerra y en el torneo tenían que ser identificadas desde lejos; que se intenta no dejar el escudo con espacios vacíos y zonas exentas de decoraciones" ${ }^{315}$, en este contexto, uno de los elementos a distinguir serán las figuras humanas, especialmente los rostros, de los que hay un gran porcentaje en estos libros y de los que sobresale uno en especial, en el Primaleón, en donde se plasman dos damas: "e luego salió de otro palacio muy rico un cavallero armado de unas ricas armas e traýa embraçado un escudo muy bien fecho y en él traýa figuradas dos donzellas, e la una parecía que tenía un velo delante del rostro, que no se lo podían bien ver, e la otra, que muy fermosa parescía, tenía un coraçón llagado en sus manos e la otra parecíale que la forçava por tomárgelo" (Primaleón, LXX); esta mención “que no se le podían bien ver” indica al lector cierto grado de complejidad en el diseño de la imagen; caso contrario se observa en la segunda parte del Espejo de príncipes y caballeros, en donde los detalles son muy minuciosos a pesar de tener más elementos pintados: "la cual traía un escudo muy rico, en

\footnotetext{
${ }^{314}$ Alberto del Río Nogueras, "Del caballero medieval al cortesano renacentista. Un itinerario por los libros de caballerías", Literatura Medieval. Actas do IV Congresso da Associação Hispânica de Literatura Medieval (Lisboa, 1-5 Outubro 1991), V. I, Lisboa, EDIÇŎES COSMOS, 1993, p.76.

315 Martín de Riquer, Heráldica castellana: En tiempos de los Reyes Católicos, Barcelona, Biblioteca Filológica Quaderns Crema, 1986, p. 160.
} 
el cual tenía pintado un árbol, el medio de plata, tenía desgajada una rama, de la cual roxa sangre le salía; la otra mitad era de oro; en él parescía un caballero, porfiando de romperle un ramo, en el escudo avía unas letras que dezían: <<Porfía a vezes vence ventura >> (Espejo de píncipes y caballeros II, XXIV). Es decir, a mayor espacio, mayor cantidad de elementos para dibujar, pero también incrementa la dificultad de distribuir adecuadamente las letras y las imágenes para que sea visible en la lejanía.

\subsubsection{Los colores}

La presencia del color es relevante en muchos episodios caballerescos, en donde la fiesta es el evento principal para mostrar sus galas, en el caso de las damas, los más elaborados trajes, llenos de pedrería e hilos de oro, mientras que en los caballeros, el espacio en donde más se distinguen por lo llamativo de sus trajes es en las justas, espacio de recreación y entrenamiento en las armas; cada uno porta las armas de su corte, en su mayoría, pero también se distinguen por el desconocimiento que ocasionan al estar ocultos tras el yelmo y llevar divisas nunca antes vistas. Sin embargo, el uso de colores en las armas no es una cuestión de mera selección al azar, sino que responde, en su mayoría, a una serie de cuestiones emblemáticas establecidas en los tratados de armas, mismas que hasta la época de esplendor de este género se siguen conservando, pero que en ocasiones presentan ciertas variantes significativas en torno a la mezcla de tonos y a la apropiación de otros por parte de ciertos personajes como una estrategia de reconocimiento en cuanto salen al campo de batalla. Por lo que es necesario distinguir cuáles armaduras conservan los lineamientos tratadistas de la época y cuáles quebrantan las normas para adquirir notoriedad en los torneos. 
Para los tonos se indica, de manera general, que siete son los colores que se utilizan para pintar y adornar los escudos: oro, plata, rojo, azul, negro, verde y morado. Sobre estos, Barthélemy l'Anglais, ${ }^{316}$ en su tratado sobre los colores, los establece en principales, negro y blanco, medios, azul, amarillo y rojo, e inferiores, que coloca al verde y al morado o púrpura, por la calidad y nobleza que cada uno presenta.

\subsubsection{Blanco (fig. 136)}

El momento de la investidura es la entrada del doncel al espacio de la guerra, es su primer contacto con las armas, por lo que debe de haber un cambio de hábito de la niñez a la juventud, en donde se despoja de sus primeros trajes ${ }^{317}$ de corte para cubrirse con el metal. Esta acción, encabezada por un rey, cuya mano tiene el poder de armar caballero a los paladines, tiene como trasfondo la selección de las armas, en cuyo caso la norma establece que deben ser blancas, debido a que: "los caballeros noveles suelen llevar armas blancas distintivas" ${ }^{318}$, por lo que al tomar las armas, todos los donceles visten de blanco: "y de la princesa Elena rescibió una espada muy rica que don Florisel le dio, estando armado de armas blancas muy ricas, como de caballero novel" (Florisel de Niquea III, IV).

Fig. 136. Triunfo del Emperador Maximiliano I (ss. XVI-XVII)

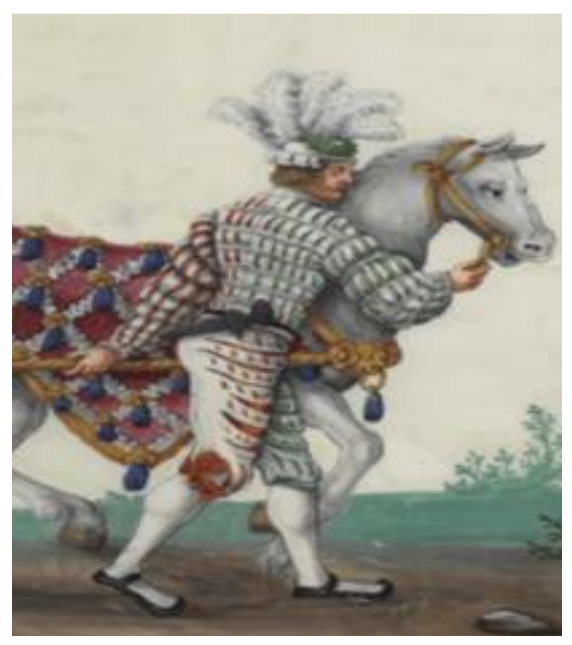

316 Barthélemy l'Anglais, El libro de proprietatibus rerum, trad. du latin en espagnol par Vicente de Burgos, Tholosa, 1494. En línea: https://gallica.bnf.fr/ark:/12148/bpt6k54513p/f6.image (20/11/2018)

317 Acerca del primer contacto de los niños con la vestimenta se puede consultar mi artículo "Moda infantil en los libros de caballerías I. Trajes de corte", en prensa.

318 Juan Manuel Cacho Blecua, Amadís heroísmo mítico cortesano... p. 88. 
También aparecen excepciones en las que se utiliza el blanco como base para colocar encima otro tono o ciertas imágenes a manera de portar sus primeras divisas: "se concertaron en fazer sus armas y devisas de una manera, y las armas eran todas blancas como convenía a los cavalleros noveles, y las sobreseñales lo mismo, sembradas por ellas muchas estrellas de oro" (Florambel de Lucea I-III, IV).

Aunque también puede ocurrir que en lugar del blanco se seleccione algún color claro para recibir la orden de caballería. Esta selección es permitida según uno de los puntos del Doctrinal de caballeros, en el que se indica que:

paños de colores señalados establecieron los sabios antiguos que trajesen vestidos los cavalleros noveles, mientras que fuesen mancebos, assi como colorados o faldes, o verdes, o morados cárdenos por que les diesse alegría. Mas prietos o los pardillos o otra color fea que les ficiesse entristecer, no tubieron por bien que los vistiesen. Esto fizieron por que vestiduras fuesen mas apuestas et ellos andobiesen más alegres et los gestiesen los corazones para ser mas esforzado. ${ }^{319}$

Aunque se da esta pauta al seleccionar las primeras armas, en general, se hallarán pocos caballeros vestidos de esta manera durante su ceremonia de investidura.

Según los ejemplos presentados se puede establecer la idea del uso del color blanco como símbolo de pureza, puesto que el caballero inicia con cierta inocencia y durante el desarrollo de sus aventuras se conocerá el tipo de caballero, defensor o vil, que será; sin embargo, también se revela el blanco como la base para el color que seleccionará el caballero a fin de que lo reconozcan en sus futuras hazañas. Es decir, se convierte en una especie de fondo neutro que acoge cualquier otro esmalte que se le coloque encima, permitiendo la facilidad de decoración y la combinación de figuras y formas.

${ }^{319}$ Alonso de Cartagena, Doctrinal de cavalleros, lib. I, t. $3^{\circ}$, p.18. 


\subsubsection{Oro y plata (fig. 137)}

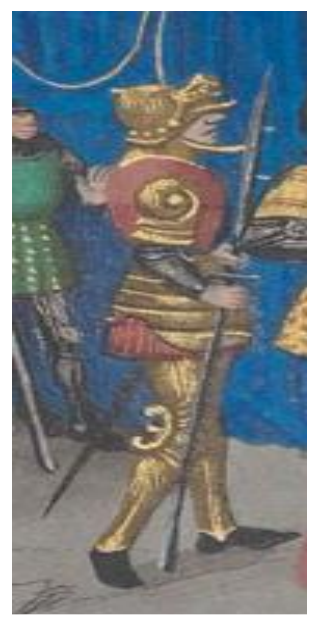

Fig. 137. Croniques abregies commençans au temps de Herode Antipas (s. XV) Biblioteca Nacional de Francia.
Posterior a la toma de armas y después de participar en varias hazañas es cuando el caballero adquiere su primera armadura, seleccionada por él u otorgada por otro personaje, en las que generalmente se fija la imagen del primer ser contra el que combatió y al que derrotó y del que adquirirá su primer sobrenombre, además de que la importancia del color es mayor por relacionarse el estado de ánimo del caballero, así como su carácter y forma de ser con los demás; factores que permiten una comprensión mayor del personaje.

Los primeros dos colores que se destacan y que al mismo tiempo fungen como metales, son el oro y la plata de los cuales se dice que:

el más noble de los colores e de los metales deve estar en el primero e más alto lugar, que son los más nobles. Por entendimiento de los quales de saber que los dos metales que se acostumbran poner en las armas passan a los colores en dignidad. La razón es por que los metales son colores, e los colores non son metales. Onde aquellas armas que un solo metal ovieren, non serán tan onorables quanto las que ovieren los dos metales. E aquesta es una de las razones por que los cavalleros armados en batalla o en fuerte conbate, por mas onor pueden traer oro e plata [...] (Cadira de honor)

Una de las reglas de la heráldica prohíbe la colocación de metal sobre metal y color sobre color; sin embargo, en estos libros hay un quebrantamiento de esta y otras normas para la conformación del emblema, por el dominio de la ficción sobre las reglas del blasón. ${ }^{320}$ En un primer momento, los cambios más significativos destacan la combinación de la plata y oro en un mismo escudo: “en el escudo que avía el campo de oro traía pintada en lo alto

\footnotetext{
${ }^{320}$ Emilio Sales Dasí, "Una primera aproximación a la heráldica literaria de las continuaciones caballerescas del Amadís de Gaula", Emblemata, 9 (2003), p. 220.
} 
d'él una media luna de plata" (Florambel de Lucea I-III, XLIII) y en una espada: "e vio la espada de Tristán a la cabecera, e parescióle hermosa, de oro e de plata bien guarnida" (Tristán de Leonís, XIII), aunque también son notorios estos metales por separado, principalmente cuando se trata de destacar su superioridad, por lo que es necesario saber que:

De los colores qual sea de más nobleza es bien de considerar, por quanto un color se puede deçir más noble que otro en dos diversos modos. El un modo es aviendo respecto a la cosa que representa; e segund esta consideración, el color del oro decir se puede más noble, por quanto representa la luz, que segund la divina e humana sçiençia después del ánima razonable, es la cosa más noble del universo. E los rayos del sol, que es cuerpo más luminoso, d[e]él se pueden más apropiadamente figurar. (Cadira de honor)

Para así comprender la importancia del oro y la plata sobre un fondo liso, sin otro tipo de esmalte porque se obtiene un contraste de tonos: "La donzella salió fuera e, yéndose contra los donzeles, ellos se fueron contra ella. Apeándose de sus caballos, vieron que traía a su cuello una espada muy ricamente guarnida e un escudo negro en el medio pintada una espera de oro" (Lisuarte de Grecia, I). Esto permite tener una primera referencia de la necesidad de destacar ciertas divisas, como un medio para retener por más tiempo la figura representativa del caballero.

\subsubsection{Rojo (fig. 138)}

Michel Pastoureau expresa que este es el color "en las novelas artúricas de los siglos XII y XIII, de los numerosos caballeros bermejos - es decir, aquellos cuya vestimenta, equipo y escudo de armas son uniformemente rojos- que aparecen en el camino del héroe para desafiarlo o para matarlo". ${ }^{321}$ Aunque es cierto que hay algunos ejemplos de armas bermejas en los libros de caballerías del siglo XVI, el sentido es opuesto al dado por

${ }^{321}$ Michel Pastoureau, Una historia simbólica de la Edad Media occidental, Buenos Aires, Katz Editores, 2004, p. 227. 
Pastoureau, ya que "lo colorado se puede a este respecto decir más exelente, en quanto representa el fuego, cuerpo luçífero, el más digno de los elementos” (Cadira de honor).

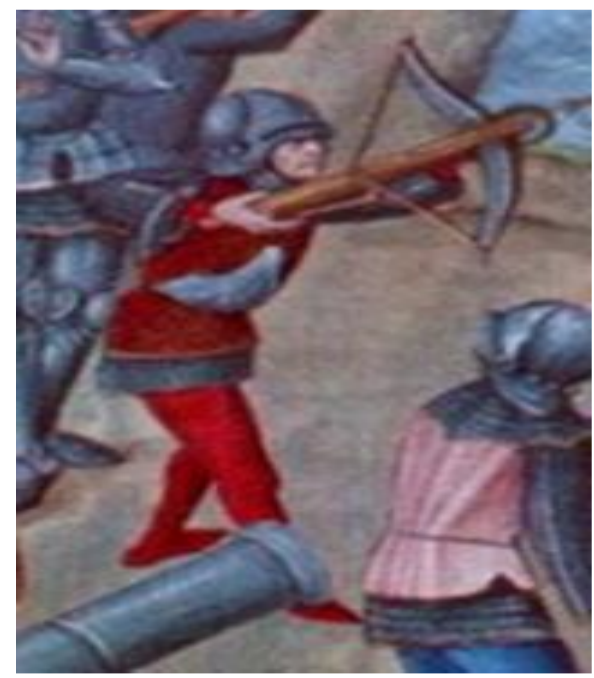

Fig. 138. Croniques abregies commençans au temps de Herode Antipas (s. XV)

Biblioteca Nacional de Francia

Esta significación se refleja en Brimartes, caballero leal en el amor y dedicado en la batalla para ganar más el aprecio de su querida Onoria. Sus armas se distinguen por la divisa que lleva: "la doncella tomando un lío que un hombre le traía lo deslió, y sacó d’él unas armas muy ricas; todas eran bermejas y muy buenas; con ellas traía un escudo de azero de la misma massa que las armas salvo que avía el campo de oro y en el medio un olmo muy bien obrado" (Amadís de Grecia, LXV).

El olmo en el escudo responde al nombre de su dama, Onoria ${ }^{322}$, que corresponde a la primera letra "O”, pero también concuerda con el significado del árbol, porque según el Tesoro de la lengua es "símbolo del que apoya a otro, que sin su favor no podría valer, ni subir como la parra que se abraça con él". Este simbolismo es visible pues el propio personaje confiesa que sólo puede ser derribado por aquella a quien pertenece su corazón. Junto a esta connotación sentimental, se iguala una divisa floral:

322 María Coduras Bruna, DINAM. Diccionario de nombres del ciclo amadisiano. Disponible en: <http://dinam.unizar.es> [Acceso el 30/11/2018]. 
un cavallero grande y bien fecho asentado en una rica silla armado de unas armas todas bermejas trenadas de oro y perlas de gran valor, sembradas todas de unos manojos de flores de oro que llaman alegría; el escudo, ansimismo, avía grande de la misma suerte, y en él seis manojos de las mismas flores. Ante la tienda estaban cuatro cavalleros todos ricamente arreados con paramentos de las mismas flores a manojos; eran de carmesí bordados de mucha argentería y aljófar, los cuales tenían hombres vestidos todos de xamete bermejo bordados de la suerte que los paramentos. (Amadís de Grecia, LVIII)

La riqueza del escudo está en la divisa y en las perlas que lo adornan. Por una parte, hay un avance significativo en torno a la decoración de las armas, pues el escritor ya no se conforma con la tinta y las letras, sino que es necesario la acumulación de más elementos. En este aspecto, destacan los manojos de una flor llamada "alegría"; ésta se trata de "la flor que da la semilla de sésamo, es de forma romboidal y en Andalucía se le da el nombre de alegría a la forma romboidal" 323 . Esta divisa oculta el deseo de Amadís de combatirse contra Lisuarte por el afecto de Abra, de ahí la simbología de los manojos de flores, que inician con la "A" de Abra y que en victoria de tal enfrentamiento otorgará alegría.

Aunque son pocos los ejemplos de armaduras bermejas, este último es el más relevante por los símbolos ocultos tras las flores y que hasta la fecha la crítica ha ignorado la importancia de que Feliciano de Silva enfatice el nombre de la flor.

\subsubsection{Azul (fig. 139)}

El cuarto color en nobleza es el azul, de éste se menciona que “después d[e]éstos, el más onorable será el azul por el qual el aire, cuerpo diáfano amigable a la luz, después del fuego el más noble de los elementos, se suele representar" (Cadira de honor). Coloración más

\footnotetext{
${ }^{323}$ François Rozier, Nuevo diccionario de agricultura, teórica-práctica y económica y de medicina doméstica y veterinaria, T. I, Madrid, Boix, 1842, p. 177.

El Tesoro de la lengua también la menciona como una semilla de granos dulces para hacer muéganos, pero no dice su forma.
} 
popular a partir del siglo XII por aparecer en el emblema real del rey de Francia, en su famoso escudo de "azur sembrado con flores de oro" ${ }^{\text {"24 }}$, cuyos elementos estarán presentes en las vestiduras reales para la coronación de Felipe II de Francia (1180) y en la de Luis VIII (1188).

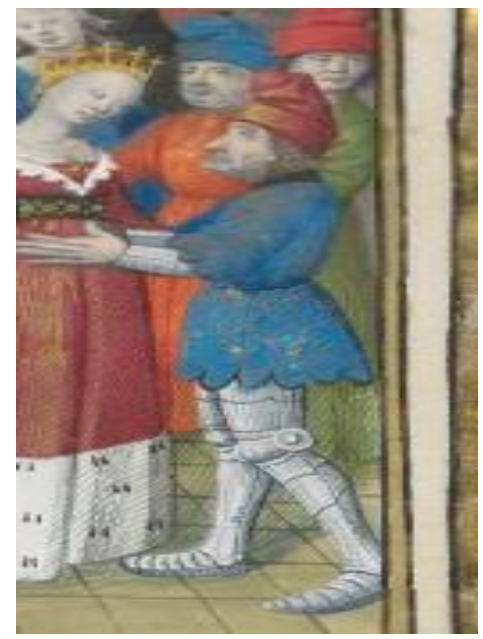

Fig. 139. Lancelot en prose (s. XV) Biblioteca Nacional de Francia.

Esta tonalidad también tendrá notoriedad en las armas, como sucede con el escudo de Dumaine de Gueules (1292), mientras que en España el escudo más representativo de este color es el de los Quiñones, cuyo centro lleva "veros azules". Esta constitución, campo azul con una imagen central es común en los libros de caballerías; uno de los ejemplos más conocidos son las armas de la reina Pitiquinestra, quien "traía unas armas azules con unas trenas de oro por ellas e un escudo grande, assí mesmo el campo de azul [y] en el medio tenía figurado un jayán muerto (este traía ella porque venció un jayán su vezino e por fuerça le tomó toda su tierra)" (Lisuarte de Grecia, XLII). En el ámbito literario, su presencia sobresale por la combinación con el oro, que en repetidas ocasiones tendrá notoriedad tanto en accesorios de palacio, como en complementos de atuendos; por ejemplo, tiene notoriedad la referencia al escudo del Caballero de los Leones, en el Florambel de Lucea: "llevava unas armas azules y leones de oro por ellas y en el escudo,

${ }^{324}$ Michel Pastoureau, Azul. Historia de un color, Madrid, Paidós, 2010, p. 62. 
qu'el campo avía azul, llevava pintado un león de oro" (Florambel de Lucea I-III, VI), hasta aquí sólo se indica la presencia del animal, pero en el Felixmarte de Hircania se menciona la posición del león: "armado de unas armas azules orladas con oro, y en el escudo en campo azul traía un león de oro levantado con los braços abiertos" (Felixmarte de Hircania, LII). Las divisas para los escudos del Florambel y del Felixmarte es la imagen del león. De éste se ha dicho que es rey de los animales, valiente y agresivo y con varias maneras para dominar ${ }^{325}$, su sola presencia impone y adquiere más relevancia según la posición de sus patas. De las imágenes descritas sólo se da una pose: "traía un león de oro levantado con los braços abiertos", ésta adquiere relevancia de acuerdo a uno de los estatutos dados por Diego de Valera, el cual indica "Ca si queremos pintar un león, que es fiero animal, en ninguna manera tanto du feroçidad paresçerá como estando levantado en salto"326, posición que otorga más notoriedad a quien lo lleva, además de que hay otra vinculación en torno al uso de animales para los emblemas, al menos en algunos libros de caballerías analizados, se trata de identificar el desarrollo del caballero, que de acuerdo a su fama y a su función bélica demostrada desde que toma las armas, será la notoriedad de sus divisas, por ejemplo, en comparación al león de Punarteo de Inglaterra, quien es el caballero que lleva ese escudo, están aquellos en los que se demuestra que por sus muchas victorias son coronados como los mejores caballeros: "y en el escudo, un león e campo verde. Y este león era coronado. Y en el cerco del escudo, unas letras que dezían: <<De tu mesma progenia $>>$ (Polindo, LXX), denotando así no sólo la fortaleza, sino la condición social a la que pertenece.

\footnotetext{
${ }^{325}$ Ignacio Malaxecheverría, Bestiario medieval, Madrid, Siruela, 2008, p. 90.

${ }^{326}$ Diego de Valera, Espejo de verdadera nobleza, ed. crítica de Federica Accorsi, Universidad de Pisa, 2011.
} 
Sin lugar a dudas, esta combinación, azul y oro, es la que más predomina en los episodios de corte en los libros de caballerías, debido al contraste que se obtiene entre el fondo azul y la pintura de oro, ya que "el escudo de armas nació para que, desde lejos, en la guerra y en el torneo, se vieran con toda claridad los elementos y tintes que acreditaban la personalidad de quien lo embrazaba" ${ }^{327}$. Por ejemplo, lo llamativo de la unión azul-oro se une al tamaño de la divisa: "Venía todo armado de unas armas muy ricas; eran todas indias y por ellas sembrados muchos luzeros de oro; traía en su cuello un escudo grande de azero, el campo ansimismo indio; en el medio avía un luzero muy grande hecho de tal suerte que resplandecía como los rayos del sol, tan claro era; en medio d'él venía un rostro de doncella con una corona en la cabeça; era tan hermoso el rostro cual nunca jamás se vio" (Amadís de Grecia, 65). Lo destacable es la luminosidad dorada que produce el destello del rostro sobre un fondo oscuro que de acuerdo a la descripción del tamaño del escudo era más fácil que lo vieran desde lejos.

\subsubsection{Negro (fig. 140)}

Sin duda alguna, el negro presenta una dualidad en su composición y en su simbolismo. Primero porque para obtenerse es necesario conocer las distintas tonalidades ${ }^{328}$ que de él se pueden tener, esto es un primer obstáculo en los ejemplos a analizar porque no se indica ninguna variante, como sí puede llegar a ocurrir con el azul. Segundo, la idea que se tiene de reflejar la bajeza y vileza, expresada por varios tratadistas, como lo menciona Rodriguez del Padrón cuando dice que:

\footnotetext{
${ }^{327}$ Martín de Riquer, Heráldica Castellana..., p.86.

328 Para conocer el proceso de obtención de los distintos tonos de negro y su aplicación a las armaduras y gualdrapas, así como de otros colores, véase: Cennino Cennini, El Libro del Arte, Madrid, Akal, 2014.
} 


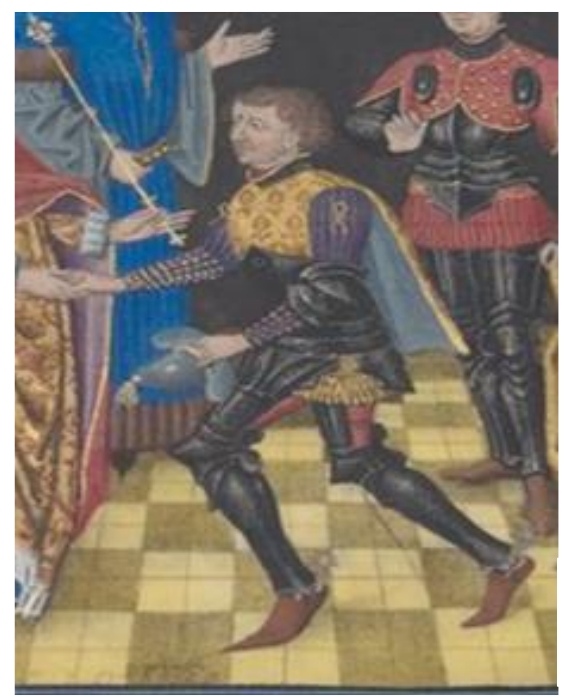

Fig.140. Croniques abregies commençans au temps de Herode Antipas (s. XV) Biblioteca Nacional de Francia.

El otro modo es quando se dize un color más exçelente, segund su propia dignidad, e non de aquella cosa representa. E commo la luz sea la más noble, e el su contrario sean las tinieblas, e por consiguiente más viles, lo blanco, que es el color más claro e más çercano a la luz, segund so propia dignidad, será más noble e más exelente; e lo negro, qu[e]es más cercano a las tinieblas, será más baxo e de menos nobleza. Onde los medios colores, segund que más menos a lo blanco o a lo negro se açercan, serán dichos nobles o menos nobles. (Cadira de honor)

Y que, generalmente, a los caballeros de acciones viles, se les caracteriza con armas negras, como sinónimo de negatividad en su andar; el más conocido personaje de este tipo y de quien la crítica ha presentado numerosos estudios es Arcaláus el Encantador, el mayor de los personajes antagónicos de estos libros. Si se recuerda su aparición desde el libro I del Amadís, es notable su formación negativa y la bajeza de sus acciones ante Amadís, reflejo de ello es su característico escudo: “campo negro y un león assí negro, pero había las uñas blancas y los dientes y la boca bermeja" (Amadís de Gaula, II, XLIV), que responde al valor negativo que se le da al negro, además de que armoniza con el desarrollo de Arcaláus, quien en algunos pasajes relevantes aparece oculto para no ser reconocido, como sucede cuando porta las armas de Amadís para tratar de engañar a toda la corte. 
Posterior a Arcalaús, los personajes que rompen las normas sociales por su comportamiento se caracterizan por llevar tonos oscuros. Un particular ejemplo, en correspondencia a nombre-color-vileza está en el primer libro del Clarián: "Boraldán el Salado vino armado de las armas negras que de antes traía, su escudo era todo negro y figurados en él siete leones" (Clarián de Landanís I, LXXVII). El color de las armas, en este ejemplo, responde a su condición vil de quererse apropiar del reino de Arminda, joven por la que pelea Clarián para restaurar su honor. Este simbolismo finaliza con la derrota del antagonista: “-Boraldán, muerto sois, si noos otorgáis por vencido y confessáis por vuestra boca ser falsedad y mentira lo que vós sosteníades y que el Ducado es de la Duquesa y de su hija Arminda" (Clarián de Landanís I, LXXVII). En armonía con su adjetivo "el Salado" está el fracaso de sus acciones, ya que ni obtuvo el ducado, ni la mano de Arminda, ni el título de esforzado caballero, por lo que su presencia finaliza con su lejanía de esta corte.

En algunos momentos se rompe esta concepción por el origen en cómo se portan las armas y con qué fin se viste de ese color, por lo que es necesario mostrar algunos episodios en donde el negro se aleja de lo bajo para convertirse en un color de duelo. Uno de los más conocidos ejemplos está en las Sergas en el personaje principal: “dexó las armas negras con aquel negro nombre que por causa dellas y de su gran tristeza tomado avía" (Sergas de Esplandián, XXXIX). El motivo que ocasiona este sentimiento y ese color es por la desaparición de su abuelo Lisuarte, por lo que, en un principio no porta colores claros.

Pero más que ocultar los sentimientos de los caballeros que se cubren de negro, también está el deseo de destacar entre los demás, ya que, al llevar toda la armadura negra, es lógico que resalte la divisa que portan, aún más cuando ésta es de color claro: “El rey Lisuarte llevaba unas armas negras y águilas blancas por ellas y un águila en el escudo, sin 
otra riqueza alguna" (Amadís de Gaula IV, CIX). En estas armas no hay necesidad de otro tipo de ornamentación porque tan sólo las águilas, reflejo de la renovación, de la realeza, de la elevación por los aires y de su mirada penetrante ${ }^{329}$ transmiten el mensaje de superioridad de Lisuarte sobre el resto de los combatientes, no sólo por ser el rey, sino por su desarrollo en combate, el cual no es opacado por los demás y por su renovación en las armas, pues deja las tradicionales para asombrar con unas nuevas. Es decir, en ciertos momentos, a menor adorno, mayor distinción, puesto que se destaca la combinación de colores y lo imponente de la imagen. Este concepto del negro como una forma de imposición visual se halla en el periodo histórico de la corte de Borgoña, quienes para sobresalir de los demás reinos "se convirtió en su divisa, en un intento de diferenciarse respecto a la corte francesa, regida por el azul [..] además del Toisón de oro" ${ }^{330}$; esta circunstancia, trasladada al ámbito literario, facilita la comprensión de la combinación del negro con el oro y el blanco por el contraste de tonos que produce una retención en la vista de los demás, principalmente cuando la divisa abarca todo el escudo:

[don Félix] salió vestido de negro e los paramentos de sus caballos de lo mismo e tomó por devisa e cimera sobre sus armas e atavíos una rosa blanca (porque aquesta era la devisa e enseña de la princesa e del rey, su padre). E sobre los paramentos ivan sembradas muchas rosas puestas por tal concierto e manera que aunque no iva tan rico como otros que a la justa salieron era el más luzido e más mirado de todos. (Claribalte, VI)

La misma situación aparece en el Claribalte, en la simplicidad del decoro de las armas al utilizar sólo dos colores, negro y blanco, pero en la lucidez que impone ante los demás.

\footnotetext{
${ }^{329}$ Ignacio Malaxecheverría, op.cit., pp. 133-137.

330 José Damián González Arce, art. cit., p.196.

La utilización de un color para establecer una diferenciación de otros lo convierte en signo de reconocimiento de entre una sociedad monárquica en la que cada corte quiere marcar su influencia por distintos medios, económicos, artísticos, guerreros, litúrgicos, etc., pero también por medio de la moda, de ahí la importancia de usar todos los recursos posibles, color, tela y diseño, para imponer su estilo.
} 
Es necesario establecer una unión divisa-color; sobre esto, Víctor Mínguez dice que "el color de la indumentaria guardaba relación, en la mayoría de los casos con el contenido de la divisa [en donde] se admira la elegancia, la galanura, la hermosura del traje y la composición de la divisa", ${ }^{331}$ por lo que esta espectacularidad oculta bajo lo negro dos motivos: el primero, la decisión de don Félix de no revelar su identidad hasta haber ganado las justas, por ello la necesidad de no llevar ninguna otra divisa para evitar ser reconocido por ellas. El segundo, la revelación de su sentimiento amoroso por Dorendayna, princesa de Inglaterra y por quien lleva como imagen la rosa blanca.

El negro, por un lado, característico de la mentira, por el otro, símbolo de distinción, es el color que presenta más variantes de significación de acuerdo al personaje que lo porta, por lo que las características que éste adquirirá serán resultado de la condición moral del caballero.

\subsubsection{Púrpura (fig. 141)}

De los seis colores principales, sin duda alguna los tonos púrpura, morado y violeta son los más difíciles de hallar en las armas de los caballeros, tal vez por el alto costo que implicaba su fabricación y porque no se concebía como un tono concreto por la mezcla de colores puros que debían unirse para conseguirlo, estos eran: "white, black and red: red in the largest proportion, black in the smallest and white as intermediate between the two" ${ }^{\prime 32}$.

De hecho, históricamente, hay un escudo que tiene relevancia por llevar estos tonos, el que perteneció a Alfonso IX de León con dos leones púrpuras, uno en la parte inferior y otro dentro del propio escudo que lleva en el brazo. Esta utilización del esmalte carece de

\footnotetext{
331 Víctor Domínguez, "Emblemática y cultura caballeresca: Divisas valencianas en la canonización de San Francisco de Borja en 1671", Ars longa: cuadernos de arte, No. 4, 1993, p. 69.

332 John Gage, Color and Culture: Practice and Meaning from Antiquity to Abstraction, California, University of California Press, 1999, p. 25.
} 
presencia en los libros de caballerías, al menos en la parte heráldica, debido a las reducidas menciones que aparecen. Una de ellas está en el Polindo: "entraron por una puerta del torneo tres cavalleros armados de unas armas moradas e unas coronas por divisas" (Polindo, XIX). Aunque no se da más detalle de la armadura, este es el ejemplo más representativo, porque son los únicos caballeros que conservan su misma armadura durante toda la historia. No hay un cambio de color ni de divisas, posiblemente, con el propósito de ser identificados en cualquier lugar al que asistan. Inconscientemente los personajes son testigos de ello: "Traía el conde Orcián e su hermano e su hijo de morado, como siempre solían andar armados" (Polindo, XLIX).

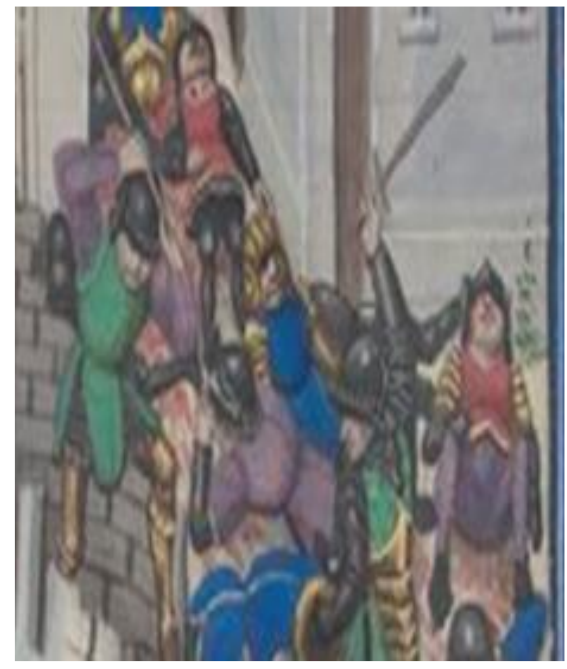

Fig. 141. Croniques abregies commençans au temps de Herode Antipas, (s. XV) Biblioteca Nacional de Francia.

Es curioso que en ningún libro de Feliciano de Silva aparezcan armas moradas o semejantes a esta tonalidad, sólo se hallan dos ejemplos de prendas de este color, una femenina, que se trata de unas garnachas de carmesí morado y un juego varonil completo de aljuba, capirote y manto. Nótese que no aparecen solos, sino en combinación con el carmesí.

El simbolismo de este color se da en la misma descripción de los objetos, todos remiten al enamoramiento y posteriormente, al amor, primero en el tocado femenino: 
"Trinea tiene una corona de oro con flores moradas, lo que significa el gran amor que la reina siente por él" (Tristán de Leonís el joven, CLXXIII); también en el vestido: "y se ve junto a Iseo, con vestiduras moradas que simbolizan el amor de su esposa" (Tristán de Leonís el joven, CCXXVI); por último, se reafirma en las armas del caballero: "El duque Armián lleva en su escudo una A morada, que significa que sólo ama a Armenia" (Tristán de Leonís el joven, CXLIV). El juego entre la representación de la primera letra del ser querido colocada a la vista de todos, pero conocida por pocos, se intensifica al reforzarse este sentimiento con el color que la pinta, porque, aunque es poco frecuente, sobresale su presencia durante el proceso de enamoramiento y se afianza una vez concretada la relación de la pareja.

2.9.2.7. Verde (fig. 142)

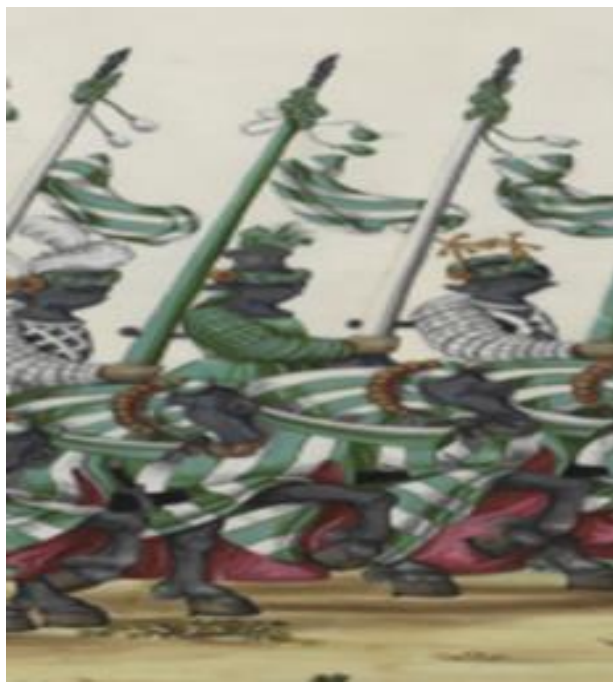

Fig.142. Triunfo del Emperador Maximiliano I (ss. XVI-XVII)
Considerado como uno de los más raros colores $^{333}$ por su poca presencia en las armas, Pastoureau lo establece como un tono ambivalente porque es "a symbol of life, luck, and hope on the one hand, an attribute of disorder, poison, the devil and all his creatures on the other" ${ }^{334}$; sin embargo, también es alegoría del amor, de los héroes y de la vegetación.

\footnotetext{
333 Johannes de Bado Aureo, Tractatus de armis, p. 99.

${ }^{334}$ Michel Pastoureau, Green: The History of a Color, p. 7.
} 
Estos dos últimos aspectos adquieren relevancia en conjunto, unidos por los diversos tonos de verde que se pueden observar en las plantas y en las armaduras, ya que, en palabras de algunos heraldistas, ${ }^{335}$ hay una problemática en torno al uso de armaduras y escudos verdes, por su escasa aparición por confundirse con la naturaleza, ${ }^{336}$ principalmente, en el bosque. Pero en los libros de caballerías, al menos en la mayoría de estos, no se presenta este tipo de desconcierto por los colores, sino al contrario, hay varios ejemplos de armaduras verdes que, generalmente, adoptan el simbolismo anímico del personaje que las usa, es decir, de la esperanza. Un ejemplo se halla en el Amadís de Gaula, con el protagonista de esta historia, quien, durante su periodo de penitencia amorosa, porta unas armas verdes que él mismo manda a fabricar: "[Beltenebros] seyendo ya con el gran placer en mucho de su salud y fuerça tornado, que mandó a Enil le fiziese fazer en aquella villa cerca donde estava unas armas, el campo verde y leones de oro menudos cuantos en él cupiessen, con sus sobreseñales y le comprasse un buen cavallo" (Amadís de Gaula, II, LV). Después del proceso de reconciliación entre Amadís y Oriana, aparece la prueba de los leales amadores, en la que el caballero convence a la dama para que ambos participen y comprueben si son merecedores de tal título. Por lo que su armadura no es negra, sino verde, porque conserva la esperanza de que, al terminar este transcurso, Oriana lo acepte nuevamente. Pareciera que por la situación de lamento de Beltenebros, debiera portar armas negras, como transmisoras del luto, sufrimiento, lamento y muerte sentimental que ambos padecieron, pero, ante esta negativa, predomina la esperanza de la reconciliación, por lo

\footnotetext{
${ }^{335}$ Ibid, p.82.

${ }^{336}$ En oposición a la dificultad que presenta el uso de armas verdes en la naturaleza, esta connotación es favorable para la figura del cazador, debido a que "el verde se convirtió en un color de buen tono social al introducirse en la indumentaria de los cazadores, a los que servía de camuflaje", como un medio para moverse entre la hierba sin ser vistos por los animales. José Damián González Arce, "Los colores de la corte del príncipe Juan (1478-1497), heredero de los Reyes Católicos. Aspectos políticos, estéticos y económicos", Espacio, Tiempo y Forma, Serie III, H. ${ }^{a}$ Medieval, t. 26, 2013, p. 189.
} 
que su confianza debe demostrarla tanto en su semblante como en el vestir, y, aún más, en unas armas nuevas que debe llevar para evitar ser identificado en la corte. Es así que la selección de colores responde al cambio de ánimo del personaje, del cual no sólo se fija un anhelo de reconquista, sino que, a través de las imágenes que lleva, leones de oro, se fija un significado superior por el color oro, aquel que manifiesta "firmeza, perfección y purificación" 337 en la personalidad del caballero después de superada la hazaña y de haber recuperado a la dama.

Sin embargo, a pesar de las contrariedades que presenta el color verde desde sus inicios, tanto por la complicación que tenía para obtener el tono deseado, la constitución de la mezcla para teñir las telas y pintar el acero, así como por la dificultad que presenta al confundirse con la naturaleza, además de que "symboliquement associée à tout ce qui était instable: la jeunesse (qui ne dure pas), l'amour (infidèle), la chance et la malchance, l'espérance et le désespoir, le hasard, la fortune, le destin" ${ }^{338}$, esta contrariedad de sentidos cambia a partir del siglo XIV y posteriormente, con los libros de caballerías, en los que los colores adoptan otro simbolismo, como sucede con el verde, el cual "es esperança, por ser el color de las mieses, quando prometen el fruto con que se sustenta la tierra"339, esto lo convierte en el color más usado para transmitir el motivo de la espera junto a los elementos que la reflejan, así como se muestra en los siguientes ejemplos: en el Florisel se desea el triunfo en las justas: "todos seis venían de armas verdes armados, con paramentos de terciopelo verde. Estas trayan ellos por dar a entender la esperança, que de su justicia tenían" (Florisel de Niquea IV, XXXIV); en el Amadís de Grecia la búsqueda del amor femenino "Con él venía otro cavallero grande y bien hecho armado de unas armas verdes

\footnotetext{
337 Juan de Horozco Covarrubias, Emblemas Morales, Zaragoza, Juan Bonilla, 1604, Lib. I, fol. 87.

${ }^{338}$ Michel Pastoureau, "Une couleur en mutation : le vert à la fin du Moyen Âge", p.726.

339 Juan de Horozco Covarrubias, op.cit., Lib. I, fol. 87.
} 
sembrados por ellas muchos arcos de oro; el escudo avía assimismo verde, en él figurado un arco con una mano muy delicada de donzella que lo tenía como que con él oviesse tirado a un coraçón que en el escudo estaba con una flecha atravesado" (Amadís de Grecia, XXXIII); en el Lisuarte, indica el tiempo que permanecerá Perión junto a la doncella para buscar aventuras: "vos nombredes el Cavallero de la Espera, porque quien os envió estas armas toda esperança es en vos, que por esta causa os las embió con esta orladura, e por otra mayor que cuando tiempo fuere sabréis" (Lisuarte de Grecia, III). Un caso especial aparece en el Palmerín de Olivia, en donde el conjunto de las armas lleva una doble connotación, por un lado, la esperanza de que se vuelvan a ver los enamorados, por otro, el deseo de triunfar en la batalla: "Polinarda fizo una ropa para encima de las armas a Palmerín, de un raso verde cercado de piedras preciosas sembradas de unas águilas de oro de gran valor" (Palmerín de Olivia, XXXVII).

Pero, en cierta forma, mantiene un poco su significado negativo en torno a que "le vert, c'était surtout la couleur du Diable et de ses créatures les plus étranges (serpents, dragons, crapauds, démons de toutes sortes) ", ${ }^{340}$ como se nota en las numerosas menciones a las serpientes contra las que pelean los caballeros y de cuya hazaña conservan una prueba en las imágenes que pintan en los escudos, por ejemplo, en el Florambel de Lucea: "armado de unas armas jaldes y sembradas por ellas muchas sierpes verdes, y en el escudo que tenía el campo de oro avía pintada una sierpe verde fecha por tan estraña arte que parecía estar viva"(Florambel de Lucea I, XLIV).

En los libros de caballerías el verde es una tonalidad que está presente en numerosos episodios, tanto bélicos como corteses, y que otorga una significación relevante tanto a los

\footnotetext{
${ }^{340}$ Michel Pastoureau, "Une couleur en mutation : le vert à la fin du Moyen Âge", en Comptes rendus des séances de l'Académie des Inscriptions et Belles-Lettres, 151e année, N. 2, 2007. p.726.
} 
personajes como a los objetos en que se halla, no sólo por los detallados rasgos que lo complementan, sino por las acciones que genera y la identidad que otorga al personaje; en el caso de Amadís, uno de los más destacables ejemplos, se sirve del color de sus armas para ser llamado "el caballero de la verde espada", ${ }^{441}$ de ahí adquirirán el sobrenombre del color de sus armas los demás personajes de los posteriores libros de caballerías, como un elemento más para agregar a su divisa y ser reconocidos por los colores.

En el Florisel se resume el significado de los colores, antes mencionados, en la descripción que un caballero hace de su dama: “allí parecía lo blanco de su castidad, lo colorado de mi alegría, en la presente gloria, lo negro de la tristeza de mi pena, lo verde de mi esperança, con el amarillo de su contrario, lo leonado de mi congoxa, con el añir de su firmeza, y al azul de los cielos, con lo blanco que primero dixe para la seguridad de no aver de quien se merezca podellos tener" (Florisel de Niquea IV, XVII). Arquisil dedica estas palabras a Arquisidea, en las que no sólo hace una descripción física de su belleza, sino que relaciona cada color a una de las cualidades de la joven; además de que presenta dos colores más: el leonado y el añil. Dos tonos que se contraponen en intensidad y simbolismo.

De un lado está el leonado, tonalidad media como "rubio oscuro", ${ }^{442}$ que en la Edad Media resaltaba su aspecto dudoso ${ }^{343}$; es curioso que existan pocos ejemplos del leonado para las armas; si bien, hay un mayor número de apariciones en la vestimenta de damas que

\footnotetext{
${ }^{341}$ La parodia más conocida se halla en el Quijote, con el "caballero del verde gabán" color que viste de pies a cabeza en su 'traje de camino', lo que le permite sobresalir durante su trayecto y ser visto por los demás personajes. Francisco Márquez Villanueva, "El caballero del verde gabán y su reino de paradoja", en Personajes y temas del Quijote, Madrid, Taurus, 1975, p.150.

Color para el viaje que, en cierta manera, ese significado está presente en estos ejemplos, puesto que estos caballeros se alistan para ir a combatir a otras cortes con la esperanza de regresar junto a su dama.

342 Vicente de Cadenas y Vicent, Diccionario heráldico. Términos, piezas y figuras usadas en la ciencia del blasón, Madrid, Hidalguía, 2002, p. 115.

${ }^{343}$ José Damián González Arce, “Los colores de la corte del príncipe Juan...”, p. 198.
} 
presentan una situación de pena, para los hombres la utilización es diferente en donde su uso se remite a la guerra: "Y éstos vinían armados de unas armas leonadas muy ricas. E traían unas bívoras en la cimera e las cortapisas del cavallo, de terciopelo leonado. Y en los escudos, un cavallero tendido en el campo verde e lleno su cuerpo de feridas" (Polindo, LXVII); además todo un grupo de escuderos viste acorde a su señor: "Tras él vino un cavallero pagano, señor de Siria, armado de unas armas leonadas; acompañávanle cien hombres, todos vestidos de terciopelo leonado" (Espejo de príncipes y caballeros II, XIV); pero el ejemplo en el que se da una exposición más profunda del significado de este color aparece en la quinta parte del Espejo de príncipes, en donde no sólo el estado de ánimo del personaje transmite una pena, sino que también se comunica por medio de las letras que acompañan el escudo:

[Horistoldo de Antioquía] venía armado de unas riquísimas armas amarillas con muchos lazos de leonado y oro, por las junturas lucidos diamantes, en medio del escudo, que también estaba orlado de ellos, en campo de oro estaba él mismo con muy sutil arte pintado, abierto el pecho que se le vía el corazón: estaba de una parte Congoja y de otra Desesperación, ésta toda de amarillo y aquélla de leonado, con tristes semblantes y demostración de tirar d'él cada una por su parte, con que daba a entender traía grande aflicción, acreditándolo la letra que a los pies se vía:

Herido de mi pasión

las penas de ausencia siento,

la Congojada el tormento,

muerte, Desesperación.

Venía sobre su hermoso y gran caballo con ricos paramentos y vistosas plumas (Espejo de príncipes y caballeros $V$, IV).

Toda esta procesión se da en medio de un recibimiento triunfal en el que aparece un contraste de color y emoción; por un lado, la algarabía de las damas por ver a los caballeros combatir, por el otro, la congoja que le ocasiona al personaje estar entre dos damas, 
sensación que se percibe en los rostros de Congoja y Desesperación ${ }^{344}$. Estas dos figuras no sólo presentan un deseo de retención del amor, sino que cuentan una pequeña historia, sobre Horistoldo y las cuatro damas prendadas de amor por él, y que sólo el lector conoce porque ha leído, pasajes atrás, la historia de este caballero y Olivia, Rosilbera, Liriana y Claridián, de modo que en estos libros hay una narración breve contada a través del pincel y la tinta en reducidos espacios conocidos como 'campo' 345 , una escena que narra, con ayuda de ciertos elementos simbólicos, en este caso, el corazón, las dos damas y las letras, un proceso sentimental pintado para dar a conocer con facilidad en otros reinos y que, en contraparte, se desarrollarán con más detalle este tipo de escenas en los tapetes bordados que se hallan en los castillos, por lo que es relevante destacar la función de las historias contadas en los escudos a través del recurso de la écfrasis.

\subsubsection{Escudos como microhistorias (figs. 143,144 )}

Es curioso que dentro del campo de batalla o de justas exista un orden en los colores de las armas, que a simple vista el lector no identifica por las numerosas descripciones que el narrador hace de cada uno de los participantes; sin embargo, al estar todos los caballeros reunidos "se divisan mejor de lejos los que mezclan con oro i plata otros colores, que los que trahen solos colores; i que el traer metal con metal hará a la vista demasiado obgeto que dicen disgregativo, lo qual ofenden a quien lo mira" ${ }^{346}$. Esta unión de colores es clara en las justas para celebrar una boda o la llegada de un monarca en toda Europa durante la Edad Media y el Renacimiento, porque se trata de grandes espacios en los que se capturan

\footnotetext{
${ }^{344}$ Estos dos personajes también aparecen en el Amadís de Grecia, en el sueño con el que finaliza la segunda parte de ese libro y en donde la relación congoja-leonado se mantiene en el personaje de la doncella, la cual iba: "toda vestida de leonado, tan flaca y desemejada, que solo el traje de su vestido dava a conocer ser mujer; venía dando tan fuertes sospiros que parecía querérsele [a]rrancar el alma [...]" (Amadís de Grecia, LXXII)

${ }^{345}$ Martín de Riquer, Heráldica castellana, p. 78.

${ }^{346}$ Martín de Riquer, Heráldica castellana..., p.86.
} 
especies de escenas bélicas que algunos pintores de la época y escultores plasmaron en el lienzo y la piedra. Pero qué pasa cuando estas imágenes se reproducen en los propios escudos, en donde hay menor espacio para representar toda una serie de motivos con detalles minuciosos que sean visibles a la vista del espectador, pero también del lector, quien por medio del narrador conoce los elementos que llevan las armas, como se vio en los apartados anteriores, en donde la presencia de una divisa abarcaba la mayor parte del campo, pero hay otros escudos con una mayor cantidad de formas, colores y figuras humanas que por sí mismos cuentan una historia.

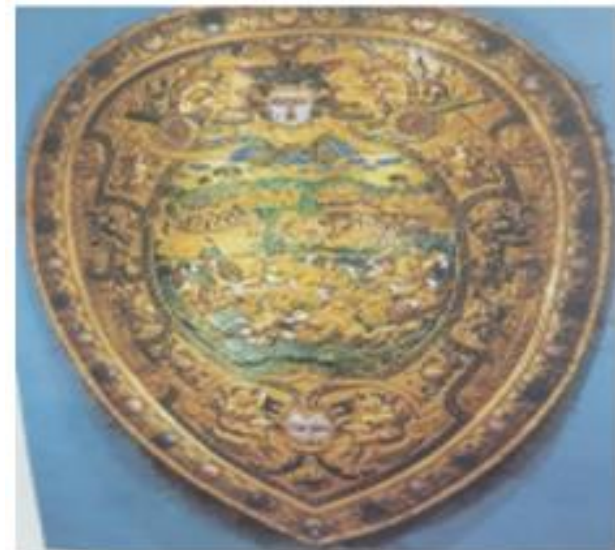

Fig.143. Escudo de oro de Carlos IX de Francia, Pierre Redon.

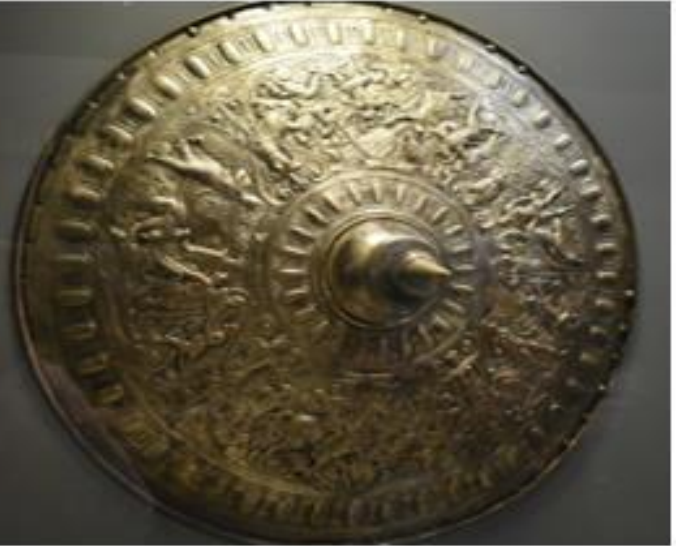

Fig.144. Escudo con grabados miológicos (s. XVI) Centro Cultural Mexiquense Bicentenario, Texcoco.

Desde la Antigüedad se conocen piezas metálicas con grabados realzados de escenas de diversas hazañas, el más conocido es el escudo de Aquiles en el que se observan varias escenas distribuidas en franjas, cada una contiene pasajes del Imago mundi, ${ }^{347}$ ciudades en guerra, mundos agrícolas, animal, aspectos de festividad y una frontera de agua que rodea todo el escudo, pequeñas escenas que necesitan estudiarse a profundidad para

\footnotetext{
${ }^{347}$ En su tesis doctoral Altamirano Meza propone el término "funciones ecfrásticas" para analizar desde la retórica las imágenes que aparecen en escudos y tiendas a partir de la écfrasis. Debido a que los ejemplos hallados en los libros de caballerías que se estudian en esta investigación no tienen una extensa descripción por parte del narrador, se tomará el concepto de la descriptio como "un discurso que representa ante los ojos aquello que muestra". Rhetoricae Exercitationes, 317.
} 
relacionar cada detalle con la historia detrás de la mitología griega. ${ }^{348}$ De cierta forma, resulta más sencillo estudiar las historias pintadas en los escudos de los libros de caballerías, porque cuentan con menos distribución espacial y menos escenas; sin embargo, tienen una dificultad mayor para el receptor, y es la necesidad de conocer toda la historia de cada libro en las que aparecen estas armaduras para identificar y relacionar a los personajes, motivos y colores que los escritores de libros de caballerías plasmaron, a diferencia de los elementos mitológicos que son más conocidos y que resultaría más sencillo recordarlos.

\subsubsection{Historias bélicas y amorosas}

Las hazañas de los caballeros preservadas en los tapices que aparecen en algunos libros de caballerías, como ya lo ha mencionado Axayácatl Campos, es una "fama historiable de los caballeros, no es únicamente registrada por la memoria a través de la palabra oral y escrita. Su alcance llega también al texto iconográfico. De este modo, las artes plásticas son un medio idóneo para dejar testimonio de aquella fama y fijar así el momento histórico"349 en el que los personajes fueron partícipes de hazañas amorosas, bélicas, mágicas, etc. Este medio de conservación también se localiza en las armas del caballero, específicamente en el escudo, cuyos campos conservan ciertas aventuras, por ejemplo, los enfrentamientos contra animales: El rey Grifilante traía unas armas verdes sembradas de sierpes, y en el escudo una sierpe con dos cabeças cortadas (eso traía él por una sierpe ${ }^{350}$ muy fiera que él mató, que

\footnotetext{
348 Gerardo Román Altamirano Meza, Thauma idestai. La écfrasis medieval de dos motivos descriptivos: escudos y tiendas historiadas, Tesis doctoral. México, UNAM, 2015.

${ }^{349}$ Axayácatl Campos García Rojas, "Historia y amor ex arte en los libros de caballerías: Espejo de príncipes y caballeros", Actas del IX Congreso Internacional de la Asociación Hispánica de Literatura Medieval (A Coruña 18-22 de septiembre de 2001), A Coruña, Toxosoutos, 2005, pp. 608-609.

${ }^{350}$ La sierpe será una de las imágenes más recurrentes en las armas de los caballeros, especialmente cuando aparece un pasaje en el que se combate contra esta alimaña. Esta importancia también aparece en el Polindo, cuando el protagonista obtiene su fama con su primera hazaña, en la que combate contra una serpiente para liberar al rey, el padre de Belisia, su dama.
} 
mucho daño en su tierra fazía)" (Lisuarte de Grecia, XLII). El primer rasgo que se distingue es la brevedad de la imagen, de la que se menciona el color de las armas y la criatura derribada. Mas hay una característica especial, el narrador indica la causa de esa imagen. Este comentario para recordar, también lo dan los personajes:

El Rey de la Ínsula Gigantea lo mirava, que muy grande y hermoso le parecía. Pero todos estavan espantados de la su grandeza, assí de miembros como de buena marca de cuerpo, como ya vos hemos dicho. Aqueste rey no era gigante, mas muy poco le faltava para serlo. E traía en el escudo dos jayanes muy grandes muertos. El rey Amadís lo mirava e dezía a Argamonte que cabe sí tenía:

-¿Qué os parece de aquel caballero que a mí muy bien me parece?

Argamonte le respondió:

-Paréceme tan bien que me pesa, porque lo conozco en las armas que en el escudo trae. Sabed, señor, que trae aquellos dos jayanes, padre e hijo, porque los venció a ambos dos juntos en una batalla que con ellos solos uvo. (Lisuarte de Grecia, XLV)

El personaje que declara este hecho tiene dos posibles posiciones, como testigo, al haber presenciado la aventura, o como oyente, si es que alguien más le contó la hazaña y él sólo transmite lo que recuerda. Es de notar que no hay una descripción completa del suceso en el escudo, sino que ésta se complementa con los comentarios de otros. Aunque no siempre aparece esta ayuda para los lectores, ya que, para comprender algunas imágenes se deben leer otros capítulos para conocer el motivo de esa historia. Generalmente acontece en los sucesos de amor:

Estando ellos en esto, a las bozes de las doncellas del través de la floresta salió un caballero de gran cuerpo armado de todas armas, que cosa no [1]e faltava, encima de un caballo ruano; traía las armas indias sembradas de flores de fino oro; en él, assentado de la misma color, traía figurada una doncella negra y muy hermosa con corona como infanta, la cual traía una mano de un jayán que le quería quitar la 
corona de la cabeça y un cavallero todo armado que le estava tajando la cabeça; parecía en él aver toda bondad. (Amadís de Grecia, XC).

El primer elemento que destaca es el color de las armas, azules con flores de oro. Una combinación llamativa, como ya se mencionó anteriormente. Enseguida la mano que sujeta la corona a modo de querer arrebatarla y, por último, el porte del caballero "todo armado que [...] parecía en él aver toda bondad”. Aunque no se detallan más rasgos hay ciertos conocimientos implícitos que el lector puede deducir en estos tres ejemplos, en todos está la presencia de una figura guerrera, por lo que, en cuanto a su traje, es evidente que "el cuerpo bélico, no hace falta decirlo, es un cuerpo revestido; en su venir a hacerse es necesario implicar y asumir unas defensas y ofensas objetuales: <<armarse caballero>>"351, así que no hay necesidad de que el narrador afirme que lleva armadura, puesto que es algo esencial de todo caballero. Este último ejemplo requiere de un elemento más, la explicación para conocer quién es la doncella que aparece en el escudo y el caballero a su lado. Se trata de la hija de la reina Calafia, quien es intimidada por un jayán para que se despose con él, o de lo contrario le quitará el reino. El caballero en la imagen desea ayudarla, primero porque ambos se quieren, segundo para regresarle el reino. Es así que la persona que cuenta la historia del escudo es directamente uno de los implicados.

A pesar de las condiciones favorables que brinda la amplitud del espacio de las paredes en las que se recrean los momentos de triunfo de los caballeros, presentan un gran inconveniente, y es que se trata de pruebas estáticas, fijas en lugares a los que sólo tienen acceso los personajes que transiten por las cercanías de esos castillos; a diferencia de la movilidad que brinda el escudo y la facilidad para ser llevado de una corte a otra, por lo que

\footnotetext{
${ }^{351}$ Fernando R. de la Flor, Imago. La cultura visual y figurativa del barroco, Madrid, ABADA Editores,
} 2009, p. 259. 
las hazañas pintadas en escudos se convierten en una especie de recuerdo movible que incrementa la fama del caballero al ser conocidas en diversos reinos.

Cuando el doncel recibe las armas comienza su proceso de conquista de honra y fama en el exterior de su reino. Debe comenzar a crearse un sobrenombre que, generalmente, será el resultado de su más conocida hazaña, ya sea que luche contra un animal, un gigante o le sea encomendada una aventura específica, su desenvolvimiento le brindará una divisa y una letra, las cuales llevará en sus armas.

Es decir, el metal como una fina hoja de lámina se moldea para adquirir la forma deseada, ésta se cubre de esmaltes diversos que se adhieren al acero para formar imágenes representativas en torno al amor, el lamento, la muerte o la desesperación; sensaciones que se transmiten por medio de las figuras y las letras y que adquieren sentido dentro de la historia al ser partícipes, en voz de los personajes, del motivo por el que son llevados y de la microhistoria en sí que relatan dentro de los límites del escudo; por lo que su función no sólo es decorativa ni sirve sólo para otorgar protección contra los golpes del enemigo, sino que además es un medio más por el que se transmite una parte de las hazañas del caballero, hechos en los que el amor y la guerra se unen para dar a conocer quiénes son los enamorados y las empresas que se han realizado en su nombre.

Asimismo, es notoria la importancia que adquieren al constituir un catálogo descriptivo de divisas e invenciones, para conformar un emblema que identifique a cada caballero dentro de las justas y en cada corte a la que asista, a fin de ser único e irrepetible, de ahí la necesidad de que los escudos presenten variaciones en el linaje y en la gesta. 


\section{Simbolismo de la vestimenta}

\subsection{Prendas de amor y desafío: Letras bordadas}

En el apartado sobre los vestidos de boda aparecen ciertos ornamentos que a simple vista funcionan como decoración, pero en realidad mantienen un significado superior dentro de la historia, se trata de las piedras preciosas, bordados de flores y letras en el atuendo de la dama que, en clara alusión, son una especie de comunicación con el caballero, el cual responde a través de sus armas, a través de las divisas que lleva en ellas a modo de continuación del lenguaje pictórico.

En ellos hay dos recursos importantes: imagen y letra. Desde palabras de desafío, letras rimadas, descripciones de damas, revelaciones de enamoramiento y símbolos de poder, establecen una línea de investigación particular sobre "el motivo de los bordados en los libros de caballerías", en donde las prendas se convierten en transmisoras de textos breves e imágenes que permiten descifrar la condición social, sentimental y la identidad del personaje que las porta.

Esto se realiza por medio de la confección de trajes, en los que los autores en algunos pasajes se convierten en diseñadores y sastres, habilidad poco mencionada en estos textos, pero que permite descubrir nuevos elementos de confección para establecer una breve catalogación de los motivos, letra e imagen tejidos en la indumentaria caballeresca. 


\subsubsection{Bordados para los enamorados}

A finales del siglo XV y principios del XVI los excesos de la nobleza en el vestir obligaron a los Reyes Católicos a proclamar leyes que moderaran el gasto en las telas y piedras preciosas. ${ }^{352}$ Algunos de los excesos en los atavíos se debieron a la gran cantidad de adornos en los trajes de los nobles. Desde jubones, capas y vestidos, hasta prendas íntimas como la camisa, las calzas y el cos, sobresalieron por el color, el bordado y las piedras preciosas. Estas prohibiciones ${ }^{353}$ no se cumplieron del todo por el empeño de la burguesía para continuar "expresando en sus trajes su privilegiada categoría", 354 a través del exceso de adornos con que decoraban sus prendas.

Los trajes vistosos no se hicieron esperar por los autores de la materia caballeresca, quienes, al estar en contacto con la corte y la sociedad española del siglo XVI, crearon en la ficción novedosos atavíos, aún más ornamentados que los de la propia realidad, como se ve en el siguiente pasaje del Polindo:

La reina vino vestida de brocado rico con la guarnición e letra que sus damas, cuando en Macedonia entró, traían. E sus damas, vestidas muy ricamente. Salió la princesa Belisia con una saya de plata tirada, con unas aves por ella sembradas que ivan bolando e por guarnición, la divisa de su amante. Y las donzellas, de lo mesmo. Salió la infanta Lidama con una saya de brocado raso e encarnado, enforrada en terciopelo carmesí e la ropa de encima, dadas muchas cuchilladas, de tal manera que fazían las cortaduras unos falcones. E sus damas e donzellas, de la mesma manera. Y ansí otras damas e señoras vinían bien atabiadas. (Polindo, LXVII) ${ }^{355}$

\footnotetext{
${ }^{352}$ María Carmen Marín Pina, "Seda y acero. La indumentaria...", p.301.

${ }^{353}$ Carmen Bernis, Indumentaria española en tiempos de Carlos V..., p.9.

${ }^{354} \mathrm{Ibid}$, p. 7.

${ }^{355}$ Una descripción similar de esta vestimenta se encuentra en Cárcel de Amor en el capítulo "Cómo las damas salieron el día de la tela".
} 
Tres descripciones de tres damas, cada una con un tipo de vestido y color, pero principalmente dos distintas guarniciones, las de sus respectivos amados. La divisa de la reina se trata de un bosque y en lo alto una garza con una letra que dice "Toda en todo", aludiendo a su presencia durante todo el torneo junto al rey. La segunda se trata de una sierpe dorada, la cual alude a don Polindo. La princesa la lleva como muestra de amor al joven, ya que éste liberó al padre de Belisia de una cueva custodiada por un basilisco; desde entonces se le conoce como el Caballero de la Sierpe. Este afecto se seguirá demostrando en los obsequios que la joven dé a su amado: "E luego vino don Polindo armado de unas armas rosadas, llenas de piedras preciosas puestas de manera que fazían unas sierpes. E truxo por cubiertas de su cavallo un cendal que su señora le envió. Y este cendal estaba texido con sus sierpes. (Polindo, LXVIII). La mujer demostrará su afecto a través de los obsequios dados y serán más valiosos cuando estén hechos por ella misma.

En el Florambel se encuentra una vestimenta que enfatiza el deseo de aprisionar el amor de un caballero: "y la infanta estaba vestida de una ropa de seda verde, sembradas por ella muchas rejas de oro a significación que esperaba prender alguno, [...] y ella estaba tan fermosa y loçana esperando ver y ser vista de los mejores caballeros del mundo, que quien quiera que la mirara no la juzgara por cosa terrenal”. (Florambel de Lucea I, I-III). Implícitamente, el vestido transmite el deseo de retener el amor de un caballero. No hay una elección especial, solamente el deseo de cualquier joven. En este ejemplo se trata de prendas bordadas de seducción, pues aún no hay una pareja conformada.

En oposición a los ejemplos pasados, existe otro modo de portar códigos de amor en las prendas y es por medio de las letras: "Insignias y distintivos [...] su función de representar simbólicamente conceptos trascendentales de la vida social e histórica de un pueblo. [...] el color del tejido y las figuras heráldicas bordadas ofrecían, a golpe de vista, 
la señal suficiente de identificación del noble señor y sus soldados" 356 . Sin embargo, esta identificación en el ámbito militar se traslada al sentimental, a través de las imágenes, letras y símbolos bordados en las prendas de las damas como una forma de manifestar su amor hacia el caballero, pero con la peculiaridad de que sólo la pareja puede descifrar estas divisas.

El juego de estos emblemas consiste en utilizar una o varias letras del nombre de la persona amada, de su sobrenombre o la imagen del animal que porta el caballero en su escudo y bordarlo de forma que muchos lo vean pero que pocos lo entiendan. Por ejemplo, en la segunda parte del Florisel de Niquea: "La hermosa Oriana llevava vestida una ropa de terciopelo azul aforrada en tela de oro, y la tela de zebellinas ${ }^{357}$ toda golpeada con unos golpes que hazían unas aes griegas, los bordes de gruessas perlas, y tomados con cordones de oro y seda verde [...]" (Florisel de Niquea II, LXIII). Las "aes" griegas parecieran ser simplemente un adorno del vestido; sin embargo, éstas significan el nombre de su amado Anaxartes. (fig. 145)

El autor y los personajes juegan con las letras y los diseños, lo mismo ocurre en el Policisne: "El rey vestía unos paños de carmesí forrados en paños de plata, bordada toda la ropa de unas aes griegas de muy ricas perlas" (Policisne de Boecia, LXXII), en este ejemplo se trata de la vestimenta del rey Arsandos, cuyo bordado representa la letra inicial de su esposa la reina Arminea. Este tipo de bordados puede enredar al lector, porque se necesita conocer la historia de la pareja protagónica para entender el significado de las letras, de lo contrario sólo se verían como simples insignias. (fig. 146)

\footnotetext{
356 María Ángeles González Mena, Colección pedagógico textil ..., p.70.

357 Tela como la piel de la comadreja.
} 


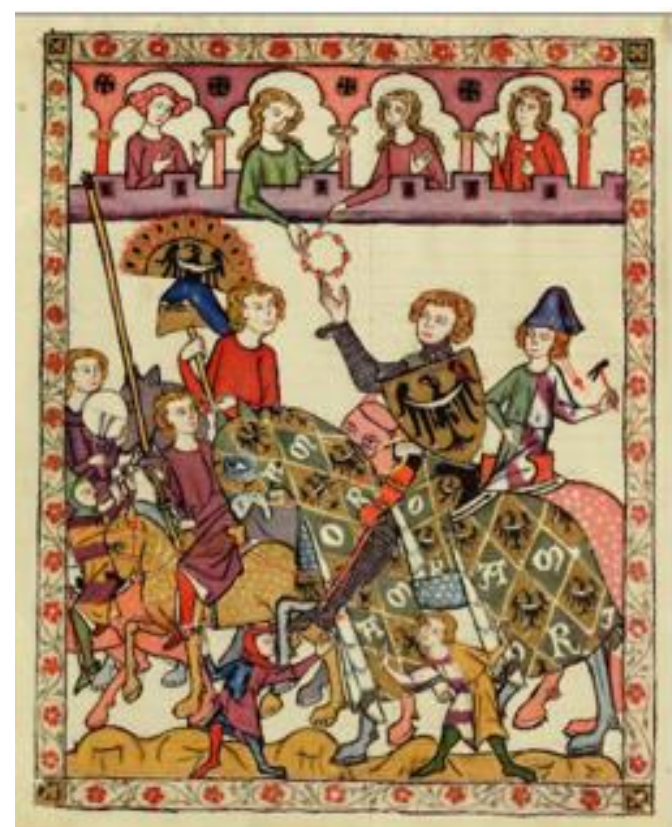

Fig. 145. 'El caballero recibe un regalo de su dama' Codex Manesse (s. XV).

En la gualdrapa se forma la palabra 'AMOR'

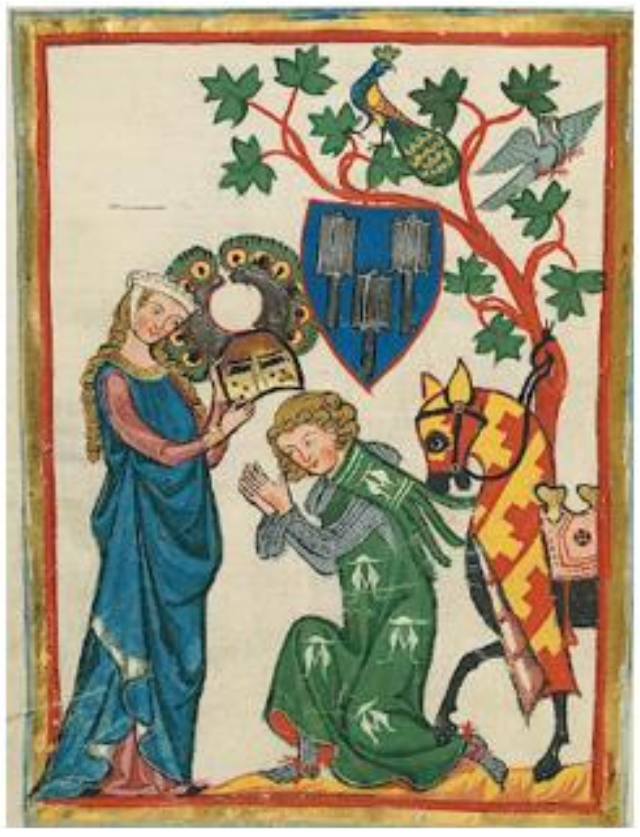

Fig. 146. Codex Manesse (s. XV). El caballero lleva varias "M" bordadas en su sobreveste.

Feliciano de Silva no se limita con integrar letras griegas en las prendas, sino también utiliza una gran variedad de objetos, formas y animales que plantean un trasfondo más desarrollado para su comprensión.

Una de las divisas más curiosas por su forma y su simbolismo es la que porta el Caballero Constantino ${ }^{358}$, unas armas:

indias, pobladas de almarraxas de oro, y el escudo de la mesma color, con una almarraxa en medio del, con unas letras de oro entorno griegas y bien talladas que dezían: <<Aquesta en el nombre muestra/ La obra que es toda vuestra >. Que como las armas se desliaron Argentaria dixo, Señor Cavallero Constantino, estas armas llevad vos, con que se os acuerde de mi, porque fueron hechas por mi abuelo, para que yo las diesse al cavallero que

\footnotetext{
${ }^{358}$ Se debe recordar el cambio de nombre que ha tenido Rogel de Grecia, en su personaje de Archileo recibe unas armas blancas, a partir de ese momento decide llamarse Caballero Constantino. Sobre el simbolismo de los nombres de los personajes en el ciclo Amadisiano véase: María Coduras Bruna, DINAM. Diccionario de nombres del ciclo amadisiano, Universidad de Zaragoza, Departamento de Filología española. Disponible en: <http://dinam.unizar.es>.
} 
la aventura del espejo acabasse, en señal de la prenda que de casamiento os di, y me distes. (Florisel de Niquea IV, I, XXIX)

En clara alusión hay un juego de palabras entre enamorados, Argentaria da unas armas al Caballero Constantino, en donde se fija la figura de una almarraja (fig.147). Pero el antecedente de esta divisa se halla en el Florisel de Niquea III, en donde aparece por primera vez en las obras de Silva como un recipiente para almacenar un líquido: “¡Ay, mi señora, que con esta agua lançada en mi rostro con las almarraxas de mis ojos, con su virtud en los grandes desmayos de mi coraçón me torna el alma y me cobra los sentidos y de todo punto sostiene la vida que no acabe!" (Florisel de Niquea III, LIII). Desde un primer momento se alude al uso de la almarraja para llevar el agua que limpia el lamento de la dama, quien debe lavar su rostro para evitar ser descubierta.

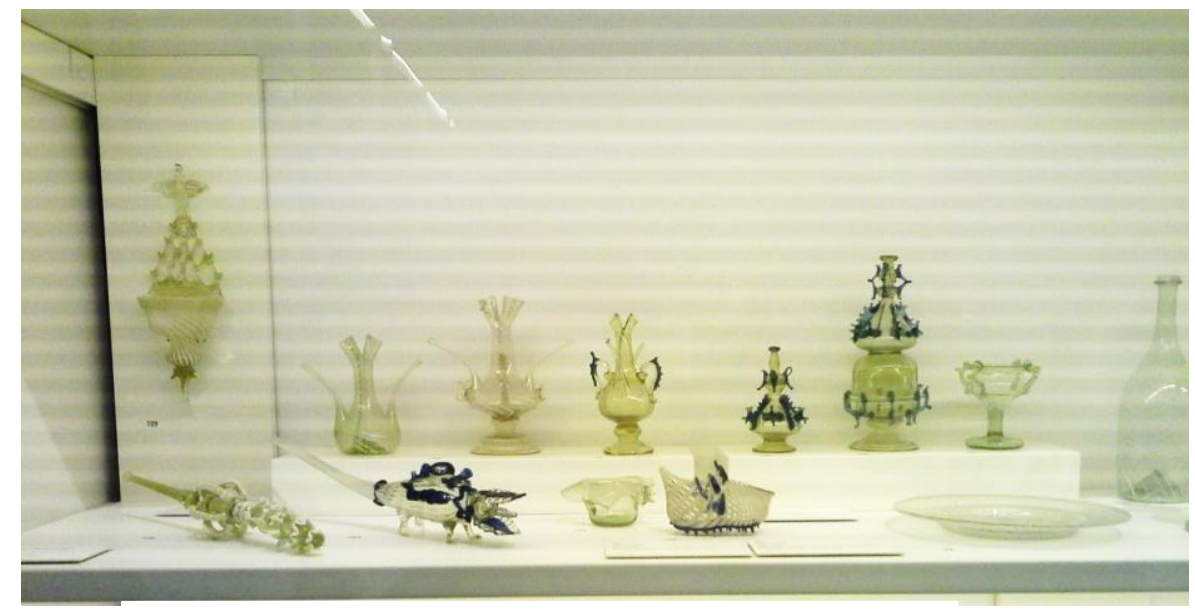

Fig. 147. Almarrajas (ss. XV-XVIII) Museo del Diseño de Barcelona

Esta utilidad se retoma en el capítulo XV de la cuarta parte del Florisel en donde Archisileo es reanimado tras el desmayo por ver el rostro de la Duquesa y cuyo instrumento para llevar el agua es una almarraja: "y socorriéndole en tal desmayo con muchas almarrajas de aguas olorosas lo hizieron tornar en si. Y dize Galersis, que tornado tales palabras dixesse. $\mathrm{O}$ vida con cuanto agravio me dexas, sin la paga que con la muerte devias 
a la gloria de tal vista" (Florisel de Niquea IV, I, XV). A partir de este momento es que la vasija aparecerá en varios momentos de la historia y su significado se intensificará cuando el Caballero Constantino porte las armas.

En este caso, Sarpenterea es la encargada de su diseño para que el Caballero Constantino se presente ante la emperatriz Archisidea: "Asi mesmo dexó mandado que muchos oficiales haziessen essa noche ropas de terciopelo indio con muchas almarraxas de oro bordadas por ellas, para que otro dia fuesse a besar las manos a la Emperatriz" (Florisel de Niquea IV, I, XXXVII). Esta presentación ante la dama revela el significado de la insignia, puesto que se trata de la futura esposa del caballero, así que, como preámbulo a la relación sentimental, éste dispone de un elemento con el que pueda manifestar el amor a la dama. Este sentimiento es partícipe con su séquito, quienes en honor del Caballero Constantino deciden portar la misma divisa: "El príncipe y el rey acordaron de hazer armas de una manera para aquestos hechos, y fueron indias pobladas todas las guarniciones, y paramentos de almarraxas de oro, como el príncipe don Rogel las traya" (Florisel de Niquea $I V, \mathrm{I}, \mathrm{XXX})$. Sin embargo, Rogel presentará un juego de divisas intercaladas, ya que junto a la almarraja llevará unos arcos en señal de amor por Arquisidea: “Él se halló sin armas y con una rica ropa y manto toda bordada de arcos de oro" (Florisel de Niquea IV, I, $\mathrm{XXV).} \mathrm{La} \mathrm{unión} \mathrm{entre} \mathrm{la} \mathrm{almarraja} \mathrm{y} \mathrm{los} \mathrm{arcos} \mathrm{se} \mathrm{da} \mathrm{por} \mathrm{la} \mathrm{letra} \mathrm{"A"} \mathrm{como} \mathrm{manifestación}$ amorosa por las damas, ya que en un primer momento Rogel tiene una relación con Argentaria, de la que nace su hijo Argento Constantino. Sin embargo, se mantiene un doble juego en el que el amor es la causa por la que Rogel porta ambas divisas, ya que, a pesar de haber mantenido una relación con Argentaria, al final permanecerá con Archisidea, con quien también procreará un hijo, Felismarte de Grecia. Así los arcos también van representados por un séquito femenino: "todas las que en el carro ivan llevavan ropas de 
raso blanco golpeadas sobre tela de oro tomados los golpes con estampas de aes griegas de oro" (Florisel de Niquea IV, II, LXIV).

Rogel de Grecia presenta un doble canal de comunicación encabezado por las "AA", Archisidea-Rogel-Argentaria, cuya representación sentimental mantiene el mismo principio alfabético arcos-Rogel-almarrajas, en referencia a las dos damas y cuya complicidad alcanza, por un lado, a las damas de su cortejo, quienes llevan arcos bordados en su ropa, y por el otro, a sus compañeros, quienes llevan por divisa unas almarrajas. En donde el metal mantiene el primer juego de palabras pero que, al mudarse las armas, también se cambiará el afecto, por lo que la tela es la que mantendrá en permanencia la elección de Rogel de Grecia, los arcos, y que se consolidará a través de la culminación del matrimonio entre Rogel y Archisidea.

En este mismo canal de comunicación aparece otro ejemplo, en el que la princesa Arlanda lleva "vestida de una ropa de terciopelo verde sobre tela de oro, toda golpeada y tomada los golpes con unas efes de oro muy bien obradas, y sus cabellos sueltos con una rica guirnalda de pedrería sobre ellos puesta, con una harpa que delante una hermosa donzella la llevaba". (Florisel de Niquea II, VII). La representación simbólica de su amor por Florisel se manifiesta a través del hilo de oro, cuyo entramado en cada golpe forma una "f" a manera de costura que permite demostrar su afecto en público. Pero este simbolismo no se limita sólo como una decoración, sino que hay un juego de colores entre los tonos verdes y dorados, puesto que, por una parte está la esperanza de culminar su sentimiento, por el otro, el modo de atraer la mirada del caballero a través del brillo del oro.

Sin embargo, los bordados de amor también presentan un lado doloroso, cuando el objetivo de ensaltar a la amada no se cumple: "[el rey de Acaya] venía todo armado de armas indias, sembradas de onças de oro, en el escudo traía una onça que despedaçava un 
coraçón. Que como llegó en el escudo del rey de Susiana tocó, y tocado dixo: -Rey de Susiana a punto estás de pagar tu locura y conocer que a la hermosura de Onçiana, reyna de Asiria, ninguna otra es igual" (Florisel de Niquea IV, I, LXXVII). A pesar de los intentos bélicos del rey de Acaya por sostener que Onciana es la más hermosa, es derrotado por el rey de Susiana. La representación del amor a través de las letras forma parte del decorado metálico, en ellas se une la imagen con la letra, la cual está implícitamente escrita en la imagen de las onças, la cual, al tratarse de un amor en riesgo porque teme que Onciana se pueda casar con otro, se manifestó en el corazón destrozado y, por consiguiente, en la derrota del rey de Acaya a manos de un caballero que sí tiene la certeza de ser correspondido en amores.

\subsubsection{Bordados de desafío}

En los libros de caballerías los acontecimientos más llamativos por el color y la variedad de divisas que se describen son las justas. Eventos en los que se demuestran las habilidades guerreras de los caballeros y en los que éstos son reconocidos por la insignia de su reino. Cada justador tiene su propia insignia pintada en su escudo, pueden ser jóvenes arrodillados ante unas damas, leones combatiendo contra dragones, una rosa blanca que representa el reino de Inglaterra o simplemente el escudo decorado con piedras preciosas.

Ante la variedad de diseños, hay otros que destacan por la singularidad de sus motes en las demás armas, por ejemplo, aparecen bordadas en unas lanzas las siguientes letras: "Si lo verde es esperança/ del bien que puede venir, / lo amarillo lo alança/ e lo tray al morir” (Polindo LXVII). Se trata de un claro desafío entre el rey de Tracia, caracterizado por su armadura dorada y don Polindo, conocido por sus armas verdes con sierpes de oro que su 
amada Belisia le regaló. Ambos combaten por el amor de la joven, pero, como es costumbre, el caballero protagonista gana y lo verde triunfa sobre lo dorado.

En las justas hay una característica especial sobre los motes y divisas de los caballeros, se trata de una elección personal de los justadores, porque ellos mandan hacer su armadura con las letras acorde al reino en el que participan, para ello se sirven del oficio de artesanos, herreros, bordadores y pintores para crear las armas perfectas en color, grabado e imagen, porque son piezas exclusivas; es decir, "cuando en las justas o en la guerra, un caballero es reconocido por las armas, es reconocido por las sobrevistas, señas y emblemas que porta, cuyos colores no son colores heráldicos, porque no responden a los esmaltes de determinadas armas, sino fruto de la elección personal del caballero o de algún allegado; son armas personales". 359

La configuración del personaje se va creando desde el momento en que selecciona sus armas, hasta su participación en el combate, pues de acuerdo a su actuación en el campo será recordado y reconocido cada vez que participe en las justas, pero también por su armadura, ya que habrá personajes que conserven la misma indumentaria por mucho tiempo, como ocurre en el Lisuarte de Grecia, en donde Perión de Gaula deberá cumplir un don a Alquifa, que consiste en estar con ella un año y combatir cuando ella lo pida, pero siempre deberá traer su misma armadura.

En el Florambel de Lucea aparece un grupo de justadores con el mismo color y divisa en el traje:

Y ansí estuvieron aquellos tres días adereçando sus armas de nuevas devisas por no ser conocidos y pensaron de fazerlas todas de una guisa, porque se conosciessen en

\footnotetext{
${ }^{359}$ Alberto Frutos Montaner, "Emblemática caballeresca e identidad del caballero", en Libros de caballerías (de "Amadis" al "Quijote"). Poética, lectura, representación e identidad, eds. Eva Belén Carro Carbajal, Laura Puerto Moro, María Sánchez Pérez, Salamanca, Seminario de estudios Medievales y Renacentistas, p. 274.
} 
el torneo pues avían de ferir todos seis juntos. Y ansí lo hizieron, porque las armas blancas como convenía cavalleros noveles, y por ellas sembradas unas efes de oro muy ricamente obradas. Y esta devisa llevaban porque ivan en demanda de Florineo. (Florambel de Lucea I, VIII) (fig. 148)

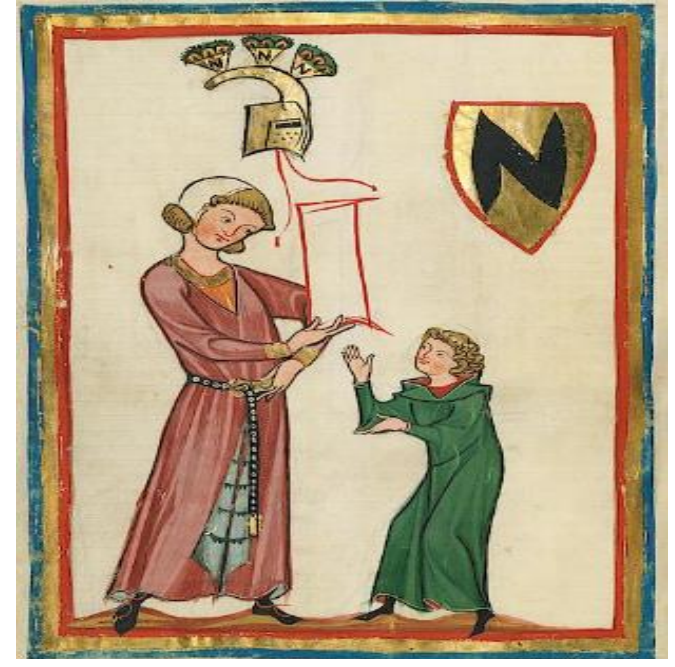

En este ejemplo hay un elemento importante, se trata del color de las armas que acostumbraban traer los jóvenes principiantes para combatir, ${ }^{360}$ debían portar prendas coloridas, en este caso blancas con motivos que sobresalieran, como las letras doradas.

Fig. 148. Codex Manesse (s. XV) Las letras también pueden ir en la cimera, en armonía con la del escudo.

El segundo rasgo que destaca es que, a diferencia de los ejemplos anteriores, en éste se da el simbolismo de la letra inserta en la armadura, la "f", la cual representa el desafío directo hacia Florineo, pues el propósito de este grupo de jóvenes es lidiar sólo contra él, por lo que han bordado en todo su traje muchas " $\mathrm{f}$ " en señal de advertencia contra Florineo.

Además de las lanzas y la armadura, hay otros elementos textiles con inscripciones, como los carteles de desafío, en los que se pintan largas amenazas en contra del oponente, lo mismo ocurre con estandartes, yelmos y espadas. La originalidad recae en que entre más diminuta sea la pieza, más breves serán los versos en los que el autor deberá transmitir un mensaje completo y claro para el lector.

\footnotetext{
360 Sobre el color de las armas, Alonso de Cartagena explica en su Doctrinal de cavalleros, los caballeros noveles debían vestir paños de colores para que les diesen alegría y sus armaduras fueran más vistosas. Alonso de Cartagena, Doctrinal de cavalleros, ed. de José María Viña Liste, Santiago de Compostela, Universidad de Santiago de Compostela, 1995.
} 


\subsubsection{Ornamentos florales}

Una de las características más llamativas del atuendo de los personajes caballerescos es el uso de materiales como tela, metal y tinta para adornar los espacios del traje, desde la saya, la falda y las mangas, hasta el yelmo, la sobreveste y el escudo, todo en función de ser los más vistosos al momento de asistir a las justas y torneos, pero también como una forma de comunicación entre los enamorados.

El lenguaje bordado, estudiado en apartados anteriores, sobre las letras de amor llevadas en las armas del caballero es un principio sobre el lenguaje oculto en la vestimenta caballeresca del siglo XVI que tiene como referente las letras de justadores recogidas en los catálogos de emblemas desde la Edad Media; al respecto, Alberto Montaner ${ }^{361}$ se ha interesado sobre el significante y el significado de los signos que aparecen en las armaduras de los justadores, a quién van dirigidos y quién los comprende a simple vista. Esta misma idea se presenta en los libros de caballerías, pero no sólo en el traje metálico, sino también en la tela que confecciona los vestidos femeninos, como un espacio en el que se puede responder la confesión amorosa del caballero con ayuda del hilo y las piedras preciosas, pero ahora mediante figuras florales, que no sólo manifiestan el mutuo sentimiento, sino que desencadenan acciones favorables y melancólicas a fin de poner a prueba la dicha esperada, el amor.

${ }^{361}$ Alberto Montaner, "Emblemática caballeresca e identidad del caballero", en Libros de caballerías (de $\langle<$ Amadís $\rangle>$ al $\langle<$ Quijote $>>)$ Poética, lectura, representación e identidad, Salamanca, SEMyR, 2002, pp. 267-306. 


\subsubsection{Flores de adorno}

La primera presencia de flores textiles surge como simple ornamentación para las prendas, sin que su uso adquiera una importancia mayor a la del modo en cómo están representados en la tela, por medio de hilos de oro y piedras preciosas. Generalmente, la delicadeza del diseño está en las imágenes realzadas, es decir, el volumen otorga una mayor vista a la prenda. En el caso de los pétalos, esta técnica adquirió notoriedad en los vestidos de las cortes europeas del siglo XVI por la detallada confección en los accesorios femeninos, guantes, sombreros y bolsos debían confeccionarse acorde al resto de las prendas. En algunos casos, su reducido tamaño dificultaba la colocación de perlas, plumas y broches. Por ejemplo, en el retrato A Young Lady Aged 21 (1569) el bonete lleva pequeñas flores de doble pétalo realzadas, en el centro lleva una especie de piedra por la que está cosida a la tela, en armonía con las flores bordadas de la blusa, que también tienen una piedra dorada y con los anillos de la misma figura.

Este retrato es solo un ejemplo de lo detallados que eran los trajes de la realeza y responde al modelo de vegetación inserta tanto en las pinturas como en la indumentaria ya que "la flor se presenta en los bordados y dechados de muy diversas formas: en la mano de la dama medieval, llevando también un espejo como símbolo de amor o de seducción; formando guirnaldas, ramilletes, coronas." ${ }^{362}$ en los que se deja huella de las flores más comunes: "azahar, flores de mil hojas, clavelillo, roseta, tulipán, margarita, lirio, azucena, etc." ${ }^{363}$. En los libros de caballerías la principal presencia de flores está en las guirnaldas, ya sean de flores naturales o de cristal, hay numerosas referencias al tipo de piedra con las que se forman, diamantes, zafiros, rubíes y perlas; asimismo en las prendas, como una

\footnotetext{
${ }^{362}$ María Ángeles González Mena, Colección pedagógico textil..., p. 151.

${ }^{363}$ Idem.
} 
forma de incrementar su belleza: "La condesa Roseta vestía unos paños de seda morada con unas flores de oro muy ricas" (Policisne de Boecia, XVI). Pero también hay algunos ejemplos en los que el caballero las porta en las armas: "No tardó mucho que Carleseo, Duque de Tebas, vino armado de unas armas jaldas e unas rosas por divisa" (Polindo, XLIV) sólo por decoración, o en la cabeza:

un doncel de edad de once años, de tan grave y hermoso rostro que ser señor del mundo representava; venía vestida una aljuba de encarnado terciopelo, bordado de plata de canutillo y un pequeño manto de tafetán blanco con unas flores de oro, en la cabeça una montera blanca, con una toca de gasa de plata hechas unas graciosas bueltas y muchas rosas grandes de la propia toca con unos labirintos de reluciente argentería y al un cabo sobre una rosa una garçota encarnada (Flor de caballerías, XXXV)

Para armonizar su tocado con el resto de su ropa y para exteriorizar el poder y la categoría social a la que se pertenece.

Por otra parte, también aparece la presencia de diversos elementos florales en los atavíos en torno a diversas situaciones que pasan los personajes, generalmente por cuestiones sentimentales, bélicas y festivas, cuya función central indica su afición por un personaje en particular a manera de recurso para comunicarse sólo con ciertas personas sin necesidad de palabras, a través de mensajes cifrados.

\subsubsection{Clavel}

Una de las estrategias que más utilizan los autores de libros de caballerías es la transmisión del linaje y del amor a través de la joyería, esto mediante figuras de flora y fauna creadas con piedras preciosas y llevadas tanto por los caballeros, en torneos y bailes, como por las damas, en banquetes y justas; la utilización de este sistema de comunicación responde a códigos secretos entre la pareja protagónica, pues recordemos que su relación no debe ser conocida por los demás, sino hasta la culminación del matrimonio en público. Por lo que 
hay una necesidad de hablar de su relación de forma secreta, ya sea por medio de cartas, mensajes llevados por los criados de la pareja o por la vestimenta, una nueva forma de comunicación que se pretende demostrar en este apartado.

Los testimonios de flores presentes en la indumentaria desde la Antigüedad hasta la fecha son numerosos, pues se hallan tanto bordados, pintados y realzados, como hechos con todo tipo de materiales como metal, cristal, porcelana, tela y piel, materiales que se adecuaban a cada clase social. Nieves Fresneda comenta que durante los siglos XIII y XIV las flores más usuales estaban hechas de laminillas de plata a las que daban forma de hojas $^{364}$, su estructura era sencilla y de un solo color. Después, a finales del siglo XV, los motivos florales tuvieron mayor presencia en todo tipo de joyería, desde coronas, collares y prendedores. Muestra de ello son las numerosas joyas de la reina Juana con flores de distintas clases. Uno de los más llamativos es "un collar de oro hecho de rosas esmaltadas de blanco y negro y pardillo, con unos gusanicos con los que se asen las unas pieças con las otras esmaltadas de rosiquel y verde que ay cuarenta y cuatro rosas y cuarenta y tres gusanicos"365. Los ornamentos son más elaborados conforme pasa el tiempo, pues las reinas pretenden atraer la mirada de los demás con lo que llevan puesto. Lo mismo ocurre en los libros de caballerías, en los que los adornos para el cabello sobresalen por su estructura y simbolismo.

Entre las flores y frutos que más aparecen en las obras de Silva destacan la bellota y el clavel, esta última principalmente en la joyería; ya sea en la cabeza en guirnaldas o bordadas en el vestido. Esta flor se conoce por su "olor grande que tiene del clavo aromático y por ser clavel en España por ser olorosa su flor, como los clavos de especias”

\footnotetext{
${ }^{364}$ Ibid., p. 545.

365 José Ferrandis, Inventarios reales..., p. 29.
} 
(Autoridades); se trata de la flor que más "se representa en todas las escuelas artísticas de bordado representado de formas diversas, de tal modo que se distingue perfectamente el clavel de un solo verticilo de estilo toledano, el clavel o trébol de dos verticilos en las labores cacereñas, el clavel de varios verticilos de la escuela segoviana, el de estilo zamorano con sus tallos acodados, etc." ${ }^{366}$ La importancia del clavel ${ }^{367}$ en España viene desde que Carlos V le regalara esta flor a su esposa Isabel de Portugal, quien asombrada por su belleza y aroma ordena cultivarla en los jardines del palacio en Sevilla ${ }^{368}$, de ahí la popularidad que recibe entre poetas, escritores y pintores.

Es a partir de este gusto por esta flor roja que los autores la toman como inspiración y crean una gran variedad de escritos en torno al clavel. El primero de ellos es el propio Feliciano de Silva, quien a partir del Florisel de Niquea incluye algunas presencias del clavel. La primera de ellas es como parte del paisaje: "aunque las paredes del jardín eran muy altas e lisas, y sentóse en un poyo que en el jardín se hazía, donde muchos claveles y flores avía, gozando de la suavidad de aquel olor "(Florisel de Niquea III, XXVII). A pesar de la abundancia de flores, el autor hace referencia sólo a los claveles, como elemento natural del espacio, en el que sobresale su fragancia, ya antes señalada por Covarrubias. Este primer acercamiento se detiene sólo en el aroma; sin embargo, enseguida se presentan tres escenas en las que el clavel aparece como joya.

\footnotetext{
${ }^{366}$ María Ángeles González Mena, Colección pedagógico textil de la Universidad Complutense de Madrid: Estudio e inventario, Madrid, CSUCM, 1994, p.151.

${ }^{367}$ San Isidoro de Sevilla no menciona esta flor en sus Etimologías. Antes de Feliciano no hay registro alguno del clavel en alguna obra literaria, por lo que se le puede considerar pionero en el uso de este elemento floral, su obra es de 1532. Posteriormente, ya en 1536, se inicia una serie de escritos sobre esta flor por el gusto que los reyes, Carlos V e Isabel de Portugal, tomaron por esta planta. Sólo hasta 1599 Francisco de Barahona, en su Flor de caballerías, utilizará esta flor como parte del espacio, principalmente en ínsulas en las que destaca dos tipos de claveles, pequeños de ramilletes y leonados.

${ }^{368}$ Durante su viaje a Túnez, Carlos V trae consigo esta planta y la ofrece como regalo a su esposa. José Quer y Martínez, Flora española o historia de las plantas que se crían en España, Madrid, Joachin Ibarra, 1784, p. 347.
} 
La primera es cuando Alastraxerea se arregla para ver las pruebas entre los

caballeros y, aunque lo disimule, su intención es atraer la mirada de Falanges.

La infanta Alastraxerea, que para ese día se quiso levantar por ver la prueba, la qual venía vestida de una larga ropa, toda plegada y muy ceñida de tela de gruessas perlas, toda sembrada de claveles de oro con las hojas de rosicler por gran arte en sus hojas entexidas, las cuales de esmeralda eran hechas, y sobre un hombro caído llevava una mantilla de raso verde sembrada, toda de claveles blancos con los peçones y hojas de oro muy bien obrados, traía sobre su cabeza un tocado hecho como guirnalda, todo cubierto de claveles de oro y rosicler, texidos con hojas de esmalte verde y por entre ellos por todas partes salían aguedexas los sus muy hermosos cabellos hechos todos lazadas en lo alto de la cabeça (Florisel de Niquea I, LXVIII).

El clavel representa "el amor vivo y puro"369; simbólicamente se transmite el sentimiento de la joven por el caballero, a quien en un principio desairó por mucho tiempo. La importancia del atuendo está en los claveles que aparecen de tres colores, oro, blanco y rosicler. Debido a la composición de la obra, 1532 es una fecha temprana para el conocimiento de los claveles en España, ya que el rey Carlos V lo obsequia a su esposa en 1535 y a partir de 1536 se registran las primeras obras en las que se menciona a esta flor. La respuesta es incierta, aunque cabe la posibilidad de que Feliciano conociera esta planta en alguno de sus viajes.

La segunda aparición es cuando la princesa Diana se atavía para recibir a la reina Cleofila:

[Diana] se tocó de tal manera sus muy hermosos cabellos, sueltos y algo encrespados, y sobre ellos una manera de guirnalda a manera de claveles hechos de finos rubíes, la cual se fixava en la cabeça yendo atada de seis lazadas de guedejas de sus hermosos cabellos y en medio del ñudo de la lazada un joyel de hermosos diamantes (Florisel de Niquea III, XXXIII).

${ }^{369}$ Basilio Sebastián Castellanos de Losada, La galantería española, Madrid, 1848, p.220. 


\section{De la misma manera que Diana se viste Daraida $^{370}$ :}

E sus cabellos que muy hermosos eran le ponen cogidos con una red de oro y en cada ñudo d'ella una gruessa perla e por los lados del rostro le saca tres laçadas de cada parte y en el ñudo de la lazada un joyel y un resplandesciente diamante y encima de la red le ponen una guirnalda de claveles, con que quedó tan hermosa (Florisel de Niquea III, XXXIII).

La importancia del tocado está en las flores que se describen. En ambos ejemplos llevan claveles rojos formados con rubíes. De esta gema ya se ha dicho que "es tan preciosa piedra, que tiene el principado, majestad, y señorío entre todas las piedras ardientes de color"371, cuya virtud "ultra de ser tan hermoso [y] más resplandeciente que las demás piedras" ${ }^{372}$. A vista del caballero éste es el valor de su dama, la más bella y virtuosa de entre todas las demás, por ello la representación de sus cualidades a través del color y la forma de su tocado será importante para el reconocimiento de la dama, pues Diana es la única mujer que lleva tocado de claveles.

Como se puede notar en la descripción de ambas damas, a pesar de estar vestidas y ataviadas de manera semejante, predomina la belleza de Diana, por ser la principal de entre las tres. La primera diferencia es el número de lazadas, Diana lleva seis y Daraida tres. A pesar de la gala de esta última, su belleza no es suficiente para superar a la de su señora, pues la propia Lardenia lo confiesa: “a la sazón en aquel hábito ninguna doncella le hazía

\footnotetext{
${ }^{370}$ Es necesario aclarar que Daraida es la personificación femenina de Agesilao, Príncipe de Colcos, quien, enamorado de Diana, se disfraza de dama para poder estar cerca de ella, por ello adopta el nombre de Daraida y viste prendas femeninas. Lo mismo ocurre con Arlanges, príncipe de Grecia y rey de España, quien se disfraza de Garaya para ayudar a Agesilao a conquistar a Diana. Durante el transcurso de la historia, Arlanges se enamorará de la reina Cleofila, a quien servirá como dama de compañía bajo el disfraz de Garaya. Para esta investigación no se estudiará el motivo del disfraz, sino que solamente se analizará la vestimenta femenina que ambos caballeros usan y se destacarán los elementos simbólicos que la integran y su función como generadora de acciones.

${ }^{371}$ Gaspar de Morales, De las virtudes y propiedades ..., p.271.

${ }^{372}$ Ibid, p.272.
} 
ventaja fuera de Diana" (Florisel de Niquea III, XXXIII). Sin embargo, hay una razón superior para la suprema belleza de Diana sobre la de Daraida, la dama protagónica siempre será superior en belleza a las demás; sin embargo, en esta pareja entra un juego de apariencias que será importante para el uso de la vestimenta, pues Agesilao, al querer estar más cerca de Diana, necesita del ingenio para vestir y atraer, por medio de la ropa, la mirada de Diana, así que se disfraza de dama cantora. Posteriormente, Daraida y Garaya vuelven a usar un atuendo similar al anterior, esta vez para reunirse con los reyes Amadís de Gaula, Esplandián, Oriana, Amadís de Grecia y Niquea: "En la cabeça se puso una guirnalda a manera de claveles de muchos rubíes, iva fizada de cada lado con dos lazadas de cabellos" (Florisel de Niquea III, CXVI). La importancia del clavel prevalece, aun cuando la dama principal no esté presente, el caballero, en su traje de mujer, debe portar la flor de su amada.

La combinación de animales y plantas, en vestimenta y tocado, será frecuente en estas historias, una de las más significativas la protagoniza nuevamente Alastraxerea, quien "llevava sus hermosos cabellos sueltos y hechos de guedejas d'ellos, de los cuales pendían doze joyeles que no tenían precio, de forma de harpías hechos, y sobre la cabeza una guirnalda de dança de joyeles de las mismas arpías (Florisel de Niquea II, LXIII). Flora y fauna se unen en el ajuar de Alaxtraxerea. Confeccionado con bellotas bordadas en el vestido y con joyeles, hacen de su insignia una de las más importantes en esta historia, debido al simbolismo que revelan los animales fijados en su guirnalda, el carácter fuerte de la dama y su forma de comportarse con Falanges, su caballero, pues al ser desdeñosa y fría hacia el joven, esa es la forma de transmitirle sus sentimientos. En un principio se oculta bajo la imagen de la arpía, pero finalmente accede a la petición del caballero. Recordemos 
que la arpía simboliza el tormento y sufrimiento por el deseo ${ }^{373}$, en este caso, el amor de Falanges que en un principio no fue correspondido, por lo que durante el transcurso de la historia la dama muestra indiferencia por el joven y lo refleja a través de su vestimenta.

A la par de las representaciones negativas en el amor, también están las de correspondencia, aquellas en las que la joven será ingeniosa en la forma de demostrar su amor por medio del color y la imagen.

La reina salió vestida una ropa de raso verde y encima d'ella se hazía una [mane]ra como de red de las aves de su devisa, enlazadas con las uñas e picos, todas de fino oro con las llamas de rosicler [...] los cabellos llevava hechos lazadas en lo alto de la cabeça, y sacadas las lazadas por una manera de red hecha de la misma devisa de los fénix hechos muy sotilmente de oro, y los ñudos de la red eran de finos rubíes para suplir las llamas de fuego de los fénix; de cada lazada de las que sacan, pendía una gruessa perla (Florisel de Niquea III, XXXIII).

La importancia de las piedras que conforman la insignia de la divisa tiene que ver con el nombre de la reina, Cleofila. María Coduras comenta que 'Cleofila' "es nombre de origen griego. Compuesto de kilo, "gloria, renombre, fama" + filia "hija", hija de la gloria",374. La gloria del nombre se refleja en la insignia, el fénix, símbolo de esplendor que renace de entre sus cenizas; este proceso vive Cleofila, quien, enamorada de Amadís, debe despojarse de ese sentimiento para enamorase de Arlanges; al mismo tiempo, deberá olvidar su condición guerrera, pues una vez bautizada, se convierte en reina. De este modo pasa por un cambio de vida que la asemeja a su insignia.

\footnotetext{
${ }^{373}$ Jean Chevalier, Diccionario de los símbolos, Barcelona, Herder, 1986, p.552.
}

${ }^{374}$ María Coduras, La antroponimia en los libros de caballerías españoles..., p.882. 


\subsubsection{Flor de lis (fig. 149)}

Es común la presencia de entrega de obsequios entre los enamorados, entre los que predominan libros, coronas, ropajes y diamantes de gran valor monetario, así como algunas armas recuperadas en batallas: "Y sacó de una caxa que dos moços le traían una espada gineta y una celada y un barbote que las avía avido en el real del Gran Turco, que no avía en el mundo tales como aquellas de su manera, que fueron estimadas en cincuenta mil ducados, según las piedras que avía engastadas en ellas" (Lepolemo, CXI). En correspondencia a estos obsequios, el joven agradece de la misma forma, enviando un regalo semejante a la infanta, en este caso, a la infanta Andriana, y a partir de esta entrega es cuando comienza el juego de palabras a través de los objetos. El presente es "una cruz hecha de tres flor de lises sobre un pie" (Lepolemo, CXI), cuyo simbolismo es doble, porque se trata de "las armas de Francia, junto con la cruz, la cual ha sabido que fue del rey, vuestro bisagüelo, que fue preso de turcos, y él la cobró en la gran batalla qu'el soldán ovo con el turco y lo desbarató" (Lepolemo, CXI).

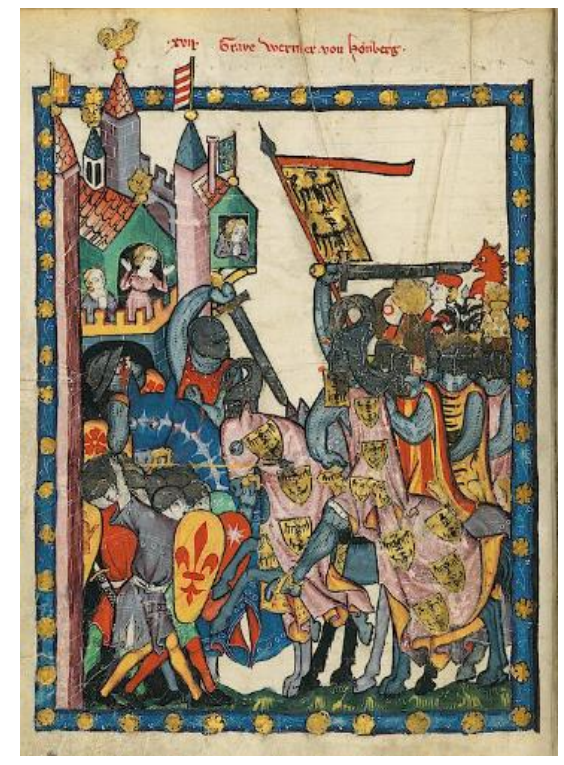

Fig. 149.Codex Manesse (s. XV)

Flor de lis en el escudo 
La infanta, al conocer acerca de la historia de dicha joya, perteneciente a sus antepasados: "pareció que le atravessavan un puñal por el coraçón" (Lepolemo, CXI); esta misma sensación le ocurre al Caballero de la Cruz cuando recibe la cruz de diamantes: "[El Caballero de la Cruz] mandó sacar de sus arcas muy ricos vestidos a maravilla, qu'en todos ellos avían sus cruzes coloradas en los pechos. Y vistióse muy apuestamente y no quiso ponerse otra joya sino la cruz que la infanta Andriana le avía embiado, y levávala sobre todos los vestidos." (Lepolemo, XXIV). El código de comunicación es mediante "la cruz", porque el caballero lleva esta divisa en sus armas, ahora también en su ropa y se fortalece con la presea de la infanta, por lo que hay una triple manifestación del amor que se sostiene con la presencia de un tercer personaje, el intermediario.

La participación del hermano de la infanta Andriana es relevante en la comunicación de la pareja no sólo por ser el mensajero entre ellos, sino porque está en contacto con ambos, por lo que es testigo del uso de las joyas de amor, además de que es quien confirma los sentimientos de ambos:

\section{Dixo Hermana:}

-Si él alguna dama sirviera, no hos embiaria a vós los presentes y prisioneros. De más d'esto, no traería como trae siempre la + que vós l'embiastes al cuello, teniendo otras muchas joyas que traer. ¿Y queréislo ver más claro creo que hos ama, que hos embió a vós su devisa y vuestras armas, todo junto en un joyel? Que es claro señal de deseo de serviros. Y esto en la + de las flor de lises venía todo junto. (Lepolemo, CXXVIII)

Es decir, en un solo objeto se alberga la entrega del amor, cuyo significado se desdobla en los dos motivos relevantes para el caballero, el amor y las armas; por un lado, la cruz como divisa de sus armas; por el otro, la flor de lis, como emblema del 
reino de Francia y de su dama. A esto se une la confidencialidad depositada en su hermano, a fin de tener un testigo que confirme su entrega total a su señora.

\subsubsection{Ramos de oliva}

La necesidad de rescatar al amado obliga a la doncella a tomar las armas como un medio de transformación para ocultar su identidad femenina y así acceder con más facilidad a la prisión en donde lo tienen encerrado. Para ello, necesita una divisa que la identifique con sus amigos, pero también con la que pueda demostrar sus sentimientos: "Y mandó la infanta qu'el campo del escudo fuesse blanco con unos ramos verdes de oliva sembrados por aí con sus sobreseñales con los mismos ramos, y vos digo que era bien luzido todo" (Platir, LXX). Florinda no duda en portar las armas y aventurarse a la cueva para justar contra Peliandos y lograr ver a Platir. La insignia que manda dibujar, unos ramos verdes de oliva, además de simbolizar la paz, representa "la fuerza y la victoria"375 que Florinda necesita y desea para rescatarlo de la cueva, pero también representa “oro y amor"376, motivo por el que debe arriesgar su vida y liberar a su amado. Esta imagen de los ramos de oliva, que será motivo de una búsqueda insistente en esta historia por parte de otros personajes: “Avedes, señor, de saber -dixo Mirnalta- que yo á mucho tiempo que ando en busca de un cavallero que por mi mal yo conocí, el cual trae un escudo blanco y unos ramos de oliva sembrados por él y las sobreseñales de lo mismo" (Platir, LXXVII), conlleva una posible vinculación al linaje de Platir, a manera de conservar de algún modo la pertenencia sentimental de la doncella, quien, de alguna forma, desea mantener su lazo afectivo en relación al apellido. Sobre esto Marín Pina expresa que "el topónimo $<<$ de Oliva $>>$

\footnotetext{
375 Jean Chevalier, Diccionario de los símbolos, p. 775.

${ }^{376}$ Ibid, p. 776.
} 
responde al nombre de la montaña y es el clásico sintagma que caracteriza a los caballeros por su procedencia", ${ }^{377}$ es una estrategia para revelar su lugar de pertenencia sin notificar a cuantos personajes halle en su camino su unión amorosa por un miembro de esta familia.

\subsubsection{Flor verde (fig. 150)}

En el ejemplo anterior la dama requirió ir a las afueras del reino llevando consigo la imagen floral, pero también hay momentos en los que se invierte el motivo, es decir, ir en búsqueda de este elemento natural como muestra del amor que se tiene por la dama: "Y pues os ofrecéis a hazer tanto como dezís, desde agora podéis procurar de aver un ramo del árbol de la verde flor. Y si vós éste me traéis, yo consentiré que me podáis ver e no más, porque pensar en ál para vós e a todos los del mundo sería tan imposible como vós traerme lo que os he dicho" (Félix Magno IV, CLIIII). Desamado, que así se llama el caballero, esperanzado en las palabras de la dama, emprende el camino en busca de la flor verde.

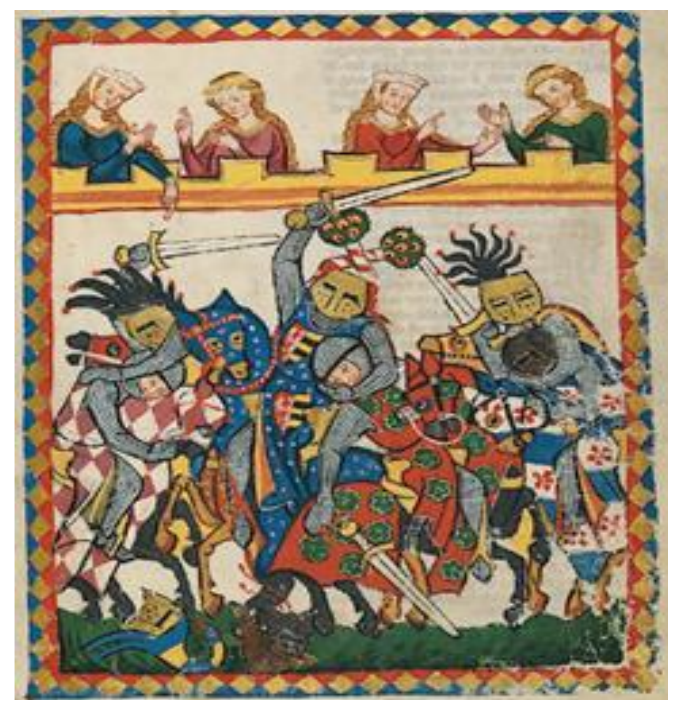

Fig. 150. Codex Manesse (s. XV) Flores verdes pintadas en la gualdrapa.
Triste y fatigado por el viaje, el caballero se encuentra con un hada, quien lo ayuda a obtener la flor. Primero le indica el lugar en el que se halla, para acceder debe tañer y cantar para adormecer a las bestias que custodian el árbol y así obtener el ramo. Una vez que lo hace y regresa con el hada, decide llamarse el Cavallero de la Verde Flor, en directa alusión a la presea para la dama.

\footnotetext{
377 María Carmen Marín Pina, "El personaje y la retórica del nombre propio en los libros de caballerías españoles”, Tropelías, $\mathrm{N}^{\circ} 1,1990$, pp. 168-169.
} 
Sin embargo, se presenta una situación en contra de este caballero; el hada había prometido ayudarlo a conseguir el amor de la dama, pero antes de que esto ocurriera, ambos se ponen a cantar y bailar. Ante tal espectáculo, el caballero se burla del hada y ésta en venganza revierte el amor en desamor: "-Mal aya quien aquí te truxo que mucho has perdido de la tu ventura. Que sábete que la buena voluntad que yo tenía es tornada en mala. Y en lugar del bien que te avía de hazer, doite por hado que nunca, de la cosa del mundo que dizes que más amas, puedas aver otra cosa sino solamente miralla. Y de cada vez que la mirares, se te doble tu gran pena e nunca sanes d'ella hasta que mueras." (Félix Magno IV, CLIIII)

El simbolismo de esta situación es aún más extenso y recae en el color de la flor: "lo que buscaba era verde y en buscarlo avía esperança de hallarlo, en lo cual se podía decir aver parte de consuelo. Lo cual todo era agora buelto al revés, porque toda esta esperança e lo verde de su ramo e lo que más podía tener, todo le parecía que se le avía buelto muy negro, porque la su gran tristeza a par de muerte le semejava que allegava" (Félix Magno $I V$, CLIIII). Nótese esa doble alusión a lo verde, como representación de la esperanza y la tonalidad del ramo, cuya propiedad mágica de otorgar el amor de la dama que lo tuviera en las manos le fue quitada por la profecía del hada. Pastoureau otorga una ambivalencia a éste por ser "el color de la suerte y de la mala suerte, el color de la Fortuna y del Destino"378 que en esta historia hasta en los nombres se comprende esta oposición Desamado y Bienamada, pues al tener la flor entre sus manos, el caballero creería que la correspondencia en amores se realizaría, pero la mala fortuna del hada lo impidió.

${ }^{378}$ Michel Pastoureau, Diccionario de los colores, Barcelona, Paidós, 2009, p. 30. 


\subsubsection{Lirio (fig. 151)}

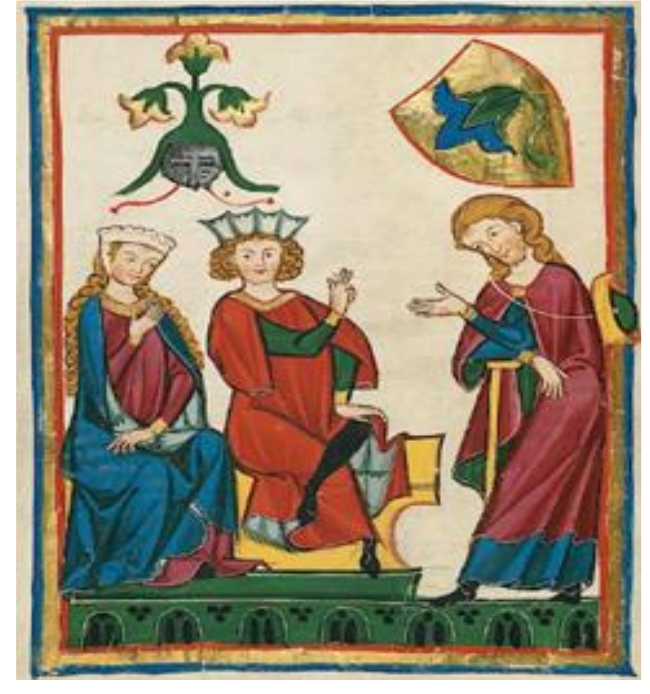

Fig. 151. Codex Manesse (s. XV) Lirios en el escudo y en el yelmo.
La demostración afectiva también se realiza con la colocación de imágenes florales hechas con cristal o metal, como una forma de atraer la mirada por medio del brillo de estos materiales y con especies vegetales poco recurrentes en estas historias, es el caso del lirio, el cual sólo aparece en dos libros, Baldo y Flor de caballerías, con distinto significado pero una coincidencia, el color.

En el Baldo se localiza en la ropa de la dama: "estaba la hermosa Baldovina, cubierta de una aljuba de carmesí, sembrados en ella lirios cárdenos de maçonería" (Baldo, I, II). Este método localizado en el Baldo presenta un interesante simbolismo por la forma en cómo se desarrollan los amores de Baldovina y Guidón, además de los rasgos que rodean a la prenda de la dama: el color, el tipo de flor y la forma en como está creada.

En primer lugar, el lirio, símbolo de "blancura, pureza, inocencia y virginidad", ${ }^{379}$ contrasta su significado con las acciones realizadas por la pareja, debido a que Baldovina y Guidón, ante sus deseos pasionales, huyen a Paris, en donde consuman su amor, hecho que desencadenará una serie de desventuradas situaciones para la pareja. Por un lado, del resultado de sus afectos nace Baldo, pero Baldovina muere durante el parto; en seguida, Guidón se retira a una isla como penitencia por su pecado por no controlar sus deseos y haber perdido a su dama; por último, el pequeño es nombrado Baldo para mantener un recuerdo de su madre y es criado por un aldeano.

\footnotetext{
${ }^{379}$ Jean Chevalier, op. cit., p. 651.
} 
El cárdeno ${ }^{380}$ era un color que estaba entre las tonalidades del azul-morado-rojo por lo que no se trataba de una pigmentación definida totalmente, sino que, dependiendo de las cantidades agregadas para su realización, se obtenía su coloración. Generalmente, predomina la gama de los morados, por ello "los reyes ostentan la insigne vestidura de la púrpura como símbolo de la dignidad regia" ${ }^{381}$, decoro que guarda la dama durante las justas en la corte de su padre, hasta que Guidón gana el premio y lo entrega a ésta en señal de su amor, pero que posteriormente pierde al huir del palacio.

La imagen floral es llevada en una aljuba carmesí, color en sintonía con el de los lirios cárdenos. En ambos elementos se inserta la importancia de tonalidades que designa la posición real de la dama, así como su correspondencia por Guidón. Pero no es casual que aparezca esta imagen, ya que cuando se ofrece esta flor al amado es una forma de decirle "deseo inspiraros un amor vivo y puro" ${ }^{382}$, mensaje que se da de manera abundante en cada uno de los lirios que adorna la aljuba.

En esta cadena de sucesos que van del amor a la muerte, la pureza de la dama, representada por medio del lirio, se fragmenta al haber sido expuesta a una relación fuera de los lineamientos reales provocados por la huida, por lo que, para este ejemplo, la manifestación del amor a través de un elemento floral llevado en la ropa, se concibe sólo durante el tiempo en que la pareja está junta, puesto que los tres elementos antes mencionados, color, flor y materiales, preservan su simbolismo mientras los enamorados lo viven, puesto que, una vez acabado este afecto, no se remite más a su imagen sentimental,

\footnotetext{
${ }^{380}$ En la actualidad, "se aplica al color morado y a las cosas que lo tienen". María Moliner, Diccionario de uso del español, Madrid, Gredos, 2007, p. 547.

${ }^{381}$ Isidoro de Sevilla, Etimologías, VII,2,2.

382 Basilio Sebastián Castellanos de Losada, La galantería española: sistema y diccionario manual del lenguaje de la galantería y sus divisas, Madrid: Imprenta de Francisco Mellado, 1848, p. 274.
} 
como sí ocurre con otras parejas en cuyas historias se remite a la insignia de amor en varios momentos de la trama. ${ }^{383}$

Caso contrario ocurre en Flor de caballerías, cuya mención es mínima, sin desatar acción alguna: "en cesando vido salir un cavallero grande de cuerpo, armado de armas açules con lirios rojos y de horo; traía en las manos una maça” (Flor de caballerías, XXIII). Quien lleva estas armas es el jayán don Urgel de la Maça, quien se enfrenta a don Rorsildarán para prohibirle el paso a la Ínsula del Lago. La única relación posible entre los lirios rojos con la aventura es que en la isla se halla un paraíso natural habitado por diferentes animales, árboles frutales y diversas flores, de las que sobresalen: "los rojos claveles, los blancos jazmínes, las matiçadas açucenas, los fragantes mosquetes. Las moradas violetas, [y] los amarillos alhelíes" (Flor de caballerías, XXIII). Nótese que no se menciona ningún lirio en el jardín.

La flor está presente en los libros de caballerías como decoración natural visible en los jardines y artificial a través de las decoraciones de la arquitectura y las pinturas que decoran las paredes de los palacios. Su imagen no se limita al adorno, sino que fuera de ella, hay una importante presencia de símbolos relacionados en torno a la relación sentimental de la pareja, cuya estrategia para la comunicación busca manifestar mensajes a través de claves pintadas y bordadas sobre la vestimenta. Es decir, abrir una nueva forma de interacción que albergue los elementos más representativos del caballero y la dama: color, figura y letra.

\footnotetext{
${ }^{383}$ Recuérdese la rosa blanca como divisa floral que Claribalte lleva en alusión a Dorendayna, así como los
} claveles que aparecen a lo largo de las obras de Feliciano de Silva. 


\subsection{Prendas de protección}

En los libros de caballerías las damas y los caballeros se caracterizan por usar atuendos vistosos de fina tela, adornados con piedras preciosas y bordados con hilos de oro. Estos atavíos resaltan en bailes y justas, en donde cada personaje es reconocido por un traje que los caracteriza durante toda la historia. Usualmente, aparecen ciertas prendas que cubren distintas partes del cuerpo, como el jubón, las calzas, la camisa y los bonetes. Otras aparecen sobre estas prendas y se caracterizan por cubrir la mayor parte del cuerpo, como el manto, la capa y la capilla. Vestimentas que cubren a todo el personaje porque son ropas amplias que ocultan desde el rostro hasta los pies.

Esta indumentaria, poco estudiada en estos libros, tiene una presencia relevante en situaciones recurrentes como los encuentros sentimentales entre el caballero y la dama. Su lugar de reunión es un locus amoenus, espacio de encuentros, confesiones y demostraciones amorosas. Sin embargo, para llegar a él es necesario trasladarse y cubrirse para no ser identificados por otros personajes, pues ponen en riesgo su honra, por lo que necesitan usos amplios para no ser reconocidos. También están los traslados de algunas damas que fungen como mensajeras, pero por algún motivo deben ocultar su rostro. Finalmente aparecerán otros eventos en los que hay una preocupación por ser conocido, por lo que se recurrirá a taparse la cara.

El propósito de esta apartado es conocer el simbolismo de protección de algunas prendas que la pareja y otros personajes usan para cubrir su fisonomía al trasladarse a diversos lugares. Esto es necesario porque en el camino se encuentran con otros personajes que al ver a la pareja pueden poner en riesgo su secreto si deciden revelar la relación amorosa, o que las encomiendas sean descubiertas y arruinados los planes de magas y 
princesas. Por ello, es necesario que la dama y el caballero se cubran para evitar ser identificados por la vestimenta que usualmente portan.

\subsubsection{Toalla y rebozo}

Uno de los preceptos de Juan Luis Vives en su obra Instrucción de la mujer cristiana, establece que las damas solteras deben usar el manto si quieren salir de casa ${ }^{384}$ para cuidar su honor y no ser avergonzadas con malentendidos. La joven desde la Edad Media solía estar con su dama de compañía, quien era intermediaria y confidente de sus amores. Con ella asistía a los encuentros del caballero, para salir ambas iban cubiertas por una tela. Un ejemplo lo tenemos en el Claribalte: "y la princesa iva como criada de Fulgencia e llevaba una tovalla delante del rostro porque nadie la pudiesse conocer" (Claribalte, XVI).

El trayecto de la habitación de la joven a la iglesia no era muy largo; sin embargo, Dorendayna se pone en riesgo dentro de su propia corte, por lo que su cuidado al salir debe ser aún mayor para no ser vista por sus padres. Otro de los motivos por los que va oculta es que ésta es la primera reunión con Claribalte, por lo que apenas descubrirá si es requerida en amores por el caballero.

La tela que lleva en el rostro es una toalla, que según el Tesoro de la lengua se trata de "paños de manos, suelen ser de un lienzo crespo, diferente la trama de la urdimbre 385 ". Los lienzos crespos eran una tela de lino gruesa ${ }^{386}$ que servían para confeccionar distintas

\footnotetext{
${ }^{384}$ Juan Luis Vives, Instrucción de la mujer cristiana, Madrid, Fundación Universitaria Madrid/Universidad Pontificia de Salamanca, 1995.

385 Urdimbre: Conjunto de hilos colocados en paralelo y a lo largo en el telar para pasar por ellos la trama y formar un tejido. (DRAE)

${ }^{386}$ Carmen Bernis, Trajes y modas en la España de los Reyes Católicos: I. Las mujeres..., p.26.
} 
prendas. Las más comunes para llevar en el rostro durante un viaje eran "la toca de rebozo colocada bajo el sombrero, un volante, un rostro o un antifaz" ${ }^{387}$ (figs. 152-157).

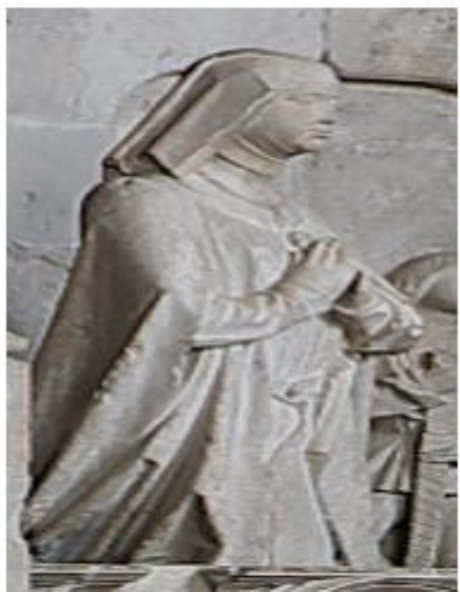

Fig. 152. Sepulcro de Isabel de Cuadros (1467) Monasterio de Guadalupe. Rebozo en la barbilla

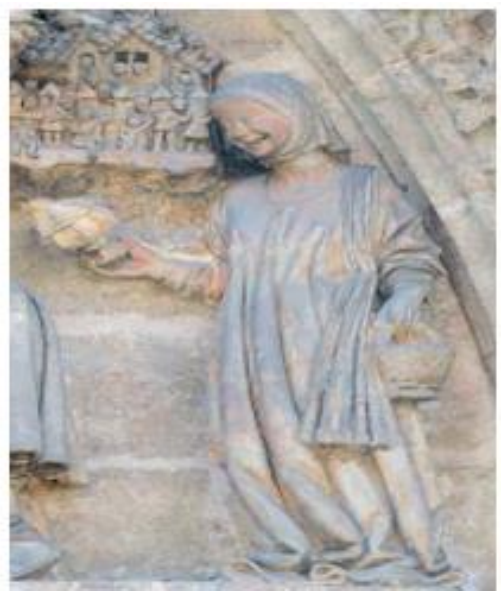

Fig. 153. Adoración de los pastores (1464-1467) Lorenzo de Mercadante, Sevilla. La mujer lleva una toca con rebozo.

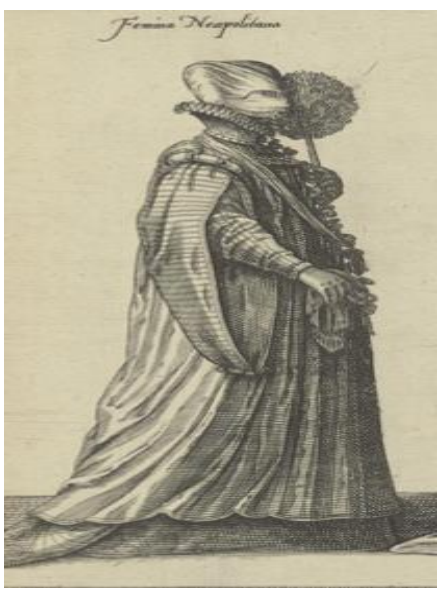

Fig. 154. "Dama napolitana", Habituz variarum orbis gentum (1581) Jean Jaques Boissardi. Lleva 'volante' en el rostro.

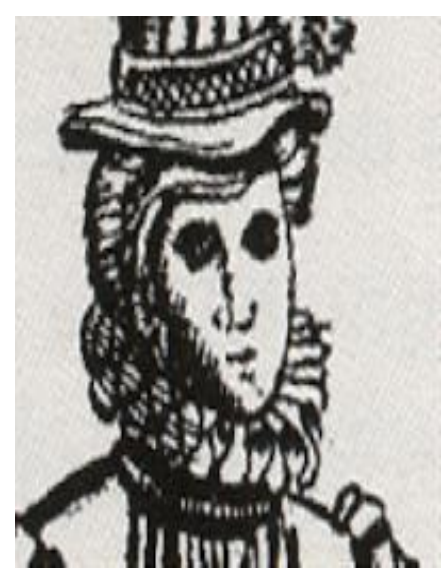

Fig. 155. Diversarum nationen habitus (1594) Pietro Bertelli.

Dama con 'rostro' en la cara, como una careta que solo deja visible los ojos.

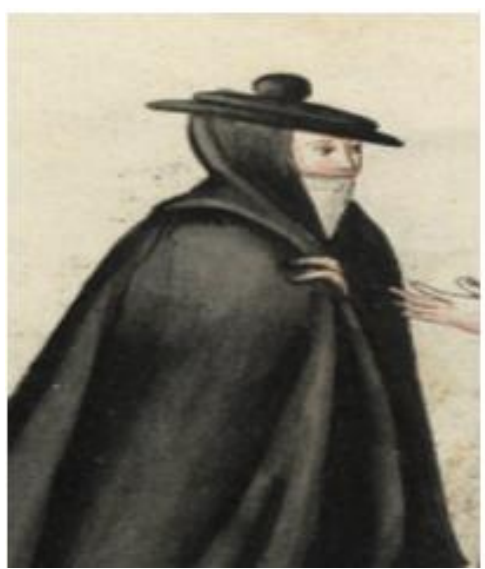

Fig. 156. Códice de Trajes (s.XVI) Dama con paño de rostro.

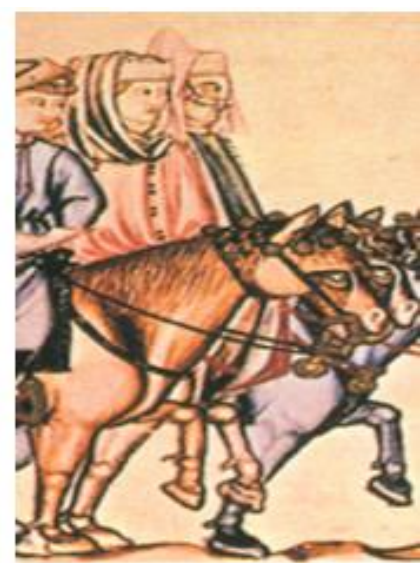

Fig. 157. Cantigas de Santa María (1280-84) Alfonso X La dama de en medio lleva tocas para el camino.

Además, se debe considerar la ilustración del folio 19v de la edición de 1519 del Claribalte (fig. 158), en la que se nota claramente que se trata de "la toca de rebozo", no sólo por la utilización del sombrero, sino porque en páginas posteriores se menciona que:

${ }^{387}$ Carmen Bernis, El traje y los tipos sociales en el Quijote, Madrid, El Viso, 2001, p. 54. 
Y como la paciencia de Dorendayna no pudo ya sofrirse más encubierta, aunque hasta allí ninguno la avía conoscido, abaxó el reboço que delante de la cara tenía y dixo: <<Cavallero, más testigos tenéys de los que pensáys. Yo me he determinado de hablaros aquí para ver si te<n>go en vos la parte que creo. Y si os quise por mi caballero, no es para que sea causa de poner vuestra persona y vida en la aventura y peligro que agora dezíades [...] >> (Claribalte, XVI).

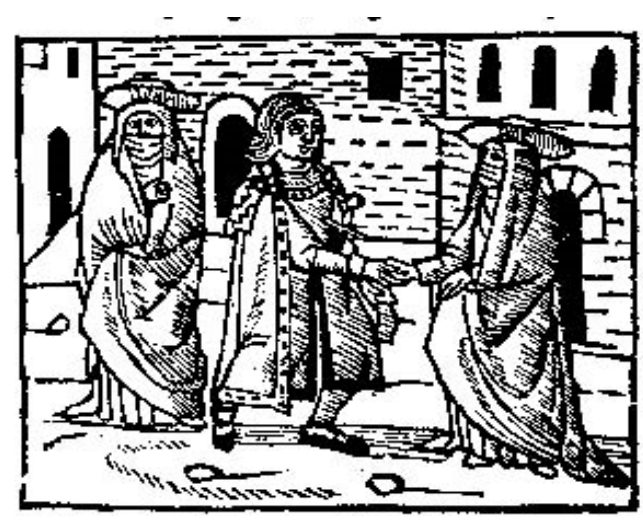

Fig. 158. Cap. XVI, fol.19v.

Esta tela es una breve barrera de comunicación para Dorendayna porque impide que la dama confiese sus sentimientos hasta estar segura del corazón del joven. Claribalte hace una larga declaración de amor que pretende decir a Dorendayna cuando la vea; sin embargo, desconoce que la persona sentada junto a Fulgencia es la misma princesa. En esta descripción, dos elementos requieren especial atención, la primera el cambio de nombre de la prenda, un "reboço"; el segundo, la expresión "aunque hasta allí ninguno la avía conoscido". Referente al rebozo, el Tesoro de la lengua dice que se trata de "una toca, conque cubrimos el rostro porque se da una y otra vuelta a la boca”, es decir, hay mayor cantidad de tela para rodear la cara sin temor a ser descubierta.

En cuanto la expresión “aunque hasta allí ninguno la avía conoscido”, es evidente que ni Laterio ni Claribalte son conscientes de las mujeres que están ante ellos, pues de la primera saben que es Fulgencia, ya que reconocen su voz por los anteriores encuentros que 
tuvieron, pero de la segunda, suponen que es criada de Fulgencia por la vestimenta que lleva.

Algunos moralistas consideraban la cara tapada como un arma en favor de la dama puesto que "conocía sin ser conocida" 388 y podía con ello tener muchas ventajas, en este caso, se presenta una doble función en el uso de la tela, primero, como una barrera protectora para cuidar su honor, en armonía con el resto de su atuendo, a fin de no ser identificada por ningún miembro de la corte durante su trayecto del palacio a la iglesia y posteriormente, durante su permanencia en la iglesia. Segundo, ayuda a la dama a escuchar y ser testigo de los sentimientos de Claribalte, de manera que sea ella misma quien descubra si realmente es correspondida por el caballero.

La princesa responde favorablemente a la petición de Claribalte. La doncella se sirvió de la vestimenta para cuidar sus salidas, pues no fue descubierta durante este proceso de conquista. Por lo que se puede ver a la toalla como "un velo que cubre a toda la mujer y a su rostro" ${ }^{389}$, ya que no fue identificada ni por el rostro ni por su vestido.

\subsubsection{Antifaz}

En el capítulo LVI del segundo libro del Amadís de Gaula, se describe el atuendo que Beltenebros aconseja a Oriana que lleve para presentarse ante el rey Lisuarte, su padre, a fin de no ser reconocida por ningún miembro de la corte y no revelar su relación sentimental. El traje es el siguiente:

Beltenebros le dixo:

-Yo ganaré seguro de vuestro padre que me no será demandada cosa contra mi voluntad, e iré armado de todas armas, y vos, señora, llevaréis una capa brocada y

\footnotetext{
388 Antonio de León Pinelo, op.cit., p. 279.

${ }^{389}$ Elena Varela Merino, Los galicismos en el español de los siglos XVI y XVII..., p. 1545.
} 
antifaces delante del rostro, de guisa que a todos ver podáis y ninguno no a vos, y de esta forma iremos y veremos sin que se pueda saber quién somos.

[...] y vestiéndola de la forma que había de ir, con sus lúas en las manos y sus antifaces, la traxeron delante de Beltenebros, y por mucho que él y ellas la miraron a todas partes, nunca pudieron hallar cosa por donde conoçida dellos ni de ninguno otro ser pudiesse; y dixo Beltenebros:

-Nunca pensé, señora, que tan alegre fuera de vos no ver ni conoçer.

(Amadís de Gaula, II, 56). ${ }^{390}$

Tres elementos destacan de su atuendo: la capa, los guantes y los antifaces. Como una forma de ocultar todo el cuerpo, Amadís piensa tanto en las extremidades, como en la amplitud del vestido, por lo que utiliza la capa para cubrir desde el cuello hasta el borde de la falda y las lúas para las manos. (figs. 159-161)

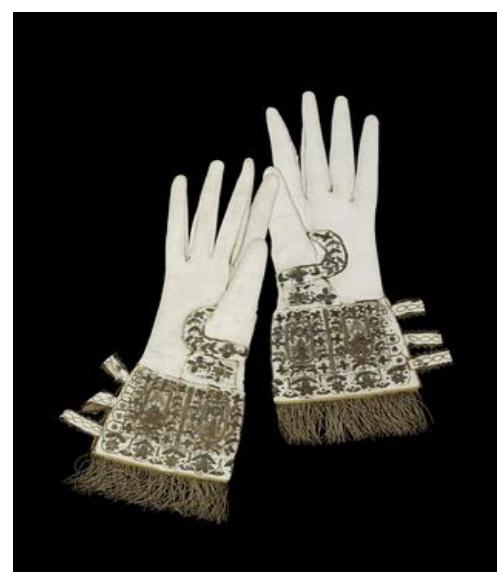

Fig. 159. Guantes de la Reina Elizabeth I (s. XVI)

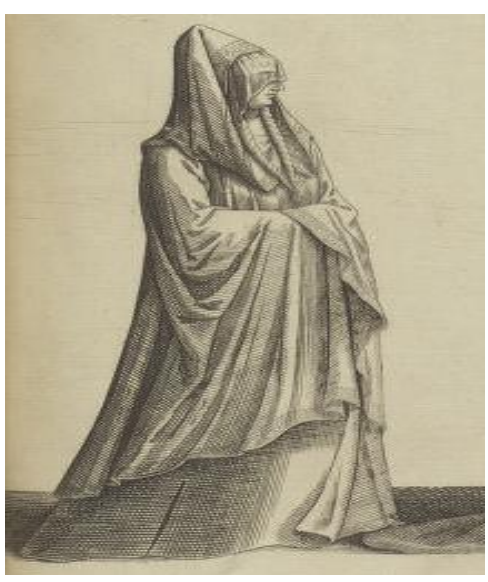

Fig. 160. 'Dama siria', Habituz variarum orbis gentum, (1581) Jean Jaques Boissardi. Mujer tapada con manto y tocado con velo que cubre los ojos.

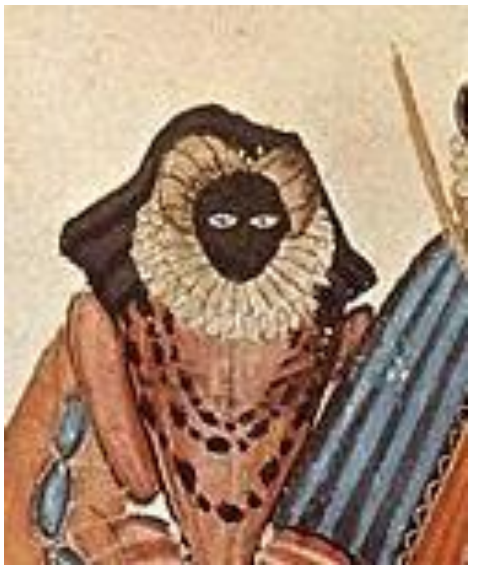

Fig. 161. Book of italian costumes (1588) Niclauss Kippell Dama con antifaz en todo el rostro.

Aunque no se dan muchos detalles de las prendas de Oriana, es necesario aclarar que no se trata de una capa brocada porque no lleva ningún bordado, sino que se refiere a una capa abrochada por la parte de adelante. La falta de imágenes se debe a los siguientes motivos:

\footnotetext{
${ }^{390}$ La prueba que deben superar es la del arco de los leales amadores. Amadís debe sacar la espada y Oriana debe hacer florecer el tocado de flores. Con ello probarán que son los más leales amadores del mundo.
} 
El primero es que en estas historias los personajes se suelen reconocer por las prendas llamativas que portan. Por ejemplo, habrá caballeros que conserven la misma indumentaria por mucho tiempo, como ocurre en el Lisuarte de Grecia, en donde Perión de Gaula deberá traer su misma armadura por un año. Sobre estas armas lleva la tela que lo representa en toda la historia, "un manto de raso verde forrado en carmesí, bordadas por él las mesmas esperas de oro" (Lisuarte de Grecia, LVIII). Lo mismo ocurre con las damas, quienes diseñan sus vestidos con la guarnición de su caballero; por ejemplo, en el Polindo la princesa Belisia, como ya se dijo, se caracteriza por usar prendas bordadas con imágenes de serpientes en alusión a su amado. De esta manera, los personajes se mandan a hacer atavíos especiales para ser reconocidos por su ropa en distintos eventos.

Segundo, si la joven quiere ocultar su identidad, debe llevar una capa lisa, sin bordado ni guarnición, porque sería más notorio su trayecto hacia el castillo de sus padres. Por lo que, si se requería discreción para salir sin ser vista, entonces también es necesario que estás prendas sean discretas, es decir, sin colores llamativos ni imágenes.

Otro accesorio que sobresale son las lúas, guantes que se caracterizan por ir sujetos con cordones de seda ${ }^{391}$. Con esta prenda se deduce que la joven iba totalmente cubierta para evitar ser reconocida por alguna parte de su cuerpo.

Más adelante se da un detalle que completa el atuendo de Oriana, el silencio. Al llegar al palacio de sus padres, la pareja se postra frente a ellos: "A Oriana le tremían las carnes del miedo que ovo en se ver delante su padre y madre, temiendo ser conoçida, mas su amigo nunca de la mano la dexó" (Amadís de Gaula, II, 57). La escena finaliza cuando "la Reina los alçó por las manos, y dixo: -Donzella, yo no sé quién sois, que vos nunca vi

391 Gual Camarena, M., Vocabulario del comercio medieval, 2014, http://www.um.es/lexico-comerciomedieval [Consulta: miércoles, 23 de septiembre de 2015]. 
[...] mas Oriana no respondió ninguna cosa, y tenía la cabeça baxa en lugar de humildad"

(Amadís de Gaula, II, 57). La joven permanecerá callada ante el temor de ser descubierta. Al estar inmóvil y en silencio pretende cubrir dos aspectos, fisionomía y voz.

La necesidad de que ambos vayan cubiertos es que tanto los reyes como los otros personajes desconocen la relación sentimental de Oriana y Amadís, por lo que deben mantener en secreto su amor hasta después de superada la prueba de los "leales amadores".

Sin embargo, de estos llama la atención el antifaz, porque se desconoce el tamaño, el material y la forma. Además, que, para la época, se considera que en el Amadís aparece "el primer antifaz de la literatura española" ${ }^{392}$, así que el lector interesado deberá hallar las características que lo conforman en obras posteriores y en la moda adyacente a las afueras de España.

De acuerdo con el Diccionario de autoridades, el antifaz es "el velo que se pone delante del rostro, como en algunas partes se usa tener la novia puesta en el tálamo". Esta primera definición, otorga un rasgo, un velo, pero aún es insuficiente, debido a que:

el velo ha sido siempre y es entre los latinos el género en que se comprehenden todas las especies de telas que sirven para cubrir, y, en particular acepción, las cortinas y otros paños que pueden tener este efecto $[\ldots]$ en cuanto a los rostros de las mujeres, llamamos velo a lo que los cubre, aunque tenga nombre especial, como manto, toca, embozo o cendal, tomando la materia por la forma. ${ }^{393}$

Es decir, conocidos bajo la generalidad de "velos", los lienzos de tela para cubrir el rostro de la mujer, presentan algunas diferencias significativas en torno al modo de llevarse y la

${ }^{392}$ Rafael M. Mérida Jiménez, "El primer antifaz de la literatura española", en Transmisión y difusión de la literatura caballeresca. Doce estudios de recepción cultural hispánica (siglos XIII-XVII), Lleida, Edicions de la Universitat de Lleida, 2013, pp.99-104.

393 Antonio de León Pinelo, Velos antiguos y modernos en los rostros de las mujeres: sus conveniencias y daños, ed. de Enrique Suárez Figaredo, Lemir, 13, 2009, p. 276. 
forma de sujetarse, ya sea mediante un botón, listón o prendedor, su finalidad es mantenerse firmes, a fin de evitar su constante caída durante el trayecto.

No hay una descripción exacta de esta prenda, debido a que sólo se dice que cubre la cara. ¿Se tratará de una máscara ${ }^{394}$ para todo el rostro o sólo para los ojos o de una especie de velo al modo oriental? Para tratar de construir una imagen, se necesita conocer otras prendas de la época que tengan similitud en uso y significado.

Carmen Bernis explica que en los accesorios para la cabeza y rostro está el velo o velillo, el cual "debía su nombre a la tela con que estaba hecho, [aunque] había de seda, lino y algodón"395. La estructura del antifaz se puede conformar con las referencias halladas en los libros de caballerías, en donde se alude al modo de llevarlo, por ejemplo, en el libro cuarto del Florisel de Niquea se dan dos detalles; el primero se refiere a la forma de sujetarlo: "Más por no faltar de su palabra, alçando sus muy hermosas manos, quitando dos alfileres, ${ }^{396}$ el antifaz cayó, y ella descubrió la más acabada y excelente hermosura que nunca en humana criatura se vio. Que como Arquileo la vio, fue tanto el espanto y la crueldad con que su coraçón de tal vista fue rasgado" (Florisel de Niquea IV, XV) (figs.162-163 y detalles); el segundo, al tipo de tela: "De una redecilla de oro de mucha pedrería, que en lo alto de la cabeça estava, de la cual caya un antifaz sobre su rostro, que cosa del se parecía, de un paño delgado, que podía ver, sin ser vista" (Florisel de Niquea

\footnotetext{
${ }^{394}$ Entre 1534 y 1537 Carlos V dicta una ley que prohíbe usar máscaras en bailes, fiestas, paseos, etc. Que las mujeres utilicen para no ser reconocidas. La misma ley la aplica Felipe II en 1586. El castigo era pagar tres mil maravedíes. Ruth de la Puerta Escribano, "Reyes, moda y legislación jurídica en la España moderna", Ars Longa, 9-10, 2000, p. 68. (pp. 65-72)

${ }^{395}$ Carmen Bernis, Indumentaria española..., pp.107-108.

${ }^{396}$ Los alfileres se utilizaban para sujetar diferentes tipos de tocados, como el que se usa a la gineta: "La vuelta que cae sobre el pecho se llama barbicacho, y se ha de abrir y cruzarse de manera que a los lados venga a hacer dos cornejales; los cuales se prenden con dos alfileres, quedando la toca tendida por el pecho". Juan Arias Dávila Puertocarrero, Discurso para estar a la gineta con gracia y hermosura, Madrid, 1951, p.57. Además, aparece en algunos romances como uso en la ropa, pero también como una alusión a la forma de prender el amor del enamorado: "Diráme: - ¡Traidora, /Que con alfileres/ Prendes de tu cofia/Lo que mi alma prende!
} 
$I V$, I, XI). Con lo que el antifaz también se configura como una prenda de gala, que se integra al tocado para lucir en público, y no es totalmente un accesorio para salir y no ser reconocida, sino para intrigar aún más a los personajes a su alrededor. (fig. 164)

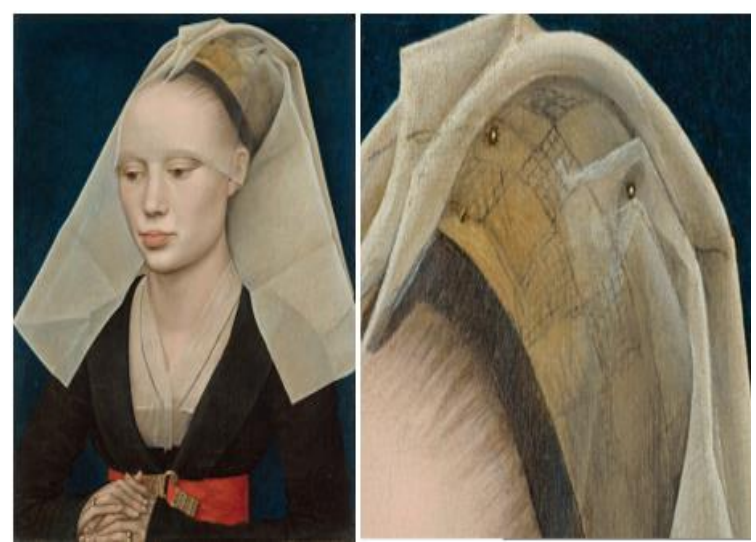

Fig. 162. Retrato de una dama (1460) Roger van der Weyden Detalle de los alfileres que sujetan el velo en el cabello

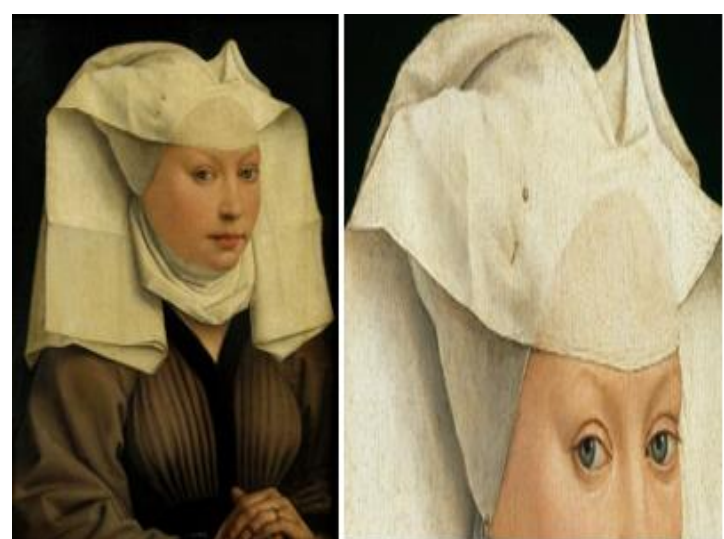

Fig. 163. Retrato de una dama (1440)

Roger van der Weyden

Detalle de los alfileres que se sujetan de la misma

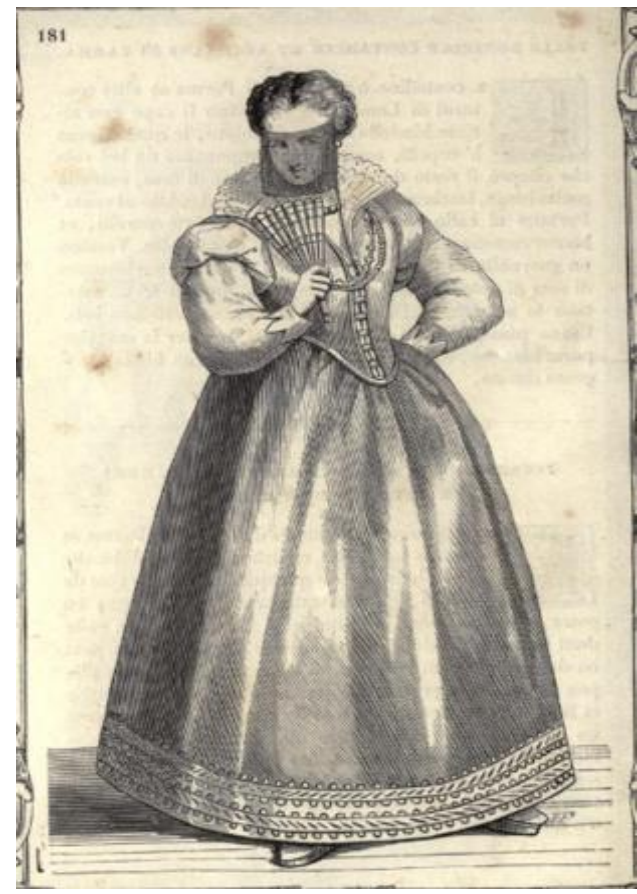

Fig. 164. 'Donzelle contadine', Habiti antichi e moderni (1860) Cesare Vecellio.

Mujer con velo sujetado por el cabello. 
Estas especificaciones, un velo de tela delgada que se sujeta con alfileres ${ }^{397}$ y cae desde la cabeza, permite conformar una imagen más concreta de esta cobertura, al menos hasta cierto grado, ya que, posteriormente, se confeccionará otro modelo de antifaz presente en los viajes de la Corte española, especialmente en los desplazamientos de damas, como es el caso de la Emperatriz María durante su partida desde Praga y en cuya pintura se muestra la utilización de un antifaz que cubre todo el rostro, dejando sólo al descubierto parte de la barbilla y de la frente (fig. 165). De éste, Carmen Bernis ${ }^{398}$ resalta su practicidad porque no hay necesidad de sostenerlo con las manos, sino a través de unas cintas que se sujetan por detrás de la cabeza. Este tipo de antifaz cobra importancia en un pasaje del Florisel de Niquea, porque es visible que el tejido para su fabricación ha cambiado, ya que tiene mayor grosor la tela: “-Pues alçad ese antifaz que traéis sobre el rostro -dixo él-, para que vea quién me ruega, que por el vestido ni sé si sois hombre o muger" (Florisel de Niquea III, XVII). La barrera de tela ahora complica más el acercamiento del caballero a la dama, puesto que, en los anteriores ejemplos, se sabía que se trataba de una mujer; sin embargo, ahora existe la duda de quién está realmente detrás de la tela, por lo que el caballero se ve forzado a pedir que la otra persona se descubra el rostro.

Esta nueva complicación también se debe al color, tal como se observa en el Cristalián de España: "entró por la puerta de la sala una donzella vestida de paños de duelo con un antifaz negro puesto en su rostro y como llegó al emperador alçolo y besándole las manos dixo: -Sereníssimo emperador Escanio, yo soy venida ante vuestra magestad por el

\footnotetext{
${ }^{397}$ Otros tocados que utilizaban alfileres era la barbeta, la cual cubría el cabello y el contorno de la cara y la gorguera, la cual se sujetaba por la nuca; de esta manera, los alfileres se ocultaban bajo la tela.

Pero uno de los más curiosos protectores para la cara es el "rostro", porque pareciera una especie de tela adherible al rostro con sólo dos orificios en los ojos.

${ }^{398}$ Carmen Bernis, El traje y los tipos sociales en el Quijote..., p.54.
} 
rey de la pequeña India, que es muy cerca de la vuestra gran ciudad de Constantinopla”. 399 (fig. 166)

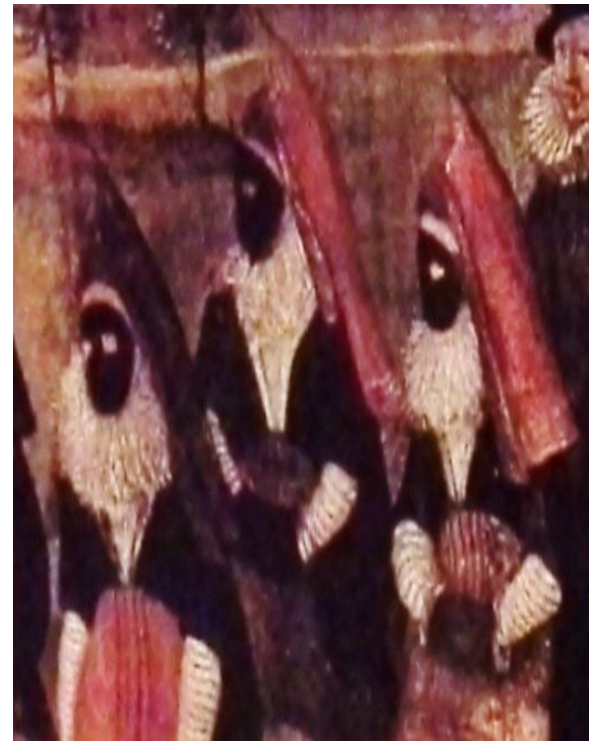

Fig. 165. Viaje de la emperatriz María desde Praga (1601) Hans van der Beken

La emperatriz y un séquito de damas se cubren el rostro con antifaces y la cabeza con capillas de camino.

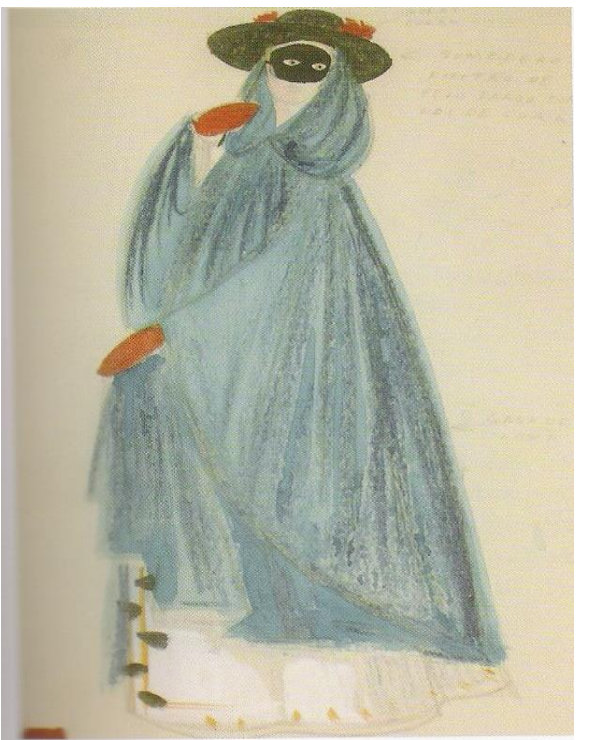

Fig. 166. "Luscinda", diseño de Javier Artiñano Luscinda con antifaz negro.

El antifaz va en sintonía con el color de su ropa, por lo que se puede deducir que había variedad de diseños y colores. Además, la forma también es importante para saber qué cantidad de la cara está cubierta: "Luego se paró un cavallero a una finestra y como las tres doncellas vio fue muy espantado en ver las dos negras y tan ricamente guarnidas, a la infanta como traya el antifaz en el rostro no vio si era negra o blanca" (Cristalián de España, III, LXXXIX, fol.199v.). Esta última expresión propone que el antifaz cubre completamente la cara, sin permitir ver ningún fragmento de la piel, ni siquiera el contorno de los ojos. Aunque también esta dificultad para ver puede ser recíproca: "La Emperatriz holgando mucho de oylle hablar, aunque con la noche y el antifaz no le divisava bien" (Florisel de Niquea IV, I, XIV), por lo que el antifaz se vuelve en obstáculo para observar

\footnotetext{
${ }^{399}$ Beatriz Bernal, Cristalián de España, Valladolid, Juan de Villaquirán, 1545, I, VI, fol. 11r. Todas las citas provienen de esta edición, en adelante citaré en el texto indicando entre paréntesis el número de capítulo y de folio.
} 
bien al caballero, aunado a esta dificultad se presenta la noche, como una barrera más que impide reconocer quién está frente a la dama.

La repuesta a esta incógnita se halla en el grabado que aparece en la edición de Salamanca de 1519 del Amadís de Gaula, en donde se ilustra el modo en cómo va vestida Oriana con el antifaz. (fig.167)

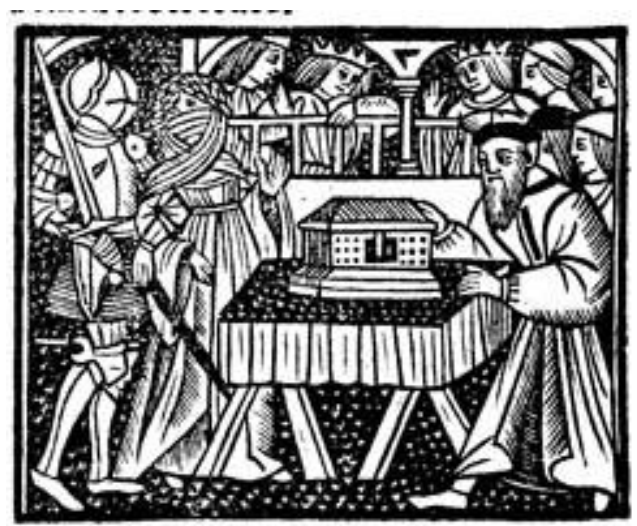

Fig. 16̈. Amadís đe Gaula, cap. LVI, fol.109r.

Sin duda alguna, para esta investigación, esta imagen es una de las más importantes en torno a las prendas para cubrir el rostro, porque deja registro del modo en cómo eran y se usaban los antifaces en esa época. En el grabado aparece Oriana con el rostro cubierto de la nariz hacia abajo, dejando los ojos y parte de la frente al descubierto, tal como se propone el uso del antifaz que se sujetaban con alfileres. Además, es muy parecido a la toca de rebozo que lleva Dorendayna y tiene relación con la definición del Tesoro y los estudios de Carmen Bernis acerca de los grabados de los libros, en la que expresa que:

Cuando el miniaturista gótico realizaba sus obras con el explícito deseo de encontrar algo, tomaba sus imágenes del mundo que lo rodeaba; por ello, el historiador encontrará en esas obras un tipo de información que no puede ser transmitida por el relato escrito, información especialmente valiosa para el mejor conocimiento de cualquier época del pasado. ${ }^{400}$

\footnotetext{
${ }^{400}$ Carmen Bernis, “El manuscrito de París. Estudio arqueológico”, p.195.
} 
Así que el antifaz conocido en esa época era una tela que cubría parte de la cara, por lo que está la posibilidad de considerar que en un primer momento el antifaz se trataba de una toca a modo de velo que ocultaba la parte baja del rostro y que posteriormente tuvo modificaciones, hasta convertirse en el antifaz que se conoce actualmente.

\subsubsection{Motivos para cubrirse}

El interés principal de ocultar el rostro es para no ser identificado en diversas situaciones.

Esta negatividad a revelar su identidad aparece de manera general en la mayoría de los libros de caballerías, en donde sin importar el accesorio que utilizan para cubrirse, se niegan a quitarse dicha prenda. Por ejemplo, en el Quijote se menciona que el cura "suplicaba asimismo que no la mandase quitar su antifaz, ni la demandase cosa de su facienda" (Don Quijote, I, 26) ${ }^{401}$, para no ser descubierto por sus barbas (fig. 168).

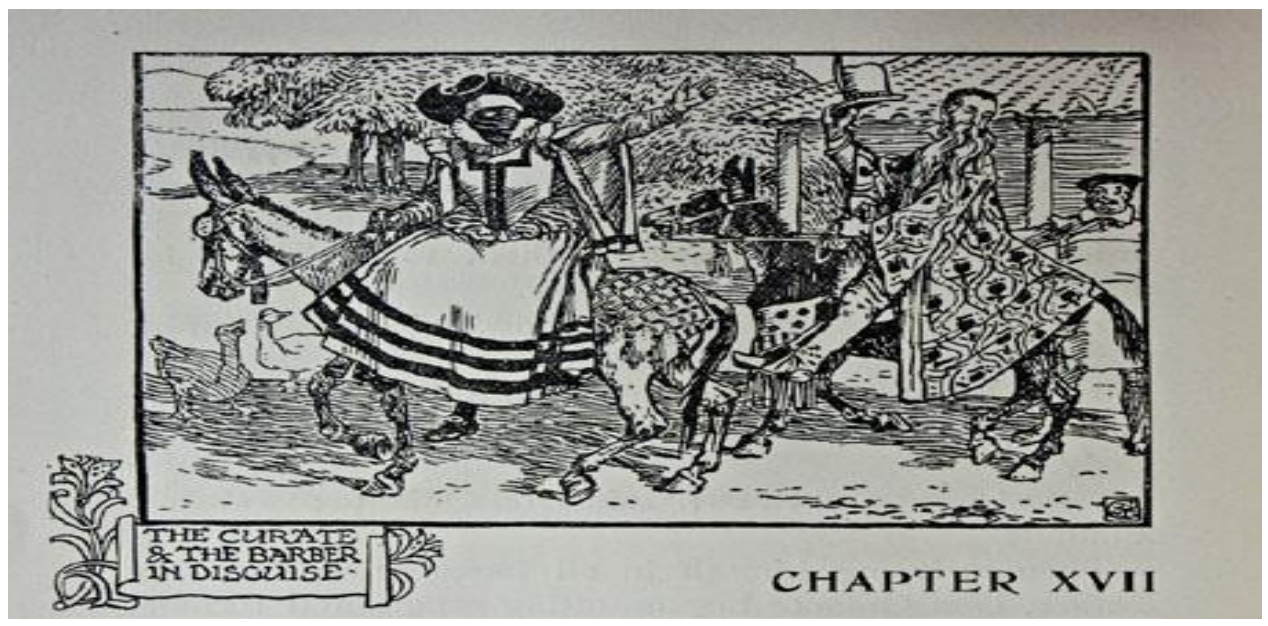

Fig. 168. "The Curate and the Barber in disguise", Walter Crane. El antifaz deja al descubierto parte de la frente.

También aparece en el Belianis de Grecia, en donde unos caballeros: "en el camino hallaron un cortejo muy lujoso en el que iba una doncella con un antifaz y se produjo un enfrentamiento entre ambos grupos porque ninguno quería revelar al otro su identidad,

${ }^{401}$ Miguel de Cervantes, Don Quijote de la Mancha, ed. de Francisco Rico, México, Alfaguara, 2004. 
como consecuencia del suceso resultaron todos muy malheridos" (Belianis de Grecia I, 59) ${ }^{402}$. Lo mismo sucede en Florisel de Niquea III: "Y estas donzellas avían desembarcado en otro puerto cerca de aí y venían muy ricamente guarnidas y en muy buenos palafrenes y con antifazes puestos por no ser conocidas, porque Galtazira traía pensamiento si topasse con Fraudador de procurar le hazer algún engaño" (Florisel de Niquea III, CL). En todos estos ejemplos hay distintos motivos para ocultar el rostro. En el primero se debe a que es el cura disfrazado de mujer y para continuar el engaño debe permanecer con el antifaz. En los dos últimos se debe a que se conocen caballeros y damas y aunque inconscientemente no lo saben en ese momento, si se descubrieran serían afrentados, porque son sus damas las que están fuera de la corte en busca de aventuras. Pero también hay situaciones curiosas: "Y passando sobre esto graciosas burlas, representando entre sí de la suerte que se avian de disffraçar y fingir no conoser a sus esposos si los topassen y como los tentarían y provarían sus lealtades con mucha risa pasaron hasta que fue hora de dormir" (Florisel de Niquea IV, II, VII), en las que el antifaz se convierte en la herramienta de espionaje para las damas a fin de vigilar qué hacen sus esposos cuando salen y tener la certeza de que podrán estar frente a ellos sin ser reconocidas. Además de estos breves pasajes, se localizan otras situaciones que requieren un desarrollo más amplio en donde el rostro cubierto provoca diversos sucesos.

\subsubsection{Para llevar mensajes}

Toda princesa tiene una dama confidente, aquella a quien cuenta sus penas de amor y a quien demanda favores para llevar mensajes. Como se vio anteriormente, en el Claribalte Fulgencia llevaba los recados de la pareja. Su labor era ser intermediaria en amores. Sin

402 Jerónimo Fernández, Belianis de Grecia I, ed. de Lilia E.F. de Orduna, Kassel/Edition Reichenberger, 1997. Todas las citas provienen de esta edición, en adelante citaré en el texto. 
embargo, para el presente estudio, no me referiré sólo a las damas mensajeras de amor, sino también a aquellas que deben recorrer una gran distancia para llevar un recado bélico o mágico pero que por algún motivo no deben ser conocidas ante los demás, sino sólo por la persona que recibirá el encargo.

Por ejemplo, en el Cirongilio de Tracia ${ }^{403}$ aparece Panistrea, dama mensajera de la infanta Palingea, quien envía una carta a Cirongilio. Para que ésta pueda entregársela, debe cubrir su rostro, ya que en repetidas ocasiones deberá presentarse ante el caballero sin que éste la vea hasta después de varios días: "Y descubriéndose el rostro, que avía tenido cubierto, fue conocida por el cavallero; que sabed que era Panistrea" (Cirongilio de Tracia, p. 134). No hay alguna referencia al tipo de prenda que portaba, pero es probable deducirla por las vestimentas de 'encima' de la época. Sobre esta forma de vestir se dice que:

De la cabeza a los pies iba cubierta, tapada o arrebozada. Estos mantos se hacían de tejidos ricos de paño o seda, a veces ribeteados de galones, terciopelo y guarnecido de pasamanos o abalorios. Se usaban igualmente a modo de velo dispuestos sobre la cabeza cuando eran tejidos finos y opacos, como los mantos de estrado para estar en casa y los mantos de luto o velos de luto o de pena confeccionados. ${ }^{404}$

La importancia del rostro cubierto se debe a los dones que Palingea entregará, un caballo y unas armas, ambos mágicos, pues tienen la virtud de no ser traspasados ni heridos por arma alguna, por lo que la joven debe ser discreta al entregarlos. Este trayecto pareciera rápido, pero en realidad el camino se vuelve difícil porque es vista por otros personajes y su identidad está en peligro de ser revelada.

${ }^{403}$ Bernardo de Vargas, Cirongilio de Tracia, ed. de Javier Roberto González, Alcalá de Henares, Centro de Estudios Cervantinos, 2004. Todas las notas provienen de esta edición, en adelante se citará en el texto.

${ }^{404}$ Margarita Tejeda Fernández, Glosario de términos de la indumentaria regia y cortesana en España: siglos XVII y XVIII, Málaga, SPICUM, 2006, p. 330. 
Este recorrido le concierne cierta libertad a la joven por andar sola en lugares no apropiados para la mujer de la época, pero también le confiere una gran responsabilidad, al ser la encargada de la enmienda que debe entregar. Por lo cual, debe ser cuidadosa y prever no ser vista para no revelar quién la ha mandado.

Los tejidos usados a modo de velo, antes mencionados, se caracterizan por su longitud, por su capacidad para rodear la silueta de la persona y por no dejar ver las prendas de debajo. Entonces es claro que se trata de un manto o capa, puesto que las capillas y los mantillos no llegaban hasta el suelo, sino un poco más arriba de la falda. ${ }^{405}$ En las Sergas de Esplandián también se observa un ejemplo similar, la dama entra a la habitación del caballero, cubierta por una capa que oculta todo su ser, clase social y género, pues es tan amplia que no se puede distinguir quién la porta. Nuevamente se presenta una mujer mensajera con identidad oculta. El valor de esta situación aumenta al trasladarse directamente a la alcoba del caballero, sin temor de ser descubierta por los reyes ni las demás personas del castillo.

Caso contrario ocurre en el Cirongilio, en donde el caballero tarda un poco en reconocer a la persona cubierta, a pesar de haber interactuado con ella por más tiempo:

[...] la donzella estraña entró en la sala donde los dos estaban, descubierto el rostro, así que bien pudo el cavallero conoscerla; y él pensando que era otra persona, volvió a mirarla [el cavallero le dixo] - ¿Es posible, buena donzella, que vos seáis, y tantos días ayáis andado en mi compañía sin conosceros ni quereos descubrir? (Cirongilio de Tracia, III, XXI).

${ }^{405}$ Carmen Bernis, Indumentaria española en los tiempos de Carlos V..., p. 80-82. 
Nuevamente se trata de Panistrea, dama que se ha convertido en este libro en una doncella mensajera encubierta, por mandato de su señora, la infanta Palingea, para no ser descubierta por los demás personajes. Antes la doncella había traído el rostro cubierto todo el tiempo, pues es hasta este momento que el caballero puede conocerla físicamente. En el texto no se menciona con qué lo tenía tapado, sin embargo, por las descripciones hechas por los personajes se puede plantear la idea de que se trate de una capa o manto que tapa el resto de su vestimenta.

Estas damas mensajeras son importantes para la relación de la pareja protagónica, para el desarrollo del caballero al recibir los dones de magas y para transportar noticias, confesiones íntimas y mágicas; por lo cual deben cuidar su identidad para no ser señaladas ni obstaculizadas en su camino.

\subsubsection{Para evitar una pena}

El uso de la toalla predominaba en las mujeres de Arabia, quienes "con un manto o toalla se cubren la cabeza y el rostro" ${ }^{\$ 406}$ por ser la parte de su honestidad que más deben cubrir. De la misma manera, las mujeres turcas se caracterizaban por llevar velos o volantes sujetados de un extremo del tocado y suelto del otro para facilitar su colocación después de comer o beber agua, pero principalmente "para que, habiendo de salir de casa o ser vista en ella de algún hombre, levantando lo pendiente del velo se cubran el rostro sin dejar libres a la vista del varón más de los ojos"407. Este elemento, la necesidad de quitarse el velo para satisfacer la sed se halla en el Primaleón, pero, el segundo aspecto, colocarlo deprisa para evitar que la miren, no sucede, ya que, en la historia de Finea y Tarnaes, el calor y el tiempo son el

\footnotetext{
${ }^{406}$ Antonio de León Pinelo, op.cit., p. 302.

${ }^{407}$ Ibid, p. 303.
} 
inicio de una tragedia amorosa. El narrador relata cómo la dama es llevada para ver a su padre enfermo; sin embargo, al regreso del viaje se presenta la primera dificultad, el clima, el cual los obliga a detenerse para descansar un poco:

Y como la calentura fazía grande siendo ya medio día, Finea rogó al cavallero viejo que se apeassen en una fuente que fallaron en el camino que estava entre unos árboles y el cavallero viejo lo fizo por su ruego. Y ella quitó los antifaces que tenía delante del rostro y lavóse sus manos y cara en la fuente. [E Briceo] vino por [a]quel lugar donde estava Finea y no pudo ella, como lo vido, tanto fazer que se encubriesse d'él [...] E llegóse a ella y diziéndole: -Amiga fermosa, ¿por qué vos encobrís de mí? Que la vuestra gran fermosura para ver es. (Primaleón, CXXXIX)

En este episodio el velo se configura como una barrera protectora contra la muerte que la abuela de Finea había profetizado desde hacía muchos años, la condición advertía que la joven no debía ser vista por ningún hombre; sin embargo, la tela que se desprende para dejar al descubierto la belleza de la dama, provoca el enfrentamiento entre padre e hijo, así como el tormento amoroso de la joven, quien al final muere.

\subsubsection{Para ocultar las imperfecciones}

En la Edad Media, el ideal de belleza femenina se caracterizaba por "la blancura de tez realzada por un toque rosado en las mejillas, cabellera rubia, disposición armoniosa de los rasgos, rostro alargado, nariz aguda y regular, ojos vivos, labios finos y bermejos" ${ }^{\text {408, }}$ dichos atributos predominan en las doncellas de los libros de caballerías, entre ellos, en el Palmerín de Olivia con la Infanta Zerfira, cuya belleza era admirada por todos, puesto que "era tan fermosa que en todo el señorío del gran Soldán de Persia no la avía más" (Palmerín de Olivia, CXXI). Si bien Zerfira posee todas estas cualidades, hay un periodo

\footnotetext{
${ }^{408}$ Cristina Sigüenza Perlada, La moda en el vestir en la pintura gótica ..., p.115.
} 
en que su hermosura se ve opacada debido al malestar causado por el gusano que se le introduce por oler unas flores, como resultado, constantemente le brotan gusanillos de la nariz, acompañados de un mal olor; esta situación la obliga a cubrir parte de su rostro:

Como la infanta fue en su tienda, descubrió su rostro, que fasta allí andava tan cubierta que no se le parecían sino los ojos, e puso las flores a las narizes e súpito le cayeron todos los gusanos que ella tenía, muertos; ella se sentió tan sana como lo era antes, salvo que le quedavan unas señales feas de las llagas que los gusanos le avían fecho. E de aquello no se dio ella nada en verse guarida, especialmente que tenía esperança que del todo avía de sanar por el ave. (Palmerín de Olivia, CXXXIV)

Como debe poner remedio a la extrañeza que ocasiona su nariz y al olor que de ella se desprende, recurre a la tela como un medio para evitar que, durante su trayecto del palacio hasta el lugar en el que se halla el remedio contra su mal, sea vista por los demás. Sin embargo, aún después de ingerir el primer remedio, conserva secuelas de los gusanos, las llagas no desaparecerán hasta que Palmerín consiga el ave y el agua sanadora. De esta manera, el rostro cubierto responde a una necesidad de ocultar la vergüenza por una imperfección en la piel, y el velo se convierte en una prenda protectora de la apariencia.

De acuerdo con las características de los velos cada uno se amolda al rostro en función de la cantidad de piel que se desea tapar, estableciendo al volante en mayor cobertura, por asemejar una máscara que oculta toda la cabeza, seguido del antifaz y el velo porque cada uno cubre la mitad del rostro y deja al descubierto la otra parte.

El rostro cubierto presenta diversos motivos: discreción, misterio, amor, engaño, pena, malestar, etc. La mayoría de las damas de los libros de caballerías se cubren para cuidar su honra durante los encuentros con el caballero, a fin de no ser identificadas en el 
camino. En el ejemplo del Claribalte, es relevante que el autor haya dejado muestra del tipo de la toalla que llevaba la protagonista, a través de la ilustración que aparece en la edición de 1519 al igual que Montalvo con el antifaz que lleva Oriana, lo cual permite conocer uno de los modelos de prendas para la cabeza durante el siglo XVI, que suelen ser escasos en otros títulos del género, al menos en lo que respecta a los atavíos de protección para el rostro. Éste último se puede ver como un instrumento que crea enredos, por la posibilidad de ocasionar equívocos entre las parejas, pero también sirve de protección de la identidad del personaje, al cubrir su rostro para evitar que su belleza sea conocida por los demás.

Asimismo, cubrirse para ocultar daños en la piel responde a la necesidad de conservar el modelo de belleza ideal por una enfermedad que sólo por medio de la magia será restaurada; en contraposición, se manifiesta la ausencia de telas para evitar una tragedia, por lo que llevar el rostro cubierto es benéfico en los ejemplos analizados, ya que ser capaz de ver y no dejarse ver otorga ventajas a quien porta el velo, puesto que puede decidir el curso de la historia.

\subsubsection{La armadura}

En el capítulo anterior se analizó la función defensiva-ofensiva de cada una de las piezas que conforma la armadura del caballero para combatir y se estableció el uso del yelmo como arma protectora de la cabeza y del rostro contra los golpes. Pero para este apartado se analizará su propósito de resguardar la identidad del caballero a fin de alcanzar mayor fama sin demostrar quién es, ni de dónde procede, hasta ser digno de ser llamado "el más esforzado caballero del mundo". Por lo que una vez que le es quitado el yelmo estará en riesgo de que descubran su verdadero nombre, así que deberá actuar rápido para volver a cubrirse. 
Uno de los preceptos del caballero es que "está en función de sus armas que forman parte inseparable de su indumentaria, y son instrumento sin el cual no puede ejercer su función" ${ }^{409}$, su labor de defender al menesteroso, rescatar a las doncellas y explorar tierras lejanas lo exponen al encuentro con otros guerreros y personajes mágicos que pueden dificultar su desarrollo y poner en riesgo la pérdida de alguna de sus armas. Así mismo, en la corte, debe ser capaz de sobresalir de entre los demás y alcanzar la honra necesaria para revelar su nombre: “-Cavallero, dezid a su alteza que soy estranjero en verdad y que pues de dos cosas le he dicho la una, que suplico a su alteza no quiera saber mi nombre hasta que el nombre sea digno que se sepa" (Claribalte, VI). El primer acercamiento de don Félix a otro reino es para participar en sus primeras justas, por lo cual la discreción y la mesura deben estar a su lado, así evitará revelar su identidad.

Resguardar el nombre requiere de dos elementos, el silencio y la cobertura de metal que protege su cuerpo. El primero implica el desconocimiento de la voz y de los movimientos por parte de sus compañeros, porque, aunque tenga puesto el yelmo, es posible que lo identifiquen: "A la boz que Lisuarte dio, la princesa le conoció" (Lisuarte de Grecia, XXXIV), por lo que será útil fingir otra voz o evitar hablar.

\subsubsection{El yelmo (figs. 169-172)}

La primera pieza que lo cubre es el yelmo. A la par que en algunas ocasiones la dama usa máscaras o antifaces para trasladarse de su alcoba al lugar de encuentros con su amado, ahora éste debe procurar no ser visto, incluso hay momentos en que ambos llevan cubierta la cara a fin de realizar una hazaña: "Y llevando puestos unos antifaces en el rostro [la dama] salió del castillo de la manera que oídes, y Florineo llevava el yelmo en la cabeça

${ }^{409}$ Juan Manuel Cacho Blecua, Amadís: Heroísmo mítico cortesano..., p.131. 
por no ser conocido" (Florambel de Lucea, XVII). El metal y la tela son el dúo de protección facial, su uso es motivado por distintas circunstancias, por ejemplo, en el Primaleón, será para trasladar a una joven que nunca ha salido del castillo y que no puede ser vista por ningún hombre, porque provocará su muerte. En el Florisel el fingimiento de personajes los lleva a ocultar su rostro para no revelar si es hombre o mujer quien lo usa. Mientras que en el ejemplo de Florineo, la necesidad de llegar con la Dueña del Fondo Valle los lleva por un camino peligroso en el que deben ocultar sus rostros para no ser identificados.

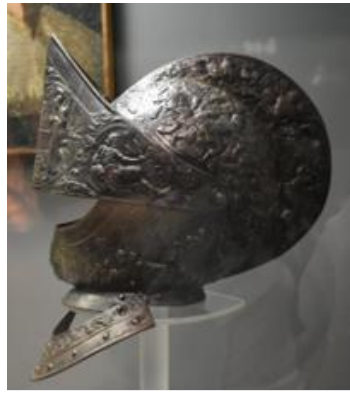

Fig. 169. Yelmo con escenas mitológicas (s. XVI) Centro Cultural Mexiquense Bicentenario, Texcoco.

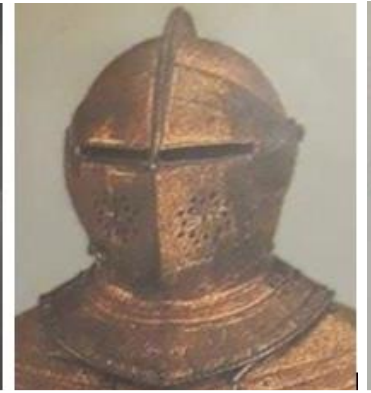

Fig. 170. Yelmo de Carlos I de Inglaterra (1612) Armería Real de Londres.

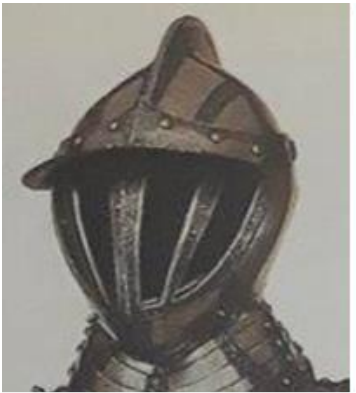

Fig. 171. Yelmo fabricado por Kunz Lochner (1549)

Nuremberg

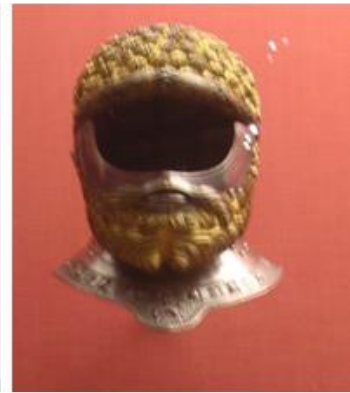

Fig. 172. Celada de Carlos V (1533) Palacio Real de Madrid

En otros momentos, habrá una petición directa de descubrirse el rostro:

Amadís dixo a la reina:

-Señora, rogad a esse cavallero que se quite el yelmo, pues más por vos que por nadie lo hará, porque según su bondad no creo que le falta buena criança.

Oriana dixo:

-Cavallero, ruégovos que hagáis lo que el rey mi señor vos dize.

Él le dixo:

-Señora, bastara que él me lo mandó, pero yo voy a hazer una cosa por mandado de una donzella, e fasta que esto cumpla no tengo poder para poderme quitar el yelmo en ninguna parte delante de nadie, que assí me lo tiene mandado aquella por cuyo mandado vengo. Por ende, pido's por merced, señora, que me perdonéis, pero en todo lo demás estoy presto para lo hazer. (Lisuarte de Grecia, LVI) 
Pero será negada por un don, conservar el yelmo hasta finalizar la aventura. Caso contrario ocurre en el Florisel: "Y, bolviéndose para los príncipes, los ruega que los yelmos quiten y, ellos, viendo que les era forçado hazerlo, los quitan" (Florisel de Niquea II, XL). Es en contra de su voluntad que los caballeros son obligados a descubrir su rostro, con el peligro de ser identificados y de que sea publicado su nombre; sin embargo, en ciertas ocasiones, la fortuna los ayuda a no ser reconocidos, a pesar de tener algunos rasgos físicos que los distinguen de entre los demás:

Y, tomándolos por las manos, assí a pie con ellos los llevava a sus palacios, muy alegre de llevar consigo tal presa, paresciéndole que según su hermosura, que no podía dexar de ser alguno d'ellos aquel príncipe don Falanges con quien ella casar deseava.

[...] Que como a sus palacios llegaron, ella les manda desarmar y dar ricos mantos con que se cubriessen, con que quedaron tan apuestos que nada de antes parescía su apostura y la reina como assí los vio les ruega que les digan quién son.

-Mi señora -dixeron ellos-, nós somos cavalleros que hemos tan poco hecho según la obligación de aquellos do venimos, que suplicamos a la vuestra merced no quiera saber más de nós de que somos cavalleros de alta guisa [...]

-No quiero yo saber más d'esso -dixo ella. (Florisel de Niquea II, XL)

La curiosidad de la reina permanece, ya que durante el banquete ella "jamás apartó de mirarlos los ojos y más al príncipe don Falanges, paresciéndole por las señas que d'él tenía ser él" (Florisel de Niquea II, XL). La duda continúa, porque la reina no está completamente segura de estar junto a don Falanges, a pesar de que sí es el caballero a quien ella ama, no lo puede reconocer en su totalidad. Aunque no tiene el rostro cubierto, no hay una identificación porque lo conoce por señas, pero no físicamente, así que no puede confirmar si es la persona buscada. 
La necesidad de utilizar el yelmo como armadura protectora de la identidad es un recurso que aparece en todos los libros de caballerías, en algunos se le da prioridad a la forma en cómo el caballero permanece en silencio o lo lleva puesto por mucho tiempo, sin oportunidad de quitárselo. En otros hay una petición forzosa de revelar quién la usa, situación que obliga al joven a faltar a su promesa de no decir su nombre hasta que haya ganado fama en varias hazañas. El metal se funde para crear las armas, en este caso, el yelmo, el cual "disimula la identidad de quien lo usa" ${ }^{410}$ por un breve periodo hasta que, por voluntad propia u obligado, se despoja del mismo para hacer público su linaje.

Damas y caballeros son protagonistas, portadores de mensajes y creadores de encuentros sentimentales. Sus movimientos son vistos por los personajes que los rodean, por lo que deben ser cuidadosos en su andar para no revelar su relación. La identidad del caballero tanto en el campo de batalla como en los encuentros amorosos debe ser protegida por las prendas que porta, pues el yelmo y la armadura ocultarán su rostro hasta haber conseguido honra y fama y ser merecedor de revelar su nombre.

En cuanto a la dama, el manto y la capa dan cobertura a todo el cuerpo, permitiendo ocultar desde la cabeza hasta los pies. Para trasladarse al locus amoenus, también se hará uso del rebozo y de la toalla como prendas protectoras de encuentros sentimentales. $\mathrm{Su}$ función es ocultar quiénes son los enamorados y evitar que el cabello, la boca y la nariz los delaten. Por ello deben ser cuidadosos y evitar que los usos se desprendan.

La última indumentaria, el antifaz, es, a mi parecer, la prenda que más dificultades presenta en su concepción como máscara, velo o medio velo, pues, a pesar de existir diversos ejemplos, en el corpus consultado no se da una descripción específica como en los anteriores atavíos.

${ }^{410}$ Michel Pastoureau, Una historia simbólica de la Edad Media occidental, Buenos Aires, Katz, 2006, p.263. 
Estas representaciones generales obligan a seguir en la búsqueda de más descripciones de personajes cubiertos para hallar elementos que brinden más detalles y permitan hacer una catalogación de este tipo de prendas, las cuales son necesarias para guardar la identidad de los personajes. Además, es importante ver que cada vestimenta tiene una función especial en la historia, pues no se trata de un simple vestuario que sirve para cubrir a los personajes, sino que es un complemento que interviene en situaciones específicas para ayudar al caballero y a la dama a proseguir y prolongar sus encuentros sin el temor a ser descubiertos.

\subsection{Prendas de seducción: La vestimenta como estrategia de conquista}

El arte de la seducción en los libros de caballerías, analizado por María del Rosario Aguilar Perdomo en sus artículos dedicados a las figuras de la doncella seductora y del caballero amante, resalta la importancia del lenguaje y de la mirada, ${ }^{411}$ elementos de conquista que, al parecer de la autora, se establecen como medios para crear formas con las que el caballero entreteje un espacio de conquista sentimental para conseguir el favor de la dama y de ésta para responder a esa petición; la imagen femenina "recurre a todo tipo de estrategias y artimañas para obtener el amor de los héroes" ${ }^{412}$, hecho que delimita la función amorosa de la mujer a un plan de seducción. De esta función, de la imagen ejemplar de la dama seductora, se establecen las siguientes características: "la mujer pasiva cuya belleza fascina al hombre, [de ella] se enamora el hombre y la mujer parte con él, son amadas, son

\footnotetext{
${ }^{411}$ María del Rosario Aguilar Perdomo, "«Las doncellas seductoras y requeridoras de amor en los libros de caballerías españoles», Voz y Letra, 15.1 (2004), pp. 3-24; y "De vuelta sobre la seducción en los libros de caballerías. Con especial atención a la figura masculina y el "donjuanismo", Revista de Poética Medieval, 26 (2012), pp. 31-51.

${ }^{412}$ María del Rosario Aguilar Perdomo, "De vuelta sobre la seducción...", p.32.
} 
tentación", ${ }^{413}$ no actúan solas sino con ayuda de sus fieles servidoras, capaces de encubrir toda situación.

Por otra parte, los recursos que destacan pertenecen al ámbito del lenguaje, dejando de lado un elemento más que favorece este tipo de situaciones, la vestimenta, especialmente aquella que pasa desapercibida por estar oculta, la cual, en voz de un caballero considera que: "Lo encubierto es lo mejor,/ que lo que se puede ver/ no da tanto placer" $" 414$.

A lo largo de esta investigación se ha establecido la importancia de la indumentaria como generadora de acciones, en diversas situaciones tanto de tema bélico como sentimental, este último sólo en el aspecto festivo, a través de la demostración de correspondencia afectiva por medio de bordados que manifiestan la reciprocidad de amores; sin embargo, para el aspecto más íntimo de la pareja, los atavíos representan otro medio de comunicación superior, por tratarse de la expresión sensual para conseguir el galardón femenino y, al mismo tiempo, el masculino; acto en donde el sentido de la vista tendrá su mayor satisfacción, delectarse con la mirada a través de la camisa, la cual al ser una especie de barrera delicada, aumentará el deseo del caballero por acceder a lo que siempre estuvo oculto bajo la tela, el cuerpo de su dama.

\subsubsection{La camisa}

La primera definición que se da de la camisa es la de ser "vestidura a rayz de las carnes" (Tesoro de la lengua) esto la convierte en el primer contacto de la piel con un textil ${ }^{415} \mathrm{y}$,

\footnotetext{
413 Rafael Beltrán Llavador, "Tres magas en el arte de la seducción: Trotaconventos, Plaerdemavida y Celestina", El arte de la seducción en el mundo románico, medieval y renacentista, coord. por Elena Real, 1995, pp. 29-38.

${ }^{414}$ Isabel Vega Vázquez, Libro de motes de damas y caballeros de Luis de Milán: Edición crítica y estudio, Santiago de Compostela, Universidad, 2006, p.82.

415 Pocas son las prendas que anteceden a la camisa como prenda interior. Se tiene registro del uso de la fascia pectoralis, por las mujeres romanas para cubrir sus pechos. Francisco Danvila y Collado, Trajes y armas de los españoles desde los tiempos prehistóricos hasta los primeros años del siglo XIX, Madrid, Imprenta de T. Fortanet, 1877, p.56. En España no se tiene algún testimonio de que ésta se halla usado.
} 
por consiguiente, en la prenda más oculta. Su uso cotidiano la hacen visible en las labores domésticas, festividades y el espacio para dormir, incluso hay ciertas referencias a su uso en juegos nocturnos:

-Como quiera que avenga, mi señora, tuviéssemos ya venida la mi Daraida y anduviéssemos a la luna saltando por el jardín en camisa y después lavándonos en la fuente las manos y los rostros para quitar el calor que, assí goze yo, gloria era de ver los donaires que con Daraida passávamos, y ella con nosotras, sobre cuán era mejor dispuesta para donzella de lo que encubren las faldas, ella o nosotras. (Florisel de Niquea III, LVIII). (fig. 173)

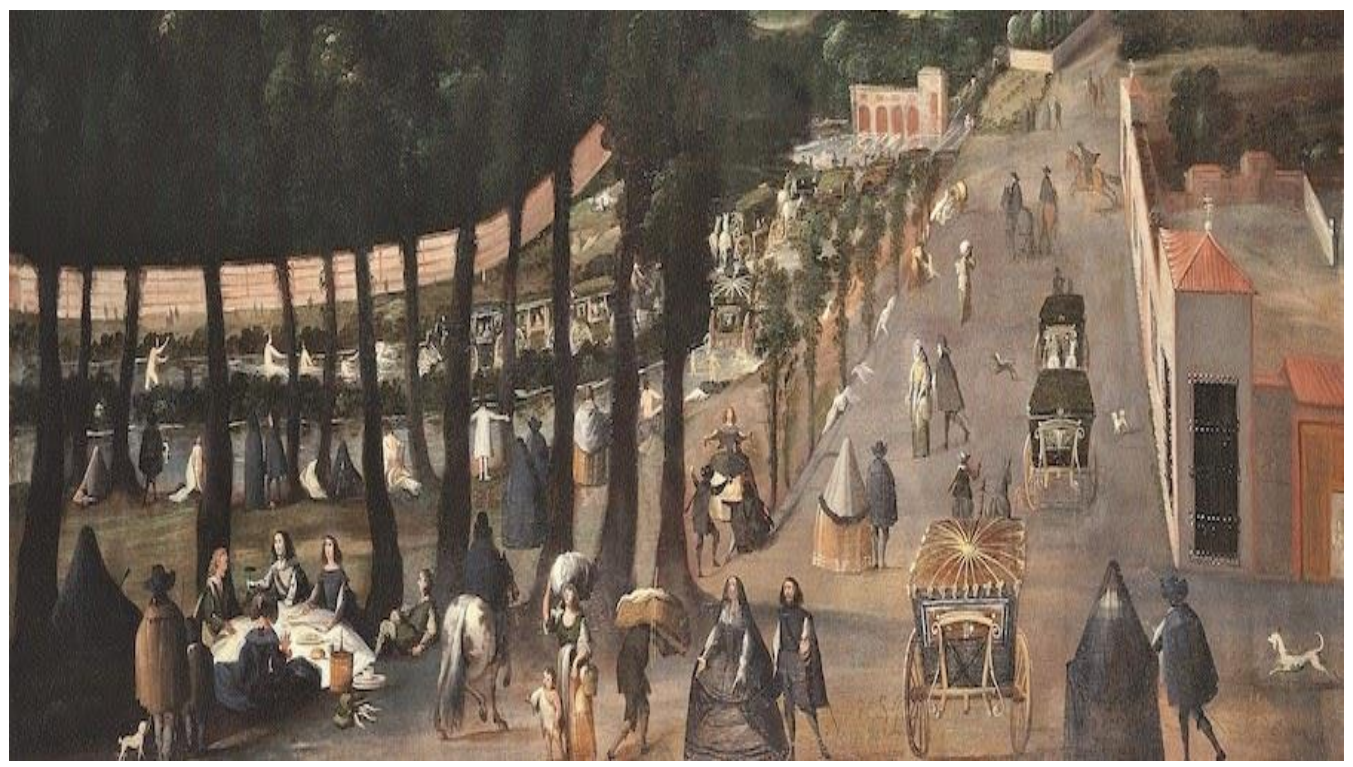

Fig. 173. El baño en el Manzanares durante la fiesta de San Juan (s. XVII)

Nótese la presencia de hombres y mujeres en camisa y otros más desnudos en el agua, tal como se imagina en el Florisel.

Aunque es necesario diferenciar el uso de la camisa como prenda que complementa la vestimenta del diario, de su uso como ropa interior, ambas tienen elementos que sobresalen como el bordado, el tejido y el tipo de tela con el que están hechas. Por ejemplo, en su uso diario se observan los detalles que se alcanzan a percibir principalmente en mangas y

Carmen Bernis y Menéndez Pidal comentan que "la única prenda interior femenina de que tenemos noticia es la camisa. En las miniaturas se representan dos tipos de camisa: camisas amplias y despegadas del cuerpo, largas hasta casi los tobillos, y camisas muy ceñidas, con cuerdas en un costado", La España del siglo XIII leída en imágenes, p.73. Ellos tampoco aluden a la fascia pectoralis romana. 
cuellos. Sobre esto, “en la variante de mujer resalta la deslumbrante ornamentación geométrica, fitomorfa, y zoomorfa- en los cabezones y mangas de la <<camisa galana $>\gg 416$ por ser las partes que salían de las cuchillas, tal como se observa en algunos ejemplos caballerescos que fueron analizados en páginas anteriores, cuyas orillas están adornadas con bordados y pedrería: "Y de las muñecas salía así mismo una punta de camisa que hasta el suelo llegaba, con cintas de muchos joyeles que venían ceñidas" (Florisel de Niquea III, CXLVIII). A pesar de ser la prenda más oculta, tiene ciertas partes visibles que deben ser ornamentadas acorde a la festividad, por lo que para bodas, banquetes y entradas triunfales lo común será el uso de piedras preciosas, como adorno, mientras que debajo de esta ornamentación se halla un significado poco estudiado, la camisa y todo el conjunto de sus partes como prenda de atracción física para el caballero, como una especie de reliquia que lo cautiva hasta seducirlo. (fig. 174)

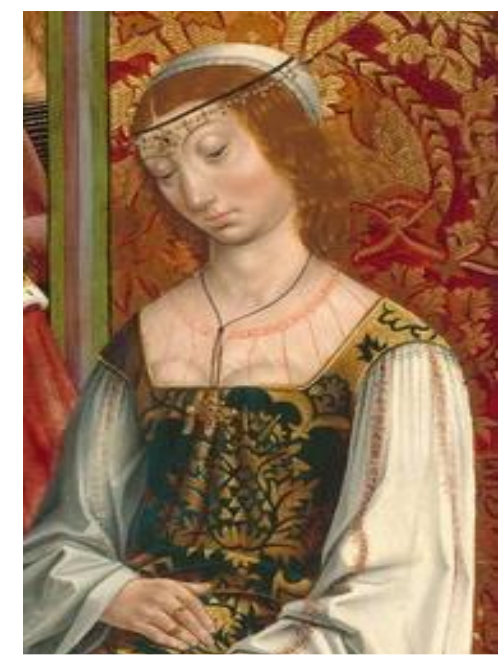

Fig. 174. Las bodas de Canaán (1495-1497) Maestro de los Reyes Católicos

Galería Nacional de Arte de Washington

Detalle de la camisa que permite ver el pecho de la mujer.

En principio, se debe establecer que son pocos los pasajes que la describen, no se menciona el color, la tela o si lleva algún bordado, sólo se hace referencia a la idea de

\footnotetext{
416 Antonio Cea Gutiérrez, "La camisa en la indumentaria salmantina: Características, evolución y
} connotaciones sociales", Revista de Dialectología y Tradiciones Populares, vol. LXIX, no. 2, 2014, p. 488. 
desnudez que lleva implícita, pero en esos pocos pasajes hay un gran valor descriptivo en todos los elementos que aparecen en escena.

\subsubsection{La camisa como cobertura del cuerpo}

La prenda íntima más conocida, hasta ahora, en la literatura caballeresca es la camisa que lleva Helisena en su primer encuentro concertado con Perión de Gaula, ésta adquiere tal protagonismo que es el propio narrador quien le da prioridad a su descripción al comienzo del primer capítulo del Amadís de Gaula, por lo que es de considerarse su aparición en los títulos posteriores del género e identificar si en ellos se le da la misma relevancia en los encuentros sentimentales. La escena comienza con la descripción física de la dama, cuyo cuerpo se puede observar debido al modo en cómo está la camisa:

Como la gente fue sossegada, Darioleta se levantó y tomó a Helisena así desnuda como en su lecho estava, solamente la camisa, y cubierta de un manto, salieron ambas a la huerta, y el lunar hazía muy claro. La donzella miró a su señora, y abriéndole el manto, católe el cuerpo y dixo riendo:

-Señora, en buena ora nasció el caballero que vos esta noche avrá, y bien dezían que ésta era la más hermosa donzella de rostro y de cuerpo que entonces se sabía. (Amadís de Gaula I, I)

Juan Manuel Cacho Blecua menciona que esta aparición es "una exaltación del cuerpo

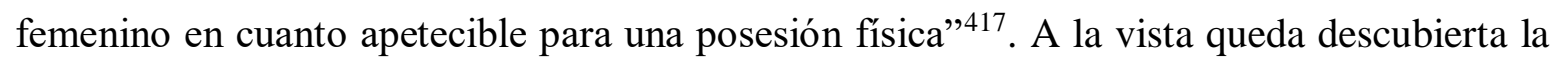
intimidad femenina, aquella que desde la niñez se ha enseñado que debe mantenerse oculta, por considerarse un pecado permitir que otros la vean. Hernando de Talavera lo consideraba un pecado vergonzoso heredado por Adán y Eva, incluso Ovidio reconoce la

417 Juan Manuel Cacho Blecua, Amadis, heroísmo mítico cortesano ..., p.27. 
utilidad de la ropa para esta situación: “con nuestros vestidos cubrimos vergonzosas desnudeces" (Arte de amar, I, v.620). Pero, consciente de su condición, Helisena no duda en acudir al encuentro y satisfacer sus deseos.

Esta escena arroja ciertos elementos que se repetirán en los posteriores libros de caballerías, el lugar de reunión, generalmente caracterizado por la oscuridad, pero con cierta luminosidad que les permitirá contemplar sus cuerpos, en el caso de Perión y Helisena, la luna favorece su vista. Por último, la ropa que siempre llevará la dama, una camisa. De acuerdo con los ejemplos hallados, hay más detalles en cada historia, por ejemplo, el tipo de tela:

y ella tan abastada de hermosura que contemplando de la suerte que la veýa a qualquiera coraçón mouiera amarla. Ella estaua desnuda con sola vna camisa tan delgada que por ella no se impedía la vista de lo que debaxo de sí tenía encerrada, tan derrocada de los hombros que descubría la mayor parte de sus muy agraciados pechos y garganta, no teniendo sobre ellos saluo vn pequeño collar de oro poblado de infinitos esmaltes negros (Belianís de Grecia, II, CXLIV). (figs. 175,176)

Algunos de los registros más antiguos establecen que las primeras camisas eran de lino, cáñamo, lienzo, seda, lana, etc.; por sí sola, la camisa dona una particularidad, la calidad del tejido, muy delgado que permite ver lo que cubre. 


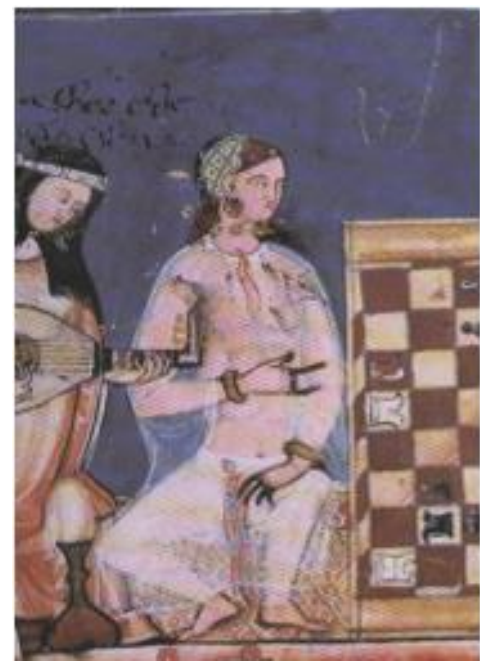

Fig. 175. Libro del ajedrez, dados y tablas (fol.18r) Alfonso X.

Camisa morisca, nótese lo delgado de la tela que permite ver el cuerpo de la mujer.

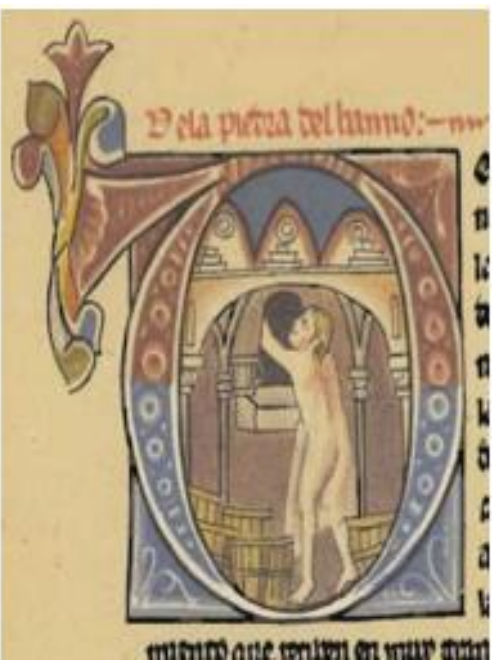

Fig. 176. Lapidario (fol. 69r) Alfonso X. (1283) Camisa de hombre la cual deja al descubierto todo el cuerpo.

Esta acción de "mirar" es primordial en estos pasajes, debido a que generalmente se observa la apariencia externa, en los caballeros "su belleza corporal y, a veces, la suntuosidad de sus vestimentas o armaduras" ${ }^{\not 18}$, con las damas sucede lo mismo, porque la vista se asombra en las prolongadas descripciones de sus vestidos. Por eso, en los pasajes íntimos, la mirada se cautivará con la poca vestimenta que lleve la mujer y con los elementos que aparezcan en el espacio de los encuentros nocturnos.

Si en la lírica tradicional hay varios motivos que integran el simbolismo sexual de la camisa, como el agua y la acción de lavar la prenda ${ }^{419}$, en el contexto caballeresco, ciertos objetos que se repiten en los encuentros sentimentales adquieren importancia por ser favorecedores de la unión sexual, la lámpara y el manto.

\footnotetext{
${ }^{418}$ Emilio Sales Dasí, “'Ver’ y 'mirar’ en los libros de caballerías”, Thesaurus, Tomo LIV, Núm. 1, 1999, p. 7.

${ }^{419}$ Hay un importante antecedente de símbolos eróticos relacionados con la mención de la camisa en la lírica tradicional que van desde elementos naturales hasta el cuidado del cuerpo que se utilizan como medios para aludir al encuentro entre la pareja. Egla Morales Blouin, "La camisa de amor", en El ciervo y la fuente. Mito y folklore del agua en la lírica tradicional, Madrid, José Porrúa Turanzas, 1981, pp. 207-222.

En cierta manera este tipo de menciones de ciertos objetos aparecen en algunos de los momentos de intimidad de la pareja caballeresca, tal vez no con el mismo nivel simbólico, pero sí con cierta referencia a la búsqueda del galardón.
} 
Y con esto se va, y don Filisel quedó aguardando el tiempo de su gloria, haziéndosele mil años cada ora de tardança, según el desseo que ya tenía de se ver con la linda Marfiria. Pues de aí a una pieça que assí estuvo, Caria vuelve con una vela en un candelero de plata que en la mano traía, y detrás d'ella venía la linda Marfiria, toda desnuda excepto de una ropa de seda que sobre la camisa traía; que como llegó, don Filisel con mucha gracia la besó en su fermosa boca e dixo:

- ¡Ó, mi señora, gran merced es ésta, que con lumbre me quisistes ver! [...]

Mas viendo que era forçado apartarse, abraçandola y besándola muchas veces, se despide d'ella, y Caria lo lleva allí do avía dexado sus ropas, donde, antes que acabasse de vestirse, Marfiria en camisa se llega diciendo que no hiziesse ruido y don Filisel a su señora recibió con muchos amores [...] y él abraçándola muchas veces le dixo:

-Mi señora, váyase la vuestra merced a acostar, no os haga daño estar desnuda.

(Florisel de Niquea III, XCIX)

Es necesaria la luz porque de lo contrario el caballero no puede contemplar el cuerpo de su dama en la oscuridad. Ese reflejo de luz es el que da más motivo al joven para querer estar con la amada, porque es una especie de invitación a tocar lo oculto en las sombras; sin embargo, aunque en el ejemplo del Tirante, cuando Placerdemivida participa como intermediaria física entre Carmesina y Tirante, no está la presencia de la lámpara para evitar que éste sea descubierto, porque el contacto se da directo entre la mano del caballero y el cuerpo de la joven, aquí lo que funciona es el sentido del tacto y la imaginación masculina, pues Tirante hace uso de su mente para recrear el cuerpo que palpa.

En este pasaje se entrelaza el deseo, la forma y el tacto, lo cual agrega una posibilidad más para los encuentros nocturnos, el uso de la imaginación para recrear aquello que se anhela y que por motivos de discreción y riesgo no se puede mirar con la luz. 
Otra de sus características es que brinda facilidad de movimiento y comodidad en el momento de la unión amorosa:

-Señora, -dixo Zafira-, yo tengo concertado con el rey que vós vais para su lecho, donde vos atiende; y con el doncel Elisandro, que abrirá la puerta. Y paréceme ${ }^{420}$, señora, que porque no os ocupéis en desnudaros y en vestiros, que vais en una muy rica camisa y encima una ropa forrada, que no tengáis más hazer salvo soltar la ropa y metervos en la cama $[\ldots]$

-Començaos a desnudar, señora, -dixo Zafira-, y aparejaos, que es hora. No se nos vaya la noche en pláticas.

La reina, que no dexava de temblar, como iva a cosa que ella nunca hizo, no acertava a desnudarse. Y Zafira la desnudó y vistióle una camisa muy rica, y sobre la camisa echóle una ropa de carmesí pelo forrada en martas [...]

Y diziendo estas palabras soltó la ropa y quedó en camisa, y lançóse con el rey en la cama. [...] el rey tan contento d'ella y tan enamorado que pocas eran las noches que no se vían. (Tristán de Leonís el joven, CLXIX).

Pero no por tratarse de una prenda oculta, significa que no tenga calidad de género y estilo en el diseño y bordado: "Y Zafira la desnudó y vistióle una camisa muy rica" (Tristán de Leonís el joven, CLXIX). Algunas de las camisas medievales fabricadas para la monarquía se caracterizaban por el uso de telas como el lino, la seda y la holanda, las aplicaciones más comunes eran los hilos de oro, los cordones y los bordados, incluso, existían críticas morales por el prolongado escote que se descubría a fin de enseñar los adornos.

En este ejemplo lo que predomina es el tiempo. El lapso de las reuniones secretas, generalmente, está marcado por las expresiones del día:

¡Ó, mi señora! ¡Y cómo pienso que con la gloria de gozaros se acabara mi vida si no se templara el gozo con pensar que antes del día y con tanta brevedad del tiempo me tengo de partir de vós!

\footnotetext{
${ }^{420}$ Nótese cómo la dama de compañía es quien encuentra la utilidad de la camisa y quien indica a la princesa qué debe hacer en todo momento, como si su experiencia en amores fuera frecuente.
} 
Y así estuvieron hasta el tiempo que ya la luz del día vino a dar testimonio para poner mayores tiniebras en don Filisel, apartado de la luz de estar con Marfiria, e quisiera se quedar el día allá escondido si ella lo consintiera" (Florisel de Niquea III, XCIX).

La necesidad de disfrutar el mayor tiempo posible de los placeres del amor obliga a implementar estrategias de agilidad para evitar tardarse en otras cosas, una de ellas es el momento de desvestirse. Cuando Zafira expresa: "porque no os ocupéis en desnudaros y en vestiros, que vais en una muy rica camisa y encima una ropa forrada, que no tengáis más hazer salvo soltar la ropa y metervos en la cama" (Tristán de Leonís el joven, CLXIX), es consciente de la dedicación que lleva desatar y desabotonar una prenda, por lo que posiblemente le colocara a la reina una "camisa holgada" 421 , porque por su amplitud era fácil de poner y quitar. Incluso otra recomendación que le da es "mejor no hablar demasiado", sino disfrutar del encuentro, en el que aparecerán algunas situaciones a favor y en contra, la obtención de un recuerdo y la dificultad para tenerlo.

\subsubsection{Entregar la camisa}

Cuando el caballero está en el proceso de seducción y la dama ha aceptado dicho galanteo, se crea un vínculo de comunicación que permite a los dos estar juntos sin la necesidad de estar frente uno del otro, sino por medio de un objeto que simbolice la pertenencia mutua. Generalmente son joyas, mantos bordados, espadas, etc., pero para acrecentar la unión sentimental favorecen mejor otros accesorios. En Cligés aparece uno de los más simbólicos ejemplos: “él estaba complacido de poseer esta prenda de su amada, ya que él nunca esperó tener nada de ella, de ninguna otra manera. Aunque su deseo lo hizo temer, cuando él estaba solo y a gusto, besó la camisa más de cien mil veces, toda la noche él abrazó la

${ }^{421}$ Nieves Fresneda González, Moda y belleza ..., p.62. 
camisa", es relevante porque se trata de una pertenencia a través de la ausencia, un "estatuto de recuerdo de quien ama y de garantías de servicio amoroso" ${ }^{422}$, en donde hay una promesa de amor. Dicho elemento le fue entregado al caballero y tiene el privilegio de disfrutarlo en privado, pero también es posible la intervención de la camisa para un juramento, sin que ésta se aparte de la dama:

Don Galtazar como en desdén de sus palabras le dixo:

-Señora donzella, yo no haré con vos batalla sino a condición que seáis casada conmigo como pienso casar a vuestras señoras la reina y la princesa con los reyes de Ruxia y Gaza.

-Poco aventuro yo en esso -dixo Daraida- en casar con tan buen cavallero como vós. Y por tanto si hazerlo puedo yo os otorgo la batalla con tal condición y doy para ello mi gaje.

Y como esto dixo tendió la manga de la camisa y don Galtazar la tomó, el más ledo caballero que nunca fue, pareciéndole que tenía cobrada por mujer la más hermosa doncella que nunca avía visto. (Florisel de Niquea III, LI)

Por lo que la manga no sólo es parte de la prenda de seducción, sino que también se presenta como una prenda de juramento amoroso, en el que la entrega de la dama al compromiso se lleva a cabo por medio de la tela.

\subsubsection{Dificultades de la tela}

Si en la literatura cortesana las mangas "comunican el deseo amoroso" 423 , en la literatura caballeresca se conserva un poco de ese simbolismo, pues aunque no se explicite su función dominante en las escenas de amor, sí se alude a ellas como componentes de toda la camisa, que en ocasiones son motivo de estorbo: "Y ella se puso al pie de la cabecera del lecho, y puso su cabeza entre Tirante y la princesa, con la cabeza vuelta hacia ésta; como las

\footnotetext{
${ }^{422}$ Antonio Cea Gutiérrez, "La camisa en la indumentaria salmantina" ..., p.13.

${ }^{423}$ Loreto Casanueva Reyes, "Prendas de vestir y prendas de amor en la literatura cortesana: El caso de las mangas", Revista Historias del Orbis Terrarum, No. 15, 2015, p. 9.
} 
mangas de la camisa le estorbaban, quitósela" (Tirante el Blanco, CCXXXIII). Un ligero error puede arruinar el encuentro secreto que Plazerdemivida preparó para Tirante. No se trata sólo de que estén a oscuras y en silencio, sino de evitar que el roce de las mangas despierte a Carmesina. Éstas eran amplias, basta recordar los diversos pasajes en los que se alude a su largura, la cual las hacía arrastrar por el suelo: "las mangas eran estrechas del nascimiento y tan anchas de las bocas que llegavan hasta el suelo" (Florisel de Niquea III, CXI). Pareciera que las mangas tienen una doble función, por un lado, son las extremidades que siempre verá el caballero a pesar de estar ocultas debajo de otras prendas, por otra parte, su decoración es parte de lo llamativo que atrae la mirada del caballero, pero en contraparte, su holgura en ocasiones complica la delicadeza del acercamiento.

Así como la manga crea algunas complicaciones, hay otras partes cuya confección pueden desesperar al joven, las cuales, aún en sueños, toman relevancia por la forma descriptiva: "Después en visión, he visto cómo él os besaba a menudo y desatándoos el cordoncillo de los pechos, os besaba con gran prisa las tetas" (Tirante el Blanco, I, CLXIII). El cordón, a la vez decoración y también sujeción, retrasa la mirada varonil para el cuerpo femenino, pues es necesario desatarlo para descubrir lo deseado. Placerdemivida da un detalle de la camisa que sí aparece en algunos registros históricos de prendas usadas por la monarquía y la clase noble, los cordones. De acuerdo con Nieves Fresneda, "el escote solía ser de forma redondeada, presentando frecuentemente una pequeña abertura en forma de $\mathrm{V}$ en la parte frontal [denominado] escote en forma de amigaut. En ocasiones dicha abertura iba cerrada mediante cuerdas" ${ }^{424}$. Aunque se trata de un sueño, se recrea la

${ }^{424}$ Nieves Fresneda González, Moda y belleza femenina ..., p. 64. En esa época hay otro tipo de camisa llamada "encordada" que se sujetaba con cordones por el costado, era de alto costo por su complicada elaboración. Amparo García Cuadrado, Las Cantigas: el códice de Florencia, Murcia, Universidad de Murcia, 1993, p.88. 
conducta de Tirante cuando está ante Carmesina, ansioso y un tanto desesperado por acariciarla; por lo que, la camisa se convierte en una especie de obstáculo porque retrasa el deseo de palpar aquello que cubre.

Es curioso que en los encuentros amorosos sólo se haga referencia a la ropa que lleva la mujer sin hacer alguna mención a la que viste el caballero; esto no sólo dificulta el estudio de las prendas íntimas masculinas, sino que también obstaculiza la aportación de diseños caballerescos que sólo pueden ser recreados a través de los testimonios de bragas, camisas y pañetes, de la sociedad española medieval y renacentista conservados en pinturas, grabados y dotes expuestos en los museos. Por lo que el valor erótico-seductor recae, principalmente, en la dama, al ser el modelo descriptivo que predominó en estos episodios.

La camisa como cobertura delicada del cuerpo es un motivo más que genera acciones, pues el caballero anhela regresar a los aposentos de la dama para vislumbrar y gozar de sus favores. Es la barrera que permite contemplar el cuerpo femenino y la que da paso al deseo y a la búsqueda del encuentro, porque cubre y descubre al mismo tiempo la silueta de la dama, es protectora contra la intemperie y reveladora de las partes íntimas.

Es notorio que todo este proceso de seducción y, principalmente del énfasis que se le da a la camisa sea antes del matrimonio, precisamente en los encuentros nocturnos al margen del peligro por ser descubiertos y teniendo como testigos a su dama de compañía y a su escudero. Pareciera que el arriesgarse en cada salida convierte a la dama en un ser inalcanzable y como tal debe mostrarse al caballero, más llamativa, más seductora, puesto que después del matrimonio las escenas de conquista terminan porque ya se ha obtenido aquello por lo que se ponía en peligro la honra, el galardón femenino. 


\subsubsection{La camisa como deshonra}

Pero no en todos los casos la camisa tiene una connotación erótica, también son recurrentes los momentos en los que los personajes, cuando están durmiendo, por algún motivo deben levantarse a media noche y combatir o intervenir en asuntos políticos ${ }^{425}$. Por ejemplo, cuando el sueño de Anaxartes es interrumpido porque los habitantes del castillo de Argandel quieren matarlo:

todos juntos dixeron a la dueña que lo querían matar por vengar la muerte de sus señores; mas ellas no lo queriendo consentir, y ellos poniéndolo por obra, al príncipe desapercibido mataran sino que la dueña y su hija, teniéndolo por divino más que humano, bozes que se guardasse dieron. [A] las cuales el príncipe, con grande sobresalto, saltó en camisa del lecho y con sola su espada que cabe sí vio se puso a la puerta de la cámara, donde ya los del castillo llegavan (Florisel de Niquea $I, \mathrm{XXXIX)}$

El acto de saltar de la cama en camisa debido a un ataque sorpresivo adquiere relevancia en varios pasajes caballerescos por el modo descriptivo del narrador, porque se enfatiza la desnudez del personaje y su olvido de estar en ropa íntima. Por lo que no siempre se unirá el simbolismo camisa-erotismo, incluso, en algunas ocasiones, su uso será sinónimo de

${ }^{425}$ Incluso hay algunos eventos históricos que tuvieron este tipo de situaciones:

El mismo Rey se levantó desnudo en camisa y entrándose en medio de los que reñían, les dixo: ¡Oh valerosos soldados! ¿dónde está vuestra fe? No ensangrentéis vuestras espadas contra vuestras camaradas, y con militones, sino en mí, que os truxe aquí. Pero como no bastasse esto para sossegarlos, el mismo Rey assí como estaba desnudo, y desarmado, arrebató una lança.

Juan Eusebio Nieremberg, "XV. Disciplina de armas y doctrina de letras en el Rey Don Sancho el Bravo", en Obras espirituales que contienen los tratados que más ayudan al cristiano a levantar el espíritu y unirse con Dios con vida perfecta III, 1651, p.294.

De acuerdo con los registros de la época, para dormir, el hombre usaba camisa y, probablemente, calzoncillos, de holanda, lino y seda, textiles que dejaban traspasar un poco las formas del cuerpo. Miguel García Herrero, Estudios sobre indumentaria española en la época de los Austrias, Madrid, Centro de Estudios Europa Hispánica, 2014, pp.19-20. Para las mujeres, este tipo de géneros será más favorecedor durante los encuentros sentimentales, porque será un recurso que ellas utilizarán para atraer aún más a los caballeros. 
deshonra, especialmente cuando se descubre a la pareja infiel en la cama, así que se traduce en castigo: "Tristán iva caballero en una mula, e en camisa e en pañetes" (Tristán de Leonís, XXXIV), para ser ahorcado (fig. 177 y detalle). Aunque se libra de la pena, hay una deshonra momentánea durante el lapso que es llevado del castillo a la horca, trayecto en el que lo ven los falsos caballeros contra los que peleó y otras gentes, así que el deshonor de su cuerpo sólo es visto por pocos. Posteriormente se restablecerá su honra.
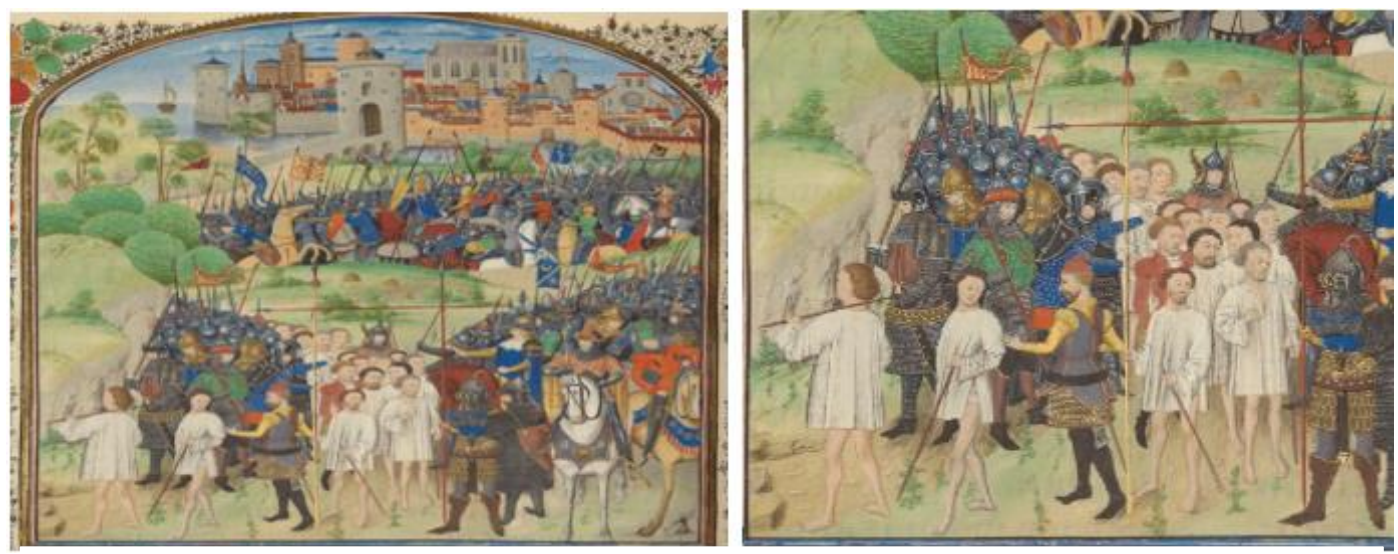

Fig. 177. La Fleur des histoires (s. XV) Jean Mansel, Biblioteca Nacional de Francia. Detalle de hombres llevados en camisa y bragas por la ciudad.

Pocos son los ejemplos en los que la prenda más oculta adquiere un simbolismo importante por ser el primer contacto con la piel. En su mayoría, la función erótica-sensual predomina entre sus hilos, esto le permite ser testigo de los numerosos encuentros íntimos de la pareja, cuya confección la convierte, brevemente, en un obstáculo, porque es la frontera entre la protección y el deseo, entre el sentir y el contemplar; a la vez satisface la vista, pero también es motivo de momentos deshonrosos cuando su delgada tela se vuelve un castigo para quien la lleva.

Aunque se ubica por debajo del resto de la vestimenta, es visible en ciertas partes, lo que deja al caballero imaginarse cómo será el resto de su confección. El largo de las mangas le sirve de adorno, pero también como testigo de ciertas situaciones sentimentales, 
además de que su longitud permite a su punta estar en contacto con otros accesorios que también fungen como elementos de seducción, aquellos que a través del movimiento dan apertura a una conquista silenciosa en público iniciada por el meneo de las manos con los enseres para refrescar la cara, que veremos a continuación.

\subsubsection{El abanico, el ventalle y el moscador ${ }^{426}$}

Una de las principales críticas que Hernando de Talavera expresa en su tratado es el que las mujeres, principalmente, tengan exceso de vestiduras para cada ocasión, "para mudar cada mes e cada semana, e aun cada día e cada rato. Cierto es que ay personas que no se contentan de salir a las viesperas con las ropas e vestiduras que llevaron a las missas, e no porque en el tiempo ovo mudança ni porque ovo necessidad de hazerla sino por apetito de vestir demasiado" (Tratado sobre el vestir ..., XII, 85). Esta crítica a la abundancia de ropa incluye todas las prendas que conforman el atuendo, desde la cabeza hasta los pies, por lo que también se incluyen los accesorios como guantes, sombreros, abanicos y bolsos, especialmente estos últimos porque los fabricaban en pieles, seda, brocado, etc., y eran un elemento costoso que transmitía la condición social.

Al igual que estos, la situación con los abanicos y otros enseres como ventalles, espejos y moscadores eran elementos que demostraban la alta condición social a través de los materiales con los que se creaban, marfil, piel, lentejuelas, hueso, concha nácar, etc. ${ }^{427}$

\footnotetext{
${ }^{426}$ En mi tesis de maestría propuse una primera línea de comunicación entre la pareja enamorada a través de ciertos accesorios femeninos utilizados como medio para atraer la atención del caballero, principalmente en las justas. Este acercamiento permitió establecer una relación común entre estos objetos: dar satisfacción física a la dama y ser el instrumento para cautivar la atención del amado (Andrea Flores García, Doncellas, princesas, reinas y sabias..., p. 81). Sin embargo, para la presente investigación hay un nuevo objetivo, el de dar a conocer las acciones que desencadenan estos objetos y cómo son testigos de la promesa de amor que inicia con una mirada y finaliza con la relación de los protagonistas.

${ }^{427}$ Esther Aldave Monreal, "Traje y moda en la Zaragoza de Carlos IV (1788-1808)", Trabajo de fin de Máster, Universidad de Zaragoza, 2012, p.52.
} 
Sin embargo, a medida que aparecían nuevos modelos, también se modificaba su uso, ya no sólo era un accesorio de utilidad para el clima, sino también un medio de comunicación visual. (fig. 178)

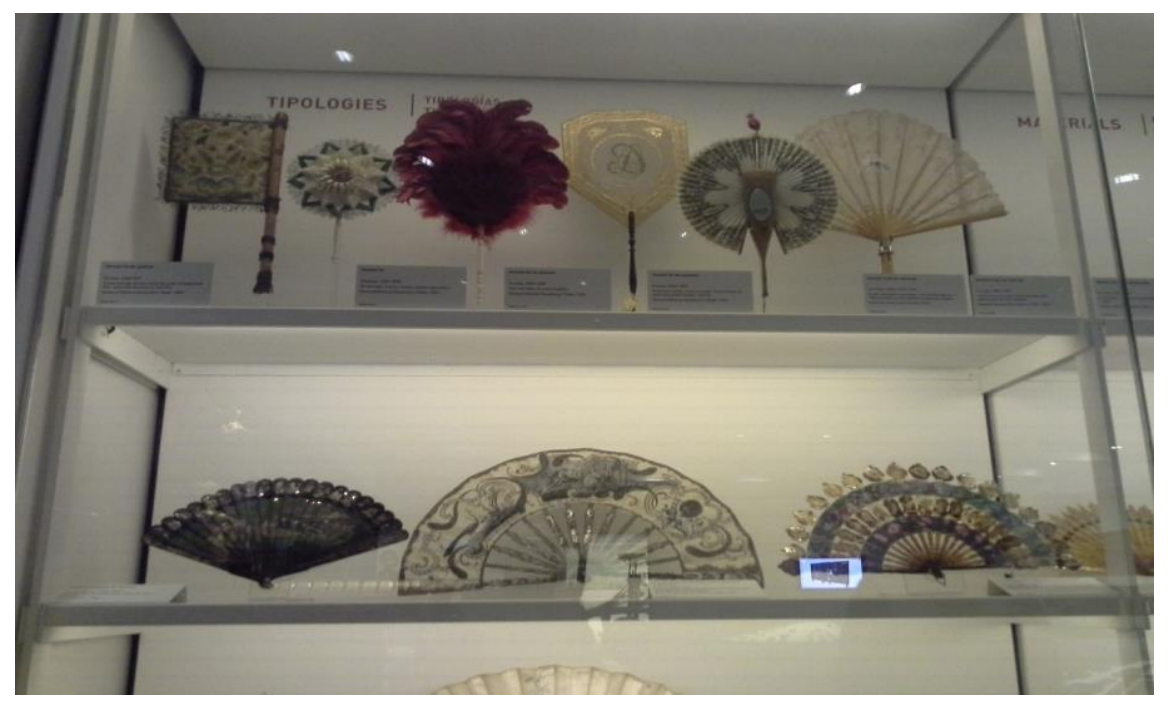

Fig. 178. Abanicos y ventalles de los siglos XV-XVII, Museo del Diseño de Barcelona

Este instrumento presenta un doble simbolismo, primero, incrementan el costo y la calidad del atuendo, pues entre más elementos se sobrepusieran al vestido, más valor monetario adquiría, y segundo, era usado para atraer la mirada, condición conocida desde la Antigüedad hasta la ficción literaria:

Las cuales de allí siempre andavan más loçanas e alegres, vestiendo cada día muchas vestiduras muy ricas e parándose más galanas. Y ansí robaban más los coraçones de sus cavalleros, por lo cual vivían muy penosos en ver a sus señoras tan hermosas e de tal manera. Que ansí <como> es propiedad de mujeres que tienen amantes, como estas dos princesas, de vestirse e atabiarse con muchas vestiduras muy preciosas e tener en la mano un moscador para que sean más miradas, como dizen acá las comunes <<mira la del moscador > o otra cosa semejante. E también cuando las damas están juntas, adoba la una a la otra el tocado e quítalle los pelicos blancos de la ropa. E sacudirse el polvo de las sayas e adobarse en todas partes porque les vean las manos blancas e lindas; las cuales maneras son para que el hombre más se encadene en su querer e amor. (Polindo, XXXVII) (figs. 179,180) 
El arreglo de las vestiduras y el movimiento de las manos son estrategias que implícitamente atraen la vista de quienes las rodean, su único propósito es que sean miradas y admiradas por sus caballeros.

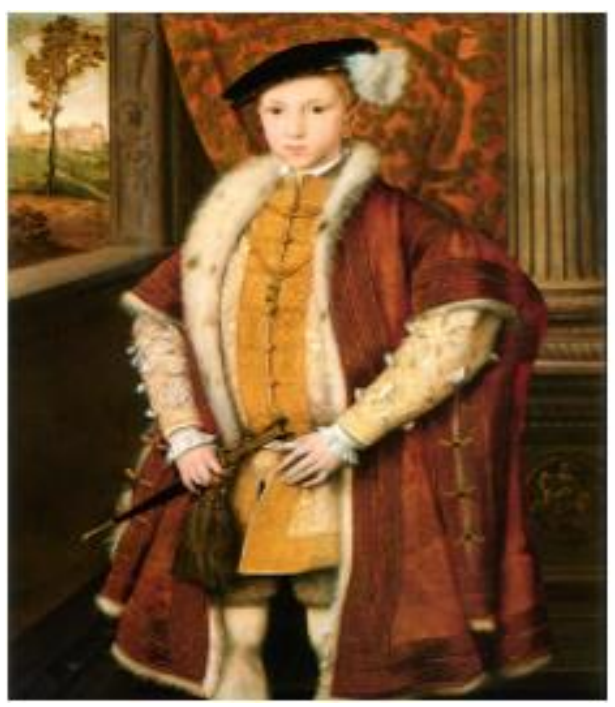

Fig. 179. Eduardo VI de Inglaterra (1546) William Scrots Lleva una daga con moscador en la mano derecha.

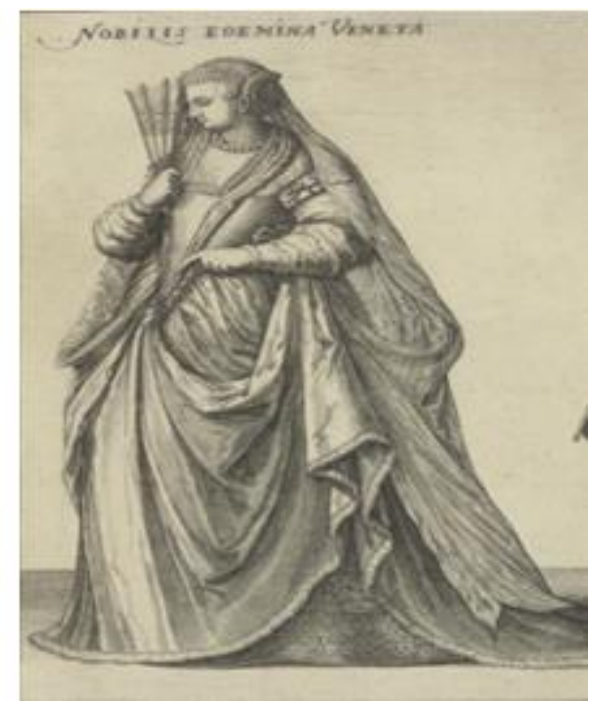

Fig.180. "Dama noble veneciana", Habituz variarum orbis gentum (1581) Jean Jaques Boissardi.

Dama juega con su abanico para atraer la mirada de los demás.

Desde la Edad Media, las manos tienen una significación importante, porque expresan "la idea de actividad al mismo tiempo que la de potencia y dominio" 428 , con ellas juegan, acarician, agradecen y entregan regalos, pero también llevan objetos que necesitan de su movimiento para expresar algo: "Cada una traía en la una mano un ventalle de muy hermosas plumas de aves, y en cada ventalle dos hermosos espejos engastados de sotiles engastes de oro" (Florisel de Niquea III, CXLVIII) (fig. 181). Este complemento por sí solo únicamente sirve de decoración a juego con el resto de la indumentaria que llevan las damas, pero, al entrelazarse con la vista de los demás, especialmente del caballero, adquiere un valor especial: "Pues de tal suerte estas dos hermosas hermanas salieron, donde fueron muy miradas e bien recibidas de aquellos príncipes e princesas, y entraron todos a una gran

\footnotetext{
${ }^{428}$ Jean Chevalier, Diccionario de símbolos, p. 682.
} 
sala" (Florisel de Niquea III, CXLVIII). La primera impresión es la belleza que genera el movimiento de las plumas, la segunda, el asombro que causa en los caballeros que las miran: "Con cuya vista todos los cavalleros cobraron gran esfuerço, que ya estavan antes de la hora en la plaça, paresciendoles que era más justo aguardar a la reyna, que no que ella los aguardasse" (Florisel de Niquea IV, I, LVI); este acto de caminar frente al joven es una motivación más para que en los combates los justadores recobren fuerzas y peleen con más ánimo, pues han visto a su dama y por ella deben ganar. ${ }^{429}$

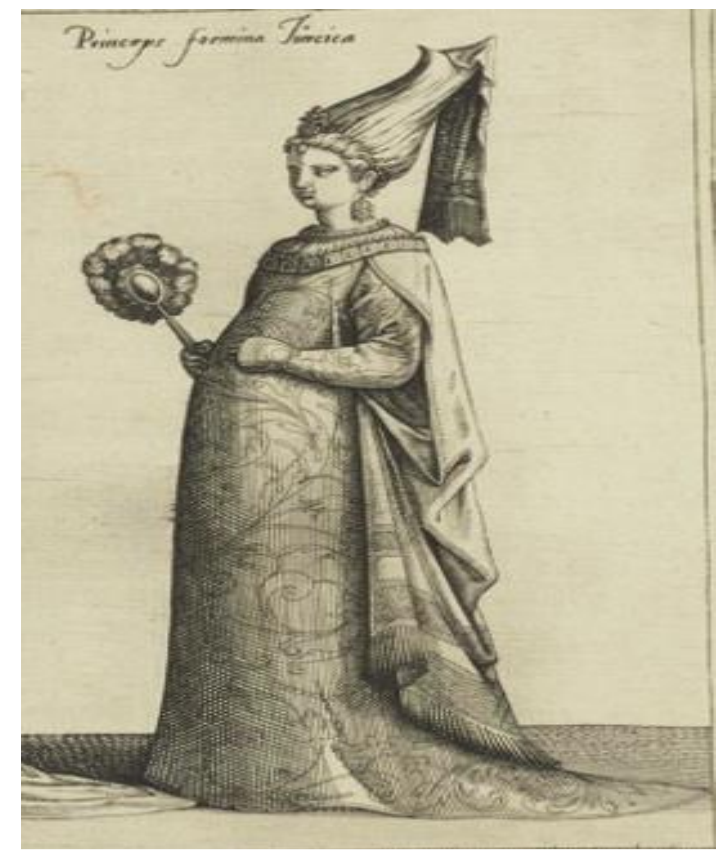

Fig. 181. "Princesa turca", Habituz variarum orbis gentum, (1581) Jean Jaques Boissardi.

Ventalle con espejo, en el óvalo de en medio se colocaba el espejo que servía para arreglarse el cabello y el rostro y, como sucede en el Florisel, para mirar al caballero.

Será un tiempo de comunicación visual entre la mano y los ojos, teniendo como intermediario un objeto. Es decir, "el abanico ha sido durante largo tiempo atributo de la

${ }^{429}$ Aunque en los libros de caballerías no se dice si los ventalles contienen alguna inscripción grabada, fuera de la ficción sí se tiene registro de abanicos con mensajes y nombres inscritos, de estos "había toda una tipología de abanicos: de invierno y verano, de hombre y de mujer, para el campo, la playa, de lujo, de luto, de bodas. En algunos se escribían textos o versos y se pintaban diferentes motivos". Ruth de la Puerta Escribano, "Moda, moral y regulación jurídica en la época de Goya", Ars Longa, 7-8, 1996-1997, p.216. 
feminidad. La mujer empleaba el abanico no sólo para el fin obvio que le ha dado nombre, sino también para semiocultar el rostro, descubrirlo y velarlo alternativamente, etc., en un juego seductor de revelación y retraimiento" ${ }^{\text {430 }}$, se trata de un lenguaje gestual, elevado y disfrazado, entendible sólo para los enamorados. Su fin es la comunicación a través de las señas y de la correspondencia con la mirada; al fijar los ojos en la dama, el caballero es cautivado y dominado por un interés de transmitir un mensaje a medias para que el varón se interese más, ya que "la mujer en cuanto vista y no vista, propicia y esquiva al mismo tiempo, se hacía tanto más deseable" ${ }^{431}$, situación que se satisface cuando se encuentran juntos. (fig. 182)

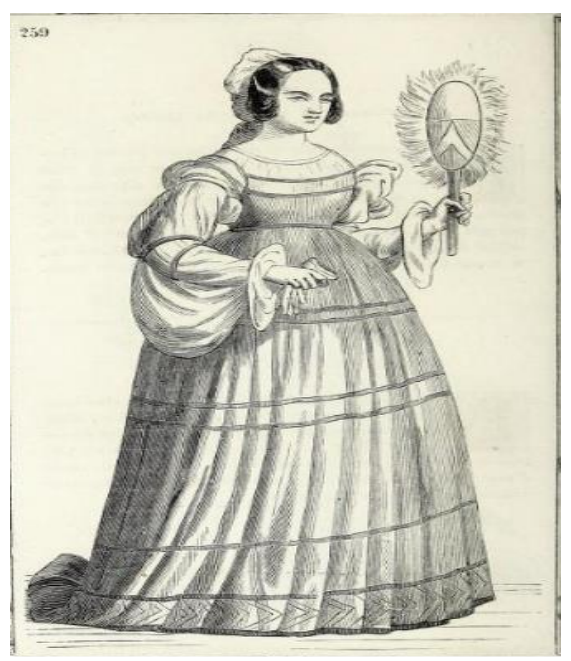

Fig. 182. "Dama antigua de España", Habiti antichi e moderni (1860) Cesare Vecellio.

Abanico redondeo de plumas.

Este tipo de objetos adquiere relevancia en la historia porque también genera otro tipo de acciones cuando se les ha agregado una especie de encantamiento, revelar si realmente la pareja está destinada a estar junta.

\footnotetext{
${ }^{430}$ Federico Revilla, Diccionario de iconografía, Madrid, Cátedra, 1990, p. 12.

${ }^{431}$ Idem.
} 
Y luego una doncella de las suyas a Sinestasia dio un ventalle, de tan hermosas plumas que no se consentían mirar, con los resplandores y vislumbres que hazían a la vista, tenían en medio, un espejo de muy resplandeciente cristal, engastado en Oro con sutiles esmaltes de Rosicler, para dar ayre, y ponello a quien lo llevava. (Florisel de Niquea IV, I, LII)

Un dúo de accesorios se une en una sola pieza para insertar un nuevo tipo de enser femenino, un ventalle-espejo cuya función es refrescar y reflejar un rostro; dicha imagen es resultado de la composición mágica del padre de Sinestasia, quien crea el ventalle con el fin de preservar sólo la cara de su hija, para que aquél a quien sea entregado tenga la fortuna de mirar siempre el rostro de la joven, sin importar qué tan lejos estén. El afortunado en recibirlo es el príncipe Rogel:

Mi señora -dixo él- no quiero hazer tanta sin razón al espejo, con quitallo de tal mano. No hazeys -dixo ella- porque a mí qualquiera espejo me mostrará lo que me muestra, y a vos mostraros a ese, lo que sin él nos vereys, en la parte que mas desseays veros, que es el alma; porque quiero que lo lleveys para acordaros de mí. Mi señora -dixo él- essa memoria en mi alma la tendré yo más por no negar tal gloria a la vista corporal, como la vuestra merced y por ella beso vuestras hermosas manos y en ellas lo pongo en depósito hasta el tiempo de mi partida.

Y con esto se lo retorno a dar, y -ella dixo- yo lo recibo con essa condición. Y tomolo, dexando al príncipe más ledo con tal don, que si le diera un reyno. (Florisel de Niquea IV, I, LII).

Promesas de amor que se hacen ante objetos que adquieren un valor sentimental porque son prendas entregadas a la persona amada, cuya función en la historia es traer a la memoria el recuerdo de su amor y fidelidad, por lo que, en un principio, se establecen como enseres de conquista, porque a través del movimiento se atrae la mirada, después comienza el juego de palabras y por último se accede a la entrega del galardón. En el ejemplo anterior, el motivo de la conversación es el espejo-ventalle que Sinestasia tiene entre sus manos, cuya virtud 
está en que sólo su rostro se quedará grabado en el espejo y todo aquel que se mire, sólo la podrá contemplar. Dichoso de esta imagen, Rogel la atesora y la lleva consigo.

El espejo, "reflejo de la verdad, la sinceridad, el contenido del corazón y de la conciencia" 432 ha revelado la imagen de una dama, que en el pensamiento de Sinestasia es ella misma la que ven los demás. Sin embargo, en la historia Sinestasia y Rogel, su amor no está destinado a concretarse debido a que el caballero no ve la imagen de la dama, es decir, el precepto de que el amor entra por la mirada ${ }^{433}$ no se realiza en esta pareja porque desde el principio no estaban sentenciados a terminar juntos, ya que Rogel siempre estuvo enamorado de Arquisidea y como ella era físicamente parecida a Sinestasia, por eso un sentimiento de atracción surgió en él, pero no de amor.

El verdadero amor siempre se revela a través de los ojos y del espejo, reflejo de los sentimientos del alma y de la verdad oculta. El ventalle y el espejo son conectores de los sentimientos de la pareja, aquella que busca distintos medios para comunicarse en secreto y en público. La dificultad está en que ambos comprendan lo que tratan de decir y que el mensaje sólo sea entendible para ellos. ${ }^{434}$

\footnotetext{
${ }^{432}$ Jean Chevalier, Diccionario de los símbolos, p. 474.

${ }^{433}$ Según Culianus "la imagen de la mujer penetra en el espíritu a través de los ojos y, mediante el nervio óptico, se transmite el espíritu sensible que forma el sentido común". Ioan P. Culianu, Eros y magia en el Renacimiento, Madrid, Siruela, 1999, p.49. De este modo la figura femenina se refleja en el espejo a través de los ojos de quien se mira. Incluso en voz de los propios personajes se indica que es su alma la que miran: "Y con esto lo tomó y mirándose en él, quedando sin color, ella le dixo: Que es esso cavallero, como desamparays el rostro de la vida. Es -dixo él- que los espíritus socorren al coraçón, el qual el alma a desamparado saliendo del al espejo, donde presente la veo. Como es esso -dixo ella riendo-. Es -dixo él- que nunca rostro corporal mirándose en espejo dexo de verse, con ver su alma como agora yo la veo" (Florisel de Niquea IV, I, LII). El estado de enamoramiento de Rogel es tal que en sus ojos sólo puede ver el reflejo de Arquisidea, y por ello, cree ver su rostro en el espejo, aunque en realidad es el de Sinestasia, por lo que se trata de una felicidad momentánea que desaparecerá cuando sus verdaderas parejas sean reveladas.

${ }^{434}$ En el Tirante aparece un ventalle, se usa para limitar el campo de batalla: "Los fieles elegidos por los jueces tomaron primero a Tomás de Muntalbá, puesto que era el requeridor, y lo pusieron dentro del campo en un pequeño pabellón que cada uno tenía, de satén, a un lado del campo. Y cada uno llevaba en la mano un ventalle para señalar las cuatro esquinas del campo" (Tirante el Blanco, LXXXI). Éstos eran más grandes, parecidos a los que llevaban los sirvientes de los egipcios y romanos para cubrir del sol y dar aire a sus señores.
} 


\subsection{Prendas de luto}

En un apartado del capítulo dos de mi tesis de maestría abordé brevemente el tema de la vestimenta de luto en dos libros de caballerías: Primaleón y Platir, específicamente en tres situaciones: Muerte, encantamiento de un personaje e imposición matrimonial. En estos ejemplos sólo analicé "los paños negros con el significado de pena en la que entraría sufrimiento por alguna acción que afecte a un personaje, como es el caso de un matrimonio por obligación, un encantamiento o la muerte de un familiar" ${ }^{435}$. Sin embargo, aún quedan más simbolismos del uso de esta prenda como transmisora de dolor en distintas circunstancias, así como la necesidad de conocer los tipos y los materiales con que estaban hechas y otros accesorios del cortejo fúnebre.

En el Tesoro de la lengua se denomina luto a "la vestidura lúgubre que se ponen los conjuntos al difunto, en significación de dolor y tristeza, y así se dijo luto del nombre latino luctus, que es lloro" y el duelo es "el dolor, el llanto, la aflicción y el trabajo". Estos dos significados son relevantes para esta investigación, debido a que ambas participan en los aspectos físicos y sentimentales de los personajes. De un lado está la transmisión del estado de ánimo a través del color de las prendas, el cual puede prolongarse hasta varios capítulos, este equivaldría al duelo; por otra parte, está la constitución física de la prenda, en la que sobresaldría la tela, los adornos y los accesorios que complementan todo el atuendo, aquí pertenece el luto. Es decir, el duelo es la tristeza por lo ocurrido y el luto la manifestación del dolor a través de las prendas. (fig. 183)

\footnotetext{
${ }^{435}$ Andrea Flores García, Doncellas, princesa, reinas y sabias..., p.84.
} 


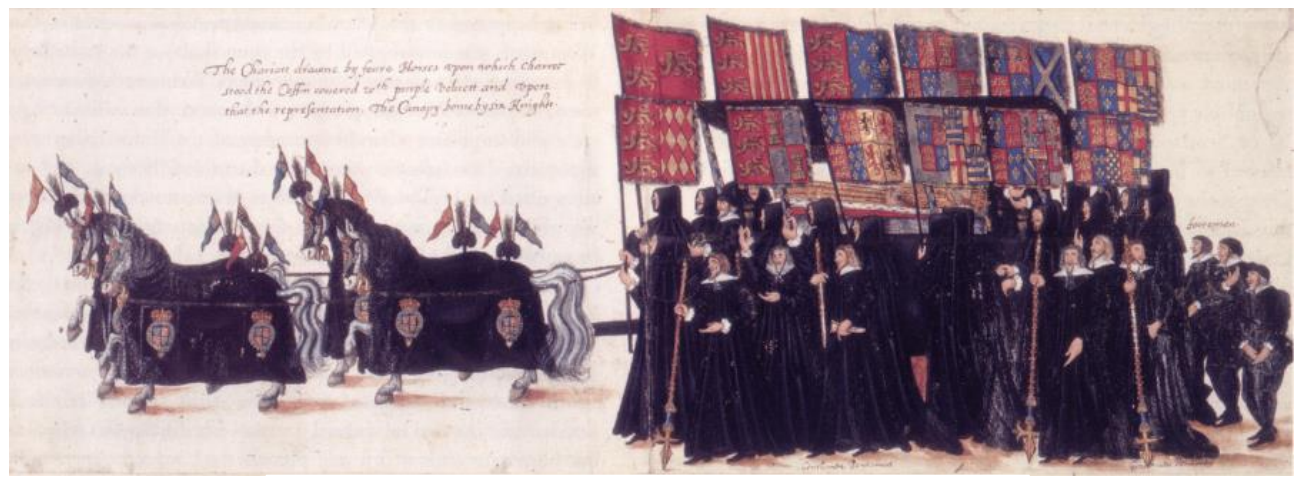

Fig. 183. Cortejo fúnebre de la reina Elizabeth I 1603, fol. 37v.

Esta expresión del dolor será por medio de un color en específico en ciertas culturas, tal como se explica del negro, ${ }^{436}$ color de 1 luto $^{437}$ en Occidente. Por lo que serán numerosos los accesorios y las prendas que se mencionen de este color.

Con base en diversos testimonios como leyes, testamentos, herencias, cartas e inventarios se puede conocer históricamente este color como el transmisor de tristeza y pena, por su sobriedad y seriedad. El elemento que lo completa es el diseño de las prendas elaboradas según sexo y estamento social. Para ello, algunas leyes expresaban que para los funerales reales los hombres debían llevar luto de paño, lobas cerradas, capirotes o capillas y las mujeres tocas negras. ${ }^{438}$

Algunas de estas prendas aparecen en los libros de caballerías de Silva, en donde tendrán distinta relevancia acorde a la situación y al personaje que las use.

\footnotetext{
${ }^{436}$ Michel Pastoureau, Breve historia de los colores, Barcelona, Paidós, 2006.

${ }^{437}$ En el Policisne de Boecia aparece un caso particular, se trata de la especificación del uso de prendas azules por ser el color de luto en el reino de Panoria: "Entraron doze enanos con ropas largas de un tamete azul que en su reino por luto se traía" (XXX). En el caso de Silva, este color no se menciona en ninguna situación de luto.

438 Margarita Cabrera Sánchez, "Funerales regios en la Castilla bajo medieval", Acta historica et archaeologica mediaevalia, 22 (2), 2001, p.559.
} 


\subsubsection{El manto negro}

En estas historias son frecuentes las llegadas de damas, caballeros y ancianos a la corte para pedir ayuda, ya sea para vengar una muerte, rescatar a alguien, restablecer el honor o recuperar bienes; en estas peticiones el personaje demandante se caracteriza por su fisionomía y por los usos que lleva puestos: "entró por la puerta de la sala una donzella hermosa vestida de paños de duelo e un cavallero anciano la traía por la mano. Con ella venían dos donzellas e veinte cavalleros con otros tantos escuderos" (Lisuarte de Grecia, LIX), cada uno de ellos vestidos de igual forma. Los primeros cortejos de Silva se caracterizan por los mínimos detalles que el autor da de la ropa. En este caso sólo se conoce que la dama lleva "paños de duelo". Con esta mención no se puede clasificar la tela ya que en el siglo XVI "para la mayoría de las vestiduras de luto se utiliza paño negro de distintas calidades"439, según la clase social a la que se pertenecía. Existían géneros de seda, terciopelo, lana, lino y algodón ${ }^{440}$, el costo dependía del tipo de brocado y del diseño que tuviera bordado.

La distinción entre uno y otro personaje dependerá de los accesorios que lleve y de la tela con que esté hecho el manto, tal como se ve en el siguiente ejemplo: "Todos fueron llevados a un campo que entre ambos exércitos Abra avía mandado hazer, y ella vino muy ricamente guarnida a ver la batalla, y Axiana también, vestida de paños negros de muy fina seda; ambas traían coronas de emperatrices." (Amadís de Grecia, II, CVI). Se puede ver que en este pasaje se especifica el tipo de tela de la segunda joven, "de muy fina seda", mientras que de la primera no se menciona este rasgo.

\footnotetext{
${ }^{439}$ Carlos Polanco Melero, Muerte y sociedad en Burgos en el siglo XVI, Salamanca, Diputación Provincial de Burgos, 2001, p.198.

${ }^{440}$ Carmen Bernis, Trajes y modas en la España de los Reyes católicos. I. Las mujeres..., p. 18.
} 
En algunas provincias como Castilla durante el siglo XVI se caracterizaban las prendas de luto tanto para hombres como para mujeres. Estas últimas llevaban "la cabeza cubierta con pañuelo negro, mantos largos y muy tupidos. Todas las prendas negras, medias, zapatos" 441 . Para los varones había algunas excepciones, ya que "si no llevaban todo negro, se ponían cinta negra en el sombrero o en la manga derecha de la chaqueta o abrigo" $" 442$, con lo cual se puede ver que había distintas formas de llevar el luto.

Estas situaciones, generalmente, se dan en justas, en donde las damas van vestidas acorde al color de las armas de su reino. En esta descripción se establece, a simple vista, una sola connotación de esta prenda, festejo. Sin embargo, en este ejemplo se trata de un luto prolongado, pues ya han pasado varios días desde la muerte de la princesa Onoloria y aún se continúa manifestando la tristeza a través del color negro. Aunque en el texto no se indiquen "paños de luto", sino "paños negros de muy fina seda", el contexto de este y de los capítulos anteriores reafirman el significado de estas prendas.

En la segunda parte del Florisel de Niquea se describe en un episodio un proceso funerario por la muerte del rey de Boecia: "doze cavalleros e donzellas eran, que gravemente con lágrimas y palabras de gran dolor el de aver perdido un cavallero que en unas andas cubiertas de luto llevaban iban lamentando, el cual todo armado iva grande y bien hecho, con la cabeça junto con el yelmo de un golpe de espada hendido. Y dentro con él en las andas iva una dueña muy hermosa" (Florisel de Niquea II, VII). En ese traslado del cuerpo sobresalen las andas y la dueña. Las andas toman relevancia al equipararse con las descritas en la realidad, por ejemplo, se sabe que:

el cadáver era transportado directamente sobre las andas cubiertas con un amplio paño negro, [y que] las viudas gastaban cobija como vestido lúgubre. Se describe

\footnotetext{
${ }^{441}$ María Ángeles González Mena, Colección pedagógico textil ..., p.34.

${ }^{442}$ Idem.
} 
siempre esta prenda en los documentos como de color negro, guarnecida con bordes de terciopelo y fábrica de paño fino, identificándose cobija y manto de luto. ${ }^{443}$

Es posible que esta dueña llevara un manto fino al igual que la tela que cubría las andas, debido a que en esa época las damas nobles utilizaban los mejores géneros.

\subsubsection{Paños para la ausencia}

La separación de personajes por motivos como combates, búsqueda de personajes, enmiendas, promesas de dones, etc., es una situación de dolor y desesperación por estar lejos del ser querido. Se desconoce si está bien o herido, cuándo regresará y con quién estará.

En el Amadís de Grecia hay un caso particular en el uso de esta prenda, se trata de la ausencia del rey Amadís, la cual es sentida por la reina Oriana como una especie de muerte (por la lejanía del ser amado). Ésta manifiesta su dolor a través de los paños negros, los cuales usa hasta el retorno de Amadís: "hallaron a la puerta de una sala a la reina Oriana vestida de paños de seda negros, que por la absencia del rey Amadís no se quiso ella vestir más ricamente, que por honrar al Emperador hasta los corredores salió a recebirlos". (Amadís de Grecia, I, LVII). El luto de Oriana se justifica por la prolongada separación entre ella y Amadís, pues desconoce del todo la condición del joven. La dama usará sus prendas de diario al regreso del caballero.

443 Antonio Cea Gutiérrez, "Ritos y costumbres en torno a los difuntos en Salamanca", Revista de dialectología y tradiciones populares, vol. 40, 1985, p. 62. 


\subsubsection{Paños de encanto}

Además del manto por ausencia, aparece otro simbolismo de esta prenda cuando la pareja enamorada está ausente del reino por motivos mágicos: “y otro día acabando la reina de comer en la sala una donzella entra. Venía vestida de paños de duelo y dos cavalleros ancianos venían con ella, armados salvo las cabeças y las manos" (Florisel de Niquea III).

El uso de esta prenda se debe a que en el reino de Tesalia vivían una reina y su hermosa hija Artifira. Ésta fue requerida en amores por un jayán, pero ambas se rehusaron a esa petición. Pasado un tiempo, Artifira se casó con Rosafar. Al enterarse el jayán y su madre, lanzaron un hechizo en contra de los enamorados, que consistía en que la pareja sentiría gran dolor al salírseles el corazón, por lo que debían quedar unidos para cubrir su corazón con sus manos.

Todo el reino lamenta este dolor de los jóvenes, que aún están con vida, por lo que deben ir en busca de la persona que "en pena de amar tuviere mayor herida" para que termine con el encantamiento. Aunque la pareja es la que está encantada, los demás personajes transmiten esa condición a través de las prendas que usan, ya que ellos mismos

confiesan que "por esta desventura traemos hábitos de duelo" (Florisel de Niquea III, LXIX). En este caso, el encantamiento de personajes adquiere la connotación de muerte, ya que la reina, las doncellas y los caballeros así sienten la situación inmóvil de la pareja.

\subsubsection{Manto negro por pérdidas de bienes}

El último simbolismo del uso del manto negro aparece en una situación de herencia: "e aviendo comido con mucho solaz, entraron tres donzellas vestidas de duelo, y assaz eran hermosas" (Florisel de Niquea III, CXIIII). En este ejemplo se toma el simbolismo de duelo por la muerte del padre, pero también por el despojo de bienes materiales; se trata de 
la toma de tres castillos heredados a cada una de estas doncellas: "Y estábamos en la ciudad de Esparta, y tres cavalleros de nuestro linage como vieron muerto a nuestro padre se metieron en nuestros castillos y nos los tienen tomados" (Florisel de Niquea III, CXIIII). Esta especie de luto se prolonga un poco hasta la recuperación de los castillos.

El manto negro funciona de la misma manera en los ejemplos anteriores, emite la tristeza y el duelo por la pérdida y separación de familiares y bienes en distintas circunstancias. Es un proceso en el que, aunque no haya una muerte física, los personajes así la sienten.

\subsubsection{Armas de luto}

Distintas armas coloridas han desfilado por las páginas de estos libros, en las que el diseño, la insignia y el mote han caracterizado a cada uno de los caballeros por su originalidad y distinción de entre los demás. A pesar de lo llamativo de estas prendas, también están las armas que se distinguen por emitir melancolía.

En Flor de caballerías aparecen las tiendas de luto, espacios en donde algunos personajes se preparaban para combatir y vengar la muerte de un familiar: "vido dos grandes tiendas cubiertas de luto y los sirvientes que en ellas entravan y salían vestidos de negro [...] vido un gigante vestido de luto sentado en una silla, armado de unas armas de acero negro" (Flor de caballerías, XXXXV). En este ejemplo es importante aclarar que la armadura negra ${ }^{444}$ no es el color de identificación de combate del gigante, sino que es otro elemento para demostrar la tristeza del personaje, por lo que sólo la usará en ese periodo de luto hasta conseguir su venganza. Después retomará sus armas de siempre. (fig. 184)

\footnotetext{
${ }^{444}$ En este caso es importante aclarar que no en todos los episodios en los que aparezca una armadura negra se relaciona con el luto, sólo será cuando en el texto se indique, debido a que en otros episodios se hace referencia a la armadura negra como color de identificación de un reino o de un personaje en combate, como sucede en el Amadís de Grecia: "La princesa miró al cavallero que la quería vengar, y violo que era grande y bien hecho y estaba todo armado de unas armas negras sin otra pintura salvo en el escudo [...]" (I, LV).
} 


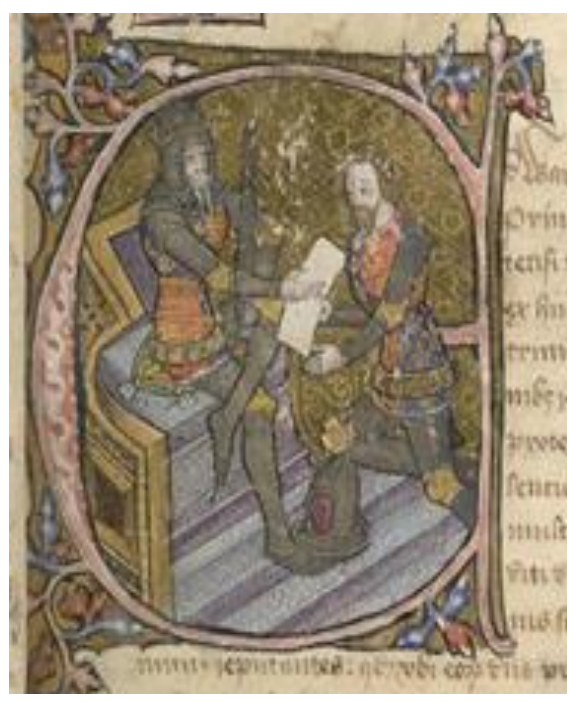

Fig. 184. Eduardo el Príncipe Negro recibe Aquitania, fol. 31r (1390).

El caballero usa armas negras.
En el Amadís de Grecia se observa que el uso de estas armas puede prolongarse por varios episodios, específicamente en este ejemplo será hasta que cambie el estado de ánimo del rey: "Essa tarde fue acordado que los diez cavalleros, por causa de la tristeza del emperador, fuesen de armas negras y sobreseñales de lo misma y los paramentos assimesmo, con cruces coloradas en los escudos" (Amadís de Grecia, II, CVI). El motivo del lamento del rey se debe a la muerte de su esposa después de parir.

Esta nostalgia se contagia a todo el reino, sobre esto había una ley que establecía que todos los habitantes debían hacer luto por la muerte de ciertas personas por un tiempo, “por Rey, quarenta días, ó por Reina ó por Infante heredero treinta días [...] por pariente quatro meses, é la mujer por su marido que pueda traer duelo el tiempo que quisiere $[\ldots]^{\natural 445}$. Es posible que Silva conociera estas leyes y que las incluyera implícitamente en sus obras, pues en este ejemplo el emperador guarda luto a la reina por un tiempo y todo el reino se viste acorde a la situación.

Mantos, jubones, sayas, capillas y tocados negros son sólo algunas de las prendas que Feliciano de Silva recreó en pasajes de cortejos fúnebres, encantamientos, ausencias de familiares y despojo de bienes. En cada situación los personajes manifestaron su dolor a través de la tristeza, el llanto y las prendas que portaban, pues, aunque, en ocasiones, no se

\footnotetext{
${ }^{445}$ Academia de la Historia, "Cortes de Burgos de 1379", en Colección de cortes de los reynos de León y de Castilla, Madrid, Imprenta de don Marcelino Calero y Portocarrero, 1836, p.7.
} 
trataba de muertes físicas, sí eran situaciones en las que el mal por la pérdida momentánea de algo provocaba sufrimiento en los personajes.

En cuanto a las telas, como la seda, el tafetán o el paño de luto fueron signos de lujo por el valor monetario que tenían en la época, esto permitía distinguir entre una dama de la corte y una dama de compañía, pues la primera solía llevar más accesorios como collares, coronas y broches, mientras que la segunda sólo usaba el vestido.

El simbolismo de la indumentaria de luto está en que ésta no sólo representa el dolor por la muerte de un ser querido, como lo fue en el episodio del gigante o en el del rey triste por la muerte de su esposa, sino que también refleja el dolor por la pérdida de algo, ya sea por un breve tiempo o para siempre, como los castillos, la ausencia del caballero y la necesidad de esconderse por temor a ser herido. Este dolor estará en las telas negras de los vestidos, mantos, armaduras, andas y cubiertas, hasta que los personajes se venguen, obtengan de vuelta sus pertenencias o se repongan de la muerte de su familiar. 


\section{Feliciano de Silva frente a otros autores}

En los tres capítulos anteriores se ha propuesto una serie de categorías en torno al tipo, uso y función de la vestimenta en los libros de caballerías de Feliciano de Silva; cinco obras en las que se ha podido identificar el avance creativo en cuanto al diseño de textiles y ornamentos de metal, piel y cristal, no sólo como accesorios, sino como elementos con un lenguaje propio, apegado a la moda de la época pero con una cualidad importante, tener una función narrativa que genera acciones, tales como establecer jerarquías en las armas de los justadores, motivar el triunfo del paladín en la batalla, ser un lenguaje seductor para los encuentros íntimos, transmitir diversas emociones a través del color y la más importante, ser intermediarios en la comunicación del caballero y la dama.

Estas aportaciones tuvieron un proceso evolutivo durante 37 años, el periodo más largo que tuvo un escritor de este género, gracias al éxito de sus obras, y que en cada una de ellas introdujo estilos nuevos de confección, joyería y enseres que fueron motivo de imitación por parte de autores posteriores, muchos de ellos respetando la línea creativa de Silva, algunos aportando sus propias invenciones y otros imitando los mismos modelos de este autor.

Para este último capítulo se propone una clasificación con base en tres aspectos. Primero se pretende realizar una categoría de la presencia del atuendo en algunos pasajes, no antes mencionados, de los demás libros del género que presenten aspectos diferentes a los ya analizados; después, ampliar el conocimiento de dichas prendas a través de las xilografías halladas, principalmente en las primeras ediciones de algunos de estos libros, para comparar sus diseños con los encontrados en retratos, pinturas y otros libros de la 
época. Por último, se destacarán las creaciones de Silva frente a las de los otros autores, a fin de considerar sus innovaciones en la línea textil del siglo XVI.

\subsection{Variedad de prendas}

Para establecer una comparación entre Feliciano de Silva con los demás escritores se tomarán como base los 71 títulos caballerescos de origen hispánico y 11 procedentes de la materia de Bretaña que recoge la Antología de libros de caballerías castellanos editada por el Centro de Estudios Cervantinos, de los cuales cerca de 50 se han podido consultar para esta investigación y se han extraído los pasajes en los que la indumentaria adquiere una relevancia por la función actancial que cumplen: hazañas, accidentes, enredos, incomodidades, molestias, entre otras.

En todos los títulos revisados se hallan los siguientes modos y tipos de prendas, accesorios y joyas, además de una gran variedad de armas y usos del color para manifestar un sentimiento: Proceso de coronación, prendas como identificación de un personaje perdido; referencias al uso diario de la ropa (acciones de vestir y peinar); vestimenta y armas de luto; entrega de joyas como pago y como premio; hábitos de predicador (la mayoría de las veces no se describen); precio de joyas; telas para aderezar el palacio; ir desnudos en camisa; referencia general para indicar "vestido de ricos paños"; joyas dadas entre los enamorados; mantos para cubrir a los caballeros cuando se quitan las armas; mención sobre la importancia de portar un atuendo diferente cada día y situaciones curiosas como la necesidad de cambiar su ropa porque está mojada, rota o sucia. Aparte de éstas y algunas otras se han seleccionado cuando presentan una innovación importante para esta investigación. 


\subsubsection{Vestir acorde al estado de ánimo}

Es recurrente hallar la relación sentimiento-color también en las prendas relacionadas a las situaciones de lamento, por ejemplo, en el Cirongilio de Tracia se cuenta la historia de Parpasodo Piro, jayán muerto por Cirongilio de Tracia. Su hija, la jayana Panizara, busca vengar la muerte de su padre, así que pide a su esposo Buzaratangedro que combata contra don Cirongilio. Para realizar el combate, la jayana asiste a la corte del emperador Corosindo de Constantinopla, porque ahí se halla don Cirongilio. A su llegada todos se asombran porque "venía vestida de unas vestiduras negras, bordadas de unas cabeças que en las faiciones e phisionomía d'ellas parecían de jayán, e un tocado de la mesma color que le caía sobre los ojos, y tan corta la vestidura que apenas le passava de las rodillas (Cirongilio de Tracia II, XXI). Dos accesorios destacan, el tocado, a manera de velo porque cubre los ojos y el diseño del vestido, en donde las cabezas bordadas están en armonía con la tela negra; además, la propia doncella da la explicación de su atavío:

vengo a trocar en tu corte las tristes vestiduras que vees, cobrando el placer que perdido tengo, y entonces trocaré la amarga bordadura que en ellas viene poniendo otras en su lugar que den conocimiento de mi vengança; que las cabeças que en ella vienen son en memoria de la que ante las puertas de tu palacio es fixada en vituperio y ultraje de mi padre generoso y fuerte, la cual no será enteramente purgada aunque la tuya fuesse en el mesmo lugar. (Cirongilio de Tracia II, XXI)

Tres elementos se destacan en este ejemplo, color-imagen-estado de ánimo, todos ellos en sintonía con la tristeza y el deseo de venganza transmitidos en "la amarga bordadura". Este ejemplo, aunque es similar a los analizados en los apartados de las prendas de duelo, presenta una singularidad importante, la de conservar la caracterización de jayana tanto en su físico como en su vestido, puesto que no hay un intento de agraciar, embellecer o cubrir 
al personaje con elementos decorativos de alto precio, sino que el diseño se ajusta a su cuerpo y los elementos decorativos a la situación de sufrimiento.

Este tipo de labores también aparece en las damas de la corte que por algún motivo pierden a su caballero: “Aquella donzella tenía vestida una ropa de cetí negro con una letra en torno della que dezía "Mi grandeza y hermosura me vistieron de tristura" (Cristalián de España, I, XXXII, fol. 71 v.). La princesa Penamundi en un lamento eterno por el príncipe Atalenda, muerto de amor por ella, porta la tristeza, tanto en color como en letra. Esta composición textil es más común hallarla en las armas de los caballeros; sin embargo, al igual que en el ejemplo anterior, el ingenio femenino está en los detalles. Nótese cómo a pesar de tratarse de un suceso triste, se conserva el lujo del tejido, un cetí negro con letras a la redonda. Este tipo de vestido con inscripciones se puede notar en ciertas obras del siglo XVI, en donde generalmente aparecen en la parte inferior de la falda.

Esta unión del color con la prenda puede presentar un desarrollo más complejo debido a la intervención de otros elementos como las prendas de reconocimiento y el tiempo transcurrido entre las acciones.

Cuando los pequeños son separados de sus padres, ya sea porque se abandona en el campo, se arroja a las aguas o un personaje mágico lo desaparece, en cada una de estas situaciones está presente un rico manto ${ }^{446}$ en el que es envuelto y junto a él algunos objetos que servirán para reconocerlo en el futuro, generalmente se trata de una espada, un anillo o una carta. Sin embargo, hay algunos ejemplos en donde el niño se pierde cuando es mayor y como recuerdo quedan algunas prendas de su

\footnotetext{
${ }^{446}$ Sobre la importancia del manto infantil véase mi artículo "Moda infantil en los libros de caballerías I. Trajes de corte", en El rey Arturo y sus libros: 500 años, Aurelio González, Karla Xiomara Luna Mariscal y Axayácatl Campos García Rojas (eds.), México, El Colegio de México, 2019, pp. 355-371.
} 
vestimenta diaria, tal como ocurre en el Lepolemo, cuyo protagonista es alejado por el mar junto con su ama:

Que alguna vallena o otra cosa semejante los ha comido, que veis aquí el bonete y el çapato de vuestro hijo y el rosario del ama que fue hallado junto a la mar y ellos no parecen en el mundo [...] y con estas y otras semejantes palabras se sossegó algo el llanto de la emperatriz. Pero Dios sabe el coraçón del emperador qué tal estava aunque lo dissimulava, y tomó de las manos de la emperatriz, el bonete y el çapato del príncipe, que no hazía sino mirarlos y hablar con ellos como si le ovieran de dar cuenta de su hijo. (Lepolemo, VI)

Este lamento por la pérdida de su hijo permanecerá por varios años en la contemplación del zapato, pero también en la vestimenta que el ama del niño lleva desde el momento en que ambos se extravían: "Estando las cosas en este estado, entró por la sala Platina, la ama del Cavallero de la + , con sus ropas de paño negro como ella las acostumbrara levar" (Lepolemo, CXLV). Esta entrada es el preámbulo para una confesión:

“-Pues aunque no me conozcáis, yo quiero confessaros ante todos estos señores que vosotros me encomendastes y distes en mi poder la mayor y mejor cosa de todo vuestro imperio, muchos días ha, por lo cual avéis passado gran desseo junto con infinitas angustias amargas, hasta oy, la cual hos ha hecho harta falta. Y porque la muerte y la vida está en las manos de Dios, no quiero llevarme este cargo sino restituiros lo vuestro, pues lo puedo hazer. Y porque cuando yo la llevé prometí de no me quitar este vestido negro de encima, el cual siempre ha traído hasta tornároslo, agora, de oy más, no quiero más luto ni vestido de tristeza.

Y rasgose un ábito negro que llevava encima y quedó toda vestida de carmesí, y díxoles:

-Señores, bien veo que mi edad no quiere el vestido d'esta color, pero para tan alegre nueva como ésta, todo se sufre, y porque véais que tengo razón, sabé que yo soy Platina, a quien encomendaste que criase a vuestro hijo, el 
príncipe Lepolemo, el cual he criado con la ayuda de Dios. Y veislo aí, que se llama el Cavallero de la Cruz, tal que cualquiera lo querría por hijo. De oy más, soy fuera de la obligación de tornároslo. (Lepolemo, CXLV)

Han pasado varios años desde el extravío de Platina y Lepolemo, suceso en donde hay una relación de color-sentimiento que se conecta por causa de una situación de penalidad ocurrida en el pasado, en cuya desventura la dama se vio forzada a vestir de negro en representación de la tristeza por la pérdida del niño, pero, al reunirse nuevamente, la amargura se torna alegría, así como los paños negros en coloridos. El contraste de tonos es una forma para manifestar el estado de ánimo, por lo que el autor pasa del negro al carmesí como sinónimo de melancolía-regocijo.

\subsection{Valor monetario de prendas y joyas}

Una circunstancia poco recurrente en los libros de caballerías es que aparezca el valor monetario de los objetos, ya sea que se trate de muebles del palacio, ropas, joyas, comida, armas, etc., siempre aparece la expresión "de gran precio" sin que se especifique la cantidad. Muchas veces dirán "llevar los dineros para el pago", pero no se indica el tipo de moneda. Solamente en contados libros hay una marcada presencia del costo de las cosas, por ejemplo, de las joyas: "Y esa noche dio don Clarián a don Téstor un firmalle o joyel

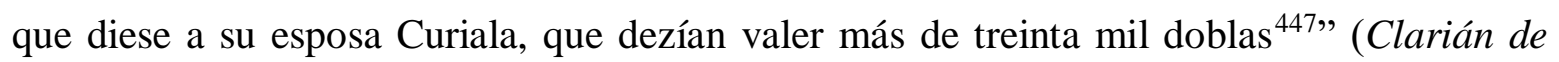
Landanís II, LXI). En esa época este tipo de joyas tenía un precio mayor al sueldo mensual de un barbero; ${ }^{448}$ sin embargo, se debe considerar un exceso ficticio de su valor en estos libros. En otros casos se indica el precio del atuendo: "E iba vien vestido e ricos paños de

\footnotetext{
${ }^{447} \mathrm{La}$ equivalencia monetaria de la época es la siguiente: 1 ducado $=375$ maravedís, 1 escudo $=400$ maravedís, 1 dobla= 800 maravedís, 1 real= 34 maravedís, 1 blanca= 1/2 maravedí. José Ángel Ortega Dato, "Los dineros en el Quijote", SUMA, 52, junio 2006, pp. 33-40.

${ }^{448}$ Ibid, p.34.
} 
jamete con peñas armiñas y llebava una guirnalda de oro con muchas piedras preciosas que valían más de setenta libras de esterlines" (Lanzarote del Lago, CCCXI). El caso de prendas con pieles presenta su valor que podía aumentar según las condiciones de este material y por los precios establecidos por la Ordenanzas de gremios, en este caso, el de los peleteros, lo mismo ocurría con las piezas de tela:

Al salyr de la barca dyxo al pescador que le avya prestado el gaván: "Hermano myo, sy querés my sayo por vuestro gaván, tomaldo".

El pescador dyxo: "Más vale vuestro sayo que veynte gavanes y yo no tengo dyneros que os dé syno estos dos ducados que nos distes; tomaldos y sy más tuvyera más os dyera" (La corónica de Adramón, II, XXVIII)

Carmen Bernis expresa que el gabán lo usaban pastores y labradores, aunque también los había de lujo ${ }^{449}$, en este es claro que se trata de un gabán de labrador debido al precio que sugiere el pescador, (fig.185) y como su oficio lo menciona, para trabajar en el agua no debía llevar una prenda lujosa.
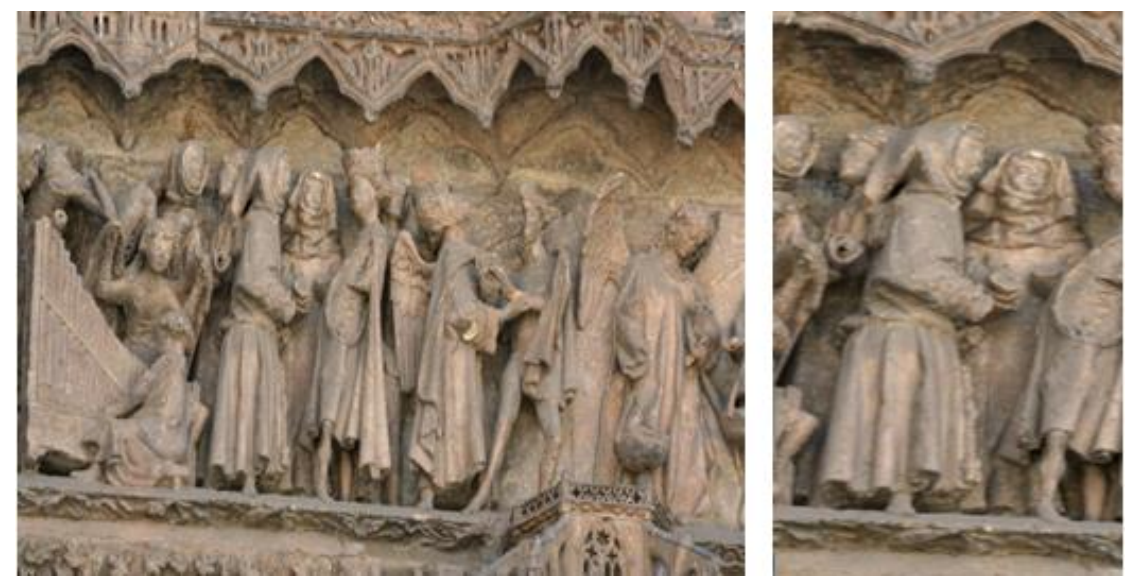

Fig. 185. El juicio final, Catedral de León. El gabán cubría la cabeza y los brazos.

${ }^{449}$ Carmen Bernis, Indumentaria medieval..., p.40. 
Los elementos de armas también alcanzan un gran valor monetario, principalmente cuando poseen cualidades mágicas:

La donzella dixo:

-Señor, el falcón tiene treinta e dos plumas en entrambas alas, en cada una dieziséis. Avéseme de dar vos o quien me lo comprare por la primera una meaja, e por la segunda dos, e por la tercera cuatro, e por la otra ocho, e por la quinta dieziséis, e así ha de ir creciendo el precio en cada una fasta cumplir a las treinta e dos. E por la espada me darán otro tanto quien la quisiere. Éste es el precio de las joyas: cómprelas quien las quisiere. E si este número no se pudiere cumplir, prométame de ir conmigo a entrar en la aventura de Cartilanda e yo se las daré entrambas pieças. (Clarián de Landanís II, LIII)

Dichos objetos merecen tal precio debido a las propiedades que poseen: "La espada tiene tal virtud que si el doncel que la trae diere con ella algún golpe, aunque sea a un hombre que esté armado todo en blanco, lo traçará por medio o henderá desde la cabeça hasta los pies. El falcón tiene tal propiedad que ninguna ave en el mundo, de cualquier calidad que sea, se le irá que no la mate. (Clarián de Landanís II, LIII)

Cuando se trata de la realización de objetos con tal arte, evidentemente habrá una estrategia de compra-venta, un interés por adquirirlo porque será mayor el beneficio que se reciba, en este caso, la protección cuando se combata, pero también la recuperación de un familiar perdido. Esto ocurre en el Clarián de Landanís, en la historia de Curiala, hija del rey Quirianda, que fue raptada por unos paganos y vendida a un mercader que al verla sintió compasión por ella. Este comerciante estaba casado, pero no tenían hijos, así que, al ver a la joven, pensó que podría ser como su hija. Aunque la quieren y es bien tratada, Curiala desea regresar con sus verdaderos padres, así que utiliza su ingenio y su capacidad con la aguja y el hilo para crea un medio de liberación: 
Y como fuesse donzella que sabía muy bien broslar e labrar dixo a su padre: $<<$ Si vos querés ganar muchos dineros, yo os labraré una pieça que no avrá precio que vos por ella pidáis que no os lo den>>.

>>El mercader le dio un gran pedaço de damasco blanco e mucho oro y sedas de colores, cuantas ella pidió, y labró un pendón, el más rico que en el mundo hallarse podía. Y en medio d'él hizo un escudo todo bordado de hilo de oro. Y en medio d'él, puso las armas del Rey, su padre, y en derredor del escudo figurada toda la historia de su cautividad y el lugar donde estava. Y por las letras escripto la casa donde estava y el nombre del mercader que la tenía. (Clarián de Landanís II, LVIII)

Lo que parece un ingenio de bordado se convierte en una estrategia de auxilio, cuya táctica de salvación consiste en el uso de la tela y el hilo para hablar a través del tejido; mediante letras e imágenes se formará una especie de mapa que guiará a los padres para hallar a su hija:

La Reina la miró e, como conoscía bien la obra que su hija hazía (que era señalada en el mundo), luego la conosció. E mirándola más e vista la historia que en el pendón venía historiada y leyendo las letras de enderredor, dixo: $<<$ Esta obra de mi hija es $>>$ " (Clarián de Landanís II, LVIII)

Cuando la madre expresa <<Esta obra de mi hija es $>>$ implícitamente alude a una de las características de los paños, la "señal de hilo conocida" ${ }^{450}$ la cual se trataba de una marca propia que el fabricante de telas y el bordador colocaban para identificar quién había realizado ese tejido. En este caso la forma del bordado y las letras son las marcas de identificación que permiten hallar a la doncella.

\footnotetext{
${ }^{450}$ Gonzalo Anes y Álvarez De Castrillón “Tejidos, corambre y leyes en la castilla del siglo XVI”, Anuario de Estudios Atlánticos, Núm. 50, 2004, p.457.
} 
Estos son algunos pasajes en los que se observa el valor monetario de ciertos accesorios que al comprarlos permiten el desarrollo de hazañas, que concluirán cuando el objeto llegue a la persona para la que fueron hechos.

\subsubsection{Joyas dedicadas}

La acumulación de objetos como símbolo de belleza ideal, tanto física como espiritual, se ha desarrollado con diferentes matices en cada una de estos libros, desde la aventura de la guirnalda en el Amadís de Gaula, la obtención del yelmo de diamante en el Lisuarte de Grecia hasta la guirnalda de rosas en el Primaleón, cada una presenta un mismo motivo, la obtención de un premio, pero con algunas variantes. En el Félix Magno esta joya tiene un diseño especial por los materiales de los que está hecha:

-Cavallero, tomá esta donzella de oro que así como en el mundo otra tal joya como ésta yo creo que no ay, así se ha hecho a semejança de la donzella que en su tiempo par no tendrá [...] La donzella de oro era del tamaño de una mano, tenía una corona de piedras sobre la cabeça que el valor d'ellas no tenía cuento y eran hechas por tal arte que dezían en arávigo el nombre de la donzella que Félix Magno avía de amar sobre todas las cosas del mundo [...] Tenía más cinco piedras en los pechos puestas en cruz, que cada una d'ellas era de muy gran valor y de tantas virtudes que sería largo de contar. (Félix Magno I, II)

La afortunada en recibir dicha joya será Leonorinda, hija del rey de Sirián de España. El motivo del nombre oculto de la dama amada aparece de diversas formas en numerosos libros, ya sea grabado en la piel del caballero, como ocurre con Esplandián y Leonorina, o a través de reliquias que el joven debe entregar en la 
propia mano de la dama, etc., todos ellos tienen en común la lengua extraña, que sólo será revelada hasta haber obtenido su amor. En el caso de Feliciano de Silva, este tipo de hazañas se construye a través de la guirnalda de la duquesa Silverna, el yelmo de Lisuarte, la espada de Amadís, el joyel de Arquisidea, entre otros, preseas que se otorgan a la pareja destinada por la fuerza de su amor.

Pero, sin duda alguna, estas joyas y accesorios adquieren notoriedad en la aventura de la Gran Tienda, en donde los caballeros deben defender la belleza de su señora, quien gane debe colocar una joya de tan gran valor como su dama. El caballero que mantiene la defensa es el rey de Dinamarca y de Normandía, cuyo objetivo es ganar la aceptación de Leonorinda, por ello coloca en la tienda una guirnalda de flores de oro y de piedras preciosas; sin embrago, es vencido por Félix Magno, quien en honor de su dama coloca la figura de oro de la doncella. El vencedor debe entregar estas dos preseas a la ganadora en belleza.

Pero, una posible rivalidad aparece entre dos joyas femeninas; por un lado, la figura de la Dama de Oro que la infanta Califa dio a Félix Magno como reliquia de amor de Leonorinda; por el otro, "un collar muy rico en que avía muchas perlas y piedras de gran valor. Entre las cuales avía una piedra que era mayor que todas las otras. La propiedad de la cual era contra el mal del coraçón, el cual mal muchas vezes a esta donzella traía al punto de la muerte" (Félix Magno II, XC), obsequio dado por la misma infanta Califa a Armandia, confidente de Leonorinda, situación que genera un breve momento de rivalidad entre las damas por saber quién conserva la mejor presea y que, sin duda, como ocurre en todos los libros, la protagonista gana este honor. 
En otro momento de la historia aparece otra alhaja, se trata de un tocado de perlas que al momento de ser destinado para la aventura genera dudas en la doncella: "El rey le dixo a la infanta que diese a Tardamar una joya y ella por hazer el mandado del rey, aunque contra su voluntad, le dio un tocado de muchas perlas y piedras de gran valor, el cual Tardamar tomó y le puso contra la joya del jayán” (Félix Magno III, LXXXIX). Clarinea, la dama cuyas joyas están en juego, se aflige por la derrota de Tardamar y muchos otros caballeros que tratan de defender su belleza ante el jayán; sin embargo, debe aguardar la llegada de Félix Magno para que éste sea el vencedor en este combate de bellezas. Para ello, la joven le da "un collar de oro muy rico de muchas piedras e perlas de gran valor" (Félix Magno III, $\mathrm{XC}$ ), como prenda para participar en tal enfrentamiento. Asombrados, se mara villan de la rapidez con la que vence al jayán y recupera todas las joyas de Clarinea. El lector curioso podrá identificar la inmensa cantidad de joyas que las damas poseían en su joyero personal, debido a que, ante cada intención de defender su belleza, ella debía preparar una nueva reliquia, ya fuera un accesorio para el cabello, las manos o el cuello o una presea que tuviera algún componente mágico. Sin importar cuál fuera, debía permanecer un motivo relevante y es la superación de precio y diseño tras cada premio, pues ante cada entrega ésta debía ser más asombrosa que la anterior.

En dichos combates, la dama se desprende de sus joyas como accesorios de gala para convertirlos en joyas de paso, por la incertidumbre de si regresarán a su poder como garantías de superioridad en la belleza o quedarán en poder de las demás damas defendidas, por ello la necesidad de que no solo la joven estimule al caballero 
para ganar, sino también la alhaja, puesto que en muchas ocasiones es el propio combatiente quien se asombra por dicho premio.

\subsection{La vestimenta como generadora de males}

En los capítulos anteriores la vestimenta ha destacado por los elaborados detalles con los que se confecciona; asimismo, por ser un canal de comunicación entre los enamorados; también por resguardar la identidad de quien la porta y por ser un elemento de distinción entre las clases sociales. Todos estos aspectos demuestran el lado positivo de la indumentaria; sin embargo, dentro de las páginas de estos libros aparecen singulares momentos en los que el atuendo es incómodo por su diseño, ruidoso por los materiales con los que está hecho, estorboso por la amplitud de tela que requiere e incluso indecoroso por la delgadez del tejido, rasgos que en ciertos momentos la convierten en generadora de males.

\subsubsection{Prendas ruidosas}

En algunos pasajes caballerescos hay una necesidad de hacer el menor ruido dentro y fuera de la corte, ya sea para ir al encuentro con la dama, para no ser descubierto por el enemigo o porque se desea dejar el reino para ir en busca de aventuras. Sin que nadie lo perciba, los personajes usan su ingenio para salir sin ser descubiertos, pero en algunos momentos son ellos mismos quienes se delatan por el sonido de sus prendas: "Floriano, que ya en aquellos días no traía la condición tan enamorada, por no oír pasiones agenas tornóse a venir por donde viniera con Targiana, mas al tiempo de levantar el Caballero de los Fresnos sintió el ruido de la seda que traía vestida, e porque no le viesse el rostro, primero que <se> levantasse los ojos enlazó el yelmo" (Palmerín de Inglaterra, LXXXVII). Un leve 
movimiento de la tela obliga al caballero a cubrir su rostro por temor a revelar su identidad. Como este, son pocos los ejemplos en los que el tejido delata la presencia de un personaje.

\subsubsection{Prendas asfixiantes}

Una situación incómoda para la época es la falta de aire en el cuerpo a causa de las múltiples prendas que se llevan. Como se observa en el primer capítulo, la conformación del traje renacentista requería entre cuatro a cinco bloques de piezas que se colocaban una tras otra, además los diferentes tipos de tela y la combinación de materiales como la piel, el metal y el forro incrementaban considerablemente el peso de la vestimenta, lo cual duplicaba la sensación de calor por toda la piel.

Así que, la forma más fácil para disminuir este malestar es despojarse de varias capas de ropa y permanecer en las más allegadas al cuerpo, entre las interiores y las semiinteriores, tal como se observa en Florisel de Niquea I: "al tiempo que don Florisel y Darinel, como solían para acostar, se apartaron no podiendo suffrir el calor grande porque era en aquel mes en que el sol los fuegos de amor mayor lo tienen, Silvia se desnudó una ropa de seda de la forma pastoril que sobre otra traía" (Florisel de Niquea I, XII), y se recuesta en la hierba hasta quedarse dormida. La sensación de calor también es producida por el modo de confección de la prenda: "que porque haze algún calor, dixo el, y las garnachas os darán mucho peso, para caminar a pie, que las desnudeys" (Florisel de Niquea $I V$, II, XX). Como se recordará, la garnacha era un sobretodo con mangas largas y amplias.

La misma situación se halla en el ciclo del Espejo de príncipes y caballeros: "Y ansi como entro vio que a la una parte de los corredores estava una compañía de donzellas muy hermosas todas en faldillas, (fig. 186) y vestidas de muy delgadas ropas de seda con los pechos descubiertos tan blancos como la nieve, como si estuvieran aquexadas del calor” 
(Espeio de príncipes y cavalleros I, I, XLIV). Para aliviar este malestar ocasionado por la naturaleza, se emplearán las prendas adecuadas para cada estación; sobre esto, Carmen Bernis expresa que "en verano se llevaban ropas menos abrigadas, pero como el forro era imprescindible se empleaba tela en vez de piel”451 y curiosamente una prenda de este tipo aparece en la Tercera parte del Espejo de príncipes y cavalleros: "No tardaron que en recogiéndose la gente, con ropillas de verano baxaron al vergel, tornando a cerrar a puerta. Llevava Venus una ropa de Damasco con muchos torçales de oro, encima sola del rofajo, que de raso pardo era, con muchos pasamanos de oro" (Espejo de príncipes y cavalleros III, II, XXIV). La ropilla, una especie de chaqueta corta y el refajo, una falda corta que va encima de la ropa interior, son las únicas piezas que usan para aminorar la temperatura. Incluso hay referencias directas a la estación en que se usan: “y él traía una capa de verano d'escarlata enforrada en sendal" (Lanzarote del Lago, V). Se debe recordar que el cendal era una tela delgada, adecuada para los momentos de calor y que se empleaba en la fabricación de varias prendas. (fig. 187)

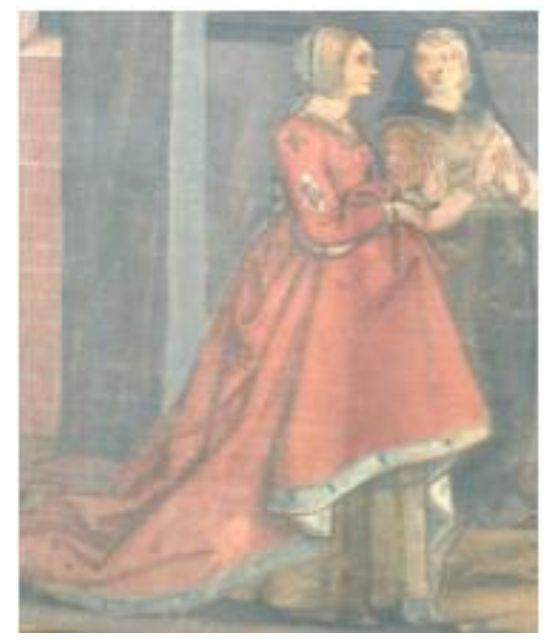

Fig. 186. Retablo de la Capilla de Santa Catalina, Catedral de Toledo.

La dama deja ver debajo de su saya una faldilla, prenda que sólo llevaban en época de calor debido a que la tela era más delgada y brindaba frescura.

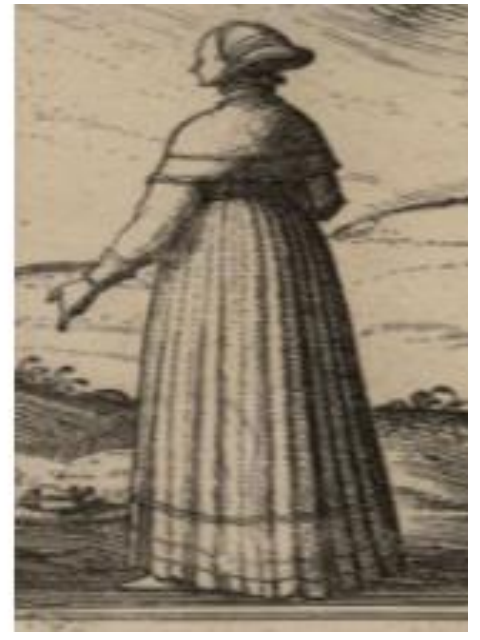

Fig. 187. Civitates orbis terrarum. Liber primus (1588) Georg Braun

La dama lleva una capa corta que sólo le cubre los hombros.

${ }^{451}$ Carmen Bernis, Indumentaria medieval española, p. 76. 
Las plumas son otro accesorio para quitar el calor: "vestidas de ropas de oro, con guirnaldas de mucha<s> pedrería sobre sus hermosos cabellos. Todas traían en sus manos, por el calor, plumas tan albas como nieve, con que davan aire a sí y a su hermosura" (Florisel de Niquea I, XXII), éstas confromaban los ventalles, los cuales junto a los abanicos se prendían de la falda por medio de la cinta de caderas. (fig. 188)

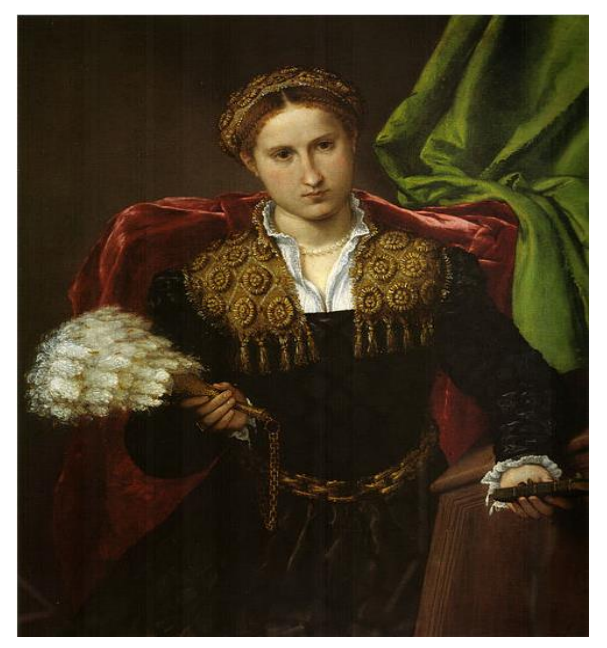

Fig. 188. Retrato de Laura de Pola (1543) Lorenzo Lotto, Pinacoteca de Brera, Milán.

El ventalle va sujetado con una cadena a la cinta de caderas.

La misma afectación del clima les ocurre a los caballeros, quienes en su traje de armas les es más complicado conciliar la brisa del aire por lo pesado del metal, por lo que deben desarmarse la parte del cuerpo que desean refrescar, desde la cabeza: "Porque como hiziesse gran calor llevava quitado el yelmo, puesto en la cabeça un chapeo de seda" (Espejo de príncipes y cavalleros I, I, XXXVII); hasta las manos: "hallaron a la puerta d'ella sentada a la mala de Falerina y junto con ella, en una silla, don Renaldos de Montalván, sin yelmo y las manos desarmadas, por gozar del aire que corría" (Libro segundo de espejo de caballerías, XXXIII). A comparación de las damas, los caballeros padecen más las altas temperaturas por la condición de su traje, dos bloques de tela y una de metal, situación que en algunas veces es desfavorable para su desarrollo guerrero. 


\subsubsection{Prendas travadas}

En ciertos momentos el diseño de la vestimenta se vuelve en contra de las necesidades del personaje, por ejemplo, al caminar: "Pero era la escalera tan angosta, que sola una persona podía subir por ella. Quitaron los chapines para hacerlo mejor, y començo Venus a subir temblando, y Fausta, que aunque yva travada de la manga de la ropa, no podía dar passo" (Espeio de príncipes y cavalleros III, II, XXIV). Como se observa en las figuras 189 y 190 el grosor de la suela del chapín dificultaba caminar y subir, incluso correr era una acción complicada de realizar.

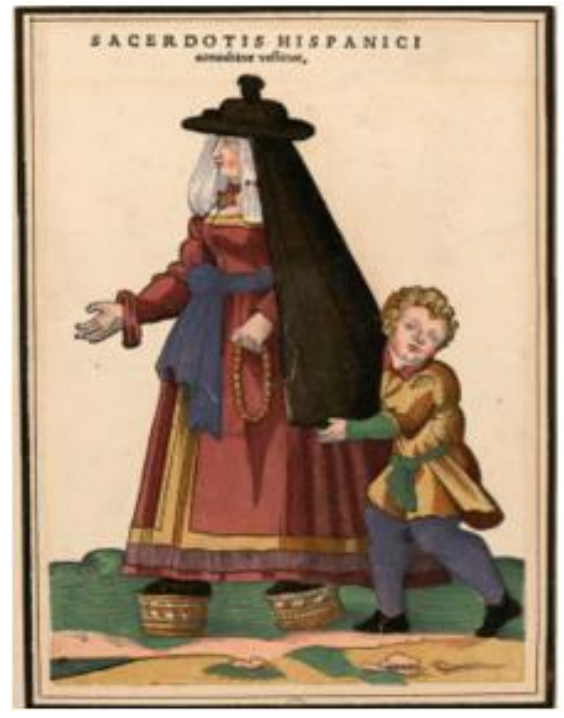

Fig. 189. Ensemble de gravures de costumes espagnols du XVIe siècle (fol. 130), (h.1600). Roger de Gaignières

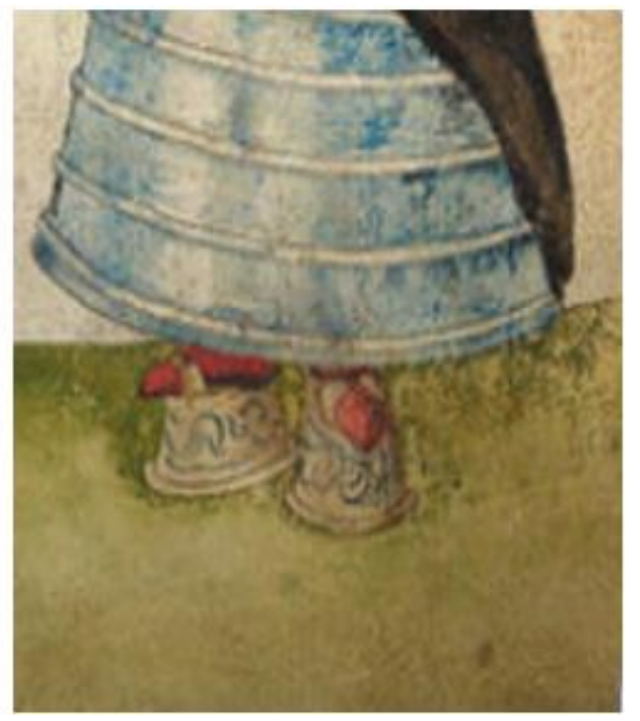

Fig. 190. Chapines (detalle) Códice de trajes, BNE, 1529.

En cuanto a las extremidades superiores, también presentan problemas por la tela que las cubre: "No le pudo alargar tanto, que al fin no la alcançasse y travandola de una delgada manga que llevaba" (Espeio de príncipes y cavalleros I, III, IV). Las mangas son objeto de alcance debido a lo largo y amplio de la tela, por lo que en repetidas ocasiones se hallarán ejemplos en los que los personajes son alcanzados por la manga y trabados por estos extremos. 


\subsubsection{Prendas voluminosas y pesadas}

Uno de los pasajes más curiosos se halla en la primera parte del Espejo de príncipes y caballeros, cuando el Donzel del Febo y su ama van a un río para jugar; el pequeño, inquieto por entrar al agua, se aleja en un barquito hasta desaparecer, lo que provoca la desesperación y angustia de la nana, pues teme revelar lo sucedido a la reina. Este miedo la lleva a intentar ahogarse, por lo que se avienta al río, pero surge un obstáculo para realizar dicho deseo: "con acelerada corrida se lanço en el rio todo lo demás que pudo con voluntad de se ahogar, lo qual ella hiziera, sino que las faldas largas que llevava la tuvieron en peso, hasta quel hortelano que a los gritos era ya llegado, entro por ella, y la saco a tierra toda mojada y sangrienta de los muchos golpes quella mesma en el rostro se avía dado" (Espejo de príncipes y caballeros I, XV).

Como se observa, la amplitud de la falda se convierte en un obstáculo para sumergirse, en principio por la cantidad de prendas que solían llevar: ropas de encima, de debajo e interiores; aunado a eso el tipo de tela: tafetán, terciopelo, seda, raso, etc. Pero sobretodo, la cantidad de adornos que llevaban: perlas, joyas, piezas metálicas, etc., las cuales dificultaban el doblez del tejido. Lo más importante es que desde el siglo XV se usaban los verdugos (figs. 191), cuyos aros daban la rigidez y estructura a la falda, los cuales funcionaban a modo de salvavidas (fig. 192). 


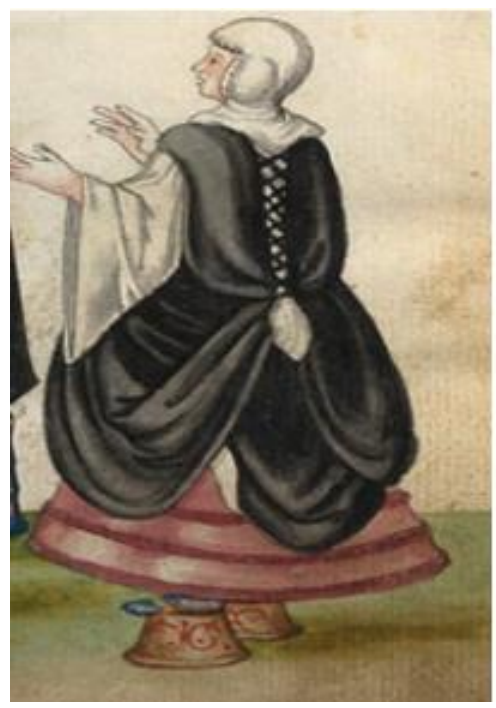

Fig.191. Códice de trajes, BNE, 1529. Verdugo con chapines

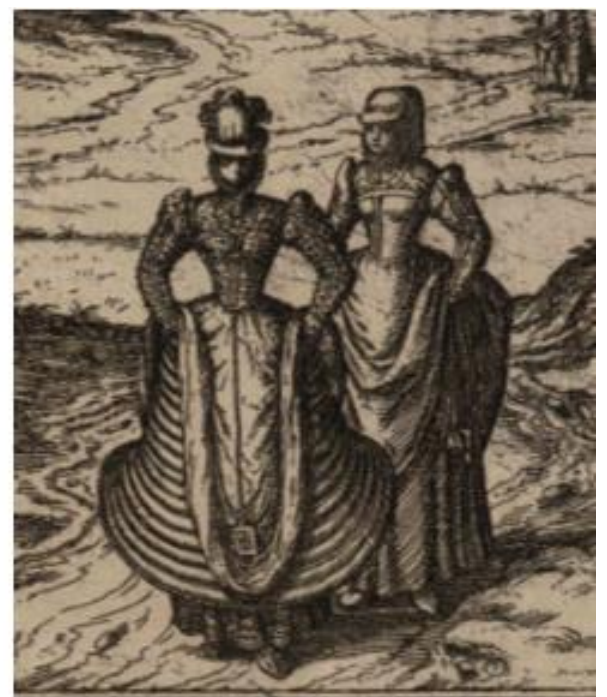

Fig.192. Civitates orbis terrarum. Liber primus (1588) Dama con verdugo. Nótese la composición de los aros a manera de estructura rígida que de acuerdo con su forma dificulta hundirse en el agua.

Estas son algunas de las posibles causas, en cuanto a la estructura de la prenda para que el ama flote; sin embargo, otra probable respuesta para esta situación se debe a que, de acuerdo con los tratados de natación de la época, para nadar bien y sumergirse en el agua la persona se debía quitar toda la ropa, ${ }^{452}$ tal como se observa en la imagen (fig. 193 y detalle) cuyo personaje sentado en el pasto está en proceso de quitarse todas sus prendas.
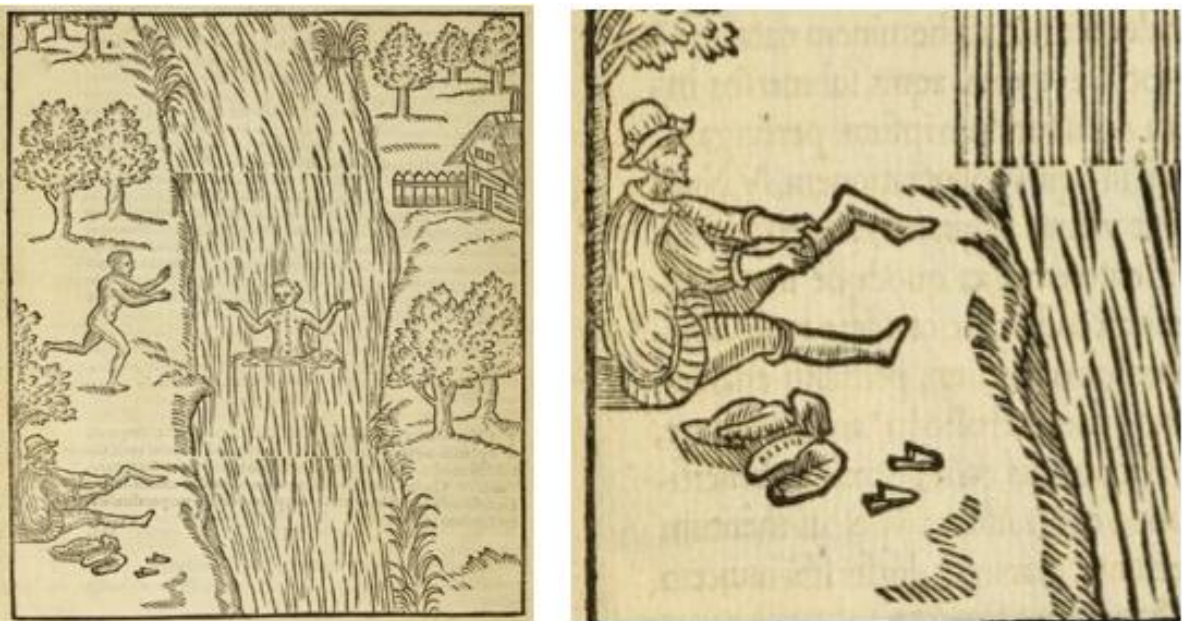

Fig. 193. Everard Digby, De arte natandi libri duo, quorum prior regulas ipsius artis, posterior vero praxin demonstrationemque continet, 1587.

${ }^{452}$ Everard Digby, De arte natandi libri duo, quorum prior regulas ipsius artis, posterior vero praxin demonstrationemque continet, Londini, Excudebat Thomas Dawson, 1587. 
Esta situación, de la vestimenta como tropiezo, ya sea por la forma del diseño o el peso de la misma, es más común hallarla en torno a la armadura, no sólo por el ruido que ocasiona al caminar, sino también porque ésta sí facilita el hundimiento: "Los cuales todos de una finestra del castillo en el lago fueron lançados, que con el peso de las armas luego fueron al suelo" (Florisel de Niquea I, II). Además, el material de las armas puede generar dudas por su peso: "mas para pasar de la otra parte no podía si no era a nado por el largo que ya se dixo, e porque lo sabía mal hazer recelava el passo de la otra parte [...] e que allende de todo el peso de las armas le podrían ahogar, aquí fue puesto en tan gran confusión que ni su esfuerço bastava para cometer tan gran cosa, ni su ingenio para aconsejarle, de manera que de todos los remedios carecía" (Palmerín de Inglaterra, XCIX), el temor de Palmerín es en vano, puesto que la providencia lo ayuda a pasar sin ninguna complicación. Algo similar ocurre en el libro segundo del Clarián de Landanís, en donde durante una pelea en mar los caballeros deben saltar a una zambroa; sin embargo, Leonistán no lograr llegar porque: "se le fueron los pies e cayó en la mar, mas teniéndose a una cuerda tornó a subir en la zambroa" (Clarián de Landanís II, III). Acto seguido se quita la armadura: "Leonistán se desarmó para mudarse otros paños, que los que tenía estavan muy mojados, porque cuando cayó hasta los pechos se metiera" (Clarián de Landanís II, III). La ayuda también puede provenir de su propio caballo: “e firió al cavallo de las espuelas e lançóse en el agua, e el caballo començó de nadar luego e perdió tierra en tal manera que pasó de la otra parte del agua, mas ante bevió el cavallo del agua e si el caballo tan bueno no fuera sin dubda él moriera en el agua, e Boores por el peso de las armas que llevaba" (Lanzarote del Lago, CLI). Nuevamente la presencia de un elemento de salvación otorga estabilidad a los 
caballeros, quienes sin duda alguna se hundirían en el agua por el peso de las armas. (fig. 194)

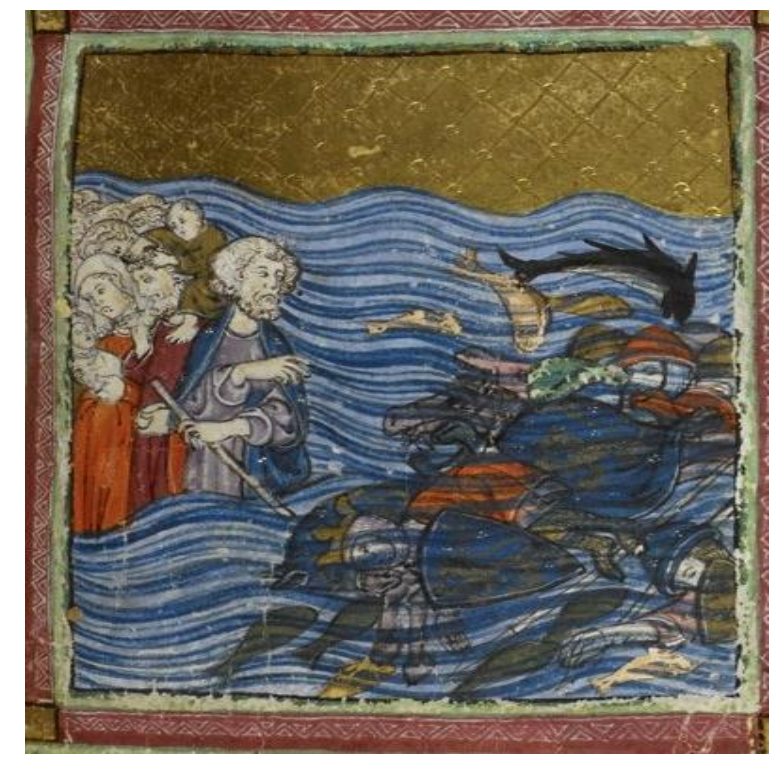

Fig. 194. Escenas del Éxodo (fol. 14v.) 1320, Biblioteca Nacional de Israel.

\subsection{Prendas para ocultar la preñez}

En el Libro segundo de Espejo de Caballerías aparece un personaje singular en comportamiento y hazañas por la forma de desenvolverse en los sucesos bélicos y el uso de prendas que porta en ellos, se trata de madama Brandamonte, esposa de Rugiero y futura madre de Rugerín. Su vida transcurre entre el amor y la batalla, pues se trata de una virgo bellatrix que junto a su esposa va en busca de aventuras. Pero a diferencia de las tradicionales guerras que portan su armadura, con ella se presenta un nuevo prototipo de dama bélica, una guerrera preñada, que oculta en primera instancia su embarazo para seguir en el combate, pero que conforme avanza el tiempo debe modificar su armadura a fin de moldear su vientre en ella.

Durante el primer contacto entre Bradamonte con su armadura y el exterior se encuentra la dama Marfisa, otra dama guerrera cuya primera impresión al verla es 
la de una corpulenta y bella dama que en cada enfrentamiento obtiene la victoria, motivo por el que es admirada por sus compañeros, quienes, en cierto momento, se impresionan al descubrir su embarazo:

Luego, todos asentados sobre la yerva, comieron de buenos manjares que allí avía traído Malgesí y bevieron de muy buen vino. Mas la linda Bradamonte, que otra novedad en sí sentía de lo que hasta que fue dueña monstrava, no podía comer, y aunque se esforçava a disimularlo, no podía, que la mudança de la color de su hermosa cara y el desabrimiento de su comida dava testimonio de su lavor [...] Luego allí vieron todos por lo que lo dezía Malgesí, que no era muy dificultoso de conocer, ca ya estaba en término de cuatro meses la preñez de la linda Bradamonte. Y ella, avergonçada de se ver así motejar con la verdad, de gran vergüersa no respondía palabra alguna, de lo cual todos avían gran plazer. Y el buen Renaldos dixo:

-Cómo, señora hermana, ¿y tan poco os valieron las fuertes armas que traés, que no os escusaron de ser ferida de llaga que tantos desmayos os causa? Plega a Dios que no sea mortal. (Libro segundo de Espejo de Caballerías, VIII $)^{453}$

En primera instancia nótese su negativa a comer y a beber vino. Enseguida, el asombro de los personajes por su habilidad para combatir a pesar de su estado y finalmente el modo en cómo la armadura oculta el embarazo. Esta inserción de un tipo de armadura especial es inusual en este género, debido a que generalmente las damas que desean ocultar su condición de preñez se aíslan hasta que nazca el niño, pero Brandamonte, deseosa de la aventura, se arriesga a combatir en dicho estado. Sin embargo, este gusto por las armas es interrumpido por su propia condición, debido a que "madama Brandamonte también se quisiera armar, salvo que el peso de su preñez no se lo consentía porque ya entrava en el séptimo mes" (Libro segundo

\footnotetext{
${ }^{453}$ Pedro López de Santa Catalina, Libro segundo de Espejo de Caballerías, ed. de Juan Carlos Pantoja
} Rivero, Alcalá de Henares, Centro de Estudios Cervantinos, 2009. 
de Espejo de Caballerías, XIII) (figs. 195, 196). Dos obstáculos se interponen entre la dama y las armas; el peso y la adecuación de las armas. El primero referente a su condición de gestación, el segundo, al aumento del vientre y a la forma que adopta durante el embarazo. Esto complica la adecuación del metal a su cuerpo y en consecuencia su falta de protección desde el pecho hasta la cintura.

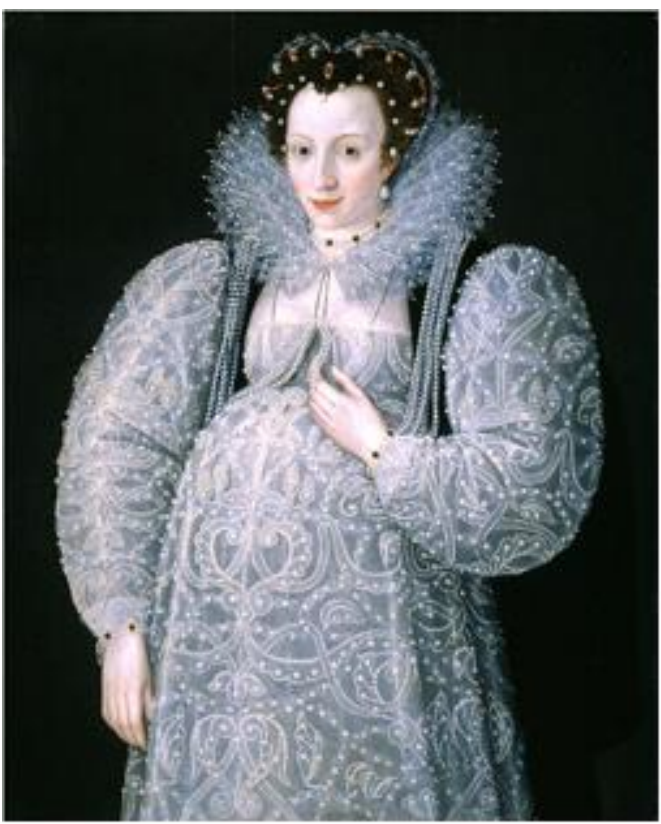

Fig. 195. Retrato de una dama desconocida (1595) Marcus Gheeraerts el Joven, Colección Tate Britain, Londres.

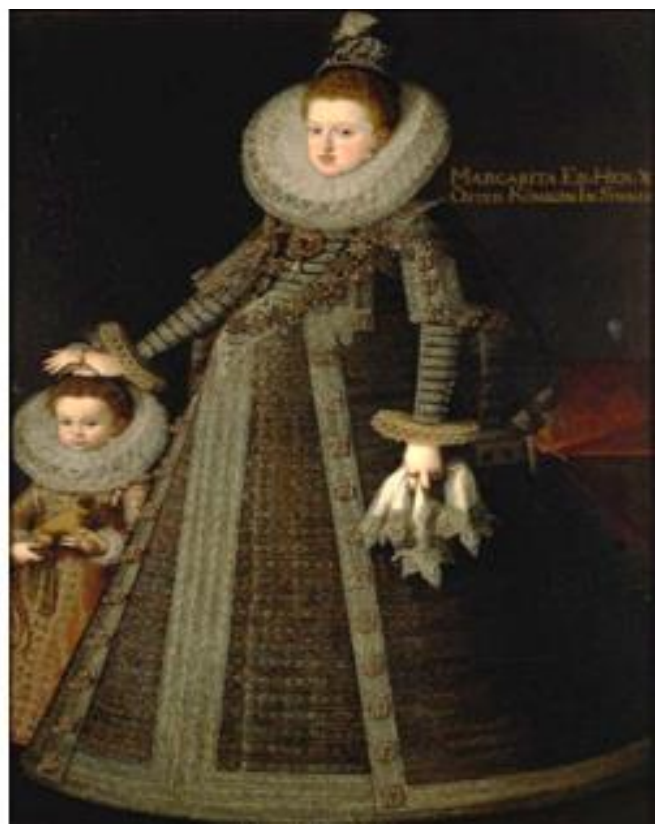

Fig. 196. Retrato de Margarita de Austria embarazada (1601-1603) Bartolomé González.

La dama no puede combatir contra su propia naturaleza femenina, por un lado, bélica, por el otro maternal, que la obliga a desistir de la primera, por amor y conservación de su hijo como único recuerdo de su esposo Rugiero, quien muere en un combate. Así que Brandamonte se resigna a dejar las armas para proteger a su único hijo.

En estos ejemplos, el material presenta una dualidad significativa durante el desarrollo de las hazañas; por una parte, el peso del metal facilita la sumersión; por la otra, la ligereza de la tela ocasiona el flotamiento. Aunado a estos sobresalen otras dos 
características como resultado de las primeras, el grosor y la largura, éstas, a pesar de pertenecer a piezas de los extremos, también complican el desarrollo de la trama, sobre todo por aparecer en momentos donde la rapidez es necesaria para escapar de la escena. Por lo que de acuerdo con el tipo de material que se porte, será la condición del desarrollo de la hazaña, en situaciones de emergencia en donde la rapidez y la ligereza sean lo fundamental para culminar la aventura.

\subsection{Ropa vejatoria}

Ya desde la Edad Media, a los pecadores, por cualquier motivo: robo, asesinato, lujuria, traición, etc., se les colocaba un atuendo, color, marca o señal para distinguirlos entre la comunidad y que ésta conociera que había hecho algo malo. Esta misma situación se presenta en algunos libros de caballerías. En el Morgante se describen los accesorios que debía usar el malhechor:

Mas el traidor, por más vituperar al Señor de Inglaterra, le avía hecho sobir e atar sobre un carro muy alto con una corona en la cabeça y un jubón de brocado, como es costumbre de sentenciar a los traidores y assimesmo le avía hecho poner un cabestro dorado como a famoso ladrón, todo lo cual era peor que la muerte al esforçado paladín (Morgante I, XXXIX)

Tres elementos sobresalen, una corona, un jubón de brocado y un cabestro dorado. Es curioso que se indiquen estos tres accesorios como traje para los traidores, ya que de acuerdo a las leyes de la Corona de Castilla para los sentenciados a muerte "quienes deseaban vestirse de luto, se les consentía. La Hermandad, por el contrario, les obligaba a llevar un hábito verde típico, y la Inquisición le cubría con los célebres sambenitos"454 (fig.

\footnotetext{
${ }^{454}$ José Luis de las Heras Santos, La justicia penal de los Austrias en la Corona de Castilla, Salamanca,
} Universidad de Salamanca, 1994, p. 319. 
197). Este episodio permite que el lector conozca el atuendo referido a través de una xilografía que se reproduce de la edición de 1533, (fig. 198) en la cual se observa a Estolfo, quien es el caballero sentenciado a muerte, vestido con jubón, botas, calzas, tiene las manos atadas y una venda en los ojos, no lleva el cabestro ni la corona que antes se menciona; además, el jubón pareciera llevar unas cuantas aplicaciones circulares.

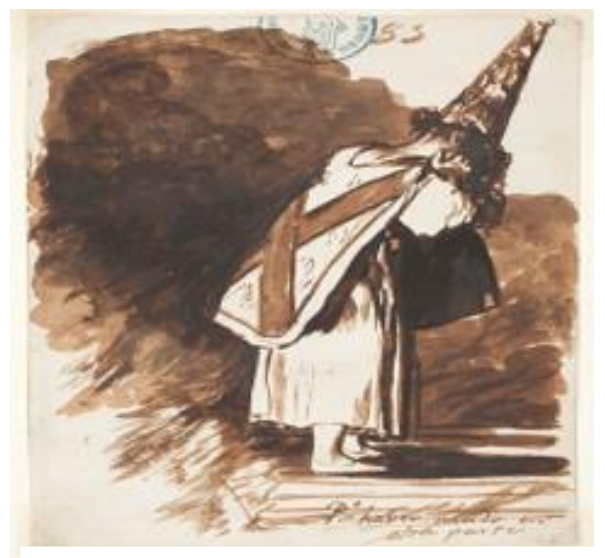

Fig. 197. Condenado por la Inquisición vestido con un sambenito que lleva la cruz de San Andrés Francisco (1810-1811) Goya

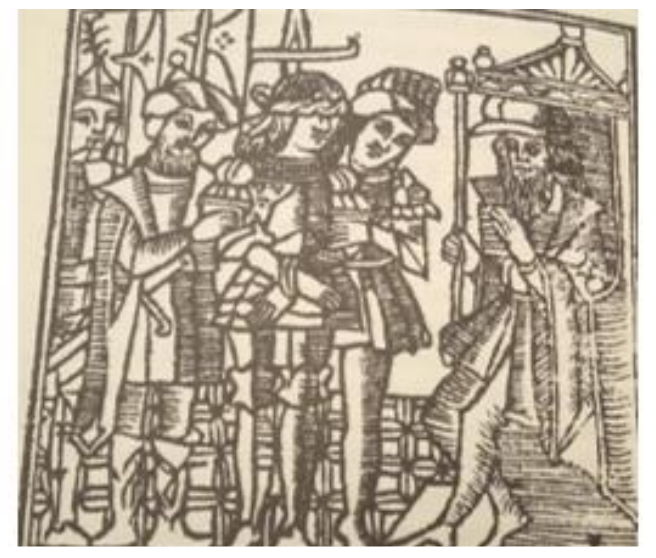

Fig. 198. Morgante (1533)

Estolfo es sentenciado a muerte

La dificultad que presenta este ejemplo es que el mismo grabado aparece en capítulos anteriores durante una justa entre Matafellón y Berenguel, este último también encarcelado por supuestamente perder en la justa; sin embargo, en ninguno de los dos casos hay una repercusión entre los inculpados, ya que son defendidos por otros caballeros y es demostrada su inocencia.

\subsection{Ropas para difuntos}

Un tipo de vestimenta que aparece en todos los libros de caballerías es la de luto, ya sea por la muerte de un personaje, un encantamiento, el extravío de niños o un casamiento forzado, todas estas situaciones se relacionan por el color de que usan, el negro como símbolo de tristeza y como un medio para transmitir el llanto; sin embargo, son pocos los pasajes que 
relatan con qué ropa fue enterrado el personaje. Sobre esto, en el Arderique se descubre la tumba de un santo:

Continuaron siempre en cavar hasta que de aquella huesa sacaron un cuerpo muerto con gran reverencia y acatamiento. Vestido con ropas de buriel, estava cubierto con un manto pardillo, de manera que de su persona no se mostrava cosa ninguna, sino sólo las manos y los pies. E tenía en la mano una carta cogida [...] y, antes de leerla, desnudóle la cara, que tenía tan fresca y colorada como si fuera hombre bivo. E parescía la ropa que vestía que nunca oviesse estado debaxo de la tierra. Y era hombre muy viejo, y tanto que todos los cabellos tenía blancos como la nieve y la barba muy larga y cana. (Arderique, I, VI)

El buen estado de conservación del personaje permite identificar el tipo de telas que lo cubren, una ropa de buriel y un manto pardillo. Se recordará que la ropa consistía en un sobretodo, con mangas y en ocasiones forrada de piel, en este ejemplo está confeccionado con el buriel, una especie de paño pardo como la lana, ${ }^{455}$ adecuado para las labores rústicas. Además, se complementa con un manto pardillo; según Carmen Bernis, el uso de mantos para los hombres era casi una prenda para ceremonias, ${ }^{456}$ característica que tiene conexión en este episodio, al tratarse de una cortejo fúnebre de un religioso, ya que se enterraba con su traje, el cual incluía un manto semicircular con capuchón. ${ }^{457}$ Los monarcas también eran enterrados con sus mantos, joyas y algunos otros accesorios que establecían antes de morir (figs. 199, 200 y detalle), como una forma de reconocimiento en el futuro; esta identificación no sólo consiste en conocer a la persona a través de las reliquias, su nombre, estado y condición social, sino también su sexo, principalmente cuando se les cortaban las cabezas: "[el Cavallero del Febo] vio que estavan cuatro cuerpos muertos, los cuales tenían

\footnotetext{
455 María del Carmen Martínez Meléndez, op.cit., p.57.

456 Carmen Bernis, Indumentaria española en tiempos de Carlos V..., p.97.

457 Ana María Ágreda Pino, "Indumentaria religiosa", Emblemata, 17 (2011), p.118.
} 
quitadas la cabeças, que según los vestidos que tenían, los dos eran de mujeres y los dos de cavalleros" (Espejo de príncipes y cavalleros II, V).
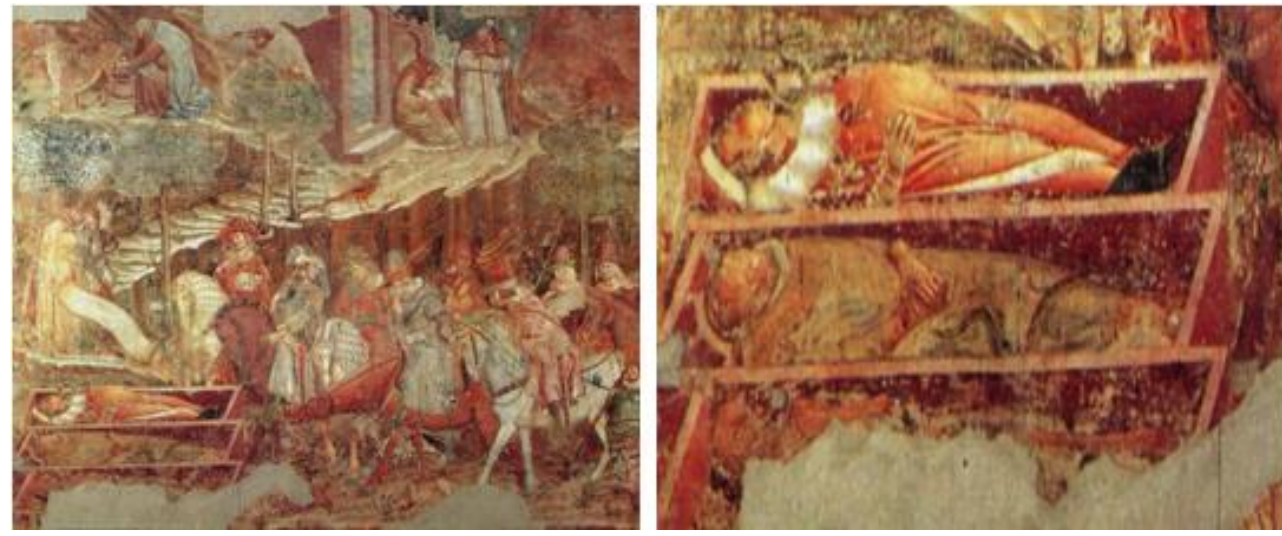

Fig. 199. El triunfo de la muerte (1355) Camposanto de Pisa

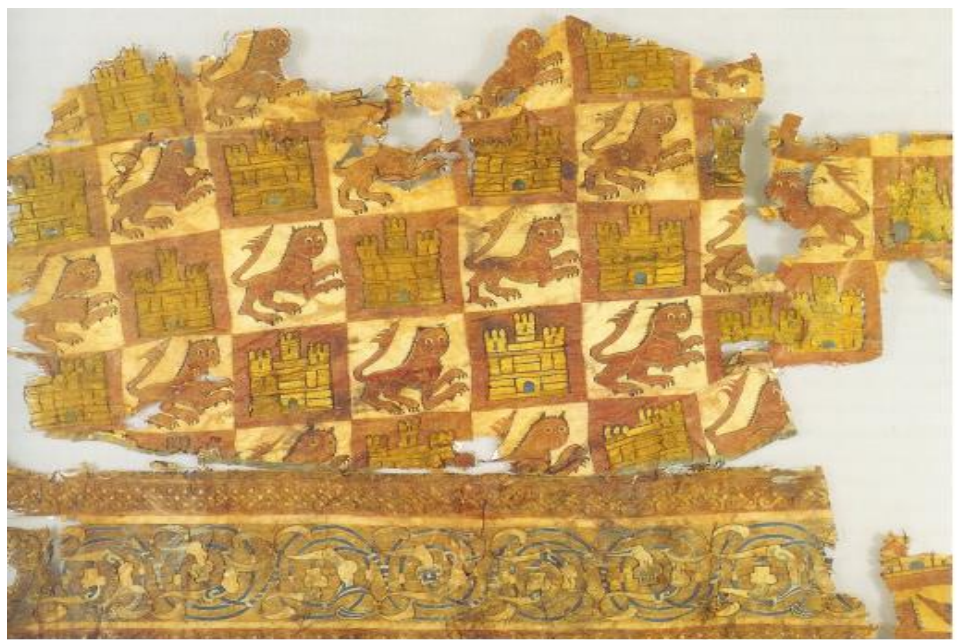

Fig. 200. Fragmento del manto de Fernando III procedente del sepulcro del rey en la catedral de Sevilla, Armería del Palacio Real, Madrid.

Necesariamente la identificación se da por las clases de prendas: faldas para las damas, calzas para los varones y aunque pareciera obvia esta distinción habría un problema en las prendas de arriba, ya que, al estar envueltos en mantos, se complicaría conocerlos por la parte del torso, sin retirar dicho manto ni observar sus brazos y piernas, a menos de que exista un sentido intuitivo por la vista: "Que en lo cierto, aunque viene cubierto el rostro, su 
cuerpo me dize ser el de mi hijo" (Floriseo, II, LI), en este caso, la fuerza de la sangre es la que permite reconocer la fisionomía del infante.

Para los caballeros muertos también hay un modo de preparación para su entierro, éste se describe en el proceso funerario de Galeote: "Lançarote mesmo puso dentro el cuerpo de Galeote, armado de todas armas así como hera costumbre, e cubriólo con un muy rico paño obrado de oro e piedras preciosas" (Lanzarote del Lago, CLII). El entierro de los caballeros conlleva la utilización de tejidos lujosos acorde a su condición y de la colocación de sus armas, tanto en su interior como en la lápida, tal como se observa en algunas tumbas de reyes para ser recordados aún después de muertos.

\subsection{Enredos en el vestir}

Un aspecto en el vestir puede tener su lado cómico al ser generadora de males, regaños y situaciones vergonzosas cuando se confunden las prendas, lo cual puede ocasionar que se delate una relación sentimental, lo cual se plantea en el Morgante a manera de enseñanza didáctica para los caballeros:

Que no querría que hos aconteciesse a vós como a la abadesa de uno de nuestros monasterios, la cual sintiendo gran ruido entre sus religiosas y queriendo ver lo que sería, por se poner la cofia se puso las pañetes o bragas del confesor en la cabeça, las cuales tenia a la cabeça y saliendo a ver lo que era, le fue dicho como una monja avía sido hallada con un enamorado suyo. E como la abadessa mucho por ello la reprehendiesse, la monja le dezía: <<Madre, adobaos la cofia >>. <<Cómo metistes el hombre en casa me dezí>> -dezía el abadessa-. 〈<Dexa el tocado〉>, la monja le tornava a responder: $<<$ Madre, adobaos la toca $>>$. E como el abadessa pusiese la mano a la cabeça halló que se avía puesto las bragas del fraile con quien dormía. Y hubo de callar cada una con la suya. Y de allí adelante no curó más de reprehender a sus monjas. (Morgante I, LXII) 
Pero también la comicidad se produce por estar desnudo frente a los caballeros:

halláronse desnudas encima del prado, d'ellas con camisas, d'ellas sin ella, como cada una se avía acostado y sus vestidos junto con ellas. [...] y como alçaron los ojos y vieron a las ventanas a sus señores, ovieron tan grande empacho que a[r]rebataron sus ropas y fuéronse huyendo a poner entre matas, donde se vistieron, y después no osavan salir de vergüença, pero como supieron que no las avían visto sino sólo sus señores, no lo tuvieron en nada. (Lepolemo, CXLVII)

Las damas pasan por un momento de vergüenza que las obliga correr desnudas hacia las matas. Su única opción es vestirse con rapidez entre los arbustos.

\subsection{Usos de las mangas}

En varios episodios hay una referencia directa al modo en cómo llevan las mangas, la amplitud, el tipo de tela y la forma. Esta última les asigna su primera característica: "estrechas las unas mangas con muchos recamados de oro, y las otras largas, que sólo servían de ornamento" (Espejo de príncipes y caballeros III, III, XXIII), rasgo que permite establecer una decoración por niveles, debido a cada prenda que lleva encima la dama, camisa, saya, ropa, etc., cada una con sus respectivas mangas, lo cual permite rodear a los brazos de diversas telas: "El cual manteo llevava cubierto por debaxo del braço derecho por donde se parecía la manga del gonete, que era del mesmo brocado, en la cual iva figurado un árbol con una letra que dezía: Quien no teme la justicia /El fruto come vedado, /Mas al fin paga el bocado" (Florindo, XVIII). Como se nota en las pinturas de Alonso Sánchez Coello, específicamente en los retratos de damas, las mangas se distinguían de tres tipos, justas, abullonadas y colgantes, tres formas que en los libros de caballerías sirven de cavidades para guardar cosas, como cartas: "E diciendo esto sacó una carta que en la manga 
de su vestidura traía" (Cirongilio de Tracia, II, XXI); guirnaldas: "E la princesa sacó de su manga una guirnalda de oro con unas flores verdes" (Polindo, LXX); tablas: "echando mano de la tabla en que estava sacada por el natural que allí la truxera Beroldo, la metió en la manga de una ropa que traía vestida" (Palmerín de Inglaterra, XXVI), entre otros objetos.

También su función será la de servir como pañuelo: “con su propia manga le limpió las lágrimas de sus hazes" (Florisel de Niquea III, LIII), o como prenda de juramento: "Y como esto dixo tendió la manga de la camisa y don Galtazar la tomó, el más ledo cavallero que nunca fue, pareciéndole que tenía cobrada por mujer la más hermosa donzella que nunca avía visto" (Florisel de Niquea III, LI). Es decir, las mangas adornan el vestido con los detalles que llevan bordados y resguardan objetos, gracias a la amplitud que las caracteriza, podían llevar entre la manga de la camisa y del sayo, ropa o garnacha una diversidad de piezas de metal, papel y tela sin temor a que se les cayera.

En este aspecto, Feliciano de Silva tiene un ejemplo curioso sobre los objetos guardados en las mangas: “ella sacó una candela encendida en una pequeña lanterna que en la manga metida traía" (Amadís de Grecia, II, X). Una linterna encendida en una manga plantea dos curiosidades; la primera, es el grosor de la tela para que no haya sido vista por los demás personajes; segundo, la amplitud que debió tener para no afectar la tela y evitar que se incendiara.

Asimismo, el vestido podía contener espacios para llevar pequeñas piezas, tales como el dinero: "y en los vestidos levavan cosidos los dineros necesarios para las limosnas e camino" (Floriseo, I, IV). Lo más curioso era colocarlos en las calzas: "llevando los dyneros y joyas en arcas o en fardeles, se pierden juntamente con las naos. Llevándolos los honbres cosidos en sus jubones y calças - muy pocos honbres se pierden - y salvándose 
ellos, se sálvanse los dyneros" (La corónica de Adramón, II, XXVI). Esto ocasionaba cierta incomodidad al transportar ciertos objetos por su volumen: "Y por esto yo he rrepartydo algunas cosillas de plata y de oro y algunas joyas en estos costalejos para que cada uno de nosotros lleve dos cosydos en el jubón, debaxo del sobaco" (La corónica de Adramón, II, XXVII), o por la excesiva cantidad de cosas que en ellas se guardan:

halló una rropa luenga con sus mangas toda llena d'espejos indianos y chinos y de papeles y de alfyleres y agujetas y cyntas y peynes y tijeras y cuchillos y muchas maneras de cuentas y otras cosas de mercerya. Sylvestre se espantó y santyguava; su amo se enpeçó a rreyr, dyziendo: "Hermano, nuestras amygas y señoras andan por aquí: con esto quiero salyr oy", y myrando bien hallaron una trufa con muchas tyras, del mismo paño toda, llenas de las cosas que la rropa. (La corónica de Adramón, V, XXII)

A manera de una especie de traje de carnaval por la variedad de objetos que lleva cosidos, se completa con la trufa, una especie de sombrero que lleva cosido los mismos accesorios, es el único ejemplo de este tipo que se halla en estos libros. (fig. 201)

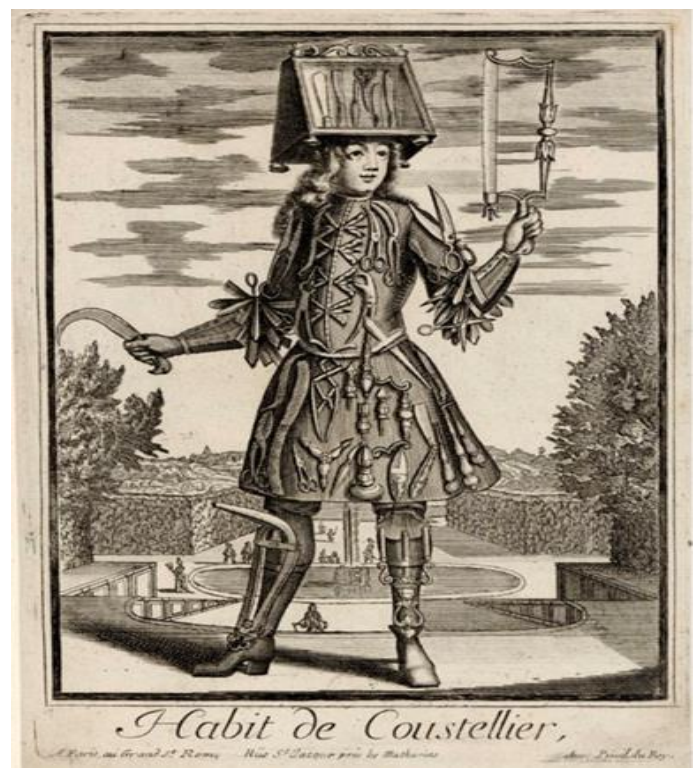

Fig.201. Costumes Grotesques et métiers (1700) Nicolas Larmessin

Variedad de objetos de costura sobre la ropa 
Con los anteriores ejemplos, se propone una función de utilidad en las extremidades de la ropa, como medio para transportar objetos y medio de comunicación, ya sea escrito o en señal de juramento. Con ello nuevamente se sostiene que el uso de vestimenta no sólo sirve para cubrir el cuerpo, sino también como un elemento que genera acciones.

\subsection{Testimonios textiles a través de los grabados}

La primera impresión visual de un libro es su portada, en palabras de Lucía Megías ésta "nace como una etiqueta que personaliza el género editorial y atrae de este modo la atención del posible comprador, quien automáticamente va a identificar aspecto externo con un modelo literario específico" ${ }^{458}$, en el caso de los libros de caballerías son evidentes las innumerables imágenes de caballeros armados con espada en mano, escudo y yelmo montados en su caballo que adornan las primeras páginas de estos textos. En ellas hay una clara identificación del contenido de la historia, batallas, torneos y numerosas hazañas bélicas; sin embargo, aunado a esas aventuras hay un predominio importante de sucesos amorosos, mágicos y fúnebres que también requieren un medio gráfico para visualizar un fragmento de la historia, las xilografías. Estas ilustraciones al interior del libro, ocultas a primera vista, pero exponentes de importantes episodios, se caracterizan por plasmar un suceso determinado que las convierte en "<<viñetas $>>$ narrativas que condensan una anécdota, un mínimo cuadro argumental"459 que en pasajes relacionados con descripciones textiles y funciones de atavíos permiten el resguardo de atuendos de la época y proporcionan la creación de un mini catálogo de accesorios en donde las prendas para el

\footnotetext{
458 José Manuel Lucía Megías, Imprenta y libros de caballerías, Madrid, Ollero y Ramos, 2000, p.145.

459 José María Díez Borque, "Las ilustraciones del Lazarillo de 1554", en Paratextos en la literatura española: siglos XV-XVIII, María Soledad Arredondo, Pierre Civil y Michel Moner (eds.), Madrid, Casa de Velázquez, 2009, p. 509. (pp.499-518)
} 
rostro, el calzado, los sombreros, los bolsos, entre otros, adquieren un simbolismo en cuanto a su armonía con la historia contada.

Carmen Bernis los llama:

vehículo de expresión estética, tienen el enorme valor de visualizar para nosotros el mundo real y particularizado de un caballero español en la segunda mitad del siglo $\mathrm{XV}$. Cuando el miniaturista gótico realizaba sus obras con el explícito deseo de encontrar algo, tomaba sus imágenes del mundo que lo rodeaba; por ello, el historiador encontrará en esas obras un tipo de información que no puede ser transmitida por el relato escrito, información especialmente valiosa para el mejor conocimiento de cualquier época del pasado. ${ }^{460}$

Los detalles que se ocultan en la escritura son especialmente la forma de las prendas, tales como el corte de las faldas, puesto que algunas eran más largas que otras y permitían dejar a la vista las prendas de abajo, como se observa en el grabado "La reina a Laureola" de Cárcel de amor (fig. 202), en donde la reina lleva una saya con abertura de lado por la que se ve una faldilla interior. En semejanza a este grabado, en el Valerián de Hungría aparece un ejemplo en el que se percibe la prenda de abajo la cual lleva unas letras labradas que se pueden leer gracias a que la ropa de encima es más corta: “el manto que sobre el sayo llevava, como era corto y echada la una parte d'él sobre el hombro, no ocupava la lectura d'ellas, antes las sacava más claras (Valerián de Hungría, XVI)

${ }^{460}$ Carmen Bernis, "El manuscrito de París. Estudio arqueológico”, p.195. 


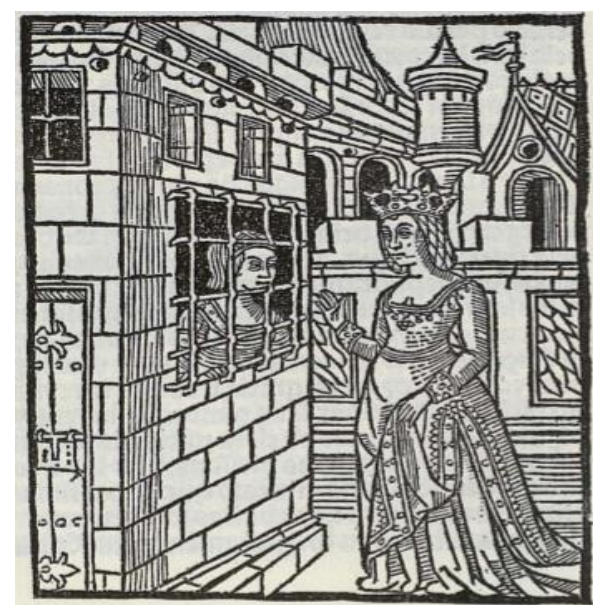

Fig. 202. La reina a Laureola

Diego de San Pedro, Cárcel de amor, Barcelona, Lambert Mata, 1906.

El interés de este apartado es destacar algunas de las xilografías con un gran contenido de elementos textiles que permitan recrear los modelos de confección que se usaban en la época y complementar dichos diseños con las pinturas y demás materiales gráficos hallados a fin de establecer similitudes y diferencias en cuanto a la labor creativa de los impresores. Se considerarán no sólo las halladas en las obras de Feliciano de Silva, sino también en otros títulos con la intención de extraer y agrupar la mayor cantidad de prendas, materiales y accesorios textiles.

\subsubsection{Amadís de Gaula: Variedad de atavíos}

En 1508 aparece la primera edición completa del Amadís de Gaula ${ }^{461}$ historia que presenta los amores del rey Perión de Gaula y la infanta Helisena y posteriormente los de su hijo Amadís con Oriana. En esta línea sentimental el uso de los grabados es importante para fijar en la memoria algunos de los accesorios textiles más relevantes que identifican a un personaje especial con una prenda específica. El primero de ellos se halla al inicio de la obra, cuyo enlace pictórico-narrativo se introduce hasta la edición sevillana de 1526 en el

\footnotetext{
${ }^{461}$ Se consultó la edición de Salamanca de 1519, la cual tiene 132 grabados. Garcí Rodríguez de Montalvo,
} Amadís de Gaula, Salamanca, Antonio de Salamanca, 1519. 
primer capítulo porque presenta innovaciones importantes antes no vistas, pues de acuerdo con la propuesta que se hizo en el tercer capítulo de esta investigación en torno a la camisa como prenda de seducción, es la primera vez que se recrea la escena del encuentro entre Perión de Gaula y Helisena, en donde la camisa es el elemento textil que permite el desarrollo de la historia, al dejar visible el cuerpo de la dama y retener el interés del caballero.

Como se recordará el pasaje descrito es el siguiente:

El Rey, que la conosció, miró y vio a Helisena su muy amada, y echando la espada y escudo en tierra, cubrióse de un manto que ante la cama tenía con que algunas vezes se levantava, y fue a tomar a su señora entre los braços, y ella le abraçó como aquel que más que a sí amava [...] Y Darioleta miró por la espada do el Rey la havía arrojado y tomóla en señal de la jura y promessa que le avía hecho en razón del casamiento de su señora, y salióse a la huerta. (Amadís de Gaula, I, I)

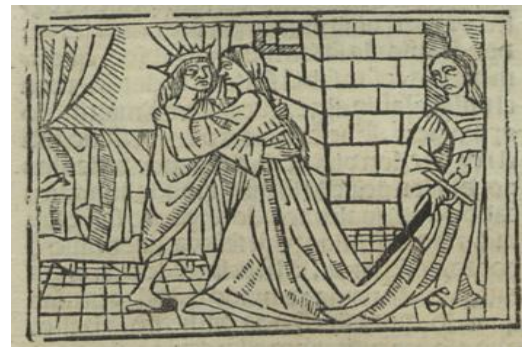

Fig. 203. Cap. I, fol.4r.

En el grabado (fig. 203) se notan varios elementos importantes para el inicio de esta obra, el primero de ellos es la espada, la cual se conserva como "elemento de juramento y seña de identidad" 462 y que en el grabado es introducida con un tono más remarcado para que los lectores de la época la conservaran en la memoria. El siguiente es la corona que lleva el personaje, a manera de identificación del rey. Asimismo, el manto con el que se cubre Perión en las mañanas. Este se diferencia claramente en la imagen, puesto que el personaje

462 Juan Manuel Cacho Blecua, Amadís heroísmo mítico cortesano ..., p. 43. 
lo lleva atravesado y sujeto por uno de los hombros, lo que permite ver su camisa. Sin embargo, un elemento extra que se da en el grabado, pero no en la narración es el calzado. En este caso se trata de unos pantuflos de casa por la comodidad que brindaban, pero también existían de materiales más resistentes para las actividades fuera del hogar.

En esta misma línea de las xilografías minuciosas se coloca en la historia del nacimiento de Florestán, hijo de Perión y de la hija del Conde de Selandia. En ella un referente gráfico importante, el momento en que la dama amenaza con suicidarse ante el rechazo del caballero (fig. 204). El texto dice:

Entonces se levantó fue tomar la espada del Rey, que cabe su escudo estava; y aquélla fue la que después pusieron a Amadís en el arca cuando le echaron en la mar, como se os ha en el comienço de este libro contado: y tiróla de la vaina y puso la punta della en derecho del coraçón, y dixo:

-Agora sé yo que más le pesará a mi padre de mi muerte que de lo ál. (Amadís de Gaula, I, XLII)

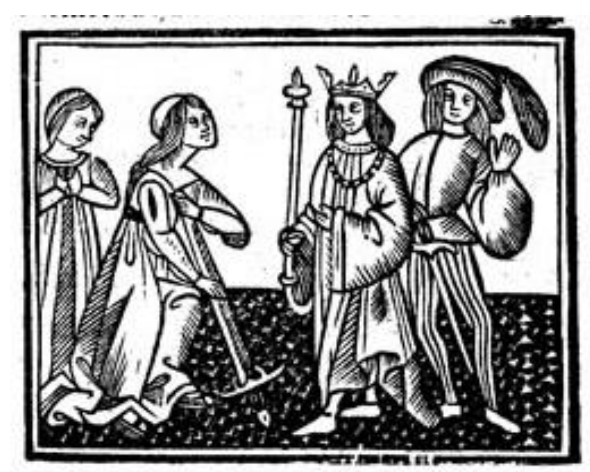

Fig. 204. Cap. XLII, fol.71r.

Aunque se trata de la misma espada, para este episodio ya no se remarca, puesto que ahora no funge como un objeto de reconocimiento que debe ser recordado, sino como un instrumento ofensivo para la vida de la dama. Además, nuevamente se dibujan complementos extras que permiten conocer la moda de la época. El primer caballero de la derecha lleva 'calzas bandadas' con jubón. El rey una ropa rozagante. Las dos damas portan 
sayas y tocas en la cabeza. Sin embargo, es importante destacar el detalle de los zapatos de la dama principal:
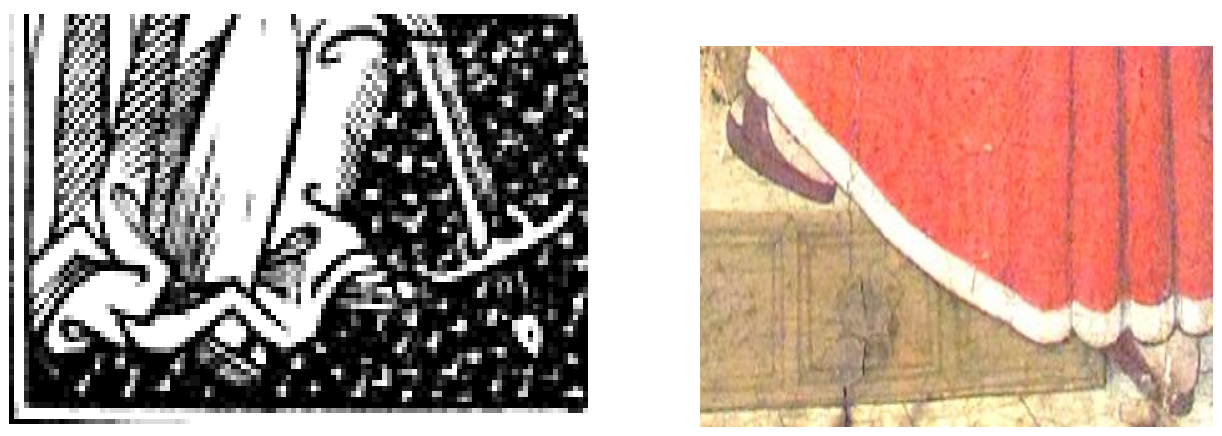

Fig. 205. Nacimiento de San Juan Bautista, (1480-90) Domingo Ram, Museo Metropolitano de Arte de Nueva York

Se trata de los alcorques, calzado de herencia musulmán ${ }^{463}$ que se caracterizaba por no llevar talón ni punta. Su suela era un poco gruesa, pero mucho más delgada que la de los chapines. Éstas se pueden ver en varias pinturas del siglo XV, como se detalla en la de Nacimiento de San Juan Bautista (fig. 205).

De entre las prendas de gala sobresalen dos grabados. El primero presenta todo un atuendo varonil:

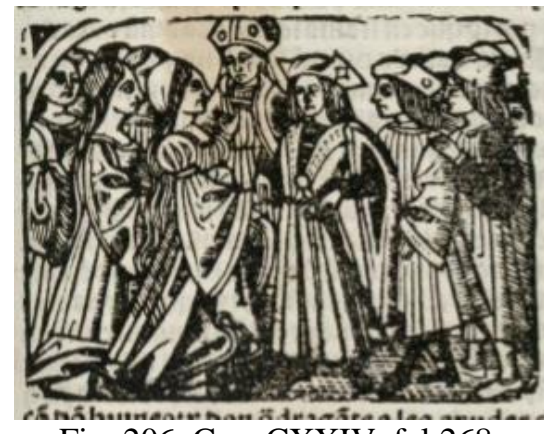

Fig. 206. Cap. CXXIV, fol.268r.

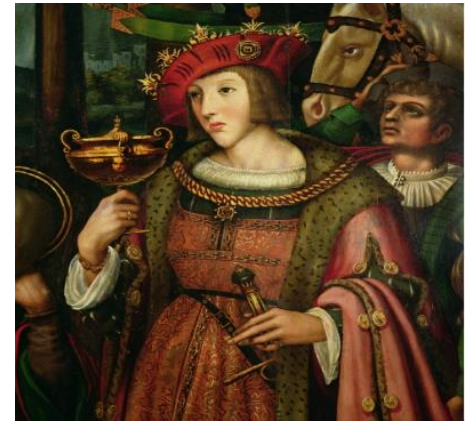

Fig.207. Adoración de los Reyes Magos (1519) Marco Cardisco, Museo Cívico Castel Nuovo Nápoles.

Se debe notar el detalle de las gorras de media vuelta con aplicación metálica en el extremo. El personaje central lleva una ropa con mangas largas (fig. 206). Su postura y la

${ }^{463}$ Carmen Bernis, Trajes y modas en la España de los Reyes Católicos I. Las mujeres..., p. 18. 
forma como sostiene la espada lo asemeja mucho al retrato de Carlos V (fig. 207), la diferencia es que el emperador la lleva desabrochada y Amadís cerrada.

El segundo atuendo es femenino, en donde hay una gran similitud de vestimentas y peinados con los de las damas nobles del periodo, éste aparece en el capítulo tres del Amadís, en donde se cuenta la partida del rey Languines, la Reina, Amadís y Gandalín a la corte de Escocia. De estos cuatro, la dama presenta mayor relevancia en su atuendo por la forma de su tocado (fig. 208), una cofia de papos que sirve de sostén para la corona, este tipo de peinado está presente en varias pinturas de la época; sin embargo, uno de los más conocidos es el que se observa en la Catedral de Burgos (fig. 209):

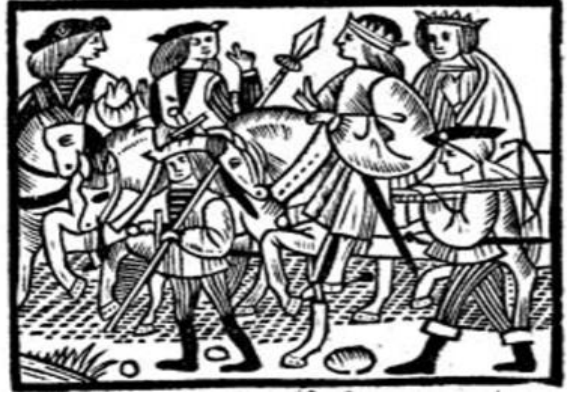

Fig. 208. Cap. III, fol.7v.

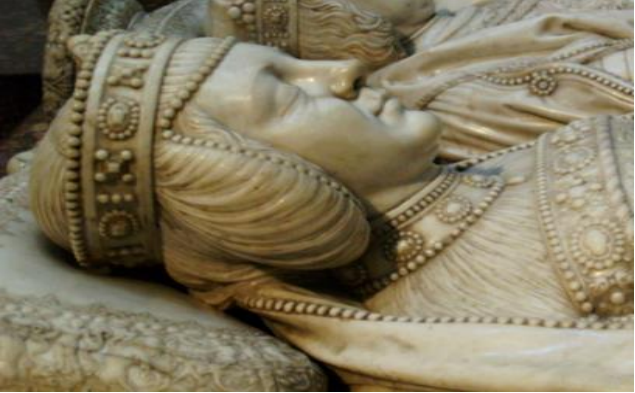

Fig. 209. Sepulcro de los Condestables (h.1500) Felipe Vigarny, Catedral de Burgos

En el peinado de la condesa Mencía de Mendoza y Figueroa sobresale el detalle de los papos con un contorno de perlas en consonancia con las que lleva en la ropa, ambas damas tienen a sus espaldas unos mantos, pero la del sepulcro lleva detalles de pedrería.

Por otra parte, uno de los accesorios que más sobresale son los sombreros, tal como se nota en la siguiente imagen (fig. 210): 


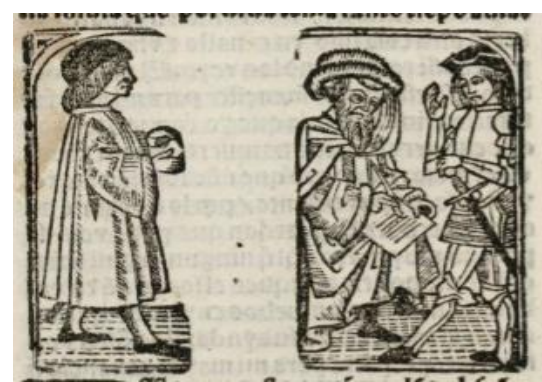

Fig. 210. Cap. LXXIV, fol.173v.

Aunque se trata de un grabado compuesto por dos diferentes litografías, es necesario destacar el capirote que lleva el personaje de la carta. Claramente sobresale la tira de tela que atraviesa por el cuello y se sostiene del lado izquierdo. Este accesorio es uno de los más usados en las distintas clases sociales, la única diferencia es la calidad del tejido y las aplicaciones. Por ejemplo, en la imagen inferior, el rey Felipe II lleva un capirote en terciopelo rojo con un broche de oro con una gema en el centro y una perla colgante, que va a juego con el resto de su indumentaria. (fig. 211)

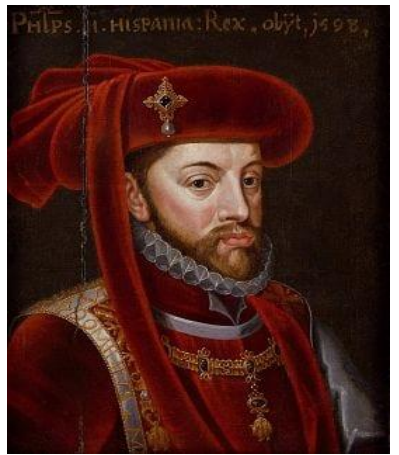

Fig. 211. Felipe II, rey de España (s. XVI) Anónimo, Museo del Prado

Pero en el grabado del Amadís, el personaje que aparece es el maestro Elisabad, quien por orden de Amadís escribe una carta al Emperador de Constantinopla para contarle varios hechos, posteriormente la dan a un mensajero para que la entregue. Carmen Bernis expresa que los médicos se caracterizaban por usar capa y gorra ${ }^{464}$ además llevar algún instrumento

\footnotetext{
${ }^{464}$ Carmen Bernis, El traje y los tipos sociales ..., p. 120.
} 
o guantes en las manos, pero no se acostumbraba a que fueran prendas adornadas. En este sentido, Elisabad conserva ciertos rasgos que caracterizaron a los practicantes de la medicina en los siglos XVI y XVII. Este mismo concepto aparece en capítulos posteriores, en donde una comitiva de personas se reúne en torno al Emperador de Roma, quien falleció a causa del combate contra Amadís. (fig.212)

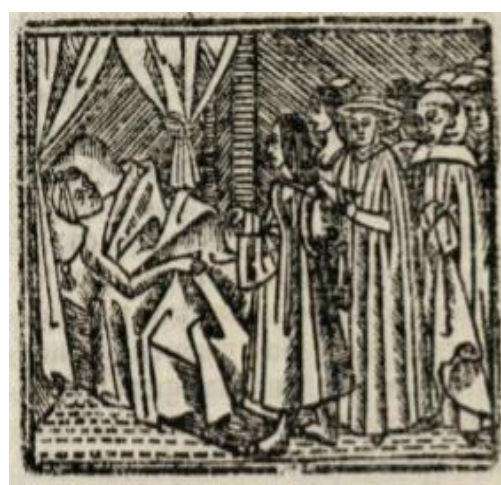

Fig. 212. Cap. CXII, fol.239v

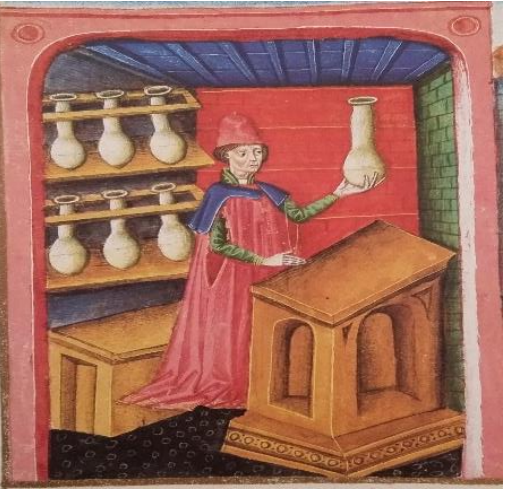

Fig. 213. Zifar, fol. 97v.

Las situaciones médicas permiten reunir una variedad de trajes, en este ejemplo aparecen médicos, caballeros y religiosos; los tres portan una prenda en común, la loba, la cual a partir del siglo XVI se convirtió en "un traje propio de médicos, doctores, estudiantes y clérigos"465, en ella claramente se distingue la abertura entre los costados para que salgan los brazos.(fig. 213)

Por último, en cuanto a las miniaturas de combate la que presenta más detalles aparece en el capítulo seis, la descripción es la siguiente: "Y metió mano a la espada y dexóse ir a ellos y dio a uno que alçava un acha para lo ferir tal golpe, que el braço le cortó y le echó en tierra" (Amadís de Gaula, I, VI).

${ }^{465}$ Carmen Bernis, Indumentaria española en tiempos de Carlos V..., p. 95. 


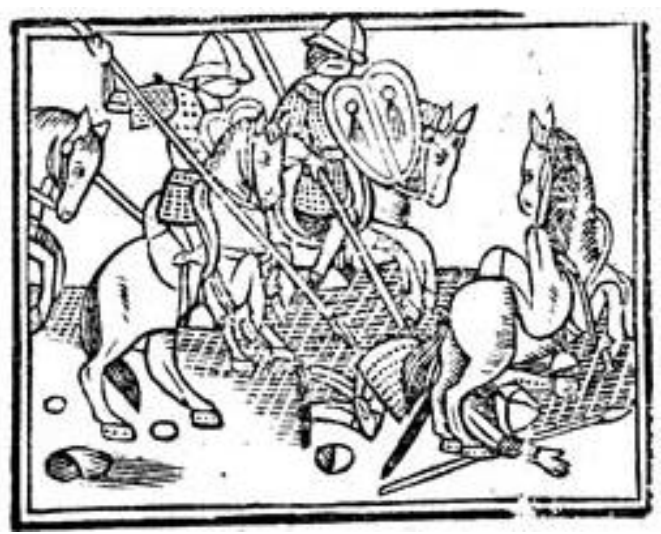

Fig. 214. Cap. VI, fol.13r.

En la imagen hay dos armas de defensa que presentan relevancia, el casco y la adarga (fig. 214), ésta de origen musulmán fue muy usada en el siglo XV. Se le colocaban dos borlas con tira de tela, cuero o piel. Ejemplo de esta pieza aparece en el folio 50r del manuscrito de París del Zifar y también en un tallado en madera en una representación de la guerra de Granada. (Fig. 215)

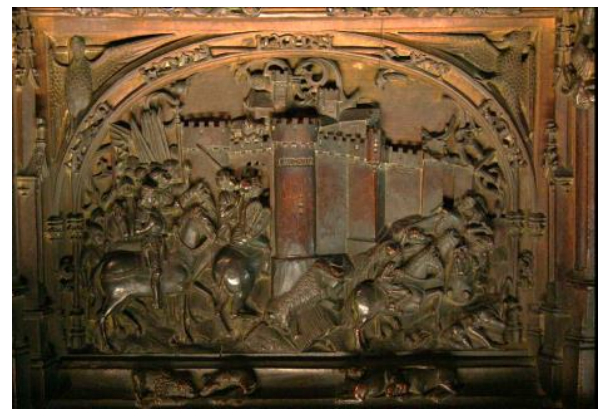

Fig. 215. Guerra de Granada. Rendición de Cártama (1495-1498) Rodrigo Alemán, Sillería del coro bajo, Catedral de Toledo.

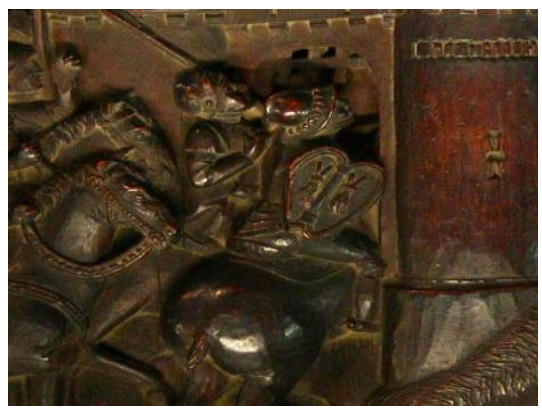

Detalle del casco y el escudo.

En este primer apartado de la vestimenta retratada a través de las xilografías se puede observar que hay una gran variedad de elementos textiles que se pueden extraer de las miniaturas para analizar el tipo de prenda, el tejido, los adornos y relacionarlos en función de la explicación dada por el relato, en algunos momentos, hay una directa relación entre la imagen y la palabra, pero en otros es necesario profundizar en el capítulo para comprender el contexto y darle sentido al grabado. 
De esta manera, se puede realizar una especie de catálogo de las prendas que aparecen en los demás libros de caballerías que resguardan este tipo de grabados al interior de sus capítulos y que algunos de ellos se han podido extraer para esta investigación, por lo que sin importar si en ciertos momentos aparecen xilografías repetidas se analizarán si presentan elementos novedosos acordes a los títulos en los que se hallan. Dado que el Amadís se considera el libro fundacional del género caballeresco es del que se toman la mayoría de sus grabados para insertarlos en las obras posteriores; sin embargo, en ellas se notara el cambio de sentido en la ropa según la propuesta de cada escritor y miniaturista, además de que hay algunos títulos que presentan sus propias imágenes y es donde aparecerá la aportación de más atavíos para esta investigación.

\subsubsection{Lisuarte de Grecia: Entre metales y telas}

En el caso de las obras de Feliciano de Silva lamentablemente no se cuenta con la primera edición del Lisuarte de Grecia ${ }^{466}$ de 1514 de Juan Varela en Sevilla, sino con la de 1525 realizada en la misma ciudad a cargo de Jacobo y Juan Cromberger en la que aparecen 97 grabados, la mayoría pertenecientes a otras ediciones tanto del género caballeresco como de otros títulos de la época y es el único libro de caballerías de Silva que presenta estas imágenes, por lo que se desconoce si la primera edición contaba con alguna xilografía.

En este aspecto, Lucía Megías, al referirse a las reediciones, destaca algunas variantes que el impresor hace en el texto, tales como el íncipit, las grafías, signos de puntuación ${ }^{467}$, etc., pero también hay modificaciones en los grabados, como agregados decorativos, elementos florales y en el caso de la vestimenta aparecen detalles importantes,

\footnotetext{
${ }^{466}$ El ejemplar se halla en la Biblioteca de Catalunya. Código: Bon. 9-IV-10. De los 97 grabados, 19 se repiten y 5 aparecen una sola vez.

${ }^{467}$ José Manuel Lucía Megías, Imprenta y libros de caballerías..., p. 129.
} 
tales como piezas metálicas: botones, broches; rayas que decoran la ropa y un mejor diseño en el contorno de algunas prendas, como en los zapatos, sombreros y bolsos. Aunado a estas características, la parte más relevante es su relación con el contexto, identificar si su inserción es relevante en la historia y si presentan los accesorios y tipo de vestimenta descritos en el texto, por lo que para este apartado se toman las xilografías más relevantes en torno al uso de prendas, sin importar si aparecen en otros títulos, como es la situación del Lisuarte, cuyas imágenes aparecen por primera vez en títulos como el Amadís de Gaula o el Oliveros de Castilla y los impresores deciden retomar dichos diseños con ligeras modificaciones.

De entre las que se insertan en esta edición del Lisuarte, tres presentan una propuesta interesante para este estudio por el modo en como los impresores las colocan en el texto. La primera se halla en el capítulo nueve, en el que se cuenta la batalla entre el Duque de Orlitensa y Florestán contra el Rey de la Bretaña. En el combate se enfrenta Florestán contra Groter y se dice que "Florestán [lo] encontró por mitad del escudo, que armadura que tuviesse no le prestó cosa; e haciéndole una llaga en el costado, dio con él en el suelo una gran caída" (Lisuarte de Grecia, IX), que es el momento exacto que se plasma en las imágenes inferiores. (Figs. 216-217)

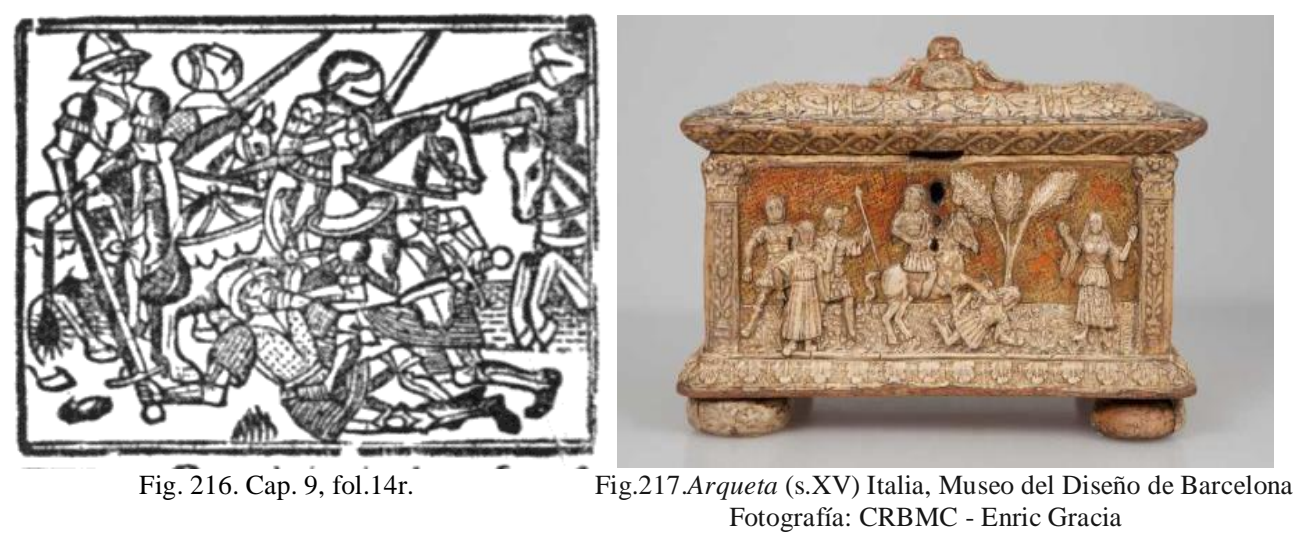


Tanto en el grabado como en la caja se puede notar la semejanza del caballero caído, además de las faldas de los jubones y algunas armas como las espadas, los yelmos, las lanzas y una maza, y la gualdrapa, lo que permite conocer el tipo de armamento usado en la época y la decoración textil de los caballos. Estas xilografías bélicas nivelan el traje de armas con el cortesano, puesto que generalmente imperan los diseños de tela y se le da una menor porción a los de metal.

La segunda se trata de una imagen de camino, en la que Alquifa pide al Conde Gandalín la acompañe, así que: "e cavalgando ella en su palafrén y él en un cavallo, la sacó fuera de la villa a la parte de la mar, e como fazía muy buena luna, estava todo tan claro como de día" (Lisuarte de Grecia, LXVI).

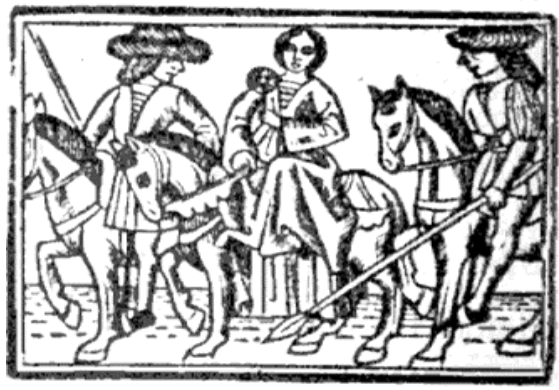

Fig. 218.Cap. LXVI, fol.78v.

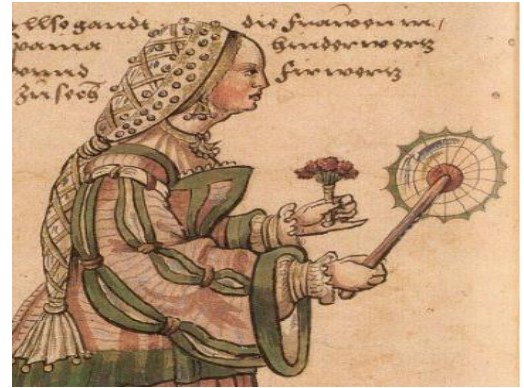

Fig. 219. Das Trachtenbuch des Christoph Weiditz nach Spanien (1529)

Nuevamente aparece un accesorio que no se menciona en el relato un abanico en la mano de la doncella (figs. 218-219), el cual se caracterizaba por brindar frescura durante los viajes. A través de estas miniaturas se puede conocer la estructura de los tres utensilios utilizados para refrescarse, el ventalle, el abanico y el moscador, los cuales mantienen cierta similitud en su forma por ser enseres de mano.

Lamentablemente, el Lisuarte es la única obra de Feliciano de Silva que presenta este tipo de testimonios, ya que al menos las ediciones que se conservan en las diferentes 
bibliotecas del mundo no tienen grabados. A pesar de esta ausencia en sus otras obras, en ésta se introduce un aspecto relevante, el diseño de las prendas de matrimonio (fig. 220):

[Lisuarte e Perión] otro día ellos se vistieron muy ricamente cubriéndose dos mantos d'escarlata muy fina, bordados de oro e muchas perlas, tan apuestos que a todos ponían espanto [...] Onoloria e Gricileria tenían los sus muy fermosos cabellos sueltos sin otra cosa sobre ellos sino sendas redes de oro, sembradas por ellas muchas piedras e perlas. Dando las manos ellas a ellos, y ellos a ellas, se desposaron e passaron con mucho gozo. (Lisuarte de Grecia, XCVI)

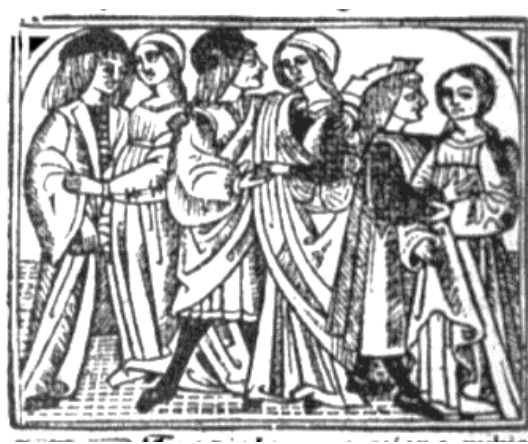

Fig. 220. Cap. XCVI, fol.108v.

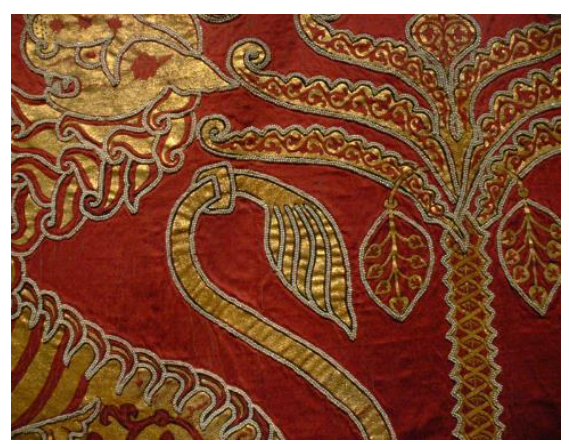

Fig. 221. Manto de la Coronación de Rogelio II de Sicilia (1133-1134) Talleres Reales de Palermo

En la descripción se aprecia la riqueza de la tela de los caballeros; ambos llevan mantos de escarlata con bordados de oro y perlas, descripción que se asemeja mucho al manto de Rogelio II de Sicilia (fig. 221), en el que las siluetas de las flores están aderezas con perlas. A pesar de ser un atuendo de diario, es la primera boda que crea Feliciano de Silva. En este primer intento introduce dos elementos que visualmente atraen la mirada del lector, el manto y las redes de oro con piedras preciosas que las damas llevan en sus cabellos, pequeños detalles con los que el autor comienza a perfilarse en el diseño de ajuares de boda, puesto que en las obras posteriores es el elemento textil en el que más sobresale, tal como se ha establecido en los capítulos precedentes a éste. 
El lector docto en el ciclo amadisiano reconocerá el grabado de las tres parejas, pues aparece al final del libro primero del Amadís de 1547; sin embargo, ahí simplemente se inserta a manera de decorado gráfico. Pero el impresor de la edición del Lisuarte de 1525 hace una reutilización xilográfica que la pone en contexto dentro de un episodio amoroso, acorde a lo que revelan las tres parejas que manifiestan un grado de complacencia por el rostro y la posición de las manos.

Aunque aparecen otras xilografías en esta edición del Lisuarte, las tres anteriores son las que toman más relevancia por el tipo de prendas que presenta en relación con el contexto en el que se insertan. Especialmente, la última, la cual es el inicio para la presentación de los pasajes de boda, los cuales en pocas ocasiones se pueden recrear a la par del texto y la imagen, y que, a partir de esta aparición, algunos impresores comenzarán a utilizar grabados que asemejen festejos matrimoniales para colocarlos en los episodios con este motivo. Por lo tanto, el valor de las miniaturas en la obra de Silva recae en esta última imagen, al ser el precedente de las ilustraciones de ámbito nupcial.

\subsubsection{La Trapesonda: Pieles}

En 1533 se publica en Sevilla La Trapesonda, en la que aparecen 92 grabados cuyo elemento textil que más destaca es la piel. Desde la portada se observa la influencia de la moda de Carlos V, quien se caracterizó por el uso de sobrerropas con forro, mangas y cuellos de piel. En el caso de esta portada, Lucía Megías expresa que se trata de "una imagen más cortesana, en donde se añade al estrado real, un suelo ajedrezado y dos ventanas en los laterales desde las que divisan detalles del paisaje" ${ }^{468}$ (fig. 222), este ambiente noble y minucioso también se presenta en el atuendo del rey, el cual se compone

\footnotetext{
468 José Manuel Lucía Megías, Imprenta y libros de caballerías ..., p.226.
} 
de una ropa rozagante, con abertura en el medio que permite ver el sayo bordado. Éste lleva aplicaciones de pedrería con un broche o prendedor en el centro. Su confección es similar al que aparece en varios personajes de los tapices de la reina Isabel la Católica.

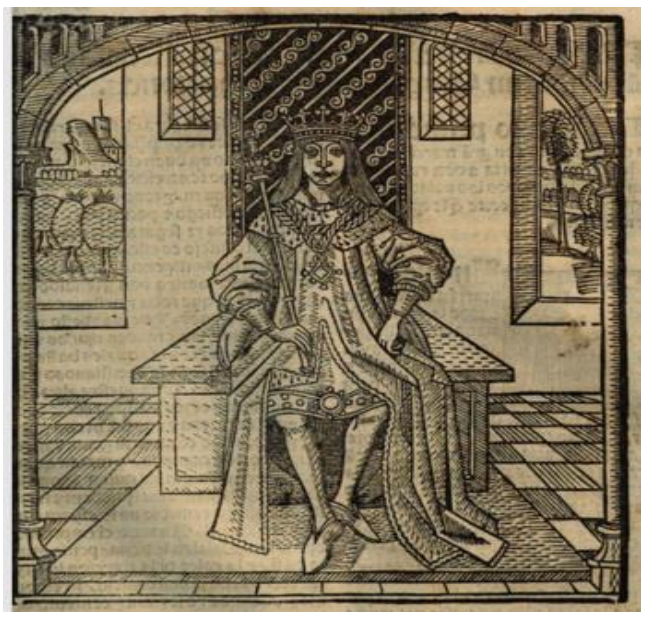

Fig. 222. Portada

Además de las piezas textiles, sobresale el calzado, llamado 'zapatos', su punta no es tan alargada. Los principales materiales para su fabricación eran tela, cuero y adornos de oro, lo más interesante es que en la parte de adentro solían ir forrados con algún tipo de piel de ardilla, ciervo, marta, etc. En la pintura de Diego Hurtado de Mendoza aparecen unos del mismo estilo (fig. 223).

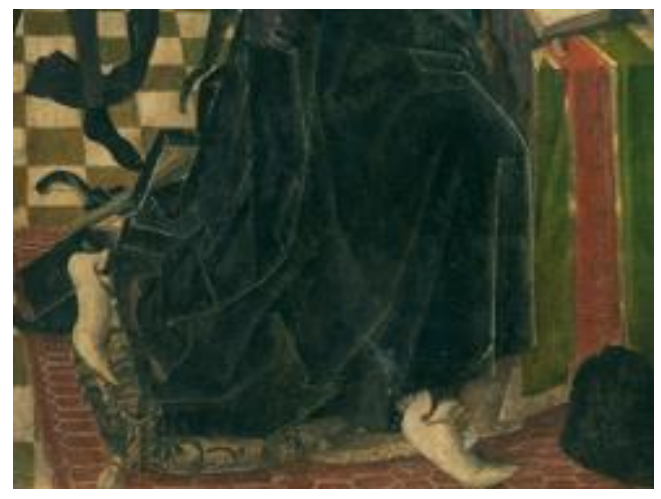

Fig. 223. Diego Hurtado de Mendoza, segundo Marqués de Santillana (1470) Maestro de Sopetrán, Museo del Prado. 
Las confecciones con piel aparecen en varios capítulos y su referencia a este material se detalla tanto en el texto como en la imagen. Nótese la descripción con la que inicia el capítulo nueve:

Estando todos en la manera que aveys oydo arribo al palacio el gran conde don Roldan armado de sus armas y con la señal del quartel y encima del arnés llevava una rica ropa de brocado carmesí enforrada en armiños toda bordada de perlas orientales y encima llevava un rico collar de oro muy ancho con muchas piedras preciosas de grandissimo valor y llevava una rica espada de hilo de oro con muchas piedras por ella de gran valor y en la cabeça llevava un sombrerete de seda vedijudo blanco todo sembrado de rubis (Renaldos, IX, fol. 14r) (69 $^{469}$

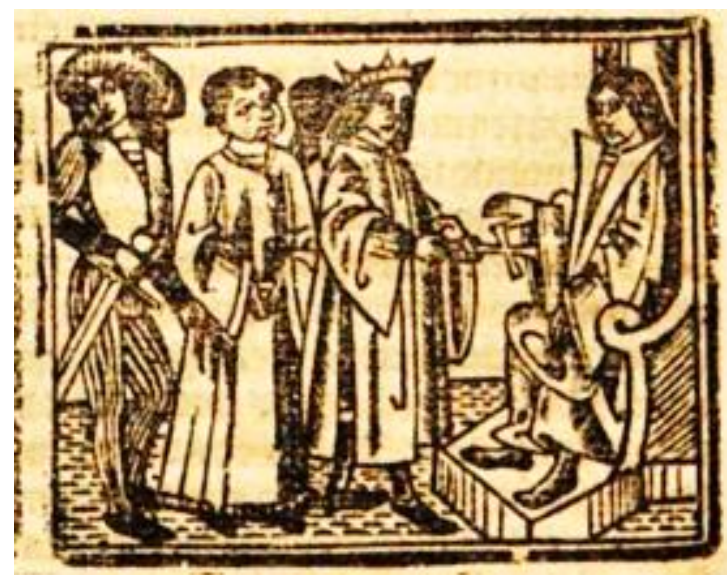

Fig. 224. Cap. IX, fol. 14r.

El personaje de don Roldán es el hombre sentado en la silla (fig. 224), puesto que más adelante se indica que se sentó para que el rey le tomara el juramento. En su atavío sobresale el ropón, cuyo corte se asemeja al que lleva un caballero en el Retablo de la iglesia de Berlanga, además del modo en cómo ambos sujetan el sombrero (fig. 225). Lo más detallado es el cuello prolongado de solapa de pico en corte "V" o de vueltas que

\footnotetext{
${ }^{469}$ Renaldos de Montalbán, La trapesonda que es tercero libro de don Renaldos y trata como por sus cavallerias alcanço a ser emperador de trapesonda y de la penitencia y fin de su vida, Sevilla, Jacobo Cromberger Impressor, 1548. El ejemplar se conserva en la Biblioteca Estatal de Baviera.
} 
permite ver el contraste entre las telas. En el caso de la Trapesonda se trata del brocado carmesí con forro de armiño, mientras que el del retablo lleva un brocado en tonos amarillos. Estos dos tejidos son la clásica combinación para un proceso ceremonial y que se puede observar en numerosos cuadros de coronación.

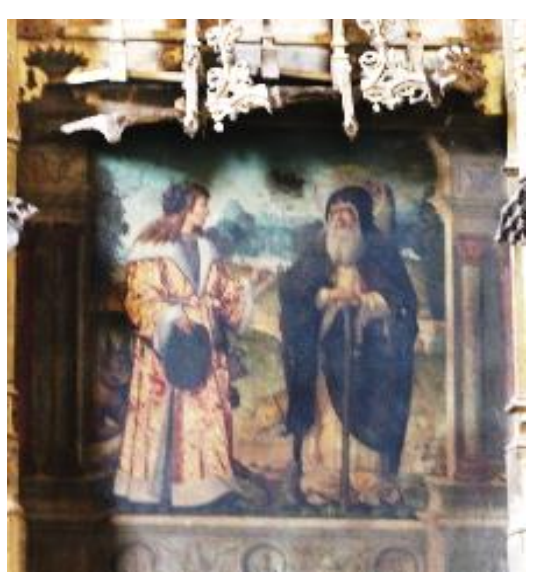

Fig. 225. Retablo de la iglesia de Berlanga de Duero, Soria, s. XV.

El segundo detalle que sobresale es el "sombrerete de seda vedijudo". Éste consistía en una especie de sombrero que iba encima de otra prenda para la cabeza, bonete, gorra, capirote. ${ }^{470}$ Lo más importante es el adjetivo 'vedijudo', el $D R A E$ lo define como “que tiene la lana o el pelo enredado o en vedijas", es decir, como especies de mechones de lana. La textura debía quedar como pequeñas fibras de lana volando. En algunas pinturas se puede ver este tipo de accesorio en el que se distingue en el contorno ligeros pelillos, por ejemplo, en el cuadro Banquete de Herodes se aprecia esta técnica. (fig. 226)

${ }^{470}$ Carmen Bernis, Trajes y modas en la España de los Reyes Católicos. Los hombres ..., p.127. 


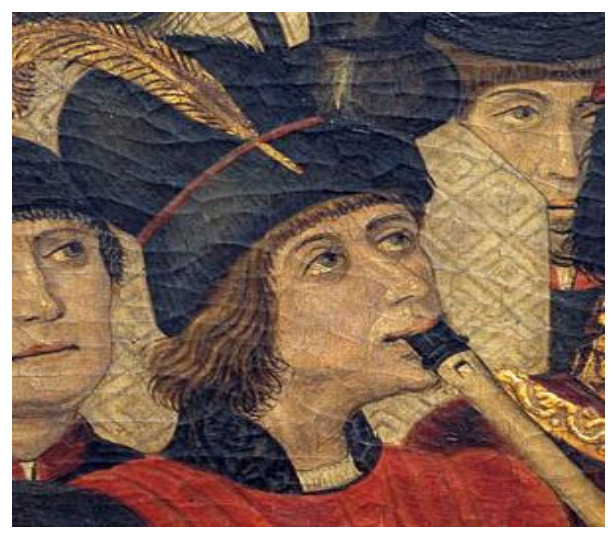

Fig. 226. Banquete de Herodes (h. 1473-1482)

Pedro García de Benabarre

Museo Nacional de Arte de Cataluña

En otro momento de la historia Organtino, embajador de don Renaldos, llega a la corte del emperador Carlos para contar lo sucedido durante el enfrentamiento con los moros. Durante el relato, no se da ninguna descripción de la vestimenta, pero en el grabado de este capítulo se nota la ubicación central de tres personajes, el emperador, Organtino y una dama, todos rodeados por muchas personas.

En el caso de los recibimientos es común que la persona que entra a la corte lleve un tipo de prenda que cause asombro entre los miembros de ese reino. Pero en la imagen inferior se puede notar la armonía entre la vestimenta del caballero y la dama y con las ropas descritas anteriormente (fig. 227).

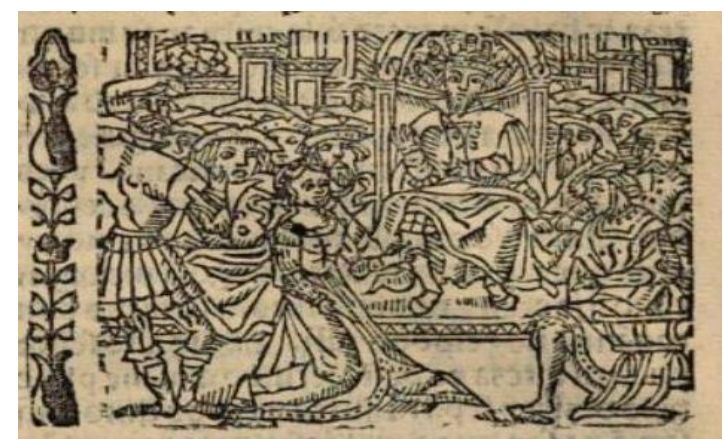

Fig. 227. Cap. LIII, fol. 69r. 
En el grabado se observa el armiño en el filo de la saya de la dama y del jubón del caballero que está sentado. Como una típica escena de retrato de las cortes europeas, en las que sobresale la presencia de tres personalidades, los reyes y el papa, en los eventos de coronación y casamiento. La dama parece llevar una hopalanda forrada de armiño. Mientras que el caballero lleva un jubón con el mismo forro.

La última xilografía también aparece en la edición del Amadís de Gaula de 1519. Se trata de la celebración de la boda de Joneto y Armelina, hijo de don Renaldos. Para este apartado se analiza la piel de armiño que rodea la ropa del personaje de en medio, en la que se nota el detalle de las puntas negras de los rabos (fig. 228).

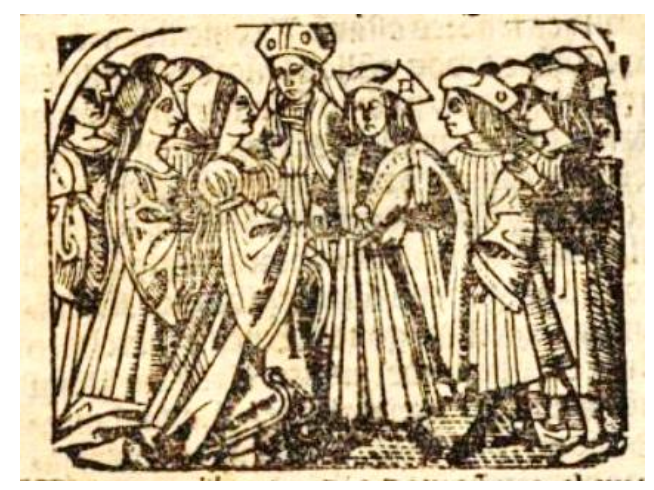

Fig. 228. Cap. LXXXIX, fol.130r.

Para los ajuares de boda hay pocas referencias que determinan un tejido especial para su elaboración, así que los novios se cubrían con las más finas telas y adornos que enriquecieran aún más el traje, además de que era notoria su relevancia porque portaban colores más llamativos que el resto de las personas a su alrededor. Un testimonio de este tipo se halla en la pintura Las bodas de Canaán, en donde los esposos lucen un atavío similar al de este grabado (fig. 229). 


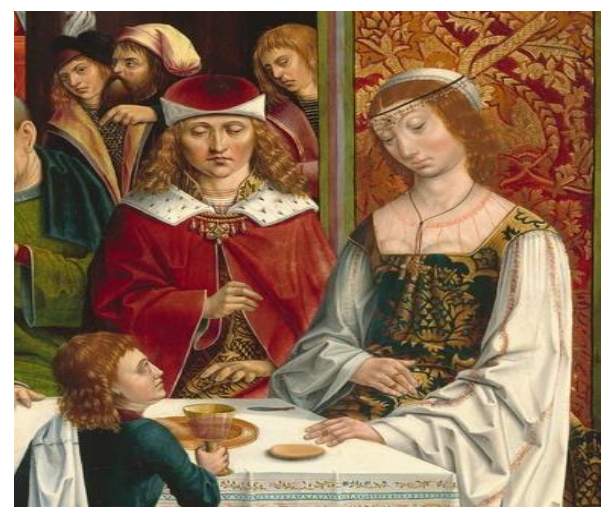

Fig. 229. Las bodas de Canaán (1495-1497)

Maestro de los Reyes Católicos

Galería Nacional de Arte de Washington

Nótese la semejanza en las gorras, el armiño en el cuello de las ropas, mientras que ambas damas llevan cofias y mangas amplias.

Las imágenes sirven como testimonio de la moda, no sólo de aquella transmitida en los libros de viajes de la monarquía, sino también de la impuesta por los escritores del siglo XVI y que gracias a los miniaturistas se perciben algunos detalles en los sombreros, las mangas y los zapatos. En la Trapesonda se conserva el uso de la piel como aplicación y forro para diversas prendas, desde sombreros, vestidos, y jubones hasta las prendas de abrigo. Lo más significativo es que se trata de prendas para actos ceremoniales, como las coronaciones, bodas y recibimientos, en donde la piel que más se distingue es la del armiño por las manchas negras; sin embargo, había otras con poca presencia como la del cisne, utilizada solo para la ropa del rey Felipe II; además, un ejemplo curioso está en el Adramón, en el personaje del correo, quien lleva: "una rropa de carmesy altybaxo, forrada de gatos y una cofya muy gentil" (Adramón, I, XVI). Se tiene conocimiento que el uso de la piel del gato era para la fabricación de "agujetas, correas o cintas que servían para unir algunas partes de las prendas de vestir masculinas (calzas y jubón) o femeninas (mangas y 
manguitos)" ${ }^{471}$; sin embargo, puesto que el correo, actualmente el cartero, cuyo oficio lo obligaba a recorrer distancias largas, debía utilizar materiales que lo abrigaran a bajo precio, además de que llevaba consigo "alforjas al cuello y una azcona o chuzo en la mano, propio talle de correo a pie" ${ }^{472}$, a manera de materiales rústicos que le permitieran resistir el clima.

En los grabados anteriores se muestra el uso de las pieles en distintos usos textiles, los cuales en muchas ocasiones no son descritos por el narrador, sino que solamente hace referencia a las prendas que tienen una mayor relevancia en la historia, como los mantos y las capas. Por ello, es necesario recurrir a los testimonios de la época que contienen enseres similares a los localizados en los libros de caballerías, para catalogar, en este caso, los tipos de pieles que más se usaban desde la Edad Media y distinguir qué materiales de procedencia animal se utilizaban para cada atavío.

\subsubsection{Espejo de príncipes y caballeros I: Cuellos}

En 1555 se publica la primera parte del Espejo de príncipes y caballeros, historia de amor de Trebacio y Briana y de las aventuras de sus hijos; en ella se desarrollan los tradicionales sucesos de combate, amor, magia, fiestas de palacio, etc., que la colocan en la misma línea de tópicos caballerescos con los demás libros del género; sin embargo, hay un elemento de originalidad $^{473}$ que destaca en esta primera parte, un grabado único e irrepetible, los rostros de los protagonistas a manera de retrato (fig. 230).

\footnotetext{
${ }^{471}$ María Martínez Martínez, "Oficios, artesanía y usos de la piel en la indumentaria ...”, p. 265.

${ }^{472}$ Carmen Bernis, El traje y los tipos sociales ..., p.18.

${ }^{473}$ Además de este elemento gráfico, hay varios pasajes en donde la indumentaria adquiere relevancia por los accidentes que provoca y las acciones que se desarrollan en torno a ella. Véase en este mismo capítulo el apartado dedicado a las aportaciones textiles del ciclo de Espejo de príncipes y caballeros en comparación con las de Feliciano de Silva.
} 


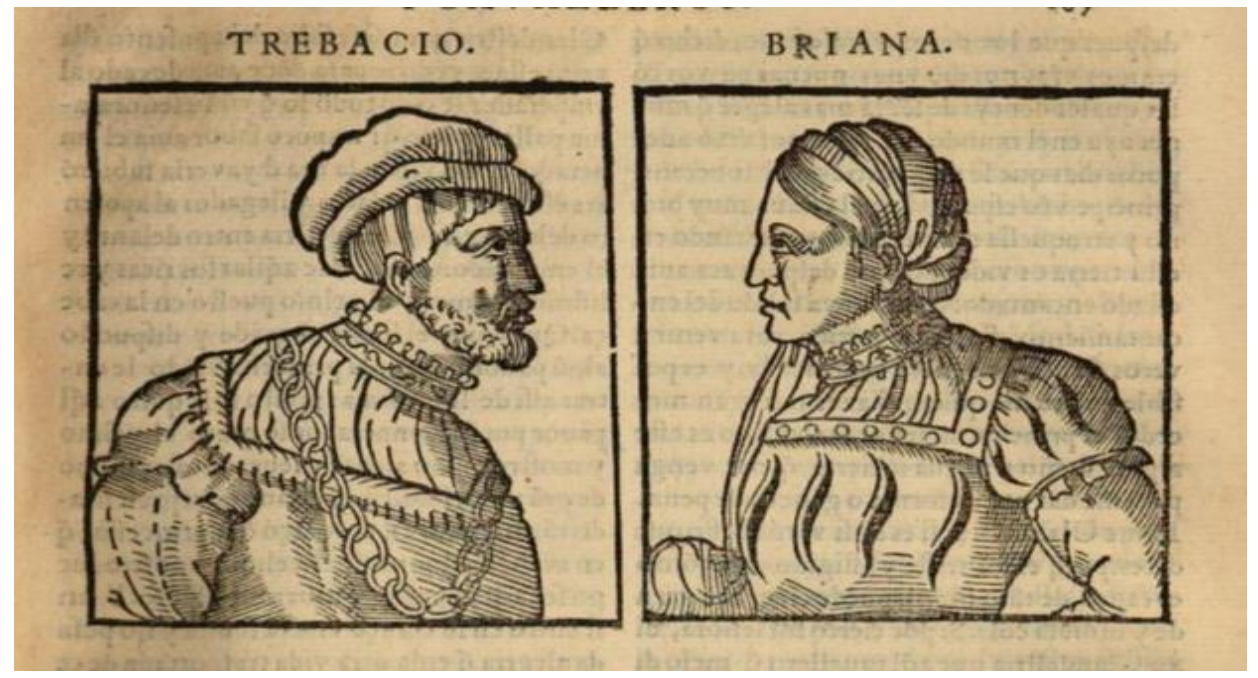

Fig. 230. Espeio de príncipes y cavalleros $I, \mathrm{LI}^{474}$

En el capítulo LI se cuenta el regreso de Trebacio al Monasterio de la Ribera, después de estar encantado en la ínsula de Lindaraxa, para reunirse con su esposa Briana, situación que se desarrolla entre lágrimas y muestras de afecto por el largo periodo que estuvieron separados. La pareja conversa sobre los sucesos ocurridos durante su ausencia y se entera del nacimiento de sus dos hijos. En medio de estas confesiones, se inserta la imagen anterior, los retratos de la pareja protagónica cuya identidad se da por los nombres que el impresor coloca.

\footnotetext{
474 Diego Ortúñez de Calahorra, Espeio De Principes Y Cavalleros: En el qual se cuentan los inmortales hechos del Cauallero del Febo, y de su hermano Rosider hijos del grande Emperador Trebacio. Con las altas cauallerias, y muy extraños amores de la muy hermosa y estremada princessa Claridiana y de otros altos principes y caualleros, Volumen 1, Çaragoça, Estevan de Najera, 1555, p.187. [En línea] https://reader.digitale-sammlungen.de/de/fs_1/object/display/bsb10943839_00001.html

La imagen procede del ejemplar conservado en la Biblioteca Estatal de Baviera.

Es curioso que de las tres primeras partes de esta primera edición sólo aparece esta imagen de la pareja de Trebacio y Briana. A la fecha, la crítica no ha establecido relación alguna entre el texto y los dos grabados, ni se hace mención a ellos en ninguno de los artículos acerca del ciclo de Espejos de príncipes y caballeros; además, en las ediciones de los siglos XVI y XVII de esta primera parte tampoco vuelven a aparecer dichas imágenes, al menos en las que se han podido consultar para esta investigación, las de 1580 y 1617. Será hasta la edición de Daniel Eisenberg de 1975 cuando vuelvan a aparecer los retratos.
} 
En primera instancia se nota un modelo de iconografías alejado de los comunes del siglo XVI, en los que los ornamentos florales, los marcos decorados y la presencia de fondos están ausentes en este ejemplo. Los adornos más detallados están en la portada, pero lejos de ese primer acercamiento con la obra, no hay más elementos de decoración gráfica.
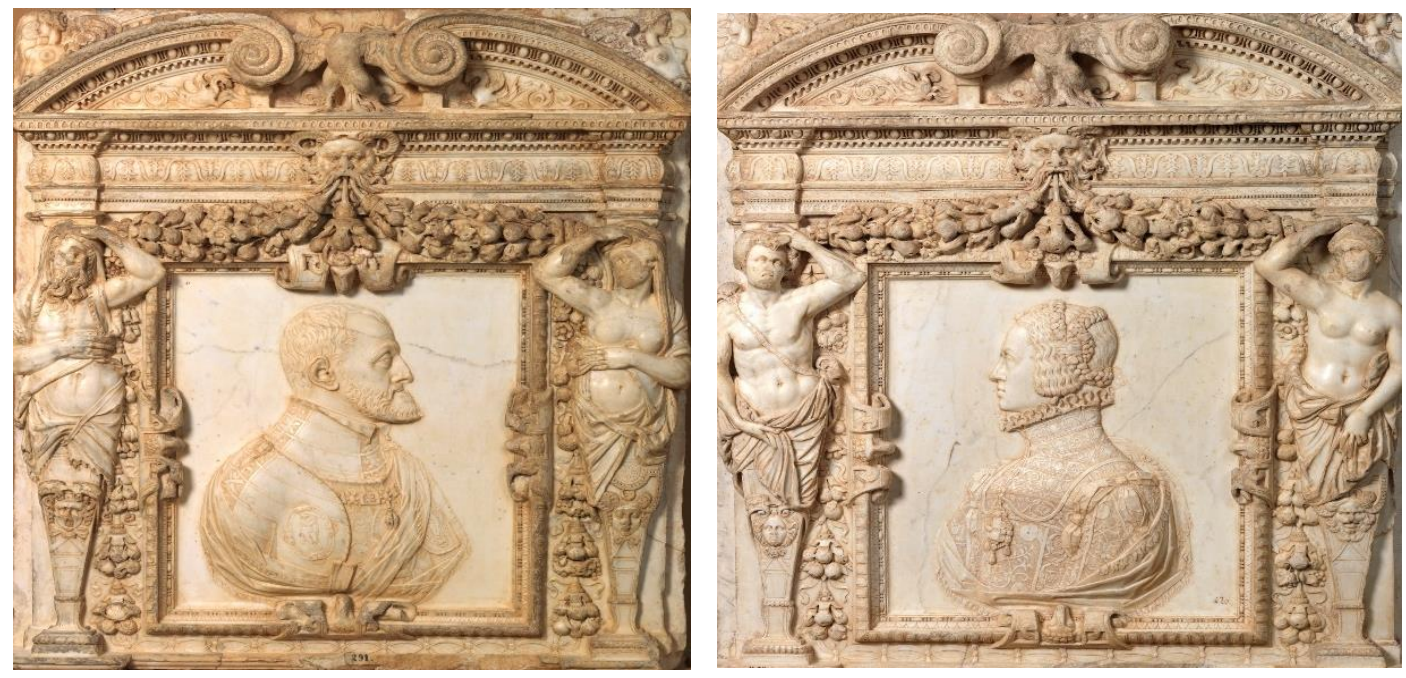

Fig. 231. Relieves de Carlos Ve Isabel de Portugal (1550-1555) Leone Leoni, Museo Nacional del Prado

Lo primero que se es observa es que se trata de dos imágenes a manera de retrato, similares a los relieves de Carlos V e Isabel de Portugal (fig. 231) realizados por Leone Leoni. Estos grabados en mármol son los más parecidos en cuanto a perfil y prendas que se hallan en la misma época. En ellos destaca el detalle del cuello, una gorguera alta, similar en ambas imágenes. La lechuguilla es más visible en la pintura de los emperadores (fig. 232) en donde el contraste del terciopelo negro con el blanco muestra una de las características de la moda española desde los Reyes Católicos, el uso de prendas negras por considerarse el “"color de la etiqueta' porque daba realce a las joyas y pieles" ${ }^{475}$; en el caso de Trebacio, se aprecia que la angosta tira que rodea la lechuguilla posiblemente es una piel

475 María Martínez, "La creación de una moda propia en la España de los Reyes Católicos", Aragón en la Edad Media, N․ 19,2006, p.357. 
de marta, cebellina o cisne, pero no de armiño, puesto que no se notan las características manchas negras.

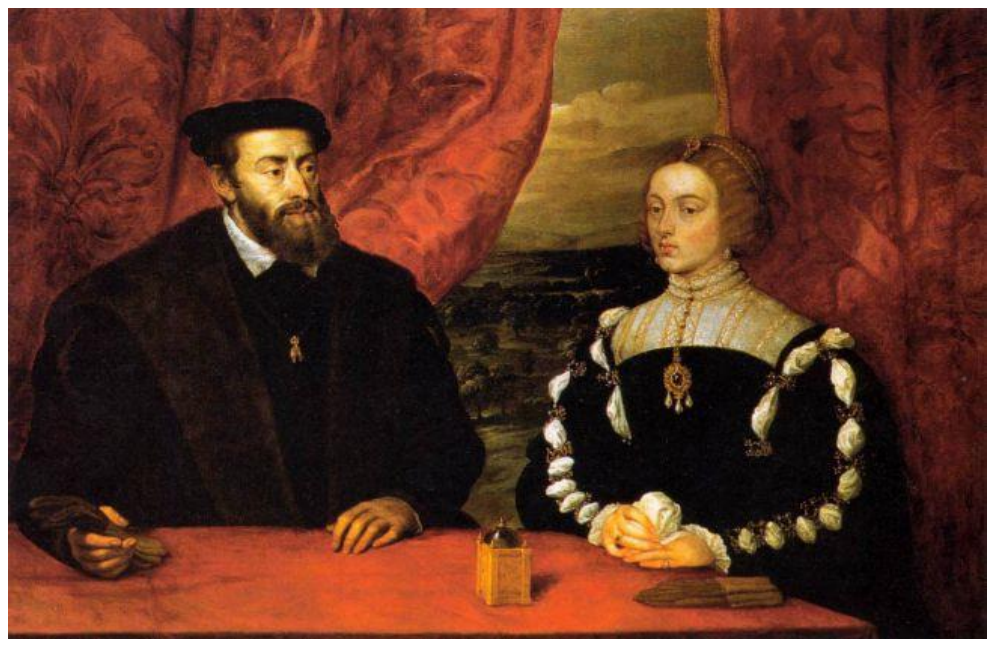

Fig. 232. El emperador Carlos V y la emperatriz Isabel de Portugal (1648) Peter Paul Rubens, Palacio de Liria.

Lo que más predomina en estos retratos son los pequeños detalles que adornan la ropa. Por un lado, las mangas llevan entretallados, a manera de pequeñas pestañas cuadradas; la cadena de Trebacio recuerda a las que llevan Carlos V y Felipe II en numerosos cuadros. Así mismo, los botones, con uso funcional y ornamental colocados alrededor de la lechuguilla mantenían una doble utilidad; por una parte, como adorno para enriquecer más la tela, por el otro, para sujetar la saya con la lechuguilla a fin de poder intercambiar ambas prendas y tener más combinaciones posibles en los vestidos, lo cual era una estrategia femenina que permitía usar cada día diferentes atuendos. Por ejemplo, en el armario de Isabel de Portugal predominan los sayos altos negros, ${ }^{476}$ los cuales son la base para la combinación de trajes. Esta alternancia de prendas se observa en las figuras DD y 233, en ambas lleva la misma saya entera, con la característica de que en la figura EE la

476 Carmen Bernis, Indumentaria española en tiempos de Carlos $V$, Madrid, Instituto Diego Velázquez/Consejo Superior de Investigaciones Científicas, 1962, p. 65. 
ornamentación rectangular de metal son sujetadores para prender el cuello, a fin de desprenderlo para llevarla con otros tipos de tela como el encaje y la gasa.

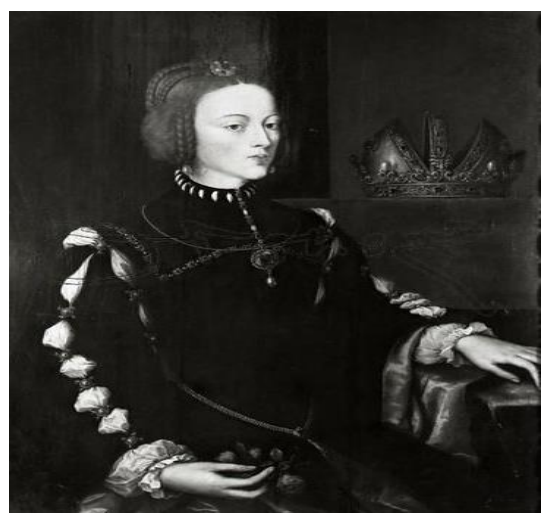

Fig.233. Emperatriz Isabel de Portugal (h.1530-1539) Sánchez Coello, Colección León Roblot, París.

Uno de los rasgos más distintivos son las cuchilladas, las cuales se pueden observar en varias pinturas de los monarcas porque marcaron una moda en las prendas españolas de la época, en un principio, de influencia italiana, ${ }^{477}$ primero en las mangas y posteriormente en todo el cuerpo, esta técnica fue propia de la moda europea, ocasionando la disputa entre Alemania, Italia, Flandes, Inglaterra y España ${ }^{478}$ por establecer quién fue el iniciador de las cortadas en la tela (fig. 234).

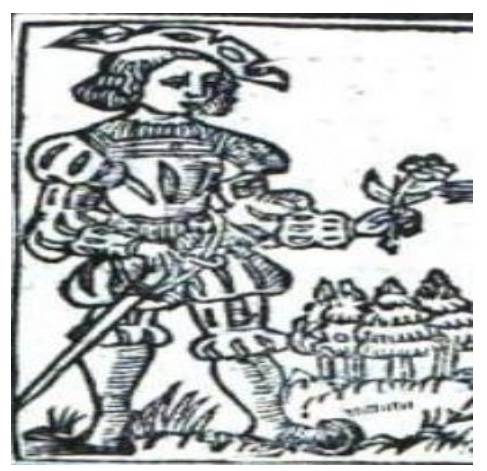

Fig. 234. Tragedia Policiana $(1547)^{479}$

${ }^{477}$ Cristina Sigüenza Perlada, La moda en el vestir en la pintura gótica ..., p.151.

478 Hay una hipótesis que plantea la introducción de los acuchillados a través de los trajes del ejército de Carlos V a su llegada a España. Véase Francisco de Sousa Congosto, Introducción a la historia de la indumentaria en España, Madrid, Itsmo, 2007.

${ }^{479}$ Nótese el mismo estilo en el corte de las cuchillas en el pecho de Briana y Policiano. En esta imagen se trata de un jubón acuchillado. 
Las imágenes anteriores manifiestan un conocimiento de la técnica de grabados y retratos hechos por impresores y pintores, en donde los detalles permiten identificar las prendas y el origen de éstas; sin embargo, hay un vacío en la conexión del texto con la historia, no sólo por ser la única, sino porque sólo se dan los nombres de los protagonistas. Ante la falta de elementos de la crítica caballeresca hacia esta xilografía, es necesario abordar la posibilidad de su simbolismo a través del tipo de obra en que se presenta y profundizar en una de sus características, el espejo como reflejo de lo que se vive. Sobre esto, Axayácatl Campos expresa que "en ella hallan reflejo los valores que sirven para subrayar el proceder de un buen príncipe y de un buen caballero. Se trata de educar a través de las imágenes y de las acciones de los personajes" 480 . Este comportamiento, que en un primer plano está presente en todos los libros de caballerías, en los Espejos es necesario hallar en el mismo texto la relación entre imagen-texto y de acuerdo al capítulo LI, se puede considerar este fragmento:

[...] quando le Emperador se perdió no tenia mas edad de catorze años y contado el tiempo que avía pasado hasta allí tenia entonces treynta y quatro años, que conforme a las edades largas de aquel tiempo, era la edad en que la hermosura estaba en su perficion, y en mas vigor y fuerça. Y ansi era la verdad, que si la demasiada tristeza de la Princessa no la tuviera algo flaca, muy mas hermosa y fresca estaba en este tiempo que quando la vio el emperador, y tiempo vino presto que con el demasiado placer se puso tal que muy pocas avia en el mundo a quien ella no hiziera ventaja en hermosura. (Espeio De Principes Y Cavalleros I, LI)

El mal de amores por la ausencia del amado provoca varios malestares físicos en la pareja, tristeza, flaqueza, debilidad y melancolía, pero ante esta adversidad prevalece la vitalidad de ambos, como una especie de valentía ante los infortunios, lo que permite que este

\footnotetext{
${ }^{480}$ Axayácatl Campos García Rojas, "El ciclo de Espejo de príncipes y caballeros [1555-1580-1587]”, Edad de Oro, XXI (2002), p. 396.
} 
capítulo se centre en las emociones afectivas de la pareja. Sin embargo, sigue un poco ausente la relevancia de la historia en las ilustraciones, ya que este tipo elementos gráficos “constituyen un poderoso recurso argumental que utilizan los autores de los libros de caballerías" $" 481$ porque sirven como referente de la trama para dar a conocer a los personajes posteriores las hazañas pasadas de sus antecesores; sin embargo, en el ejemplo de las xilografías de Trebacio y Briana, hay una singularidad en comparación con otros libros de caballerías; primero, es la única que se halla en todo el libro, no hay una significación en cuanto al lugar en el que aparece (cap. LI), no revela ninguna acción, ni preserva algún suceso, como en el caso de los murales, sino que se inserta como recurso gráfico para resguardar en la memoria del lector la imagen de los protagonistas, y de las condiciones físicas y sentimentales anteriormente descritas, por lo que en este sentido, mantiene cierta relación con algunas xilografías de Cárcel de amor y es que "en este caso se relega el protagonismo de la pareja de amantes, sin utilizar grabado alguno que dé cuenta de aspectos concretos de la narración" 482 lo que permite establecer otra posibilidad para dicha ilustración, la preocupación del impresor de resaltar con sencillez sólo los pasajes sentimentales, o la condición de principiante en el tema caballeresco de Esteban de Nájera, ${ }^{483}$ quien al tener una sola obra de esta materia y conocer el auge de estos libros, probablemente quiso diferenciarse de entre los demás títulos y tipos de grabados, no

\footnotetext{
${ }^{481}$ Axayácatl Campos García Rojas, "Historia y amor ex arte en los libros de caballerías: Espejo de príncipes y caballeros, en Mercedes Pampín Barral y Carmen Parrilla García (coord.), Actas del IX Congreso Internacional de la Asociación Hispánica de Literatura Medieval (A Coruña, 18-22 de septiembre de 2001), I, A Coruña, Universidade da Coruña, Departamento de Filoloxía Española e Latina: Toxosoutos 2005, p.612. ${ }^{482}$ Carmen Parrilla García, "Vestir las palabras: grabados xilográficos en la ficción sentimental", Revista de poética medieval, 30 (2016), p.264.

${ }^{483}$ Entre sus obras impresas destacan: De vini commoditatibus de Alfonso López de Corella (1550), el Libro de Apothegmas de Erasmo de Rotterdam (1552), el breve tratado Arte subtilissima, por la qual se enseña a escreuir perfectamente de Juan de Icíar (1553), La Vida del Gran Capitán de Paolo Giovio (1553), el Espeio de principes y cavalleros de Diego Ortúñez de Calahorra (1555), el Enchiridion Passionis Christi de Juan de Torralba (1556) y la Cuarta parte de la Contemplación de Fray Luis de Granada (1558).
} 
colocando una viñeta al principio de cada capítulo, ni con demasiados detalles como elementos naturales, animales, arquitecturas, barcos, etc., sino simplemente dos retratos con una posible alusión a ciertas personalidades de la corte española, o, tal vez, como lo hizo con su impreso de Cárcel de amor, "tuvo un deseo de renovar la iconografía". ${ }^{484}$

Este par de imágenes es único en los libros de caballerías, no sólo por la posición de perfil que tiene, sino porque el simbolismo ${ }^{485}$ debe comprenderse en las palabras del narrador en una situación que no depende de las acciones bélicas o mágicas, sino del estado emocional de los personajes.

Es diferente lo que sucede con los apartados precedentes, en los que se toman como base los modelos iconográficos de la época para representar a través de imágenes algunas de las escenas de sus historias, ya sea que estén completamente relacionadas con el capítulo o que hagan referencia a una parte en específico. En el caso del Claribalte, analizado anteriormente, es evidente la relación de la ilustración del folio 19 con el capítulo XVI por la vestimenta que lleva Dorendayna para ocultar su identidad, por lo que en ésta se dibuja la toalla a fin de cubrir el rostro de la dama. Sin embargo, en este ejemplo del Espejo de príncipes y caballeros, la conexión imagen-trama tiene que ver con el estado de ánimo de los personajes después de la aventura del encantamiento y que en voz del narrador se hace

\footnotetext{
${ }^{484}$ María del Carmen Marín Pina, "Adaptación de grabados de Hans Holbein para la Cárcel de amor (Zaragoza, Esteban de Nájera, 1551)”, JANUS 6 (2017), p. 141.

Se debe destacar que los grabados que usa en Cárcel de amor son más detallados, tienen más elementos de decoración e incluso la vestimenta de los personajes se presenta de cuerpo completo, entre las que predominan capas, jubones, sayas, incluso algunos calzados, tanto de hombres como mujeres.

${ }^{485}$ En el capítulo XLIV el Caballero del Febo entra al castillo de Lindaraxa y en una pared ve figurados los grandes caballeros, entre ellos estaban Trebacio y Rosicler, cada uno con sus nombres. También ve a la princesa Briana cubierta de luto. Más adelante hay una plática entre él y Lindaraxa, en la cual el caballero menciona a la princesa Briana. En este pasaje Daniel Eisenberg en su edición comenta a pie de página que "¿Cómo pudo saber el Caballero del Febo el nombre de la esposa de Trebacio? Descuido del autor, o debemos entender que su nombre estaba pintado en la pared". Diego Ortúñez de Calahorra, Espejo de príncipes y cavalleros (El cavallero del Febo), T.II, ed. de Daniel Eisenberg, Madrid, Espasa-Calpe, 1975, p. 201.

Posiblemente los retratos que se hallan siete capítulos después sean los mismos que estaban pintados en el castillo de Lindaraxa; sin embargo, de acuerdo a la descripción hecha de Briana, con lágrimas en los ojos, no hay tanto parecido con el retrato. Eisenberg no hace ninguna otra referencia a estos retratos.
} 
énfasis sobre el estado físico, la edad y la belleza de ambos. Es así que la indumentaria se utiliza para reforzar la fisionomía de los personajes, de quienes, a pesar de que se menciona la flaqueza de la dama y la tristeza del caballero, no aminora su simpatía, sino que se incrementa con su atuendo.

De este modo, este episodio reúne tres elementos importantes: 1) Imagen de rostros (única de este tipo en todos los libros del género); 2) Presentación de vestimenta (muy similar a la de varios retratos de la época); 3) Relación de la xilografía con el contexto dado por el narrador. Estos rasgos abren la posibilidad para un nuevo tipo de grabados, aquellos que necesitan un contexto para poder ser relacionados con la historia, porque enmarcan a dos personajes, pero su significado está en la condición del tiempo que estos han estado alejados, por lo que la apariencia es el elemento que motiva su inserción en medio del capítulo.

La presencia de los anteriores grabados es una herramienta de estudio para el conocimiento de ropas en el siglo XVI. Dentro de cada viñeta se albergan materiales textiles, tipos de bordados y diseños de metal y tela que permiten construir un catálogo de prendas extraídas de los mismos libros. Esto no sólo es un acumulado de accesorios, sino una base que sustenta el conocimiento de la vestimenta de la época, puesto que como ya lo mencionó Carmen Bernis el impresor “tomaba sus imágenes del mundo que lo rodeaba" ${ }^{486}$, con lo cual, se trasladaban los diseños textiles al papel en forma que la moda de la época se conservara a través de la tinta. Como se ha visto, hay varios referentes a los enseres, pequeños detalles que muchas veces dentro de la historia no cobran relevancia, puesto que ésta se les da a las prendas de mayor volumen, como sayas, mantos y faldas; sin embargo, la importancia de las miniaturas se basa en recrear exactamente los accesorios: joyas,

\footnotetext{
${ }^{486}$ Carmen Bernis, "El manuscrito de París. Estudio arqueológico”, p.195.
} 
sombreros, abanicos y calzado, este último de mayor importancia debido a que había modelos para todas las clases y oficios, por lo cual era necesario detallar las suelas, el tacón y la chinela para armonizarlos con el resto de la vestimenta. Por lo que las xilografías se convierten en centros de confección que almacenan tipos de tela, bordados y diseños que estuvieron en auge durante el siglo XVI.

\subsubsection{Aportaciones indumentarias al género}

Una de las características que se dan de los libros de caballerías es que mantienen “idénticos esquemas de aventuras, algunos auténticos calcos, perpetuando sagas de personajes, o encareciendo el narrador o los mismos personajes el parecido de situaciones, de forma que la obra se imbrica totalmente en la anterior y con ello se alcanza la cohesión y la unidad del conjunto narrativo" ${ }^{" 487}$. Elementos narrativos que los escritores recrean con similitudes e invenciones nuevas; al respecto, Marín Pina expresa que este tipo de imitación sobre "el arquetipo heroico propuesto conjuga los materiales heredados"488 que de una u otra forma se establecen en todas las obras y cada escritor le da el tratamiento a su manera. Este mismo método, se ajusta a las necesidades de la época para el aspecto de la indumentaria, cuya característica principal es que hay un gran dominio de tejidos, modelos y formas en todos los libros de caballerías, por más mínima que sea la alusión a su presencia, en cada título caballeresco sobresale un tipo de diseño textil y una forma singular de los autores para insertarla en la historia.

En el caso de Feliciano de Silva, es evidente el amplio y laborioso estilo retórico que lo identifica para lograr una descripción detallada, de pies a cabeza, de todos los

\footnotetext{
${ }^{487}$ María Carmen Marín Pina, "Introducción”, en Primaleón...,p. 13.

${ }^{488}$ María Carmen Marín Pina, "La recreación de los modelos narrativos caballerescos en la Historia del invencible caballero don Polindo (Toledo 1526)”, C.I.F., T.XV, fasc. 1 y 2, (1989) p.94.
} 
accesorios que conforman el atavío de cada personaje, desde el color de la tela, la forma en cómo están colocadas las perlas, hasta las figuras bordadas en los vestidos y las piedras que adornan los sombreros. Todo ello permite una clara identificación de la moda que Silva pretende transmitir y de las influencias extranjeras, de Europa y Asia, principalmente, que recibió y observó durante su presencia en la corte.

Además de esto, los autores caballerescos, herederos de la tradición medieval en el arte de crear, debían imponer estilos, modas, modelos de confección tan deseables como con los que convivía la sociedad de la época; para lograrlo, recurrieron a las fuentes históricas, relaciones de bailes, recibimientos triunfales, coronaciones, viajes de la monarquía, etc., en cuyo ambiente imperaba el estilo de la época. En el caso de Silva, no sólo fue testigo de estos eventos, sino partícipe en algunos de ellos al fungir como regidor de Ciudad Rodrigo y estar al servicio del emperador Carlos V. Gracias a su presencia en este ámbito, Silva pudo conocer a fondo los gustos en telas, colores y accesorios de las doncellas de la corte, observar las formas de comportamiento y el modo de usar la ropa, por ello, logró profundizar en los pasajes de fiesta a fin de detallar más a sus personajes, principalmente los femeninos.

Sobre esto, es importante recordar uno de los preceptos de Lipovetsky en cuanto a que la moda tiene "la vocación de asombrar, de inventar novedades sin cesar" ${ }^{489}$, en este sentido, Feliciano de Silva se coloca como uno de los más grandes creadores de estilo de atuendos caballerescos convirtiéndose en modelo de imitación por muchos de sus contemporáneos, quienes de una u otra forma extraen los elementos más llamativos de su vestimenta y los ajustan a sus obras.

${ }^{489}$ Gilles Lipovestky, El imperio de lo efímero. La moda y su destino en las sociedades modernas, trad. de Felipe Hernández y Carmen López, Barcelona, Anagrama, 1990, p.111. 
En este sentido existieron otros ciclos caballerescos que gozaron de fama en su época como el Espejo de príncipes y caballeros (1555- principios siglo XVI), Clarián de Landanís (1518-1528), Belianís de Grecia (1545-finales siglo XVI), etc. Cada uno de estos ciclos tiene entre cuatro y cinco partes escritas por un autor distinto, lo cual, a mi parecer, no permite que haya continuidad en la creación artística de la vestimenta, debido a que de forma individual recreaban los modelos sin que se pudiera ver su evolución en obras posteriores. Sin embargo, en Feliciano de Silva, al ser el único creador de su saga, se puede observar su madurez creativa en el detalle de las prendas.

Además, algunos tintes de Feliciano de Silva resuenan en numerosos pasajes en donde la "claridad de su prosa", como lo identificara Cervantes, se asoma en las formas descriptivas de las prendas, incluso en obras de otros géneros pareciera haber destellos de su retórica, baste el siguiente ejemplo cuya expresión se pensaría ser la voz de Feliciano:

Vistieron ellas mismas a Felismena una ropa y una basquiña de fina grana, recamada de oro de canutillo y aljófar, y una cuera y mangas de tela de plata emprensada. En la basquiña y ropa havía sembrados a trechos unos plumages de oro, en las puntas de los cuales havía muy gruessas perlas. Y tomándole los cabellos con una cinta encarnada se los rebolvieron a la cabeça, poniéndole un escofión de redezilla de oro muy sutil, y en cada lazo de la red assentado con gran artificio un finíssimo rubí. En dos guedellas de cabellos, que los lados de la cristalina frente adornavan, le fueron puestos dos joyeles, engastados en ellos muy hermosas esmeraldas y çafires de grandíssimo precio. Y de cada uno colgavan tres perlas orientales hechas a manera de bellotas. Las arracadas eran dos navezillas de esmeraldas con todas las xarcias de cristal. Al cuello le pusieron un collar de oro fino, hecho a manera de culebra enroscada, que de la boca tenía colgada una águila, que entre las uñas tenía un rubí grande de infinito precio. ${ }^{490}$

\footnotetext{
${ }^{490}$ Jorge de Montemayor, Los siete libros de la Diana, Madrid, Editora Nacional, Libro IV, 1976, p. 166.
} 
Nótese la semejanza con el siguiente pasaje en el que se describe el vestido de Archisidea:

Una ropa larga y muy ceñida de raso carmesí hazia se sobre ella una red de torcidos de raso blanco de anchura de un dedo que dexava entre torcido y torcido en las vandas y tiras que hazian la red descubierto tanto como medio dedo de ancho del carmesí y dexavan hechos los cuadrados de la red del tamaño de los cuadros de un xedrez [...] detrás de cada oreja salían dos hermosas y largas guedexas de sus cabellos que dexavan sus muy ricas y resplandescientes arracadas por medio descubiertas y las guedejas se cruzaban por embaxo atadas con un joyel de un rico diamante de cada parte y las puntas trocadas en la cruz, que della se hazía la una se esparzía por sus hermosos pechos y riquissimo collar de rubies y diamantes que llevava y la otra por las espaldas juntamente con cinta de lo mesmo del collar. (Florisel de Niquea IV, II, LXXIII)

En ambos ejemplos hay una detallada descripción de cada uno de los elementos que portan ambas damas, desde el modo del peinado con su tocado, el estilo de la ropa, la tela y los adornos, hasta las joyas y piedras preciosas, de las cuales sobresale la forma y el tamaño. Sydney P. Cravens expresa que "por su delectación en las telas finas, los metales y las piedras preciosas, Silva antecede a Montemayor, que hace una descripción semejante del vestido que las ninfas le ponen a Felismena" ${ }^{\text {491, }}$, como ya se vio en el ejemplo antes citado. Además de eso, se debe considerar la fecha de publicación de las obras de Silva (1514, 1530, 1532, 1535 y 1551) frente a la Diana (1559) y que en el Amadís de Grecia (1530) ya se introducen elementos pastoriles aunados a las detalladas composiciones textiles, por lo que hay un considerable tiempo para que los demás autores conocieran el estilo de Silva y recrearan algunos de sus pasajes.

\footnotetext{
${ }^{491}$ Sidney P. Cravens, Feliciano de Silva y los antecedentes de la novela pastoril en sus libros de caballerías, Estudios de Hispanofilia, Madrid, Castalia, 1978, p.78. Además, propone la idea de la influencia de algunos nombres de sus personajes en obras posteriores, por ejemplo, Darinel y Silvia como posible influencia para Daranio y Silveria, los novios de La Galatea, además de su propio nombre, Feliciano, para Felismena y Felis.
} 
En su afán de captar la atención del lector, Silva ensaya propuestas innovadoras: la complicación argumental, la proliferación de personajes, el recurso del equívoco o la reelaboración de tópicos precedentes son reflejo de esta estética. Ahora bien, aparte de esta tendencia innovadora, Silva no renunciará a las propuestas literarias puestas en circulación por él mismo. Cuando estas novedades estén consolidadas, no tendrá ningún reparo en que la peripecia de sus criaturas sea el resultado de la geminación de otros modelos anteriores. Todo ello, porque Silva es un escritor que crece conforme se suceden sus crónicas, y que cada vez es más consciente del alcance de su propia inventiva. ${ }^{492}$

Y que el mismo Feliciano será capaz de superar sus propios modelos textiles creados en sus primeros libros, para culminar en la cima de la confección, de lo cual se propuso la posible influencia en la creación de una capa confeccionada 66 años después de que la imaginara en el Lisuarte y que presenta una gran semejanza con la descrita en la historia, por el color y los bordados de oro.

Entonces ¿cuál fue la clave del éxito de las creaciones de Silva? La respuesta se da en distintos elementos, el primero de ellos es el público. De manera general, los lectores, aficionados de ese imaginario mundo de gigantes, magas y castillos “cada vez exigen más de estos libros de entretenimiento"493, por lo que los escritores debieron cubrir las peticiones de los lectores para seguir vigentes en el mercado editorial. Estos requerimientos no bastaban con los mismos episodios bélicos, sino que requerían de innovaciones que abarcaran al otro sector lector, las mujeres, ya que, "mientras los caballeros podían

\footnotetext{
492 Emilio José Sales Dasí, "Princesas "desterradas" y caballeros disfrazados. Un acercamiento a la estética literaria de Feliciano de Silva", Revista de Literatura Medieval, XV/2 (2003), p. 105.

493 José Manuel Lucía Megías, Imprenta y libros de caballerías..., p. 272.
} 
aprender con los hechos militares, las damas se deleitaban con los amorosos", ${ }^{494}$ pero también buscaban en ellos las novedades textiles que se usaban en otros países y a las que sólo tenían acceso a través de la lectura.

Al respecto hay tres categorías en las que Feliciano supera en gran medida a todos los demás autores por la forma en cómo las desarrolla: las prendas para cubrir el rostro, los vestidos de novia y los bordados de amor del caballero y la dama.

Para los bordados de amor relaciona la tela con el metal, por medio de los tocados, que como ya se hizo mención en los capítulos anteriores es el episodio de las bodas en donde su imaginación alcanza la perfecta creación como diseñador, porque al entretejer las historias de amor en la propia vestimenta, se establece un doble canal de comunicación en el que los lectores de la época debieron captar los mensajes encriptados a través de la tela, para así comprender cada uno de los adornos que llevaban las damas. Sobre esto, el ejemplo más llamativo es el tocado de Alastraxerea, la cual llevaba "doze joyeles que no tenían precio, de forma de harpías hechos, y sobre la cabeça una guirnalda de una dança de joyeles de las mismas harpías" (Florisel de Niquea II, LXIII), además de las “aes” griegas bordadas en el vestido de Oriana en clara alusión a Anaxartes. Este desarrollo de letras de amor en los trajes de boda fue imitado y copiado especialmente por dos autores, el primero de ellos Dionís Clemente, en su Valerián de Hungría, quien trata de imitar el estilo descriptivo de Silva al colocar dos letras bordadas "F y P" por Finariel y Polidia; sin embargo, su estrategia se rompe ante la falta de interés por la misma, ya que se queja de lo laborioso que es describir los atuendos femeninos, por lo que prefiere no hacerlo. Así que, a pesar de detallar los trajes de la pareja, ésta pierde la calidad por la falta de interés de su

\footnotetext{
${ }^{494}$ María Carmen Marín Pina, "Lectores y lecturas caballerescas en el Quijote", Actas del III Coloquio
} Internacional de la Asociación de Cervantistas, 1993, p.270. 
autor. El segundo se trata de Esteban Corbera, quien en su Febo el troyano, no sólo anexa varios de los diseños de Silva completamente iguales, sino que le cambia algunos pequeños detalles para apropiárselos y considerarlos una creación suya, motivo por el que es criticado por formar su libro a partir de los modelos de otros escritores.

El más importante, el uso de la indumentaria para contribuir a la construcción de los personajes femeninos acorde a su presencia en las historias a través del atuendo; es decir, la dedicación de realizar un traje especial para cada dama, princesa, guerrera, viuda, niña, reina, etc., con los ornamentos adecuados a su estado y condición sentimental. Esto implicó la reelaboración de ciertos accesorios como el antifaz, que innovó a través del motivo por colocarlo en el rostro de las jóvenes, desde una situación de resguardar su identidad, hasta la comicidad por vigilar a los esposos. En este sentido, el uso de velos, antifaces y rebozos dejaron de ser simples coberturas de la cara para integrarse, en algunos pasajes, al tocado femenino, a modo de una prenda de gala.

En cuanto a los varones, la condición de su vestimenta se adaptó a las necesidades sentimentales para estar con su dama; hecho que originó el uso de atuendos femeninos en los hombres para tener libre acceso a los espacios femeninos de la corte, sin temor a ser descubiertos y con la certeza de que podrían estar tanto tiempo como quisieran junto a la joven. Pero también, la armadura mantuvo su vistosidad a través de las sobrevestes, en donde la tela y el metal se integraron para portar las divisas de amor de las damas.

Otro factor que contribuyó fue la continuación de los personajes caballerescos con un estilo novedoso, pues a pesar de los años establecidos en la ficción, la presencia de Amadís, Oriana, Esplandián, conservan tintes de su juventud, pero aún más de su imagen regia, al ser partícipes en cuestiones de juicios en los que deben solucionar conflictos 
sentimentales, por lo que no se olvidó de ellos, como lo hiciera Juan Díaz en su Lisuarte de Grecia, cuya trama alberga la muerte de Amadís, motivo por el que no tuvo el éxito esperado.

Ante la vestimenta analizada en los capítulos anteriores se logró comparar las funciones que establece Silva con otras que aparecen en los demás títulos caballerescos, en las que se diferencian por el modo en cómo las detallan los autores, pero que de alguna forma aparecen en las obras de Silva. Por lo que sólo en ciertos aspectos, hay relevancias, entre las que destacan la presencia del calzado y el material del que está fabricado y la forma del borceguí, así como la dificultad de las prendas para estar en el agua. 


\section{Conclusiones}

A través de los capítulos anteriores se han establecido diferentes funciones de la vestimenta que aparecen en los libros de caballerías de Feliciano de Silva con apoyo de otros títulos del género, además de fuentes históricas, pictográficas y crítica sobre la moda y la vestimenta desde la Antigüedad hasta el siglo XVI. Este recorrido textil inició con una frase general "ricamente vestida" en la que se encierra todo un universo de tejidos, patrones y diseños que estaban a la espera de ser desenvueltos.

La base principal fue el análisis de la presencia de la indumentaria en diversos episodios, en donde las hazañas bélicas, amorosas, fúnebres y festivas fueron el eje del que se partió para considerar cuáles elementos de la confección otorgaban un desarrollo de la aventura, por lo que fue necesario indagar acerca de todas las prendas que aparecieron, desde las interiores como la camisa y las bragas; las de encima como la saya, el jubón, las calzas y las medias calzas y los sobretodo, como el abrigo, la capa, el manto, etc.; de cada uno de ellos se presentó su tipo de confección, no sólo relacionada con la calidad de los paños, y el modo de costura empleado para su fabricación, sino también se establecieron las marcas de reconocimiento que permitían diferenciar su uso en las distintas clases sociales del siglo XVI, al igual que establecer los precios para comparar si correspondían los hallados en la ficción con los que aparecen en los libros de cuentas.

A partir de este momento se estipularon las Leyes suntuarias que controlaban el comercio textil en toda Europa y particularmente en España, restricciones establecidas por los Reyes Católicos a fin de aminorar los gastos de la sociedad y evitar que se endeudaran con la adquisición de nuevas prendas por querer imitar a la monarquía. En este aspecto se 
hallaron algunos ejemplos de personajes que, de acuerdo a su función en las obras, quebrantaban estos estatutos jurídicos, como fue el caso de Merlín, quien, en sus muchas transformaciones en personas de bajo estamento, aparecía con ornamentos de oro, generalmente en los zapatos.

Este fue el primer acercamiento a la vestimenta desde el aspecto histórico. Posteriormente, se consultó la crítica de la moda a través de las aportaciones de especialistas en el ámbito textil como Carmen Bernis, Ulinka Rublack, Roland Barthes, Sigüenza Perlada, entre otros, para formar una línea de investigación en torno al corpus seleccionado; ésta se estableció con base en dos motivos: uso funcional para cubrir el cuerpo y función simbólica que genera acciones en tres situaciones esenciales: amor, guerra y luto. A partir de este momento se comenzó el análisis en los títulos seleccionados: Lisuarte de Grecia, Amadís de Grecia y las cuatro partes del Florisel de Niquea, obras que comprenden un periodo de 37 años en los que hay tres influencias en la moda, los Reyes Católicos, Carlos V y Felipe II, por lo que fue necesario identificar los cambios de la ropa en relación al modelo, tela y adornos para descubrir las evoluciones de cada uno. Esto fue más visible en los tocados femeninos, en cuyo inicio predominan las tocas para finalizar con las guirnaldas y los tocados de ruedas y rollos. En cuanto a los hombres el cambio más interesante estuvo en las prendas de encima, debido a las aplicaciones de piel que estuvieron en auge con la llegada de Carlos V.

Asimismo, se establecieron las influencias de otros países en territorio español a través de los habiti, libros que recopilaron los trajes de la época de diversos continentes, y que se adaptaron a la península, pero también se logró identificar la influencia española en los trajes europeos, principalmente a través de 
la apropiación del color negro como signo de distinción. Sin embargo, uno de los mayores problemas a los que se enfrentó esta investigación fue la escasa bibliografía especializada en la vestimenta en los libros de caballerías, debido a que desde el inicio de este estudio sólo había tres artículos que analizaban la función social de las prendas como signo de distinción, por lo que fue necesario que se realizaran propuestas en diferentes aspectos como los trajes infantiles, la ropa de los gigantes, los elementos florales bordados como lenguaje de comunicación entre los enamorados y un panorama general de este tema, cuya realización se desprendió de algunos apartados de esta investigación.

La primera aportación que se realizó fue establecer un "lenguaje entre hilos" para las parejas enamoradas. Este análisis implicó la búsqueda de elementos decorativos como flores, animales y figuras geométricas que revelaran una comunicación secreta entre el caballero y la dama, con el objetivo que solamente ellos lo pudieran comprender a pesar de estar en un espacio público, rodeados por muchas personas. Así, se descubrió que dichas confesiones están más presentes en los trajes de novia, principal aportación de Feliciano de Silva, y en los trajes para las justas, en donde hay una comunicación de confesión-aceptación a través de la tela y el metal. Soportes que no sólo fungen como protectores del cuerpo, sino como una especie de catálogo que resguarda una gran diversidad de elementos de comunicación, que van desde una letra, hasta motes, cuya respuesta aparece en los vestidos de las damas.

Otro de los elementos de comunicación que más destacó fueron los tocados de las damas, los cuales, a través de las guirnaldas con piedras preciosas, permitieron el análisis del uso de las gemas a manera de escritos de cristal, mediante 
la composición de flores y animales en clara alusión a su amado y que, en la mayoría de los ejemplos, los caballeros responden favorablemente al incrustar las piedras preciosas en sus armaduras, de modo que recreen la misma imagen de su señora. En relación con el traje metálico, se analizó el color como una forma de manifestación del estado de ánimo del caballero, ocasionado por la dama y que muchas veces influyó en su participación en las justas. Esto fue posible a través de los tratados de heráldica y emblemas para relacionar la tristeza, el desamor y el sufrimiento con las divisas de los escudos, en donde la mayoría de las veces los corazones partidos y las serpientes fueron las principales imágenes para transmitir la pena amorosa.

Por último, se distinguieron cuatro categorías de prendas para transmitir mensajes: amor, protección, seducción y luto. En cada una de ellas se señaló la importancia de su confección para permitir el desarrollo de la hazaña, como fue el caso de la camisa, de la cual se señaló la necesidad de que su tejido fuera delgado para que permitiera descubrir el cuerpo de la dama y sedujera al caballero. También, el uso de accesorios para el rostro como el antifaz, el rebozo y el velo permitieron identificar la protección que brindan a la dama al cubrir su rostro y evitar ser identificada durante su travesía a distintas partes. En cuanto a las prendas de luto, se hallaron ejemplos en donde el lamento no siempre se relaciona con una muerte, sino con la desaparición, el alejamiento, el matrimonio forzado, etc., que provocan melancolía, la cual se manifiesta como una forma de duelo por las condiciones que obligan al personaje a separarse de su ser querido.

Finalmente, todos estos aspectos que crean una miscelánea de aventura textiles, en donde la vestimenta adquiere relevancia en torno a situaciones específicas, únicas e irrepetibles que otorgan originalidad e innovación a sus creadores, en el caso de Feliciano 
de Silva, permitió establecer una superioridad de este autor en cuanto a diseño y creación de la indumentaria femenina, desde las apariciones más sencillas como encuentros con el enamorado, bailes, justas, etc., hasta las más amplias y emocionantes hazañas, tales como bodas y desfiles. Estas últimas lo colocan en los primeros antecedentes de los trajes de boda, singulares por sus detalles e interesantes por la prolijidad de las descripciones que les dedica y aunque en otros libros del género aparece la descripción de algunas bodas, ninguna se le compara en cuanto a confección y diseño. Además de que este ajuar se complementa con los tocados y las piedras insertas en el cabello de la dama a manera de lenguaje, como un medio más de expresión amorosa y como hilo narrativo entre las reconciliaciones de los enamorados, cuya presencia se concreta en voz del narrador al rememorar ciertas situaciones de enojo que vivió la pareja y que a modo de recordatorio se insertan en el atuendo matrimonial. Todo esto permitió realizar una aportación en torno a la función de la vestimenta en los libros de caballerías de Feliciano de Silva, como un patrón que inició con unos cuantos tejidos y que ahora se ha transformado en todo un guardarropa conformado por una diversidad de modelos a la espera de ser usados. 


\section{Bibliografía}

Academia de la Historia, “Cortes de Burgos de 1379”, en Colección de cortes de los reynos de León y de Castilla, Madrid, Imprenta de don Marcelino Calero y Portocarrero, 1836.

Aguilar Perdomo, María del Rosario. “«Las doncellas seductoras y requeridoras de amor en los libros de caballerías españoles», Voz y Letra, 15.1 (2004), pp. 3-24;

---------«La arquitectura maravillosa en los libros de caballerías españoles: a propósito de castillos, torres y jardines», Lingüística y Literatura, 51 (2007), pp. 127-148.

-_De vuelta sobre la seducción en los libros de caballerías. Con especial atención a la figura masculina y el ‘donjuanismo"”, Revista de Poética Medieval, 26 (2012), pp. 31-51.

Aldave Monreal, Esther. “Traje y moda en la Zaragoza de Carlos IV (1788-1808)”, Trabajo de fin de Máster, Universidad de Zaragoza, 2012.

Alemán, Mateo. Guzmán de Alfarache II, ed. de Benito Brancaforte, México: REI, 1990.

Alfau de Solalinde, Jesusa. Nomenclatura de los tejidos españoles del siglo XIII, Madrid: Anejos del Boletín de la Real Academia Española, (XIX), 1969.

Alfonso X. Lapidario, ed. de María Brey Mariño, Madrid, Castalia, 1997.

Altamirano Meza, Gerardo Román. Thauma idestai. La écfrasis medieval de dos motivos descriptivos: escudos y tiendas historiadas, Tesis doctoral. México: UNAM, 2015.

Arderique, ed. de Dorothy Molloy Carpenter, Alcalá de Henares, Centro de Estudios Cervantinos, 2000.

Aunés, Jerónimo de. Libro segundo de Morgante, Valencia, Duran Salvanyach, 1535.

http://access.bl.uk/item/viewer/ark:/81055/vdc_100034155269.0x000001\#?c=0\&m=0\&s=0 $\& \mathrm{cv}=2 \& \mathrm{xywh}=-393 \% 2 \mathrm{C}-304 \% 2 \mathrm{C} 6103 \% 2 \mathrm{C} 3370$

- Morgante I, ed. de Marta Haro Cortés, Alcalá de Henares: Centro de Estudios Cervantinos, 2010.

Arbeteta, Letizia. La joyería española de Felipe II a Alfonso XIII en los museos estatales, Madrid: Nerea, 1998.

Arguijo, Juan de. Relaciones de fiestas de toros de Sevilla, 1617. 
Barthélemy l'Anglais, El libro de proprietatibus rerum, trad. du latin en espagnol par Vicente de Burgos, Tholosa, 1494. [en línea] https://gallica.bnf.fr/ark:/12148/bpt6k54513p/f6.image

Barthes, Roland. Sistema de la Moda, Barcelona: Gustavo Gili, 1978.

Basurto, Fernando. Florindo, ed. de Alberto del Río Nogueras, Alcalá de Henares: Centro de Estudios Cervantinos, 2007.

Beltrán Llavador, Rafael. "Tres magas en el arte de la seducción: Trotaconventos, Plazerdemavida y Celestina", El arte de la seducción en el mundo románico, medieval y renacentista, Elena Real, (coord.) 1995, pp. 29-38.

Bernal, Beatriz. Cristalián de España, Valladolid: Juan de Villaquirán, 1545.

Bernal, Fernando. Floriseo, Alcalá de Henares: Centro de Estudios Cervantinos, 2003.

Bernis, Carmen. Indumentaria medieval española, Madrid, CSIC, 1956.

--"Modas españolas medievales en el Renacimiento europeo II", Waffen und Kostümkunde, 1960, pp. 27-40.

---------Indumentaria española en tiempos de Carlos $V$, Madrid: Instituto Diego Velázquez/ CSIC, 1962.

-Trajes y modas en la España de los Reyes Católicos I. Las mujeres, Madrid, Instituto Diego Velázquez/ CSIC, 1978.

--Trajes y modas en la España de los Reyes Católicos II. Los hombres, Madrid, Instituto Diego Velázquez/CSIC, 1979.

--------“Traje, aderezo y afeites”, en La España del siglo XIII, Madrid: Real Academia de la Historia, 1987, pp. 51-104.

--_El manuscrito de París. Estudio arqueológico", en Libro del caballero Zifar. Códice de París, estudios publicados bajo la dirección de Francisco Rico, Barcelona: Moleiro Editor, 1996, pp. 193-244.

-El traje y los tipos sociales en el 'Quijote', Michigan: El Viso, 2001.

Boissard, Jean Jacques. Habitus variarum Orbis Gentium, Cologne: Caspar Rutz, 1581.

Boletín de la Real Academia de la Historia, Madrid, tomo CCI, Número III,2004.

Boucher, Françoise. Historia del traje en Occidente desde la antigüedad hasta nuestros días, Barcelona: Montaner y Simón, 1967. 
Cabrera Sánchez, Margarita. "Funerales regios en la Castilla bajo medieval", Acta Historica et Archaeologica Mediaevalia, 22 (2), 2001, pp.537-564.

Cacho Blecua, Juan Manuel. Amadís: heroísmo mítico cortesano, Zaragoza: CUPSA, 1979. -_Las señales de las maravillas en el Libro del caballero Zifar", en Zifar y sus libros: 500 años, Karla Xiomara Luna Mariscal, Axayácatl Campos García Rojas y Aurelio González (eds.), México: El Colegio de México, 2015, pp. 17-59.

Cadenas y Vicent, Vicente de. Diccionario heráldico. Términos, piezas y figuras usadas en la ciencia del blasón, Madrid: Hidalguía, 2002.

Calvo, Raquel y Diego Catalán, Romancero general de Segovia: antología, 1880-1992, Segovia: Diputación Provincial de Segovia, 1994.

Campos García Rojas, Axayácatl. "El ciclo de Espejo de príncipes y caballeros [15551580-1587]”, Edad de Oro, XXI (2002), pp. 389-429.

- "Historia y amor ex arte en los libros de caballerías: Espejo de príncipes y caballeros", Actas del IX Congreso Internacional de la Asociación Hispánica de Literatura Medieval (A Coruña 18-22 de septiembre de 2001), A Coruña, Toxosoutos, 2005, pp. 608-609.

Cantar de los Nibelungos, ed. de Emilio Lorenzo Criado, Madrid, Cátedra, 2007.

Cartagena, Alonso de. Doctrinal de cavalleros, Burgos: Fadrique de Basilea, 1487. http://bibliotecadigital.rah.es/dgbrah/es/consulta/registro.cmd?id=44458

Casanueva Reyes, Loreto. "Prendas de vestir y prendas de amor en la literatura cortesana: El caso de las mangas", Revista Historias del Orbis Terrarum, No. 15, 2015, pp. 824.

Castellanos de Losada, Basilio Sebastián. La galantería española: sistema y diccionario manual del lenguaje de la galantería y sus divisas, Madrid: Imprenta de Francisco Mellado, 1848.

Castiglione, Baltasar de. El Cortesano, Madrid: Cátedra, 1994.

Castro, Álvaro de. Libro segundo de don Clarián de Landanís, ed. de Javier Guijarro Ceballos, Alcalá de Henares: Centro de Estudios Cervantinos, 2000.

Cea Gutiérrez, Antonio. "Ritos y costumbres en torno a los difuntos en Salamanca", Revista de Dialectología y Tradiciones Populares, vol. 40, 1985, pp. 21-68. 
-"La camisa en la indumentaria salmantina: Características, evolución y connotaciones sociales", Revista de Dialectología y Tradiciones Populares, vol. LXIX, no. 2, 2014, pp. 487-520.

Cennini, Cennino. El Libro del Arte, Madrid: Akal, 2014.

Cervantes, Miguel de. El ingenioso hidalgo don Quijote de la Mancha, ed. de Diego Clemencín, Madrid: E. Aguado,1835.

https://books.google.com.mx/books?id=srFdAAAAcAAJ\&printsec=frontcover\&hl=es\&so

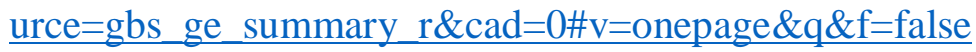

--------Don Quijote de la Mancha, México: Real Academia Española/ Asociación de Academias de la Lengua Española, 2005.

Checa Cremades, Fernando. Los inventarios de Carlos V y la familia imperial: Isabel de Portugal, Madrid: Fernando Villaverde Ediciones, 2010.

Chevalier, Jean. Diccionario de los símbolos, Barcelona: Herder, 1986.

Clemente, Dionís. Valerián de Hungría, ed. de Jesús Duce García, Alcalá de Henares: Centro de Estudios Cervantinos, 2010.

Coduras Bruna, María. La antroponimia en los libros de caballerías españoles: el ciclo amadisiano (Tesis doctoral), Zaragoza: Universidad de Zaragoza, 2013.

--------DINAM. Diccionario de nombres del ciclo amadisiano. Disponible en: <http://dinam.unizar.es $>$ [Acceso el 30/11/2018].

Craik, Jennifer. The face of fashion. Cultural studies in fashion, London: Routledge, 1994.

Cravens, Sidney P. Feliciano de Silva y los antecedentes de la novela pastoril en sus libros de caballerías, Estudios de Hispanofilia, Madrid: Castalia, 1978.

Croce, Benedetto. España en la vida italiana durante el Renacimiento, trad. de Francisco González Ríos, Sevilla: Renacimiento, 2007.

Culianu, Ioan P. Eros y magia en el Renacimiento, Madrid: Siruela, 1999.

Cuentas de Gonzalo de Baeza, tesorero de Isabel la Católica (1492-1504), T. II, ed. de Antonio de la Torre, Madrid: CSIC, 1956.

Crónica de Enrique IV de Castilla 1454-1474, María Pilar Sánchez Parra (ed.) Madrid: Ediciones de la Torre, 1991.

Dávila Puertocarrero, Juan Arias. Discurso para estar a la gineta con gracia y hermosura, Madrid, 1951. 
Danvila y Collado, Francisco. Trajes y armas de los españoles desde los tiempos prehistóricos hasta los primeros años del siglo XIX, Madrid: Imprenta de $\mathrm{T}$. Fortanet, 1877.

Delicado, Francisco. La Lozana andaluza, ed. de Bruno M. Damiani, Madrid: Castalia, 2001.

Díez Borque, José María. "Las ilustraciones del Lazarillo de 1554", en Paratextos en la literatura española: siglos XV-XVIII, María Soledad Arredondo, Pierre Civil y Michel Moner (eds.), Madrid: Casa de Velázquez, 2009, pp.499-518.

Duce García, Jesús. «Fantasías caballerescas: aproximación al motivo de los castillos encantados», en Parrilla, Carmen y Pampín, Mercedes (eds.), Actas del IX Congreso Internacional de la Asociación Hispánica de Literatura Medieval (A Coruña, 18-22 septiembre 2001), A Coruña, Universidad de Coruña, Toxosoutos, 2005, vol. 2, pp. 213-232.

Esteban Erlés, Patricia, «Aproximación al estudio de la magia en los primeros libros del ciclo amadisiano», en Cacho Blecua, Juan Manuel (Coord.); Bueno Serrano, Ana Carmen, Esteban Erlés, Patricia Y Luna Mariscal, Karla Xiomara (eds.), De la literatura caballeresca al «Quijote», Zaragoza, Prensas Universitarias de Zaragoza, 2007, pp. 185-199.

-"Magia y maravillas en los libros de caballerías hispánicos”, en Amadís de Gaula: quinientos años después. Estudios en homenaje a Juan Manuel Cacho Blecua, José Manuel Lucía Megías y María Carmen Marín Pina (eds.), Alcalá de Henares: Centro de Estudios Cervantinos, 2008, pp. 1991-200.

Félix Magno I-II, ed. de Claudia Demattè, Alcalá de Henares: Centro de Estudios Cervantinos, 2001.

Félix Magno III-IV, ed. de Claudia Demattè, Alcalá de Henares: Centro de Estudios Cervantinos, 2001.

Félix Magno III-IV. Guía de lectura, introducción y edición de Claudia Demattè, Alcalá de Henares, Centro de Estudios Cervantinos, 2002.

Fernández, Jerónimo Belianis de Grecia I, ed. de Lilia E.F. de Orduna, Kassel/Edition Reichenberger, 1997. 
Fernández de Oviedo, Gonzalo. Claribalte, ed. de María José Rodilla León, México: UAMI/UNAM, 2002.

Ferrandis, José. Datos documentales para la historia del arte español III. Inventarios reales (Juan II a Juana la Loca), Madrid: CSIC, 1943.

Flores de Setién, Enrique. Memorias de las reinas católicas. Historia genealógica de la casa real de Castilla y de León, Madrid: Antonio Marín, 1770. https://books.google.com.mx/books?id=CIhbAAAAcAAJ\&pg=PA887\&lpg=PA887

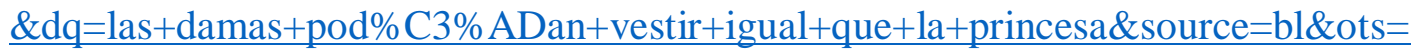
vYj5RUQNBh\&sig=qnmSLtkbn9-

$\underline{\text { Fx3x7QntRhpF0318\&hl=es\&sa=X\&ved=0ahUKEwjGrtfLgvnLAhVkvYMKHeq3C }}$ GQQ6AEIQDAG\#v=onepage\&q=las\%20damas\%20pod\%C3\%ADan\%20vestir\%2 0igual\%20que\%201a\%20princesa \&f=false

Flores García, Andrea. Doncellas, princesas, reinas y sabias: Interacción de la mujer en los libros de caballerías, tesis de maestría dir. por María José Rodilla León, Universidad Autónoma Metropolitana-Iztapalapa, 2014.

-_"La vestimenta en el mundo caballeresco", en Caballeros, damas y maravillas: Aspectos de la literatura caballeresca, Axayácatl Campos García Rojas, Lucila Lobato Osorio, Gabriela Martin y Carlos Alberto Rubio Pacho (eds.), México: UNAM/ FFyL, 2018, pp.37-45.

"Moda infantil en los libros de caballerías I. Trajes de corte", en El rey Arturo y sus libros: 500 años, Aurelio González, Karla Xiomara Luna Mariscal y Axayácatl Campos García Rojas (eds.), México: El Colegio de México, 2019, pp. 355-371.

-“Atuendos galanes para criaturas extrañas en los libros de caballerías I: Los gigantes", En línea caballeresca 1, [en prensa].

-------“"Flora de cristal, tela y tinta. La rosa blanca en el Claribalte", en Claribalte y sus libros: 500 años, [en prensa].

Fresneda González, Nieves. Moda y belleza femenina en la corona de Castilla durante los siglos XIII y XIV, Madrid: Dykinson, 2016.

Gage, John. Color and Culture: Practice and Meaning from Antiquity to Abstraction, California: University of California Press, 1999. 
García de Cortázar, José Ángel. "El vestido: de protector del cuerpo a signo exterior”, en Historia de España. La época del gótico en la cultura española, Madrid: EspasaCalpe, 1994.

García Cuadrado, Amparo. Las Cantigas: el códice de Florencia, Murcia: Universidad de Murcia, 1993.

García Herrero, María del Carmen. "La educación de los nobles en la obra de don Juan Manuel”, La familia en la Edad Media: XI Semana de Estudios Medievales, Nájera, del 31 de julio al 4 de agosto de 2000, coord. por José Ignacio de la Iglesia Duarte, 2001, pp. 39-92.

García Herrero, Miguel. Estudios sobre indumentaria española en la época de los Austrias, Madrid: Centro de Estudios Europa Hispánica, 2014.

--------Los tejidos en la España de los Austrias. Fragmento de un diccionario, Madrid: Centro de Estudios Europa Hispánica, 2014.

García Marsilla, Juan Vicente. "El lujo cambiante. El vestido y la difusión de las modas en la Corona de Aragón (siglos XIII-XV)”, Anales de Historia del Arte, 24, 2014, pp. 227-244.

Gómez-Salvago Sánchez, Mónica. Fastos de una vida real en la Sevilla del quinientos, Sevilla: Universidad de Sevilla, 1998.

González Arce, José Damián. "Los colores de la corte del príncipe Juan (1478-1497), heredero de los Reyes Católicos. Aspectos políticos, estéticos y económicos", Espacio, tiempo y forma, Serie III, H. Medieval, t. 26, 2013, pp. 185-208.

González Marrero, María del Cristo. "Un vestido para cada ocasión: la indumentaria de la realeza bajomedieval como instrumento para la afirmación, la imitación y el boato. El ejemplo de Isabel I de Castilla”, Cuadernos del CEMyR, 22, abril 2015, pp. 155194.

González Mena, María Ángeles. Colección pedagógico textil de la Universidad Complutense de Madrid. Estudio e Inventario, Madrid: Consejo Social de la Universidad Complutense de Madrid, 1994.

Gonzalo Sánchez-Molero, José Luis. El aprendizaje cortesano de Felipe II, 1527-1546: la formación de un príncipe del Renacimiento, Madrid: Sociedad Estatal para la Conmemoración de los Centenarios de Felipe II y Carlos V, 1999. 
Gran crónica de Alfonso XI, ed. de Diego Catalán, Madrid: Gredos, 1977.

Gual Camarena, Miguel. "Para un mapa de la industria textil hispana en la Edad Media", Anuario de estudios medievales, No4, 1967, pp. 109-168.

--Vocabulario del comercio medieval, Barcelona: El ALBIR, 1976.

-------- Vocabulario del comercio medieval, Barcelona, 2014, http://www.um.es/lexicocomercio-medieval

Heras Santos, José Luis de las. La justicia penal de los Austrias en la Corona de Castilla, Salamanca: Universidad de Salamanca, 1994.

Herrero Carretero, Concha. Tapices de Isabel la Católica. Origen de la colección real española, Madrid: Patrimonio Nacional, 2004.

Horcajo Palomero, Natalia. Joyería europea del siglo XVI. Estudio tipológico y temático, (Tesis doctoral dirigida por D. Víctor Manuel Nieto Alcaide), Universidad Complutense de Madrid (Historia del Arte), 1991.

Horozco Covarrubias, Juan de, Emblemas Morales, Zaragoza: Juan Bonilla, 1604.

Il libro del sarto, Ferrara: Edizioni Panini,1987.

Iradiel Murugarren, Paulino. Evolución de la industria textil castellana en los siglos XIIIXVI, Salamanca: Universidad de Salamanca, 1974.

Irigoyen Troconis, Martha Patricia. La mujer romana a través de fuentes literarias y jurídicas, México: Centro de Estudios Clásicos de Investigaciones Filológicas, 1985.

Köhler, Carl. "Sarmatians, Dacians, and Illyrians", A History of Costume, New York, Dover Publications, 1963, pp.85-87.

La corónica de Adramón, ed. de Gunnar Anderson, Newark, Delaware: Juan de la Cuesta, 1992.

Lanzarote del Lago, ed. de Antonio Contreras Martín y Harvey L. Sharrer, Alcalá de Henares: Centro de Estudios Cervantinos, 2006.

Lapidario Órfico, traducción, introducción y notas de Carmen Calvo Delcán, Madrid, Gredos, 1990, pp.345-409.

León Pinelo, Antonio de. Velos antiguos y modernos en los rostros de las mujeres: sus conveniencias y daños, ed. de Enrique Suárez Figaredo, Lemir,13 (2009)- Textos, pp.235-388. 
Libro del Caballero Zifar, ed. de Cristina González, México: REI, 1990.

Lipovestky, Gilles. El imperio de lo efímero. La moda y su destino en las sociedades

modernas, trad. de Felipe Hernández y Carmen López, Barcelona: Anagrama, 1990.

Llull, Ramón. Libro de la orden de caballería, Madrid: Siruela, 2009.

López de Santa Catalina, Pedro. Libro segundo de Espejo de Caballerías, ed. de Juan Carlos Pantoja Rivero, Alcalá de Henares: Centro de Estudios Cervantinos, 2009.

López y Soutar Moroni, Sevillano. "Comercio de perla entre los siglos II a.C. y X d.C.", Boletín Geológico y Minero, 123 (2), pp. 139-155.

Lucía Megías, José Manuel. Imprenta y libros de caballerías, Madrid: Ollero y Ramos, 2000.

Malaxecheverría, Ignacio. Bestiario medieval, Madrid: Siruela, 2008.

Marín Pina, María Carmen. "La recreación de los modelos narrativos caballerescos en la Historia del invencible caballero don Polindo (Toledo 1526)", C.I.F., T.XV, fasc. 1 у 2, (1989), pp.87-98.

_-"El personaje y la retórica del nombre propio en los libros de caballerías españoles”, Tropelías, №1, 1990, pp.165-175.

"Lectores y lecturas caballerescas en el Quijote", Actas del III Coloquio

Internacional de la Asociación de Cervantistas, 1993, pp. 265-274.

«Motivos y tópicos caballerescos», en RICO, Francisco (coord.), Don Quijote de la Mancha. Edición del Instituto Cervantes (1605-2005), Barcelona, Galaxia Gutenberg, Círculo de Lectores, Centro para la Edición de los Clásicos Españoles, 2004, vol. 2, pp. 896-938.

“Seda y acero. La indumentaria en el Palmerín de Inglaterra como signo cortesano", Tirant, 16, 2013, pp. 295-324.

“Adaptación de grabados de Hans Holbein para la Cárcel de amor (Zaragoza, Esteban de Nájera, 1551)”, JANUS 6 (2017), pp. 138-168.

Márquez Villanueva, Francisco. "El caballero del verde gabán y su reino de paradoja”, en Personajes y temas del Quijote, Madrid, Taurus, 1975.

Martínez de la Parra, Juan. Luz de verdades católicas, Barcelona: Rafael Figuer, 1705.

Martínez Martínez, María. La industria del vestido en Murcia (siglos XIII-XV), Murcia: Universidad de Murcia, 1988. 
_-"Indumentaria y sociedades medievales (ss. XII-XV)”, En la España Medieval, 26, 2003, pp. 35-59.

--------“La creación de una moda propia en la España de los Reyes Católicos”, Aragón en la Edad Media, №. 19, 2006, pp.343-380.

Martínez Meléndez, María del Carmen. Los nombres de tejidos en castellano medieval, Granada: Universidad de Granada, 1989.

Martorell, Joan. Tirant lo Blanc, Madrid, Alianza Editorial, 1988.

Medel, Ramón. El blasón español o la ciencia heráldica, Barcelona: J. Guerrero, 1846.

Menéndez Pidal, Gonzalo. La España del siglo XIII leída en imágenes, Madrid: Real Academia de la Historia, 1987.

Mercado, Pedro del. Dialogos de Philosophia natural y moral dirigidos al ilustrissimo y reverendissimo S. don Pedro Guerrero Arçobispo de Granada, Granada: Casa de Hugo de Mena, 1574.

Mérida Jiménez, Rafael M. "El primer antifaz de la literatura española”, en Transmisión y difusión de la literatura caballeresca. Doce estudios de recepción cultural hispánica (siglos XIII-XVII), Lleida: Edicions de la Universitat de Lleida, 2013, pp.99-104.

Mínguez, Víctor. "Emblemática y cultura caballeresca: Divisas valencianas en la canonización de San Francisco de Borja en 1671”, Ars longa: cuadernos de arte, $\mathrm{N}^{\mathrm{o}}$. 4, 1993, pp. 65-70.

Moliner, María. Diccionario de uso del español, Madrid: Gredos, 2007.

Montalbán, Renaldos de. La trapesonda que es tercero libro de don Renaldos y trata como por sus cavallerias alcanço a ser emperador de trapesonda y de la penitencia y fin de su vida, Sevilla: Jacobo Cromberger Impressor, 1548.

Montemayor, Jorge de. Los siete libros de la Diana, Madrid: Editora Nacional, Libro IV, 1976.

Montaner Frutos, Alberto. "Emblemática caballeresca e identidad del caballero", en Libros de caballerías (de <<Amadís $>>$ al $<<$ Quijote $>>)$ Poética, lectura, representación e identidad, Salamanca: SEMyR, 2002, pp. 267-306.

--“Identificación, evocación y conformación en los emblemas heráldicos: el caso de las armas parlantes", Emblemata, 18 (2012), p.41-70. 
Moraes, Francisco de. Palmerín de Inglaterra, ed. de Aurelio Vargas Días-Toledo, Alcalá de Henares: Centro de Estudios Cervantinos, 2006.

Morales, Gaspar de. De las virtudes y propiedades maravillosas de las piedras preciosas, ed. de Juan Carlos Ruiz Sierra, Madrid: Editorial Nacional, 1977.

Morales Blouin, Egla. "La camisa de amor", en El ciervo y la fuente. Mito y folklore del agua en la lírica tradicional, Madrid: José Porrúa Turanzas, 1981, pp. 207-222.

Nieremberg, Juan Eusebio. "XV. Disciplina de armas y doctrina de letras en el Rey Don Sancho el Bravo", en Obras espirituales que contienen los tratados que más ayudan al cristiano a levantar el espíritu y unirse con Dios con vida perfecta III, 1651, pp. 294-295.

Núñez de Taboada, Manuel. Diccionario de la Lengua Castellana, París: Imprenta de Lachevardière, 1825. [En línea]

https://books.google.com.mx/books?id=X3wCAAAAQAAJ\&pg=PA416\&dq=cuajado\&hl =es\&sa=X\&ved=0ahUKEwjjup6QgYDOAhXk54MKHWomBGQQ6AEINDAD\#v $=$ onepage $\& \mathrm{q}=$ cuajado $\% 20 \& \mathrm{f}=$ false

Ortega, Melchor de. Felixmarte de Hircania, ed. de María del Rosario Aguilar Perdomo, Alcalá de Henares: Centro de Estudios Cervantinos, 1998.

Ortúñez de Calahorra, Diego. Espeio De Principes Y Cavalleros: En el qual se cuentan los inmortales hechos del Cauallero del Febo, y de su hermano Rosider hijos del grande Emperador Trebacio. Con las altas cauallerias, y muy extraños amores de la muy hermosa y estremada princessa Claridiana y de otros altos principes $y$ caualleros, Volumen 1, Çaragoça, Estevan de Najera, 1555. [En línea]

https://reader.digitale-sammlungen.de/de/fs1/object/display/bsb10943839_00001.html

------- Espejo de príncipes y cavalleros (El cavallero del Febo), T.II, ed. de Daniel Eisenberg, Madrid, Espasa-Calpe, 1975.

Ovidio. Arte de amar, ed. de Rubén Bonifaz Nuño, México: Universidad Nacional Autónoma de México, 1975.

Parrilla García, Carmen. "Vestir las palabras: grabados xilográficos en la ficción sentimental", Revista de poética medieval, 30 (2016), pp.259-285.

Pastoureau, Michel. Figures et couleurs: études sur la symbolique et la sensibilité médiévales, Paris : Léopard d'or, 1986. 
-Breve historia de los colores, Barcelona, Paidós, 2006.

-Una historia simbólica de la Edad Media occidental, Buenos Aires: Katz, 2006.

--“Une couleur en mutation : le vert à la fin du Moyen Âge”, en Comptes rendus des

séances de l'Académie des Inscriptions et Belles-Lettres, 151e année, N. 2, 2007, pp. 705-731.

---------Diccionario de los colores, Barcelona: Paidós, 2009.

Azul. Historia de un color, Madrid: Paidós, 2010.

-Negro, historia de un color, Madrid, 451 Editores, 2010.

Pastrana Santamarta, Tomasa. "La indumentaria como símbolo de poder en Renaldos de Montalbán”, en El universo simbólico del poder en el Siglo de Oro, ed. Á. Baraibar y M. Insúa, Nueva York/Pamplona: Instituto de Estudios Auriseculares (IDEA)/Servicio de Publicaciones de la Universidad de Navarra, 2012, pp. 205-217.

-------. "El atuendo en el Florindo como portador de pensamientos", Historias Fingidas, 2 (2014), pp. 117-136.

Peláez Flores, Diana. "La imagen de la reina consorte como muestra de poder en el reino de Castilla durante el siglo XV. Construcción y significado”, Medievalismo, 23 (2013), pp. 265-290.

Pellicer de Ossau Salas i Tovar, José. Avisos, ed. de Jean-Claude Chevalier y Lucien Clare, Paris: Éditions Hispaniques, 2002.

Pena Sueiro, Nieves y Sagrario López Poza, "CUALQUIER PRISIÓN Y DOLOR / QUE SE SUFRA ES JUSTA COSA, / PUES SE SUFRE POR AMOR / DE LA MAYOR Y MEJOR / DEL MUNDO Y LA MÁS HERMOSA", en Symbola: divisas o empresas históricas. - BIDISO (Biblioteca Digital Siglo de Oro), A Coruña (España) [en línea]. Publicación: 16-08-2017. Actualización: 16-08-2017. <https://www.bidiso.es/Symbola/divisa/137> [Consulta: 13-11-2018].

Pérez Morera, Jesús. "El tejido brocado en el México virreinal: sedas orientales y criollas", Cuadernos de Arte de la Universidad de Granada, 49, 2018, pp.175-195.

Pérez Vargas, Bernardo. De Re metallica, donde se trata de la forma y materia de los metales philosophicamente, [en línea] Madrid: Casa de Pierres Cosin, 1568. http://documentomovil.usal.es/visor.php? $\mathrm{v}=$ dicter\&f=metalurgia bg PerezVargasB ernardo\#1 
Pfaffenbichler, Matthias Armeros, Madrid, Akal, 1998.

Piñero Torre, Félix. "La tradición "apócrifa" del pasaje del carbunclo (Góngora, Soledad I, 74)”, en Estudios sobre tradición clásica y mitología en el Siglo de Oro, Isabel Colón Calderón (ed.), Ediciones Clásicas, 2002, pp.27-36.

Platir, ed. de María Carmen Marín Pina, Alcalá de Henares: Centro de Estudios Cervantinos, 1997.

Plinio, Historia natural, traducción por Jerónimo de Huerta, Madrid: Luis Sánchez Impresor, 1624. http://alfama.sim.ucm.es/dioscorides/consulta_libro.asp?ref=X53330435X\&idioma $=0$

Pragmática de los Señores Reyes Don Fernando y $D^{a}$. Isabel, sobre los trages; su fecha en Granada a treinta de septiembre de 1499 sobre el modo de vestir prohiviendo fuere de sedas y vordados, y de telas de ylo, oro, y plata.

Primaleón, ed. de María Carmen Marín Pina, Alcalá de Henares: Centro de Estudios Cervantinos, 1998.

Puerta Escribano, Ruth de la. "Moda, moral y regulación jurídica en la época de Goya”, Ars Longa, 7-8, 1996-1997, pp. 205-217.

---------'Reyes, moda y legislación jurídica en la España moderna”, Ars Longa, 9-10, 2000, pp. 65-72.

Puiggari, José. Estudios de indumentaria española, Barcelona: Asociación ArtísticoArqueológica Barcelonesa, 1890.

Puñal Fernández, Tomás. "El trabajo de los paños, elaboración y transformación en el siglo xv: modelos de producción y jerarquización en el eje Burgos-Madrid-Toledo", Anuario de Estudios Medievales, 48/1, enero-junio 2018, pp. 271-298. ISSN 00665061, https://doi.org/10.3989/aem.2018.48.1.09

Polanco Melero, Carlos. Muerte y sociedad en Burgos en el siglo XVI, Salamanca, Diputación Provincial de Burgos, 2001.

Polindo, ed. de Manuel Calderón Calderón, Alcalá de Henares: Centro de Estudios Cervantinos, 2003.

Quer y Martínez, José. Flora española o historia de las plantas que se crían en España, Madrid: Joachin Ibarra, 1784. 
Racinet, Auguste. The complete costume history, (2 vols.), Taschen: Köln, 2012.

Relación y memoria de las joyas de Ana de Austria, Madrid: Dalmiro de la Válgoma y Díaz-Varela, 1949.

Real Academia Española: Banco de datos (CORDE) [en línea]. Corpus diacrónico del español. http://www.rae.es.

Revilla, Federico. Diccionario de iconografía, Madrid: Cátedra, 1990.

Riquer, Martín de. Caballeros andantes españoles, Madrid: Espasa-Calpe, 1967.

---------Heráldica Castellana en tiempos de los Reyes Católicos, Barcelona: Quaderns Crema, 1986.

--“Las armas en el <<Amadís de Gaula>>”, en Estudios sobre el Amadís de Gaula, Barcelona, Sirimio, 1987.

Río Nogueras, Alberto del. "El don Florindo de Fernando Basurto como tratado de rieptos y desafíos", Alazet, 1 (1989), pp. 55-72.

-_Del caballero medieval al cortesano renacentista. Un itinerario por los libros de caballerías", Literatura Medieval. Actas do IV Congresso da Associação Hispânica de Literatura Medieval (Lisboa, 1-5 Outubro 1991), V. I, Lisboa, EDIÇŎES COSMOS, 1993, pp. 73-80.

Rodríguez de Montalvo, Garcí. Amadís de Gaula, Salamanca: Antonio de Salamanca, 1519.

-------- Amadís de Gaula, ed. de Juan Manuel Cacho Blecua, Madrid: Cátedra, 2004.

-------- Sergas de Esplandián, ed. de Carlos Sainz de la Maza, Madrid; Castalia, 2003.

Rodríguez del Padrón, Juan. "Triunfo de las donas", en Obras completas, Madrid, Editora Nacional, 1982.

Rodríguez de la Flor, Fernando. Imago. La cultura visual y figurativa del barroco, Madrid, ABADA Editores, 2009.

Rozier, François. Nuevo diccionario de agricultura, teórica-práctica y económica y de medicina doméstica y veterinaria, T. I, Madrid, Boix, 1842.

Rublack, Ulinka. Dressing Up, New York: Oxford, 2010.

Saladrigas Cheng, Silvia y Joan Soler i Jiménez. El arte real de perseguir a los sombreros. Textos y documentos para la historia del tejido y la indumentaria en las monarquías hispánicas [s. XIV-XVIII], Barcelona: Centre de Documentación i Museu Téxtil, 2008. 
Salazar, Alonso de. Lepolemo. Caballero de la Cruz, ed. de Anna Bognolo y Alberto del Río Nogueras, Alcalá de Henares/Zaragoza: Universidad de Alcalá/Prensas de la Universidad de Zaragoza, 2016.

Sales Dasí, Emilio José. “"Ver' y 'mirar' en los libros de caballerías”, Thesaurus, Tomo LIV, Núm. 1, 1999, pp. 1-32.

-------- 'Una primera aproximación a la heráldica literaria de las continuaciones caballerescas del Amadís de Gaula", Emblemata, 9 (2003), pp. 219-230.

---------"Princesas "desterradas" y caballeros disfrazados. Un acercamiento a la estética literaria de Feliciano de Silva", Revista de Literatura Medieval, XV/2 (2003), pp. 85-106.

-------- "Pinturas, tapices y libros de caballerías”, Destiempos, México, diciembre 2009 enero 2010, año 4, número 23, pp.41-68, http://www.destiempos.com/n23/sales.pdf ¿Continuador o creador? «Las entricadas razones del famoso Feliciano de Silva» In: La escritura inacabada: Continuaciones literarias y creación en España. Siglos xiii a xvii [en línea]. Madrid: Casa de Velázquez, 2017 (generado el 20 agosto 2019). Disponible en Internet: <http://books.openedition.org/cvz/3333>. ISBN: 9788490960738.

Santa Catalina, Pedro López de. Libro segundo de Espejo de caballerías, Alcalá de Henares: Centro de Estudios Cervantinos, 2009.

Santos Vaquero, Ángel. La industria textil sedera en Toledo, Cuenca: Ediciones de la Universidad de Castilla-La Mancha, 2010.

Schward, Matthäus. The first book of fashion, ed. de Ulinka Rublack and Maria Hayward, London: Bloomsbury, 2015.

Sevilla, Isidoro de. Etimologías, ed. de José Oroz Reta, Madrid: Biblioteca de Autores Cristianos, 2004.

Sigüenza Perlada, Cristina. La moda en el vestir en la pintura gótica aragonesa, Zaragoza: CSIC, 2000.

--------“La moda femenina a finales de la Edad Media, espejo de sensibilidad. Costumbres indumentarias de las mujeres a través de las artes plásticas del gótico en la Rioja”, Berceo, 147, 2004, pp. 229-252. 
Silva, Feliciano de. Libro primero de la cuarta y gran parte de la choronica del excellentisimo príncipe don Florisel de Niquea, Salamanca: Casa de Andrea de Portonariis, 1551.

-------Libro segundo de la cuarta y gran parte de la choronica del excellentisimo príncipe don Florisel de Niquea, Salamanca: Casa de Andrea de Portonariis, 1551.

-------- Segunda Celestina, Madrid: Cátedra, 1988.

- Florisel de Niquea III, ed. de Javier Martín Lalanda, Alcalá de Henares: Centro de Estudios Cervantinos, 1999.

------- Lisuarte de Grecia, ed. de Emilio J. Sales Dasí, Alcalá de Henares: Centro de Estudios Cervantinos, 2002.

------- Amadís de Grecia, ed. de Ana Carmen Bueno Serrano y Carmen Laspuertas Sarvisé, Alcalá de Henares: Centro de Estudios Cervantinos, 2004.

--------Florisel de Niquea I-II, ed. de Linda Pellegrino, rev. de María Coduras, prefacio de Anna Bognolo, Alcalá de Henares: Universidad de Alcalá, 2015.

Solanés Soteras, María Concepción. La moda en la sociedad aragonesa del siglo XVI, Zaragoza: CSIC, 2009.

Soler del Campo, Álvaro. "La real armería de Madrid”, Arbor, CLXIX, 665 (mayo 2001), pp. 143-161.

Sousa Congosto, Francisco de. Introducción a la historia de la indumentaria en España, Madrid, Itsmo, 2007.

Talavera, Fray Hernando de. Solazoso y prouechoso tractado contra la demasia de vestir y de calçar, y de comer y de beuer, Granada, Meinardo Ungut y Juan Pegnitzer Impresores, 1496.

Tejeda Fernández, Margarita. Glosario de términos de la indumentaria regia y cortesana en España: siglos XVII y XVIII, Málaga: SPICUM, 2006.

Uzzano, Giovanni di Antonio da. La pratica della mercatura, Firenze: Giuseppe Bouchard, 1766.

Valera, Diego de. Espejo de verdadera nobleza, ed. crítica de Federica Accorsi, Universidad de Pisa, 2011.

Varela Merino, Elena. Los galicismos en el español de los siglos XVI y XVIII, Madrid: CSIC, 2009. 
Vargas, Bernardo de. Cirongilio de Tracia, ed. de Javier Roberto González, Alcalá de Henares: Centro de Estudios Cervantinos, 2004.

Vecellio, Cesare. Costumes anciens et modernes : habiti antichi et moderni di tutto il mundo, Paris: Firmin-Didot, 1859.

Vega, Alejandra. «Trajes del teatro del mundo: vestimenta, sujetos y diferencia americana en la primera modernidad», Nuevo Mundo Mundos Nuevos [En línea], Debates, Puesto en línea el 03 junio 2014, consultado el 1 de julio de 2019. URL: http://journals.openedition.org/nuevomundo/66794 $; \quad$ DOI :

10.4000/nuevomundo.66794

Vega Vázquez, Isabel. Libro de motes de damas y caballeros de Luis de Milán: Edición crítica y estudio, Santiago de Compostela: Universidad, 2006.

Vélez de Guevara, Luis. El diablo cojuelo, Madrid: Castalia, 1980.

Villacorta Baños-García, Antonio. Las cuatro esposas de Felipe II, Madrid: RIALP, 2011.

Vital, Lorenzo. Relación del primer viaje de Carlos V a España (1517-1518), Madrid: Estades, 1958.

Vives, Juan Luis. Instrucción de la mujer cristiana, Madrid: Fundación Universitaria Madrid/Universidad Pontificia de Salamanca, 1995. 

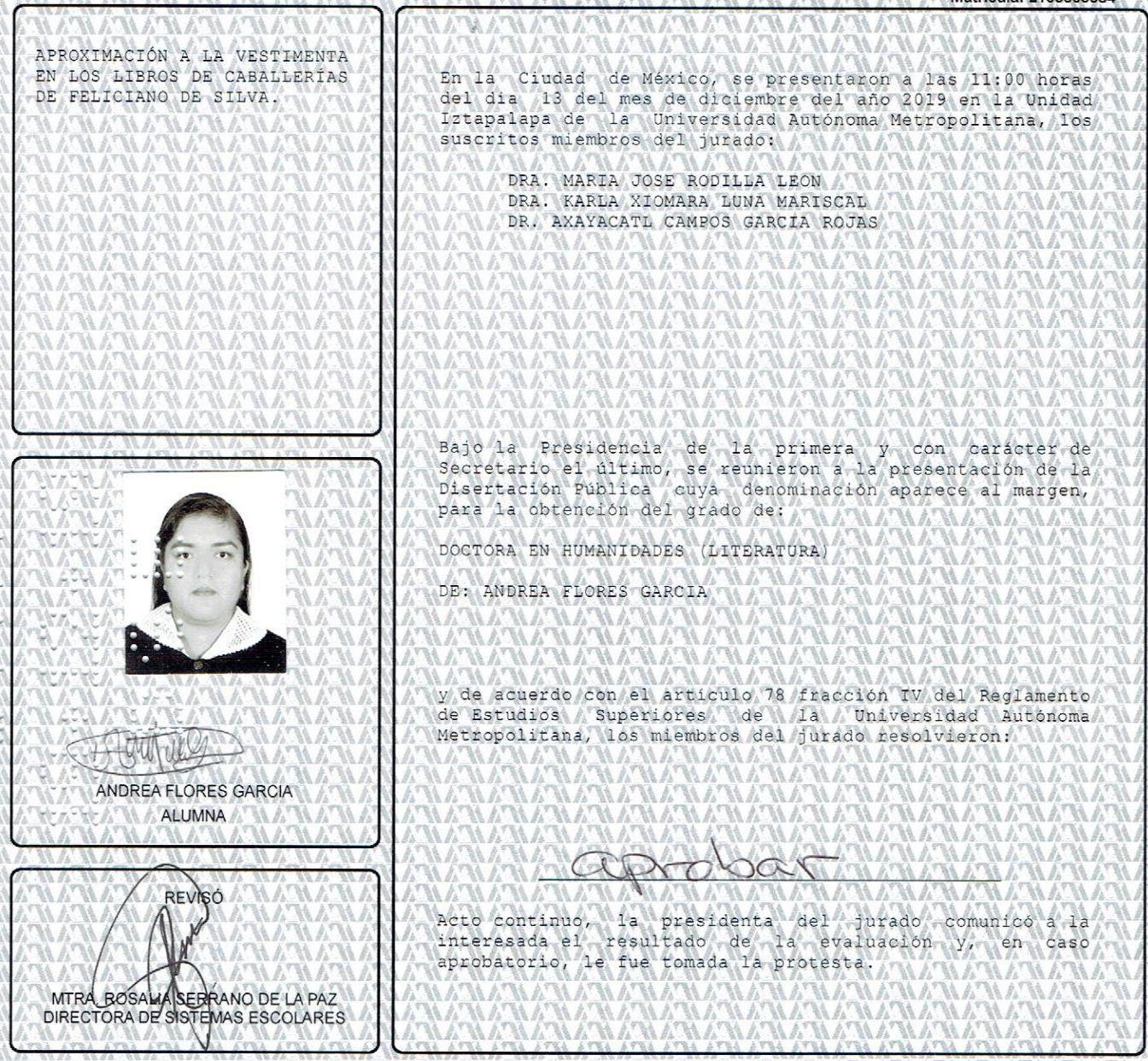

Ba

ara la obtención del grado de:

DOCTORA EN HUMANIDADES (LITERATURA

E: ANDREA ELORES GARCIA

Y de acuerdo con el artículo 78 fracción IV dell Reglanento

e Estudios Superiores de 1 a Undversidad Autónoma

letropolitana, los miembros del/jurado resolvieron:

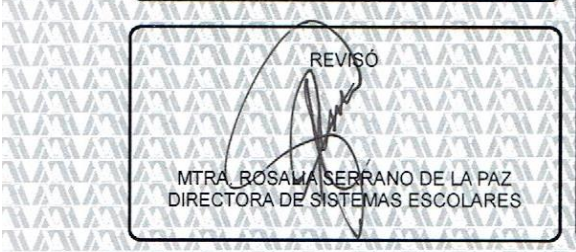

Acto continuo, 1 a presidenta del jurado comunico a la interesada el resultado de la evaluación y, en caso
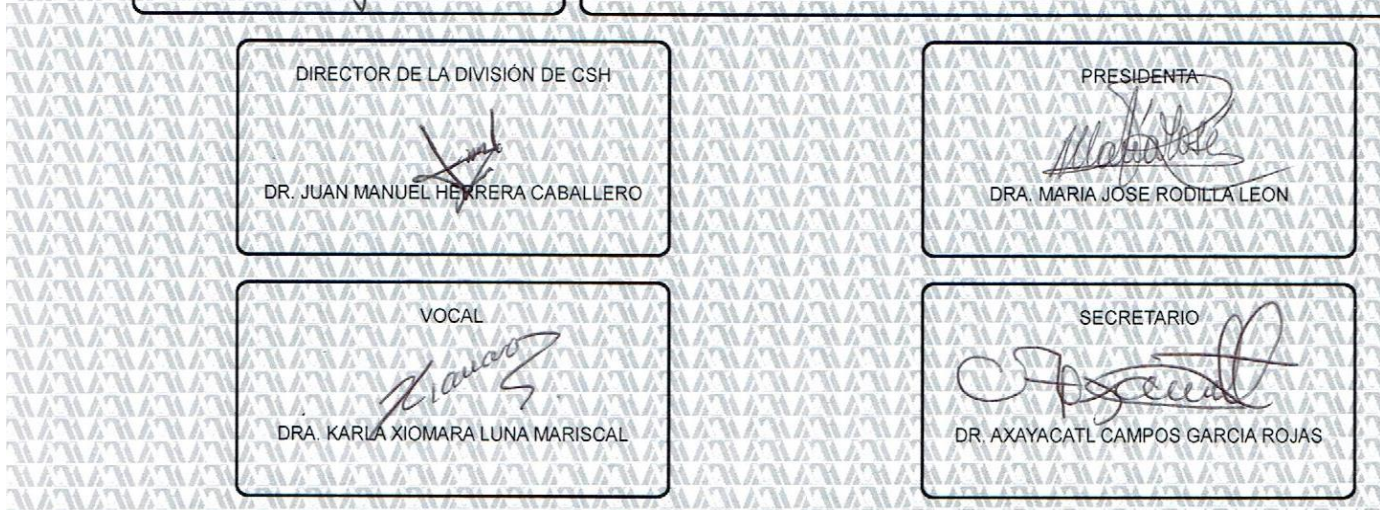